\title{
APROVECHAMIENTO ENERGÉTICO SUSTENTABLE: DESARROLLO DE UN DIGESTOR ANAERÓBICO ASISTIDO POR ENERGÍA SOLAR TÉRMICA
}

Tesis de doctorado

Martín Alberto Morales

Presentada ante la Facultad de Ingeniería de la Universidad Nacional de La Plata como requisito para la obtención del grado académico de

\section{DOCTOR EN INGENIERÍA}

Director de tesis: Dra. María Isabel Sosa

Codirector: Dra. Angélica Carmen Boucíguez

Jurados de tesis:
Dra. Silvina M. Manrique
Dra. Verónica E. Córdoba
Dra. Silvina Belmonte

Fecha de la defensa oral y pública: 20 de diciembre del 2021. 
"Andaré la huella, siguiendo una estrella que, aunque esté muy alta, yo sé que un día la he de alcanzar". 
Dedicada a Valeria, mi compañera de vida y a mi hija Antonella.

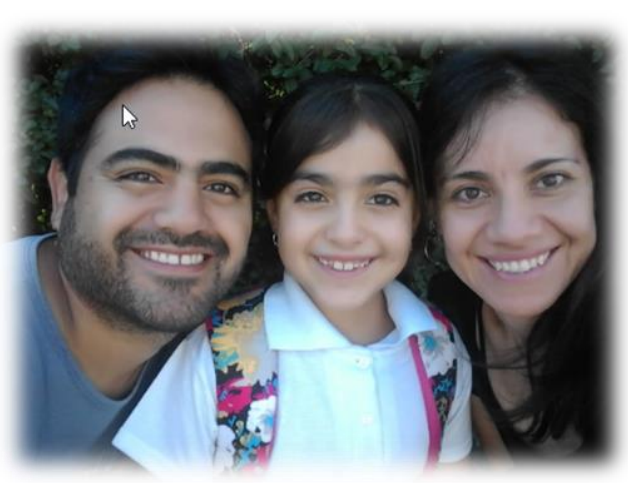




\section{Agradecimientos.}

A María Isabel y Angélica, mi directora y codirectora de tesis, quienes han colaborado en mi crecimiento personal y académico, formándome como persona y profesional, brindadose con total altruismo a pesar de los inconvenientes que se presentaron a lo largo de esta carrera.

Por acompañarme y abrirme las puertas de su casa desde los inicios cuando era un estudiante de grado, guiando y orientándome todos estos años, por inculcarme la responsabilidad por el trabajo, por todo este tiempo, nuevamente gracias Angélica.

A mi familia, amigos y compañeros por su apoyo incondicional.

Al Instituto de Investigaciones en Energía No Convencional (INENCO). Instituto UNSaCONICET.

Al Departamento de Física, Facultad de Ciencias Exactas, Universidad Nacional de Salta (UNSa) donde se realizó parte del trabajo experimental.

Al Departamento de Mecánica, Facultad de Ingeniería, Universidad Nacional de la Plata (UNLP), donde se presenta este trabajo de tesis. 


\section{Aclaración.}

Este trabajo de tesis ha sido realizado en parte gracias a la Beca cofinanciada entre la Universidad Nacional de Salta (UNSa) y el Consejo Nacional de Investigaciones Científicas y Técnicas (CONICET), la cual se otorga para realizar estudios de doctorado, los cuales debían ser desarrollados fuera del ámbito de la institución que cofinancia la beca. Por esta razón la tesis se presenta en el Departamento de Mecánica de la Facultad de Ingeniería de la Universidad Nacional de La Plata (UNLP).

Oportunamente se propuso como directora a la Dra. María Isabel Sosa de la Facultad de Ingeniería de UNLP con amplia experiencia en Uso Racional de la Energía y con amplia formación en aspectos térmicos. La Dra. Angélica Boucíguez, codirectora, trabajaba en el ámbito de Energías no convencionales, en el INENCO, lugar donde se desarrolló la beca.

Las experiencias de laboratorio han sido realizadas en el Instituto de Investigaciones en Energía no Convencional (INENCO), perteneciente a la Facultad de Ciencias Exactas de la Universidad Nacional de Salta (UNSa) y CONICET con sede en la ciudad de Salta Capital.

Los biodigestores han sido instalados en zona rural en el departamento de Rosario de Lerma, a escasos kilómetros de la capital salteña.

Varios de los resultados de esta tesis han sido publicados en congresos, como ser CLAGTEE 2011, CIBIM 2013, ASADES 2015 y 2016, CAIM 2014, 2018 y 2020, los cuales se referencian en la bibliografía. 


\section{Resumen.}

Este estudio se enmarca en la provincia de Salta, observando su capacidad productora de gas metano a partir de la degradación anaeróbica de los residuos sólidos pecuarios bovinos. Se presentan diversos aspectos del proceso de digestión anaeróbica: experiencias a escala laboratorio, construcción y experimentación con biodigestores de mayor volumen, modelo de simulación numérica y análisis de costos.

A escala laboratorio se ensayan reactores anaeróbicos utilizando residuos pecuarios y orgánicos domiciliarios en el rango psicofílico y mesofílico en forma discontinua. A partir de los resultados obtenidos, se construyen tres digestores anaeróbicos de membrana flexible de plástico PVC, uno semienterrado y dos enterrados. Finalmente, las mediciones se realizan con el enterrado de 1.200 litros, utilizando residuos pecuarios bovinos.

Para reducir las pérdidas de energía se analiza la eficiencia de botellas PET como aislante, vacías y rellena con viruta de madera. Para mantener una temperatura en el interior se construye un sistema de calentamiento hibrido solar-eléctrico, formado por un colector solar plano y una resistencia eléctrica. Se lo aplica al biodigestor conjuntamente con un invernadero.

Se estudian diversas variables, siendo la temperatura una de las más importantes, ya que el consumo de energía incide en la producción final de biogás y en la viabilidad de la instalación del digestor. Se mide la temperatura en diversos puntos del digestor, colector solar y conductos de fluido caloportador. Con datos de irradiancia solar se calcula la eficiencia del colector.

Se desarrolla un modelo de simulación numérica para predecir la energía solar y la energía eléctrica utilizada por el digestor para mantenerlo a una temperatura constante. Finalmente se evalúa la producción de biogás y su contenido de metano del digestor y se analizan los costos de producción. Con los datos reunidos del desempeño del digestor anaeróbico y las características propuestas en este trabajo se busca que los tiempos de recuperación de la inversión inicial sean factibles. 


\section{Índice general.}

Dedicatoria.

Página

Agradecimientos.

Aclaración.

Resumen.

Índice General.

iv

$\mathrm{V}$

Capítulo 1: Introducción. $\quad 1$

Capítulo 2: $\quad$ La digestión anaeróbica. $\quad 23$

Capítulo 3: Valorización energética de los residuos pecuarios bovinos de 40 la provincia de Salta.

Capítulo 4: $\quad$ Ensayos de biodigestión anaeróbica en el laboratorio. 53

Capítulo 5: Cálculo de la difusividad térmica de un aislante construido con material descartable. Método de diferencias finitas.

Capítulo 6: $\quad$ Construcción de prototipos de biodigestor y de su sistema de 86 calefacción.

Capítulo 7: Medidas de temperatura. Sistemas de calentamiento.

Capítulo 8: Aspectos teóricos de la transferencia de calor en el digestor enterrado. Modelo de simulación numérica.

Capítulo 9: Captación, conducción y cuantificación del biogás.

Capítulo 10: Cálculo y análisis de los costos constructivos del prototipo. 174 Volumen teórico de metano y su relación con el gas butano.

Capítulo 11: Análisis de los costos constructivos y de operación de una

Discusión General. planta de producción de biogás.

Conclusión final.

Perspectivas futuras.

Bibliografía.

Anexo A1: $\quad$ Detalle técnico de los componentes que integran los

sistemas de calentamiento.

Anexo A2: $\quad$ Planos del digestor anaeróbico enterrado.

Anexo A3: $\quad$ Cotización del dólar.

Anexo A4: $\quad$ Tablas de materiales y costos.

Anexo A5: $\quad$ Cálculo del área de colectores.

Anexo A6: $\quad$ Costo de la energía eléctrica en zona rural. 
CAPITULO 1 INTRODUCCIÓN. 


\section{Organización del capítulo.}

En este capítulo se detallan los objetivos del presente trabajo, sus alcances, metodología, estructura y planificación, mencionando también la motivación que condujo a esta investigación. Posteriormente se inicia con el estado del arte de la investigación en la temática.

\subsection{Introducción.}

La tecnología desarrollada en este trabajo: digestor anaeróbico con sistema de calentamiento hibrido está dirigido a poblaciones de Salta que viven de la cría de ganado. Estas se localizan en zonas donde en general no llega la red de gas, y por tanto resulta conveniente la incorporación de una fuente de energía complementaria. Tal es el caso de la digestión anaeróbica, que proporciona mejores condiciones de salubridad dada la estabilización de los residuos pecuarios. Así, el digestor con las características propuestas en este trabajo implica la utilización directa del recurso biomásico, la producción de biogás para consumo y la disminución de la contaminación ambiental por los desechos pecuarios.

\subsection{Justificación.}

Se propone la digestión anaeróbica como herramienta para gestionar íntegramente los residuos orgánicos, provenientes de la actividad ganadera. El objetivo es obtener un producto que sea asimilable por el ciclo natural del suelo, lo que conlleva otros diversos beneficios, el principal: la disminución de la contaminación. Dada las ventajas de esta tecnología se estudia la capacidad productora de biogás que tiene la provincia, derivado de la digestión que presenta diversas aplicaciones.

La inversión inicial representa un primer obstáculo a afrontar en la construcción de un digestor anaeróbico. Por esto se estudia y lleva a cabo su diseño y su construcción con materiales de bajo costo dado que entre otras ventajas tendría una aceptación más rápida en el mercado. Con la misma idea se estudia e implementa una aislación térmica fabricada con materiales descartables que se aplica al digestor anaeróbico enterrado.

Con los ensayos de laboratorio se obtiene el rendimiento de la muestra a una temperatura determinada, a una cantidad de carga orgánica, ya sea como sólidos volátiles (SV) o como demanda química de oxígeno DQO o demanda bioquímica de oxígeno (DBO) y a una determinada dilución de sólidos, por lo que también es importante medir los sólidos totales (ST). Debido a la dispersión que se obtiene en los resultados siempre es necesario realizar más de un ensayo. 
A fin de determinar el consumo de energía eléctrica y solar del digestor anaeróbico se elabora un modelo de simulación numérica que relaciona diversos parámetros como la temperatura de operación, la energía transferida por convección, y los datos meteorológicos como temperatura ambiente e irradiancia solar.

Una tarea que necesita una evaluación íntegra es la temperatura de operación del digestor, pues en su determinación intervienen diversos aspectos, tales como económicos, energéticos y técnicos. En relación a la energía que interviene en el proceso, debe considerarse el recurso utilizado para calefaccionarlo, tales como solar, eléctrico, etc. Esto influye en la parte técnica y en la inversión inicial (aspecto económico).

A fin de contar con un volumen de biogás durante todo el año, se propone la operación conjunta de dos digestores formando una planta de producción de biogás, para una producción ininterrumpida y de mayor envergadura. Se realiza un análisis de costos, a fin de descartar aquellos casos que no presenten una ventaja económica.

\subsection{Motivación y preguntas guías que conducirán la investigación.}

El aumento de la población conlleva un avance de la zona urbana sobre la rural. Los establecimientos donde se practica la cría de ganado, sea vacuno, porcino o aviar, por nombrar algunos, se sitúan cada vez más cercanos a estas nuevas residencias. Así, los problemas de contaminación que ya existían, pero se mantenían desapercibidos, se manifiestan con mayor importancia.

Las prácticas poco amigables con el medio ambiente, en la actividad ganadera, como el vertido de los residuos directamente al suelo, convierten estos en focos para la proliferación de insectos y ratas.

Los malos olores que se originan a partir de los residuos vertidos, generan molestias de los vecinos aledaños a los establecimientos donde se realizan actividades ganaderas. Las napas de aguas también se ven comprometidas, siendo éstas una vía para la conducción de patógenos contaminantes.

En estas mismas regiones rurales donde no llega el tendido de gas natural, la cría de ganado es una actividad frecuente. Existen diversos modelos de biodigestores que el mercado proporciona, pero no todos se adaptan a las condiciones climáticas y económicas que la zona rural del norte argentino pueda recibir. La misma provincia de Salta posee diversos escenarios geográficos y climáticos que exigen un estudio antes de abordar la implementación de un sistema de biodigestión anaeróbica con posibilidades de aprovechamiento energético del biogás. 
Esto plantea ciertos interrogantes, a saber:

- ¿Cómo encarar el problema de una manera integral y amigable con el medio ambiente?

- ¿Es posible contribuir a una parte del consumo de la energía de una vivienda o establecimiento rural con el biogás generado de la digestión anaeróbica del estiércol pecuario?

- ¿Cuáles son las condiciones necesarias que deben cumplirse a fin de que la implementación de esta tecnología tenga éxito?

- ¿Es el clima de Salta propicio para la implementación de la digestión anaeróbica?

- ¿Es la legislación suficiente para impedir los malos hábitos con respecto a la legislación de los residuos?

En este estudio de implementación de un biodigestor en zona rural se intenta resolver estos interrogantes.

\subsection{Objetivos del trabajo.}

Esta tesis tiene por objetivos:

- Analizar la biodigestión anaeróbica de residuos orgánicos y estudiar sus parámetros.

- Evaluar la capacidad de producción de biogás en la provincia de Salta a partir de la biomasa residual pecuaria y de los residuos sólidos urbanos.

- Diseñar y construir biodigestores anaeróbicos a escala piloto.

- Diseñar y ejecutar la construcción de un biodigestor anaeróbico enterrado.

- Mejorar las condiciones térmicas del biodigestor anaeróbico estudiando distintas alternativas que permitan elevar su temperatura.

- Desarrollar un sistema automático para el control y mantenimiento de la temperatura en el digestor anaeróbico.

- Estudiar la transferencia de energía en el digestor anaeróbico enterrado mediante el desarrollo de un modelo de simulación. 
- Realizar un análisis de costos sobre la inversión inicial del digestor anaerobio enterrado utilizado como prototipo y de una planta de producción de biogás.

\subsection{Metodología: diseño de la investigación y esquema metodológico.}

La investigación comprende diversos puntos que se detallan a continuación:

- Estudio de los datos censales de la actividad ganadera: se estima la capacidad productora teórica de biogás (potencial de producción) que tiene la provincia de Salta a partir de los residuos pecuarios de la actividad ganadera.

- Ensayos de laboratorio: se realizan a tres temperaturas diferentes: $20^{\circ}, 30^{\circ}$ y $37^{\circ} \mathrm{C}$. Se utiliza estiércol vacuno y una mezcla con residuos orgánicos domiciliarios.

-Estudio y experiencias de una aislación térmica: se diseña y construye una aislación térmica con material descartable. Se realizan medidas para determinar el coeficiente de difusión térmica.

- Construcción de digestores anaeróbicos: volumen: se diseña y construyen tres digestores aeróbicos de 200, 2000 y 1000 litros de capacidad.

-Ensayos del sistema de calentamiento de los digestores anaeróbicos: se aplican distintas técnicas de calentamiento a los digestores anaeróbicos y se evalúa el desempeño midiendo la temperatura en diversos puntos del sistema.

-Simulación numérica: se elabora un modelo de simulación numérica que calcula la energía solar del colector y la energía eléctrica requerida por el digestor anaeróbico enterrado.

-Ensayos de digestión anaeróbica en el digestor enterrado: se mide el volumen del biogás y se evalúa su composición. Se calcula la producción medida como volumen de biogás o metano por kilogramo de sólidos volátiles.

-Análisis de los costos del digestor y de una planta de producción de biogás: se realiza un análisis de costos del digestor anaeróbico y se propone otros volúmenes. Se analiza el volumen de metano para todos los casos. Se calcula la inversión inicial, es decir, los costos de los materiales incluidos el sistema de calentamiento híbrido solar-eléctrico.

1.6. Estructura y planificación de la Tesis.

Capítulo 1: estado del arte de la investigación. 
Capítulo 2: marco teórico de la investigación.

Capítulo 3: cálculo y análisis de la producción teórica de biogás de la provincia de Salta a partir de los residuos pecuarios.

Capítulo 4: ensayos en el laboratorio de digestión anaeróbica.

Capítulo 5: desarrollo y estudio de una aislación térmica de bajo costo.

Capítulo 6: construcción de tres digestores anaeróbicos y sus sistemas de calentamiento.

Capítulo 7: experiencias de medición de temperatura en el sistema de calentamiento.

Capítulo 8: aspectos teóricos de la transferencia de calor en el digestor enterrado y desarrollo de un modelo de simulación.

Capítulo 9: presentación y prueba del sistema de captación y cuantificación del biogás.

Capítulo 10: análisis de costos de la inversión del digestor anaeróbico enterrado utilizado como prototipo.

Capítulo 11: análisis de costos de la inversión de una planta de producción de biogás y su recuperación en el tiempo.

\subsection{Alcance y contribución de la tesis.}

La investigación desarrollada en la tesis comprende varios temas entorno a un eje central: mejorar las condiciones térmicas y reducir los costos de un digestor anaeróbico enterrado.

Las contribuciones principales son:

- Aislación térmica de bajo costo y determinación de sus características térmicas.

- Simulación numérica que vincula los distintos aportes y pérdidas energéticas al digestor anaeróbico, principalmente el aporte solar-eléctrico.

- Sistema hibrido solar eléctrico que controla y mantiene una temperatura constante en el digestor anaeróbico.

- Ensayos con el digestor anaeróbico enterrado con temperaturas de operación en el rango psicrofílico. 
- Análisis de costos en el digestor anaeróbico enterrado y de una planta de producción de biogás.

\subsection{Estado del arte de la investigación.}

A fin de tener un panorama de las diferentes fuentes de energía que se utilizan e inferir acerca del estado de desarrollo de las energías renovables, se presenta el consumo energético a nivel mundial y nacional. Se enumeran algunas instalaciones de biodigestión en el país y en la provincia de Salta.

Un marco legal, resulta apropiado cuando se analiza bajo qué condiciones debe aplicarse las energías renovables y en particular la biodigestión anaeróbica. Así, se enumeran, las leyes nacionales y provinciales de Salta relacionadas con las energías renovables y el medio ambiente y algunos de sus artículos considerados relevantes.

Se muestra la cobertura de la red de gas en la provincia de Salta a fin de mostrar las áreas desprovistas de este combustible.

\subsubsection{Consumo energético.}

El crecimiento de la economía mundial se debe principalmente a la utilización de los combustibles fósiles como el petróleo, el gas natural y el carbón. El empleo a nivel mundial de estos tres elementos representa el 85\% del consumo energético (Statistical Review of World Energy, 2019). Es imposible imaginar al mundo en creciente desarrollo y prescindiendo de los recursos de origen fósil. Indudablemente el agotamiento de éstos generará un impacto muy fuerte en la vida humana. En tal sentido, los países buscan una diversificación del consumo energético incorporando energías renovables a su matriz energética.

Esta incorporación conlleva a un desarrollo sostenible, entendiendo por éste a aquel que satisface las necesidades presentes, sin hacer peligrar la posibilidad de que generaciones futuras puedan satisfacer las suyas. El cambio de hábitos de consumo, las formas de producción y organización de las sociedades deben acompañar la agregación progresiva de estas energías.

En el mundo las energías renovables constituyen solo el $4 \%$ del consumo total de energía. En la Figura 1.1 se presenta la evolución del consumo energético a nivel mundial desde 1985 al 2018 (Statistical Review of World Energy, 2019). Los datos están representados en porcentajes respecto del total. En la actualidad la utilización de petróleo representa el 34\% (verde), de carbón 27\% (gris), de gas natural 24\% (rojo), la hidroeléctrica 7\% (celeste), la nuclear 4\% (naranja claro) y las energías renovables el $4 \%$ (naranja). 

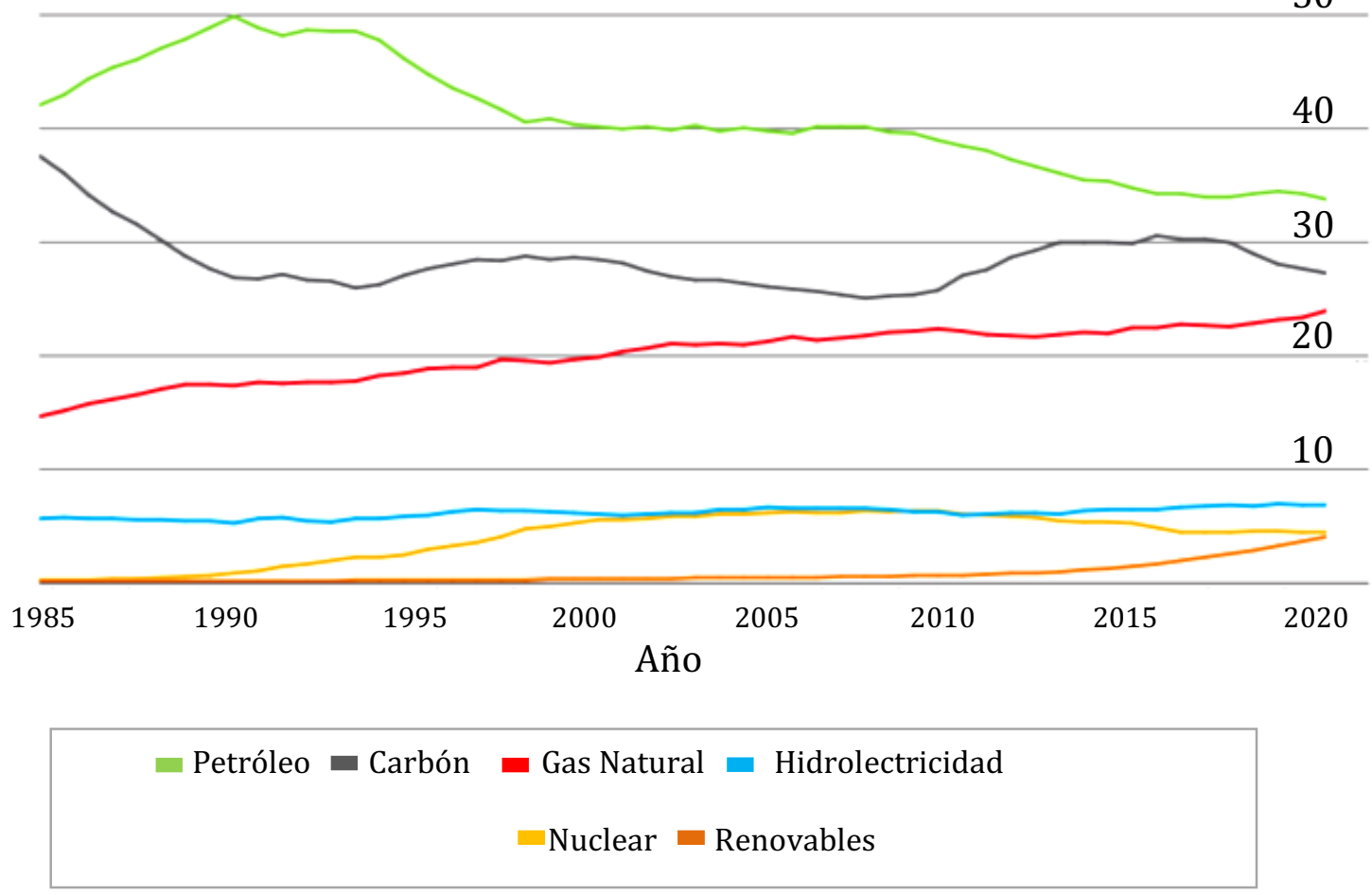

Figura 1.1. Evolución del consumo energético a nivel mundial desde 1985 al 2018. Statistical Review of World Energy, 2019).

La biomasa, como fuente de energía, constituye una alternativa en creciente desarrollo. Comprende a toda la materia orgánica de origen reciente procedente de animales y vegetales. La energía de la biomasa deriva del material vegetal y animal y de la basura industrial, humana o animal (IICA-ARPEL, 2009). Al contrario de otras energías, como la eólica o la solar, es de fácil almacenamiento; pero opera en muchos casos con enormes volúmenes lo que hace su traslado oneroso y constituye un argumento a favor de una utilización local (Instituto Interamericano de Cooperación para la Agricultura, 2009).

El balance energético nacional argentino (Secretaría de Energía de la Nación, 2018), establece que la mayor producción de energía primaria, la constituyen el gas natural y el petróleo; siendo la contribución del primero más importante que la del segundo. En un periodo que va del 2010 al 2018 la producción de energía primaria se encuentra entre los 75000 y los 80000 miles de TEP, Figura 1.2, la menor producción la constituye la eólica y solar encontrándose entre los 130 y 260 miles de TEP (1 TEP es igual a $48.86810^{6} \mathrm{~J}$ ). 


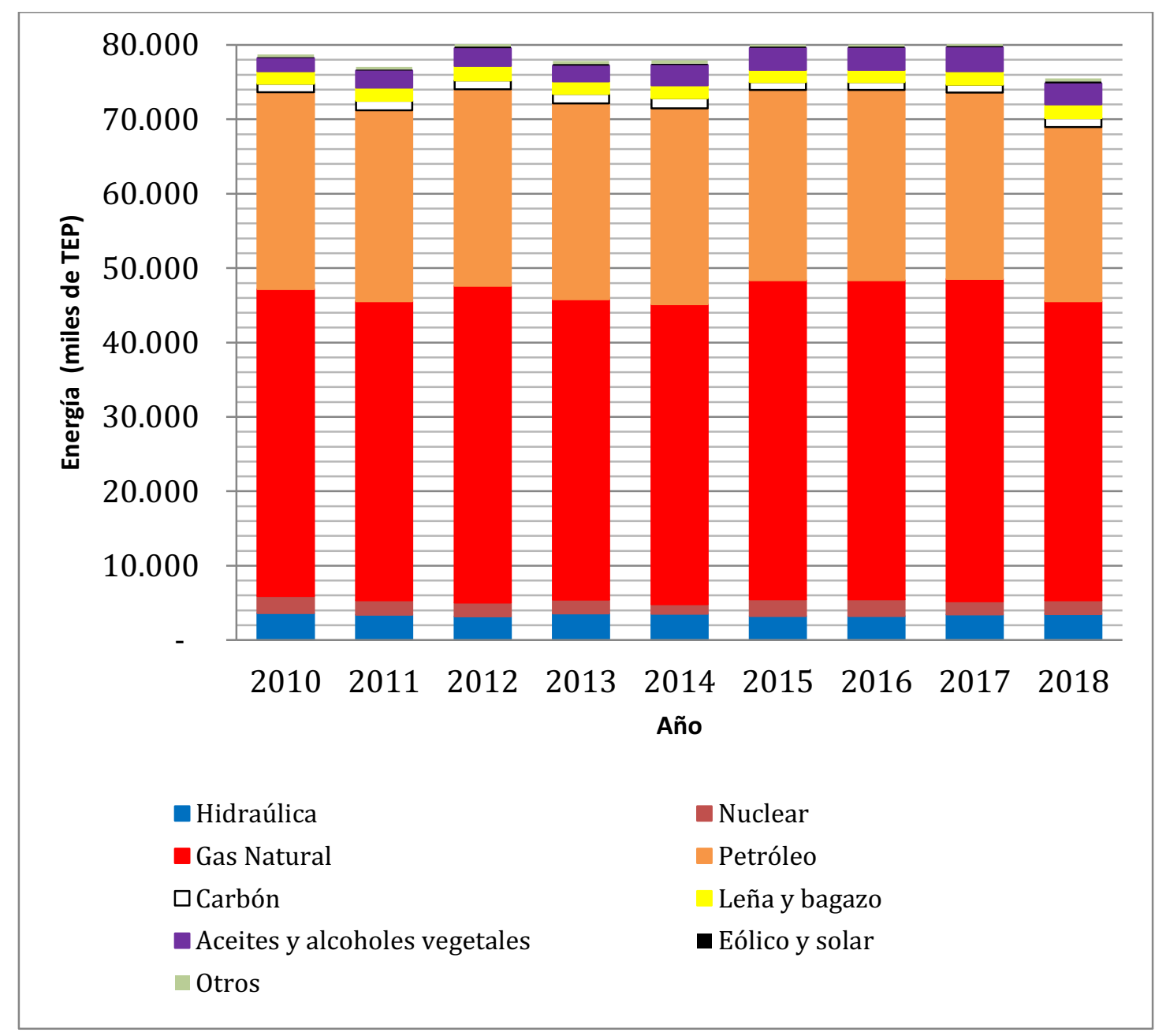

Figura 1.2. Evolución de la producción de energía primaria de la Nación del 2010 al 2018.

Fuente: Secretaría de Energía de la Nación, Balances Energéticos Nacionales, (2018).

En la Figura 1.3 se presenta la producción de energía primaria del año 2018. Esta se constituye desde la mayor a la menor, de la siguiente manera: $53 \%$ gas natural (amarillo), 31\% petróleo (naranja), 5\% hidráulica (celeste), 4\% aceites y alcoholes vegetales (violeta), 2\% nuclear (rojo), 2\% carbón (blanco), 2\% leña y bagazo (verde), $1 \%$ otros y $0,34 \%$ eólica y solar (negro). 


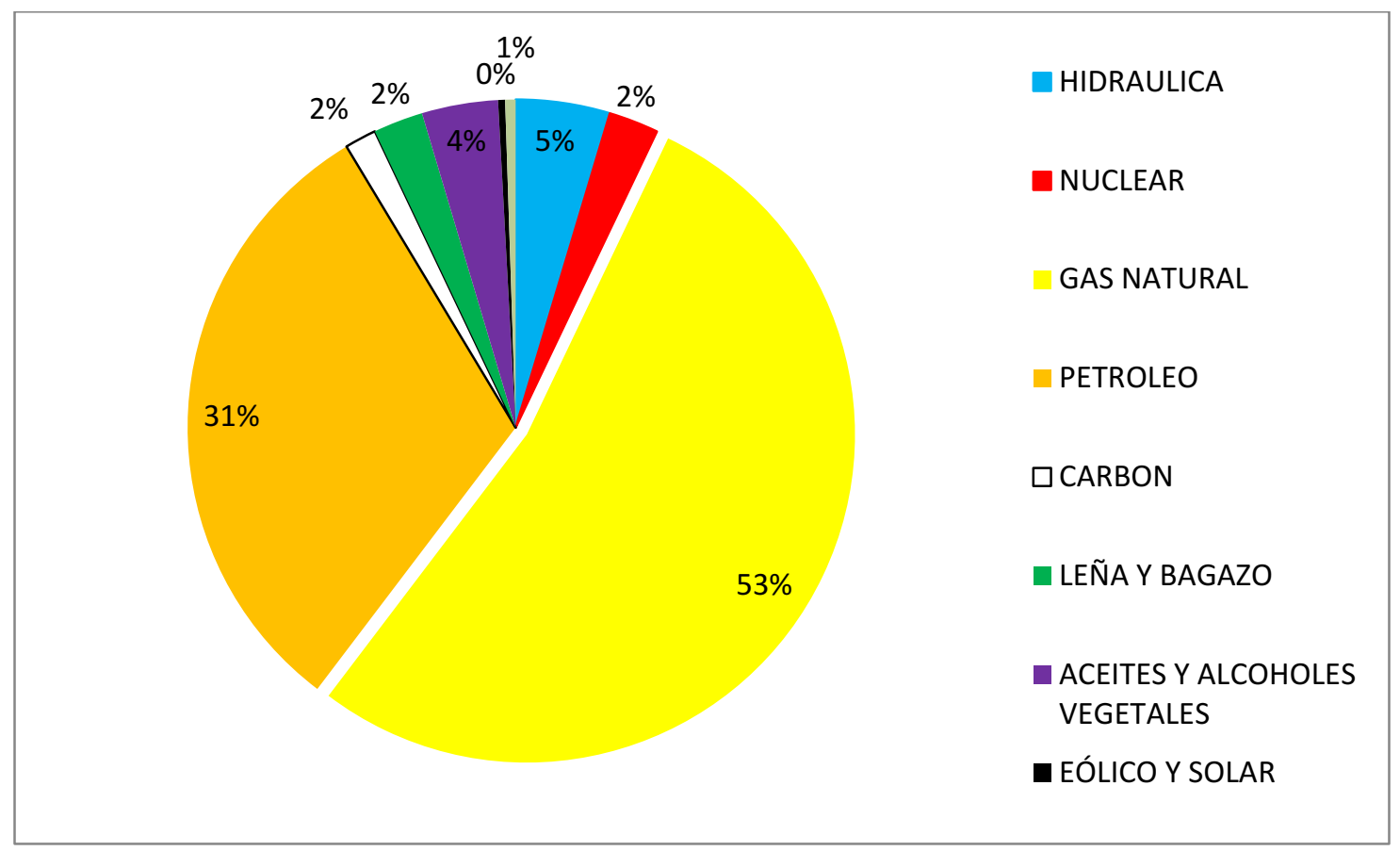

Figura 1.3. Matriz de producción energética nacional del año 2018.

Fuente: Secretaría de Energía de la Nación, Balances Energéticos Nacionales (2018).

\subsubsection{Biomasa pecuaria.}

La cría de ganado es una de las actividades más desarrolladas en Argentina. Es reconocida a nivel mundial por la calidad de su carne. El $60 \%$ del monto total de cabezas de ganado corresponden al bovino, el promedio histórico del número de cabezas de ganado en la última década es de 54 millones (www.surdelsur.com, 2018). Diversos inconvenientes surgen de esta actividad, el principal: la contaminación del aire, suelo y agua por la generación progresiva del estiércol animal. La cantidad que se produce diariamente en todo el territorio es exorbitante si se tiene en cuenta que cada cabeza vacuna adulta puede depositar hasta 25 y 40 kilogramos de estiércol por día (Hillbert, 2003), dependiendo de la actividad del animal y su locación. Claramente, se produce más residuo de lo que el propio ambiente puede absorber naturalmente.

La aplicación directa de los residuos ganaderos al suelo es una práctica poco amigable con el ambiente, si se tiene en cuenta la contaminación que produce en las aguas tanto superficiales como subterráneas. Sumado a ello se emiten al aire compuestos orgánicos volátiles tales como amoniaco $\mathrm{NH}_{3}$, sulfuro de hidrógeno $\mathrm{SH}_{2} \mathrm{u}$ óxidos de nitrógeno $\mathrm{NO}_{\mathrm{x}}$.

Para una gestión integral de los residuos se cuenta con diversas formas de tratamiento. El objetivo es obtener un producto que sea asimilable por el ciclo natural del suelo, lo que conlleva otros diversos beneficios, el principal: la disminución de la contaminación. 
La finitud de las reservas de los combustibles fósiles es suficiente para pensar en un desarrollo amplio y sostenido de las energías renovables. Una economía tan dependiente del petróleo o del gas natural resulta altamente sensible a las crisis que puedan presentarse en la producción de tales combustibles. Además, la combustión de ellos genera problemas ambientales: contaminación de aguas superficiales y subterráneas, de suelos, del aire, efecto invernadero, etc.

\subsubsection{Marco legal: Legislación Nacional y Provincial de Salta.}

Se enumeran a continuación, las leyes nacionales y provinciales de Salta relacionadas con las energías renovables y el medio ambiente y algunos de sus artículos considerados relevantes:

Resolución 1.076/2001. Secretaría de Desarrollo Sustentable y Política Ambiental. "Creación del Programa Nacional de Biocombustibles relacionado con la problemática del cambio climático".

$\checkmark$ Artículo $1^{\circ}$ : se crea el programa nacional de biocombustibles relacionado con el cambio climático y la normativa emergente de la Convención Marco de las Naciones Unidas Sobre Cambio Climático y el Protocolo de Kyoto.

$\checkmark$ Artículo $2^{\circ}$ : son funciones del programa la realización de estudios y desarrollos sobre: posibilidades de producción de biocombustibles y sustitución de combustibles fósiles, como así también de medidas y políticas que favorezcan el uso de biocombustibles. Se promueve la realización de proyectos de investigación y desarrollo incluyendo actividades como el desarrollo de las distintas formas de producción de biocombustibles (etanol, metanol, biodiesel, biocrudo y metano), en relación a las características particulares de cada economía regional.

Resolución 1.156/2004. Secretaría de Agricultura, Ganadería, Pesca y Alimentos. "Creación del programa Nacional de Biocombustibles".

$\checkmark$ Artículo $1^{\circ}$ : esta resolución resuelve la creación del programa nacional de biocombustibles bajo el ámbito de Secretaría de Agricultura, Ganadería, Pesca y Alimentos del Ministerio de Economía y Producción.

$\checkmark$ Artículo $3^{\circ}$ : en la misma se fijan como objetivos más relevantes promover la elaboración y el uso sustentable de los biocombustibles como fuente de energía renovable y alternativa a los combustibles fósiles. También se busca promover las inversiones privadas y públicas para el desarrollo de los biocombustibles.

Ley Nacional № 26.093/2006 "Régimen de regulación y promoción para la producción y uso sustentables de biocombustibles" establece en sus artículos 
$\checkmark \quad 2^{\circ}$ : la autoridad de aplicación de dicha ley determinada por el poder ejecutivo nacional.

$\checkmark \quad 3^{\circ}$ : la creación de una comisión asesora para la promoción de la producción y uso sustentable de biocombustibles, la cual tiene como funciones asistir y asesorar a la autoridad de aplicación.

$\checkmark 5^{\circ}$ : se entiende por biocombustibles al bioetanol, biodiesel y biogás, que se produzcan a partir de materias primas de origen agropecuario, agroindustrial o desechos orgánicos, que cumplan con los requisitos de calidad que establezca la autoridad de aplicación.

$\checkmark 11^{\circ}$ : se establece que el biocombustible gaseoso denominado biogás se utilizará en sistemas, líneas de transporte y distribución de acuerdo a lo que establezca la autoridad de aplicación.

$\checkmark 12^{\circ}$ : el Estado nacional, ya se trate de la administración central o de organismos descentralizados o autárquicos, así como también aquellos emprendimientos privados que se encuentren ubicados sobre las vías fluviales, lagos, lagunas, y en especial dentro de las jurisdicciones de Parques Nacionales o Reservas Ecológicas, deberán utilizar biogás sin corte o mezcla.

$\checkmark$ El Decreto reglamentario 109/2007 de la Ley 26.093 fija la autoridad de aplicación, los regímenes de promoción, habilitaciones, sanciones, promociones

Ley Nacional № 26.190/2006 "Régimen de fomento Nacional para el uso de fuentes renovables de energía destinada a la producción de energía eléctrica”, establece en sus artículos:

$\checkmark$ Artículo $1^{\circ}$ : declara de interés nacional la generación de energía eléctrica a partir del uso de fuentes de energía renovables con destino a la prestación de servicio público como así también la investigación para el desarrollo tecnológico y fabricación de equipos con esa finalidad. Esta ley promueve la realización de nuevas inversiones en emprendimientos de producción de energía eléctrica, a partir del uso de fuentes renovables de energía en todo el territorio nacional.

En el año 2015, la República Argentina promulgó la Ley № 27.191 -que modifica la Ley $\mathrm{N}^{\circ} 26.190-$, con el objetivo de fomentar la participación de las fuentes renovables de energía hasta alcanzar un $20 \%$ del consumo de energía eléctrica nacional, en 2025; y valorando a la biomasa como una fuente de alta relevancia.

La Constitución Provincial de Salta en el capítulo VIII, Titulo II de Recursos Naturales, Articulo $85^{\circ}$ de las fuentes de energía, establece que los poderes públicos promueven 
la utilización y conservación de las fuentes de energía. Como así también estimulan la investigación, desarrollo y aprovechamiento de fuentes de energía no convencionales.

Ley Provincial $N^{\circ} 7.070 / 00$ de protección del medio ambiente:

$\checkmark$ Artículo $106^{\circ}$ : establece la prohibición de enterrar residuos susceptibles de degradarse y emitir contaminantes en acuíferos y cursos de agua.

$\checkmark$ Artículo $110^{\circ}$, inciso b): establece la disposición y tratamientos separados de los residuos biodegradables, de los que no lo son da lugar a la opción del tratamiento anaeróbico de la fracción orgánica.

\subsection{Antecedentes en Argentina.}

PROBIOMASA es un proyecto para la promoción de la energía derivada de la biomasa. Es una iniciativa del Ministerio de Agricultura Ganadería y Pesca y de la Secretaría de Gobierno de Energía del Ministerio de Hacienda con la asistencia técnica y administrativa de la Organización de las Naciones Unidas para la alimentación y la Agricultura (FAO). Su objetivo principal es incrementar la producción de energía térmica eléctrica derivada de la biomasa a nivel local, provincial y nacional para asegurar un creciente suministro de energía limpia, confiable y competitiva, y a la vez, abrir nuevas oportunidades agroforestales, estimular el desarrollo regional y contribuir a mitigar el cambio climático.

Entre las líneas de acción, promueve el establecimiento de emprendimientos bioenergéticos. En tal sentido se destaca la participación de un proyecto de perteneciente al Departamento de San Ramón de la Nueva Oran de la provincia de Salta, cuyo objetivo es la construcción de un biodigestor para su aplicación en el colegio secundario $\mathrm{N}^{\circ} 5.040$ de Oran (Energía Estratégica, 2015).

Al año 2015 se conocía la distribución de 80 plantas de biodigestión anaeróbica en todo el país. En un relevamiento realizado por el INTI (2017) sobre 62 de ellas se establece que las provincias donde se encuentra mayor desarrollo son: Santa Fe, Córdoba y Buenos Aires, Figura 1.4. 


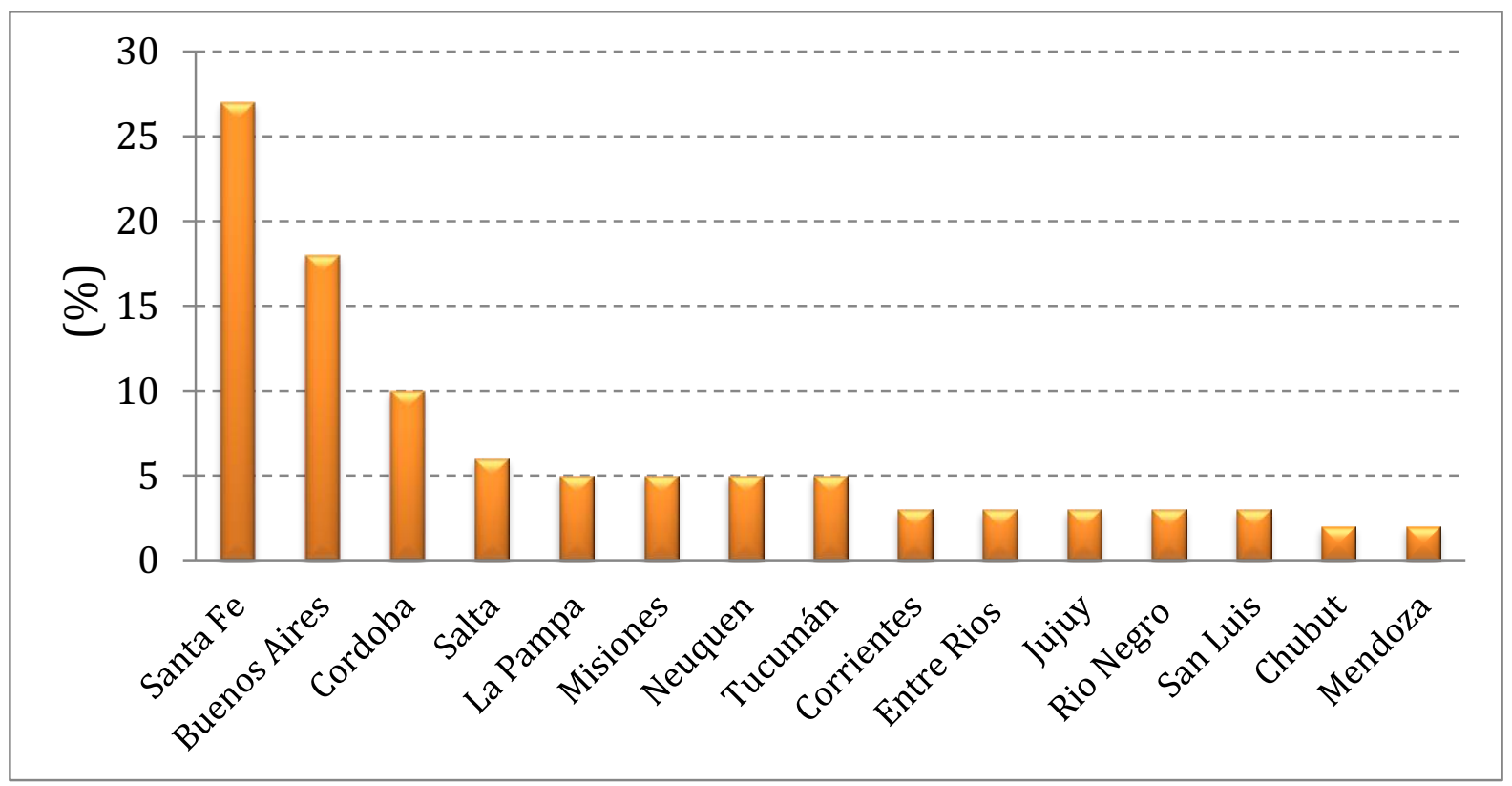

Figura 1.4. Distribución en porcentajes de biodigestores en las provincias. Fuente: Relevamiento Nacional de Biodigestores. INTI (2017).

Del total de las plantas relevadas se estima que la mayor parte de ellas con un 52,4\% se encuentra en el sector rural. Esto condice con el hecho de que el mayor sustrato utilizado es el de origen ganadero, Figura 1.5.

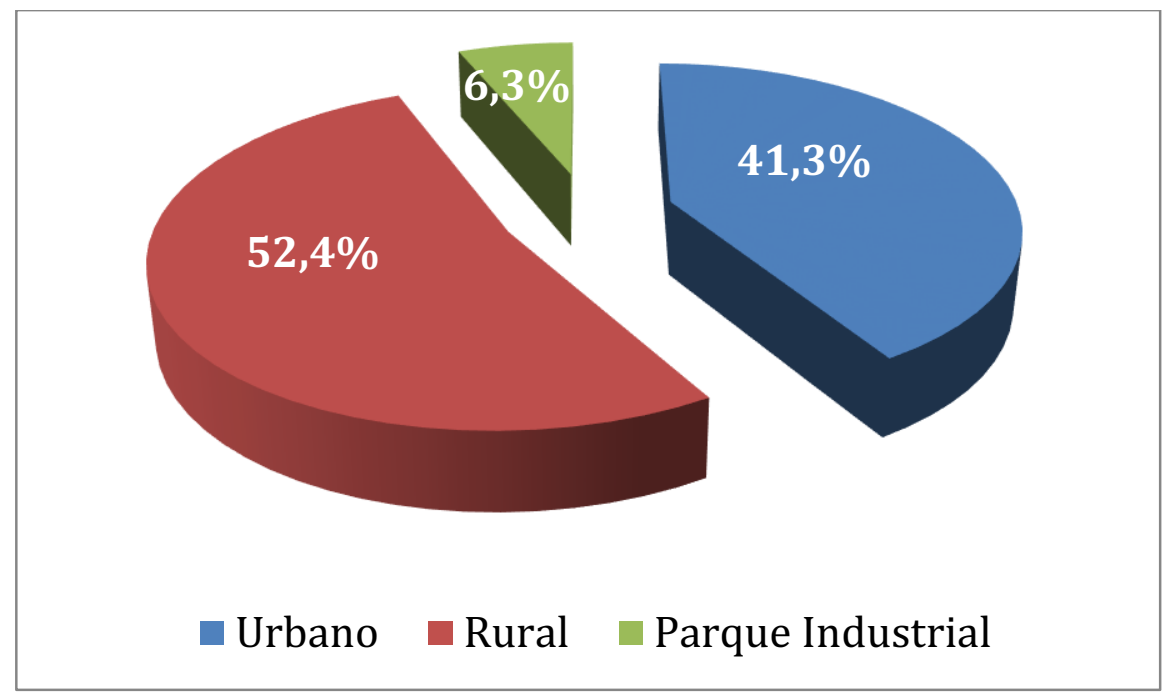

Figura 1.5. Distribución de biodigestores por sector. Fuente: Relevamiento Nacional de Biodigestores, INTI (2017).

Se enumeran algunos porcentajes de interés, extraídos del Relevamiento Nacional de Biodigestores (INTI, 2017): 
- Entre los materiales más utilizados para la construcción se encuentran las membranas en general, el hormigón y acero inoxidable, el uso depende del tipo de biodigestor: laguna cubierta, UASB o de mezcla completa.

- El 48,3 \% de los digestores tiene un sistema deficitario o no posee agitación.

- El 56,3 \% no posee sistema de control de temperatura y aislación térmica.

- El tipo de sustrato más utilizado es el ganadero.

- El $44 \%$ del biogás producido por las plantas de biodigestión privadas se utiliza con fines térmicos.

Existen diversas falencias operativas y técnicas de la construcción que se advirtieron, se enumeran algunas de ellas:

- Falta de aislación térmica.

- Falta de seguridad y mala operación de las instalaciones.

- Falta de capacidad técnica en el personal operativo.

- Adopción de tecnología no adaptada a las condiciones regionales.

- Muchas instalaciones operan de manera totalmente rudimentaria (toma decisión por aspectos visuales y experiencia).

- No hay procedimientos de operación, de seguridad y mantenimiento.

- Escaso control y seguimiento del proceso.

En la localidad de Marcos Paz en la Provincia de Buenos Aires en el año 2008 se terminó la construcción de un digestor anaeróbico de $1.750 \mathrm{~m}^{3}$ de capacidad que produce biogás para su utilización como energía térmica y su conversión a energía eléctrica (Infocampo, 2012).

En la localidad de Cevil Pozo en la Provincia de Tucumán inició su funcionamiento en el año 2009 una planta para el tratamiento de los efluentes generados en el proceso de producción de limón de la empresa Citrusvil (La Gaceta, 2009).

Central Buen Ayre, es una planta dedicada a la generación de energía eléctrica a partir del biogás extraído del relleno sanitario ubicado en el centro del Complejo Ambiental Norte III del CEAMSE, (año 2010). Es la primera planta local abocada en un $100 \%$ a la producción de energía a partir de biogás extraído de relleno sanitario. Cuenta con una potencia instalada de 11,8 MW y genera en forma permanente $10 \mathrm{MW}$, lo que equivale al consumo diario promedio de aproximadamente 15.000 habitantes (Futuro Sustentable, 2012).

En el Ingenio Ledesma ubicado en el Departamento homónimo de la provincia de Jujuy, se construyó en el año 2010 una planta piloto para el tratamiento de los desechos de la industria azucarera para la obtención de biogás. Este digestor fue construido en el marco del proyecto modelo de desarrollo de alternativas para el 
manejo de efluentes de la producción de bioetanol, que llevan adelante los ingenios de Jujuy (Ledesma) y de Salta (Tabacal y San Isidro) con el fin de lograr una producción sustentable (La Gaceta, 2010).

En la zona conocida como La Meseta en la provincia de Neuquén, en el año 2013, se habilitó una planta para la recuperación y conversión del biogás en energía eléctrica del relleno sanitario que allí funciona. La energía convertida es utilizada para el consumo interno de los artefactos eléctricos. En el predio, se perforaron siete pozos de captación de biogás de ocho metros de profundidad en un radio de 1,8 hectáreas. Cuenta también con un motogenerador eléctrico, una planta de captación y tratamiento que incluye una bomba de succión e impulsión y una antorcha (La mañana LM- Neuquén, 2013).

La Secretaría de Estado de la Energía en conjunto con el Ministerio de Educación de la provincia de Santa Fe llevó adelante, en el año 2018, el programa "Educación Energética" (Resolución SEE 095/18), para la incorporación de contenidos relacionados a la valorización de la Energía, Eficiencia Energética y Energías Renovables en todos los niveles educativos. Dentro de los objetivos del Programa, se encuentra el de incorporar sistemas energéticos en los establecimientos mencionados, que posibiliten el uso de recursos renovables para abastecer servicios generales tales como electrificación y/o agua caliente sanitaria y/o provisión de biogás (Secretaria de Estado de la Energía del Gobierno de la Provincia de Santa Fe, 2018).

En el mes de setiembre del 2019 se inauguró la Planta Bioeléctrica de 1MW de potencia en un predio cercano a la Granja Porcina "El Gran Chaparral” en el municipio de General Alvear, Provincia de Buenos Aires. Cuenta con tres biodigestores con una capacidad de $4000 \mathrm{~m}^{3}$ cada uno. La planta tiene por objetivo el tratamiento de estiércol porcino. El biogás producido es utilizado para generar energía eléctrica para la calefacción del biodigestor y abastecer del consumo eléctrico a un equivalente de 3.000 familias. La empresa Bioeléctrica General Alvear SA. fue autorizada y habilitada comercialmente por CAMMESA (Compañía Administradora del Mercado Mayorista Eléctrico Sociedad Anónima) para la generación de energía a partir del primer día hábil de setiembre inyectándola a la red nacional. La empresa además tiene en funcionamiento otras cuatro plantas, una en Justo Daract de $1 \mathrm{MWh}$ y tres en Rio Cuarto de 1, 2 y 3,9 MWh. Otras dos se encuentran en construcción (en el año 2019), en Formosa y en Holberg (Rio Cuarto) de 10MWh 2,16MWh respectivamente (Bioeléctrica, 2019).

La empresa Oilfox (2019) cuenta en la provincia de Bs. As. con un digestor anaeróbico con capacidad de tratamiento de 6 Ton de residuos. El biogás que produce es utilizado 
para abastecer de energía al mismo emprendimiento. El efluente del biodigestor una vez pasteurizado es conducido a piletas como alimento de algas del tipo Arthrospira platensis y Arthrospira máxima (espirulina), las que tienen un gran atractivo comercial. El dióxido de carbono $\left(\mathrm{CO}_{2}\right)$ que se produce en la combustión del biogás es conducido a las mismas piletas para favorecer el crecimiento de las algas.

\subsection{Antecedentes en Salta.}

En esa sección se destacan solo experiencias de digestión anaeróbica de gran envergadura en la provincia de Salta. También se han llevado a cabo otros procesos de menor tamaño, como el caso del Instituto Nacional de Tecnología Industrial, INTI (INTI, 2016) con el desarrollo de biodigestores de pequeña escala (con capacidad para $30 \mathrm{~kg}$ de estiércol y 70 de agua) para productores de ganado.

\subsubsection{El digestor anaeróbico del Departamento de La Candelaria.}

En el mes de febrero del año 2011 se terminó de construir el primer digestor de la provincia de Salta (Secretaría de Prensa y Comunicación de la Provincia de Salta, 2011). Este fue instalado en La Candelaria con el objetivo de procesar los desechos orgánicos producidos por el matadero municipal que allí funciona. La iniciativa fue posible gracias al apoyo del INTA (Instituto Nacional de Tecnología Agropecuaria) y la interacción público-privada con las empresas Constructora Norberto Odebrecht, IBS Córdoba y BTU (una empresa constructora argentina). El biogás producido sería almacenado en un gasómetro de membrana para garantizar su disponibilidad al momento de su utilización en el mismo establecimiento, principalmente para obtener agua caliente. Figura 1.6.

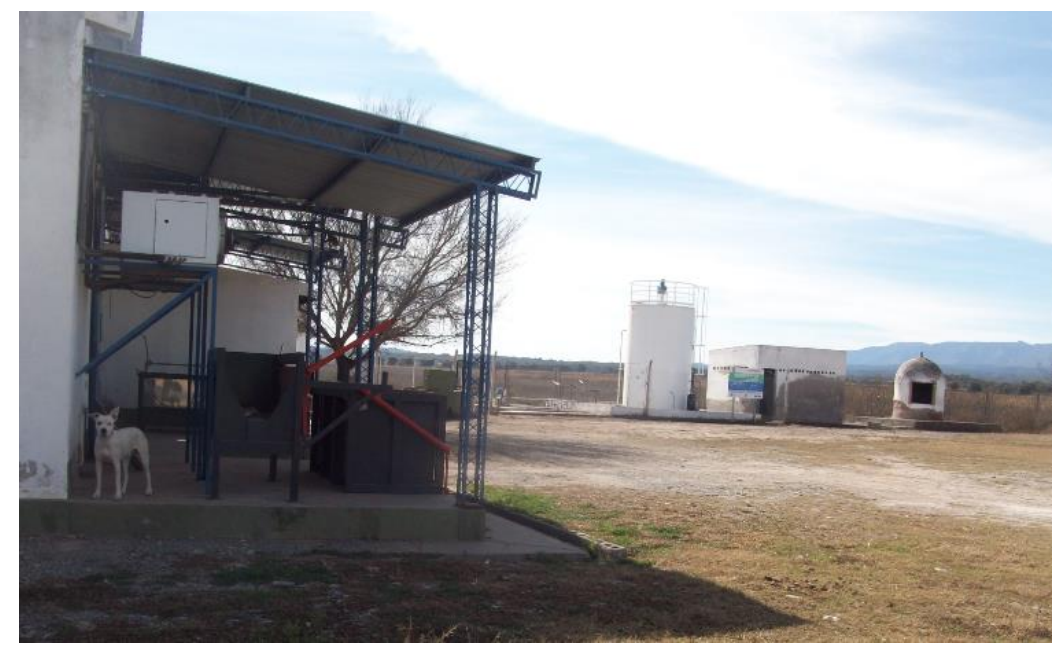

Figura 1.6. Vista del matadero municipal y el digestor anaeróbico.

Fuente: imagen propia (2014). 
En el año 2014 se realizó una visita a la planta teniendo la oportunidad de sacar fotos, consultar manuales de operación y conversar con el personal matadero.

El frigorífico del matadero proveería la materia prima necesaria: desechos pecuarios del ganado para la producción de biogás, que se utilizarían como combustible para alimentar la caldera, suministrar agua caliente al frigorífico o bien para pelar los cerdos faenados en el lugar.

El digestor cuenta con un sistema central de mezcla completa que se realiza desde la parte superior. Posee un eje vertical con paletas de plástico de tres niveles de profundidad que giran a $7 \mathrm{rpm}$, la que se acciona una vez por hora durante 15 minutos. Además, posee un sistema de recirculación por bombeo a tres niveles diferentes, para evitar la formación y sedimentación de barros, mejorar la homogeneización e impedir espacios "muertos". En la Figura 1.7 se muestran dos imágenes de motor de mezclado y los ductos de recirculación.

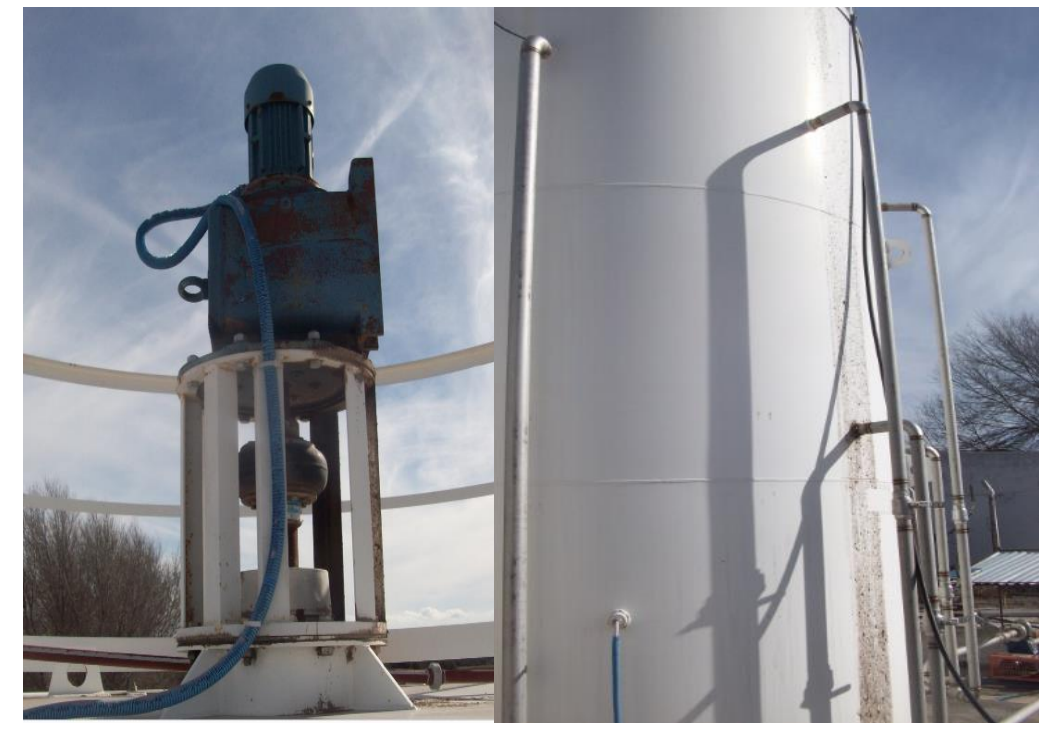

Figura 1.7. Motor para el mezclado y ductos de recirculación.

Fuente: imagen propia (2014).

El digestor cuenta además con dos cámaras de carga y descarga ambos de $15 \mathrm{~m}^{3}$ de capacidad. A la primera llegan los residuos pecuarios del matadero por un conducto y los residuos que consisten en estiércol se cargan en la misma cámara manualmente. Estos son mezclados y retenidos durante un tiempo para luego ser enviados mediante una bomba centrífuga al digestor. A la cámara de descarga llegan los residuos digeridos mediante el rebalse del digestor anaeróbico. 
El digestor fue construido en acero de $6,3 \mathrm{~mm}$ de espesor y cuenta con un volumen de $30 \mathrm{~m}^{3}$, siendo el volumen útil de $26 \mathrm{~m}^{3}$. Tiene un revestimiento interior de pintura epoxi que evita la corrosión.

Para su acondicionamiento térmico, cuenta con un serpentín interior por donde circula agua caliente y un par de resistencias eléctricas que se encienden automáticamente a la temperatura programada.

Tabla 1.1. Datos relevantes del digestor anaeróbico en La Candelaria (Salta)

\begin{tabular}{|c|c|}
\hline \multicolumn{2}{|c|}{ Algunos parámetros importantes } \\
\hline Temperatura & $30^{\circ} \mathrm{C}$ \\
\hline Consumo energético & 15,92 kW/día* \\
\hline Volumen de biogás & 22-28 Nm³/día** \\
\hline Porcentaje de $\mathrm{CH}_{4}$ & $60 \%$ \\
\hline
\end{tabular}

Se presenta en la Tabla 1.1 algunos parámetros importantes como la temperatura de operación, el volumen y porcentaje de biogás y el requerimiento energético. Estos datos fueron proporcionados por la empresa constructora al municipio de La Candelaria en el manual para el usuario, al que se tuvo acceso durante el desarrollo de este trabajo.

Al momento de la visita al matadero (año 2014), la planta de biogás se encontraba inactiva desde hacía tiempo.

1.10.2. Sistema de captación y quemado del biogás producido en el vertedero San Javier de la Capital de la Provincia de Salta.

En el año 2012 comenzó a funcionar en la capital de la provincia de Salta un sistema de captación y quema del biogás generado del vertedero San Javier del municipio. Con el fin de minimizar las emisiones de metano a la atmosfera, el biogás capturado es quemado en la caldera del sistema (Secretaría de Prensa y Comunicación de la Provincia de Salta, 2013).

El sistema de captación del vertedero cuenta con una serie de tubos verticales enterrados, éstos poseen unas perforaciones que facilita el ingreso del gas hacia su interior y de allí a la red. En el extremo superior, por encima de la superficie, se encuentran las válvulas donde se toman las muestras del gas, Figura 1.8. Toda la red 
de captación se encuentra emplazada sobre el terreno donde se compactó y enterró la basura.

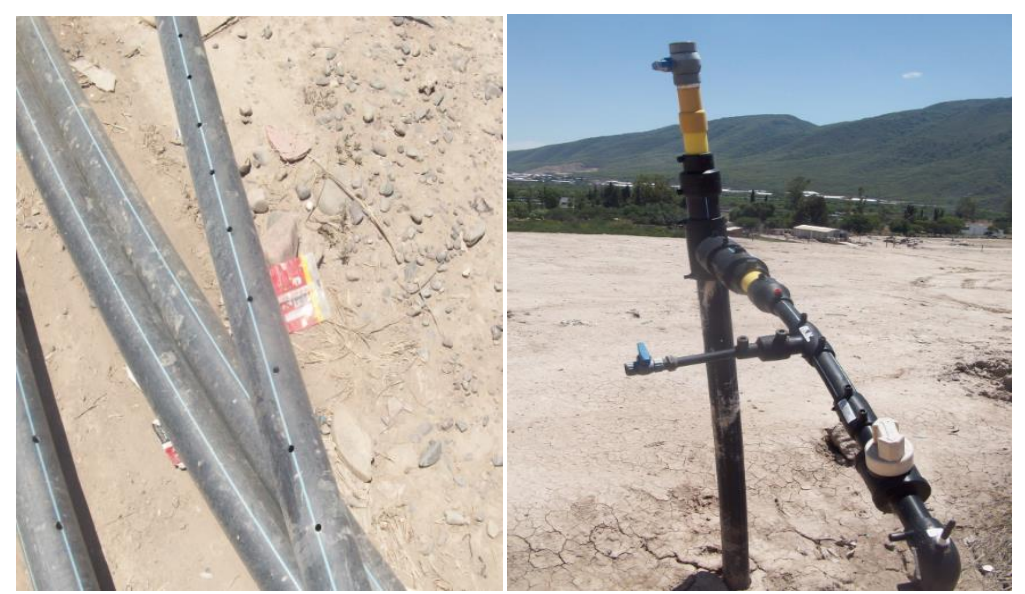

Figura 1.8. Vistas de los tubos perforados y válvula de muestreo. Fuente: imagen propia (2014).

Para eliminar los gases nocivos el biogás ingresa a un contenedor con viruta de hierro que elimina el $\mathrm{H}_{2} \mathrm{~S}$ presente en pequeñas cantidades, pero que representa un riesgo para el metal que entre en contacto con este gas, Figura 1.9. El sistema de control y monitoreo consta de un sensor portátil y un programa computacional de seguimiento para el biogás que ingresa al quemador. Al momento de medir el porcentaje de metano tanto el sensor como el programa de control dieron un valor de $45 \%$, en general la proporción ronda en torno a este valor.

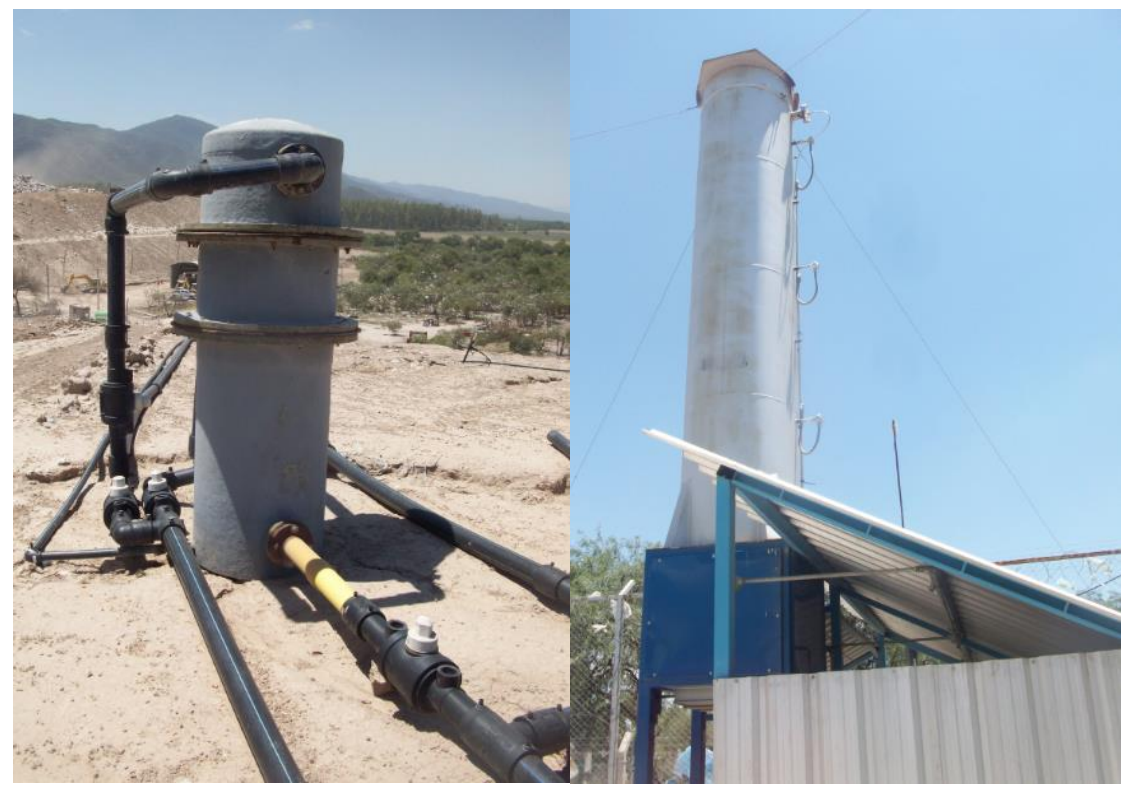

Figura 1.9. Vista del contenedor con viruta de hierro (izquierda) y quemador (derecha). Fuente: imagen propia (2014). 


\subsection{Suministro de gas de red en la Provincia de Salta.}

En cuanto a la cobertura del suministro de gas y comparando con las demás provincias del país, Salta con 1,3 millones de habitantes (DGCe,2018) se encuentra por debajo del promedio nacional siendo este del 64\% (DGCe,2018). De la cantidad de viviendas aproximadamente sólo el 40 a 50\% posee gas de red, Figura 1.10.

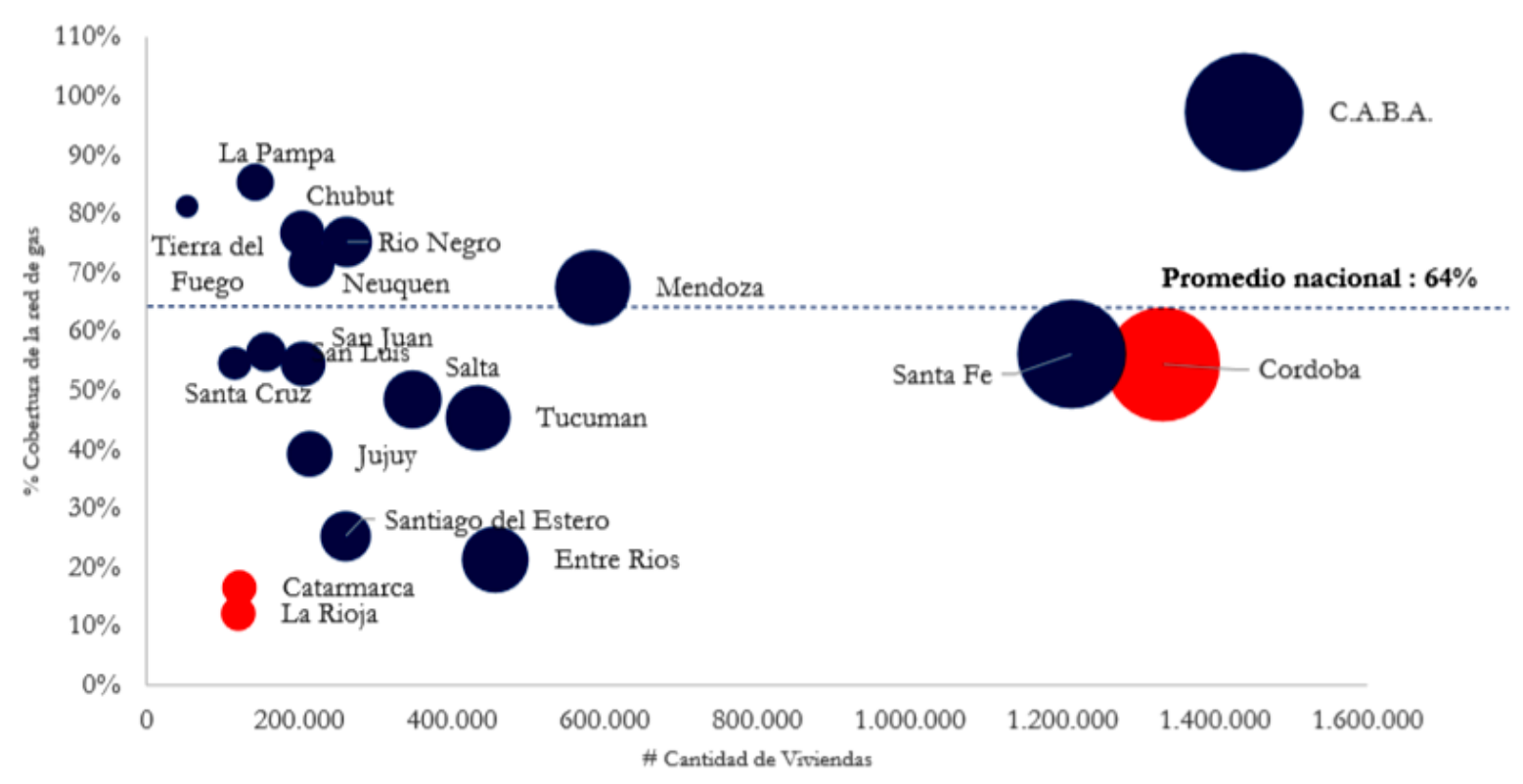

Figura 1.10. Cobertura nacional de la red de gas en \% y cantidad de viviendas por provincia.

Fuente: DGCe (2018).

En la provincia de Salta la distribución de gas natural domiciliario está a cargo de la empresa GASNOR responsable también de la distribución en las provincias de Tucumán, Santiago del Estero y Jujuy. Cuenta con 543.345 usuarios, 11.797 km de gasoductos y 111 localidades con servicio en toda la región.

La información suministrada por ENARGAS (Ente Nacional Regulador del Gas,2018) da cuenta de una red troncal principal de transporte de gas en dirección norte sur, tal como se observa en color celeste en la Figura 1.11.

Esta atraviesa la Provincia de Salta en su extremo norte en el Departamento de San Ramón de la Nueva Orán y en el sur en el Departamento de la Candelaria. Desde la red troncal se abastece mediante redes de distribución a las ciudades más pobladas con mayor intensidad en el norte y centro de la provincia. Se aprecia una escasa distribución del gas hacia el este y oeste. 


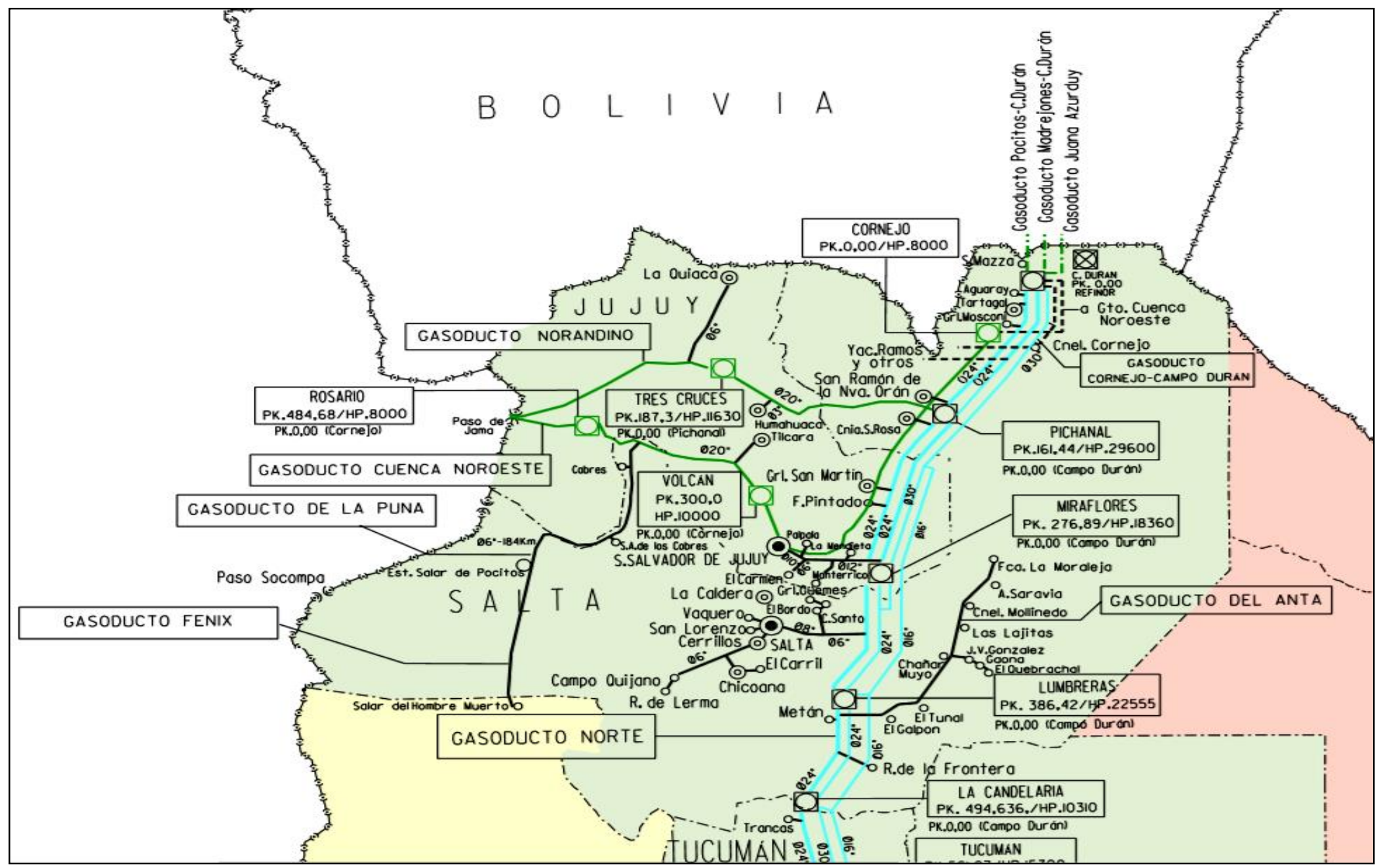

Figura 1.11. Red de gas y localidades abastecidas con gas natural Fuente: ENARGAS (2018) . 


\section{CAPITULO 2}

\section{LA DigESTIÓN ANAERóBiCA.}




\subsection{Introducción.}

La digestión anaeróbica involucra diversos factores que deben ser estudiados. Comprender como intervienen en el control del proceso es necesario a fin de lograr una práctica adecuada de los ensayos. De acuerdo al tipo de material a digerir se verá la necesidad de atender a uno u otro parámetro de control u operación.

En ese capítulo se presenta una breve reseña histórica de la digestión anaeróbica, los subproductos del proceso sus etapas o fases del proceso y los parámetros operacionales y de control.

\subsection{La digestión anaeróbica.}

La digestión anaeróbica es un proceso natural complejo en el cual, en ausencia de oxígeno, la materia orgánica de un sustrato es degradada. Un conjunto de microorganismos interviene produciendo biogás y un efluente estabilizado (lodo). Tiene lugar en distintos ecosistemas de la naturaleza, como pantanos, lagunas, etc. El hombre ha sabido aprovechar este fenómeno para su propio beneficio; sometiendo la materia orgánica a una fermentación anaeróbica en contenedores herméticamente cerrados llamados digestores o reactores anaeróbicos.

\subsection{Primeros pasos de la digestión anaeróbica.}

Se presenta en la Tabla 2.1 una breve reseña histórica hasta principios del siglo XX, con los sucesos más importantes que impulsaron el estudio de la digestión anaeróbica. Alessadro Volta fue quien primero identificó al gas de los pantanos en 1776 mientras que Propoff en 1875 observó por primera vez la formación de biogás en condiciones anaeróbicas. Ya en 1859 se construyó la primera planta de biogás en la India. La aplicación del biogás como fuente de energía surge con mayor énfasis en la segunda mitad del siglo XIX. La causa principal fue la escasez de los combustibles fósiles y el aumento de los precios de estos.

Tiempo después de la construcción del primer digestor, en la década del 60 se impulsó la tecnología del biogás a partir del estiércol animal en la India, como aprovechamiento energético y recuperación del material fertilizante. En este país se desarrolló lo que se conoce como digestor anaeróbico tipo hindú, construido en cemento y ladrillo con una cámara central de fermentación divida por un tabique. Dos cámaras sirven para la entrada y salida del material a fermentar. La cúpula es móvil, donde se acumula el biogás; lo que produce la elevación de la cúpula, que luego desciende cuando entrega el biogás a presión constante. El gasómetro de metal se instala en la parte superior del digestor, Figura 2.1. 
Tabla 2.1. Reseña histórica sobre la digestión anaeróbica.

\begin{tabular}{|c|c|}
\hline Tiempo & Acontecimiento \\
\hline 1776 & Alessandro Volta investigó e identificó el gas de los pantanos. \\
\hline 1804 & Dalton estableció la composición química del metano. \\
\hline 1868 & $\begin{array}{l}\text { Beauchamp estableció la presencia de microorganismos en los } \\
\text { procesos de producción de metano. }\end{array}$ \\
\hline 1870 & $\begin{array}{l}\text { Pasteur descubrió que mediante la temperatura se podía } \\
\text { favorecer el desarrollo de microorganismos. }\end{array}$ \\
\hline 1875 & $\begin{array}{l}\text { Propoff, descubrió que la formación de biogás sólo se producía en } \\
\text { condiciones anaerobias. }\end{array}$ \\
\hline 1859 & $\begin{array}{l}\text { Una de las primeras plantas de biogás surge en la ciudad de } \\
\text { Bombay en la India (Verma, 2002). }\end{array}$ \\
\hline 1884 & $\begin{array}{l}\text { Pasteur investigó sobre la producción de biogás a partir de } \\
\text { residuos animales, proponiendo la utilización del biogás para la } \\
\text { iluminación de las calles (Muñoz Valero et al., 1987). }\end{array}$ \\
\hline 1922 & $\begin{array}{l}\text { En Alemania, país pionero en el desarrollo de energías renovables, } \\
\text { se comienza a producir biogás a escalas industriales incorporando } \\
\text { al tratamiento de aguas residuales el estiércol que se producía en } \\
\text { los establecimientos ganaderos. }\end{array}$ \\
\hline
\end{tabular}

Fuente: Elaboración propia.

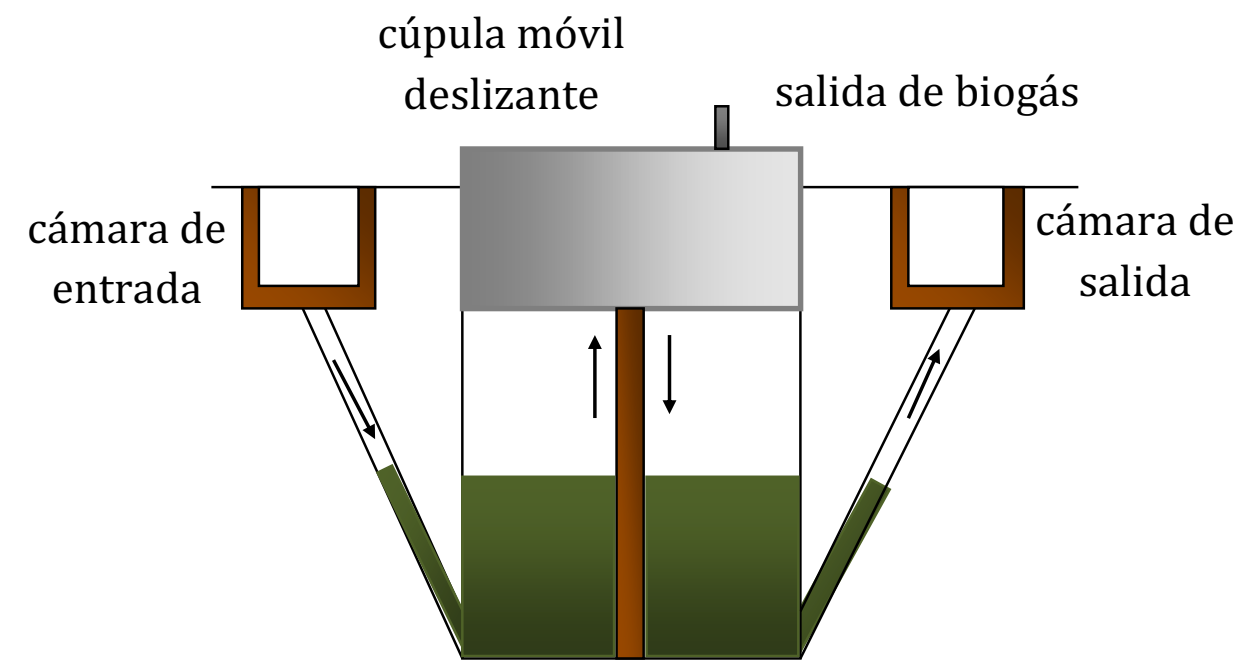

Figura 2.1. Digestor tipo hindú.

Fuente: imagen propia. 
En China en la década del 70 se promueve la construcción de digestores anaeróbicos mediante programas gubernamentales (Campos 2001). El desarrollado en este país, conocido como digestor chino, se construye con ladrillo y cemento con un cuerpo cilíndrico y cámaras de carga y descarga; todo completamente enterrado. La cúpula donde se acumula el biogás forma parte del cuerpo central del mismo y es fija. Mediante un caño en la parte superior se lo extrae del interior. En la cámara de carga se prepara el material que ingresa al cuerpo de fermentación. En la de descarga se recoge el material digerido, Figura 2.2.

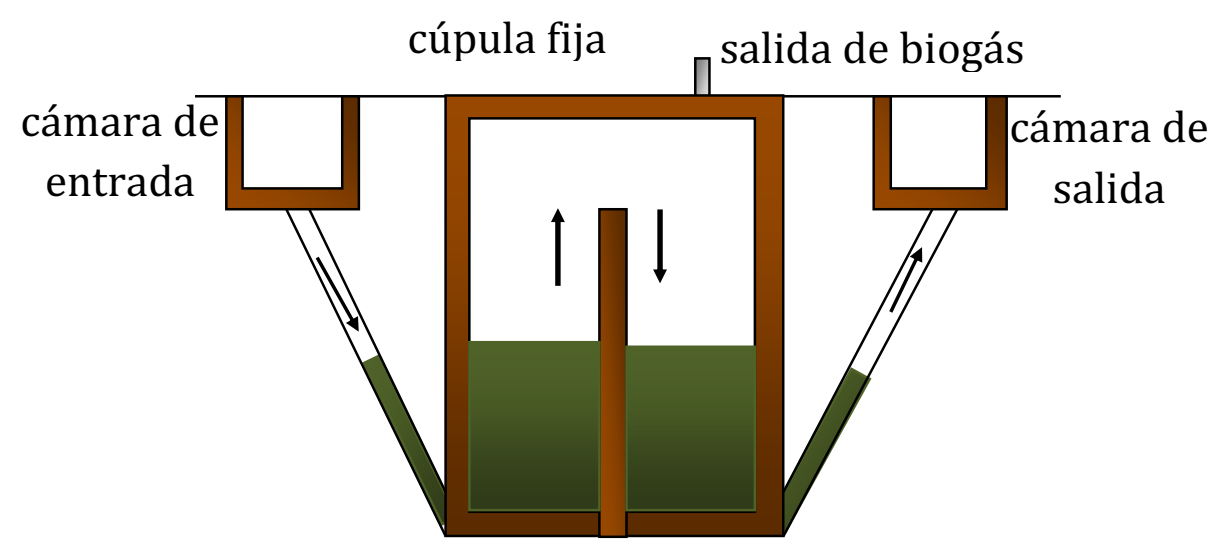

Figura 2.2. Digestor tipo chino.

Fuente: imagen propia.

En Alemania en el transcurso de la Segunda Guerra Mundial se intensificó el desarrollo de un gran número de instalaciones de digestión anaeróbica, extendiéndose luego la tecnología a toda Europa occidental.

\subsection{El Biogás.}

Este gas está compuesto principalmente por metano $\left(\mathrm{CH}_{4}\right)$ entre un 50 y $80 \%$. Contiene además dióxido de carbono $\left(\mathrm{CO}_{2}\right)$ y pequeñas cantidades de sulfuro de hidrogeno $\left(\mathrm{H}_{2} \mathrm{~S}\right)$, hidrogeno gaseoso $\left(\mathrm{H}_{2}\right)$, amoniaco $\left(\mathrm{NH}_{3}\right)$ y pequeñas cantidades de oxígeno $\left(\mathrm{O}_{2}\right)$ y compuestos orgánicos. La composición varía según el material que se esté digiriendo y de la operación del digestor anaeróbico. En la Tabla 2.2 se presenta la composición del biogás (Coombs, 1990). 
Tabla 2.2. Componentes del biogás en función del substrato utilizado.

\begin{tabular}{|lllll|}
\hline Componente & $\begin{array}{l}\text { Residuos } \\
\text { agrícolas }\end{array}$ & $\begin{array}{l}\text { Lodos de } \\
\text { depuradora }\end{array}$ & $\begin{array}{l}\text { Residuos } \\
\text { industriales }\end{array}$ & $\begin{array}{l}\text { Gas de } \\
\text { vertedero }\end{array}$ \\
\hline Metano & $50-80 \%$ & $50-80 \%$ & $50-70 \%$ & $45-65 \%$ \\
Dióxido de carbono & $30-50 \%$ & $20-50 \%$ & $30-50 \%$ & $34-55 \%$ \\
\hline Agua & Saturado & Saturado & Saturado & Saturado \\
Hidrógeno & $0-2 \%$ & $0-5 \%$ & $0-2 \%$ & $0-1 \%$ \\
Sulfuro de hidrógeno & $100-700$ & $0-1 \%$ & $0-8 \%$ & $0.5-100 \mathrm{ppm}$ \\
& ppm & & & Trazas \\
Amoníaco & Trazas & Trazas & Trazas & Trazas \\
Monóxido de carbono & $0-1 \%$ & $0-1 \%$ & $0-1 \%$ & $0-20 \%$ \\
\hline Nitrógeno & $0-1 \%$ & $0-3 \%$ & $0-1 \%$ & $0-5 \%$ \\
\hline Oxígeno & $0-1 \%$ & $0-1 \%$ & $0-1 \%$ & \\
\hline
\end{tabular}

Fuente: Elaboración propia.

El poder calorífico del biogás dependerá de la cantidad de metano que contenga, así por ejemplo el poder calorífico inferior (PCI) es de 35,8 MJ/m³ (Alzate, 2013).

En el capítulo 4 se estudiarán los residuos agrícolas tanto en ensayos de laboratorio como de campo.

\subsubsection{Almacenamiento, usos y tratamiento.}

En general, los digestores no poseen una tasa de producción continua de biogás. Así, con la aplicación de un gasómetro para su almacenamiento se logra salvar esta situación acumulando cierta cantidad.

Los gasómetros son contenedores que se construyen en diferentes materiales dependiendo de la presión interior que se alcance. En general, se utilizan materiales flexibles como lonas plásticas de alta densidad. En estos casos el biogás que abandona el digestor se acumula directamente en el gasómetro flexible. Para extraer el gas combustible se necesita de un extractor que le dé impulso hacia fuera del gasómetro dado la baja presión a la que se encuentra. En algunos casos se ejerce presión sobre el gasómetro inflable con un peso puesto sobre éste. Para el almacenamiento a altas presiones, con un mínimo de 8 bares, se utilizan los tanques convencionales como para cualquier gas.

En algunos procesos donde se utilice el biogás, deben eliminarse ciertos componentes que pueden resultar perjudiciales como el vapor de agua, el sulfuro de hidrógeno, el dióxido de carbono u otros componentes minoritarios. Los sistemas de purificación comprenden técnicas químicas, físicas y biológicas. En la Figura 2.1 se presenta un esquema de las necesidades de tratamiento según el tipo de aplicación. 


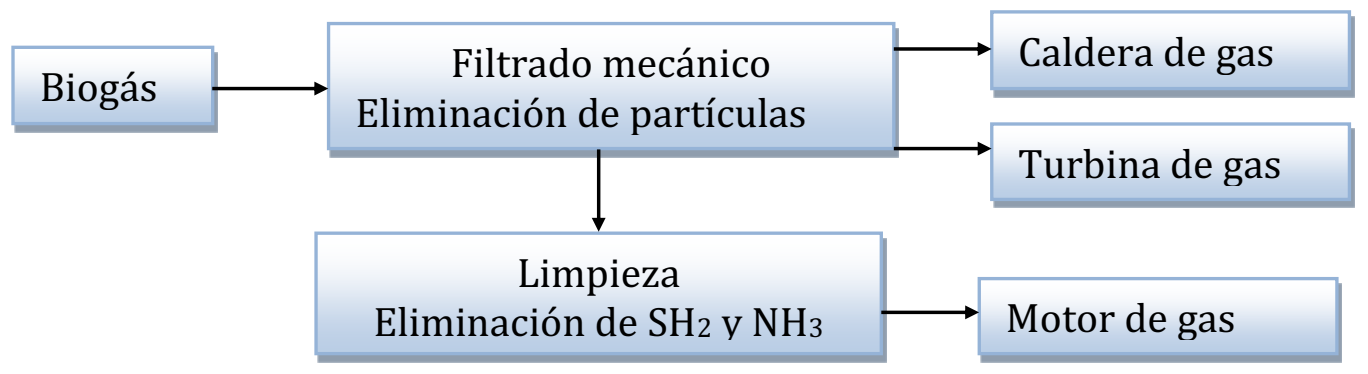

Figura 2.3. Esquema con los distintos tratamientos.

Fuente: Elaboración propia.

Los diversos usos se presentan en el esquema de la Figura 2.4. La utilización del biogás puede ser directa, es decir cuando éste se quema para aprovechar la energía térmica que libera. La utilización del biogás es indirecta cuando se procede a la conversión a energía eléctrica. Sin embargo, se debe realizar un estudio sobre los costos de inversión y el tiempo de retorno, pues los gastos iniciales serán más elevados. La energía térmica liberada en dicha conversión, se puede utilizar enviándola nuevamente al digestor para su calefacción. En las grandes plantas de producción se aplica este sistema.

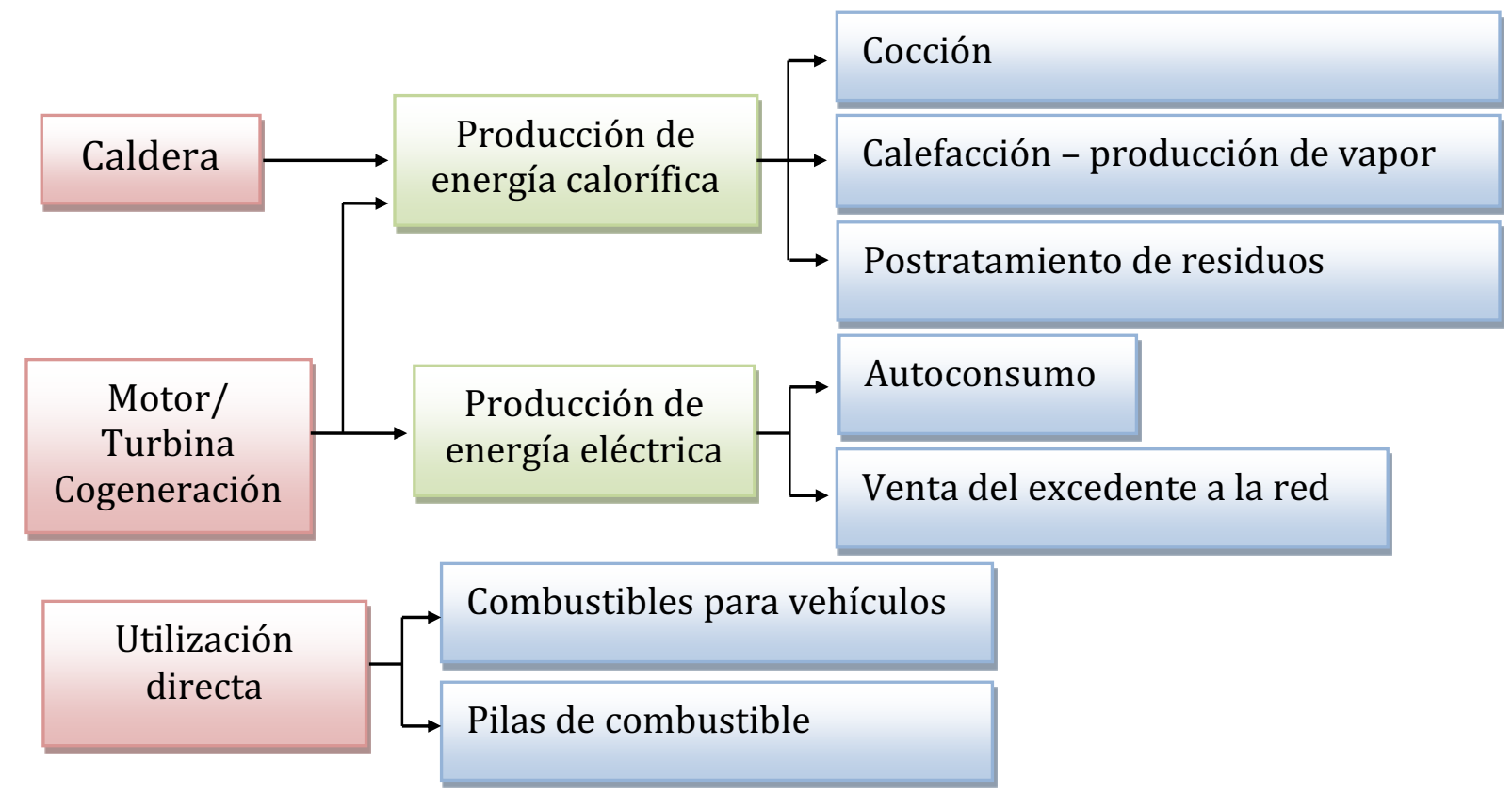

Figura 2.4. Esquema de la utilización del biogás.

Fuente: Elaboración propia. 


\subsection{Bioquímica del proceso de digestión.}

La digestión anaeróbica implica un conjunto de reacciones, algunas actuando simultáneamente e íntimamente relacionadas. Los estudios dividen al proceso en cuatro fases o etapas: la hidrólisis, la acetogénica, la acidogénica y la metanogénica. En cada etapa actúa un grupo de bacterias específicas. En la Figura 2.5 se presenta un esquema con las fases de la digestión anaeróbica.

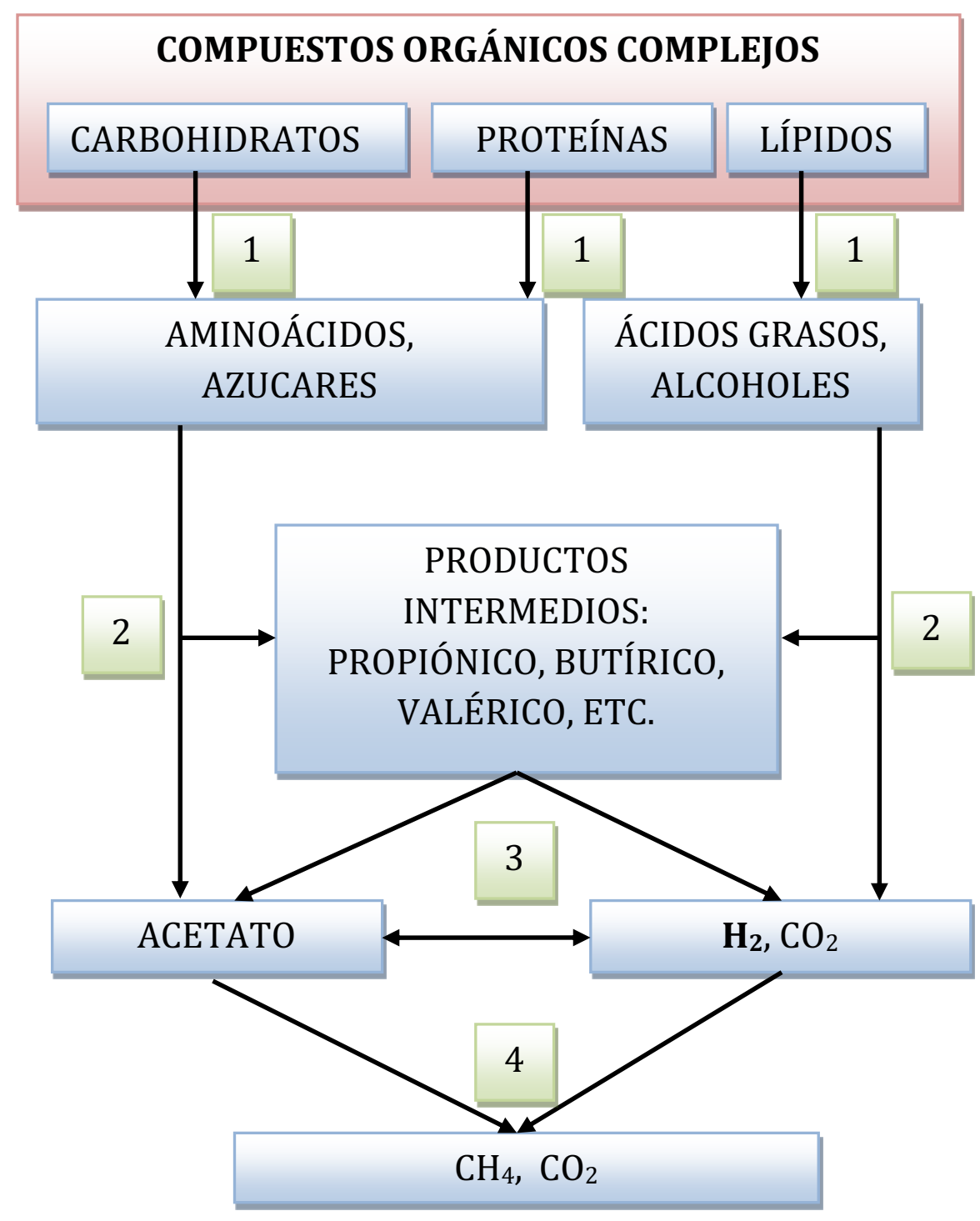

Figura 2.5. Etapas del proceso de digestión anaeróbica:

1) hidrólisis, 2) acetogénesis, 3) acidogénesis, 4) metanogénesis.

Fuente: Elaboración propia.

\subsubsection{Etapa de hidrólisis.}

La materia orgánica compleja para ser utilizada directamente por los microorganismos debe hidrolizarse en compuestos solubles, que puedan atravesar la 
membrana celular. Los sustratos compuestos por los tres tipos básicos de macromoléculas: carbohidratos, lípidos y proteínas, son hidrolizadas por diferentes grupos enzimáticos. El grado de hidrólisis y la velocidad del proceso depende de muchos factores, entre otros del $\mathrm{pH}$, de la temperatura, de la concentración de biomasa hidrolítica, del tipo de materia orgánica particulada (Pavlostathis y GiraldoGómez, 1991) y del tamaño de las partículas (Hills y Nakano, 1984).

La tasa de hidrólisis, en general, aumenta con la temperatura (Pavlostathis y GiraldoGómez, 1991; Siegrist et al., 1993; Veeken y Hamelers, 1999), independientemente del compuesto de que se trate.

Hills y Nakano (1984) demostraron que la tasa de hidrólisis depende también, del tamaño de las partículas, debido fundamentalmente a la disponibilidad de superficie para la adsorción de las enzimas hidrolíticas.

La hidrólisis puede verse afectada por la presencia de algún compuesto que sea tóxico o inhibidor de la población bacteriana responsable de la producción de enzimas extracelulares.

Se produce la hidrólisis de partículas y moléculas complejas, mediante reacciones de óxido- reducción. Los compuestos solubles resultantes como oligosacáridos, azucares, alcoholes, aminoácidos y ácidos grasos constituyen la principal fuente de energía para las células de los microorganismos (Fernández y Ollay, 1997). La actividad hidrolítica es de gran importancia en los residuos con gran cantidad de sólidos y puede convertirse en una etapa limitante en el proceso, ya que los microorganismos asimilan con mayor facilidad todo el material que ya ha sido hidrolizado (Metcalf \& Eddy, 1995).

Cuanto mayor es la velocidad de solubilización de la materia orgánica, mayor es la velocidad de producción de biogás (McCarty, 1981).

\subsubsection{Etapa acetogénica.}

Mientras que algunos productos de la fermentación pueden ser metabolizados directamente por los organismos metanogénicos (hidrógeno $\mathrm{H}_{2}$ y acetato), otros (valeriato, butirato, propionato, algunos aminoácidos, etc.) necesitan ser transformados en productos más sencillos: acetato e hidrógeno, a través de las bacterias acetogénicas.

El principal inhibidor de la acetogénesis, cuya acumulación provoca la rápida acumulación de los substratos, es el hidrógeno molecular (Ahring y Westermann, 1987a; Fukuzaki et al., 1990). Las bacterias acetogénicas son del tipo facultativas que 
viven en estrecha colaboración con las bacterias metanogénicas. Las bacterias acetogénicas no tienen otras posibilidades metabólicas, dependen necesariamente de reacciones de transferencia de hidrógeno entre distintas especies de microorganismos. Así, la principal función de estos microorganismos en el proceso de digestión anaerobia es la de donantes de hidrógeno, dióxido de carbono y acetato a los microorganismos metanogénicos.

Por medio de las bacterias acetogénicas algunos productos son transformados a elementos más sencillos para luego ser metabolizados directamente por los organismos metanogénicos, en la Tabla 2.3 se presentan algunas de las reacciones acetogénicas (Stams, 1994), donde aparecen los elementos tales como propionato $\left(\mathrm{C}_{2} \mathrm{H}_{5} \mathrm{COO}^{-}\right)$, anión acetato $\left(\mathrm{C}_{2} \mathrm{H}_{3} \mathrm{O}_{2}^{-}\right)$y butirato $\left(\mathrm{C}_{4} \mathrm{H}_{7} \mathrm{O}_{2}^{-}\right)$.

Tabla 2.3 Reacciones acetogénicas

\begin{tabular}{rl|}
\hline $\mathrm{C}_{2} \mathrm{H}_{5} \mathrm{COO}^{-}+3 \mathrm{H}_{2} \mathrm{O}$ & $\rightarrow \mathrm{C}_{2} \mathrm{H}_{3} \mathrm{O}_{2}^{-}+\mathrm{HCO}_{3}^{-}+\mathrm{H}^{+}+3 \mathrm{H}_{2}$ \\
\hline $\mathrm{C}_{2} \mathrm{H}_{5} \mathrm{COO}^{-}+2 \mathrm{HCO}_{3}^{-}$ & $\rightarrow \mathrm{C}_{2} \mathrm{H}_{3} \mathrm{O}_{2}^{-}+\mathrm{H}^{+}+3 \mathrm{HCOO}^{-}$ \\
$\mathrm{C}_{4} \mathrm{H}_{7} \mathrm{O}_{2}^{-}+2 \mathrm{H}_{2} \mathrm{O}$ & $\rightarrow 2 \mathrm{C}_{2} \mathrm{H}_{3} \mathrm{O}_{2}^{-}+\mathrm{H}^{+}+2 \mathrm{H}_{2}$ \\
\hline
\end{tabular}

Donde

$\begin{array}{clcl}\mathrm{H}_{2} & \text { Hidrógeno } & \mathrm{HCO}_{3}^{-} & \text {Ion carbonato } \\ \mathrm{H}^{+} & \text {Ion hidrógeno } & \mathrm{C}_{2} \mathrm{H}_{5} \mathrm{COO}^{-} & \text {Ion propionato } \\ \mathrm{H}_{2} \mathrm{O} & \text { Agua } & \mathrm{C}_{2} \mathrm{H}_{3} \mathrm{O}_{2}^{-} & \text {Ion acetato } \\ \mathrm{HCOO}^{-} & \text {Ion formiato } & \mathrm{C}_{4} \mathrm{H}_{7} \mathrm{O}_{2}^{-} & \text {Ion butirato }\end{array}$

Fuente: Elaboración propia.

\subsubsection{Etapa acidogénica.}

Las moléculas orgánicas solubles son fermentadas por varios organismos fermentativos formando compuestos que pueden ser utilizados directamente por las bacterias metanogénicas (ácido acético, ácido fórmico, $\mathrm{H}_{2}$ ) y compuestos orgánicos más reducidos (láctico, etanol, propiónico, butírico) que tienen que ser oxidados por bacterias acetogénicas a substratos que puedan utilizar las metanogénicas (Stams, 1994).

La actividad de algunas bacterias fermentativas y acetogénicas depende de la concentración de $\mathrm{H}_{2}$, siendo posible sólo a valores muy bajos de presión parcial de $\mathrm{H}_{2}$. La eliminación continua de $\mathrm{H}_{2}$ mediante oxidación por $\mathrm{CO}_{2}$ (bacterias metanogénicas hidrogenotróficas) estimula la acción de las bacterias fermentativas (Boone y Xun, 1987). 
Los compuestos solubles, básicamente oligosacáridos y azúcares, alcoholes, aminoácidos y ácidos grasos, son fermentados por microorganismos acidogénicos que producen principalmente compuestos de peso molecular intermedio, tales como ácidos grasos volátiles (acetato, propionato, butirato, etc.), alcoholes, y otros subproductos importantes para etapas posteriores (amoníaco, $\mathrm{H}_{2}, \mathrm{CO}_{2}$, etc.). Las bacterias formadoras de ácidos o acidogénicas son bacterias de crecimiento rápido, en comparación con los otros grupos implicados en la digestión anaerobia (Carneiro Forster, 2005) y son del tipo anaerobias obligadas o facultativas. En la Tabla 2.4 se presentan algunas de las reacciones de esta etapa, en donde se aprecia la glucosa $\left(\mathrm{C}_{6} \mathrm{H}_{12} \mathrm{O}_{6}\right)$ como reactivo.

Tabla 2.4 Reacciones acidogénicas

\begin{tabular}{|c|}
\hline $\mathrm{C}_{6} \mathrm{H}_{12} \mathrm{O}_{6}+2 \mathrm{H}_{2} \mathrm{O} \rightarrow 2 \mathrm{CH}_{3} \mathrm{COOH}+2 \mathrm{CO}_{2}+4 \mathrm{H}_{2}$ \\
\hline $\mathrm{C}_{6} \mathrm{H}_{12} \mathrm{O}_{6}+2 \mathrm{H}_{2} \rightarrow 2 \mathrm{CH}_{3} \mathrm{CH}_{2} \mathrm{COO}^{-}+2 \mathrm{H}^{+}+2 \mathrm{H}_{2} \mathrm{O}$ \\
$\mathrm{C}_{6} \mathrm{H}_{12} \mathrm{O}_{6} \rightarrow \mathrm{CH}_{3} \mathrm{CH}_{2} \mathrm{CH}_{2} \mathrm{COOH}+2 \mathrm{CO}_{2}+2 \mathrm{H}_{2}$ \\
\hline
\end{tabular}

Donde

$\begin{aligned} \mathrm{H}_{2} & \text { Hidrógeno } & \mathrm{CH}_{3} \mathrm{COO}^{-} & \text {Anión acetato } \\ \mathrm{H}^{+} & \text {Ion hidrógeno } & \mathrm{CH}_{3} \mathrm{CH}_{2} \mathrm{COO}^{-} & \text {Anión propianato } \\ \mathrm{H}_{2} \mathrm{O} & \text { Agua } & \mathrm{CH}_{3} \mathrm{CH}_{2} \mathrm{CH}_{2} \mathrm{COOH}^{-} & \text {Ácido butírico } \\ \mathrm{CO}_{2} & \text { Dióxido de carbono } & \mathrm{C}_{6} \mathrm{H}_{12} \mathrm{O}_{6} & \text { Glucosa }\end{aligned}$

Fuente: Elaboración propia.

\subsubsection{Etapa metanogénica.}

Las arquebacterias o simplemente arqueas tienen rutas metabólicas tan peculiares que las hacen únicas y diferentes de las bacterias; por ello, forman su propio reino. Las metanogénicas se encuentran dentro de este dominio. Son las responsables de la formación del metano y de la eliminación de los productos en las etapas anteriores: substratos monocarbonados o con dos átomos de carbono unidos por un enlace covalente.

El metano se produce principalmente por la reducción del acetato, aproximadamente un $70 \%$ se forma por esta vía (Ferguson, T. y Mah, R., 1987). La metanogénesis acetoclástica está representada por la primera ecuación de la Tabla 2.5, también se presentan otras reacciones de esta etapa en las que aparece el compuesto formiato $\left(\mathrm{HCOO}^{-}\right)$. 
Tabla 2.5. Reacciones metanogénicas.

Donde

\begin{tabular}{|c|}
\hline $\mathrm{CH}_{3} \mathrm{COO}^{-}+\mathrm{H}_{2} \mathrm{O} \rightarrow \mathrm{CH}_{4}+\mathrm{HCO}_{3}^{-}$ \\
\hline $\mathrm{HCO}_{3}^{-}+4 \mathrm{H}_{2}+\mathrm{H}^{+} \rightarrow \mathrm{CH}_{4}+3 \mathrm{H}_{2} \mathrm{O}$ \\
\hline $4 \mathrm{CCOO}^{-}+\mathrm{H}_{2} \mathrm{O}+\mathrm{H}^{+} \rightarrow \mathrm{CH}_{4}+3 \mathrm{HCO}_{3}^{-}$ \\
\hline
\end{tabular}

$\begin{array}{clcl}\mathrm{H}_{2} & \text { Hidrógeno } & \mathrm{CH}_{3} \mathrm{COO}^{-} & \text {Anión acetato } \\ \mathrm{H}^{+} & \text {Ion hidrógeno } & \mathrm{HCO}_{3}^{-} & \text {Ion carbonato } \\ \mathrm{H}_{2} \mathrm{O} & \text { Agua } & \mathrm{HCOO}^{-} & \text {Ion formiato } \\ \mathrm{CH}_{4} & \text { Metano } & & \end{array}$

Fuente: Elaboración propia.

Como inhibidores del crecimiento de los microorganismos metanogénicos existen diversos compuestos. Entre los más conocidos están el nitrógeno amoniacal y los ácidos grasos volátiles. La tasa de crecimiento de los microorganismos metanogénicos es mucho menor a la de los demás. Por lo tanto, limitarán el proceso de degradación. Al ser la etapa más lenta, será la que determine la velocidad total del proceso (Metcalf \& Eddy, 1995).

\subsection{Parámetros de digestión.}

Un adecuado manejo de un digestor implica el control de algunos parámetros. De acuerdo al tipo de digestor y material a digerir se priorizarán algunos más que otros. En la Figura 2.6 se presenta un esquema con algunos de los parámetros divididos en de control y operacionales.

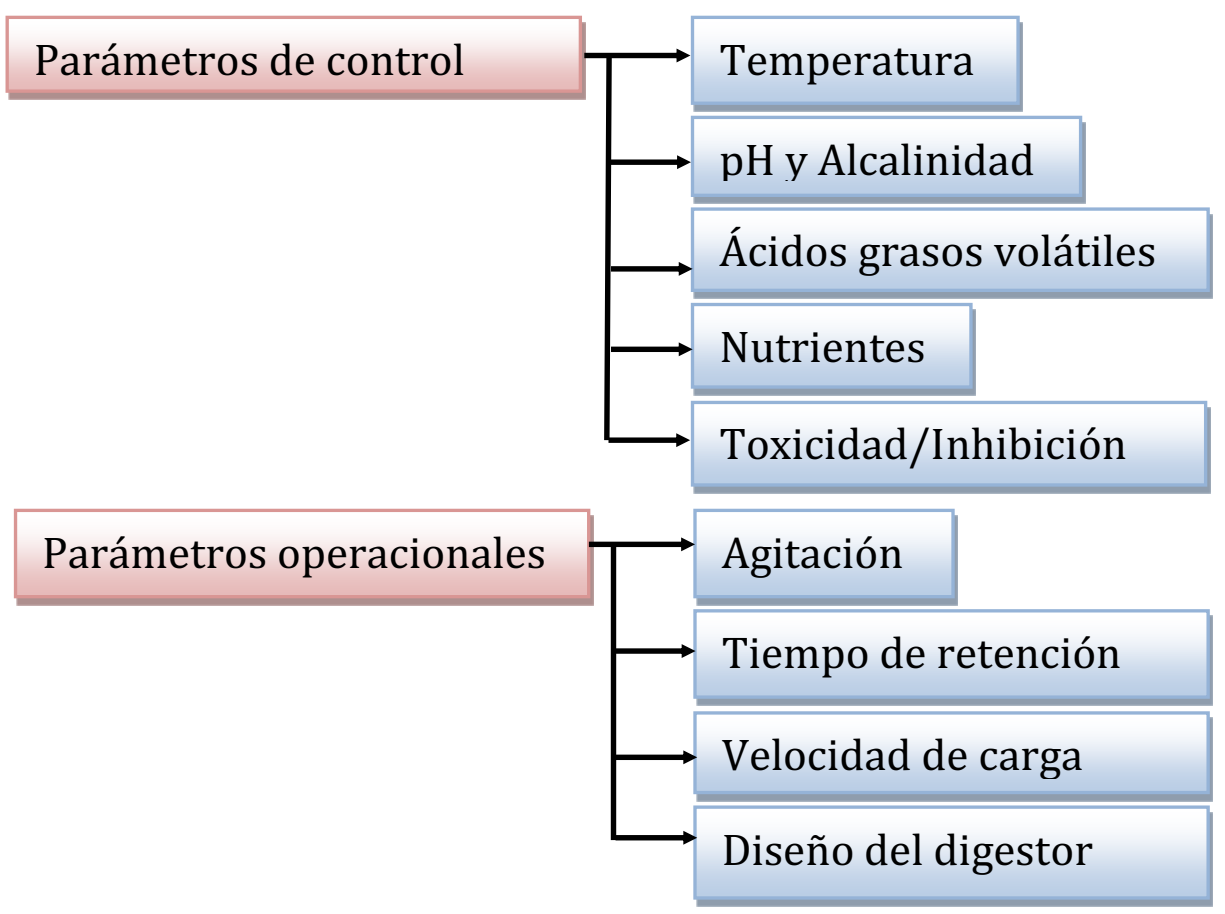

Figura 2.6. Parámetros operacionales y de control en el proceso de digestión anaeróbica. (Fuente: Elaboración propia). 


\subsubsection{Parámetros de control: Temperatura.}

La temperatura de operación del digestor, es considerada uno de los principales parámetros de control. Las variaciones bruscas pueden producir una desestabilización del proceso. Así, es necesario un sistema adecuado de agitación y un controlador de temperatura.

La digestión anaeróbica está fuertemente influenciada por la temperatura y se manifiesta en un amplio rango (Muñoz-Valero et al., 1987) divididos en: psicrofílico (por debajo de $25^{\circ} \mathrm{C}$ ), mesofílico (entre $25^{\circ}$ y $45^{\circ} \mathrm{C}$ ) y termofílico (entre $45^{\circ}$ y $65^{\circ} \mathrm{C}$ ).

Algunos digestores enterrados no requieren de mantenimiento de temperatura, mientras que otros funcionando en el intervalo mesofílico, requieren de un control para que ésta se mantenga constante.

Son diversos los aspectos positivos de mantener una temperatura elevada del digestor. La tasa de crecimiento aumenta a medida que aumenta la temperatura, así se espera que en el rango termofílico se obtenga mayor biogás en menor tiempo. La solubilidad de los gases como $\mathrm{NH}_{3}, \mathrm{H}_{2} \mathrm{~S}$ y $\mathrm{H}_{2}$ desciende al aumentar la temperatura, favoreciéndose la transferencia líquido-gas, y por tanto desapareciendo más rápidamente del medio acuoso. Por otro lado, los compuestos tóxicos también se hacen más solubles aumentado su toxicidad en el digestor. La viscosidad de la carga del digestor disminuye favoreciendo su agitación. A pesar de las variadas ventajas de la operación del digestor en el rango termofílico, el proceso puede disminuir su estabilidad (Fannin, 1987).

A bajas temperaturas la tasa de crecimiento de las bacterias es menor, siendo la producción de biogás más lenta; por esto se necesitan mayores volúmenes de digestión. A pesar de las desventajas, en la práctica se logra un mejor control del proceso.

Es importante mantener estable la temperatura de operación en el digestor, dado que las fluctuaciones impactan negativamente en el crecimiento bacteriano, especialmente en las metanogénicas (Parkin y Owen, 1986).

\subsubsection{Parámetros de control: $p H$ y Alcalinidad.}

Los cambios en el $p H$ alteran el normal funcionamiento del proceso de digestión, sin embargo, puede haber cierta oscilación (Clark y Speece, 1989). Cuando éste sube por encima de 8,3 o se encuentra por debajo de 6 puede interrumpirse la digestión (Lay et al., 1997). En este caso es conveniente corregir el problema lo más rápido posible. 
En general, todos los grupos bacterianos presentan una actividad óptima en torno a la neutralidad $(\mathrm{pH}=7)$. Un $\mathrm{pH}$ por debajo de 7 se considera ácido y por encima alcalino. Sólo el grupo de las bacterias acidogénicas tiene un pH óptimo entre 5,5 y 6,5. Para cultivos mixtos el pH óptimo se encuentra en el rango de 6,8 y 7,4, siendo ideal el pH neutro (Lay et al., 1997).

Un descenso en los valores de $\mathrm{pH}$ afecta directamente al grupo de las bacterias metanogénicas. Esto ocasiona una disminución en la cantidad de metano y por consiguiente se obtiene un biogás más pobre, por ello es conveniente mantener un pH en torno a la neutralidad.

Es conocido el estado de acidificación de un digestor con un pH bajo cuando no se lo opera correctamente. Esto ocurre cuando existe una sobrecarga en el digestor produciendo la acumulación de ácidos grasos.

La alcalinidad del medio es la capacidad de una solución para neutralizar un ácido (medida en mg $\mathrm{CaCO}_{3} / \mathrm{lt}$ ). Esta influye en el comportamiento del $\mathrm{pH}$, que bajará rápidamente si la alcalinidad es baja. Por ejemplo, en el estiércol vacuno, la alcalinidad es alta (alrededor de los $800 \mathrm{mg} \mathrm{CaCO} / \mathrm{lt}$ ). Por esta razón, el pH se mantiene en valores aceptables. Aun así, éste no es considerado un buen indicador del estado del digestor (Iza, 1995). Existen otras variables que actúan mejor en tal sentido, como los ácidos grasos volátiles (Hill et al., 1987; Ahring et al., 1995).

\subsubsection{Parámetros de control: Ácidos grasos volátiles.}

Los ácidos grasos volátiles (AGV) o de cadena corta, como el propiónico, butírico, valérico, etc. se generan de la hidrólisis de los compuestos más complejos. Surgen en la primera etapa de la digestión. Es muy importante conocer su evolución, ya que señala una rápida respuesta a las variaciones en el sistema, por ejemplo, en el caso de sobrecargas orgánicas (Ahring et al., 1995). El aumento de su concentración está relacionado con la disminución en la producción de biogás (Hill et al., 1987).

Cuando las bacterias metanogénicas se inhiben por diversos motivos tales como toxicidad, variación de las condiciones ambientales o limitación de los nutrientes, puede alterarse el equilibrio entre éstas y las acidogénicas; pudiendo acumularse acetato e hidrógeno. Una presión parcial excesiva de hidrógeno, inhibe las bacterias que degradan el ácido propiónico, lográndose una acumulación y una elevación de los AGV.

\subsubsection{Parámetros de control: Nutrientes.}

En general, todos los materiales orgánicos son capaces de generar biogás bajo condiciones anaeróbicas. Sin embargo, la cantidad y calidad de éste depende de la 
composición y contenidos de nutrientes. Si está por debajo de la óptima, el proceso es susceptible de inhibiciones. Los principales nutrientes del sistema anaerobio son nitrógeno, sulfuro, fósforo, hierro, cobalto, níquel, molibdeno, selenio, riboflavina y vitamina B12 (Speece, 1987a).

Para las bacterias metanogénicas el carbono y el nitrógeno se consideran fuentes principales de alimentación. Se utiliza el carbono como fuente de energía y el nitrógeno para la formación de células nuevas. La relación C/N (carbono/nitrógeno) óptima debe oscilar entre 15-30:1, y la necesidad de fósforo expresada como la relación C/P (carbono/fosforo) varía entre 75-113:1 (Speece, 1987a).

Con un contenido alto en carbono y bajo en nitrógeno, la digestión ocurre lentamente, pero con una producción prolongada de biogás, dado que se cuenta con abundante energía. Cuando la relación $\mathrm{C} / \mathrm{N}$ es menor a $15: 1$ se inhibe la actividad bacteriana debido a la formación excesiva de amonio, el cual se torna tóxico. Cuando no se tiene un residuo con una relación $\mathrm{C} / \mathrm{N}$ inicial apropiada, es necesario realizar mezclas de las materias en las proporciones adecuadas para que la relación $\mathrm{C} / \mathrm{N}$ se encuentre en el rango apropiado.

\subsubsection{Parámetros de control: Toxicidad e Inhibición.}

La toxicidad se debe a múltiples factores tales como (Kugelman y Chin, 1971):

$\checkmark$ Concentración

$\checkmark$ Antagonismos

$\checkmark$ Sinergismos

$\checkmark$ Formación de complejos

$\checkmark$ Aclimatación

Un componente puede resultar tóxico dependiendo de su concentración. Sin embargo, no es el único factor que afecta el equilibrio en la digestión. El antagonismo es la reducción de la toxicidad de una sustancia en presencia de otra mientras que el sinergismo es el aumento del efecto tóxico causado por la presencia de otra sustancia. Ambos factores afectan la toxicidad del medio. Cuando la población bacteriana logra adaptarse, con sus propios recursos, a los cambios en las concentraciones de algunas sustancias se habla de aclimatación.

El factor tóxico más común es la concentración y la formación de complejos. En el primer caso, la presencia de metales pesados o detergentes, frecuentes en la limpieza de corrales, pueden afectar notablemente el proceso natural de la digestión. En cuanto a la formación de complejos, la acumulación de ácidos grasos volátiles, producto de la fase acidogénica, puede interrumpir la actividad de las bacterias metanogénicas y acidificar al digestor. 
Son diversas las sustancias que pueden ser tóxicas, en bajas concentraciones la mayoría no presenta problemas. Cuando superan cierto límite se vuelven insanas para la digestión. A continuación, se listan algunas sustancias que pueden ser tóxicas:

$\checkmark$ Desinfectantes y antibióticos

$\checkmark$ Cationes y metales pesados

$\checkmark$ Ácidos grasos de cadena larga

$\checkmark$ Compuestos azufrados

$\checkmark$ Hidrógeno

$\checkmark$ Ácidos grasos volátiles

$\checkmark$ Compuestos nitrogenados

\subsubsection{Parámetros operacionales: Agitación.}

La agitación ofrece diversas ventajas, tales como:

$\checkmark$ Evitar la formación de espumas y corteza en la superficie

$\checkmark$ Favorecer la salida de los gases

$\checkmark$ Poner en contacto el material fresco con la población bacteriana

$\checkmark$ Prevenir la sedimentación

$\checkmark$ Mantener una temperatura uniforme

$\checkmark$ Eliminar la estratificación térmica

Existen diversos mecanismos para realizar la agitación de un digestor como mecánica, hidráulica o neumática. La velocidad de agitación es un parámetro que puede influir en el desarrollo del proceso, siendo necesario un equilibrio entre la buena homogeneización y la correcta formación de agregados bacterianos (Fannin, 1987). Una velocidad de agitación alta, por encima de $700 \mathrm{rpm}$, puede disminuir ligeramente la producción de biogás (Stafford, 1982).

\subsubsection{Parámetros operacionales: Velocidad de carga y tiempo de retención hidráulica}

El tiempo que la carga permanece en el interior del digestor se denomina tiempo de retención hidráulica (TRH). Algunos autores hacen la distinción entre éste y el tiempo de retención de sólidos (TRS). Este último es el tiempo que permanece la parte orgánica como sólidos dentro del digestor mientras que el TRH es el tiempo que permanece la fracción líquida. Cuando ambos, tanto sólidos como líquidos abandonan el digestor los tiempos TRH y TRS son iguales, tal como ocurre en digestores de mezcla completa. Si el digestor cuenta con algún mecanismo para retener los sólidos entonces vale la distinción de los tiempos de retención.

Es claro definir el tiempo de permanencia de la carga cuando el digestor trabaja de forma discontinua pues el material que ingresa se mantiene por un tiempo definido 
para luego descargarse completamente. Cuando el digestor tiene un funcionamiento continuo, el material fresco que se introduce se mezcla con el que está adentro del digestor y de esta manera no se respeta el tiempo de retención. Un tiempo de retención prolongado tiene la ventaja de aminorar y hasta eliminar los efectos inhibitorios (Parkin y Owen, 1986).

En general, la velocidad de carga y el tiempo de retención dependen del tipo de residuo y del digestor. Para un substrato en particular cuando aumenta la temperatura de digestión se reducen los tiempos de retención. Al disminuir la retención dentro del digestor, la velocidad de carga aumenta. Es decir, se puede digerir más material en menor tiempo.

Cuando la velocidad de carga supera el ritmo al cual el digestor puede procesar el substrato se genera una "sobrecarga" que puede derivar en una alta producción de ácidos grasos volátiles (Ahring et al., 1995).

El tiempo de retención y la velocidad de carga definen el volumen del digestor. Con un alto TRH se necesitan grandes volúmenes de digestión, mientras que con un bajo TRH éstos pueden ser menores. Lo contrario ocurre con la velocidad de carga. Por ejemplo, en las experiencias de laboratorio que se presentarán en Capítulo 4 se observarán tiempos de retención hidráulica de 50 a 97 días, dependiendo de la temperatura de operación.

\subsubsection{Parámetros operacionales: Diseño del digestor.}

En el diseño del biodigestor podemos distinguir entre diseño respecto de la carga, de la mezcla o del manejo del sustrato.

\subsubsection{Respecto a la carga del digestor.}

En un digestor de flujo discontinuo como el sistema Bach la carga que ingresa se mantiene por un tiempo prolongado, éste dependerá de la temperatura de operación (puede ser unos días o meses). Se carga una sola vez y luego se lo descarga cuando se ha agotado toda su capacidad de producir biogás. Al llenarse una sola vez, se requiere menos mano de obra, abaratando los costos de operación. Se lo implementa cuando la disponibilidad de material es discontinua o cuando éste presenta una alta concentración de sólidos.

Cuando el flujo es continuo el material a tratar que ingresa al digestor es constante (Samayoa, et al., 2012). Este sistema se utiliza cuando hay gran cantidad diaria de material orgánico disponible. Los tiempos de retención son menores en comparación a los de un sistema discontinuo y los volúmenes de los digestores para implementar este sistema son, por lo general, superiores a los $6 \mathrm{~m}^{3}$ (Vera, A. 1996). 


\subsubsection{Respecto a la mezcla.}

Con una mezcla completa el material orgánico y los microorganismos encargados de la descomposición se encuentran en un mismo contenedor (Vera, A. 1996). En general, estos digestores poseen un mecanismo central de aspas que mueven todo el contenido realizando la homogeneización. Cada vez más se utilizan este tipo de digestores de gran volumen, a nivel industrial.

En digestores de bajo costo en general puede no haber mezcla o ser ésta parcial. La agitación se realiza en forma manual o con pequeños motores. En digestores horizontales la mezcla se logra mediante la instalación de tabiques dentro del cuerpo del digestor (Hilbert, 2003).

\subsubsection{Respecto al manejo del sustrato.}

En los digestores de flujo ascendente llamados UASB (upflow anaerobic sludge blanket) el material ingresa desde abajo en sentido ascendente. Una capa de lodos con población microbiana se forma en la base. Esto disminuye la posibilidad de que abandonen el reactor ya que su gravedad específica es muy alta (Viquez, 2011). El material fresco ingresa a través de los lodos logrando una rápida degradación. El exceso de barro es descartado luego de unos meses.

Los digestores con filtro anaerobio poseen en su interior un material inerte en donde las bacterias se adhieren, evitando la pérdida de las mismas con la salida del efluente (Hilbert, 2003).

\subsection{Conclusiones.}

En ese capítulo se discutió con detalle el proceso de digestión anaeróbica. Se analizaron las reacciones químicas que ocurren en cada una de las etapas del proceso de biodigestión como así también los parámetros que inciden en su desarrollo. Se observa que presenta características complejas. Para un manejo adecuado del digestor se deberá atender a diversos parámetros de control. Cuando no sea posible controlarlos a todos, se deberá elegir los más importantes, dependiendo del tipo de sustrato que se esté utilizando.

En el Capítulo 4 se presentarán bioensayos a escala laboratorio y posteriormente en el capítulo 9 un prototipo de biodigestor enterrado. Este último operará con un flujo discontinuo y con un sistema de mezclado superior. Se considerarán los parámetros tales como sólidos totales $\mathrm{ST}$, sólidos volátiles $\mathrm{SV}, \mathrm{pH}$, alcalinidad, ácidos grasos volátiles AGV y temperatura. 


\section{CAPITULO 3}

\section{VALORIZACIÓN ENERGÉTICA \\ DE LOS RESIDUOS PECUARIOS BOVINOS \\ DE la Provincia De Salta.}




\section{1. Introducción.}

La provincia de Salta cuenta con diversos escenarios geográficos, cada uno con su clima particular. Esto influye considerablemente en la actividad ganadera del lugar. A pesar de ser una provincia con poca superficie destinada a la cría de ganado, el número de cabezas presenta un aumento considerable en los últimos años. La cantidad de estiércol que se genera en la actividad crea serios problemas sociales y ambientales. Si bien, las leyes actuales, tanto provinciales como nacionales, establecen claramente las pautas para un manejo adecuado de los residuos pecuarios, se necesita de políticas públicas que fomenten la incorporación de la tecnología del biogás.

En este capítulo se presenta la capacidad productora teórica de biogás (potencial de producción) que tiene la provincia de Salta a partir de los residuos pecuarios de la actividad ganadera.

Para el cálculo de la capacidad productora teórica de biogás se utilizaron datos estadísticos del SENASA 2016 y de la FAO 2016. Se detallan las características geográficas de la provincia y se contrasta con la actividad ganadera de cada zona.

\subsection{La provincia de Salta.}

\subsection{Ubicación geográfica.}

La República Argentina está situada en el extremo meridional de América del Sur (entre los $22^{\circ}$ y $26^{\circ}, 23^{\prime}$ de latitud sur y los $62^{\circ} 21^{\prime}$ y $68^{\circ} 35^{\prime}$ de longitud oeste), con una extensión de norte a sur de $3.800 \mathrm{~km}$ y de este a oeste de $1.425 \mathrm{~km}$ y una superficie de $2.800 .800 \mathrm{~km}^{2}$. Al oeste se extiende la Cordillera de los Andes, cuyo pico más alto es el Aconcagua, con $6.959 \mathrm{~m}$. Al este de dicha Cordillera se encuentran la Oriental y las sierras subandinas. El centro y este de la Argentina es principalmente una gran llanura con algunas ondulaciones suaves. La provincia de Salta está ubicada en el ángulo noroccidental del país, entre los $22^{\circ}$ y $26^{\circ}$ de latitud Sur y entre los $62^{\circ}$ y $68^{\circ}$ de longitud Oeste. El Trópico de Capricornio atraviesa el territorio salteño por su parte septentrional.

\subsection{Breve descripción de la orografía.}

En la Figura 3.1 se presenta un mapa físico de la provincia de Salta y su ubicación en el territorio argentino. 
La provincia de Salta presenta una variada orografía, producto de su ubicación y extensión con alturas que van de los 200 a los $6.000 \mathrm{msnm}$; lo que ocasiona diversidad de clima, flora y fauna.

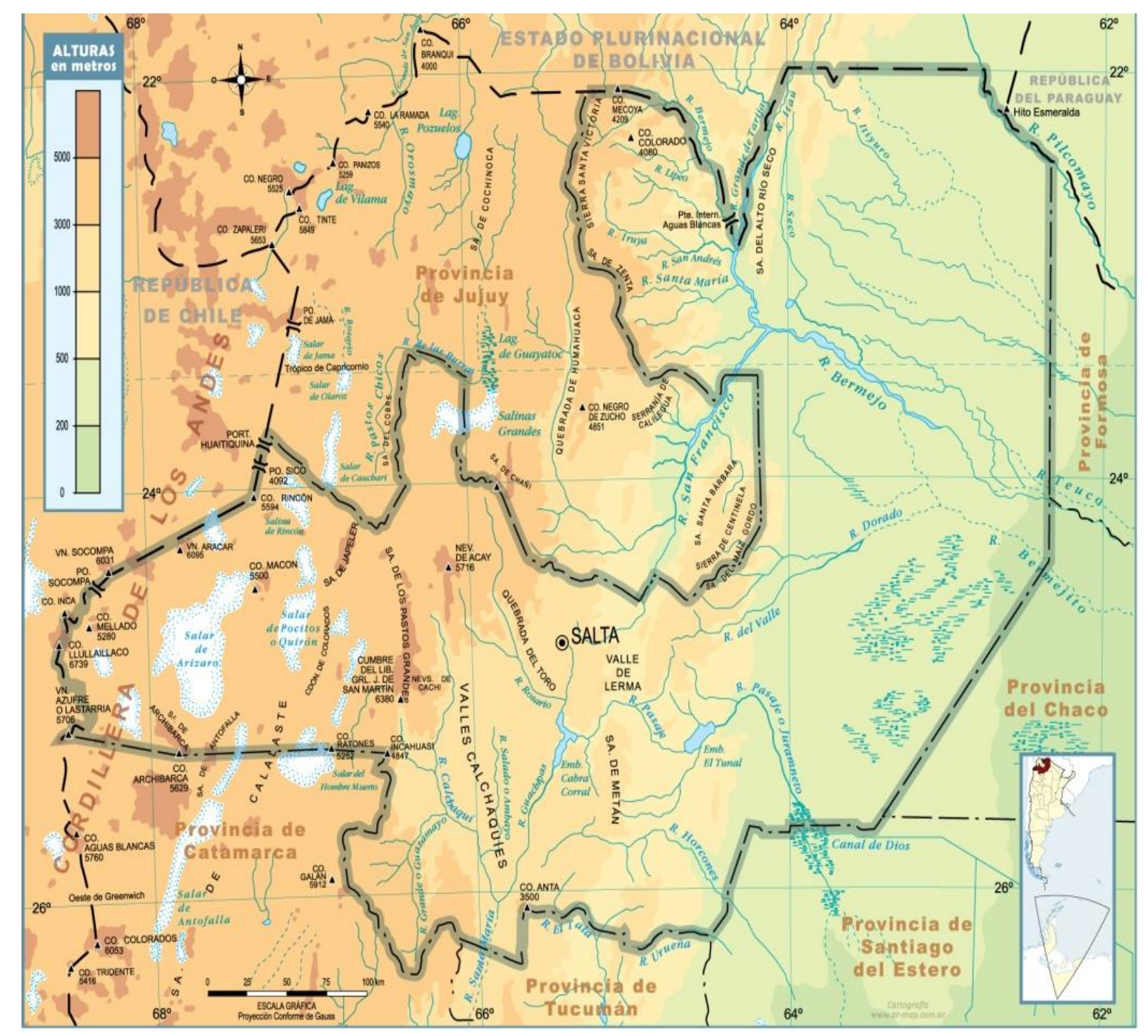

Figura 3.1. Mapa físico de la provincia de Salta.

Fuente: Mapoteca (2019).

En la provincia se distinguen cuatro paisajes diferenciados (Carlevari I. y Carlevari R., 2006):

$\checkmark$ Puna (al oeste): se caracteriza por la altura (entre los 3.400 y los $4.500 \mathrm{msnm}$ ), el clima árido y la presencia de salinas y salares, como el de Arizaro y el de Pocitos. En el nexo entre la Puna y la región Valliserrana se ubica la gran Quebrada del Toro (1.521 y $4.180 \mathrm{msnm}$ ) y en la misma se encuentra la localidad de San Antonio de los Cobres (altura media $3760 \mathrm{msnm}$ ). Predomina un clima árido y frío con 
bruscas variaciones térmicas día - noche (e incluso si se pasa de un lugar soleado a un lugar bajo sombra). En los últimos cincuenta años, la desertificación se ha agravado quedando la vegetación natural casi reducida a manchones de plantas xerófilas y psamófilas como la achaparrada tola que forma "colchones" o los grandes cactus llamados cardones; en la Puna y en las quebradas más secas se encuentran remanentes de un antiguo bosque de árboles bajos (churquis y queñoas).

$\checkmark$ Cordillera oriental (en el centro-oeste): presenta dos cordones montañosos: el occidental es más elevado y está formado por varios cordones como los Nevados de Acay (5.750 msnm), Cachi (6.300 msnm) y Chañi (5.896 msnm); el oriental es más bajo y sin cumbres nevadas. Entre estos últimas se encuentran valles y quebradas, tales como la Quebrada del Toro, los Valles Calchaquíes y el Valle de Lerma (máxima $1.100 \mathrm{msnm}$ ). Esta zona es la más densamente poblada y en donde está emplazada la capital. En la zona de los Valles Calchaquíes (oeste -centro) apenas quedan vestigios de los densos bosques de algarrobos criollos.

Sierras Subandinas (en el centro-este) (1.500 y $2.500 \mathrm{msnm}$ ): presenta un paisaje húmedo y selvático con frecuentes yungas, en donde se desarrolla un clima subtropical serrano. Los vientos húmedos del Océano Atlántico señalan una transición hacia el clima tropical húmedo, formándose en las laderas orientales una densa nimbosilva y pluvisilva que corresponde al bioma de yungas, con una enorme variedad de especies, entre las que se destacan los jacarandás (o tarcos), tipas, cebiles, molles, zapallos caspis, urundeles, guayabos, etc.

Llanura Chaqueña (al este) (200 y $800 \mathrm{msnm}$ ). Presenta un relieve bajo. Esta zona, denominada "Chaco salteño", tiene un clima subtropical con estación seca, biomasa de bosque/monte y con baja densidad de población. Se forman bosques de árboles caducifolios adaptados a las alternancias estacionales de sequías (en invierno) y "temporada lluviosa" (en verano) con ejemplares de chañares, lapachos, quebrachos, guayacán, yuchán, ñandubay, vinal y palmas o palmeras como la timbó y caranday. En esta región se ha producido deforestación para el uso de las pocas especias que existen como leña; en las yungas, así como en todo el chaco salteño, es común la práctica de la deforestación para la utilización agrícola de las tierras.

Por otra parte, en el Chaco Salteño existen amplios humedales como los Bañados de Los Colorados y los Esteros del Quirquincho. Las características climáticas y geográficas del lugar influyen considerablemente en la actividad ganadera. 
Las regiones que más se destacan en la provincia desde el punto de vista del potencial ganadero son: El Parque Chaqueño y la Selva Tucumano Boliviana (de 300 a 3.800 msnm) (se extiende desde el límite con Bolivia al norte hasta la provincia de Catamarca) La primera, con su vasta planicie y una suave pendiente noroeste sudeste y la segunda presenta un clima cálido y húmedo, ofreciendo ambas condiciones ideales para el desarrollo de la actividad pecuaria.

\subsection{Distribución del ganado bovino en la provincia de Salta.}

La provincia de Salta cuenta con regiones diferentes en cuanto a su geografía, lo que incide en el tipo de actividad ganadera que se desarrolla. En particular, el ganado bovino cuenta con un desarrollo importante que supera ampliamente las demás especies de animales utilizados para cría.

Hay diversos factores que afectan el volumen de recolección del estiércol animal. Un punto importante es el manejo del ganado, puesto que, si éste realiza pastoreo la recolección se dificulta notablemente dada la gran dispersión en su ubicación. En los últimos años, dado las ventajas que presenta la cría de ganado bovino intensiva en corral, se utiliza cada vez más este tipo de prácticas, principalmente por los costos del forraje y su relación con el peso vivo del animal. Así antes de proyectar la construcción del digestor debe considerarse este punto.

Cabe destacar que la proyección sobre la cantidad futura de biomasa residual pecuaria es favorable puesto que se observa en la provincia de Salta un mayor crecimiento de las áreas dedicadas a la cría de ganado.

Una fuente de datos importante para los estudios estadísticos relacionados con la actividad agropecuaria lo constituye el Censo Nacional Agropecuario realizado comúnmente cada 6 años. En el año 2018 desde el mes de setiembre y hasta el mes de diciembre se realizó el operativo censal que relevó las actividades agropecuarias y forestales. Los datos al momento de la escritura de esta tesis no se encontraban disponibles (INDEC, 2021).

El Servicio Nacional de Sanidad y Calidad Agroalimentaria (SENASA), organismo dependiente del Ministerio de Producción y Trabajo de la Nación y de la Secretaría de Agroindustria, es el encargado de ejecutar las políticas nacionales en materia de sanidad, calidad animal y vegetal e inocuidad de los alimentos de competencia, así como verificar el cumplimiento de la normativa vigente en la materia (SENASA, 2013). Otra actividad que realiza esta entidad es la vacunación contra la fiebre aftosa sobre el ganado vacuno para las provincias que adhieren a esta práctica en forma sistemática. 
Los datos relevados de la población bovina por esta entidad en la campaña de vacunación del 2017 (SENASA, 2017) se utilizarán para la estimación teórica del volumen de biogás que podría producir la provincia de Salta.

\subsection{Producción teórica de biogás del estiércol bovino.}

\subsubsection{Animales de pastoreo.}

De todas las especies ganaderas la más desarrollada es el vacuno. Sin duda, intervienen muchos factores siendo el principal el alto consumo interno de carne y su nivel de exportación. En la Figura 3.2 se indican los departamentos de la Provincia de Salta.

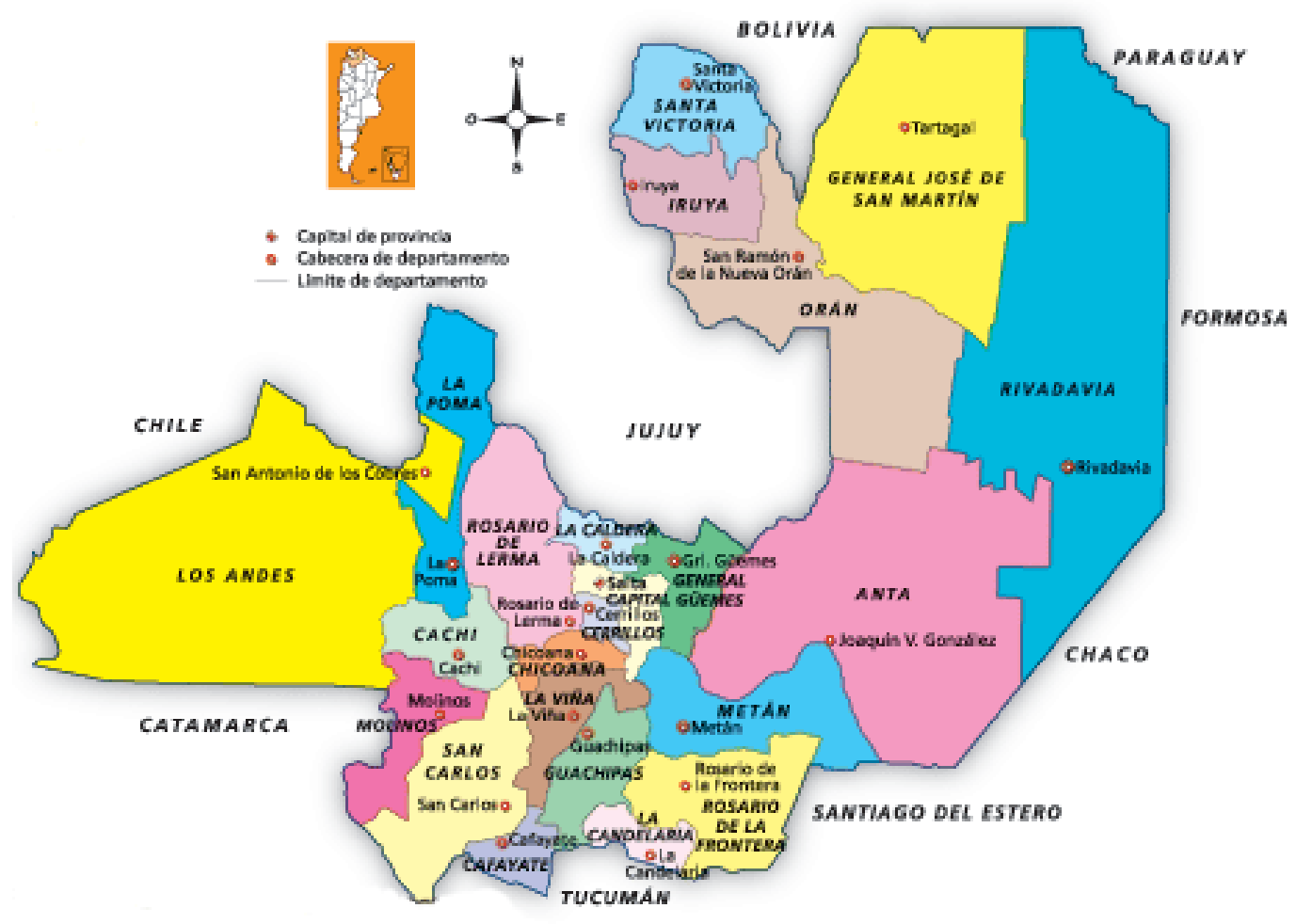

Figura 3.2. Mapa político de la provincia de Salta.

Fuente: Escribanía de Gobierno (2013).

La Figura 3.3 presenta la distribución ganadera bovina por departamentos. Los datos numéricos se encuentran en la Tabla 3.1, en la que no se discrimina entre animales de corral y de pastoreo (SENASA, 2016). 


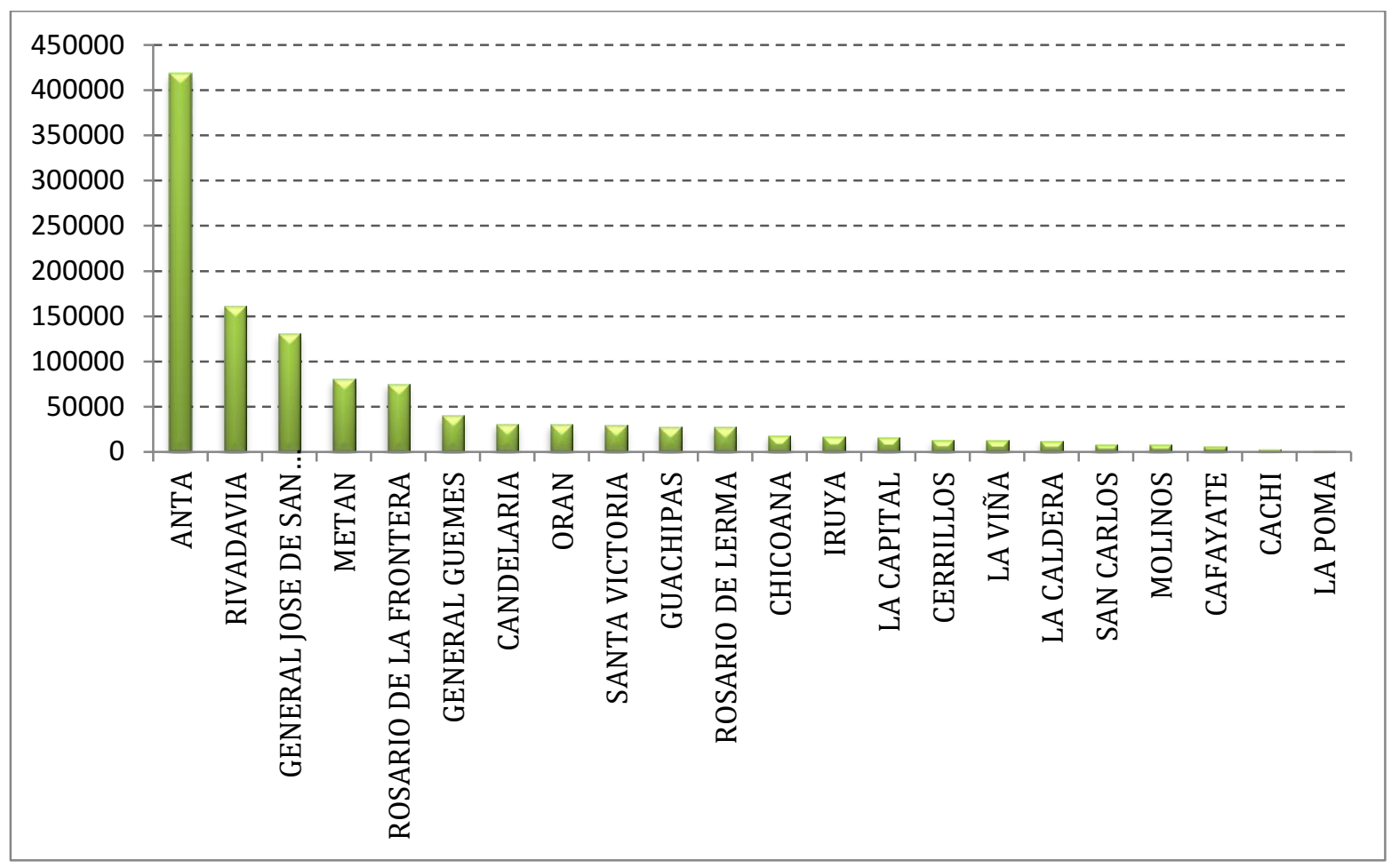

Figura 3.3. Distribución de ganado bovino por departamento.

Fuente: Elaboración propia.

El departamento de Anta posee mayor número de cabezas de bovinos, con 418.316, que representa aproximadamente el 36\% del total provincial, seguido por Rivadavia con 161.298 (14 \%) y por Gral. J de San Martin con 130.944 cabezas, (11\%). El departamento Los Andes no figura en la tabla pues presenta grandes extensiones de tierra, pero carece de explotación ganadera bovina.

La Tabla 3.2 sintetiza el número de cabezas de ganado vacuno y el porcentaje por categorías, discriminados según los datos del SENASA (2016), contabilizando más de un millón de cabezas en la provincia. 
Tabla 3.1. Datos censales del ganado vacuno de la provincia de Salta según datos de la campaña de vacunación de aftosa.

\begin{tabular}{|c|c|c|c|c|c|c|c|c|}
\hline Departamento & Vacas & Vaquillonas & Novillos & Novillitos & Terneros & Terneras & Toros & Total \\
\hline Anta & 154.826 & 83.191 & 32.391 & 38.242 & 48.860 & 52.196 & 8.610 & 418.316 \\
\hline Cachi & 1.228 & 493 & 197 & 136 & 316 & 342 & 145 & 2.857 \\
\hline Cafayate & 2.453 & 837 & 680 & 322 & 605 & 581 & 344 & 5.822 \\
\hline Candelaria & 14.293 & 5.868 & 2.007 & 1.845 & 2.891 & 2.551 & 1.176 & 30.631 \\
\hline Cerrillos & 3.597 & 2.518 & 453 & 1.932 & 1.835 & 2.795 & 101 & 13.231 \\
\hline Chicoana & 8.245 & 3.478 & 966 & 1.727 & 1.562 & 1.662 & 611 & 18.251 \\
\hline Gral. Guemes & 14.013 & 6.540 & 1.978 & 5.421 & 5.580 & 5.713 & 879 & 40.124 \\
\hline Gral. J. de San Martín & 49.808 & 27.082 & 6.398 & 19.480 & 12.282 & 12.604 & 3.290 & 130.944 \\
\hline Guachipas & 13.188 & 5.058 & 2.101 & 1.657 & 2.357 & 2.082 & 944 & 27.387 \\
\hline Iruya & 5.993 & 2.850 & 2.535 & 1.657 & 1.477 & 1.458 & 563 & 16.533 \\
\hline La Caldera & 4.993 & 1.861 & 1.068 & 817 & 1.308 & 1.357 & 343 & 11.747 \\
\hline Capital & 7.235 & 2.442 & 690 & 956 & 2.113 & 2.312 & 379 & 16.127 \\
\hline La Poma & 635 & 51 & 114 & 11 & 148 & 126 & 57 & 1.142 \\
\hline La Viña & 6.025 & 2.366 & 756 & 641 & 1.256 & 1.012 & 350 & 12.406 \\
\hline Metan & 34.850 & 13.237 & 5.474 & 7.744 & 8.564 & 8.305 & 2.113 & 80.287 \\
\hline Molinos & 3.661 & 1.266 & 828 & 482 & 613 & 809 & 492 & 8.151 \\
\hline Oran & 12.708 & 4.281 & 2.517 & 2.722 & 3.296 & 3.627 & 888 & 30.039 \\
\hline Rivadavia & 70.047 & 27.083 & 11.802 & 16.583 & 14.476 & 16.649 & 4.658 & 161.298 \\
\hline Rosario de la Frontera & 34.556 & 13.522 & 3.378 & 3.413 & 9.021 & 8.677 & 2.256 & 74.823 \\
\hline Rosario de Lerma & 10.327 & 5.275 & 1.963 & 2.642 & 3.182 & 2.998 & 739 & 27.126 \\
\hline San Carlos & 3.274 & 1.424 & 981 & 530 & 803 & 858 & 407 & 8.277 \\
\hline \multirow[t]{2}{*}{ Santa Victoria } & 10.964 & 4.400 & 4.792 & 3.177 & 2.212 & 2.201 & 1.276 & 29.022 \\
\hline & 466.919 & 215.123 & 84.069 & 112.137 & 124.757 & 130.915 & 30.621 & 1.164.541 \\
\hline
\end{tabular}

Fuente: SENASA (2016).

La categoría vaca alcanza el valor del $40 \%$, seguido por vaquillonas con un $18 \%$ (Tabla 3.2.).

Tabla 3.2. Porcentaje por categoría de ganado vacuno.

\begin{tabular}{|lc|}
\hline Categoría & $\mathbf{\%}$ \\
\hline Vacas & 40 \\
Vaquillonas & 18 \\
Novillos & 7 \\
Novillitos & 10 \\
Terneros & 11 \\
TERNERAS & 11 \\
Toros & 3 \\
TOTAL & $100 \%$ \\
\hline
\end{tabular}

Fuente: SENASA (2016). 
Para determinar la producción teórica de biogás que la provincia puede producir a partir del estiércol vacuno, se debe contar con la relación entre el volumen de biogás producido y la masa de estiércol. En general se la mide en litros por masa de sólidos volátiles.

El ganado vacuno cuenta con diversas categorías en cuanto a edad y sexo. Para estimar la cantidad de estiércol que produce esta actividad debe tomarse las deyecciones diarias que produce cada animal por peso vivo por categoría. En la Tabla 3.3 se expresan el peso promedio de cada categoría (Loughlin, 2012) tomando las deyecciones promedio de 6,25 kilogramos cada 100 kilogramos de peso vivo por día (Hilbert, 2003). En la Tabla 3.3 se establece el estiércol total al año que la provincia produce expresado en megatoneladas (Mtn).

Tabla 3.3. Estimación del estiércol vacuno total que produce la provincia de Salta.

\begin{tabular}{|lcrr|}
\hline Categoría & $\begin{array}{c}\text { Peso vivo } \\
\text { promedio (kg) }\end{array}$ & $\begin{array}{c}\text { Número de } \\
\text { cabezas }\end{array}$ & \multicolumn{2}{c|}{$\begin{array}{c}\text { Estiércol total } \\
\text { anual (Mtn) }\end{array}$} \\
\hline vacas & 450 & 466.919 & 4,7 \\
vaquillonas & 351 & 215.123 & 1,7 \\
novillos & 431 & 84.069 & 0,8 \\
novillitos & 351 & 112.137 & 0,8 \\
terneros & 300 & 124.757 & 0,8 \\
terneras & 250 & 130.915 & 0,7 \\
toros & 750 & 30.621 & 0,5 \\
TOTAL & & $\mathbf{1 . 1 6 4 . 5 4 1}$ & 10,0 \\
\hline
\end{tabular}

Fuente: Elaboración propia en base a datos del SENASA (2016), Loughlin (2012) y Hilbert (2003).

La cantidad aproximada de estiércol alcanza los 10 millones de toneladas anuales, lo que significa una cantidad importante teniendo en cuenta que en su mayoría se deposita en el suelo sin ningún tratamiento. Sin duda se genera una contaminación del aire, suelo y agua, ya que el propio ecosistema no es capaz de procesarlo naturalmente.

Para calcular la cantidad de metano que es capaz de producirse por digestión anaeróbica se toma un factor de conversión correspondiente a un proceso a $20^{\circ} \mathrm{C}$, obtenido en los ensayos de laboratorio que se expondrán en el Capítulo 4. Teniendo en cuenta una producción promedio de $0,080 \mathrm{~m}^{3}$ de metano por kilogramo de sólidos volátiles SV, se obtiene 90 millones de $\mathrm{m}^{3}$ distribuidos entre los departamentos que presentan mayor actividad ganadera vacuna, Tabla 3.1, SENASA (2016). 
Una temperatura de operación de $20^{\circ} \mathrm{C}$ no resulta atractiva puesto que el óptimo de producción se encuentra en el rango mesófilo $\left(37^{\circ} \mathrm{C}-40^{\circ} \mathrm{C}\right)$, en el que se generan mayores volúmenes de gas. Sin embargo, se necesita disponer de una gran cantidad de energía para mantener los digestores calefaccionados.

En la Tabla 3.4 se presenta una estimación de la energía que se obtendría de la combustión del biogás, tomando un poder calorífico inferior PCI del metano de 8.570 $\mathrm{kcal} / \mathrm{m}^{3}$ y una equivalencia de $1 \mathrm{Tep}$ (tonelada equivalente de petróleo) por cada $10^{7}$ kcal. Para la estimación se tiene en cuenta los valores de estiércol calculados anteriormente y presentados en la Tabla 3.3 (animales de pastoreo y corral).

Tabla 3.4. Estimación teórica de la energía.

\begin{tabular}{|c|c|}
\hline DETALLE & $\begin{array}{c}\text { PASTOREO Y } \\
\text { CORRAL }\end{array}$ \\
\hline Estiércol (Mtn) & 10,0 \\
\hline Masa de ST (Mtn) & 1,5 \\
\hline Masa de SV (Mtn) & 1,1 \\
\hline Volumen de metano $\left(\mathrm{m}^{3}\right)$ & $910^{6}$ \\
\hline Energía (106 kcal) & $771.300 \cdot 10^{6}$ \\
\hline Energía (Tep) & $\mathbf{7 7 . 1 3 0}$ \\
\hline
\end{tabular}

Fuente: Elaboración propia en base a valores medidos en el laboratorio del estiércol fresco (15\% Sólidos totales y 75\% Sólidos volátiles) y elaboración propia a partir de los datos del SENASA (2016).

La energía que se logra de la combustión del biogás (última fila de la Tabla 3.4) es el valor final calculado en la tabla.

El calor que se desprende puede aprovecharse de diversas formas, la más utilizada es la conversión a energía eléctrica. En este caso, durante el proceso de conversión sólo una parte de la energía será aprovechada y el resto se perderá al ambiente.

\subsubsection{Animales de feedlot y tambos.}

Feedlot es un término inglés para designar los corrales para engorde intensivo. Se encierran los animales en corrales donde reciben el alimento a través de comederos. El tambo es un establecimiento de ganado destinado al ordeñe, producción y venta de su leche. En estos, los animales que se encuentran en un corral son dirigidos a la zona de ordeño generalmente dos veces por día.

En el año 2012 los Ministerios de Agroindustria y de Energía y Minería solicitaron asistencia técnica a la Organización de las Naciones Unidas para la Alimentación y la 
Agricultura (FAO), a los fines de formular y ejecutar un proyecto para la promoción de la energía derivada de la biomasa con el propósito de incrementar la producción de energía térmica y eléctrica derivada de la biomasa a nivel local, provincial y nacional. En el año 2016 se publica un informe de este trabajo denominado: "Análisis espacial del balance energético derivado de la biomasa. Metodología Wisdom. Provincia de Salta", FAO (2016).

De la actividad bovina, se consideran aquellas de producción intensa como en los feedlots bovinos y los establecimientos tamberos, porque allí se simplifican las tareas de recolección del estiércol y purines, garantizando de esta manera el abastecimiento en los biodigestores.

Las estimaciones se llevaron a cabo a partir de información de la FAO (2016). En la Tabla 3.5 se presenta el factor de conversión para ganado de feedlot y de tambo.

Tabla 3.5. Factor de conversión para ganado de feedlot y de tambo.

\begin{tabular}{|l|c|c|}
\hline \multirow{2}{*}{ Factor de conversión } & \multicolumn{2}{c|}{ Masa (kg) } \\
\cline { 2 - 3 } & Feedlot & Tambos \\
\hline Estiércol fresco por animal x día & 23,9 & 3 \\
\hline Estiércol fresco por animal x año & 8.708 & 1.095 \\
\hline
\end{tabular}

Fuente: FAO (2016).

En el informe, se adoptó como poder calorífico PC del biogás $5.500 \mathrm{kcal} / \mathrm{m}^{3}$ y para el factor de conversión tonelada equivalente de petróleo (Tep) se utilizó $10^{7} \mathrm{kcal}$ por cada Tep. En la Tabla 3.6 se presenta para el feedlot y el tambo, el biogás producido por kilogramo de estiércol fresco y por animal por año. También figura la energía equivalente en kcal y tep por animal por año.

Tabla 3.6. Estimación del potencial anual de generación de biogás y de energía.

\begin{tabular}{|l|r|r|}
\hline & Feedlot & \multicolumn{1}{|c|}{ Tambo } \\
\hline Biogás (m³/kg de estiércol fresco) & 0,0315 & 0,0315 \\
\hline Biogás (m³/animal x año) & 274,30 & 34,49 \\
\hline Energía (kcal/animal x año) & 1.508 .627 & 189.709 \\
\hline Energía (Tep/animal x año) & 0,1509 & 0,0190 \\
\hline
\end{tabular}

Fuente: FAO (2016).

Con la estimación dada en la Tabla 3.5 se establece la energía en Tep por año para cada departamento de la provincia de Salta indicada en la Tabla 3.7. Los datos 
censales de los animales en tambos y en feedlot son extraídos del informe "Análisis espacial del balance energético derivado de la biomasa. Metodología Wisdom. Provincia de Salta", (FAO, 2016).

Tabla 3.7. Estimación de energía en Tep por año por departamento de la provincia de Salta.

\begin{tabular}{|l|r|r|r|}
\hline \multirow{2}{*}{ Departamento } & \multicolumn{3}{|c|}{ Energía (Tep/año) } \\
\cline { 2 - 4 } Anta & Tambo & \multicolumn{1}{c|}{ Feedlot } & \multicolumn{1}{c|}{ Total } \\
\hline Cafayate & 1,4 & $6.418,9$ & $6.420,3$ \\
\hline Capital & 1,3 & 1,7 & 3,0 \\
\hline Cerrillos & 9,8 & - & 9,8 \\
\hline Chicoana & 65,6 & 199,3 & 264,9 \\
\hline Gral. San Martín & 26,2 & 147,5 & 173,7 \\
\hline Metán & - & 702,4 & 702,4 \\
\hline Ro. de la Frontera & 1,2 & 200,2 & 201,4 \\
\hline Ro. de Lerma & 88,2 & 315,3 & 330,5 \\
\hline \multicolumn{3}{|c}{$\mathbf{7 7 , 6 9}$} & 166,59 \\
\hline
\end{tabular}

Fuente: FAO (2016).

\subsection{Discusión de los resultados.}

El informe "Análisis espacial del balance energético derivado de la biomasa. Metodología Wisdom. Provincia de Salta", (FAO, 2016) constituye una herramienta esencial para la toma de decisiones en políticas públicas y en la planificación y formulación de estrategias bioenergéticas. El análisis espacial realizado en este trabajo constituye la línea de base para la promulgación de proyectos bioenergéticos de diferentes escalas, con la posibilidad de producir diferentes vectores energéticos (biogás, electricidad, calor) de manera sustentable.

La actividad ganadera de la provincia de Salta se encuentra ampliamente desarrollada. En conjunto los departamentos que presentan mayor actividad ganadera generan una gran cantidad de estiércol vacuno, entre ellos Anta, Rivadavia y General San Martín se sitúan en las regiones centro-este y este de la provincia, 
donde se destacan climas cálidos con grandes extensiones deforestadas dedicadas a la siembra de forraje y pasturas.

Las regiones donde se observa mayor ganado son las de la zona de la llanura chaqueña, donde el departamento de Anta posee la mayor cantidad de crianza de cabezas de ganado vacuno. El clima cálido de esta zona favorece la producción de biogás en plantas de tratamiento.

Las zonas de menor producción se encuentran al oeste donde el clima se caracteriza por ser árido y frío, como en los departamentos de Los Andes, La Poma y Cachi. En esta región el tipo de cría en general no es de corral por lo tanto el poco ganado vacuno posee bastante dispersión. La implementación de digestores anaeróbicos no se recomienda.

La posibilidad de aprovechar todo el estiércol en la actividad de pastoreo se dificulta notablemente por la dispersión del ganado, la recolección disminuye cuanto mayor es el límite de pastoreo. Dada la menor cantidad de cabezas de ganado en la categoría "corral", la energía calculada es menor que en pastoreo, pero con mayores posibilidades de aprovechamiento del residuo.

\subsection{Conclusiones.}

Considerando los recursos biomásicos existentes, aproximadamente el $77 \%$ de la oferta directa accesible se distribuye al este de la Provincia, principalmente en el departamento de Anta (SENASA 2016).

Con un potencial de producción anual de metano de 90 millones de $\mathrm{m}^{3}$ para la actividad conjunta de pastoreo y corral (estimado para el año 2016) y considerando una capacidad calorífica inferior de $8.570 \mathrm{Kcal} / \mathrm{m}^{3}$ la energía equivalente alcanza los 771.300 millones de Kcal. Esta cantidad resulta interesante para pensar en una inversión a largo plazo que incentive el desarrollo de la digestión anaeróbica.

La viabilidad en la obtención de energía por digestión anaeróbica es mayor en las prácticas de feedlot y tambo pues se logra contar con la totalidad del residuo, resultando un asunto de gran interés para la aplicación directa de esta tecnología. 


\section{CAPITULO 4}

ENSAYOS DE BIODIGESTIÓN ANAERÓBICA

EN EL LABORATORIO. 


\subsection{Introducción.}

De la totalidad de especies ganaderas que se crían en la provincia de Salta la mayor parte la constituye el ganado vacuno. La masa total de estiércol que genera la provincia por año ronda los 10 millones de toneladas. Tamaña cantidad es vertida al suelo y al agua sin ningún tratamiento previo. La digestión anaeróbica es una solución que se adecúa perfectamente a la actividad ganadera.

En este Capítulo se presentan los resultados de diversos ensayos de laboratorio que se llevaron a cabo para evaluar el rendimiento de distintas muestras de residuos pecuarios vacunos y mezclas de éstos con fracción orgánica domiciliaria puesto que estos últimos forman parte de los desechos generados en un establecimiento rural.

Un ensayo de laboratorio se realiza para obtener el rendimiento de la muestra a una determinada temperatura, cantidad de carga orgánica, ya sea como sólidos volátiles (SV) o como demanda química de oxígeno (DQO) o demanda bioquímica de oxígeno (DBO) y a una determinada dilución de sólidos, por lo que también es importante medir los sólidos totales (ST). Debido a la dispersión que se obtiene en los resultados siempre es necesario realizar más de un ensayo.

Los ensayos de laboratorio se realizaron a tres temperaturas diferentes: $20^{\circ}, 30^{\circ} \mathrm{y}$ $37^{\circ} \mathrm{C}$. Esta última es considerada como la óptima del intervalo mesofílico (Lagrange, 1979). Se toma como antecedente el artículo "Bioensayo anaeróbico de estiércol de conejo" (Morales, et al., 2010), donde se muestran diversas experiencias de laboratorio con el estiércol de conejo y vacuno a distintas diluciones.

Con los datos obtenidos del volumen de biogás que se genera en cada muestra bajo condiciones controladas, se calcula la producción de metano y se analiza el efecto de la temperatura en la operación del biodigestor que permitirá elaborar conclusiones de su rendimiento.

\subsection{Materiales y métodos.}

Se detallan a continuación los métodos utilizados para determinar los parámetros medidos durante los ensayos de digestión anaeróbica, realizados en Salta, en las instalaciones del INENCO, Instituto de Investigaciones en Energías no Convencionales, Universidad Nacional de Salta/ CONICET.

En la determinación de estos se utilizaron las técnicas normalizadas de Standard Methods for the Examination of Water and Wastewater (APHA, AWWA, 1992), adaptadas para el análisis de material acuoso. 


\subsubsection{Sólidos totales (ST) y volátiles (SV).}

Los sólidos totales (ST) representan la cantidad de sólidos fijos y volátiles que contiene una mezcla dada. Representan el peso del estiércol una vez seco y, por tanto, es la carga real de materia sólida que se introduce en un digestor (Herrero, 2008). Para su determinación se lleva la muestra a $103^{\circ}-105^{\circ} \mathrm{C}$ en estufa durante $24 \mathrm{hs}$. El cálculo del porcentaje de sólidos totales (\%ST) se indica en la ecuación 4.1, donde Ms y Mh representan la masa seca y la masa húmeda, respectivamente.

$$
\% S T=\frac{M s}{M h} \cdot 100 \%
$$

Los sólidos volátiles (SV) representan la parte de los sólidos totales del estiércol que están sujetos a pasar a fase gaseosa (Herrero, 2008). El rendimiento del proceso anaeróbico, en términos de producción de gas o de remoción de materia orgánica, depende entre otros factores, del contenido volátil de los sólidos del sustrato. Por lo tanto, cuanto mayor sea el contenido volátil, mayor será el rendimiento del proceso (Lozada, 1993). Para la determinación del porcentaje de sólidos volátiles (\%SV) se lleva la muestra seca a una temperatura entre $550^{\circ} \mathrm{C}$ a $600^{\circ} \mathrm{C}$ en mufla. Su cálculo se presenta en la ecuación 4.2, donde Mc es la masa después de calcinarse la muestra en la mufla.

$$
\% S V=\frac{M s-M c}{M s} \cdot 100 \%
$$

\subsection{2. $p H$.}

El pH es la forma común de expresar la concentración del ion hidrógeno en las soluciones acuosas, tal como se muestra en la ecuación 4.3.

$$
p H=\log \left[H^{+}\right]
$$

Fue medido utilizando un $\mathrm{pH}$-metro sobre una muestra previamente filtrada del estiércol a utilizar, que fue calibrado con soluciones estándar, marca Biopack, a pH 4 y 7.

\subsubsection{Alcalinidad (Alk).}

La alcalinidad se define como la capacidad de neutralización de los ácidos hasta un determinado pH. En los ensayos la misma fue realizada por titulación potenciométrica hasta un valor de $\mathrm{pH}$ de 4,5. Se aduce que a este valor se han cuantificado todas las especies carbonáticas o no que aportan basicidad al medio (Chacón, 1987). Para su valorización se utiliza ácido sulfúrico $\left(\mathrm{H}_{2} \mathrm{SO}_{4}\right)$. 


$$
\operatorname{Alk}\left(\mathrm{mgCaCO} \mathrm{Ca}_{3} / l\right)=\frac{V_{\mathrm{H}_{2} \mathrm{SO}_{4}} \mathrm{~N}_{\mathrm{H}_{2} \mathrm{SO}_{4}}}{V} \cdot 50.000
$$

El cálculo de la alcalinidad (Alk) en mg de carbonato de calcio $\left(\mathrm{CO}_{3} \mathrm{Ca}\right)$ por litro se presenta en la ecuación 4.4, donde $\mathrm{N}_{\mathrm{H}_{2} \mathrm{SO}_{4}}$ es la normalidad de la solución del ácido sulfúrico, $\mathrm{V}_{\mathrm{H}_{2} \mathrm{SO}_{4}}$ el volumen utilizado de ácido y $\mathrm{V}$ el volumen total de la muestra, ambos en mililitros.

\subsection{4. Ácidos grasos volátiles (AGV).}

Mediante titulación potenciométrica se determinan los ácidos grasos volátiles (AGV). Se utiliza una solución básica de hidróxido de sodio $(\mathrm{NaOH})$ hasta un pH igual a 7.

$$
A G V\left(\mathrm{mg} \mathrm{CaCO}_{3} / l\right)=\frac{V_{\mathrm{NaOH}} N_{\mathrm{NaOH}}}{V} \cdot 50.000
$$

Para la determinación de los $\mathrm{AGV}$ por mg de carbonato de calcio $\left(\mathrm{CO}_{3} \mathrm{Ca}\right)$ por litro se utiliza la ecuación 4.5, donde $\mathrm{N}_{\mathrm{NaOH}}$ es la normalidad de la solución de hidróxido de sodio, $\mathrm{V}_{\mathrm{NaOH}}$ el volumen utilizado de la solución y $\mathrm{V}$ el volumen total de la muestra, ambos en mililitros.

\subsubsection{Composición del biogás: metano y dióxido de carbono.}

El biogás cuenta principalmente de metano $\left(\mathrm{CH}_{4}\right)$ (50-80\%), dióxido de carbono $\left(\mathrm{CO}_{2}\right)(40-20 \%)$ y en menor cantidad hidrógeno $\left(\mathrm{H}_{2}\right)(0-0,02 \%)$ y sulfuro de hidrógeno $\left(\mathrm{H}_{2} \mathrm{~S}\right)$ (100-700 ppm) entre otros. Determinar el volumen de metano es importante desde un punto de vista energético, ya que un biogás con mayor riqueza en metano tiene mayor valor energético. Por otro lado, su presencia indica que hay actividad de las bacterias metanogénicas. Para su determinación se inyecta una muestra del biogás en una solución de hidróxido de potasio (KOH), figura 4.1. También puede utilizarse hidróxido de sodio $(\mathrm{NaOH})$.
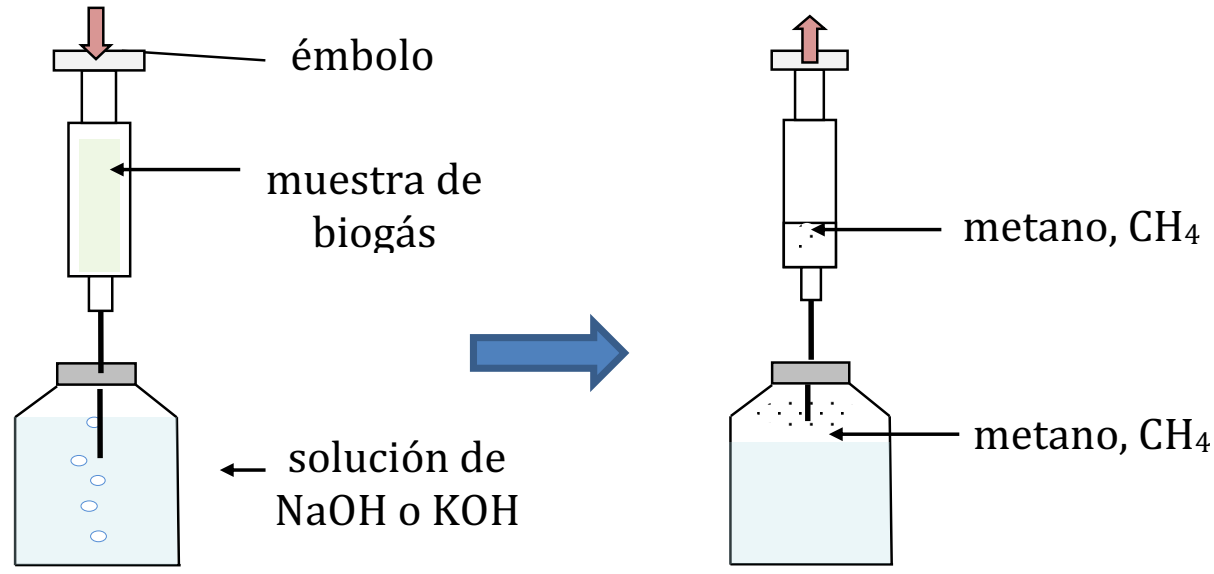

Figura 4.1. Esquema de la determinación de metano en la muestra de biogás.

Fuente: Elaboración propia. 
Se recoge con una jeringa de vidrio una muestra de biogás. Las jeringas de vidrio tienen la particularidad de tener el émbolo con poca fricción, por lo que puede desplazarse fácilmente. La muestra de biogás de un volumen conocido entra en contacto con una solución de hidróxido de potasio $(\mathrm{KOH})$.

El KOH se encuentra contenido en un frasco herméticamente cerrado. El dióxido de carbono reacciona con el hidróxido de potasio (ecuación 4.6).

$$
\mathrm{CO}_{2}(g)+2 \mathrm{KOH}(a c) \rightarrow \mathrm{K}_{2} \mathrm{CO}_{3}(a c)+\mathrm{H}_{2} \mathrm{O}(a c)
$$

En esta reacción, se forma carbonato de potasio $\left(\mathrm{K}_{2} \mathrm{CO}_{3}\right)$ quedando en la fase líquida, mientras que el dióxido de carbono $\left(\mathrm{CO}_{2}\right)$ desaparece de la fase gaseosa, quedando solo metano en el biogás, ("ac" indica acuoso y "g" gaseoso). Al estar herméticamente cerrado el recipiente, el émbolo se desplaza nuevamente hacia arriba, para igualar la presión del interior con la atmosférica. Midiendo el volumen de este gas restante se obtiene la proporción de metano en la muestra.

\subsection{Biodigestión anaeróbica. Ensayos en el laboratorio.}

En los ensayos de biodigestión se utilizaron Erlenmeyer de $250 \mathrm{ml}$ y $500 \mathrm{ml}$ de capacidad, para el digestor y el gasómetro respectivamente. Se realizaron experiencias a temperaturas de $20^{\circ}, 30^{\circ}$ y $37^{\circ} \mathrm{C}$. Tanto los digestores como los gasómetros se sumergieron en un baño térmico con control de temperatura.

Las muestras se mantuvieron homogéneas con un agitado manual diario. El volumen de biogás producido diariamente se midió mediante el desplazamiento del agua. Para analizar la composición porcentual de metano se utilizó una solución de hidróxido de potasio al $30 \% \mathrm{p} / \mathrm{p}$.

Se realizó una caracterización físico-química de las muestras que se han tomado de la mezcla de estiércol vacuno y agua al inicio de la experiencia. Mediante titulación potenciométrica (según Standard Methods for the Examination of Water and Wastewater, APHA, AWWA, 1995) se determinaron la alcalinidad (Alk) y los ácidos grasos volátiles (AGV), medidos en $\mathrm{mg} \mathrm{CaCO}_{3} / \mathrm{l}$, sólidos totales (ST), sólidos volátiles (SV) en \% y pH.

En la Figura 4.2 se presenta una foto del ensayo y un esquema de la captura y medición del volumen de biogás. 

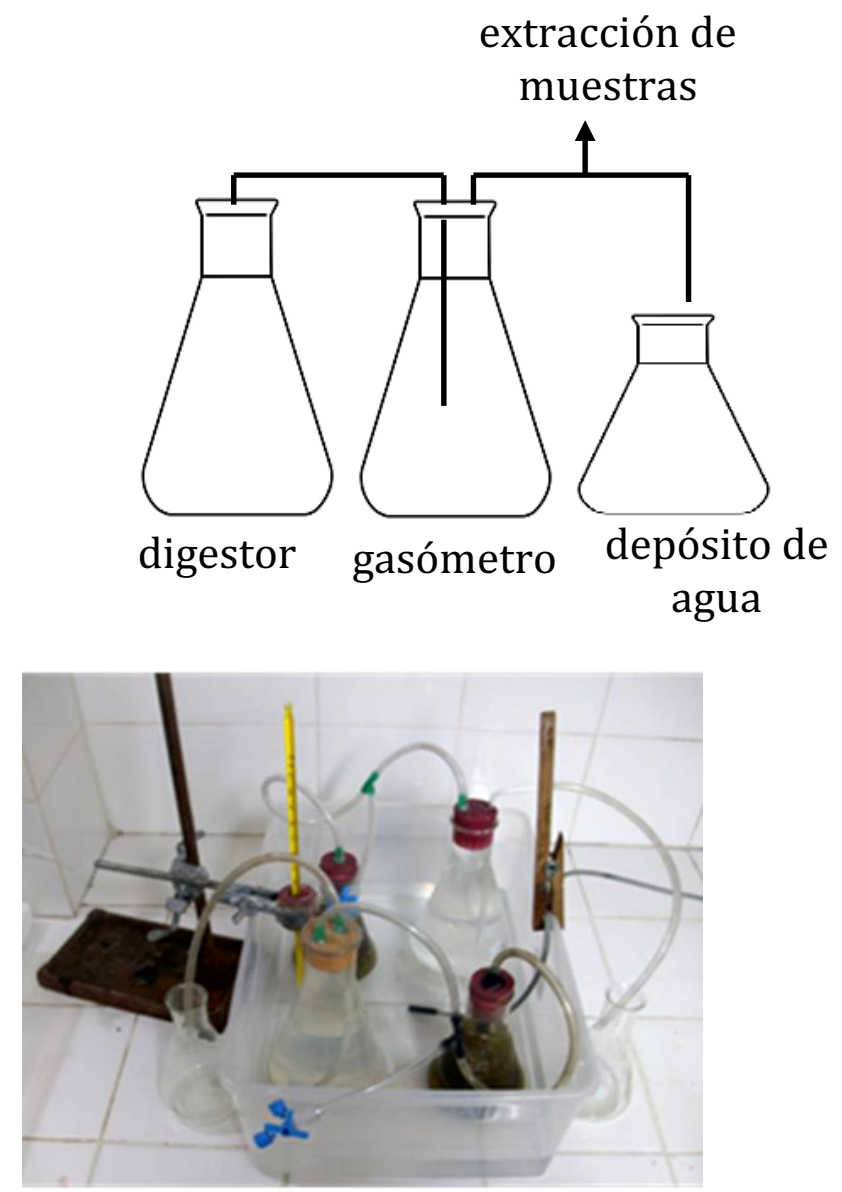

Figura 4.2. Esquema y foto del ensayo de biodigestión realizado en el laboratorio. Fuente: Elaboración propia.

\subsubsection{Ensayos con estiércol vacuno a $20^{\circ}, 30^{\circ}$ y $37^{\circ} \mathrm{C}$.}

Las muestras utilizadas de estiércol vacuno fueron recolectadas de un tambo, ubicado en la zona suroeste de la ciudad Capital de la Provincia de Salta. Se realizaron los análisis físico-químicos, que se muestran en la Tabla 4.1. La dilución con agua se realizó en los tres ensayos de la misma forma para obtener el mismo valor de los sólidos totales.

Tabla 4.1. Parámetros físico-químicos de la caracterización de la mezcla de estiércol vacuno y agua para los ensayos a $20^{\circ}, 30^{\circ}$ y $37^{\circ} \mathrm{C}$.

\begin{tabular}{|c|c|c|c|c|c|}
\hline $\mathrm{T}\left({ }^{\circ} \mathrm{C}\right)$ & $\% S T$ & $\% S V$ & pH & Alk (mg CaCO $3 / 1)$ & $\mathrm{AGV}(\mathrm{mg} \mathrm{CaCO} / \mathrm{l})$ \\
\hline 20 & 10,5 & 73,1 & 7,38 & 750 & 250 \\
\hline 30 & 10,7 & 73,0 & 7,00 & 710 & 235 \\
\hline 37 & 11,0 & 75,0 & 7,25 & 775 & 267 \\
\hline
\end{tabular}

Fuente: Elaboración propia. 
Como se aprecia en la Tabla 4.1, los valores de $\mathrm{pH}$ se encuentran en torno a la neutralidad. En la digestión anaeróbica el pH óptimo se encuentra entre 6,5 y 7,6 (McCarty, 1981). Los valores de alcalinidad triplican a los ácidos grasos. Esto resulta una gran ventaja pues se garantiza el efecto tampón o amortiguante.

Los recipientes utilizados tienen el mismo volumen. Sin embargo, la masa total de la mezcla contenida varía ligeramente entre ellos. Estos datos se muestran en la Tabla 4.2 .

Tabla 4.2. Masa de los digestores de los distintos ensayos.

\begin{tabular}{|l|c|c|c|}
\hline \multicolumn{4}{|c|}{ Masa (g) } \\
\hline Temperatura $^{\circ} \mathbf{C}$ & $\mathbf{2 0}$ & $\mathbf{3 0}$ & $\mathbf{3 7}$ \\
\hline Digestor 1 & 142,0 & 157,8 & 160,0 \\
Digestor 2 & 157,2 & 157,7 & 158,0 \\
\hline
\end{tabular}

Fuente: Elaboración propia.

Se observa en la Figura 4.2 que el gasómetro se encuentra en el baño termostatizado, así, a mayor temperatura el volumen de biogás en su interior se expandirá más. Para salvar esta situación y a fin de comparar los tres ensayos, los volúmenes en cada producción, son referidos a $20^{\circ} \mathrm{C}$ y 1 atm de presión.

Considerando al biogás como un gas ideal, se relaciona la presión $P$, el volumen $V$ y la temperatura $T$ como se expresa en la ecuación 4.7, donde $n$ es el número de moles y $R$ es la constante ideal de los gases.

$$
P V=n R T
$$

Por ejemplo, cuando la experiencia se realiza a $30^{\circ} \mathrm{C}$ se tiene la ecuación 4.8 , donde $P_{m}$ es la presión atmosférica medida en el día del ensayo, $V_{30^{\circ} \mathrm{C}}$ el volumen medido de biogás a $30^{\circ} \mathrm{C}$ y $T_{30^{\circ}} \mathrm{C}$ es la temperatura de $30^{\circ} \mathrm{C}$. Reordenando se expresa la ecuación 4.9 .

$$
\begin{gathered}
P_{m} V_{30^{\circ} \mathrm{C}}=n R T_{30^{\circ} \mathrm{C}} \\
\frac{P_{m} V_{30^{\circ} \mathrm{C}}}{T_{30^{\circ} \mathrm{C}}}=n R
\end{gathered}
$$

A $20^{\circ} \mathrm{C}$ y $1 \mathrm{~atm}$ de presión se tendrá la ecuación 4.10 y la 4.11 .

$$
\begin{gathered}
P_{1 \text { atm }} V_{20^{\circ} \mathrm{C}}=n R T_{20^{\circ} \mathrm{C}} \\
\frac{P_{1 a t m} V_{20^{\circ} \mathrm{C}}}{T_{20^{\circ} \mathrm{C}}}=n R
\end{gathered}
$$


Así, igualando las ecuaciones 4.9 y 4.11 se obtiene la 4.12 y 4.13 , de esta última se despeja el volumen $V_{20^{\circ} \mathrm{C}}$ para el correspondiente a $V_{30^{\circ} \mathrm{C}}$.

$$
\begin{gathered}
\frac{P_{1 \mathrm{~atm}} V_{20^{\circ} \mathrm{C}}}{T_{20^{\circ} \mathrm{C}}}=\frac{P_{m} V_{30^{\circ} \mathrm{C}}}{T_{30^{\circ} \mathrm{C}}} \\
V_{20^{\circ} \mathrm{C}}=\frac{P_{m}}{P_{1 \mathrm{tm}}} \frac{T_{20^{\circ} \mathrm{C}}}{T_{30^{\circ} \mathrm{C}}} V_{30^{\circ} \mathrm{C}}
\end{gathered}
$$

Se presenta en la Figura 4.3 la producción diaria de biogás por kilogramos de sólidos volátiles para los digestores 1 y 2 mantenidos a $20^{\circ} \mathrm{C}$. Se observa que existe un periodo de mayor producción entre los 8 y 45 días, luego fue decayendo hasta llegar a una producción despreciable a los 97 días.

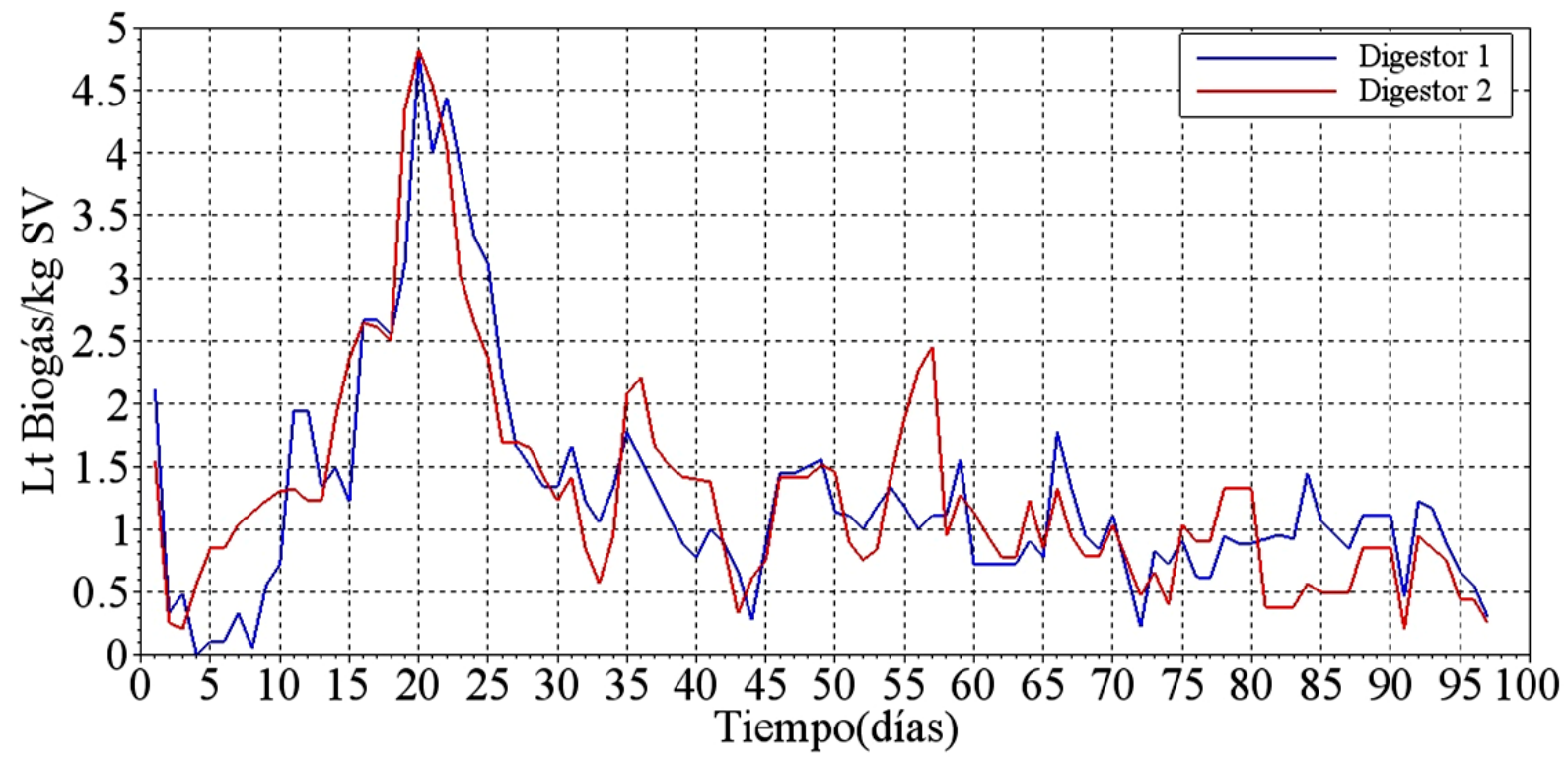

Figura 4.3. Producción de biogás del estiércol vacuno en litros por kilogramos de sólidos volátiles a $20^{\circ} \mathrm{C}$.

Fuente: Elaboración propia.

En la Figura 4.4 se aprecia el porcentaje de metano del biogás en el ensayo a $20^{\circ} \mathrm{C}$. Se observa que los valores medidos se encuentran en torno a un valor promedio de 65 $\%$. 


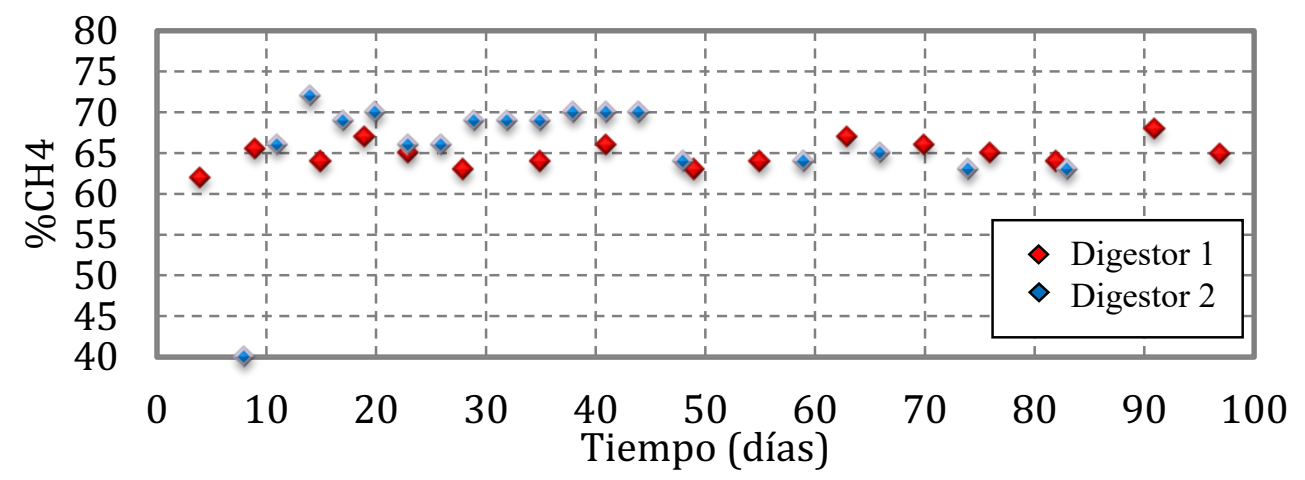

Figura 4.4. Porcentaje de metano a $20^{\circ} \mathrm{C}$.

Fuente: Elaboración propia.

Un tiempo tan prolongado se debe a que la temperatura de los digestores $\left(20^{\circ} \mathrm{C}\right)$ se encuentra muy por debajo del óptimo $\left(37^{\circ} \mathrm{C}\right)$. Esto influye considerablemente en la cinética del crecimiento de las bacterias metanogénicas, la que depende entre otros parámetros fuertemente de la temperatura (Speece, 1996). A pesar de una baja producción de biogás y un prolongado tiempo de digestión, el porcentaje de metano promedio en la mezcla durante todo el ensayo se mantuvo en 65\%. La producción total acumulada de biogás al final del ensayo fue de 1.107,8 ml para el digestor $1 \mathrm{y}$ $1.329,0 \mathrm{ml}$ para el digestor 2 -(los volúmenes se refieren a $20^{\circ} \mathrm{C}$ y $1 \mathrm{~atm}$ ).

En la Figura 4.5, se presenta la producción diaria de biogás por kilogramos de sólidos volátiles cuando la muestra es sometida a un baño termostatizado de $30^{\circ} \mathrm{C}$. Se observa un tiempo de retención de 45 y 50 días. La producción acumulada de biogás es de 1.791,8 ml para el digestor 1 y 1.595,0 $\mathrm{ml}$ para el digestor 2 (los volúmenes se refieren a $20^{\circ} \mathrm{C}$ y $\left.1 \mathrm{~atm}\right)$.

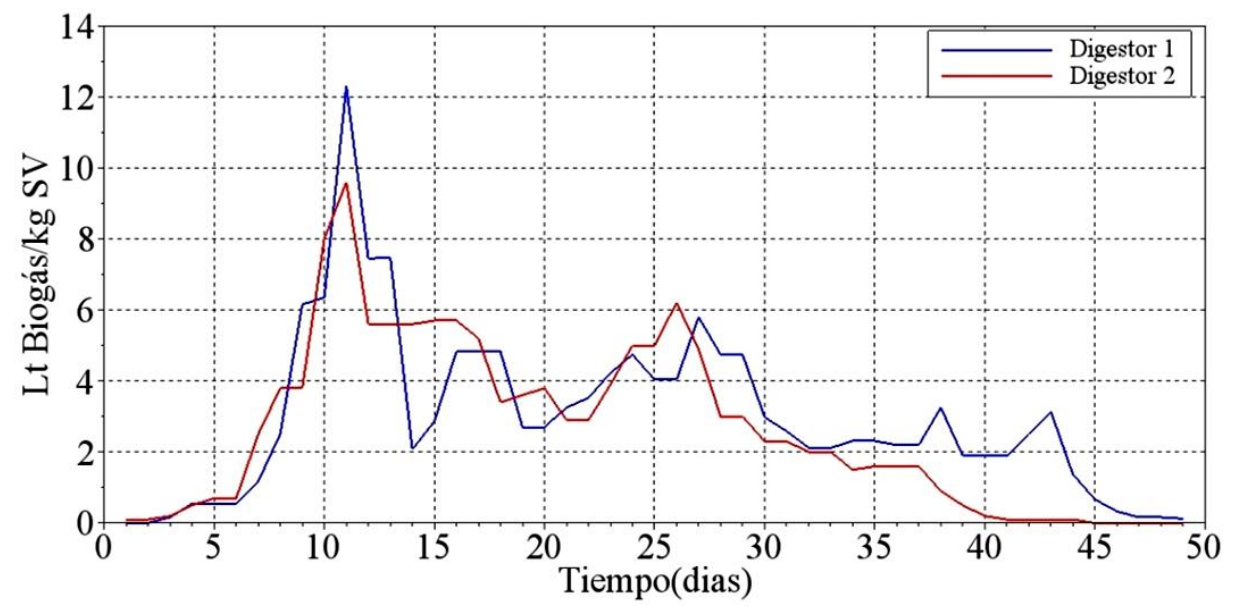

Figura 4.5. Producción diaria de biogás del estiércol vacuno a $30^{\circ} \mathrm{C}$ en litros por kilogramos de sólidos volátiles.

Fuente: Elaboración propia. 
El porcentaje de metano medido en los ensayos se presenta en la Figura 4.6. El valor promedio es del $68 \%$.

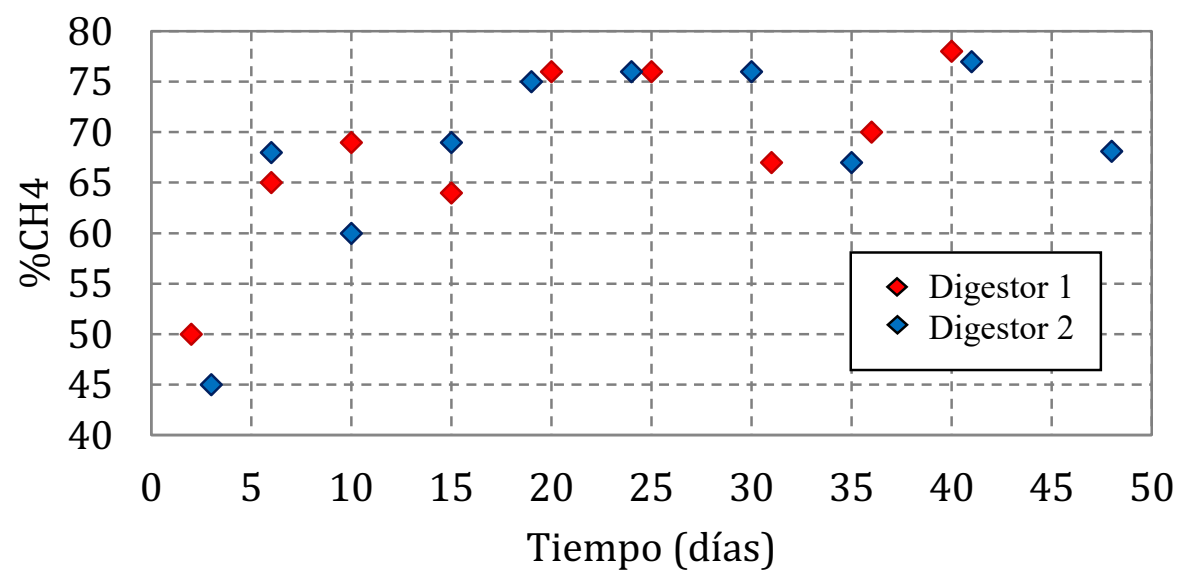

Figura 4.6. Porcentaje de metano en el ensayo a $30^{\circ} \mathrm{C}$. Fuente: Elaboración propia.

La Figura 4.7 representa la producción de biogás por kilogramos de sólidos volátiles de dos ensayos a $37^{\circ} \mathrm{C}$ para una mezcla de estiércol vacuno y agua. Las cantidades están referidas a $20^{\circ} \mathrm{C}$ y $1 \mathrm{~atm}$ de presión. La curva en color azul representa la producción del digestor 1 , y la curva de color rojo la del digestor 2 . El tiempo que duran los ensayos es de 53 días. La producción de biogás acumulada es de 4.212,8 ml para el digestor 1 y 4.060,1 ml para el digestor 2 .

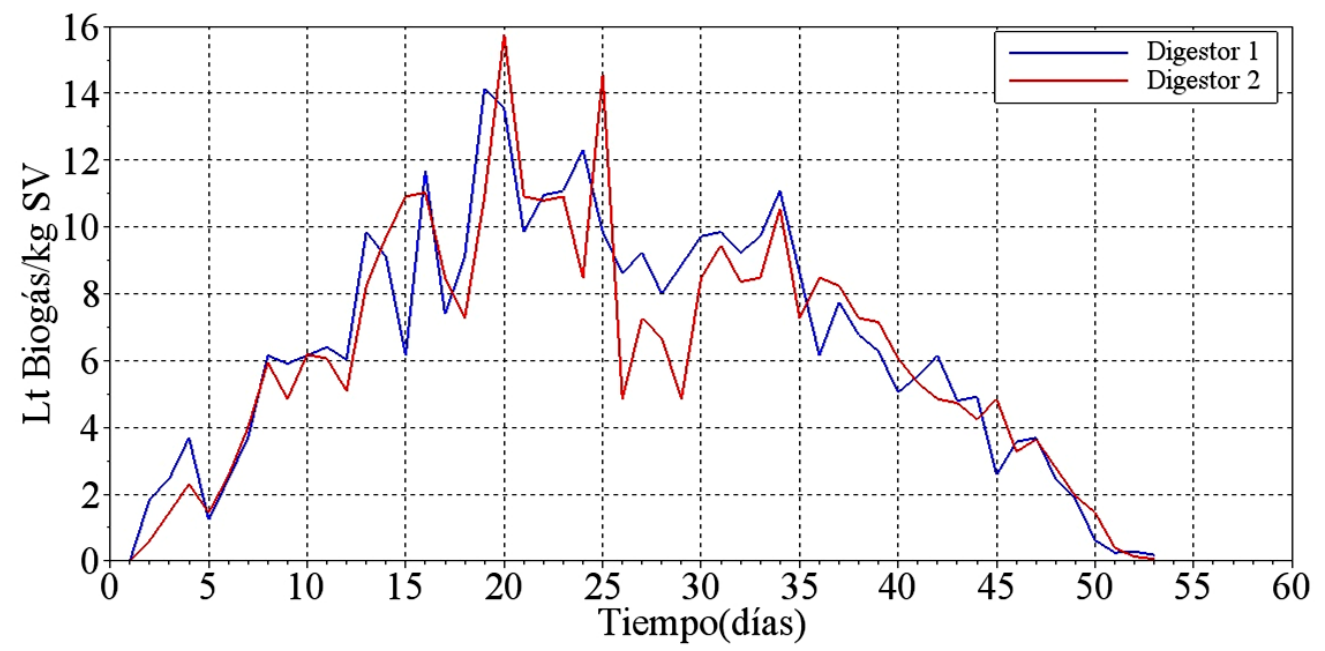

Figura 4.7. Producción de biogás del estiércol vacuno a $37^{\circ} \mathrm{C}$ en litros por kilogramos de sólidos volátiles.

Fuente: Elaboración propia. 
En la Figura 4.8 se aprecia el porcentaje de metano con un promedio del $70 \%$ en ambos ensayos.

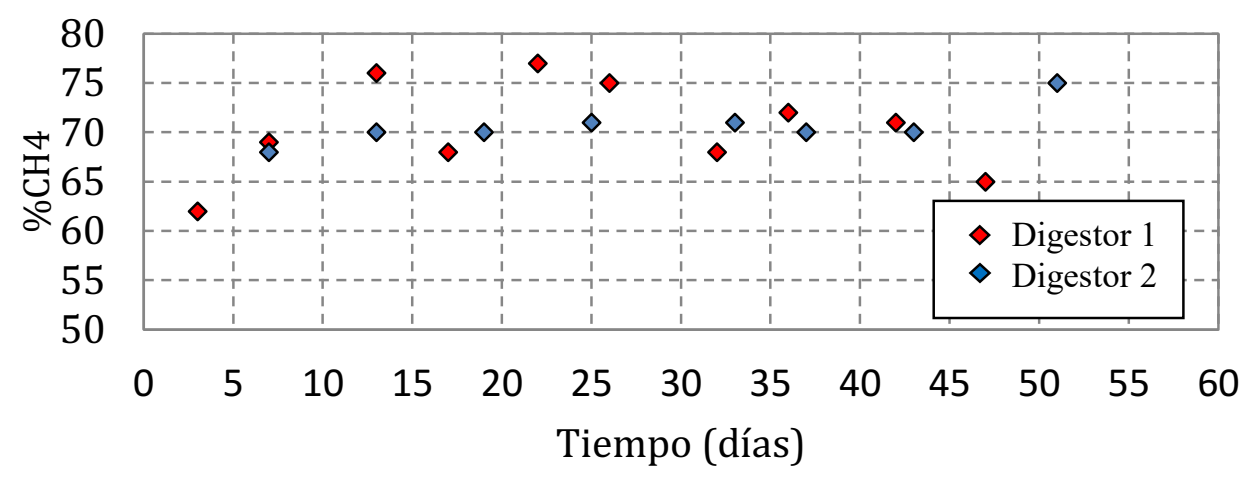

Figura 4.8. Porcentaje de metano en el ensayo a $37^{\circ}$.

Fuente: Elaboración propia.

En la Tabla 4.3 se presentan los resultados de la cantidad acumulada de metano a 15 , 30, 50 y 97 días. Los valores se calculan a partir del porcentaje de metano promedio y los volúmenes de biogás obtenido en los ensayos. Las medidas están en litros por kilogramos de sólidos volátiles. A fin de comparar estos valores son referidos a condiciones de temperatura y presión de $20^{\circ} \mathrm{C}$ y $1 \mathrm{~atm}$.

Tabla 4.3. Producción de metano para distintos tiempos de retención $\mathrm{y}$ a diferentes temperaturas.

\begin{tabular}{|c|c|c|c|c|c|c|}
\hline \multirow{4}{*}{$\begin{array}{l}\text { Tiempo de } \\
\text { retención } \\
\text { (días) }\end{array}$} & \multicolumn{6}{|c|}{ Cantidad de $\mathrm{CH}_{4}$ en lt/kg de SV } \\
\hline & \multicolumn{2}{|c|}{ A $20^{\circ} \mathrm{C}$} & \multicolumn{2}{|c|}{ A $30^{\circ} \mathrm{C}$} & \multicolumn{2}{|c|}{ A $37^{\circ} \mathrm{C}$} \\
\hline & \multicolumn{6}{|c|}{ Digestor } \\
\hline & 1 & 2 & 1 & 2 & 1 & 2 \\
\hline 15 & 10,4 & 10,6 & 37,3 & 34,4 & 53,9 & 49,3 \\
\hline 30 & 36,0 & 19,7 & 78,0 & 55,3 & 153,3 & 135,1 \\
\hline 50 & 59,4 & 32,1 & 98,7 & 87,9 & 223,1 & 202,3 \\
\hline 97 & 80,0 & 81,5 & - & - & - & - \\
\hline
\end{tabular}

Fuente: Elaboración propia. 
Se observa que a mayor temperatura se logran mayores volúmenes de metano en menor tiempo. En 50 días con temperaturas de $37^{\circ} \mathrm{C}$ se obtiene 2,2 a 2,3 veces más que a $30^{\circ} \mathrm{C}$ y asimismo con $37^{\circ} \mathrm{C}$ los volúmenes de metano resultan 2,4 a 2,6 más que a $20^{\circ} \mathrm{C}$.

Tabla 4.4. Resumen de datos de los ensayos.

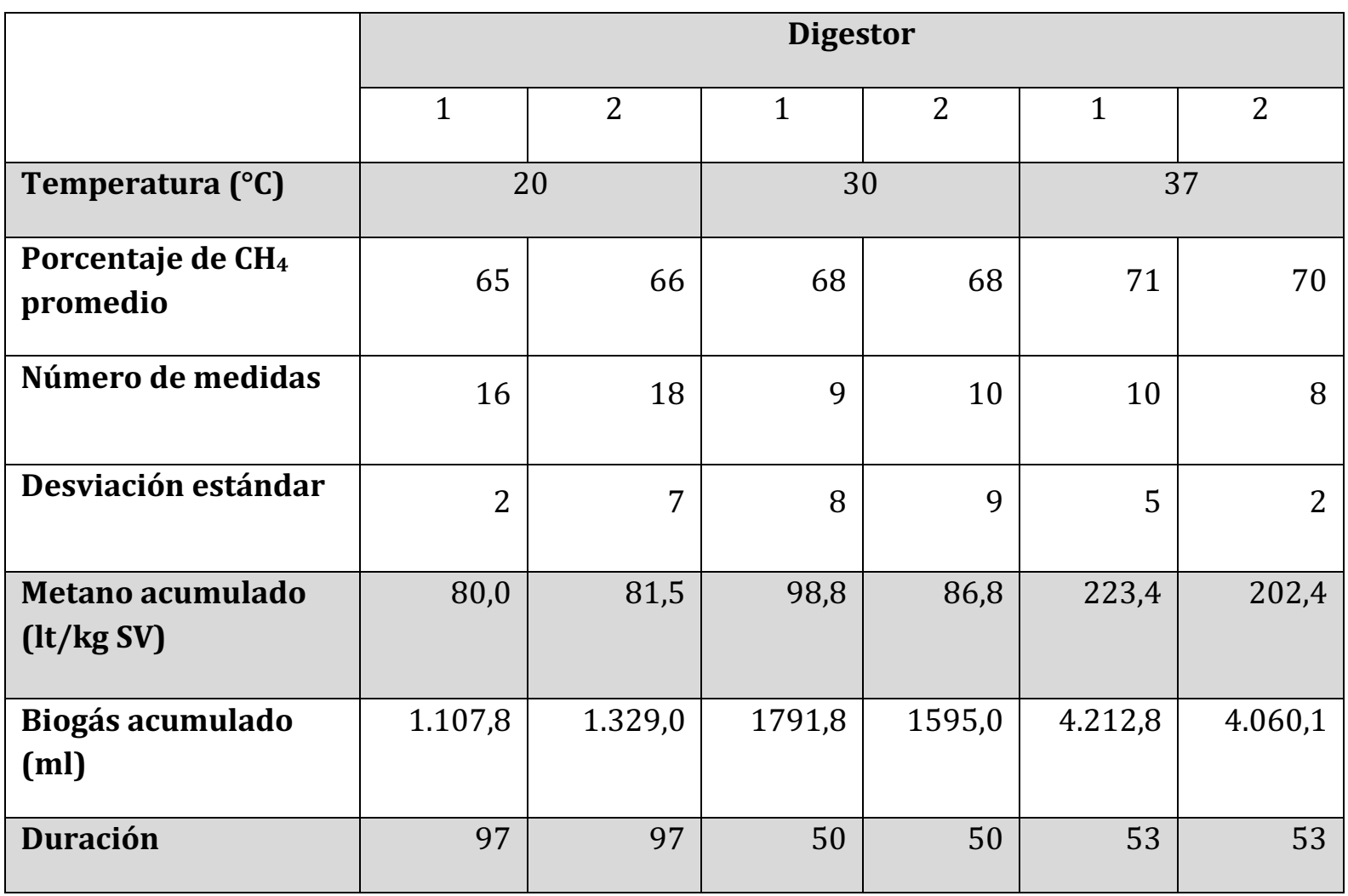

Fuente: Elaboración propia.

En la Tabla 4.4 se presenta un resumen de los resultados relevantes de los distintos ensayos: temperatura, porcentaje promedio de metano, número de medidas, desviación estándar, metano acumulado, biogás acumulado y duración del ensayo.

No se observan diferencias significativas en la producción acumulada para los ensayos a $20^{\circ}$ y $30^{\circ} \mathrm{C}$. El porcentaje de metano promedio obtenido se aproxima a: $65 \%$ a $20^{\circ}, 68 \%$ a $30^{\circ} \mathrm{C}$ y $70 \%$ a $37^{\circ} \mathrm{C}$.

Analizando el ensayo con respecto a la cantidad de metano y las tasas de conversión en $\mathrm{l} / \mathrm{kg}_{\mathrm{Sv}}$, la experiencia a $20^{\circ} \mathrm{C}$ resulta una opción aceptable, pues las diferencias no son grandes respecto a los valores obtenidos a $30^{\circ}$. 


\subsubsection{Codigestión: Fracción orgánica domiciliaria y estiércol vacuno.}

En todo establecimiento rural se cuenta con residuos pecuarios (estiércol) y también con orgánicos domiciliarios (FOD) en menor cantidad. Esto permite aprovechar y realizar la digestión de ambos residuos, codigestión. En régimen mesofílico esta mezcla resulta exitosa (Brinkman, 1999), dado que uno es rico en nitrógeno y el otro en carbono, pudiendo realizarse una adecuada mezcla de ellos, de modo de obtener una óptima relación carbono/nitrógeno, siendo éste un parámetro importante.

La fracción orgánica domiciliaria (FOD) de los residuos, también denominada FORSU, Fracción Orgánica de Residuos Sólidos Urbanos, posee una baja alcalinidad. Esto puede compensarse en principio con los pecuarios, de no ser así, es necesario atender a las variaciones del $\mathrm{pH}$ dada la falta del efecto tampón; puesto que la falta de compuestos carbonatados propicia cambios más bruscos en el pH. De esta manera es conveniente tratar al residuo (FOD) con alguna solución alcalina o amortiguante.

Se utiliza una solución amortiguante cuando no es suficiente la alcalinidad del medio para atenuar las variaciones del $\mathrm{pH}$. En este ensayo se utiliza dos tipos de soluciones el carbonato ácido de sodio $\left(\mathrm{NaHCO}_{3}\right)$ y de carbonato de calcio $\left(\mathrm{CaCO}_{3}\right)$.

En esta experiencia se utilizan recipientes de 2 litros de capacidad para trabajar con mayor comodidad, Figura 4.9.

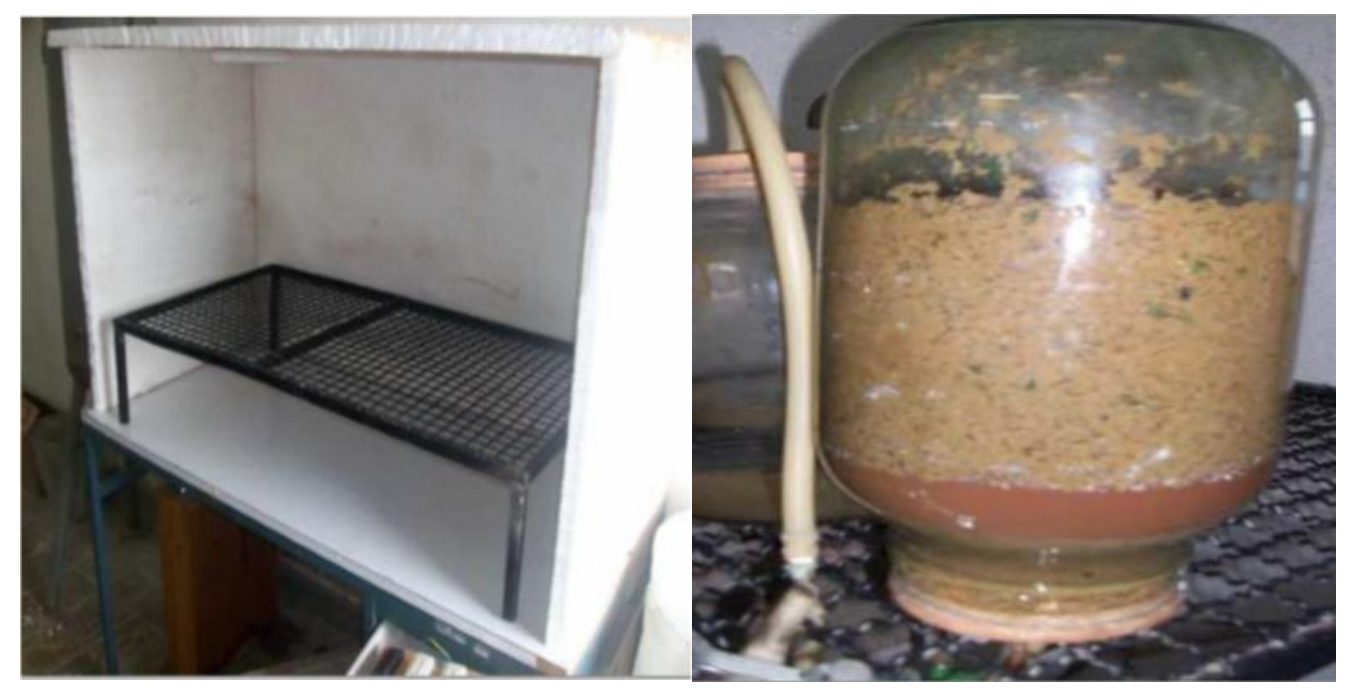

Figura 4.9. Imagen de la cámara con la parrilla y el digestor apoyado sobre ella. Fuente: Elaboración propia

Se construye una cámara con poliestireno expandido con una parrilla metálica en su interior. La parrilla permite afirmar los recipientes con la abertura hacia abajo según indica la Figura 4.9. 


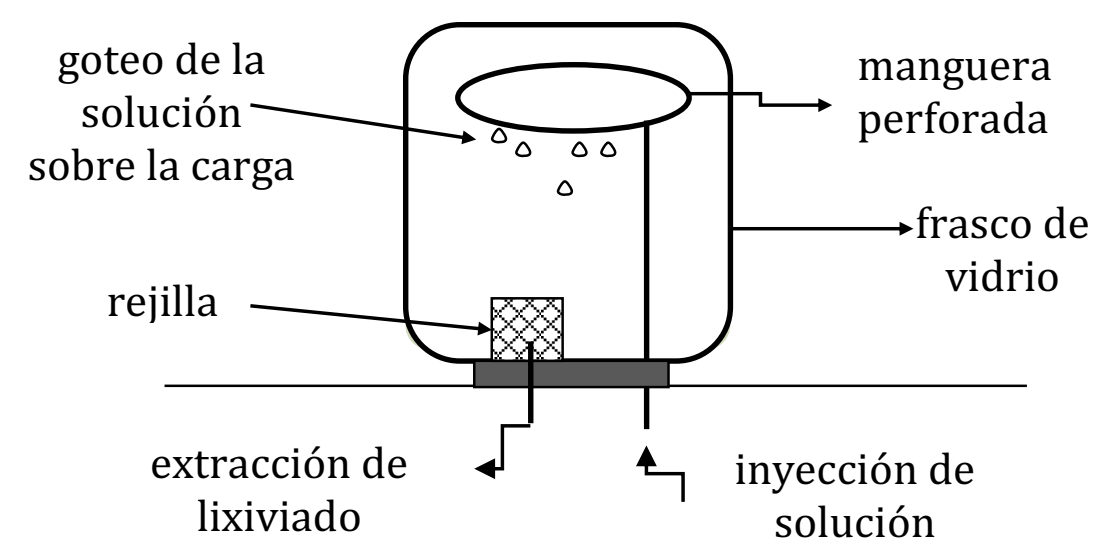

Figura 4.10. Esquema del ensayo de codigestión.

Fuente: Elaboración propia.

Se introduce una manguera en el recipiente por donde se le inyecta la solución amortiguante. La manguera se encuentra perforada en su interior para que la solución gotee sobre toda la carga orgánica. Por otra salida se extrae el líquido lixiviado, Figura 4.10.

La fracción orgánica domiciliaria utilizada contiene en su mayoría restos de frutas y verduras. Se realiza una caracterización química de muestras de FOD. Se presenta en la Tabla $4.5 \mathrm{el} \mathrm{pH}$, la alcalinidad y los ácidos grasos para dos muestras.

Tabla 4.5. pH, alcalinidad (Alk) y ácidos grasos (AGV) de dos muestras diferentes de FOD.

\begin{tabular}{|c|c|c|c|}
\hline $\begin{array}{c}\text { Muestra } \\
\text { FOD }\end{array}$ & pH & $\begin{array}{c}\text { Alk } \\
\left.\text { (mg CaCO}_{3} / \mathbf{l}\right)\end{array}$ & $\begin{array}{c}\text { AGV } \\
\left.\text { (mg CaCO }_{3} / \mathbf{l}\right)\end{array}$ \\
\hline $\mathbf{1}$ & 6,07 & 120 & 400 \\
$\mathbf{2}$ & 6,45 & 240 & 192 \\
\hline
\end{tabular}

Fuente: Elaboración propia.

Se observa para ambas muestras un $\mathrm{pH}$ por debajo de la neutralidad y una alcalinidad bastante baja en comparación con el estiércol vacuno, 710-775 mg CaCO $3 / 1$ (Tabla 4.1). Por lo tanto, es recomendable agregarle una cierta cantidad de una solución buffer a fin de elevar el $\mathrm{pH}$ y la alcalinidad. 
Se analiza la incidencia en el pH, la Alk y los AGV cuando se le agrega a la muestra 1, soluciones buffer tal como bicarbonato ácido de sodio $\mathrm{NaHCO}_{3} 0,1 \mathrm{~N}$ y carbonato de calcio $\mathrm{CaCO}_{3}$ al $5 \%$ de p/v. Los resultados se presentan en la Tabla 4.6.

Tabla 4.6. Muestras de FOD con soluciones de $\mathrm{NaHCO}_{3}$ y $\mathrm{CaCO}_{3}$.

\begin{tabular}{|l|c|c|c|}
\hline & $\mathbf{p H}$ & $\begin{array}{c}\text { Alk } \\
\left(\mathrm{mg} \mathrm{CaCO}_{3} / \mathbf{l}\right)\end{array}$ & $\begin{array}{c}\mathbf{A G V} \\
\left(\mathrm{mg} \mathrm{CaCO}_{3} / \mathbf{l}\right)\end{array}$ \\
\hline $\mathrm{NaHCO}_{3}$ & 8,09 & 280 & 96 \\
$\mathrm{CaCO}_{3}$ & 8,28 & 320 & 96 \\
\hline Sin solución buffer & 6,07 & 120 & 400 \\
\hline
\end{tabular}

Fuente: Elaboración propia.

En ambos casos tanto el pH como la alcalinidad (Alk) se ven aumentados, lo que resulta conveniente dado que cuando se somete la FOD a digestión anaeróbica hay una tendencia hacia la acidez y el aumento de los ácidos grasos volátiles (AGV). En general la Alk y los AGV presentan en su comportamiento valores inversos. Si la alcalinidad es baja, se debe a la poca presencia de compuestos carbonatados y esto facilita la acumulación de los ácidos grasos, a un pH bajo. Por el contrario, cuando aumenta el $\mathrm{pH}$ por agregado de $\mathrm{CaCO}_{3}$ se neutraliza parte de los ácidos grasos volátiles (AGV), produciendo una disminución de éstos y aumentando la alcalinidad del medio.

Se presenta la caracterización físico-química de la mezcla de 70\% de estiércol vacuno $(1,3835 \mathrm{~kg})$ y $30 \%$ de residuos orgánicos domiciliarios (FOD) $(0,5895 \mathrm{~kg})$ en la Tabla 4.7 .

Tabla 4.7. Caracterización físico-química de la mezcla de estiércol vacuno y FOD (70\% estiércol y 30\% FOD).

\begin{tabular}{|c|c|c|c|c|c|}
\hline $\mathbf{p H}$ & $\mathbf{\% S T}$ & $\mathbf{\% S V}$ & $\left.\begin{array}{c}\text { Alk } \\
(\mathbf{m g ~ C a C O}\end{array} \mathbf{/ l}\right)$ & $\begin{array}{c}\text { AGV } \\
\left(\mathbf{m g ~ C a C O}_{3} / \mathbf{l}\right)\end{array}$ & $\begin{array}{c}\mathbf{T} \\
\mathbf{(}\end{array}$ \\
\hline 7,74 & 10,2 & 76 & 500 & 300 & 37 \\
\hline
\end{tabular}

Fuente: Elaboración propia.

Se observa un $\mathrm{pH}$ por arriba de la neutralidad, una alcalinidad más elevada y por debajo de este valor los ácidos grasos volátiles. Esto es conveniente puesto que generalmente el proceso tiende a acidificarse. La temperatura del ensayo se mantuvo 
en $37^{\circ} \mathrm{C}$. Se presenta en la Figura 4.11 el volumen de biogás y el de metano en litros por kilogramos de sólidos volátiles.

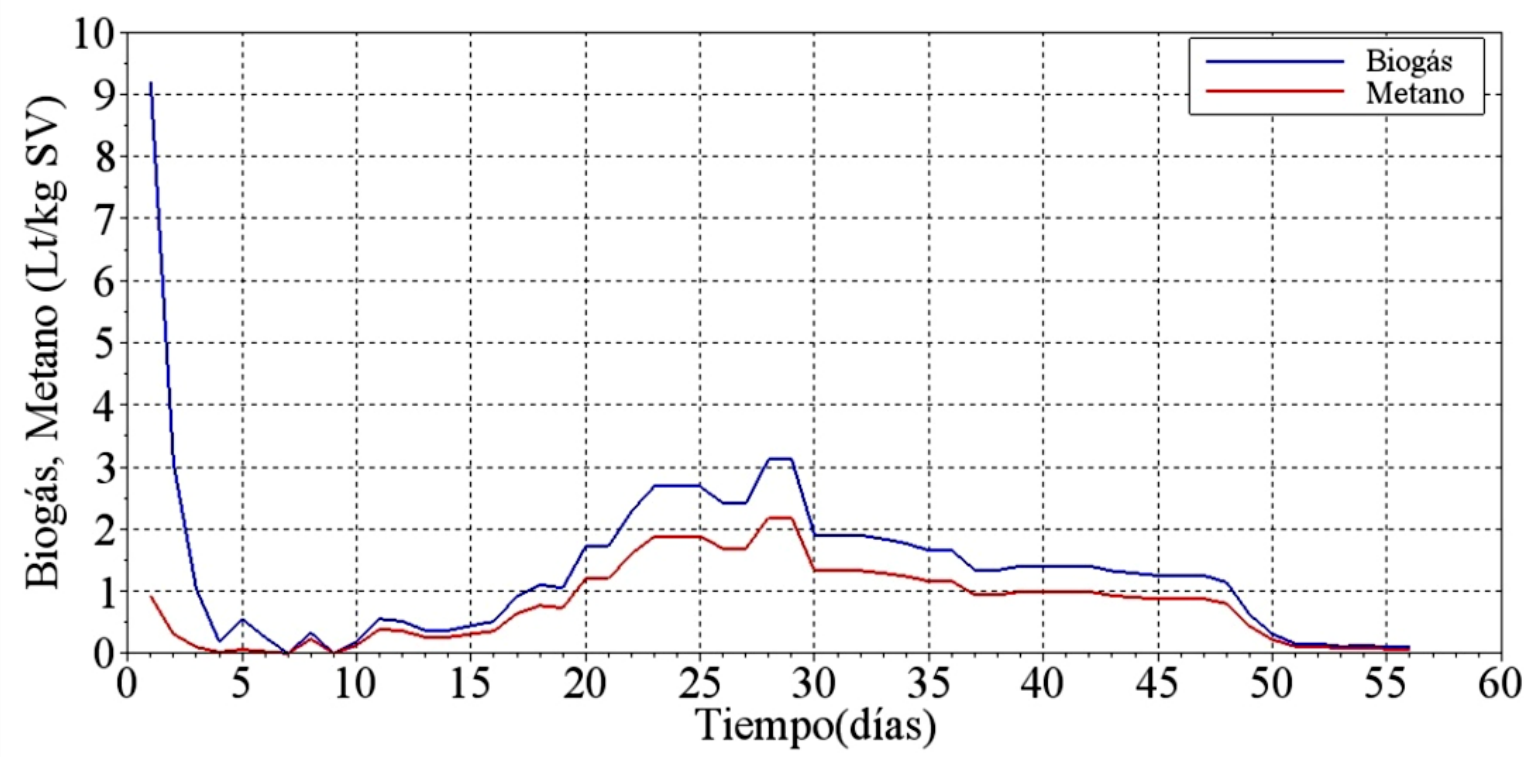

Figura 4.11. Volumen diario de biogás (azul) y de metano (rojo) en litros por kilogramos de $\mathrm{SV}$ a $37^{\circ} \mathrm{C}$.

Fuente: Elaboración propia.

Los volúmenes de biogás medidos variaron de acuerdo a la temperatura. A mayor temperatura, fue mayor el volumen total de metano. Inicialmente la producción de biogás es grande (curva azul); sin embargo, ésta contiene solo un pequeño porcentaje de metano (curva roja) que no llega al $20 \%$. No es posible una combustión del mismo a menos que se elimine el dióxido de carbono. Luego empieza a decrecer hasta hacerse cero en el día 7. Desde el día 9 comienza a aumentar progresivamente hasta llegar a un máximo de 3 litros por kilogramo de SV en el día 29. A partir de este día y hasta el día 52 la producción fue decreciendo. La producción acumulada de metano alcanza los $52 \mathrm{l} / \mathrm{kg}_{\mathrm{sv}}$ en 55 días.

Para determinar la alcalinidad de la muestra se vierte sobre ella cierta cantidad de ácido fuerte, a fin de llevarla a un pH de 4,5 o 4,0. Con el volumen de ácido utilizado se calcula dicha alcalinidad, según se ha expresado en la ecuación 4.4. Se toman dos valores de pH para determinar cual resulta un mejor indicador de los momentos críticos del ensayo. 


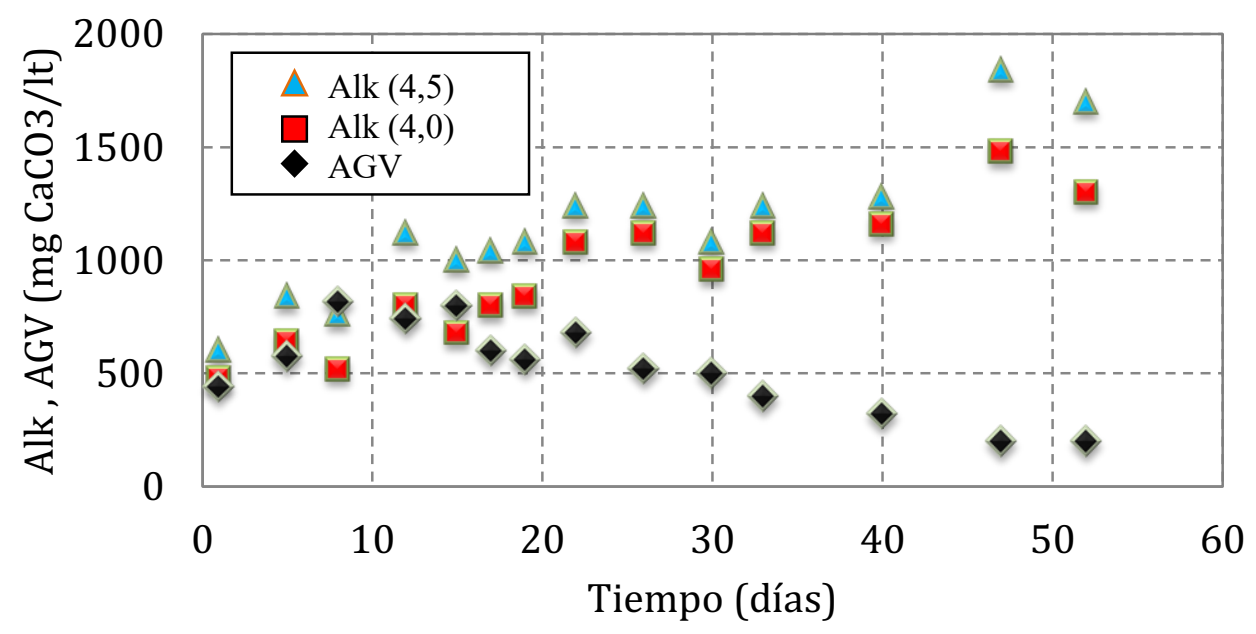

Figura 4.12. Alcalinidad a pH de 4,5 y 4,0 y AGV en $\mathrm{mg} \mathrm{CaCO}_{3} /$ litro, ensayo de codigestión.

Fuente: Elaboración propia.

En la figura 4.12 se presentan los valores de alcalinidad a pH final 4,5 y 4,0, en color azul y rojo respectivamente, también se incluye negro los ácidos grasos volátiles (AGV).

Al inicio se observa que ambas curvas de alcalinidad superan a los AGV y en general se mantiene así en todo el ensayo excepto en dos momentos en que estos son mayores a la Alk (a 4,5). Esto coincide con una disminución en el valor de $\mathrm{pH}$ tal como se observa en la Figura 4.13 en los días 8 (donde los AGV son mayores a ambos valores de la Alk) y 15 (donde los AGV son mayores solo a la Alk a 4,0).

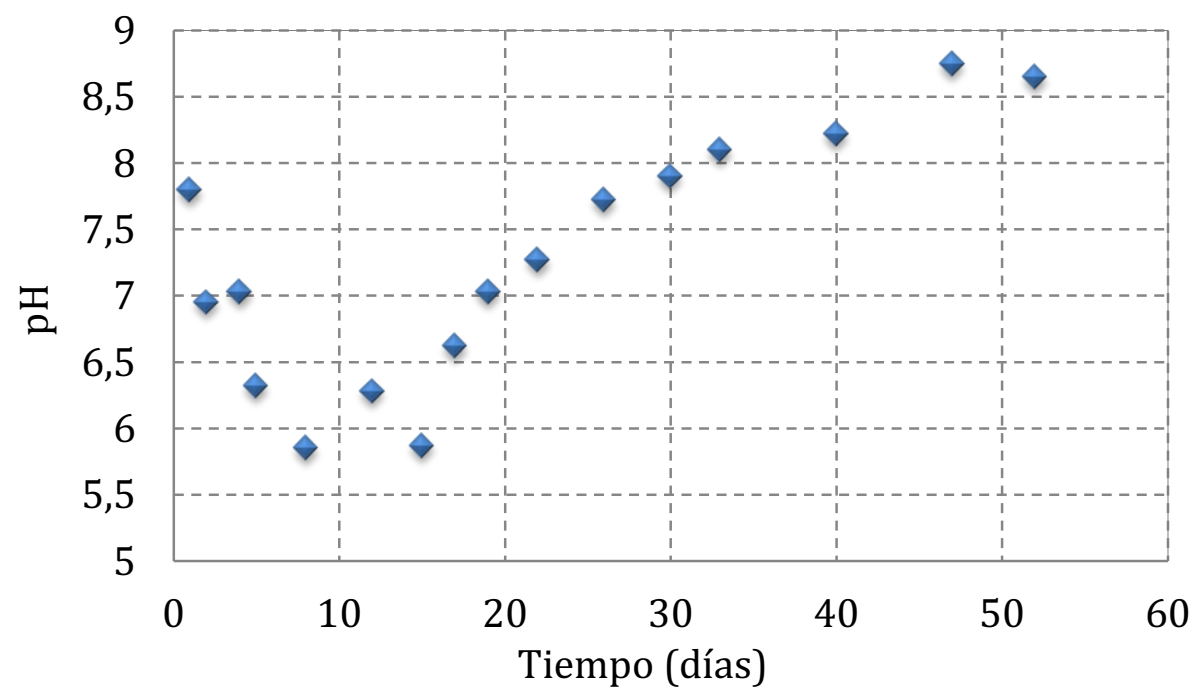

Figura 4.13 Variación temporal del pH. Ensayo de codigestión.

Fuente: Elaboración propia. 
El pH varía en el rango 5,8 a 8,7 durante este ensayo. Entre los días 7 y 19 se mantiene por debajo del valor neutro de 7. Al final del ensayo el pH logra alcanzar valores muy por encima de los 7, lo que puede explicarse por un exceso del volumen de la solución amortiguante.

\subsection{Discusión de los resultados.}

Se realizan diversos ensayos de laboratorio con el fin de evaluar el rendimiento de las muestras de residuos pecuarios (estiércol) y fracción orgánica domiciliaria (FOD), utilizando estiércol vacuno a diferentes temperaturas y una mezcla con residuos sólidos orgánicos domiciliarios.

El estiércol vacuno no presenta dificultades en su manejo. Los volúmenes de biogás medidos variaron de acuerdo a la temperatura. No se observan diferencias significativas en el volumen acumulado total para los ensayos a $20^{\circ}$ y $30^{\circ} \mathrm{C}$. A mayor temperatura, fue mayor el volumen total de metano. El porcentaje de metano promedio obtenido se aproxima a: $65 \%$ a $20^{\circ}, 68 \%$ a $30^{\circ} \mathrm{C}$ y $70 \%$ a $37^{\circ} \mathrm{C}$.

Los valores acumulados son: 80 y $81,57 \mathrm{l} / \mathrm{kg}_{\mathrm{Sv}}$ a $20^{\circ} \mathrm{C}, 98,7$ y $87,9 \mathrm{l} / \mathrm{kg}_{\mathrm{sv}}$ a $30^{\circ} \mathrm{C}$ y $223,1 \mathrm{l}$ y $202,3 / \mathrm{kg}_{\mathrm{sv}}$ a $37^{\circ} \mathrm{C}$.

Si se analiza el ensayo considerando la cantidad de metano y las tasas de conversión en $\mathrm{l} / \mathrm{kg}_{\mathrm{sv}}$, la experiencia a $20^{\circ} \mathrm{C}$ resulta una opción aceptable, pues las diferencias no son grandes respecto a los valores obtenidos a $30^{\circ} \mathrm{C}$.

Los tiempos de retención del estiércol vacuno en los ensayos difieren bastante. Los valores promedios son: 97 días a $20^{\circ} \mathrm{C}, 50$ días a $30^{\circ} \mathrm{C}$ y 53 días a $37^{\circ} \mathrm{C}$. Este resulta ser el punto de mayor desventaja para el ensayo a menor temperatura, pues el tiempo que se necesita para llegar al volumen medido es casi el doble respecto a los demás.

\subsection{Conclusiones.}

Pensando en una planta de tratamiento por digestión anaeróbica de gran volumen, operar a $20^{\circ} \mathrm{C}$ es una buena opción, ya que requerirá una inversión menor en energía para ser calefaccionada, aunque una retención hidráulica de 100 días sería desventajosa. Si la planta operara a $37^{\circ} \mathrm{C}$ se obtendría más metano y a la mitad del periodo de retención, aunque la energía invertida en mantener esta temperatura sería mayor.

Cuando se trata de fracción orgánica domiciliaria el ensayo presenta mayores dificultades. Si bien posee un porcentaje grande de estiércol vacuno (70\%), éste debe controlarse con regularidad. La alcalinidad de la carga se controla con una solución buffer, debiéndose tener mayor control al inicio de la experiencia. De no hacerse esto, 
es probable que no prospere la biodigestión- por acumulación de ácidos grasos (AGV). Es necesaria una supervisión controlando las variaciones de AGV, alcalinidad y pH.

Se advierte que una planta de codigestión de gran envergadura funcionaría mejor en modo continuo, pues la etapa inicial del proceso de digestión es crítica, dado que necesita ser supervisada a fin de controlar el $\mathrm{pH}$, la alcalinidad y los AGV.

En base a estas experiencias en laboratorio se decidió operar a $20^{\circ} \mathrm{C}$ seleccionando un periodo de retención de 120 días. En las experiencias con el prototipo del digestor anaeróbico enterrado (Capítulo 9) se operará a esta temperatura. No se practicará Codigestión. 


\section{CAPITULO 5}

Cálculo De la Difusividad Térmica De Un Aislante Construido Con Material Descartable. MÉtodo De Diferencias

FINITAS. 


\subsection{Introducción.}

La reutilización de materiales descartables favorece considerablemente la reducción del volumen de los residuos generados diariamente. Son diversos los métodos empleados y los objetos útiles que surgen de una correcta reutilización o de procesos creativos de reciclajes. Las botellas de PET (politereftalato de etileno) por ejemplo, son ampliamente utilizadas con diversos fines, siendo la construcción de viviendas uno de ellos.

En particular, en este trabajo se propone el empleo de botellas PET descartables rellenas con viruta de madera seca, para ser usadas como aislante térmico de reactores anaeróbicos.

Una botella PET vacía y llena de aire constituye un buen aislante térmico dado que el aire lo es, aunque la transmisión de calor por convección se ve favorecida cuando hay un espacio suficiente. Por esta razón, se utilizan materiales con cierta porosidad capaz de inmovilizar el aire y restringirlo en diminutas celdas o compartimientos. La viruta de madera cumple esta función, mientras que la botella PET la protege de la humedad.

En el mercado se cuenta con diferentes materiales para aislación térmica de diferentes precios. La aislación elegida dependerá de las temperaturas alcanzadas en el proceso de estudio y por lo tanto su desempeño. Existen cuatro rangos de temperaturas para las aislaciones térmicas (Cao, 2011): criogénico $\left(-260^{\circ}\right.$ a $\left.-100^{\circ} \mathrm{C}\right)$, bajas temperaturas $\left(-100^{\circ}\right.$ a $0^{\circ} \mathrm{C}$ ), intermedio $\left(0^{\circ}\right.$ a $\left.550^{\circ} \mathrm{C}\right)$ y altas temperaturas (más de $\left.550^{\circ} \mathrm{C}\right)$. En este trabajo nos ubicamos en el rango intermedio.

Entre las características que debe reunir un buen aislante es una adecuada resistencia mecánica y una efectiva barrera que impida la penetración de humedad.

Se presenta en la Tabla 5.1, el rango de temperatura, la conductividad térmica y la densidad de algunos materiales típicos.

Las botellas PET utilizadas en este capítulo tienen una densidad, temperatura de fusión y conductividad térmica de $1370 \mathrm{~kg} / \mathrm{m}^{3}, 260^{\circ} \mathrm{C}$ y $0,24 \mathrm{~W} / \mathrm{mK}$ respectivamente. En los trabajos: Evaluación de un aislamiento térmico construido a partir de materiales descartables para su utilización en digestores anaeróbicos (Morales et al., 2014) y Propuesta de un material descartable como aislante térmico: aplicación a un digestor anaeróbico enterrado. (Morales et al., 2016) se detalla el estudio de la aislación térmica que se propone en esta tesis y su aplicación a un digestor anaeróbico. Los resultados son presentados en este capítulo. 
Tabla 5.1. Rango de temperatura, conductividad y densidad de diferentes materiales.

\begin{tabular}{|c|c|c|c|}
\hline Material & $\begin{array}{c}\text { Rango de } \\
\text { temperatura } \\
\left({ }^{\circ} \mathrm{C}\right)\end{array}$ & $\begin{array}{c}\text { Conductividad } \\
\mathbf{k} \\
(\mathrm{W} / \mathrm{mK})\end{array}$ & $\begin{array}{c}\text { Densidad } \\
\gamma \\
\left(\mathrm{kg} / \mathrm{m}^{3}\right)\end{array}$ \\
\hline $\begin{array}{l}\text { Colchoneta de Fibra de } \\
\text { vidrio }\end{array}$ & -150 a 200 & 0,024 a 0,085 & 9 a 45 \\
\hline $\begin{array}{l}\text { Colchoneta de fibra } \\
\text { mineral }\end{array}$ & Hasta 750 & 0,040 a 0,050 & 110 a 170 \\
\hline Espuma uretano & -150 a 100 & 0,015 a 0,020 & 25 a 45 \\
\hline $\begin{array}{ll}\text { Fibra } & \text { mineral } \\
\text { premoldeada } & \\
\end{array}$ & Hasta 1000 & 0,051 a 0,130 & 9 a 45 \\
\hline $\begin{array}{l}\text { Paneles de fibra de } \\
\text { vidrio }\end{array}$ & 0 a 450 & 0,033 a 0,080 & 35 a 90 \\
\hline Silicato de calcio & 250 a 650 & 0,031 a 0,120 & 90 a 150 \\
\hline Vidrio celular & -200 a 250 & 0,028 a 0,100 & 100 a 140 \\
\hline Plástico PET & hasta 260 & 0,240 & 1.370 \\
\hline
\end{tabular}

Fuente: (Cao E., 2011).

En este capítulo se realizan mediciones de temperatura por medio de sensores en diferentes regiones del arreglo con botellas. Utilizando la ecuación de difusión del calor se determina la difusividad térmica utilizando el método de diferencias finitas Con el valor promedio calculado se estima la temperatura en el interior de la botella y se compara con el valor medido. Dado que hay una buena congruencia entre los datos se determina así la difusividad térmica que se utilizará en cálculos en capítulos posteriores.

\subsection{Materiales y métodos: medidas de temperatura.}

En ensayos de laboratorio se estudiaron las botellas de PET con aire y con viruta, como aislante térmico. Para ello se registraron medidas de temperaturas con termopares tipo $\mathrm{T}$, construidos en cobre y constantan, los que se anexaron a módulos ADAM de adquisición de datos que conectados a una PC permitieron el procesamiento posterior de las medidas realizadas.

Con el fin de comparar el comportamiento de la aislación, se usaron botellas descartables con y sin viruta. Se realiza una comparación entre ambas situaciones para determinar cuál resulta ser mejor aislante térmico. Se disponen las botellas 
sobre una placa calefactora de temperatura controlable, tal como se muestra en la Figura 5.1. En una experiencia se ubicaron los sensores de temperatura y se miden las temperaturas por medio de sensores ubicados en diversos puntos de la botella, a saber:

- ambiente: en el espacio del laboratorio.

- superior: en la parte superior de las botellas.

- medio: en el interior de las botellas en el medio

- inferior: en la parte inferior de la botella ubicada en contacto con la placa calefactora.
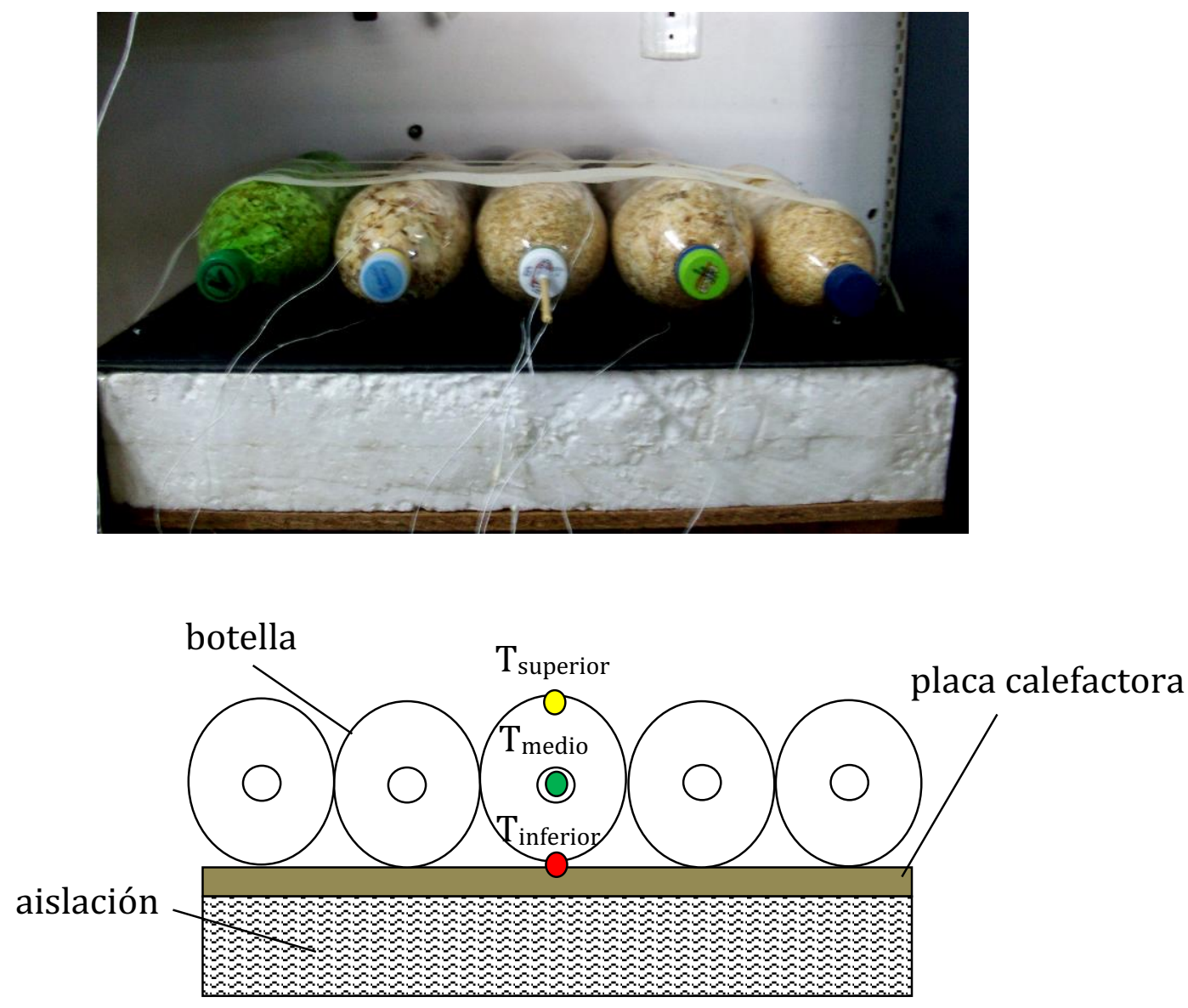

Figura 5.1. Imagen y esquema de la experiencia con las botellas.

Ubicación de los termopares (superior, medio e inferior)

Fuente: Elaboración propia.

Se miden las temperaturas que se alcanza en distintos puntos de la botella en ambos casos (con y sin viruta) con la placa calefactora llegando a los $36^{\circ} \mathrm{C}$. Cabe destacar que en las experiencias con un digestor anaeróbico enterrado se operará el mismo a temperaturas menores. 


\subsubsection{Resultados: medidas de temperatura.}

En la Figura 5.2 se presenta la variación de la temperatura en el tiempo, para ambos casos: botellas con viruta (Figura 5.2a) y sin ella (Figura 5.2b). La temperatura en color rojo es la inferior, en verde la media (dentro de la botella), en azul la ambiente, y en amarillo la superior. El periodo de tiempo es de 24 y $20 \mathrm{hs}$ en las experiencias de las botellas con viruta y sin ella respectivamente.

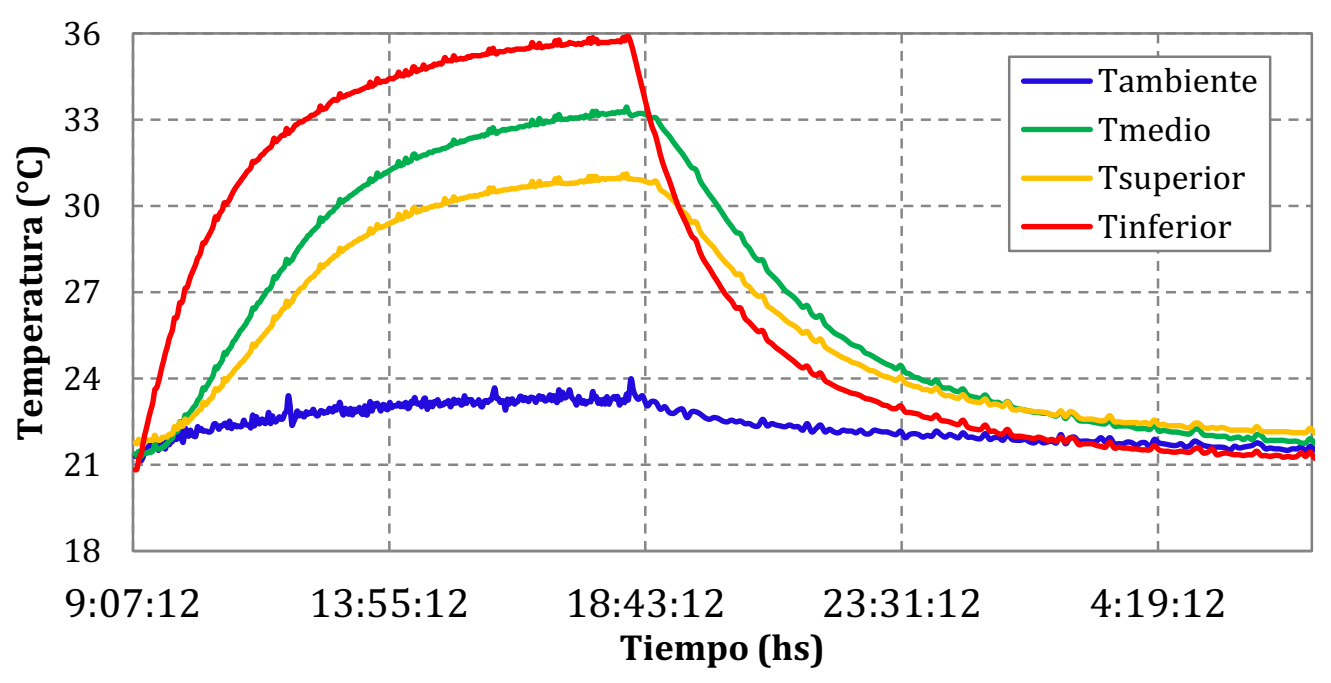

(a) botella con viruta.

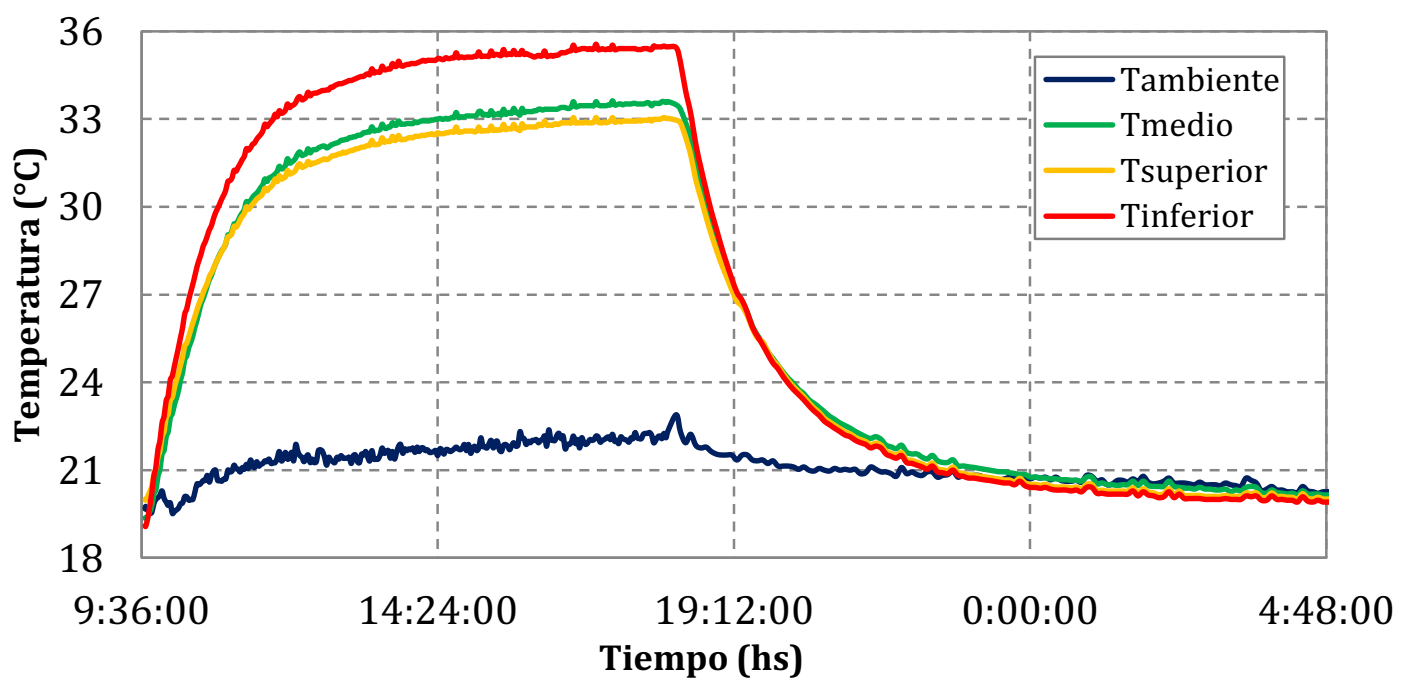

(b) botella sin viruta.

Figura 5.2. Dependencia temporal de la temperatura dentro de las botellas con y sin viruta.

Fuente: Elaboración propia. 
En ambas gráficas las temperaturas iniciales coinciden con la ambiente, luego de unas horas la placa comienza a calentarse y las temperaturas aumentan progresivamente. Cuando la temperatura inferior (en contacto con la placa) alcanza los $36^{\circ} \mathrm{C}$ aproximadamente se corta el calentamiento y la placa comienza a enfriarse. Se aclara, que los ensayos de digestión se practicarán a temperaturas menores a ésta.

En ambas graficas se observa una diferencia de temperatura entre la inferior (color rojo) y la superior (color amarillo), siendo mayor cuando las botellas contienen viruta, lo que indica una menor conducción de calor y por tanto una mayor capacidad de aislación.

Tabla 5.2. Registro de temperaturas en ambos ensayos de laboratorio.

\begin{tabular}{|cccc|cccc|}
\hline \multicolumn{4}{|c|}{ Botella con viruta } & \multicolumn{4}{c|}{ Botella sin viruta } \\
\hline inferior & media & superior & $\Delta \mathrm{T}$ & inferior & media & superior & $\Delta \mathrm{T}$ \\
30,1 & 25,2 & 24,7 & 5,4 & 30,1 & 28,3 & 28,3 & 1,8 \\
33,0 & 28,6 & 27,4 & 5,6 & 33,0 & 31,2 & 30,8 & 2,2 \\
35,4 & 32,5 & 30,9 & 4,5 & 35,4 & 33,5 & 32,9 & 2,5 \\
\hline
\end{tabular}

Fuente: Elaboración propia.

A fin de comparar ambas situaciones, se presenta en la Tabla 5.2, las temperaturas durante el proceso de calentamiento, cuando la temperatura de la superficie inferior está entre $30,1^{\circ}$ y $35,4^{\circ} \mathrm{C}$. Con $\Delta \mathrm{T}$ se representa la diferencia de temperatura entre la superficie superior y la inferior en ambas situaciones (con y sin viruta). Se observa que esta diferencia $\Delta \mathrm{T}$ es mayor cuando la botella contiene viruta. Por ejemplo, cuando la superficie inferior es $33,0^{\circ} \mathrm{C}$ en ambos casos, la diferencia de temperatura $\Delta \mathrm{T}$ es de $5,6^{\circ} \mathrm{C}$ con viruta y de $2,2^{\circ} \mathrm{C}$ sin ella. Por ello se decidió la utilización de botellas con viruta.

\subsection{Materiales y método: Cálculo de la difusividad térmica.}

La difusividad térmica $\alpha_{d}$ es una propiedad intrínseca de cada material que caracteriza su conducción térmica en condiciones no estacionarias. Permite saber cómo reaccionará cada material frente a una diferencia de temperatura. Conociendo la conductividad térmica $k$, el calor específico $C_{p}$ y la densidad del material $\rho$ se calcula $\alpha_{d}$, mediante la ecuación 5.1.

$$
\alpha_{d}=\frac{k}{\rho \cdot C_{p}}
$$


En condiciones no estacionarias el valor de la difusividad térmica varía con el tiempo. La difusividad está presente en la ecuación de difusión del calor (ecuación diferencial de Fourier de la conducción del calor), ecuación 5.2, donde $T$ es la temperatura, $t$ el tiempo y $x$ la variable espacial.

$$
\frac{\partial T(x, t)}{\partial t}=\alpha_{d} \frac{\partial^{2} T(x, t)}{\partial x^{2}}
$$

Una forma de calcular $\alpha_{d}$ es por medio de la ecuación 5,2, convenientemente discretizada (Incropera, 1999).

\subsubsection{Simulación numérica. Ecuaciones en diferencias finitas.}

Una simulación numérica se utiliza para imitar y estudiar en forma detallada un problema físico real. La herramienta de trabajo que se utiliza para desarrollar la simulación es el cálculo numérico y el nexo entre dicho cálculo y el fenómeno físico lo constituye un modelo matemático.

Se pueden citar en general cuatro pasos básicos a la hora de trabajar numéricamente un problema.

1) Determinación del problema físico: Se analiza que fenómeno está en juego; cual es la ley que lo gobierna; cuales son las variables, parámetros y constantes que definen el sistema; qué se conoce y qué se desea conocer.

2) Formulación y análisis del modelo matemático: Se traduce coherentemente lo que ocurre en el fenómeno físico a través un sistema de ecuaciones matemáticas. Se determina cuáles son las ecuaciones principales y cuáles las condiciones de contorno e iniciales del problema.

3) Discretización del problema: Se realiza la discretización de las ecuaciones. Esta es una característica propia del método de aproximación en diferencias finitas. Se aproxima el problema al reemplazar las ecuaciones diferenciales puestas en juego en él, por diferencias finitas (Gallardo J, 2018).

4) Implementación de un código computacional: Se desarrolla un algoritmo de computación bajo algún lenguaje de programación. En el mismo se vuelcan las ecuaciones discretizadas y se da solución a las mismas.

\subsubsection{Aproximación en diferencias finitas.}

Entre los métodos numéricos más utilizados se encuentra el de Aproximación en diferencias finitas. La técnica que regula este método consiste en reemplazar las 
derivadas presentes en el sistema de ecuaciones por diferencias finitas (Gallardo J, 2018).

El espacio continuo en el cual se desarrolla el fenómeno se reemplaza por un reticulado a partir del cual dicho espacio físico queda discretizado en una serie de puntos llamados nodos. Estos nodos son los puntos de intersección entre las líneas (horizontales y verticales) que aparecen en la grilla. Aunque no existen reglas absolutas para fabricar dicha grilla, la ecuación de conducción asume una forma más simple cuando las líneas de la misma son paralelas a las fronteras. Las fronteras en sí mismas son líneas pertenecientes a la grilla (Bejan, 1993). La figura 5.3 muestra parte de una grilla. Se observa como la intersección entre dos líneas genera un nodo. El subíndice $i$ hace referencia al espacio, mientras que $j$ al tiempo.

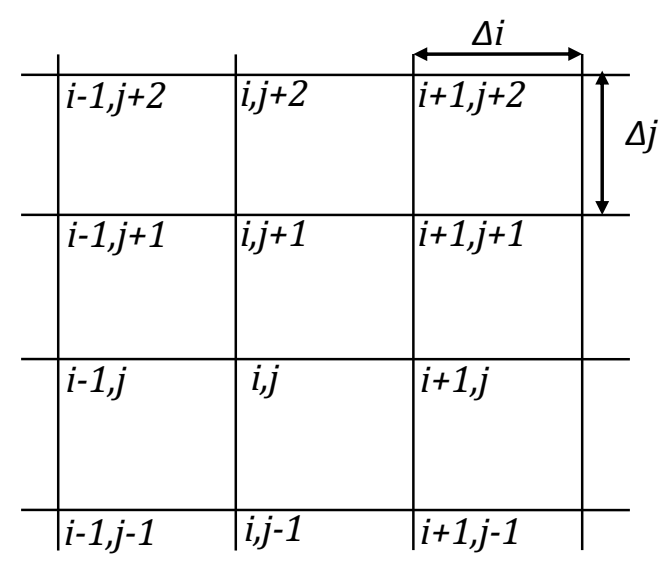

Figura 5.3. Puntos de un sector de la grilla.

Fuente: Bejan (1993).

El punto del espacio $(i, j)$ que pertenece a la grilla se encuentra rodeado de otros puntos vecinos. Teniendo en cuenta estos puntos y el desarrollo en serie de Taylor, se puede obtener el siguiente esquema de fórmulas en diferencias finitas correspondientes a derivadas de primer y segundo orden en $(i, j)$, donde $O(\Delta x)$ y $O\left(\Delta x^{2}\right)$ representan todos los términos de orden superior, es decir, los que corresponden a las derivadas de la segunda en adelante de la serie de Taylor, por ejemplo, $O(\Delta x)$ en la ecuación 5.3 se presenta en la 5.4.

$$
\begin{gathered}
\frac{\partial T}{\partial x}=\frac{T_{i+1, j}-T_{i, j}}{\Delta x}+O(\Delta x) \\
O(\Delta x)=\frac{\Delta x^{2}}{2} \frac{\partial^{2} T}{\partial x^{2}}+\frac{\Delta x^{3}}{6} \frac{\partial^{3} T}{\partial x^{3}}+\cdots
\end{gathered}
$$




$$
\begin{gathered}
\frac{\partial T}{\partial x}=\frac{T_{i, j}-T_{i-1, j}}{\Delta x}+O(\Delta x) \\
\frac{\partial T}{\partial x}=\frac{T_{i+1, j}-T_{i-1, j}}{2 \Delta x}+O\left(\Delta x^{2}\right) \\
\frac{\partial^{2} T(x, t)}{\partial x^{2}}=\frac{T_{i-1, j}-2 \cdot T_{i, j}+T_{i+1, j}}{(\Delta x)^{2}}+O\left(\Delta x^{2}\right)
\end{gathered}
$$

En la aproximación a diferencias finitas a las tres primeras fórmulas se las conoce como diferencias progresivas, regresivas y centrales respectivamente.

Trabajar en un problema de conducción implica determinar la distribución de temperatura en el medio continuo. Esta distribución está representada por una serie de nodos, donde cada uno de ellos simula una temperatura $T_{i, j}$. Físicamente dicha temperatura está en el nodo y en una pequeña región alrededor de él. Los índices $i$ y $j$ identifican las líneas de la grilla.

En la Figura 5.4, la pequeña región isotérmica (región sombreada) de temperatura constituye un volumen de control y se representa por un rectángulo $\Delta i \Delta j$ que tiene al punto $(i, j)$ como centro. Los flujos de calor "q" ingresan a la región por ambos sentidos $\mathrm{y}$ direcciones.

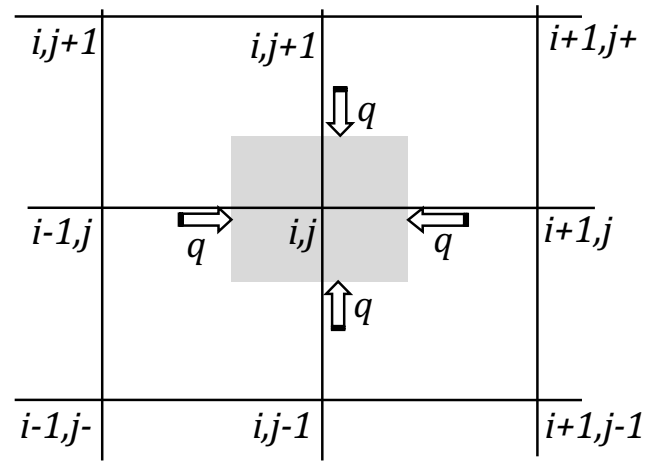

Figura 5.4. Volumen de control en un nodo de un sector de la grilla.

Fuente: Bejan (1993).

En la Figura 5.5 al eje de las ordenadas se asigna la variable temporal, mientras que al de las abscisas, la variable espacial. Los pasos temporales llegan hasta $\tau$, tiempo total de duración del proceso. La constante e representa el espesor del material a 
estudiar, $\Delta x$ y $\Delta t$ los intervalos espaciales y temporales respectivamente. Las condiciones iniciales y de contorno se indican mediante las funciones $g_{o}(t)$ y $g_{e}(t)$.

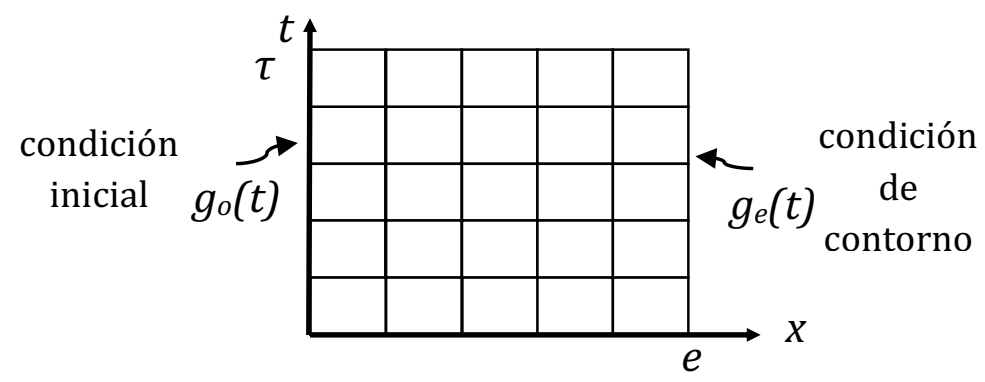

Figura 5.5. Características de la grilla de control. Fuente: Elaboración propia.

En la forma explícita se calcula la temperatura en el punto $T_{i, j}$ a partir de las temperaturas correspondientes a la posición actual, anterior y posterior en un paso temporal anterior a $j$. La Figura 5.6 muestra la situación.

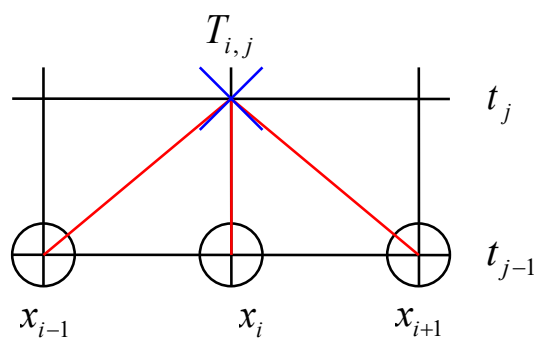

Figura 5.6. Relación entre los nodos para el cálculo de temperatura en la forma explícita.

Fuente: Elaboración propia.

La forma es llamada explícita debido a que en la ecuación de difusión discretizada aparece explícitamente la expresión de la temperatura a calcular.

De la Figura 5.5 se aprecia que para cualquier punto $(i, j)$ del reticulado no correspondiente a $i=0, i=e$ ó bien $j=0$, la distribución de temperatura se encuentra a partir de la aproximación en diferencias finitas realizada sobre la ecuación de difusión. Así se tiene:

$$
\frac{T_{x, t}-T_{x, t-1}}{\Delta t}=\alpha_{d} \frac{T_{x+1, t-1}-2 \cdot T_{x, t-1}+T_{x-1, t-1}}{\Delta x^{2}}
$$


La distribución de temperatura se encuentra a partir de la aproximación en diferencias finitas realizada sobre la ecuación de difusión térmica (ecuación 5.2). En la forma explícita se calcula la temperatura $T_{x, t}$ en el punto $x$ al tiempo $t$, a partir de las temperaturas en las posiciones $x-1, x$ y $x+1$ correspondientes al tiempo anterior $t$ 1. Conociendo estas temperaturas se calcula la difusividad térmica $\alpha_{d}$ del material bajo estudio. De la discretización surge una grilla tal como se muestra en la Figura 5.3. En la imagen central de la Figura 5.7 se indican $T_{x+1, t}, T_{x, t}, T_{x-1, t}$ sobre la botella al tiempo $t$.

En la botella se toma a $T_{x+1, t}, T_{x, t}$ y $T_{x-1, t}$ como las temperaturas en el punto superior, el medio y el inferior (en contacto con la placa), respectivamente.

En la imagen de la derecha de la Figura 5.7 se observa una grilla. Los tres puntos de la botella se expresan en un tiempo $t$, al anterior $t-1 \mathrm{y}$ al posterior $t+1$. Por ejemplo para el punto $(x, t)$, le corresponde la temperatura $T_{x, t} \mathrm{y}$ en un tiempo anterior $T_{x, t-1} \mathrm{y}$ al posterior $T_{x, t+1}$.
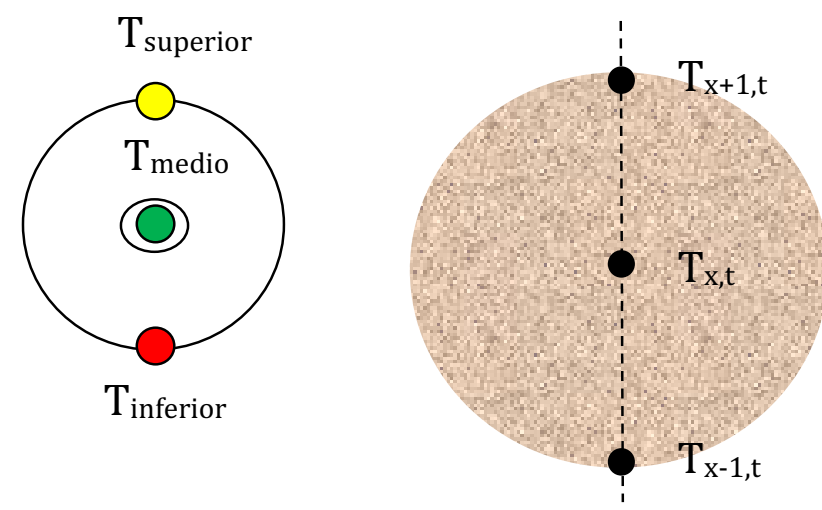

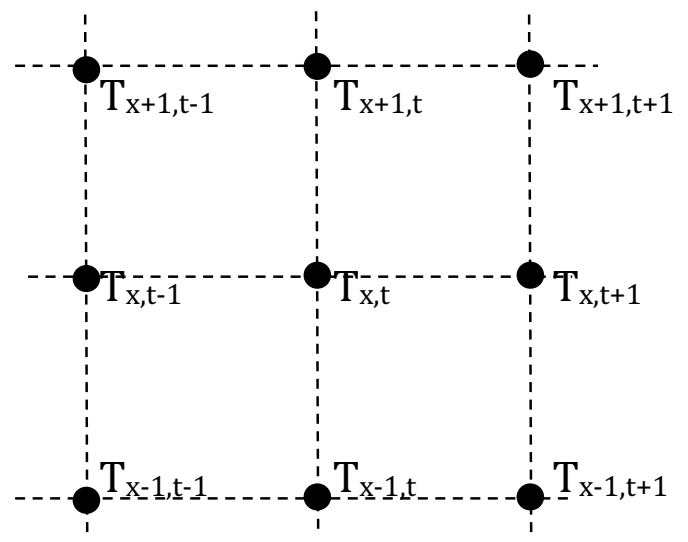

Figura 5.7 Grilla de temperaturas para la discretización de la ecuación de difusión. Fuente: Elaboración propia.

El espacio entre dos posiciones se denomina $\Delta x$ y es igual al radio de la botella: 0,05 $\mathrm{m}$ y el intervalo temporal entre medidas: 120 segundos se denomina $\Delta t$. De la ecuación 5.8, despejando $\alpha_{d}$ resulta la ecuación 5.9.

$$
\alpha_{d}=\frac{\Delta x^{2}}{\Delta t} \cdot \frac{T_{x, t}-T_{x, t-1}}{T_{x+1, t-1}-2 \cdot T_{x, t-1}+T_{x-1, t-1}}
$$




\subsubsection{Resultados y discusión: difusividad térmica.}

Los valores $T_{x, t}, T_{x+1, t}$ y $T_{x-1, t}$ se toman de las medidas realizadas, que se presentan en la Figura 5.2.a para obtener la difusividad de la botella con viruta. En cada momento se calcula la difusividad térmica en función de la temperatura media, la que se representa en la Figura 5.8.

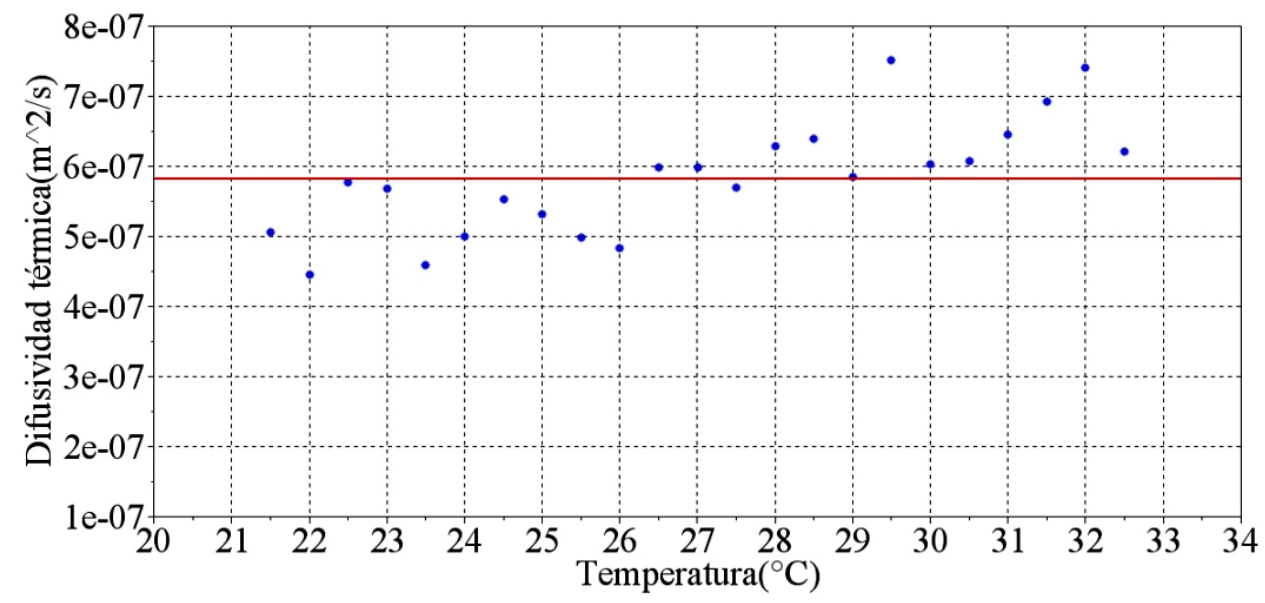

Figura 5.8. Difusividad térmica en función de la temperatura. Fuente: Elaboración propia.

Los valores de $\alpha_{d}$ se encuentran en un rango entre $4,510^{-7} \mathrm{~m}^{2} / \mathrm{s}$ y $7,510^{-7} \mathrm{~m}^{2} / \mathrm{s}$ aproximadamente, siendo $5,8210^{-7} \mathrm{~m}^{2} / \mathrm{s}$ el valor promedio que se grafica en color rojo.

Con el valor promedio de $\alpha_{d}$ y tomando como datos las temperaturas inferior y superior, se evalúa la temperatura a la mitad de la botella utilizando la ecuación de difusión discretizada. El valor calculado de esta temperatura se compara con el experimental a fin de determinar si el valor medio obtenido del cálculo de $\alpha_{d}$ (con la ecuación 5.6) es representativo de la viruta. Los resultados se muestran en la Figura 5.9 . 


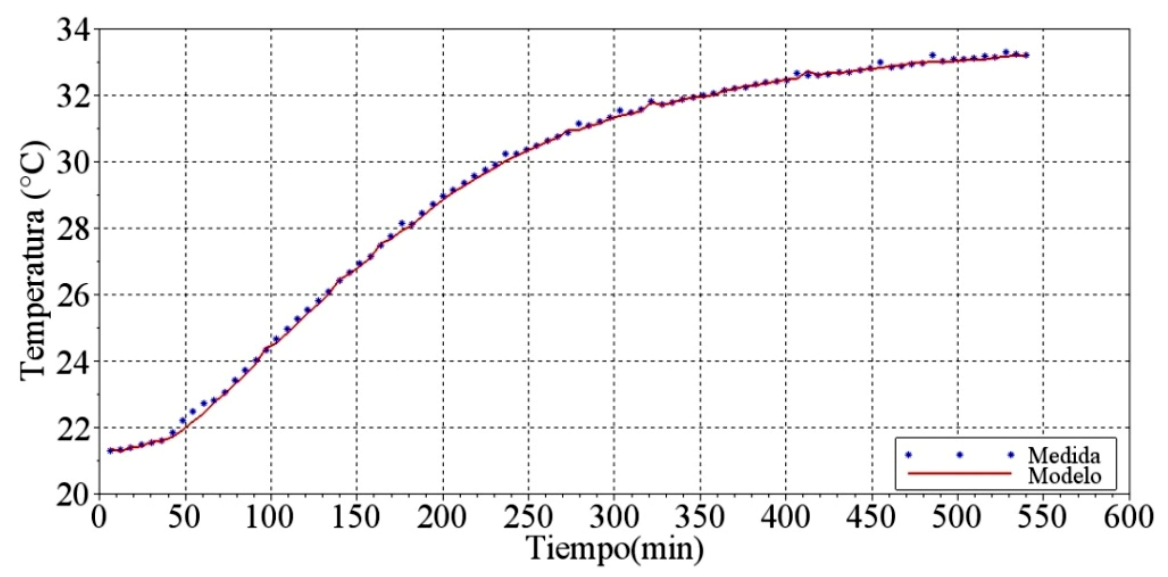

Figura 5.9. Cálculo y medida de la temperatura en el interior de la botella rellena con viruta en función del tiempo.

Fuente: Elaboración propia.

Como se aprecia en la Figura 5.9 el valor promedio de la difusividad se considera correcto para utilizarse en los modelos de cálculo que se presentarán en el Capítulo 8. En la Tabla 5.3 se presenta la difusividad térmica de diversos materiales utilizados como aislantes térmicos en la construcción.

Tabla 5.3 Difusividad térmica de algunos materiales aislantes.

\begin{tabular}{|lc|}
\hline Material & $\begin{array}{c}\text { Difusividad térmica } \\
\mathbf{1 0}-\mathbf{7}\left(\mathbf{m}^{2} / \mathbf{s}\right)\end{array}$ \\
\hline Fibra de vidrio & 6,0 \\
Espuma rígida & 4,0 \\
Poliestireno estirado $(\mathbf{r}-\mathbf{1 2})$ & 4,0 \\
Lana de vidrio & 2,3 \\
Corcho & 2,0 \\
PET con relleno de viruta & $4,5-7,5$ \\
\hline
\end{tabular}

Fuente: Incropera (1999).

El valor calculado de la difusividad térmica que se propone posee un $\alpha_{d}$ promedio de $5,8210^{-7} \mathrm{~m}^{2} / \mathrm{s}$ y se encuentra dentro del rango de los de aislantes más utilizados en la construcción indicados en la tabla 5.3 (Incropera, 1999). Dado que hay una buena 
congruencia con los datos experimentales el valor promedio de la difusividad térmica se utilizará en cálculos en capítulos posteriores.

\subsection{Discusión.}

En este capítulo se presenta la construcción y evaluación térmica de una aislación compuesta por material descartable: botellas PET rellenas con viruta de madera y sin ella, resultando ser mejores aislantes las que contienen viruta de madera.

La aislación con botellas rellenas con viruta posee excelentes propiedades como aislante térmico. Utilizando la ecuación de difusión del calor se determina la difusividad térmica mediante el Método de Diferencias Finitas.

\subsection{Conclusiones.}

La botella rellena con viruta posee dos ventajas respecto de los materiales convencionales. Por un lado, es más económico, encontrándose sin dificultad como material de descarte, tanto la botella como la viruta. Por otro lado, se encuentra protegido herméticamente de la humedad, considerando que estará expuesto a la lluvia e inclemencias del tiempo, es altamente beneficioso.

La rigidez y el tamaño de las botellas pueden constituir una desventaja, si se quiere utilizar para cubrir áreas pequeñas. Sin embargo, en la aplicación que tendrá en este trabajo no será un inconveniente, pues las paredes de los digestores construidos son extensas y contienen perfectamente a las botellas. 


\section{CAPITULO 6}

CONSTRUCCIÓN DE PROTOTIPOS DE BIODIGESTOR Y DE Su SisTema De CALEFACCión. 


\subsection{Introducción.}

Un digestor anaeróbico debe mantener su temperatura cualquiera sea su valor, tan constante como sea posible. Esto es fundamental si se desea obtener un buen rendimiento. Si se tienen en cuenta solamente las pérdidas y ganancias térmicas con el medio ambiente que rodea a un digestor de gran volumen, éste presentará poca variación de su temperatura, dada su gran masa térmica. Mientras menor sea su tamaño, se verá más afectado por estos factores externos.

Son diversos los motivos por los cuales se advierten oscilaciones de temperatura en un digestor, a saber: el ingreso de material fresco en su interior, las pérdidas de calor hacia el exterior, las que son mayores en invierno, o las ganancias en momentos de elevada radiación solar y alta temperatura ambiente. Tales oscilaciones pueden perjudicar el funcionamiento del digestor y hasta interrumpir el proceso natural de digestión. Una opción para moderar la temperatura, consiste en enterrarlo para disminuir las pérdidas.

Enterrar al digestor crea una dificultad al desagotarlo. Debe contarse con una bomba sumergible a menos que exista una pendiente cercana y así dirijir el contenido para vaciarlo por acción de la gravedad. Una solución posible, si no se cuenta con la pendiente del terreno, es preparar un terraplen para armar el digestor sobre éste. En estas condiciones, si bien se debe emplear energía para cargarlo, no se la emplea para su descarga.

La alimentación puede ser continua o no. En ambas situaciones, enterrado o por encima de la superficie, el material fresco que ingresa entra en contacto con el que está en proceso de degradación y la eficiencia del digestor se verá disminuida. Por lo tanto, siempre que sea posible es mejor alimentarlo y mantener la carga hasta agotar su capacidad de producción. En estos casos, como se verá mas adelante (Capítulo 9) será conveniente contar con más de un digestor anaeróbico.

Uno de los materiales más utilizados para su construcción es ladrillo y cemento, dada su alta durabilidad. Las cámaras sépticas y los llamados pozos negros son construidos usualmente con estos mismos materiales. Sin embargo, en los últimos años, se ofrecen diversos plásticos, que también presentan ventajas similares y superiores como alta resistencia a las sustancias químicas presentes en las aguas residuales.

En América Latina en los últimos años se hizo popular el uso de digestores anaeróbicos de bajo costo de tipo tubular flexible (Martí-Herrero, 2014). Este tipo de digestores fueron desarrollados por Preston y otros (Botero and Preston, 1987; Bui Xuan an et al., 1994). Muchos sistemas simples de tratamiento son utilizados en el mundo, diseñados para uso doméstico. Más de 50 millones de estos sistemas han sido 
implementados en economías en desarrollo (Bon and Templeton, 2011; Chen et al., 2012; Ghimire, 2013; Marti-Herrero, 2014a). En algunos países de América Latina como México, Nicaragua, Colombia, Costa Rica (Lansing et al., 2008), Perú (Ferrer et al., 2011) y Bolivia (Martí-Herrero, et al., 2014a) tienen instalada esta tecnología de bajo costo y adaptada a regiones de clima frío.

\subsection{Diseño y construcción.}

La construcción de un digestor anaeróbico requiere atender diversos aspectos técnicos: los materiales que se utilizarán, el costo y si son capaces de soportar las exigencias que les demandarán los sólidos y líquidos desechados y las inclemencias del tiempo. La inversión inicial representa un primer obstáculo a afrontar. Un biodigestor de bajo costo tendría una aceptación más rápida en el mercado.

A los efectos de determinar las dificultades y las ventajas que se presentan en su construcción se han diseñado y construido tres digestores anaeróbicos:

\section{A. digestor anaeróbico tubular flexible \\ B. digestor anaeróbico enterrado \\ C. digestor anaeróbico enterrado con mejoras}

Las características del clima influyen directamente en la temperatura del digestor y por lo tanto, en su eficiencia. La región en donde se instalaron tiene la particularidad de presentar una gran amplitud térmica diaria, la que puede superar los $25^{\circ} \mathrm{C}$, lo que interviene notablemente en el comportamiento térmico de digestores. Es necesario evaluar la temperatura del digestor antes de comenzar a operarlo.

Al primer digestor (tubular flexible- caso A), instalado en zona urbana al sur de la capital salteña, se le aplican distintas técnicas de calentamiento solar y eléctrica a fin de conocer su efectividad. Con el armado del segundo, (digestor enterrado- caso B) se pone en práctica el tipo de construcción propuesto en esta tesis, pues se observa ciertas desventajas en el digestor tubular que es conveniente superar. Se ha perfeccionado el digestor enterrado, en una segunda construcción, con la incorporación de elementos que mejoran sus condiciones de operación, como un colector solar que integra un sistema de calentamieno híbrido solar-eléctrico (digestor anaeróbico enterrado con mejoras-caso $\mathrm{C}$ ), instalado en zona rural en el Departameno de Rosario de Lerma, a escasos kilomeros de la capital salteña, igual que el segundo digestor (caso B).

\subsubsection{Digestor tubular flexible y su sistema de calefacción-Caso A.}

El digestor tubular es de fácil armado y rápida instalación. Se construye de una sola pieza de membrana, la que se sella en sus extremos, con lo cual adopta una forma 
cilíndrica con una longitud de $180 \mathrm{~cm}$ y un diámetro de $45 \mathrm{~cm}$, logrando un volumen de 285 litros aproximadamente, Figura 6.1 (imagen izquierda).
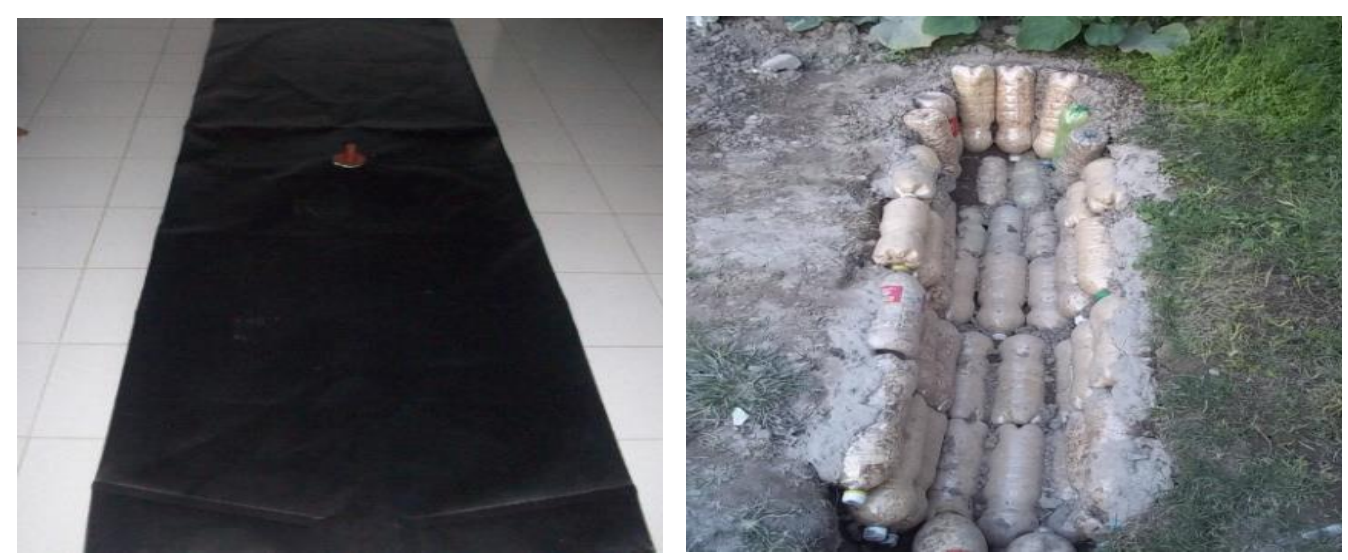

Figura 6.1. Vista del digestor desplegado sobre el suelo (izquierda), aislación cubriendo la fosa (derecha).

Fuente: imagen propia.

El digestor posee dos aberturas de $90 \mathrm{~mm}$ de diámetro en sus extremos para la carga y descarga de la materia a fermentar y una salida en la parte superior para la extracción del biogás producido. Para la instalación del digestor se cava una zanja de $50 \mathrm{~cm}$ de ancho, $200 \mathrm{~cm}$ de largo por $40 \mathrm{~cm}$ de profundidad con el objetivo de protegerlo de las variaciones térmicas diarias.

A fin de minimizar las pérdidas de calor del digestor al medio que lo rodea se utiliza la aislación térmica que se propone en esta tesis (Capítulo 5), botellas rellenas con viruta, para cubrir la fosa donde se coloca al digestor anaeróbico de membrana flexible, Figura 6.1 (imagen derecha).

Una vez acomodadas las botellas se instaló un intercambiador de calor, que opera con agua, construido con caño de PVC ( $1 / 2$ pulgada) para el calentamiento del digestor anaeróbico, por encima de las botellas.

En la publicación: "Diseño y construcción de un digestor de membrana flexible. Distintas alternativas para su acondicionamiento térmico" (Morales, et al, 2013) se muestran detalles de las medidas y construcción del digestor tubular flexible.

Por su forma, la construcción del digestor tubular flexible es sencilla, Figura 6.2. Posee solo dos aberturas, una para la entrada y otra para la salida de material; sin embargo, esto dificulta su limpieza. Además no tiene partes móviles. 


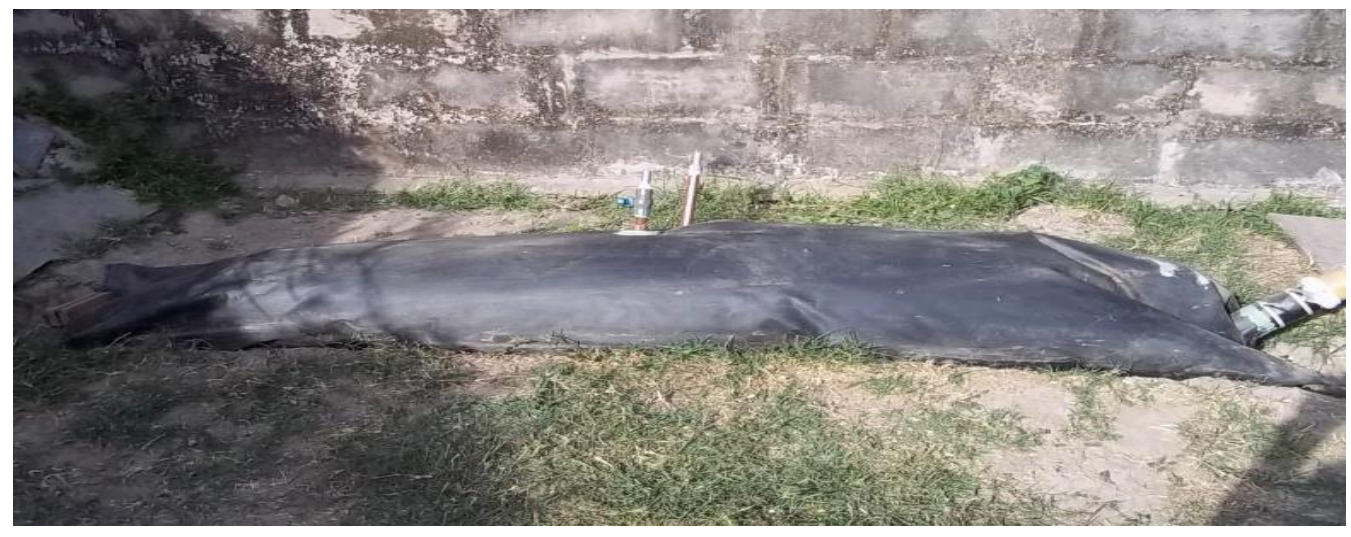

Figura 6.2. Vista del digestor tubular instalado en el terreno. Fuente: imagen propia.

Ademas se contruye un invernadero con un material plástico transparente de 0,5 mm de espesor soportado por unas varillas plásticas de $1 \mathrm{~cm}$ de diámetro, como se aprecia en la Figura 6.3, lo que permite un mejor aprovechamiento de la radiación solar incidente.

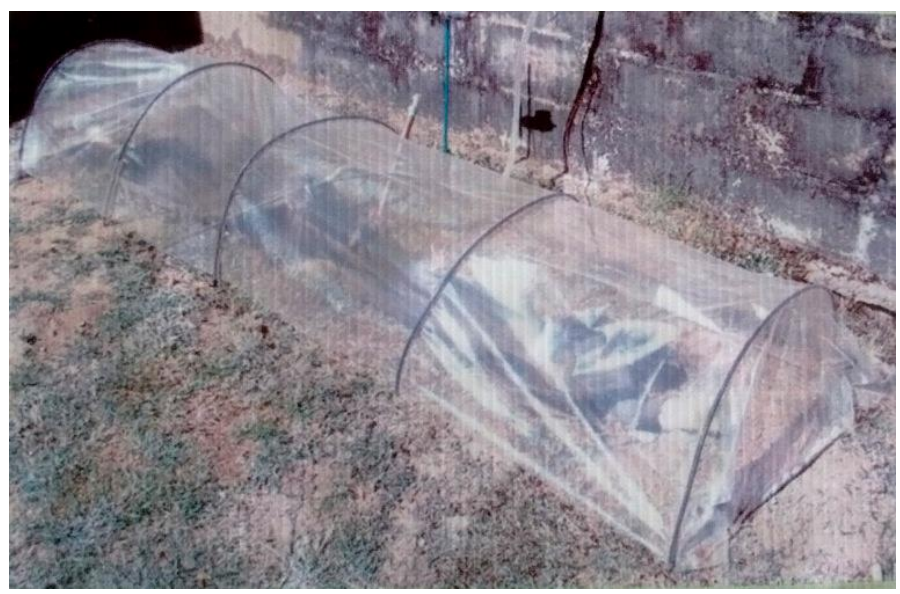

Figura 6.3. Invernadero sobre el digestor tubular. Fuente: imagen propia.

A fin de mantener las condiciones ideales de temperatura dentro de un digestor es menester disponer de una fuente de calor a ser utilizada en días nublados o durante la noche. Así, un sistema eléctrico de calefacción resulta indispensable para mantener la carga del digestor a la temperatura de operación.

Entre los diversos materiales que se encuentran en el mercado se utiliza, para el sistema de calefacción, caños de PVC, por su bajo costo y alta durabilidad. Luego de diversas pruebas con distintos prototipos, se llegó al sistema que se presenta en la Figura 6.4. 


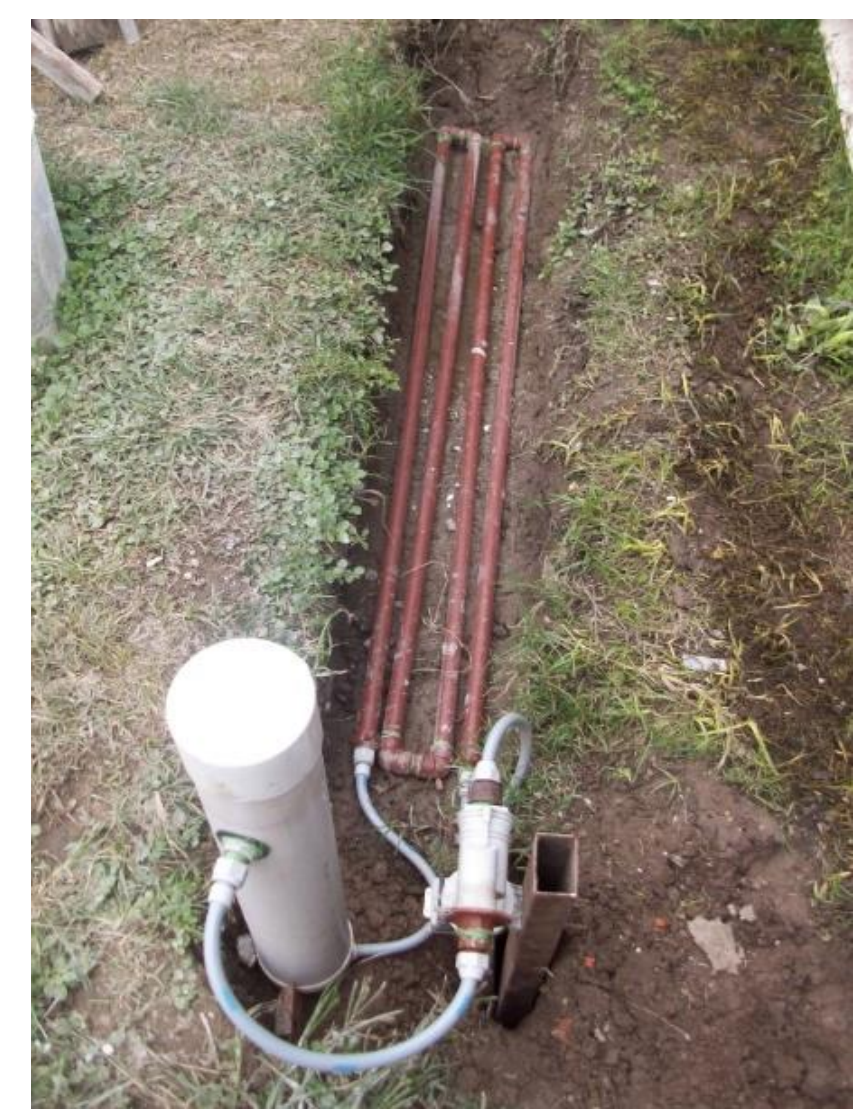

Figura 6.4. Sistema eléctrico de calefacción.

Fuente: imagen propia.

En esta figura se observa el intercambiador de calor, una electrobomba de $30 \mathrm{~W}$ de potencia que permite la circulación del agua y una resistencia eléctrica de $1200 \mathrm{~W}$ de potencia, la cual se encuentra inserta dentro del caño de PVC de $110 \mathrm{~mm}$ de diámetro. Por razones de seguridad la electrobomba debe estar por encima de la superficie del suelo y protegida de la intemperie. El largo del intercambiador de calor es igual al del digestor.

Como se muestra en la Figura 6.5, se coloca el intercambiador dentro de la fosa sobre las botellas con viruta que constituyen el material aislante.

El sistema de calefacción por circulación de agua favorece el mantenimiento de la temperatura del digestor. Un controlador con termostato permite supervisarla cortando o dando la energía cuando la temperatura en su interior se encuentra por debajo o por encima del valor fijado para su operación. El controlador tiene un sensor que se inserta dentro del digestor. 


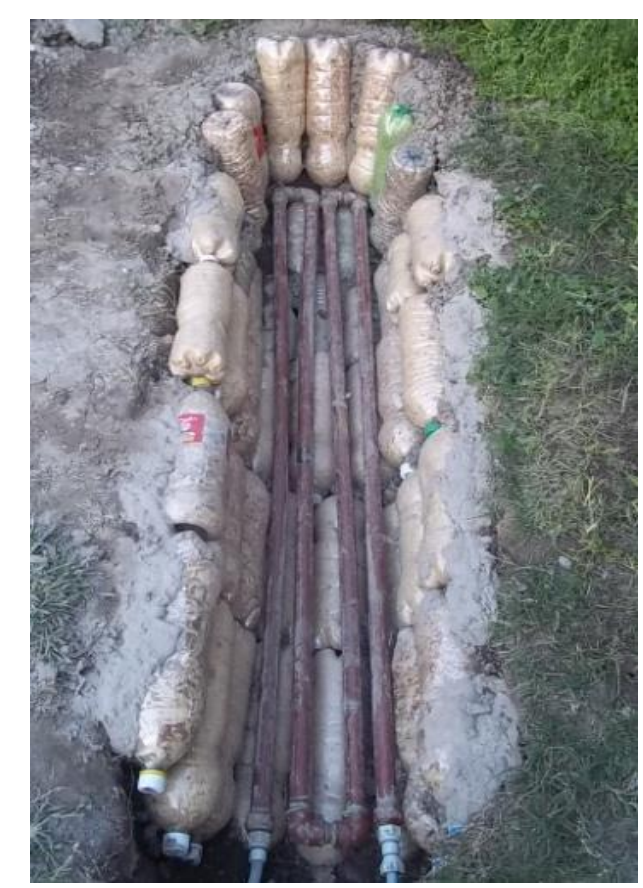

Figura 6.5. Vista de la fosa cubierta con las botellas y tubos del intercambiador. Fuente: imagen propia.

En la Figura 6.6 se presenta un esquema del sistema de calefacción, compuesto por la electrobomba, la resistencia eléctrica y el termostato (controlador de temperatura) que comanda el encendido de la bomba y la resistencia (el detalle de los componentes se presenta en el Anexo 1).

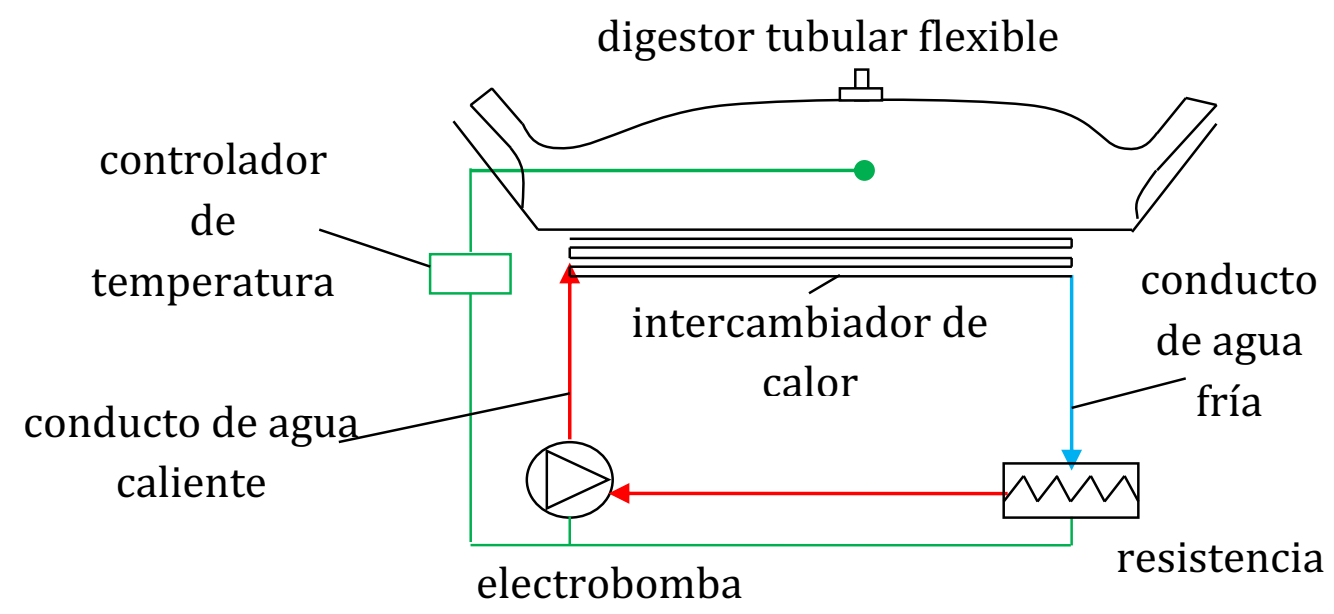

Figura 6.6. Sistema de calentamiento con control de temperatura del digestor tubular flexible.

Fuente: imagen propia. 
Se indica en color celeste el agua fría que sale del intercambiador e ingresa al recipiente que contiene la resistencia eléctrica. El agua caliente, en color rojo, ingresa luego a la electrobomba de agua y es impulsada nuevamente al intercambiador.

En el Capítulo 7 se presentan las mediciones de temperatura a fin de evaluar el sistema de calefacción y determinar las ventajas y desventajas. Desde el punto de vista constructivo se observa que el sistema de calefacción es fácil de instalar, dado que se coloca el intercambiador de calor por fuera del digestor, lo que constituye una ventaja. Sin embargo, este tipo de digestor presenta una carencia que perjudica su eficiencia como es la falta de agitación; ya que al estar compuesto de una sola pieza de membrana con una única "costura" se dificulta notablemente la incorporación de un agitador.

\subsubsection{Digestor anaeróbico enterrado- Caso B.}

Se construyeron dos digestores enterrados de características similares (casos B y C). La diferencia entre ambos modelos son las mejoras incorporadas en el caso C.

\subsubsection{Primer modelo: Digestor enterrado para residuos domiciliarios.}

Se construyó un biodigestor enterado de 2.000 litros en las proximidades de la vivienda con el fin de recibir efluentes de la misma. Opera entre $12^{\circ}$ y $18^{\circ} \mathrm{C}$ todo el año. El tipo de residuo que llega a este digestor es totalmente diferente a los pecuarios; por lo tanto su estudio en detalle no se presenta en esta tesis pues queda afuera de los objetivos fijados. Sin embargo, la construcción de éste fue altamente beneficiosa a fin de evaluar el prototipo.

Para su construcción se excava una fosa de 0,70 m ancho por 1,70 m de largo en su parte superior por $1,75 \mathrm{~m}$ de profundidad, tal como se muestra la Figura 6.7.

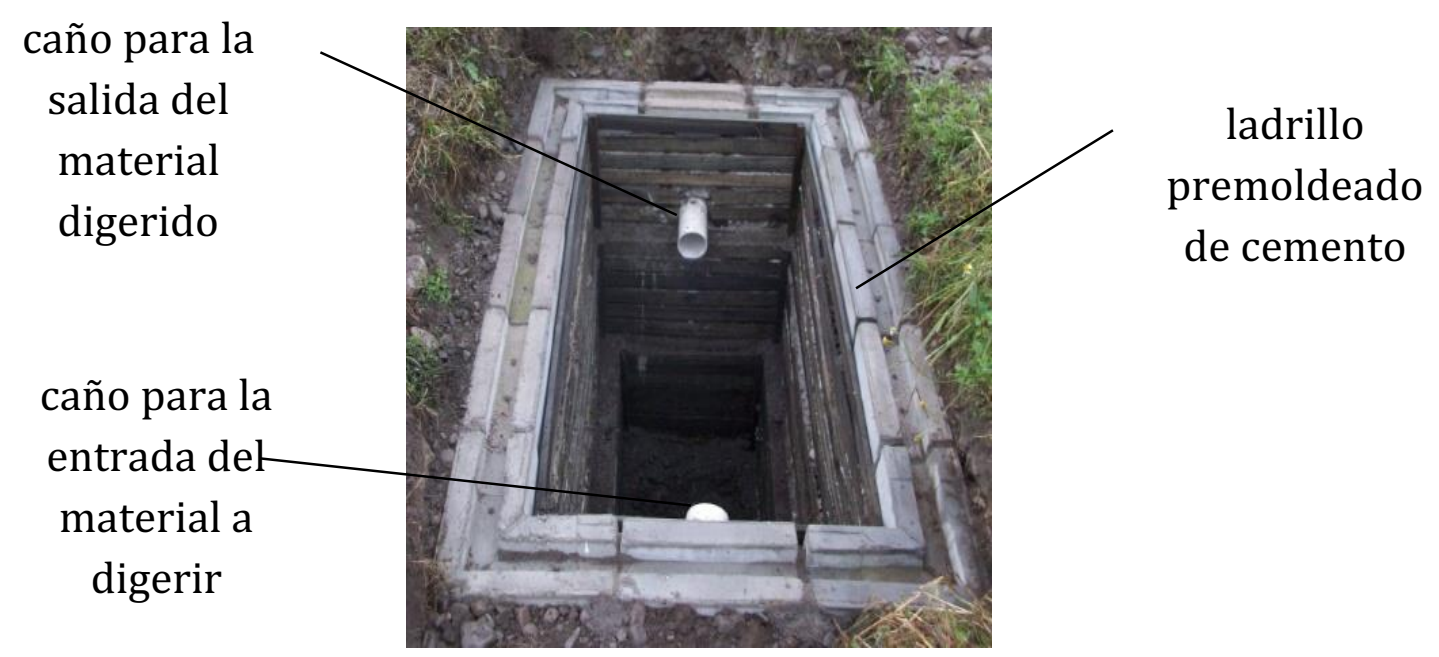

Figura 6.7. Construcción del digestor.

Fuente: imagen propia. 
En su parte superior, ubicados sobre el terreno se disponen unos "ladrillos" premoldeados en cemento. Estos se construyen mezclando 4 partes de arena con 1 parte de cemento y se utiliza un molde construido en chapa (imagen derecha de la Figura 6.9).

Se sueldan las distintas porciones de la membrana flexible de PVC para cubrir las paredes internas de la fosa. Para fijarla en su parte superior se la sujeta a los ladrillos de cemento por medio de una planchuela de hierro tal como se señala en la Figura 6.8. Dos tubos blancos de PVC de $110 \mathrm{~mm}$ de diámetro se utilizan para la entrada y salida de las aguas residuales. Estos tubos se perforan en sus paredes laterales para permitir la salida solo de líquidos, mientras que los componentes sólidos permanecen en el interior; lo que resulta útil cuando el digestor opera solamente con residuos provenientes de una vivienda.

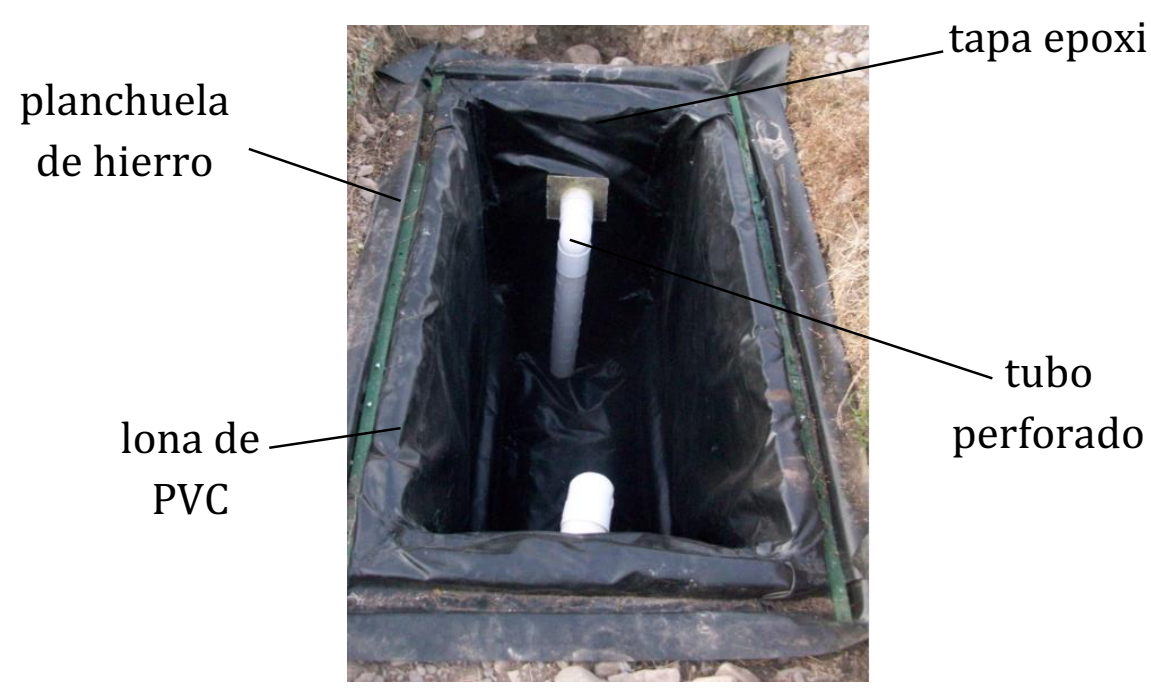

Figura 6.8. Foto del digestor anaeróbico enterrado y sus partes.

Fuente: imagen propia.

A fin de fijar los tubos de PVC al cuerpo del digestor se fabrican tapas en material epoxi y fibra de vidrio tal como se muestra en la imagen izquierda de la Figura 6.9, mientras que en la derecha se muestra un ladrillo premoldeado de cemento.
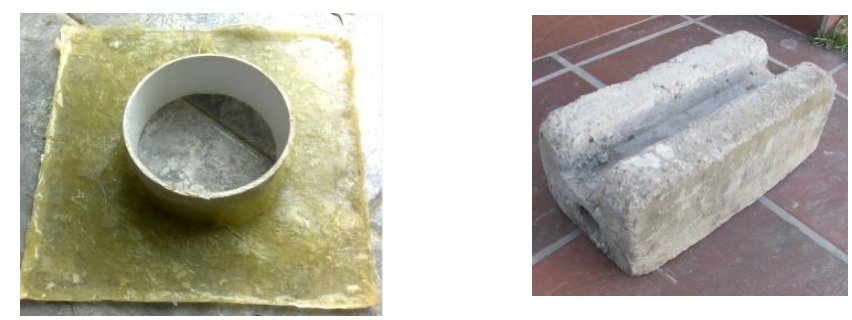

Figura 6.9. Imagen de la tapa epoxi y ladrillo premoldeado.

Fuente: imagen propia. 
Con el mismo material con que se arma el digestor se fabrica la tapa superior, la que se fija a los extremos con la planchuela de hierro. En el esquema de la Figura 6.10 se ilustra cómo se sujeta la tapa. Una abertura superior de $3 / 4$ de pulgada permite la salida del gas que se producirá en su interior.

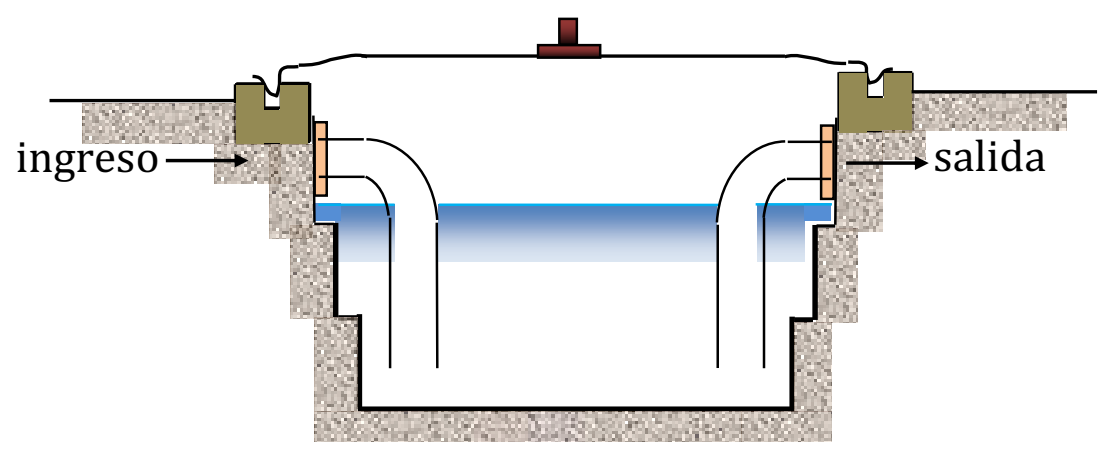

Figura 6.10. Esquema del digestor anaeróbico. Fuente: imagen propia.

El digestor funciona por rebalse; una vez cargado completamente, cada vez que ingresa nuevamente el líquido residual, rebalsa expulsando por la abertura de salida las aguas tratadas. El residuo líquido expulsado ha permanecido durante un tiempo en su interior, lo que asegura que parte de su carga orgánica haya desaparecido. Sin embargo, siempre es necesaria una evaluación de su funcionamiento, determinando el contenido de materia orgánica a la entrada y a la salida del digestor (Figura 6.10).

La construcción de este digestor demanda más tiempo en comparación con el tubular flexible. Los moldes de cemento no tienen ningún anclaje al suelo, no obstante se mantienen en su lugar. La soldadura de la membrana se dificulta en las esquinas. Este digestor se encuentra actualmente en operación, recibiendo el efluente de la vivienda. En cuanto a su temperatura, opera entre $12^{\circ}$ y $18^{\circ} \mathrm{C}$ en todo el año.

\subsubsection{Segundo modelo: Digestor enterrado con mejoras- Caso C.}

En este modelo se introducen mejoras respecto del anterior. Con el fin de mantener una temperatura adecuada y constante se agrega un sistema calefactor compuesto por una parte eléctrica y una parte solar, más un controlador de temperatura. Se incorpora también, con el objetivo de reducir las pérdidas de calor, la aislación térmica estudiada y probada en los Capítulos 5 y 7 (los planos de construcción se presentan en el Anexo A2). Como se presentará en el Capítulo 9 se realizaron ensayos de biodigestión utilizando residuos pecuarios.

Este tercer digestor se construye teniendo en cuenta la experiencia anterior. Inicialmente se cava una fosa de $0,8 \mathrm{~m}$ de ancho, $1,8 \mathrm{~m}$ de largo y 1,2 $\mathrm{m}$ de profundidad. Luego se disponen los bloques de cemento a $30 \mathrm{~cm}$ del borde de la fosa. 
Una vez llenas todas las botellas con viruta se procede a su colocación sobre las paredes de la fosa. A los efectos de asegurar la correcta colocación de las botellas, que constituyen la aislación térmica, se disponen dos hierros torsionados de 4,5 pulgadas. Estos se colocan en todo el lateral superior y en el suelo de la fosa. Las hileras de botellas se sujetan con ayuda de estos hierros, Figura 6.11.

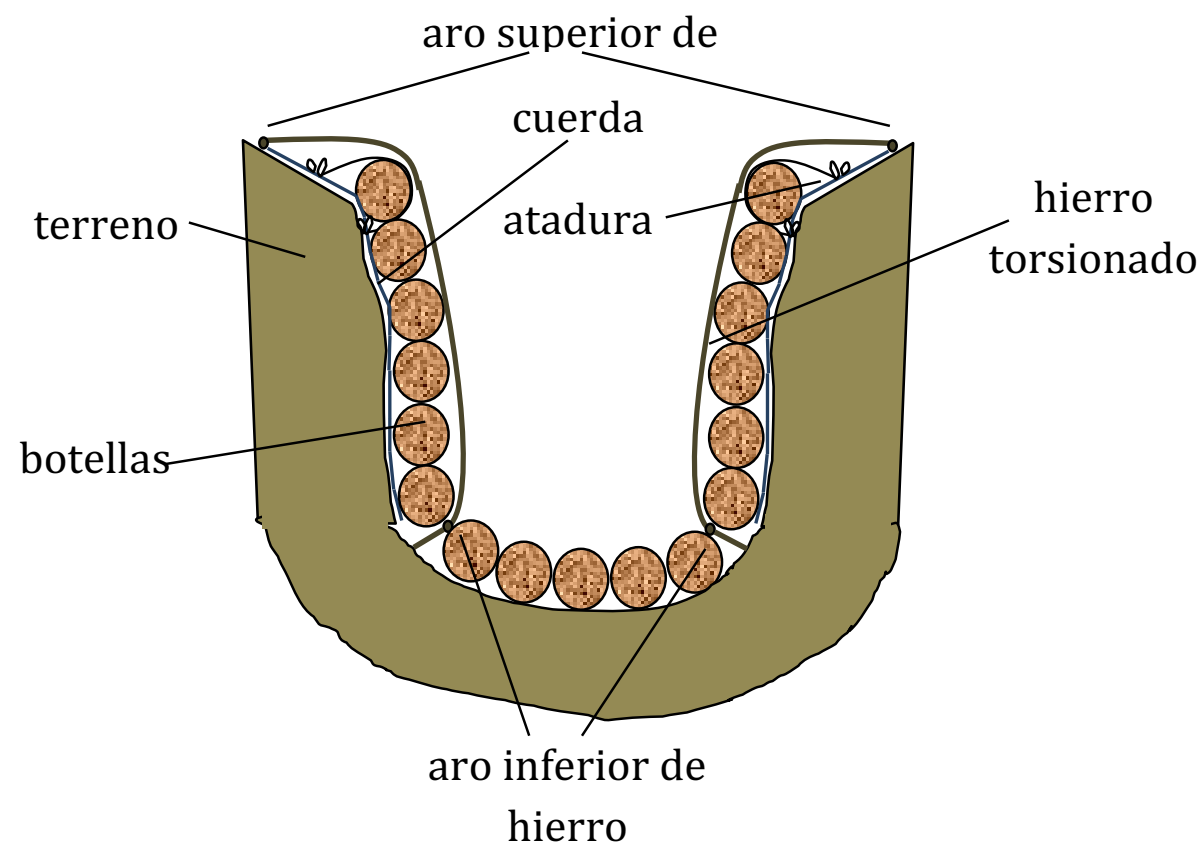

Figura 6.11. Perfil del digestor enterrado: colocación y sujeción de las botellas.

Fuente: imagen propia.

Cada botella se sujetó a las cuerdas que cuelgan desde el aro superior hasta el aro inferior. Una vez puestas todas ellas, fueron sujetas por encima con hierro torsionado de 4,5 pulgadas, como se muestra en la Figura 6.12.

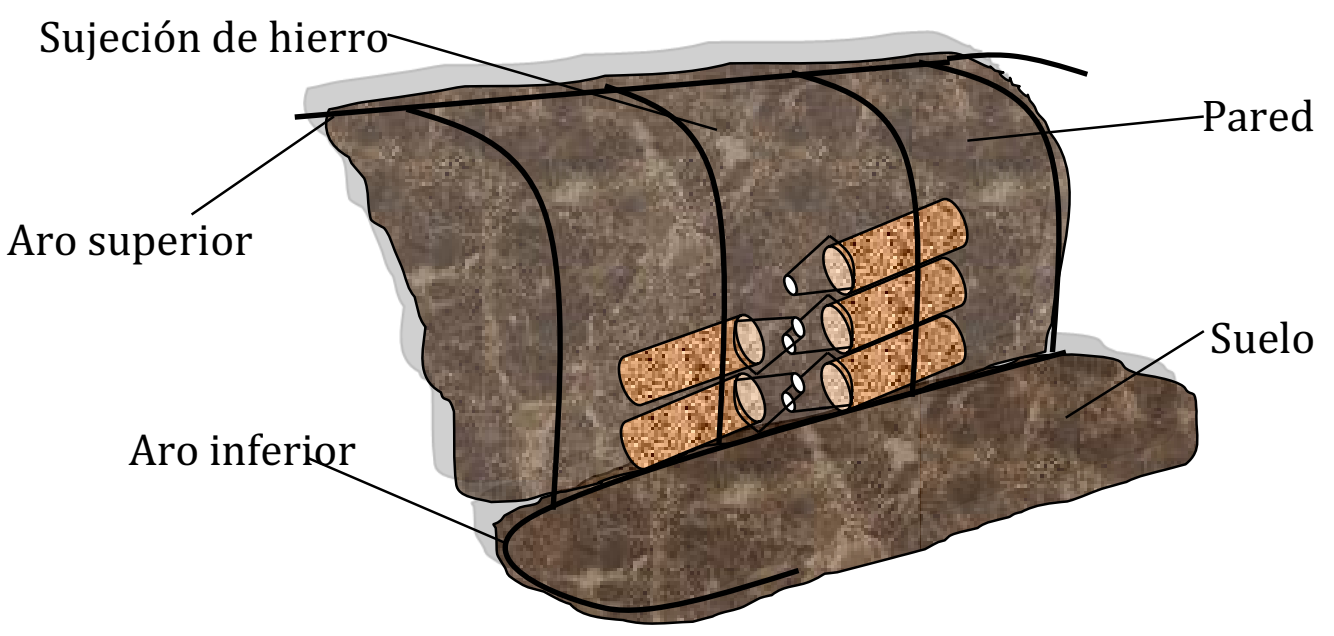

Figura 6.12. Esquema de una vista en perspectiva del modo de sujeción de las botellas con hierro.

Fuente: imagen propia. 
En la Figura 6.13 se muestran las imágenes de las distintas etapas de la colocación de las botellas.

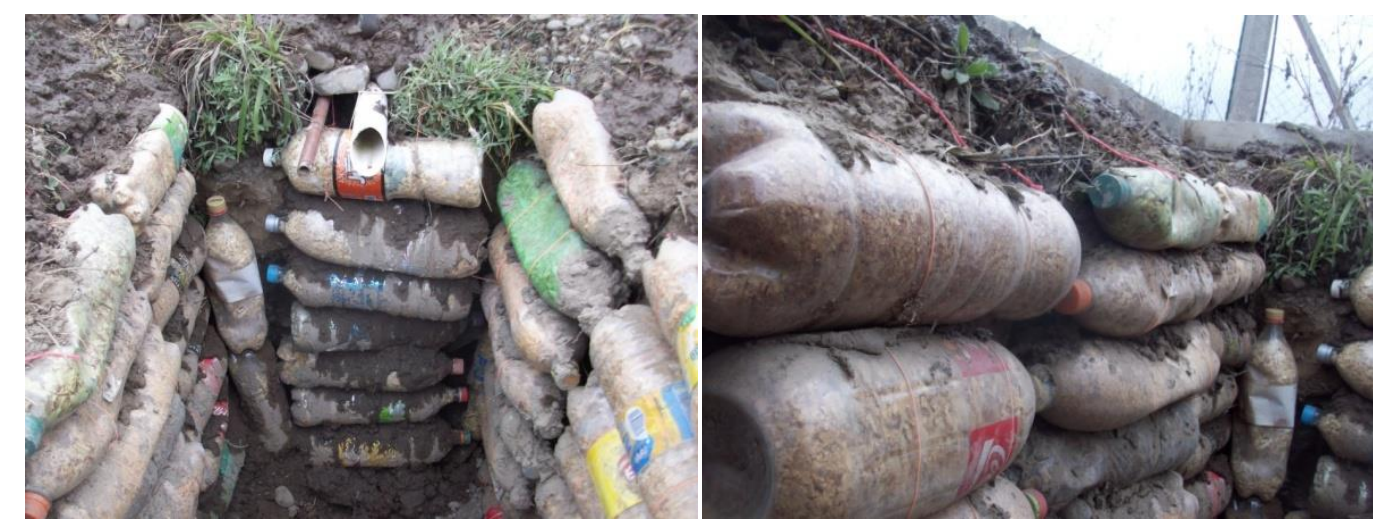

Figura 6.13. Distintas etapas de la colocación de las botellas.

Fuente: imagen propia.

Se aplica la misma técnica para soldar la membrana como en la experiencia con el primer digestor enterrado, caso B. Ésta queda totalmente sellada para evitar las pérdidas de líquido. Se instalaron un caño de entrada del material a procesar y otro de salida del material procesado, con un tubo de PVC que incialmente fue de $90 \mathrm{~mm}$ de diámetro y luego se lo cambió por uno de $110 \mathrm{~mm}$. Con caños de PVC de 1/2 pulgada se construye la entrada y salida del agua caliente que permite mantener una temperatura adecuada en el interior. Una tercera entrada con este mismo caño se utiliza para introducir el cableado de suministro de la energía electrica y para la entrada de los diversos sensores termopares.

Se muestran las imágenes de las distintas etapas de construcción del digestor anaeróbico enterrado en la Figura 6.14, con un volumen total de aproximadamente 1000 litros para la camara central.
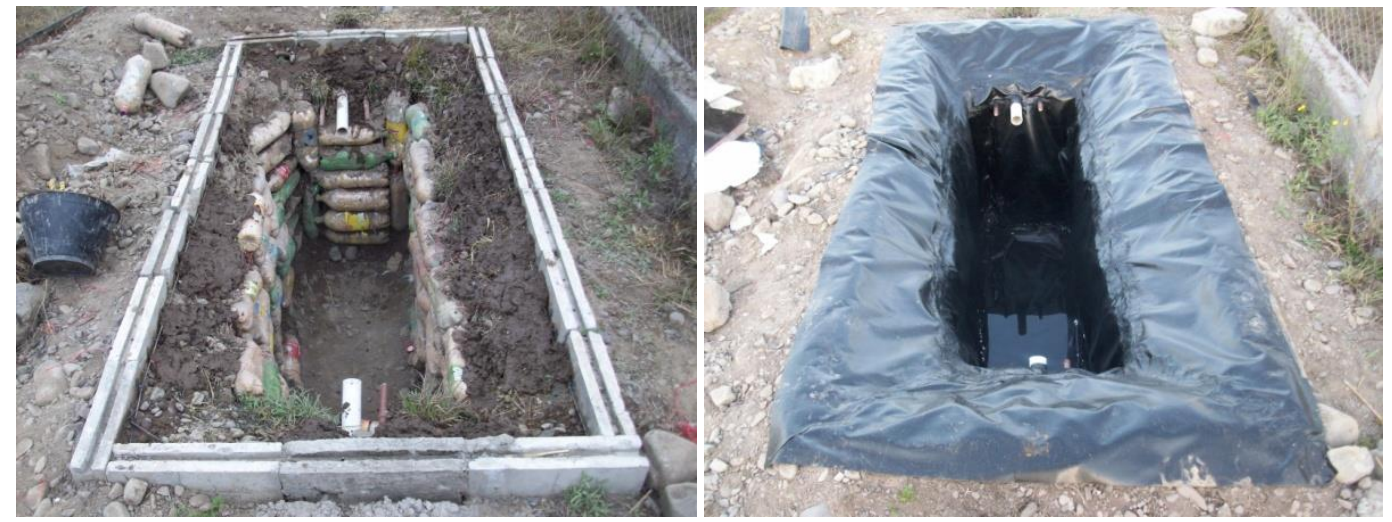

Figura 6.14. Distintas etapas de la construcción del digestor anaeróbico enterrado con mejoras, caso C. Fuente: imagen propia. 
A los costados del digestor central se instalan dos cámaras de menor tamaño, del mismo material y forma de construcción. Ambas poseen el mismo volumen de aproximadamente 200 litros. Inicialmente se piensa su función para actuar como digestores, aunque también, permite preparar la carga del digestor con la dilución correcta la que luego se incorpora por acción de la gravedad. A su vez, en la segunda cámara se puede recibir el material ya degradado. En la Figura 6.15 se presentan las cámaras junto con el digestor.
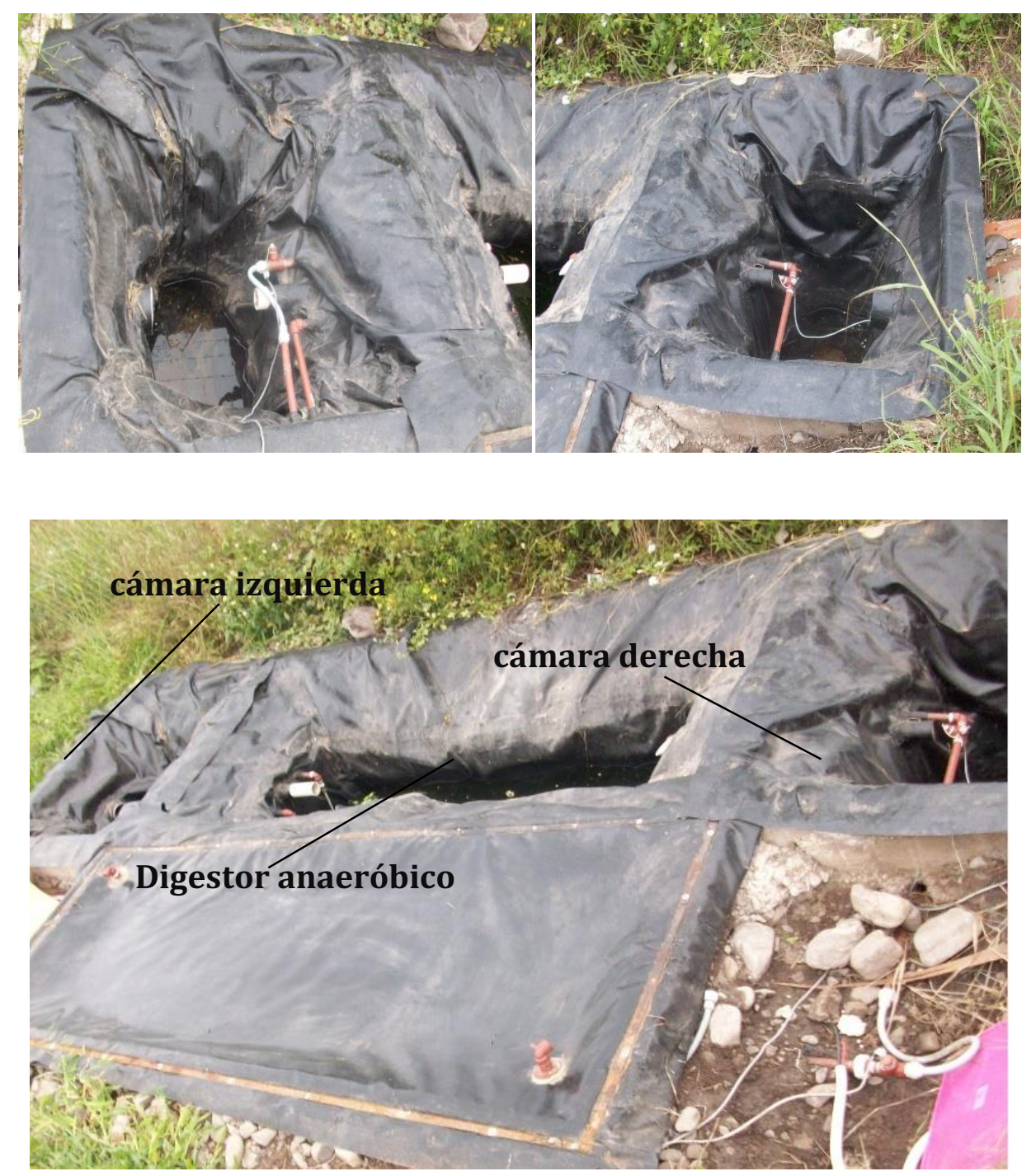

Figura 6.15. Cámaras laterales y el digestor completo- Caso C. Fuente: imagen propia.

La Figura 6.16 muestra un esquema del digestor anaeróbico con sus cámaras izquierda y derecha y el colector solar. Se aprecia los conductos por donde se desplaza el material orgánico. En la vista de planta se observa al colector solar fabricado con el mismo material al lado del digestor anaeróbico. Con este colector se logra un calentamiento con un costo menor considerando los materiales con el que está 
construido. En tal sentido se logra mejorar las condiciones térmicas agregando un sistema de calentamiento eléctrico y solar.

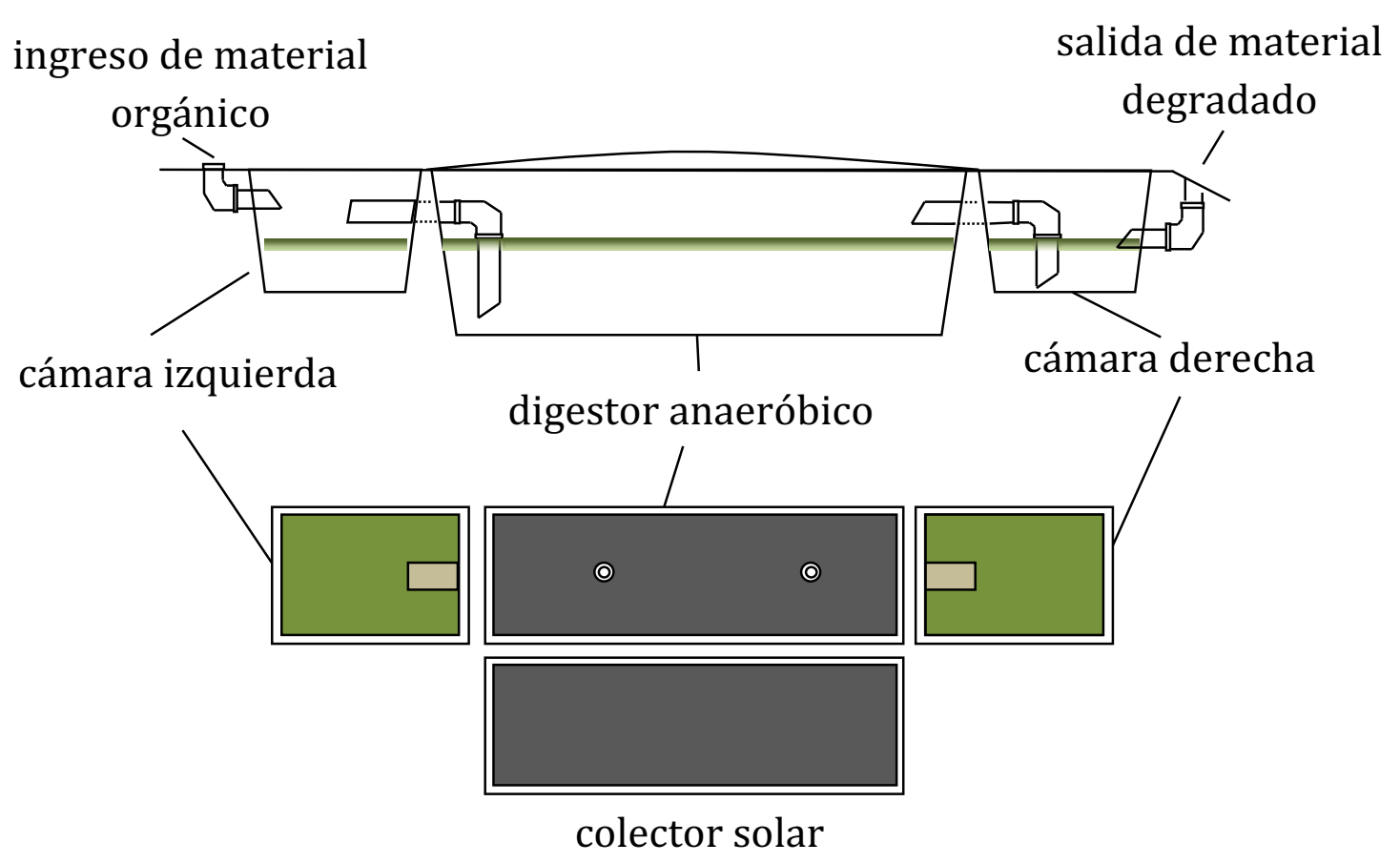

Figura 6.16. Esquema del digestor anaeróbico, cámaras y colector solar. Vista de perfil y de planta.

Fuente: imagen propia.

Para sujetar la membrana que forma el cuerpo del digestor, con el propósito de mantener un cerrado hermético, se practicaron durante el desarrollo del prototipo dos tipos de sujeción similares. La primera se observa en la Figura 6.17a, se utiliza una planchuela de hierro y una cinta de goma del mismo ancho, la membrana superior (la que forma la tapa) y la inferior (la del cuerpo) se disponen en el medio y todo el conjunto se ajusta mediante tornillos al ladrillo.
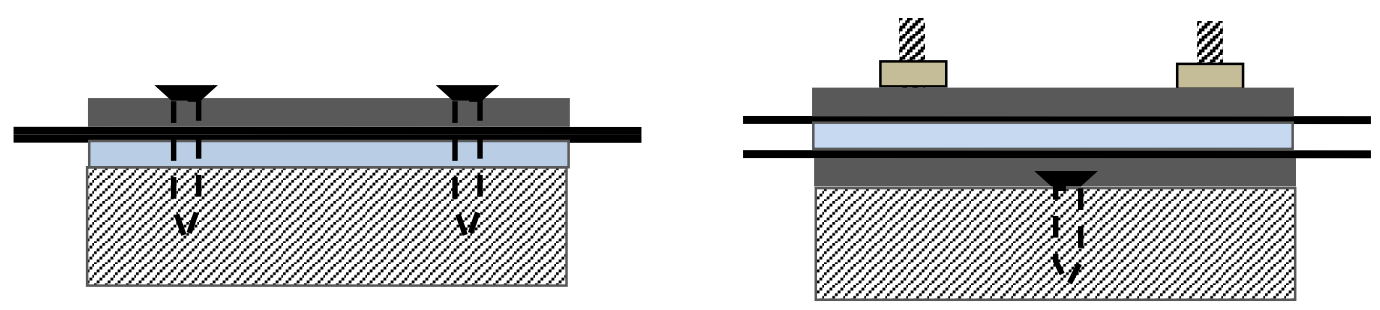

\begin{tabular}{|c|c|c|c|}
\hline 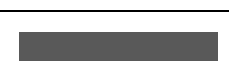 & Planchuela & & Membrana \\
\hline$\square$ & Cinta de goma & 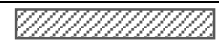 & Ladrillo \\
\hline 艺 & $\begin{array}{l}\text { Tornillo } \\
\text { superior }\end{array}$ & Iニン & $\begin{array}{l}\text { Tornillo } \\
\text { inferior }\end{array}$ \\
\hline
\end{tabular}

Figura 6.17. Sistemas de sujeción de la membrana (a) y (b).

Fuente: imagen propia. 
En la Figura 6.17b (derecha) se presenta el segundo sistema, el que finalmente se utiliza en las experiencias. Las membranas superior e inferior y la cinta de goma entre ellas se ajustan entre dos planchuelas de hierro por medio de tornillos superiores, estos están soldados a la planchuela inferior, también aquí se sujetan al ladrillo con tornillos.

\subsubsection{Sistema de calefacción hibrido solar-eléctrico del digestor enterrado.}

Una de las características de los sistemas de digestión anaeróbica, es la incorporación necesaria de energía en forma de calor, que permita elevar la temperatura del digestor a fin de lograr mayores volúmenes de biogás. Con el propósito de mejorar las condiciones térmicas del digestor se propuso incluir un sistema calefactor híbrido que conjugue dos fuentes: la solar y la eléctrica. Esta propuesta ha sido presentada en el artículo: Digestor anaeróbico enterrado asistido por energía solar térmica (Morales et al. ,2018).

Un sistema de calefacción apropiado permite mantener las condiciones adecuadas de temperatura dentro del digestor. Este debe ser robusto ya que permanecerá encendido por mucho tiempo funcionando con cierta intermitencia.

\subsubsection{Circuito hidráulico.}

Este circuito tiene la finalidad de conducir el fluido caloportador hacia el interior del biodigestor, calentado vía solar o eléctrica. Consta de un intercambiador de calor (IC), una electrobomba, el colector solar y el depósito con la resistencia eléctrica.

\section{- Intercambiador de calor}

El intercambiador de calor (IC) se construyó inicialmente con tubos de aluminio de 1 cm de diámetro exterior y caño de PVC de $1 / 2$ pulgada; por él circulará el agua caliente proveniente del colector solar y de la resistencia eléctrica. La parrilla que forma el intercambiador es de 1,60 m de largo por 0,4 m de ancho, Figura 6.18a y 6.18b. 


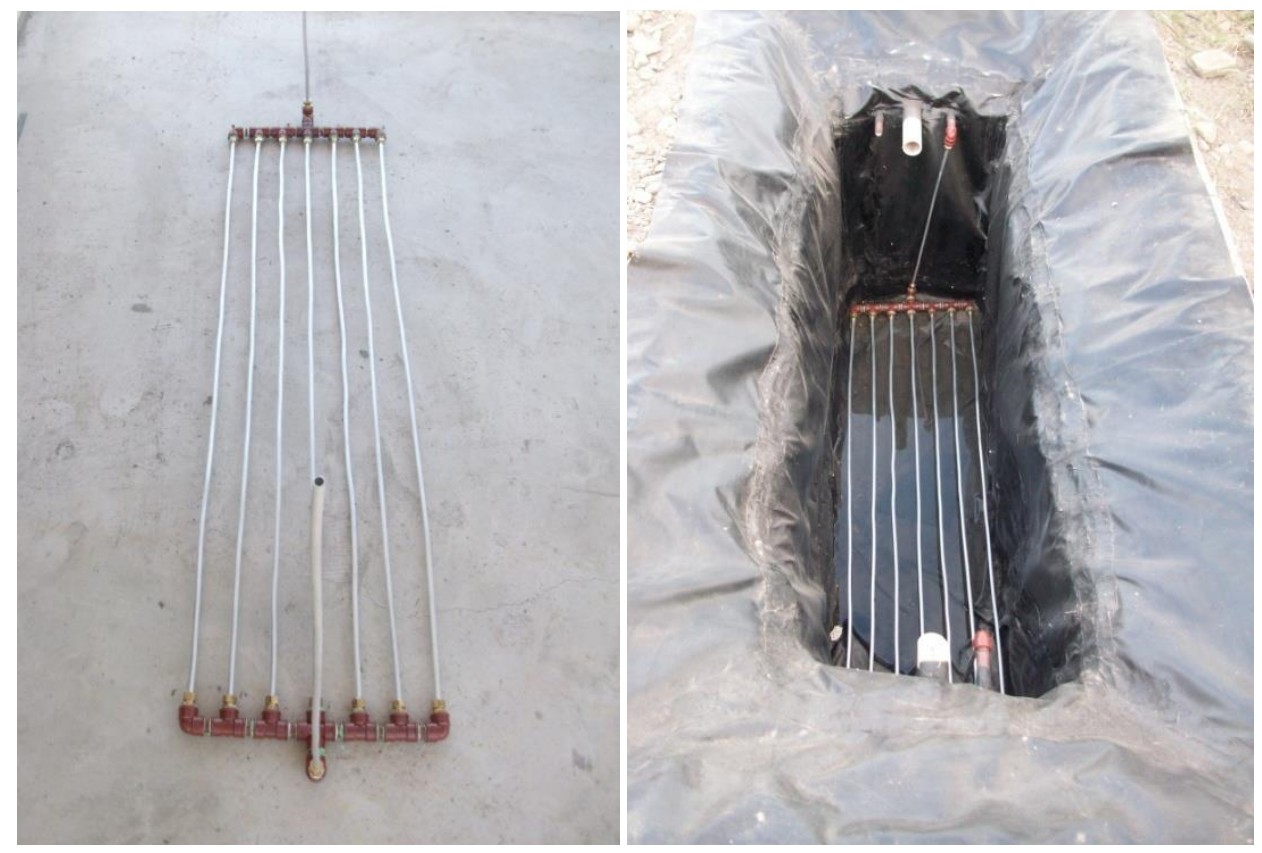

(a) vista del intercambiador de calor solo y colocado en el digestor.

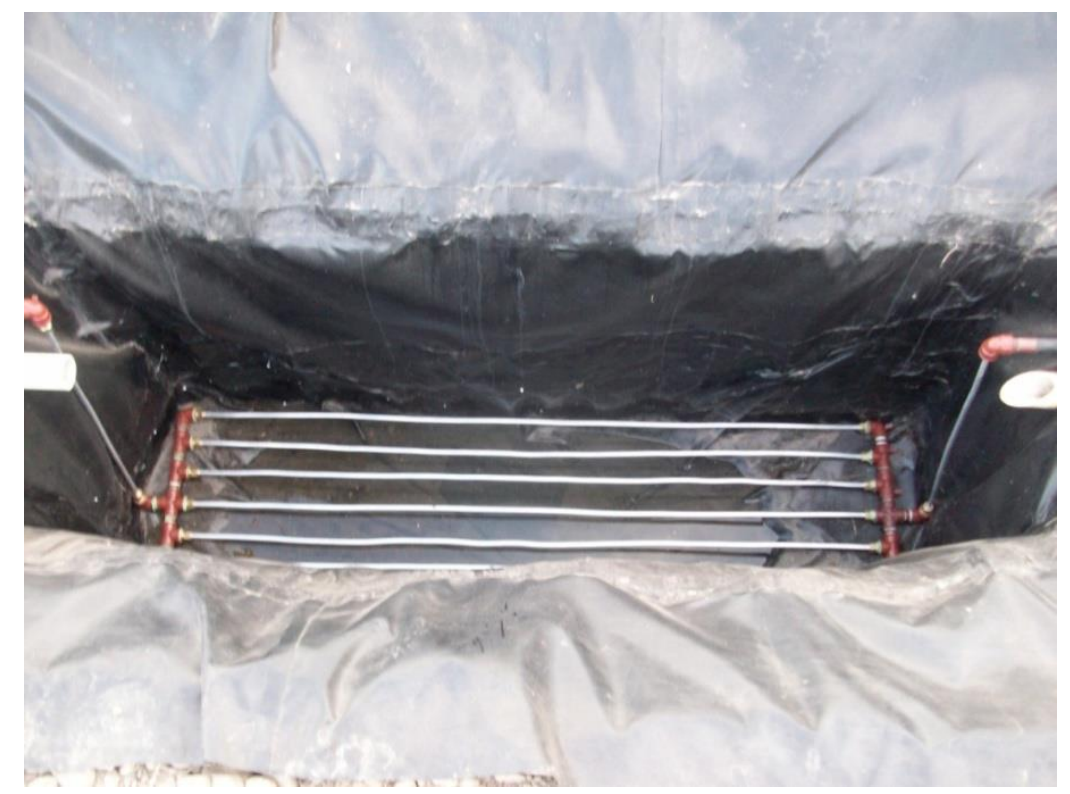

(b) vista del intercambiador de calor instalado en el digestor.

Figura 6.18. Intercambiador de calor.

Fuente: imagen propia.

El intercambiador de calor en el interior del digestor construido inicialmente en aluminio fue luego cambiado por conductos de PVC con un diámetro de $3 / 4$ de pulgada. Se observó tras este cambio una mayor velocidad en la conducción del fluido interior del conducto. 
- Colector solar.

La construcción del colector solar se realiza utilizando el mismo método del digestor anaeróbico, con la diferencia que, en vez de usar bloques de cemento se armó un encofrado. Posee una ranura central que permite ajustar la membrana a las paredes del perímetro mediante una sujeción con planchuela de hierro y tornillos. Las dimensiones del colector son de 2,1 m de largo por 1,3 $\mathrm{m}$ de ancho.

El colector solar (Figura 6.19) posee lana de vidrio como aislación térmica; ésta se encuentra protegida dentro de un plástico de polietileno sellado al calor, impidiendo que la humedad ingrese cambiando la conductividad de la misma.

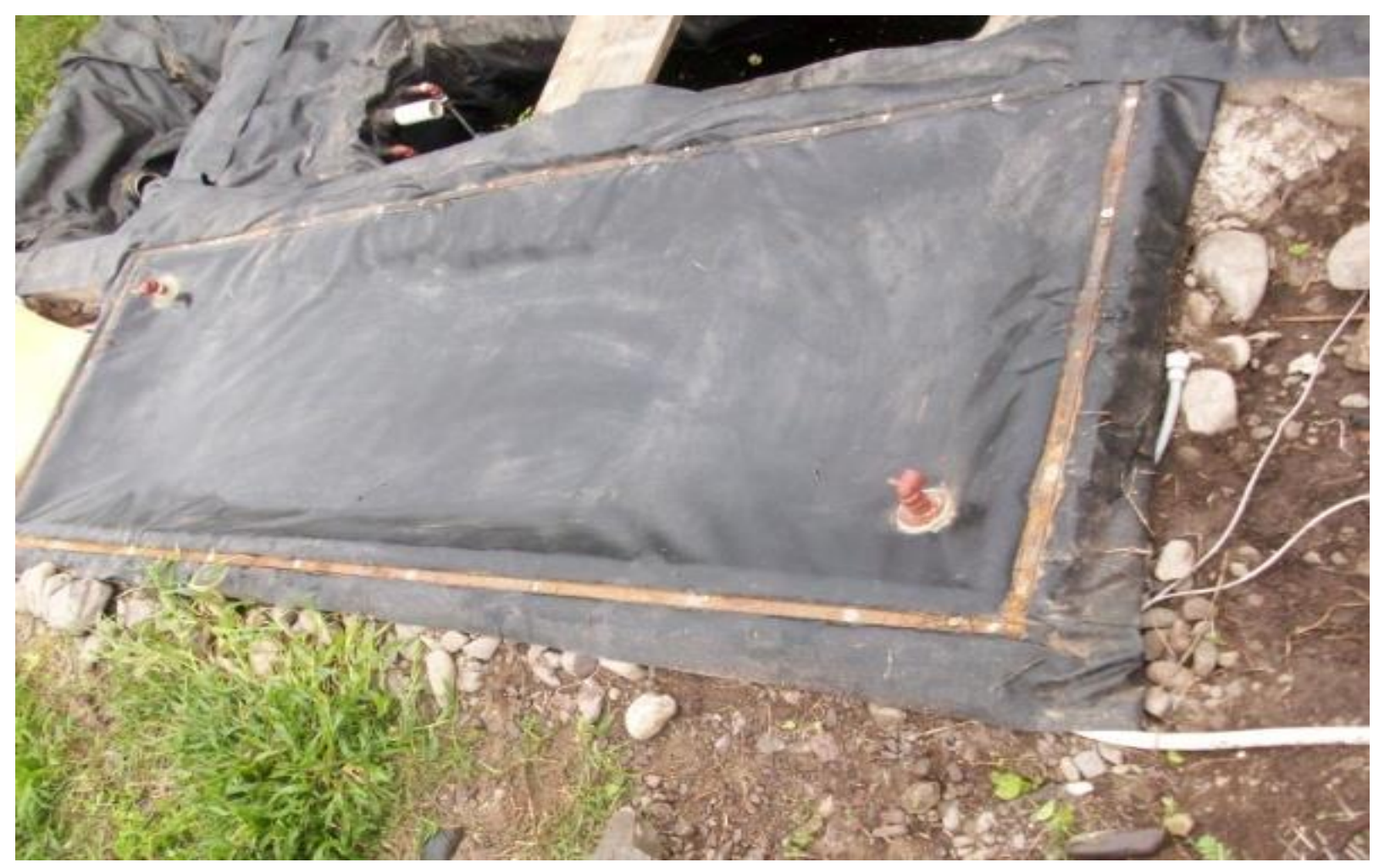

Figura 6.19. Colector solar.

Fuente: imagen propia.

Luego de diversas modificaciones se optó por incluir en el interior del colector solar un circuito construido en tubo de PVC de $3 / 4$ de pulgada, el que se encuentra sumergido en agua. Se carga por las aberturas del colector, como se esquematiza en la Figura 6.20. 


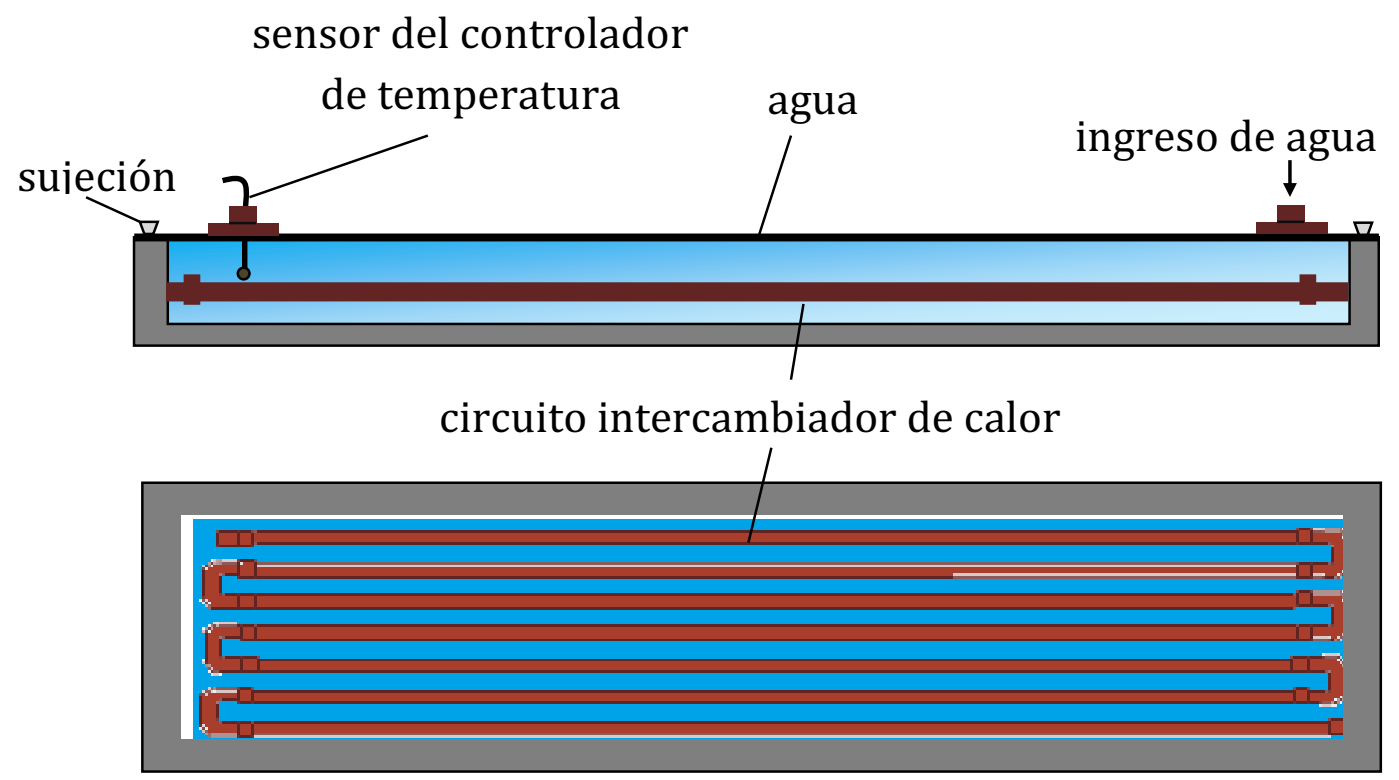

Figura 6.20. Vista transversal y frontal del interior del colector solar.

Fuente: imagen propia.

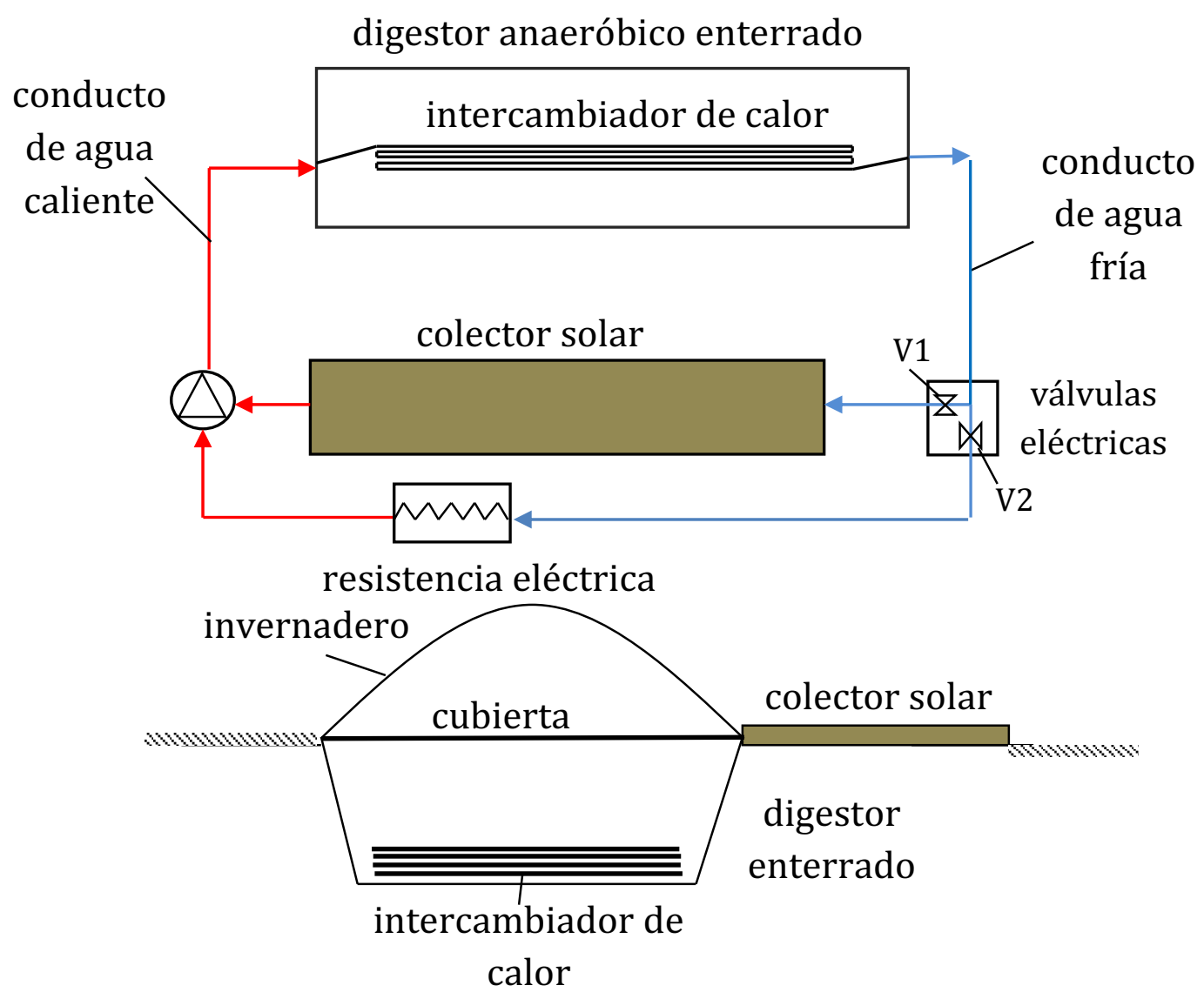

Figura 6.21. Esquema del circuito hidráulico para el calentamiento del digestor enterrado.

Fuente: imagen propia. 
Una electrobomba periférica hace circular el agua. En la Figura 6.21 se presenta un esquema del sistema de calentamiento híbrido compuesto por el colector solar, la resistencia eléctrica, la electrobomba de agua, las válvulas eléctricas de agua y el intercambiador de calor. Las flechas representan las conexiones entre los distintos elementos y el sentido del flujo de agua. En color rojo, se representa el agua caliente proveniente del colector solar o de la resistencia que llega a la electrobomba y es impulsada hacia el intercambiador de calor dentro del digestor. Luego el agua más fría, color celeste, sale del intercambiador y pasa por algunas de las válvulas para regresar nuevamente al colector o resistencia. En la misma figura, se señalan también las válvulas eléctricas V1 y V2, las que permiten la utilización del colector solar o de la resistencia, de acuerdo a la temperatura del agua del colector solar.

\subsubsection{Circuito eléctrico.}

La parte eléctrica se compone de una resistencia de $1400 \mathrm{~W}$ con termostato incluido, Figura 6.22, sumergida en agua.

controlador de temperatura CTR

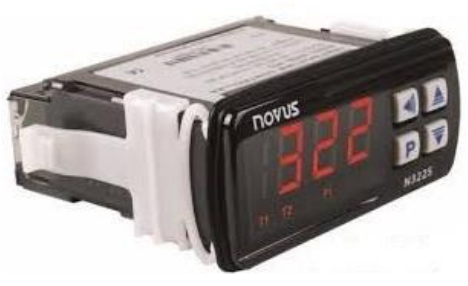

contactor eléctrico C

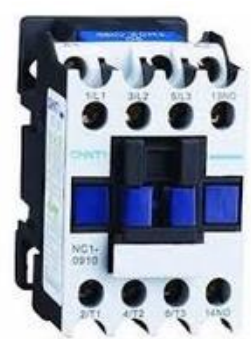

temporizador $t$

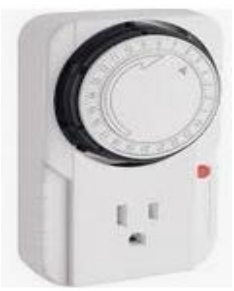

válvula eléctrica $\mathrm{V}$

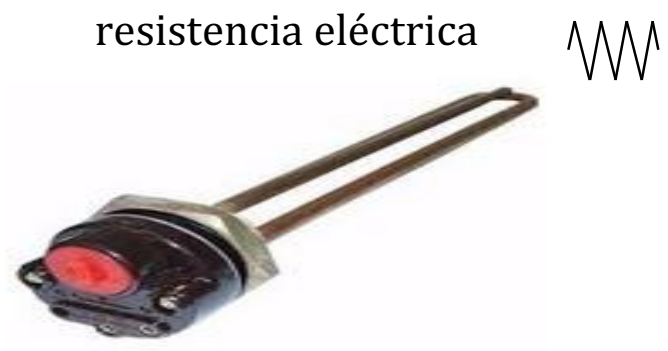

Figura 6.22. Componentes del circuito eléctrico.

Fuente: imagen propia. 
El termostato (controlador de temperatura CTR) mantiene una temperatura constante para el circuito calefactor, superior a la temperatura de trabajo del digestor.

Se utilizan dos controladores CTR para mantener la temperatura en un valor adecuado para la digestión, Figura 6.22, cada uno de ellos posee un sensor. Un relé interno se abre o cierra de acuerdo a la temperatura fijada. Uno de los controladores CTR1 supervisa la temperatura del digestor; si es menor a la establecida se cierra el relé para energizar el sistema de calentamiento, de manera que su funcionamiento eleve la temperatura. El detalle de los componentes se presenta en el Anexo 1.

En la Figura 6.23 se presenta el sistema de control. En ella se observan los controladores CTR1 y CTR2, que censan simultáneamente la temperatura del digestor y del colector solar.
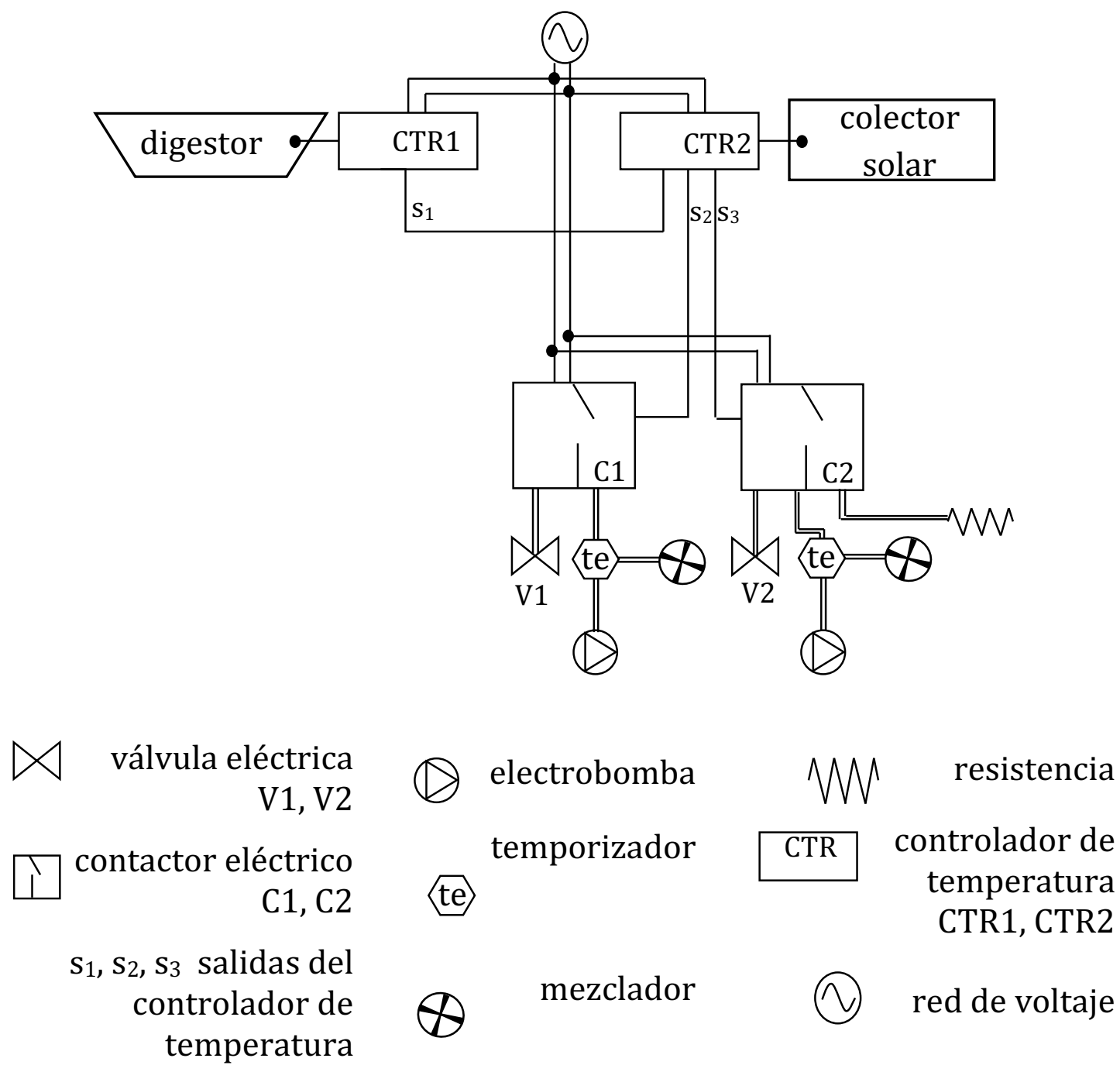

Figura 6.23. Sistema de control de calentador híbrido solar-eléctrico. Fuente: imagen propia. 
Como se mencionó, el calentamiento del digestor se produce por medio de dos elementos: el colector solar y la resistencia eléctrica. Para determinar cuál de ellas funcionará, el otro controlador CTR2 censa constantemente la temperatura del colector solar; si es mayor a la de digestión, se abre la válvula del circuito del colector (V1) y se cierra la otra (V2). Si está por debajo sucede lo contrario. En ambos casos la electrobomba se enciende junto con los dispositivos de calentamiento.

Ambos controladores se fijan a la misma temperatura, la deseada para la digestión de la carga. Si la temperatura del digestor está por debajo de este valor energiza la salida s1 para que el controlador CTR2 pueda comandar. Este sensa la temperatura del colector solar. Si está por debajo de la temperatura de operación del digestor, activará la salida $s_{3}$ y energizará el contactor eléctrico C2 (Figura 6.22) para energizar a la vez la válvula V2, la electrobomba, la resistencia y el agitador. Si la temperatura del colector es suficiente se energiza el contactor $\mathrm{C} 1$ a través de $\mathrm{s}_{2}$ y luego a la válvula V1, la electrobomba y el agitador. Como se observa en ambos casos se prende el mezclador y la electrobomba, ya que es la que impulsa el fluido caloportador.

El temporizador es un dispositivo electrónico que permite energizar un sistema o mecanismo eléctrico después de transcurrido un cierto tiempo. El tiempo para la activación se establece en el mismo dispositivo. Se opta por adicionar a la electrobomba y al agitador un temporizador (Figura 6.22 y 6.23) a los efectos de que éstos no permanezcan encendidos por largos periodos de tiempo. De esta manera se intenta alargar la vida útil de los instrumentos.

\subsubsection{Mezclador e Invernadero.}

Una estructura de hierro forma el cuerpo del invernadero que luego se recubre con una placa de policarbonato alveolar de $4 \mathrm{~mm}$ de espesor. La ventaja de este material es que tiene una rigidez suficiente para soportar los vientos, si se encuentra bien anclado al suelo. Además, posee una transparencia suficiente para actuar como invernadero.

La Figura 6.24 muestra la imagen del invernadero colocado sobre la parte principal del digestor. 


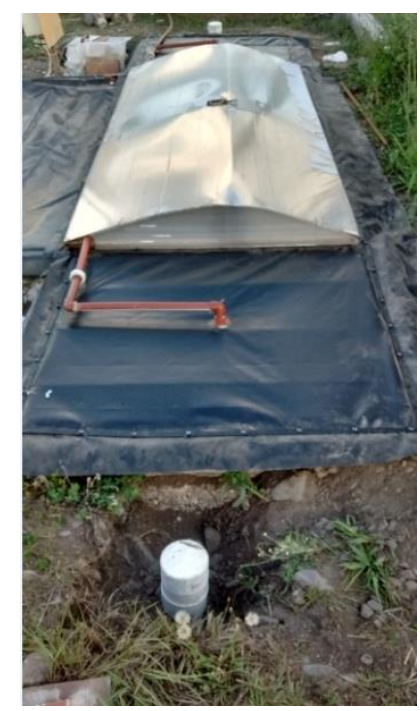

Figura 6.24. Imagen del invernadero.

Fuente: imagen propia.

Inicialmente se pretende utilizar las cámaras laterales como digestores. Por ello se conectan en su parte superior izquierda conductos plásticos (rojo) para conducir el biogás, como se observa en la Figura 6.24. También se observa en la figura un tubo de plástico de $110 \mathrm{~mm}$ de diámetro en color blanco saliendo de la superficie del terreno (en el centro en la parte inferior de la imagen y en la parte superior), los que se pensaron como ductos para ingreso y salida de material orgánico. Finalmente, las cámaras no se utilizan como digestores como se verá en el Capítulo 9 por problemas en la conducción del material orgánico ya que al parecer es chico el diámetro de los tubos por donde se conduce la carga. Sobre el digestor anaeróbico (la parte principal señalada en la Figura 6.15) se coloca el invernadero.

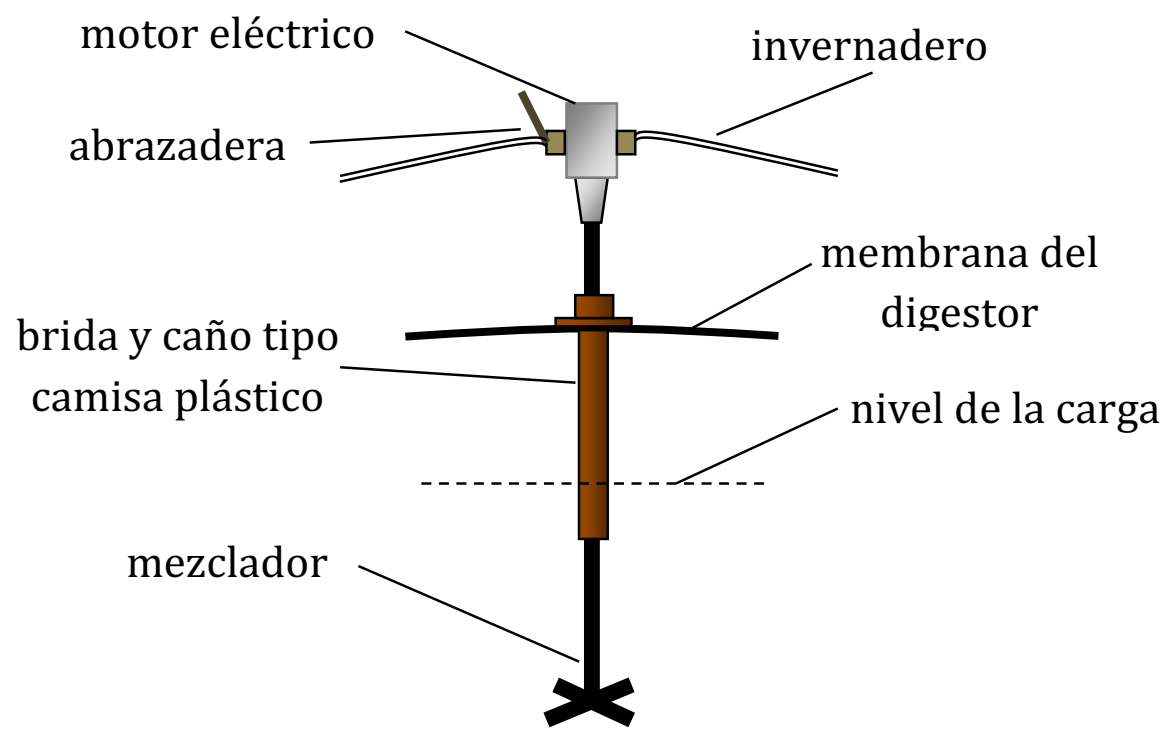

Figura 6.25. Sujeción del motor eléctrico y del mezclador.

Fuente: imagen propia. 
En la parte superior del invernadero se observa una abrazadera (Figura 6.24 y 6.25) que está soldada para sostener un motor eléctrico. Este motor hace girar unas paletas dentro del digestor. El mezclador se introduce por una brida y un caño tipo camisa al interior del digestor. El caño se encuentra sumergido en la carga para evitar las pérdidas de biogás al exterior. En la Figura 6.25 se esquematiza el sistema de sujeción del mezclador y del motor.

El mezclador funciona cuando se activa la resistencia eléctrica o el sistema de calentamiento solar. Así, cuando el digestor necesita de la fuente de calor para aumentar su temperatura, el mezclador permite aumentar la velocidad con que se transmite el calor desde el intercambiador de calor hacia la carga. A su vez, el mezclado mantiene homogénea la mezcla, lo que sin duda resulta ventajoso para la digestión de la carga.

En la Figura 6.26, en la parte superior izquierda, se observa el mezclador construido en hierro y el modo de sujeción del motor eléctrico, la abrazadera soldada a la estructura del invernadero, en la parte superior derecha. El motor eléctrico se mantiene fijo a la estructura por medio de esta abrazadera, imagen inferior de la Figura 6.26.

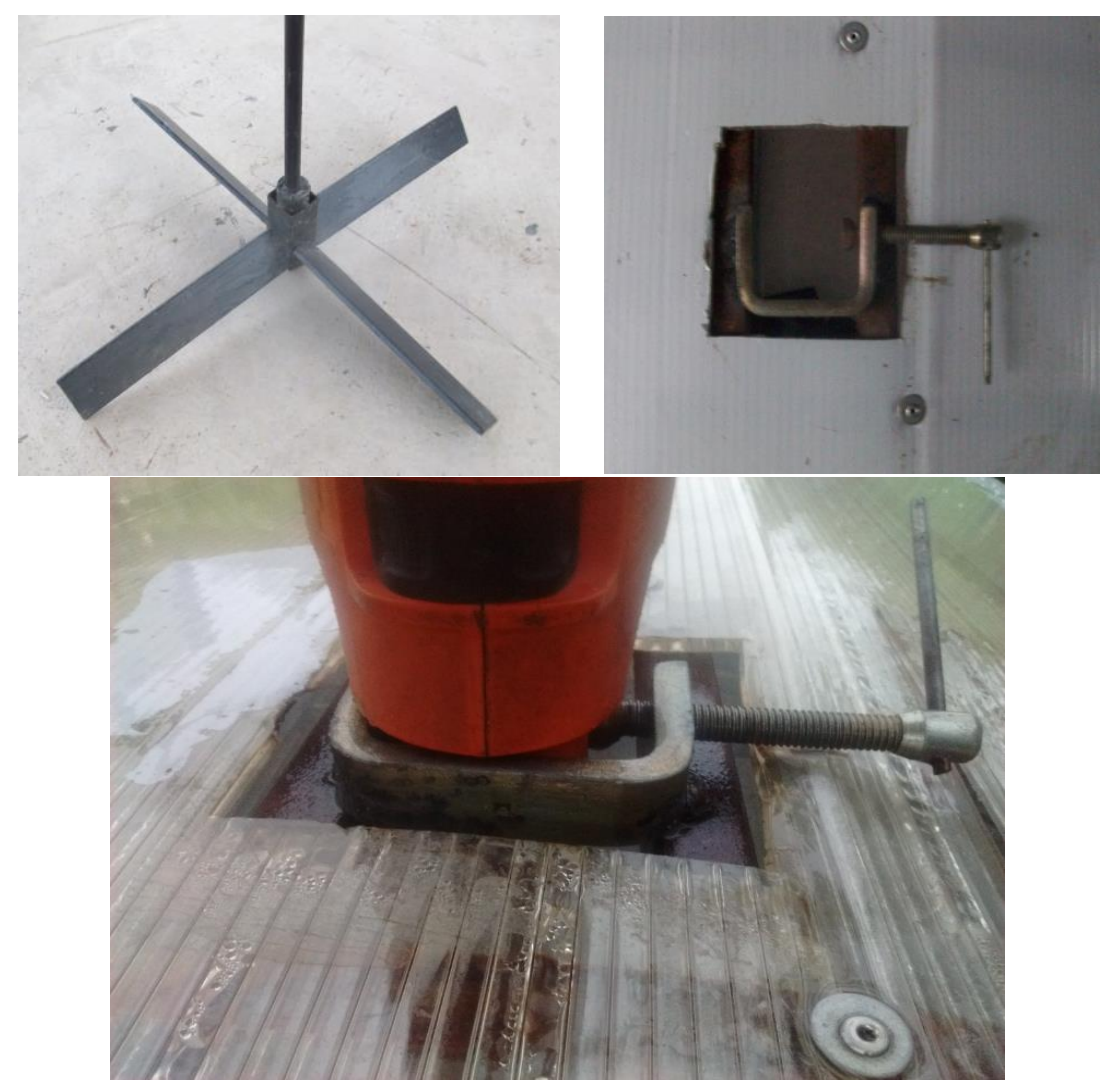

Figura 6.26. Mezclador y sistema de sujeción. Fuente: imagen propia. 
En la Figura 6.27 se presentan cuatro imágenes del digestor y el sistema hibrido solareléctrico. En la superior izquierda se señala la electrobomba y el recipiente que contiene la resistencia eléctrica. Esta última se observa con más detalle en la parte superior derecha. Debajo de ésta se muestran las válvulas eléctricas de agua, las que se señalan también en la parte inferior. En esta imagen se observa a la vez, el gabinete metálico con el control eléctrico, cuyo esquema se visualiza en la Figura 6.23.
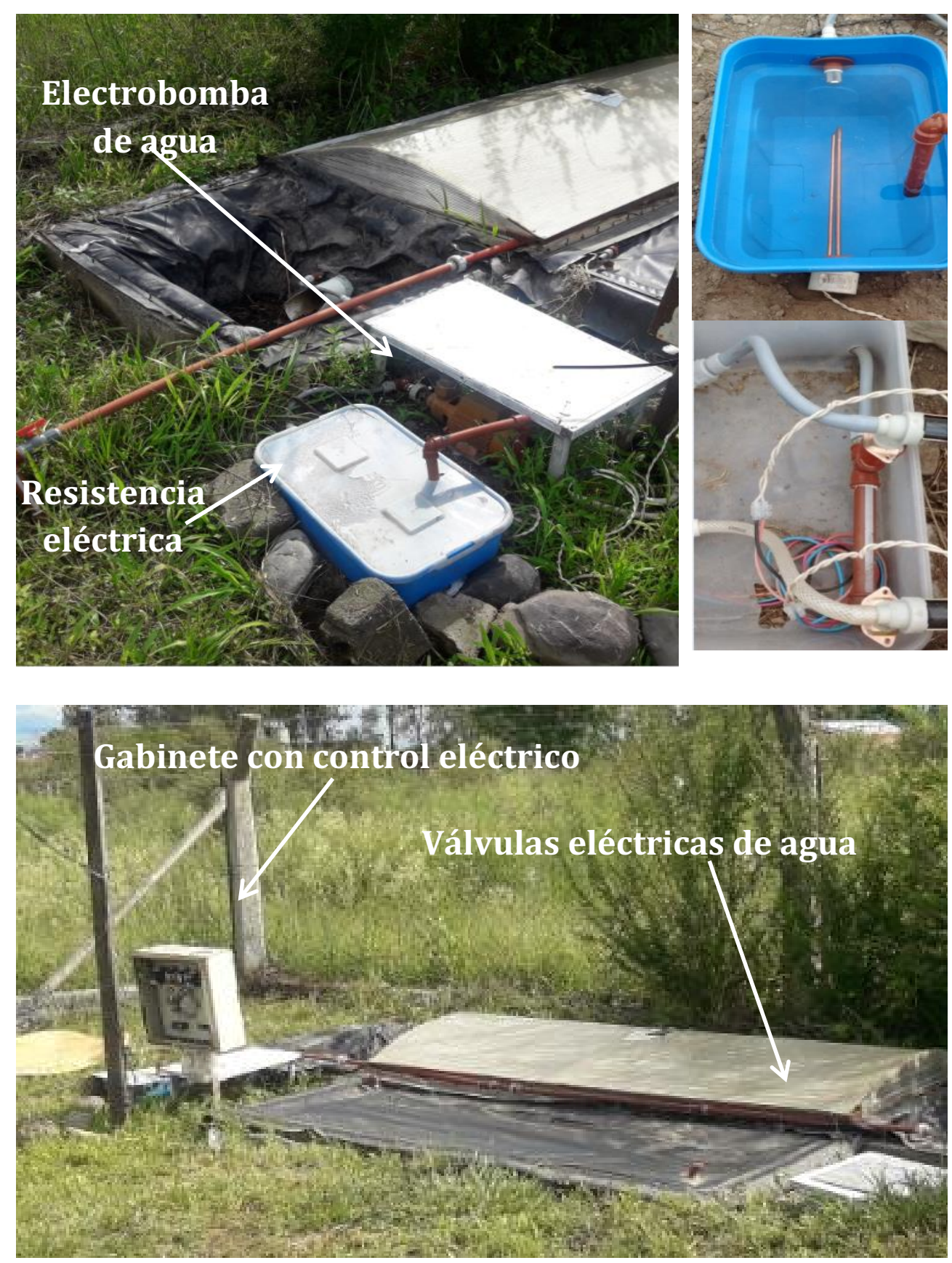

Figura 6.27. Imagen de la electrobomba, resistencia eléctrica, válvulas eléctricas y gabinete eléctrico.

Fuente: imagen propia. 


\subsection{Conclusiones.}

En este capítulo se presenta el diseño y la construcción de tres digestores anaeróbicos. El primero del tipo tubular flexible semienterrado (Caso A) sirvió para analizar el material de construcción, el sistema de calefacción y la aislación térmica. En el segundo (Caso B) se probaron técnicas de construcción de las paredes de la fosa del biodigestor. El tercer prototipo (Caso C) se diseñó tomando en cuenta las experiencias con estos dos digestores.

Las ventajas y desventajas se analizan en cuanto a su construcción y posibles problemas con la carga. Como se observa, en este capítulo se encara sólo la construcción de los digestores y los sistemas de calentamiento. En la Tabla 6.1 se mencionan las ventajas y desventajas de tipo tubular flexible (A) y enterrado (B y C).

Tabla 6.1 Ventajas y desventajas en la construcción de los digestores.

\begin{tabular}{|c|c|}
\hline & Digestor tubular flexible - Caso A \\
\hline \multicolumn{2}{|l|}{ VENTAJAS } \\
\hline Armado & $\begin{array}{l}\text { Realizado en una sola pieza de membrana, con una única } \\
\text { unión longitudinal y una única abertura en cada } \\
\text { extremo. }\end{array}$ \\
\hline Económico & $\begin{array}{l}\text { Construido mayoritariamente en membrana de PVC y } \\
\text { conductos plásticos de PVC. }\end{array}$ \\
\hline Partes móviles & Sin partes móviles: sin mezclador, ni motor eléctrico. \\
\hline Instalación & Rápida: aproximadamente de 1 día \\
\hline \multicolumn{2}{|l|}{ DESVENTAJAS } \\
\hline Agitación & $\begin{array}{l}\text { Al ser flexible y poseer solo dos aberturas se dificulta la } \\
\text { incorporación de un mezclador. }\end{array}$ \\
\hline $\begin{array}{l}\text { Pérdidas de } \\
\text { calor }\end{array}$ & $\begin{array}{l}\text { Fosa de pequeña profundidad con mayores pérdidas de } \\
\text { calor al ambiente. }\end{array}$ \\
\hline Limpieza & Se dificulta la limpieza ya que posee solo dos aberturas \\
\hline Filtración & $\begin{array}{l}\text { El tipo de fosa y colocación del digestor favorece la } \\
\text { acumulación de agua por la lluvia. }\end{array}$ \\
\hline
\end{tabular}


Tabla 6.1 Ventajas y desventajas en la construcción de los digestores (continuación).

\begin{tabular}{|l|l|}
\hline \multicolumn{2}{|c|}{ Digestor enterrado - Casos B y C } \\
\hline VENTAJAS & Sistema de agitación que mantiene homogénea la carga \\
\hline Económico & $\begin{array}{l}\text { Si bien su construcción es más compleja que el digestor } \\
\text { anterior no es costosa, pues está compuesto de } \\
\text { materiales económicos. }\end{array}$ \\
\hline $\begin{array}{l}\text { Pérdidas de } \\
\text { calor }\end{array}$ & $\begin{array}{l}\text { Al estar totalmente enterrado se reducen las pérdidas } \\
\text { de calor }\end{array}$ \\
\hline Limpieza & $\begin{array}{l}\text { La tapa del digestor se puede quitar para acceder al } \\
\text { interior del digestor facilitando la limpieza interior }\end{array}$ \\
\hline Filtración & $\begin{array}{l}\text { Al contrario de lo que ocurre con el digestor tubular en } \\
\text { este el tipo de colocación de la membrana del cuerpo del } \\
\text { digestor impide la filtración del agua en la fosa. }\end{array}$ \\
\hline DESVENTAJAS & \multicolumn{2}{|l|}{} \\
\hline Vaciado & Se dificulta su vaciado por estar enterrado. \\
\hline Instalación & Lenta: varios días \\
\hline
\end{tabular}

Fuente: imagen propia.

Los tres digestores se construyen con membrana de material PVC de $1100 \mu \mathrm{m}$ de espesor. Este es un material de fácil acceso en el mercado y bajo costo pues tiene diversas aplicaciones. Para su colocación en el digestor, se requiere de soldaduras especiales utilizando una maquinaria industrial y en algunas juntas se utiliza una pistola de calor de $1500 \mathrm{~W}$ de potencia. Las uniones con pistola requieren de mayor cuidado.

El digestor tubular flexible (caso A) es de rápida instalación ya que con un volumen de 285 litros se logra en un día de trabajo. Dado que no contiene partes móviles su colocación y mantenimiento, lo puede realizar una persona con escaso conocimiento en el tema.

El invernadero también proporciona una protección en los días de lluvia. Evita la filtración de agua entre la fosa y el digestor. Es importante que la cubierta transparente de la lona cuente, en lo posible, con filtro UV para proteger la membrana de PVC del digestor. Se advierte la fragilidad del invernadero que resulta inadecuado para los meses de vientos intensos. 
El invernadero en el digestor enterrado fue construído con una estructura de hierro hueco de perfil cuadrado y planchuela de hierro que le proporcionaron rígidez. El policarbonato alveolar utilizado tiene una flexibilidad tal que permite darle una forma concava como se observa en las imágenes. Tiene mayor resistencia que otros plásticos utilizados para ese fin. Durante los meses de agosto y setiembre se presentan en la zona fuertes vientos. No obstante, tal construcción se mantuvo en su posición sin sufrir ninguna deformación.

Cuando el digestor es enterrado y con un sistema de calentamiento la instalación requiere más tiempo y de conocimientos en electricidad, albañilería y plomería. El montaje lleva aproximadamente 3 días de trabajo para un volumen de 1.400 litros. La colocación del aislamiento necesita un tiempo adicional.

Las pruebas con el agitador indicaron que éste debe tener sus paletas con un área mayor para que ésta sea efectiva. Las pruebas de mezclado con el agitador se realizaron con un motor de $600 \mathrm{~W}$. Dado que este tipo de motor se utiliza en máquinas perforadoras y no es el indicado para realizar esta tarea, en las experiencias se trabaja con cierta intermitencia.

Con el último digestor construido (caso C) se lograron mejoras en cuanto al mantenimiento y control de la temperatura. Por un lado, se cuenta con energía eléctrica para elevar la temperatura de operación del digestor cuando sea necesario mientras que, por otro lado, en los momentos de mayor radiación solar se abastece de esta energía al digestor. Con la incorporación del mezclador se logra mantener la uniformidad de la carga. 


\section{CAPITULO 7}

\section{MEDIDAS DE TEMPERATURAS.}

Sistemas De Calentamiento. 


\subsection{Introducción.}

En el Capítulo 6 se expuso la construcción de dos tipos de digestores, uno tubular semienterrado y dos enterrados de geometría rectangular, utilizando membrana de PVC. Como se señaló, la temperatura de operación del digestor es una de las variables determinantes para evaluar el rendimiento, es decir la cantidad de biogás o metano producido por el material orgánico en un determinado tiempo.

Una tarea que necesita una evaluación íntegra es el clima de la región en donde se instalará el digestor (los prototipos ensayados se encuentran en una zona rural de la Capital de Salta). La temperatura de operación del digestor, es también un factor importante, pues en su determinación intervienen diversos aspectos, tales como económicos, energéticos y técnicos. relación a la energía que interviene en el proceso, debe considerarse el recurso utilizado para calefaccionarlo, solar, eléctrico, etc. Esto influye en la parte técnica y en la inversión inicial monetaria (aspecto económico).

En este capítulo se expondrán en detalle las distintas técnicas de calentamiento aplicadas a los digestores anaeróbicos presentados en el Capítulo 6. A fin de evaluar el desempeño se mide la temperatura en diversos puntos del sistema. Se exponen las medidas de irradiancia solar a fin de evaluar, junto a los datos de temperatura, la eficiencia del colector solar plano. La curva correspondiente se presentará en el Capítulo 8.

\subsection{Técnicas de calentamiento- caso A.}

A fin de examinar las distintas formas de calentamiento se practican en el digestor tubular diferentes técnicas. En cada práctica se midieron las temperaturas en diversos puntos. En la Figura 7.1 se presenta las ubicaciones de los sensores $\mathrm{S}_{1}$ a $\mathrm{S}_{6}$ con puntos en color rojo del digestor tubular flexible semienterrado, caso A. Se observa en ésta, el digestor con la cubierta del invernadero por encima y el intercambiador de calor y la aislación térmica por debajo.

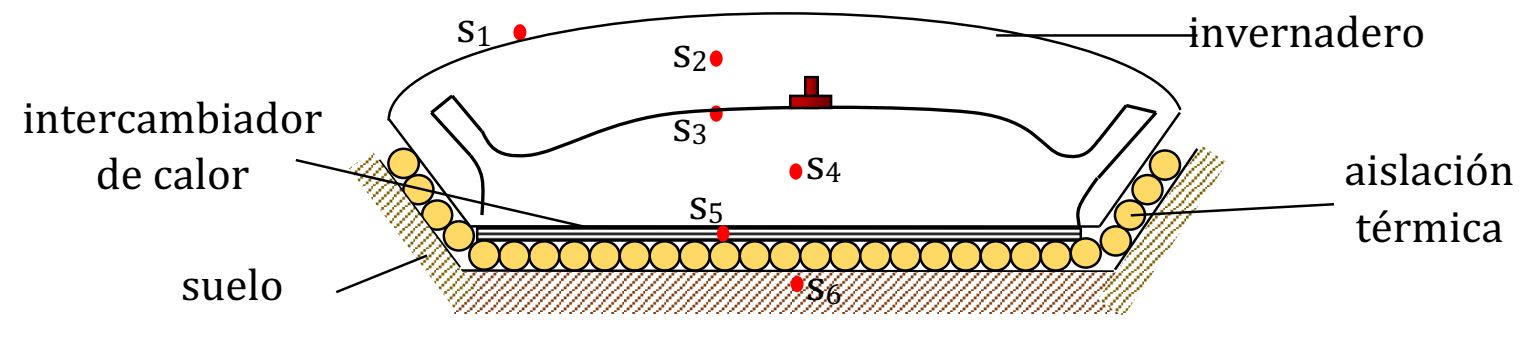

$\mathrm{s}_{1}$ : ambiente externo

$\mathrm{s}_{2}$ : dentro del invernadero

$\mathrm{s}_{3}$ : sobre la superficie del digestor
$\mathrm{S}_{4}$ : dentro del digestor

s5: $_{5}$ sobre el intercambiador de calor S6: en el suelo

Figura 7.1. Esquema de ubicación de sensores en el digestor tubular flexible semienterrado, caso A.

Fuente: Elaboración propia. 
Se miden las temperaturas en diversos puntos a fin de estudiar la incidencia de las distintas técnicas para su calentamiento. Inicialmente se evalúa al digestor solo sin ningún aditamento, luego se le agrega un invernadero y finalmente la aislación térmica presentada en el Capítulo 5 más el sistema de calentamiento eléctrico.

En la Figura 7.2 se detallan las partes del digestor anaeróbico en un esquema junto con sus imágenes.
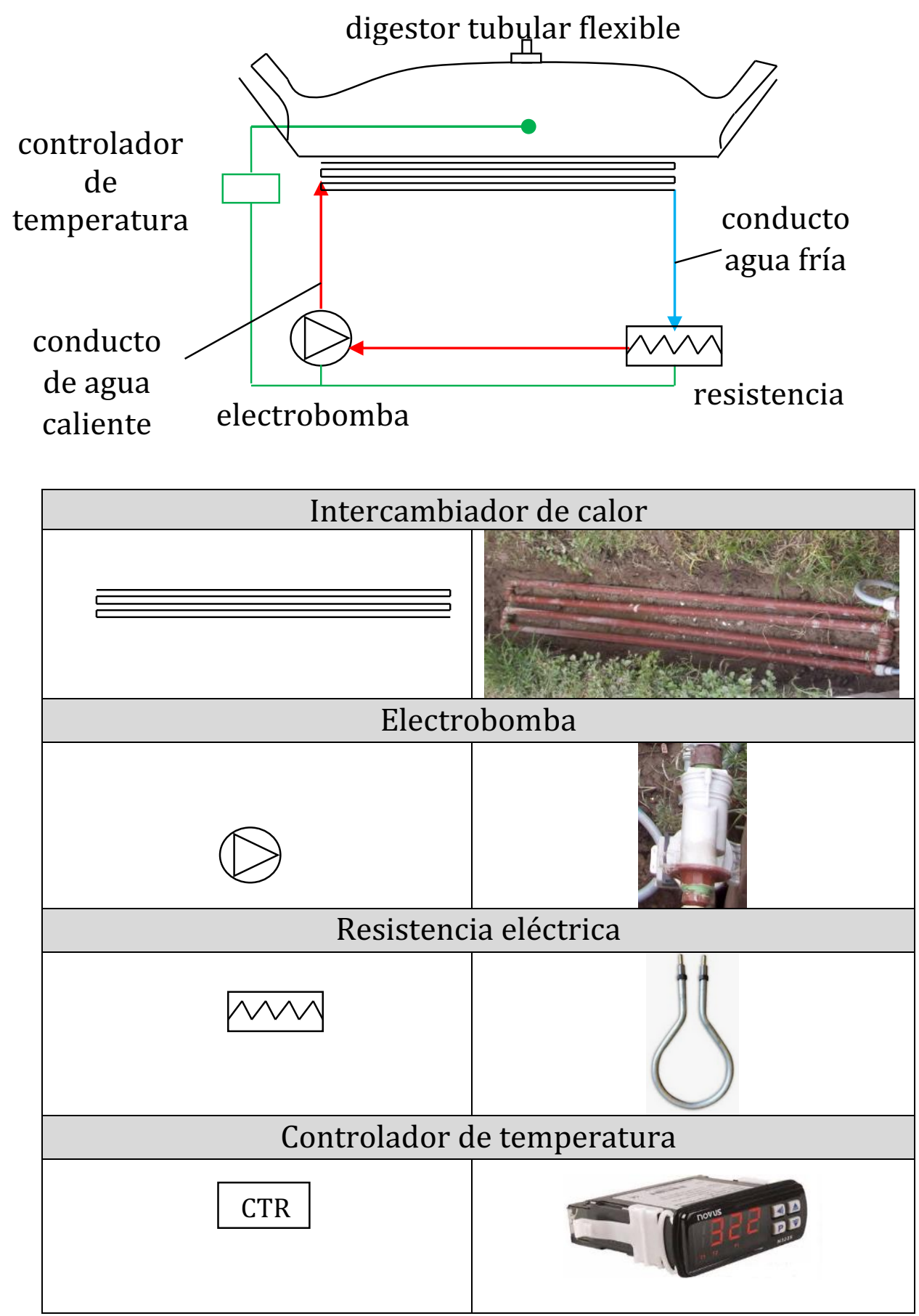

Figura 7.2. Esquema de digestor anaeróbico tubular e imágenes de los componentes del sistema de calentamiento. Fuente: Elaboración propia. 


\subsection{Técnicas de calentamiento- caso $C$.}

Un digestor más sofisticado lo constituye el tercer prototipo, caso C, enterrado con un sistema de calentamiento hibrido solar-eléctrico. Es importante que el sistema funcione con escasa intervención del operario, de modo que cuando el digestor se encuentre en funcionamiento, solo debe preocuparse de cargarlo con la periodicidad establecida.

A fin de evaluar la calefacción combinada del sistema eléctrico más del colector solar se mide la temperatura en diversos puntos, tal como se señala en la Figura 7.3.

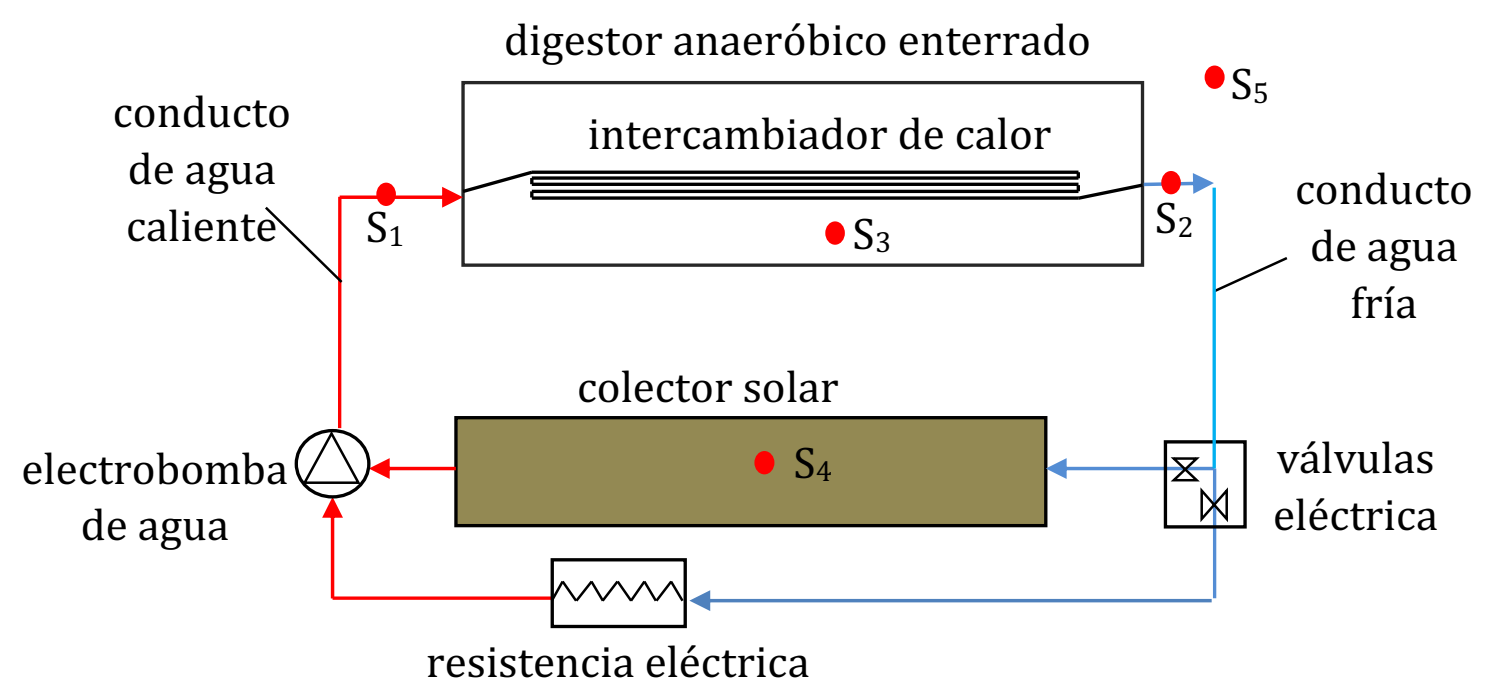

(a) esquema de planta

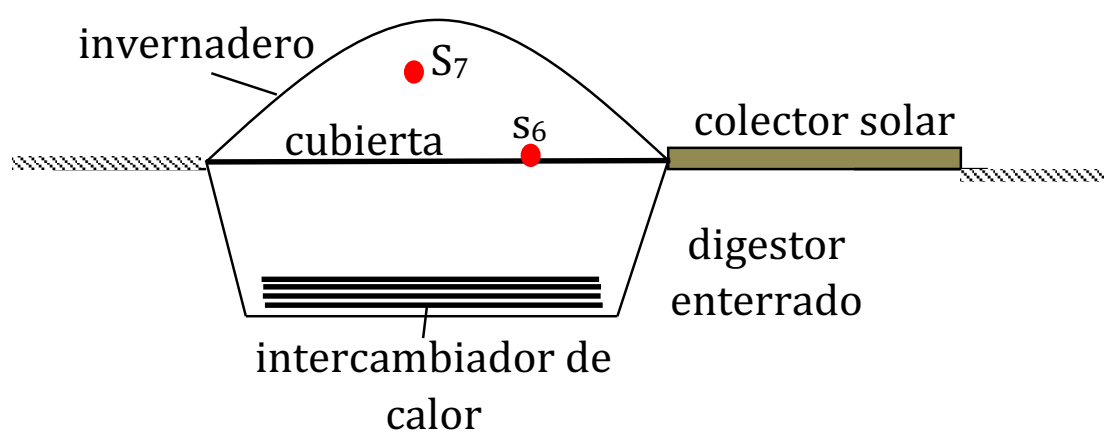

(b) esquema lateral

Figura 7.3. Esquema del digestor, caso C, y sistema de calentamiento. Posiciones de los sensores de temperatura. (a) vista de planta, (b) vista lateral.

Fuente: Elaboración propia. 
En la Figura 7.3 se esquematizan las partes del digestor y el sistema de calentamiento; en puntos rojos se representan los lugares donde se colocan los sensores termopares, desde $S_{1}$ a $S_{7}$ :

$\checkmark S_{1}$ : en el fluido caloportador antes de ingresar al intercambiador de calor

$\checkmark S_{2}$ : en el fluido caloportador después de salir del intercambiador de calor

$\checkmark S_{3}$ : dentro del digestor anaeróbico

$\checkmark$ S: dentro del colector solar

$\checkmark$ S$_{5}$ : en el ambiente externo

$\checkmark$ S$_{6}$ : en la cubierta del digestor

$\checkmark$ S $_{7}$ : en el invernadero

El aporte de la energía solar se logra mediante el colector solar plano y el invernadero colocado encima del digestor como se presenta en la Figura 7.3.b. En ella se muestra un esquema del digestor, el invernadero y el colector solar; así como el circuito del fluido caloportador (agua). Se representa en color celeste el fluido frio que sale del intercambiador de calor y en color rojo el caliente que proviene del colector solar o de la resistencia eléctrica. El intercambiador de calor se encuentra sumergido dentro del digestor.

En el ensayo se mantiene al digestor en $30^{\circ} \mathrm{C}$. Si bien no es la temperatura óptima para la digestión anaeróbica, se pensó primero en evaluar el desempeño del colector solar, a los fines de estimar la temperatura máxima que alcanza.

El sistema eléctrico contiene dos controladores de temperatura con sus respectivos sensores, como se indicó en la Figura 6.21. Uno de ellos, CTR1, se lo fija en $30^{\circ} \mathrm{C}$ con su sensor sumergido en el interior del digestor para mantener constante la temperatura. Cuando ésta decae por debajo de $30^{\circ} \mathrm{C}$ se acciona la bomba que impulsa el fluido caloportador (agua) y al mismo tiempo se enciende la resistencia eléctrica o se utiliza el colector solar, dependiendo de la irradiancia disponible.

El segundo controlador CTR2 con su sensor en el interior del colector solar comanda la apertura y cierre de las dos válvulas eléctricas que componen el circuito hidráulico. Se utiliza el colector si su temperatura está por encima de los $30^{\circ} \mathrm{C}$ de lo contrario, es la resistencia eléctrica la que eleva la temperatura del fluido caloportador.

Además de medir la temperatura en diversos puntos del sistema se mide la irradiancia solar incidente sobre la superficie horizontal, dato que resulta imprescindible para obtener la curva de rendimiento del colector solar plano.

En la Figura 7.4 se presentan las imágenes de las partes del sistema de calentamiento junto a simbología del esquema de la Figura 7.3. 


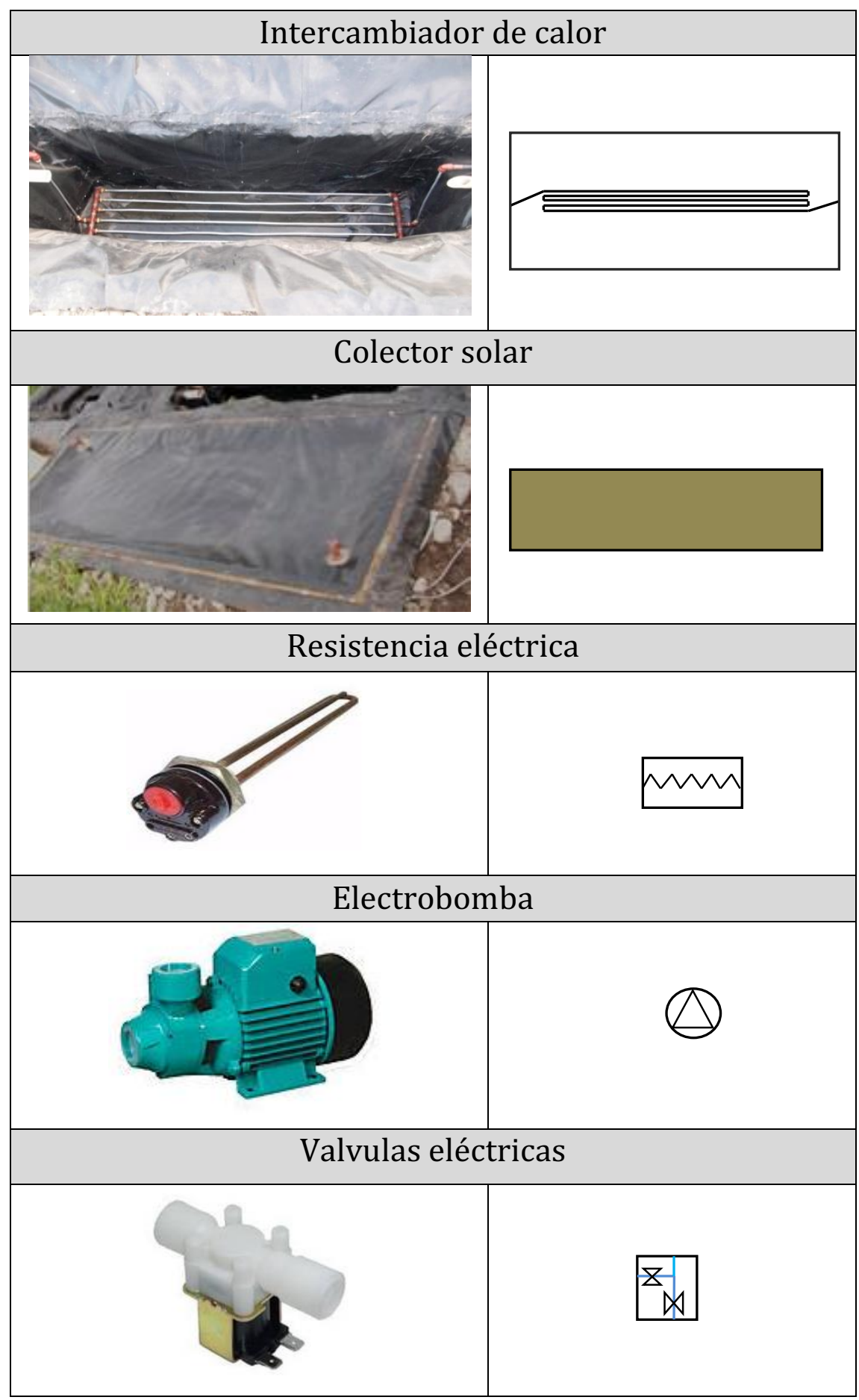

Figura 7.4. Imágenes y esquema del sistema de calentamiento. Fuente: Elaboración propia.

Se requiere que:

$\checkmark$ la temperatura en el interior del digestor se mantenga en el valor asignado de operación con oscilaciones inferiores a $2^{\circ} \mathrm{C}$.

$\checkmark$ el sistema de calefacción funcione correctamente sin ninguna intervención del usuario.

$\checkmark$ el colector solar aporte una parte de la energía calórica que necesita el digestor 
En el artículo: "Evaluación de un sistema de calefacción solar-eléctrico aplicado a un digestor anaeróbico enterrado", se publicaron datos acerca del sistema propuesto para el digestor anaeróbico enterrado (Morales et al., 2017).

\subsection{Presentación de las medidas en el digestor tubular-Caso A.}

\subsubsection{Efectos del invernadero en la temperatura del digestor tubular semienterrado.}

El digestor tubular es instalado con una parte de su cuerpo enterrado por debajo de la superficie, tal como se señaló en el Capítulo 6. De esta manera se intenta proteger la carga de las temperaturas bajas del ambiente. Por otro lado, se lo expone diariamente a la irradiancia solar directa. Teniendo en cuenta que la membrana con que está construida es de color negro, la energía que absorbe contribuye a elevar la temperatura de la carga interior.

Se monitorea durante siete días (durante el mes de octubre) el digestor semienterrado en contacto con el ambiente, cargado sólo con 150 litros de agua. El interés principal es determinar la temperatura de operación sin ninguna intervención y en particular, durante la temporada más desfavorable, invernal en el mes de julio. En un primer ensayo, cuyas medidas se observan en la Figura 7.5, se miden las temperaturas: ambiente representada en color azul, en el interior del digestor en verde, en el suelo por debajo de éste en marrón y en la cubierta en rojo, es decir en el cuerpo en la parte superior.

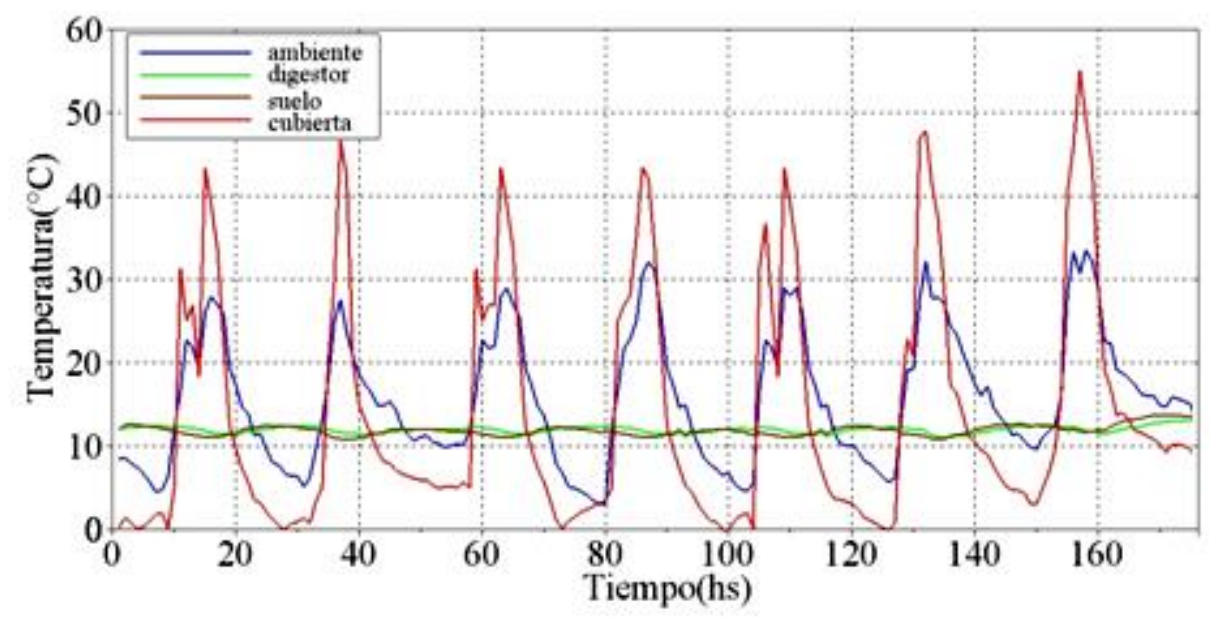

Figura 7.5. Temperaturas en el digestor tubular. Fuente: Elaboración propia.

La temperatura de la carga inicialmente a $11^{\circ} \mathrm{C}$ alcanza los $13^{\circ} \mathrm{C}$ al cabo del sexto día. La temperatura de la membrana es más alta que la máxima ambiente llegando a los $70^{\circ} \mathrm{C}$. En color marrón se observa la temperatura del suelo y sigue la misma tendencia 
que la del digestor. Las pérdidas de energía son grandes dado que su transmisión es casi inmediata.

Se observa que la temperatura ambiente, en color azul, presenta una gran amplitud térmica (del orden de $20-25^{\circ} \mathrm{C}$ ), característica climática de esta zona. Al descender ésta durante la noche, es conveniente contar con un apoyo auxiliar, para mantener la temperatura en el digestor.

A fin de mejorar las condiciones térmicas en el digestor y dado que en las medidas anteriores se observa que la temperatura de la carga no es suficientemente alta como para ofrecer una producción útil de biogás, encontrándose ésta en el rango psicofílico, se coloca un invernadero construido con una cubierta plástica transparente. Las medidas de temperatura, realizadas en el mes de noviembre, se muestran en la Figura 7.6: ambiente (azul), digestor (verde), cubierta (rojo) e invernadero (negro). Las mismas se tomaron a lo largo de 12 días (288 horas) con registros que presentan diversas amplitudes térmicas.

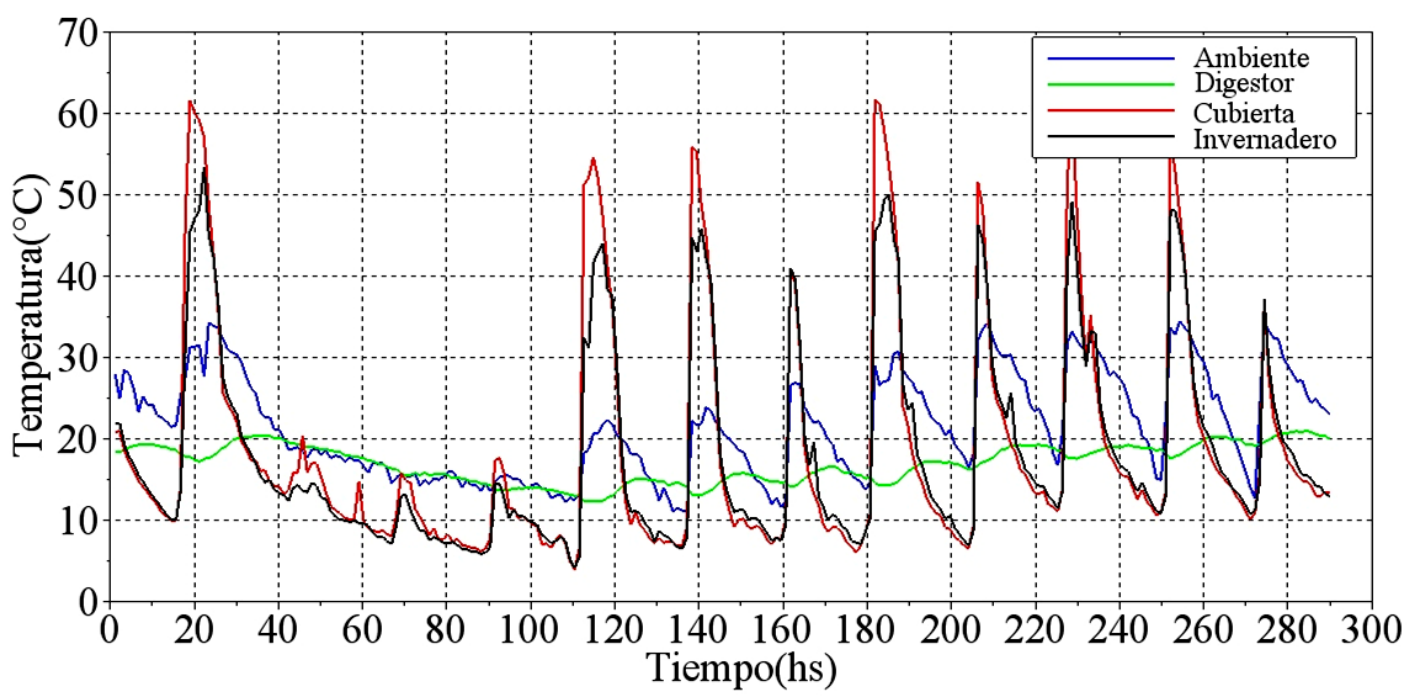

Figura 7.6. Temperaturas en el digestor tubular con invernadero.

Fuente: Elaboración propia.

Las variaciones térmicas corresponden a días fríos y cálidos, con máximas diarias de $16^{\circ}$ y $34^{\circ} \mathrm{C}$ respectivamente.

La transmisión del plástico transparente (invernadero) reduce la radiación que le llega a la membrana, de modo que su temperatura alcanza valores menores que cuando éste no estaba; sin embargo, la temperatura en el interior del digestor es considerablemente mayor, alcanzando los $20^{\circ} \mathrm{C}$, lo que resulta favorable para la digestión de la carga. Por tanto, la colocación del invernadero es una buena opción que permite mejorar las condiciones operativas del digestor. 
De los ensayos presentados, se observa que el invernadero contribuye a elevar la temperatura de la carga; pero resulta claro que es necesaria una aislación térmica a fin de evitar las pérdidas de calor desde el cuerpo del digestor al suelo.

7.4.2. Pruebas del sistema de calentamiento e incorporación de la aislación térmica en el digestor tubular.

La aislación térmica con botellas PET rellenas con viruta presentada y estudiada en detalle en el Capítulo 5 tiene excelentes condiciones como aislante. En este apartado se estudia el comportamiento del sistema de calentamiento eléctrico, presentado en el Capítulo 6, junto con la aislación térmica. En esta oportunidad el digestor es solo cargado con agua.

A fin de estudiar como incide la colocación de la aislación térmica, se realizan dos tipos de experiencias, con y sin aislación. Se mide la temperatura (en el mes de noviembre) en diversos puntos del sistema: ambiente, digestor, intercambiador de calor (IC) y suelo por debajo del digestor, presentadas en la Figura 7.7 (a) y (b).

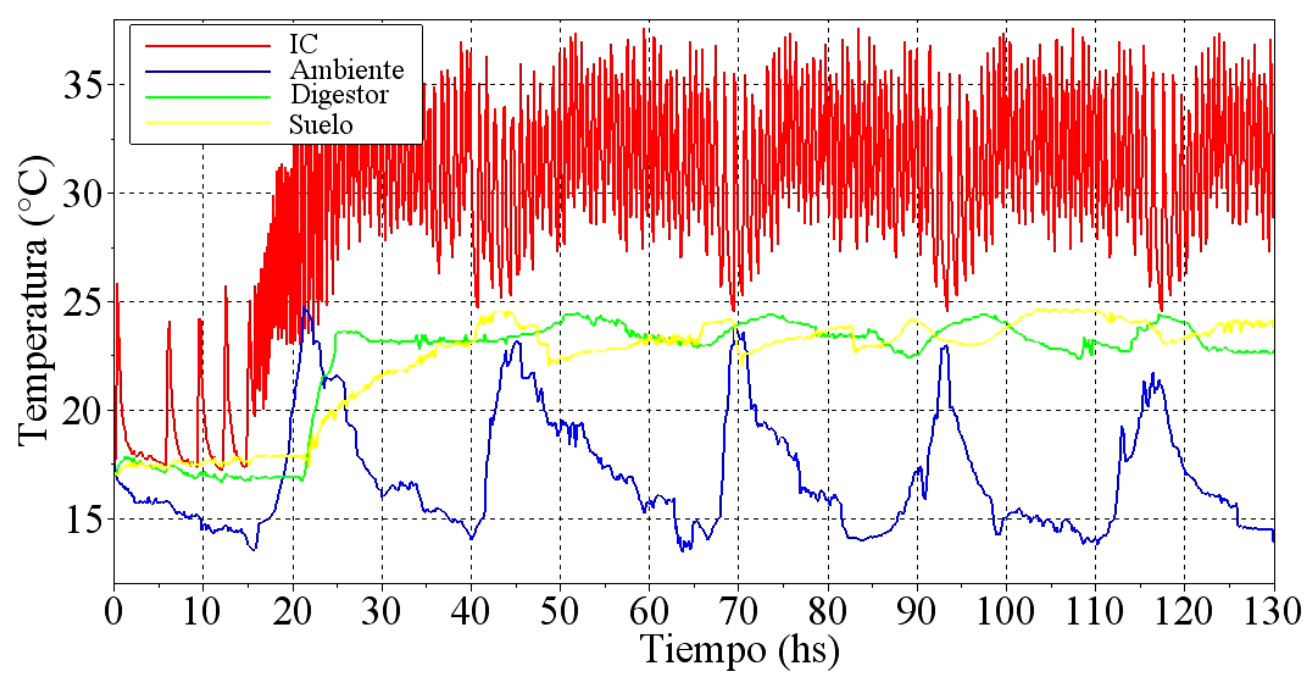

(a) sin aislación 


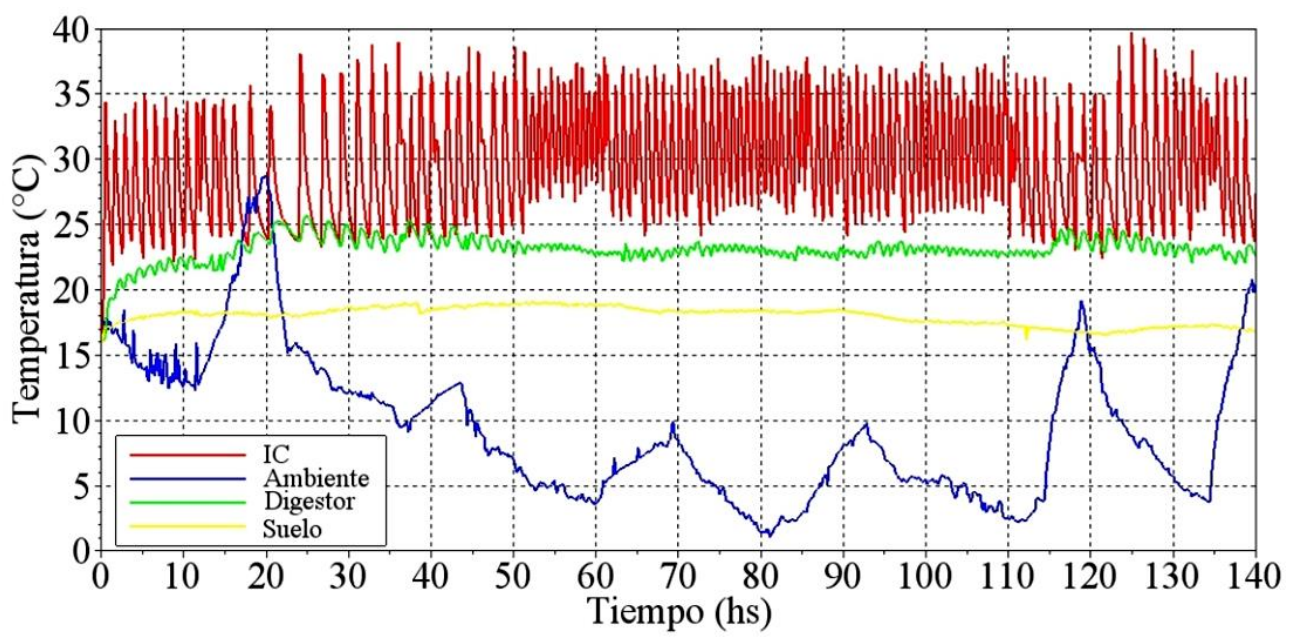

(b) con aislación

Figura 7.7. Temperaturas medidas en el intercambiador de calor, ambiente externo, interior del digestor y del suelo (por debajo del IC) sin (a) y con aislación (b). Fuente: Elaboración propia.

El controlador de temperatura se fija en $24^{\circ} \mathrm{C}$. En ambas figuras se destacan las repetidas oscilaciones en el intercambiador de calor (IC) en color rojo, debido al encendido y apagado del sistema de calentamiento. En las horas donde la temperatura ambiente y la irradiancia solar es más elevada, el sistema de calentamiento se enciende con menor frecuencia. La resistencia eléctrica y la bomba se activan una vez que el digestor alcanza los $24{ }^{\circ} \mathrm{C}$. Por el contrario, si se encuentra por debajo de esta temperatura la resistencia eléctrica se activa para volver a calentarlo.

Las medidas del digestor sin aislación se muestran en la Figura 7.7a. A lo largo de 5 días y 10 horas ( $130 \mathrm{hs}$ ) el digestor se mantiene alrededor de $24^{\circ} \mathrm{C}$, con algunas oscilaciones entre $1^{\circ}$ y $2^{\circ} \mathrm{C}$. La temperatura del suelo (en color amarillo), cuyo sensor se encuentra por debajo del intercambiador de calor, sigue la misma tendencia y en algunos casos supera a la del digestor cuando esta última desciende casi $2^{\circ} \mathrm{C}$.

En el siguiente ensayo, Figura 7.7. b, con una duración de 5 días y 20 horas (140hs), se coloca la aislación térmica por debajo del digestor y del intercambiador de calor tal como se muestra en el esquema de la Figura 7.1. Tanto en esta experiencia como en la anterior, el intercambiador de calor se encuentra entre $\operatorname{los} 25^{\circ}$ y los $35^{\circ} \mathrm{C}$.

La temperatura ambiente durante la mayor parte de los días fue considerablemente más baja que en la experiencia sin aislación. Sin embargo, el digestor se mantiene en $24^{\circ} \mathrm{C}$ con pequeñas oscilaciones (curva verde).

Es importante destacar que la temperatura del suelo (amarillo), se mantiene menor que la del digestor como consecuencia de la aislación. La humedad del suelo no afecta la efectividad de la aislación. 
Se advierte que los días en que se realizó el ensayo con aislación térmica, son más fríos que cuando ésta no está presente. Esta situación climatológica es más desfavorable, aun así, el tiempo que permanece encendido el sistema de calentamiento es menor que en el caso sin aislación.

En la Tabla 7.1 se muestra el tiempo de encendido del sistema calefactor en ambos ensayos. Como se señaló anteriormente no se han realizado simultáneamente, sino en días diferentes, siendo los más fríos para la experiencia con aislación. No obstante, el tiempo total de encendido sin aislación (sin botellas) supera en 11 horas a la experiencia con aislación (con botellas).

Tabla 7.1. Comparación de los tiempos de encendido del sistema eléctrico en las experiencias sin y con aislación.

\begin{tabular}{|c|c|c|}
\hline & \multicolumn{2}{|c|}{ Tiempo de encendido (hs) } \\
\hline Día & sin aislación & con aislación \\
\hline $\mathbf{1}$ & 5,2 & 3,0 \\
\hline $\mathbf{2}$ & 5,8 & 2,7 \\
\hline $\mathbf{3}$ & 5,5 & 4,3 \\
\hline $\mathbf{4}$ & 5,7 & 3,4 \\
\hline $\mathbf{5}$ & 5,3 & 2,9 \\
\hline Total & $\mathbf{2 7 , 5}$ & $\mathbf{1 6 , 3}$ \\
\hline
\end{tabular}

Fuente: Elaboración propia.

Si bien el suelo es un aislante térmico, a partir de los resultados obtenidos, se advierte la importancia de adicionar una aislación térmica, siendo notoria la diferencia cuando se coloca la misma aislación. Un factor que influye considerablemente es la humedad. Después de una lluvia sin duda, la tierra humedecida favorecerá el aumento de las pérdidas de calor. Por otro lado, las paredes de la fosa que contiene al digestor no están en contacto directo con el digestor, ya que como se presentó en el Capítulo 6, se recubre la fosa con una aislación térmica y el digestor es colocado sobre ella.

La colocación de un invernadero es muy conveniente. Protege, en caso de lluvia, del ingreso de agua a la fosa; mejora las condiciones térmicas dentro del digestor; con filtro UV protege la membrana del digestor del deterioro natural al estar expuesta a la irradiancia solar.

\subsection{Ensayos con el digestor anaeróbico enterrado- Caso C.}

7.5.1. Medidas del colector solar y la cubierta del digestor. Relación con la irradiancia solar incidente.

En la zona rural de Salta Capital, donde se instaló el digestor, existe una marcada amplitud térmica día-noche (la que puede superar los $25^{\circ} \mathrm{C}$ ). La Figura 7.8 muestra 
las temperaturas de la cubierta del digestor (rojo), la ambiente (verde), la del colector (azul) y del invernadero (celeste). Los días en que se realiza la experiencia son cálidos en general con temperaturas máximas que superan, en algunos casos, los $30^{\circ} \mathrm{C}$; mientras que las mínimas se encuentran entre $\operatorname{los} 2^{\circ}$ y $10^{\circ} \mathrm{C}$. Como se aprecia en la figura durante el segundo día decae la temperatura máxima, alcanzando los $15^{\circ} \mathrm{C}$.

Se evalúa el comportamiento del sistema de calentamiento para el digestor anaeróbico enterrado durante los días 19 al 26 de setiembre, 160 hs, periodo que se considera suficiente para lograr una temperatura constante en el digestor. Se carga al digestor con 400 litros de agua dando inicio a las 14 horas del primer día de ensayo.

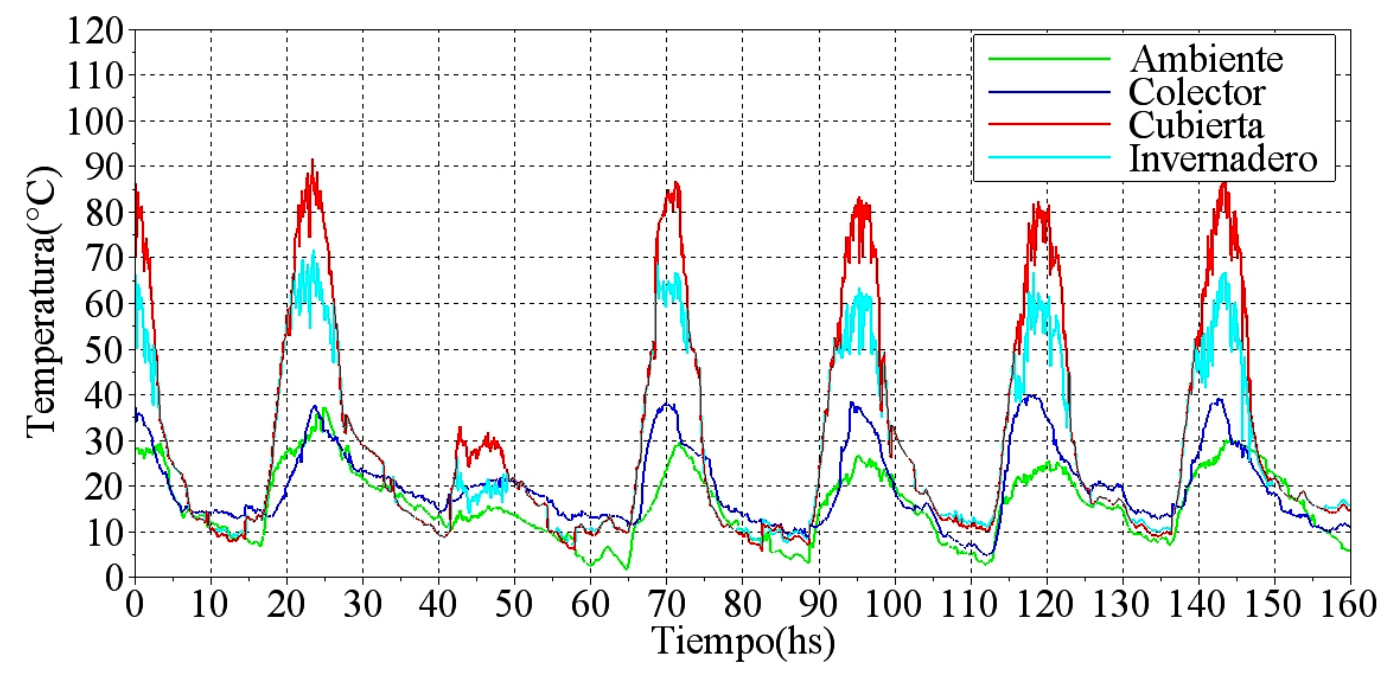

Figura 7.8. Temperaturas medidas en el digestor enterrado: ambiente, colector solar, cubierta del digestor e invernadero.

Fuente: Elaboración propia.

En los días cálidos, la temperatura del colector solar no presenta mayores cambios. Las máximas se encuentran entre los $35^{\circ}$ y $40^{\circ} \mathrm{C}$. En el día más frio llega a los $21^{\circ} \mathrm{C}$, unos $5^{\circ} \mathrm{C}$ por encima de la temperatura ambiente. La cubierta del digestor alcanza los valores más altos con máximas entre los $80^{\circ}$ y $90^{\circ} \mathrm{C}$.

En la Figura 7.9 se muestran las medidas de la irradiancia solar directa sobre plano horizontal en $\mathrm{W} / \mathrm{m}^{2}$ en los días en que se evalúa el sistema de calentamiento para el digestor enterrado. Se destaca el día más frio con máximas de $15^{\circ} \mathrm{C}$ y una irradiancia solar pico de $355 \mathrm{~W} / \mathrm{m}^{2}$. Es importante contar con días como este para una mejor evaluación en el rendimiento del colector solar. La irradiancia solar en los demás días tiene un comportamiento similar con una máxima que alcanza los $700 \mathrm{~W} / \mathrm{m}^{2}$. 


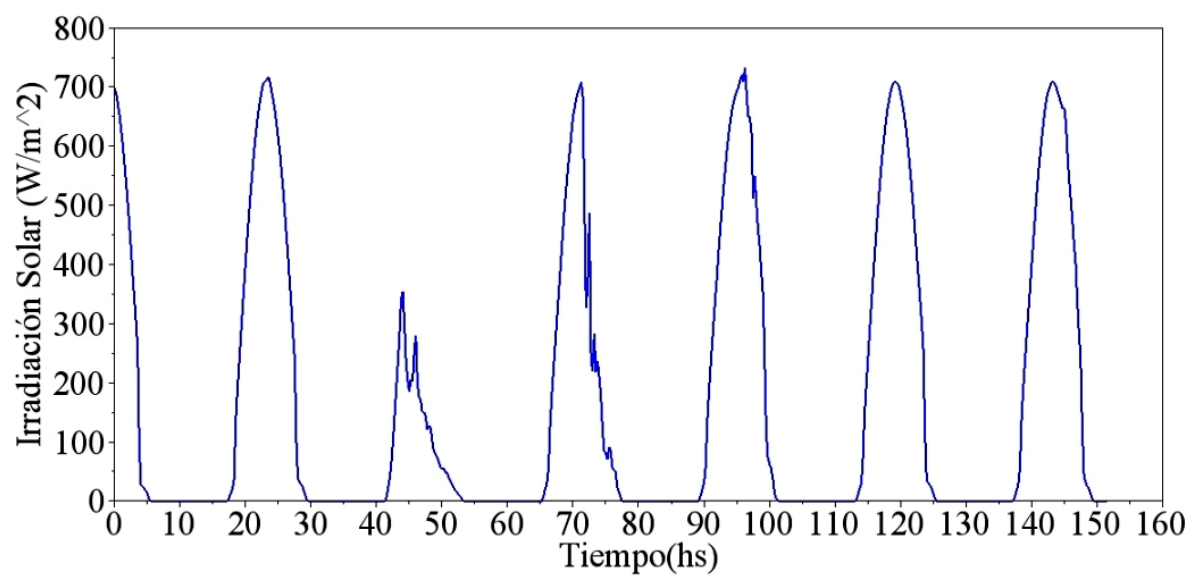

Figura 7.9. Irradiancia solar directa sobre plano horizontal.

Fuente: Elaboración propia.

En la Tabla 7.2 se muestran las temperaturas máximas: del ambiente, de la cubierta del digestor y del colector solar, así como la irradiancia solar diaria en un periodo de siete días.

Tabla 7.2. Valores máximos de temperatura e irradiancia solar.

\begin{tabular}{|c|c|c|c|c|c|}
\hline Día & & Tempera & ura $\left({ }^{\circ} \mathrm{C}\right)$ & & Irradiancia \\
\hline & Ambiente & Cubierta & Colector & Invernadero & $\left(\mathrm{W} / \mathrm{m}^{2}\right)$ \\
\hline 1 & 28 & 86 & 37 & 66 & 699 \\
\hline 2 & 37 & 88 & 37 & 71 & 710 \\
\hline 3 & 15 & 30 & 21 & 21 & 355 \\
\hline 4 & 29 & 86 & 37 & 66 & 700 \\
\hline 5 & 26 & 83 & 37 & 61 & 710 \\
\hline 6 & 25 & 82 & 40 & 64 & 709 \\
\hline 7 & 30 & 86 & 39 & 65 & 671 \\
\hline
\end{tabular}

Fuente: Elaboración propia.

Se observa que en los días cálidos la temperatura máxima del colector solar es superior a la de operación del digestor. Así, solo en el día más frio (con escasa radiación solar por la nubosidad) no se lo utiliza al colector solar para el calentamiento del digestor.

7.5.2 Temperaturas en el intercambiador de calor sumergido en el digestor.

Para evaluar el comportamiento del intercambiador de calor (IC) que se encuentra sumergido en la carga del digestor se toman las temperaturas dentro del circuito del 
flujo caloportador. Los sensores se ubican antes de la entrada (sensor $\mathrm{S}_{1}$ ) y a la salida (sensor $\mathrm{S}_{2}$ ) por fuera del digestor, como se señala en la Figura 7.10.

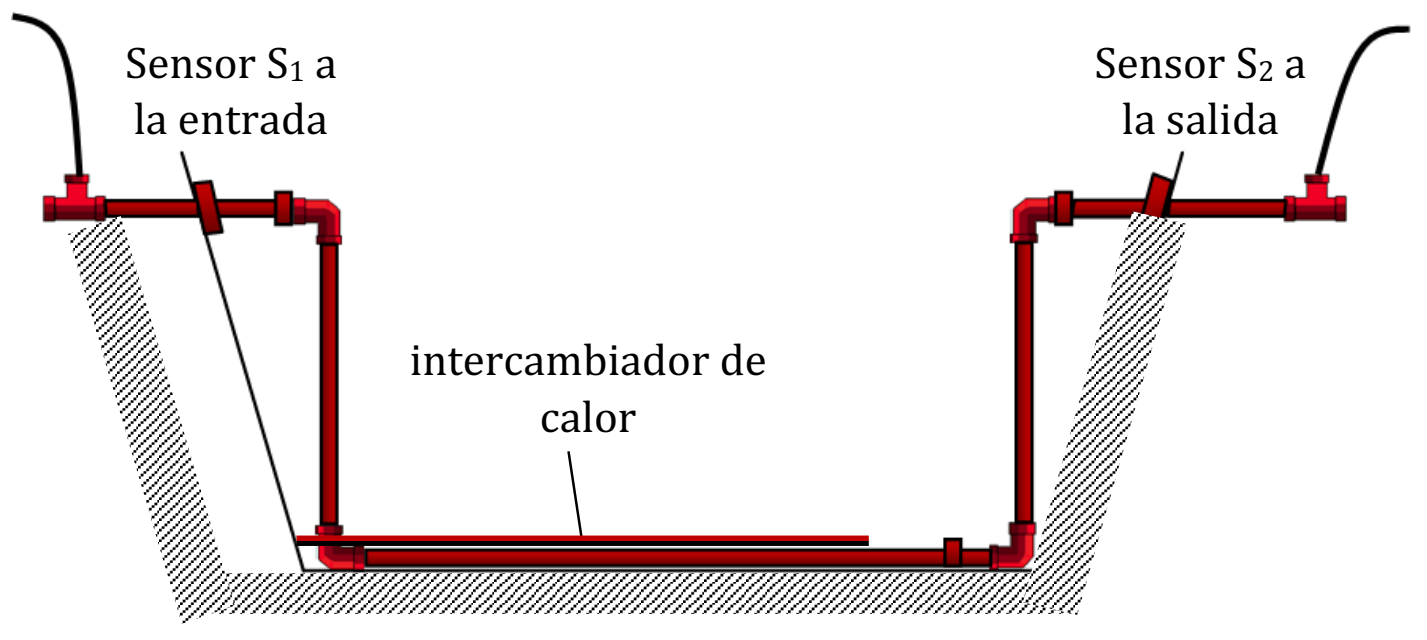

Figura 7.10. Esquema del intercambiador y ubicación de los sensores. Fuente: Elaboración propia.

En la Figura 7.11 se presentan las medidas de temperatura del fluido caloportador antes y después de pasar por el intercambiador, indicados en la gráfica como entrada y salida, en color rojo y azul, respectivamente. Se destacan los sucesivos picos y valles en los casi 7 días (160 hs) de funcionamiento del sistema. Esta intermitencia está dada por los sucesivos encendidos y apagados de la bomba que establece un flujo de agua dentro de los conductos.

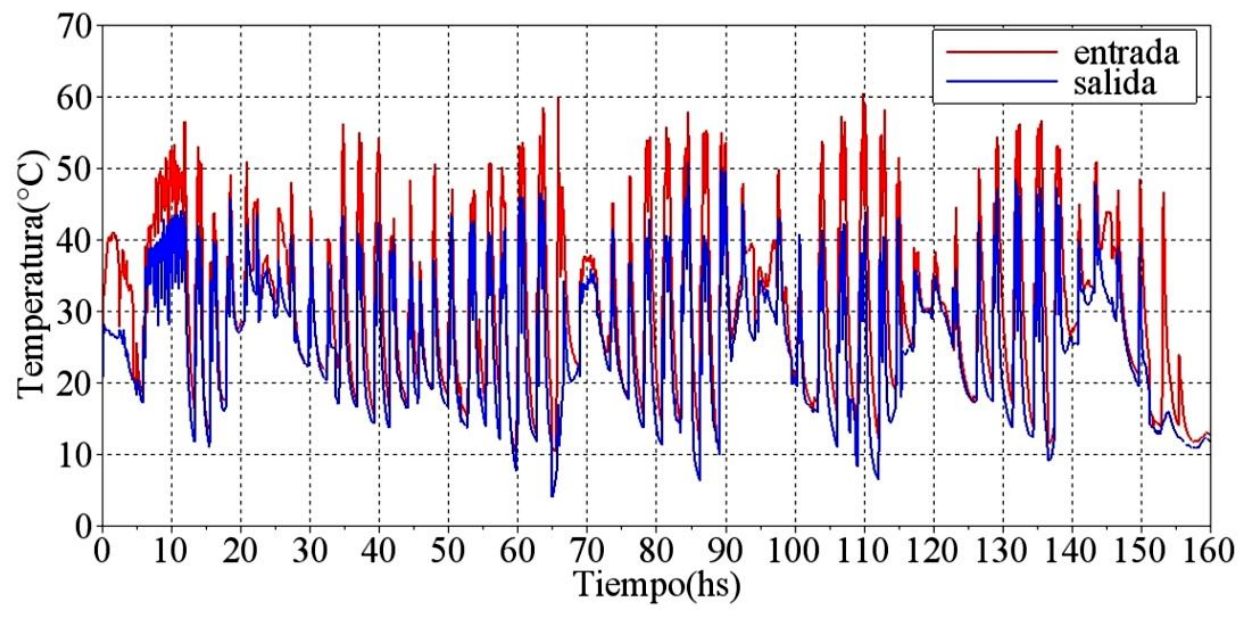

Figura 7.11. Temperatura del flujo de agua a la entrada y salida del intercambiador (IC) en función del tiempo.

Fuente: Elaboración propia.

En general, las curvas siguen el mismo patrón en los días cálidos, diferenciándose en el primer día, al inicio del ensayo y en el tercer día, que es el más frio. En la curva de 
color azul se observa que el flujo de agua sale del intercambiador con una temperatura más baja, con diferencias que van de $1^{\circ} \mathrm{C}$ a $7^{\circ} \mathrm{C}$. De la curva en color rojo se observa que los máximos valores de temperatura se encuentran entre los $50^{\circ} \mathrm{y}$ $65^{\circ} \mathrm{C}$. Estos se dan durante la noche, mientras que en las horas de radiación pico baja considerablemente para situarse entre los $30^{\circ}$ y $40^{\circ} \mathrm{C}$, tal como se presentó en la Figura 7.8.

Tabla 7.3. Temperatura del digestor y del intercambiador (IC) a la entrada y a la salida, en un período (0:10 a las 0:40 am).

\begin{tabular}{|c|r|r|r|}
\hline & \multicolumn{3}{|c|}{ Temperatura } \\
\hline $\begin{array}{c}\text { Hora del } \\
\text { día (am) }\end{array}$ & Digestor & $\begin{array}{c}\text { IC } \\
\text { Entrada }\end{array}$ & $\begin{array}{c}\text { IC } \\
\text { Salida }\end{array}$ \\
\hline $\mathbf{0 : 1 0}$ & 30,09 & 22,17 & 19,52 \\
\hline $\mathbf{0 : 1 5}$ & 29,97 & 34,54 & 27,71 \\
\hline $\mathbf{0 : 2 0}$ & 29,88 & 31,61 & 26,01 \\
\hline $\mathbf{0 : 2 5}$ & 29,85 & 29,71 & 24,81 \\
\hline $\mathbf{0 : 3 0}$ & 29,79 & 47,30 & 38,97 \\
\hline $\mathbf{0 : 3 5}$ & 29,88 & 51,82 & 41,57 \\
\hline $\mathbf{0 : 4 0}$ & 30,00 & 53,01 & 43,43 \\
\hline
\end{tabular}

Fuente: Elaboración propia.

En la Tabla 7.3 se muestra en un período de 30 minutos, que va de las 0:10 am a las 0:40 am, la temperatura del digestor y del fluido caloportador antes y después de ingresar al intercambiador de calor. Se observa que cuando la temperatura desciende de $30^{\circ} \mathrm{C}$, se enciende el sistema de calentamiento para retornar a este valor.

Si se analiza la temperatura del flujo caloportador antes de ingresar al intercambiador (IC entrada) se advierten los momentos en que funciona la resistencia eléctrica y la electrobomba. Se registran dos aumentos: a las 0:15 y a las 0:30 horas, donde la temperatura del IC a la entrada vale $34,54^{\circ}$ y $47,30^{\circ} \mathrm{C}$.

El tipo de funcionamiento que se advierte con este análisis se repite diariamente.

Se prevé que para un volumen mayor de la carga del digestor las oscilaciones de temperatura serán menores por poseer una mayor masa térmica. Hay que tener en cuenta que la mayor parte es agua pues solo un $8 \%$ o $10 \%$ del total corresponde a sólidos orgánicos.

\subsubsection{Temperatura del digestor.}

En la Figura 7.12 se presenta la temperatura del digestor anaeróbico enterrado durante 180 horas. Cabe aclarar que durante 160 horas el sistema se mantuvo en funcionamiento, luego éste se apaga, pero la temperatura del digestor sigue midiéndose hasta las 180 horas. Durante el primer día se requiere invertir la mayor 
cantidad de energía de toda la actividad del digestor, ya que la carga, que inicialmente se encuentra a $15^{\circ} \mathrm{C}$, debe elevarse hasta $\operatorname{los} 30^{\circ} \mathrm{C}$, valor que se alcanza al cabo de 11 horas, para luego estabilizarse en torno a los $30^{\circ} \mathrm{C}$. Durante las primeras 11 horas sólo se utiliza para el calentamiento la parte eléctrica, pues el colector solar no es capaz de entregar la energía suficiente para lograr tal elevación de temperatura en ese período de tiempo.

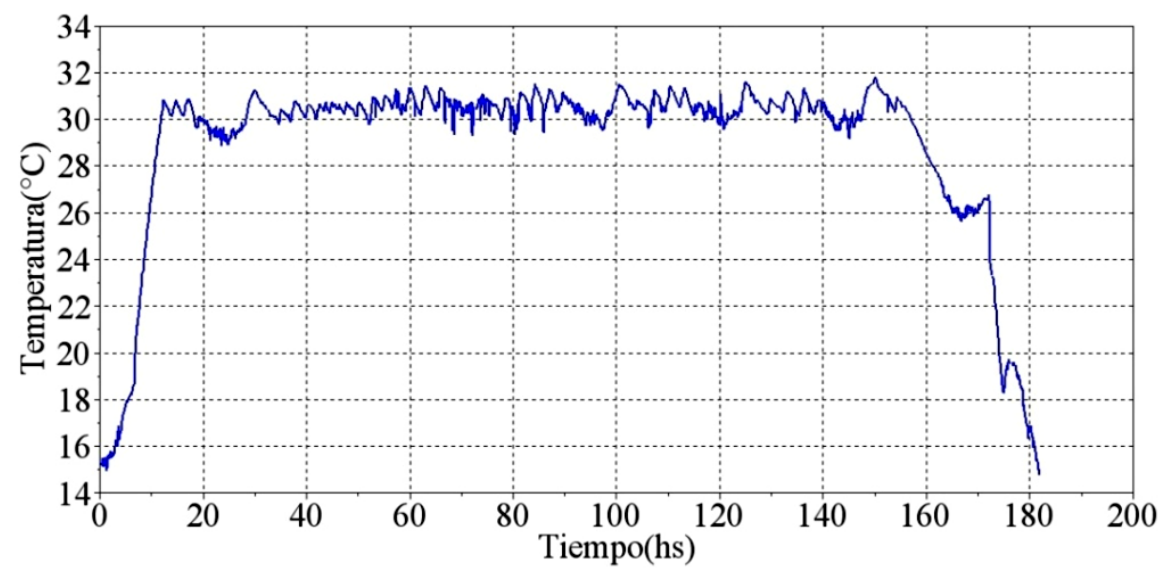

Figura 7.12. Temperatura del digestor anaeróbico enterrado. Fuente: Elaboración propia.

En el tiempo que permanece encendido el sistema de calentamiento la medida oscila alrededor de los $30^{\circ} \mathrm{C}$, entre $29^{\circ} \mathrm{C}$ y $31^{\circ} \mathrm{C}$, producto de los reiterados apagados y encendidos del sistema. Cabe aclarar que estas fluctuaciones de $1^{\circ} \mathrm{C}$ no representan un riesgo para el normal funcionamiento del digestor. Se recuerda que este prototipo funciona con un volumen pequeño, con uno mayor, las oscilaciones serán menores.

En el artículo "Digestor anaeróbico enterrado asistido por energía solar térmica", (Morales et al., 2018), se publicaron los resultados de las experiencias de medida en el digestor anaeróbico enterrado, caso $\mathrm{C}$.

\subsection{Algunas experiencias de calentamiento de digestores en el mundo.}

Son diversos los resultados en cuanto a los dispositivos desarrollados para calentar un digestor con energía solar que se encuentran en bibliografía. Difícilmente pueden compararse, ya que en general, presentan características diferentes: tipo de colector solar, volumen del digestor y materiales de su construcción, clima del lugar, etc. Sin embargo, se mencionan algunos trabajos que mantienen ciertas similitudes. Se detallan algunas características técnicas y las temperaturas de operación de los digestores.

Un digestor enterrado de concreto de $45 \mathrm{~m}^{3}$ de volumen es calentado con un colector plano que ocupa un área de $8 \mathrm{~m}^{2}$, localizado en Naxos Island, Grecia. Durante las 
experiencias la temperatura ambiente se encuentra entre $18^{\circ}$ y $32^{\circ} \mathrm{C}$. Para que el sistema de calentamiento se active, deben cumplirse dos condiciones: que la diferencia de temperatura entre la salida del colector y la carga del digestor exceda los $7^{\circ} \mathrm{C}$ y que la temperatura del digestor sea menor a $35^{\circ} \mathrm{C}$. De este modo la temperatura del digestor oscila entre los 24 y $32^{\circ} \mathrm{C}$, (Axaopoulos et al., 2001)

Kumar y Bai (2005) proponen la utilización de plásticos para el cuerpo del digestor. Asimismo, estudian y comparan la producción de biogás de digestores anaeróbicos expuestos a la radiación solar construidos en plástico negro, blanco y transparente. Exponen en su trabajo la conveniencia de utilizar los de color negro sobre los demás.

En la ciudad de Haining, provincia de Zhejiang, China, ocho reactores enterrados conectados en serie conforman una planta de digestión de $1000 \mathrm{~m}^{3}$ de volumen total de digestión. Estos son calentados mediante un conjunto de colectores de tubo de vacío con un área total de $100 \mathrm{~m}^{2}$. La temperatura promedio mensual de los digestores no se mantiene constante. Por ejemplo, cuando la temperatura ambiente en enero (el mes más frío del hemisferio norte) promedia los $5^{\circ} \mathrm{C}$, la de los digestores oscila entre $\operatorname{los} 8^{\circ}$ a los $14^{\circ} \mathrm{C}$, (Feiqing, Jiambo Lu, 2013).

En una experiencia realizada en la ciudad de La Paz, Bolivia, se instala un digestor tubular de polietileno de $8 \mathrm{~m}^{3}$ de volumen. Cuenta con un invernadero construido con paredes laterales de adobe y cubierta superior trasparente. El suelo es aislado con pasto seco. La temperatura máxima promedio del ambiente se encuentra entre los $15^{\circ}$ y $20^{\circ} \mathrm{C}$, la mínima promedio entre los $3^{\circ}$ y $10^{\circ} \mathrm{C}$. El digestor logra una temperatura promedio de $16^{\circ} \mathrm{C}$, (Martí-Herrero y Álvarez, 2014).

\subsection{Discusión.}

En este capítulo se presentaron las experiencias con el digestor aneróbico tubular y el enterrado.

Se evaluó el efecto de distintas aplicaciones al digestor tubular, caso A, para incrementar su temperatura:

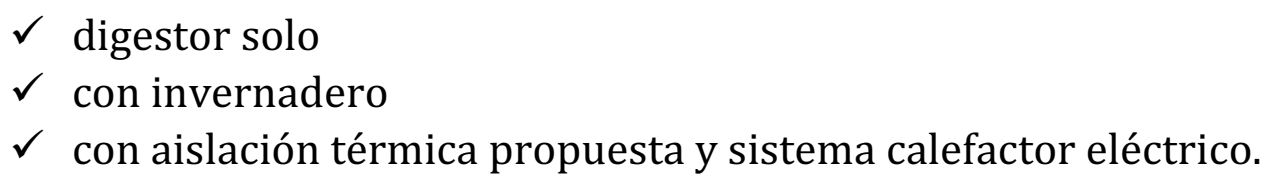

En base a estas experiencias se proyectó y construyó el sistema de calefacción híbrido solar-eléctrico para el digestor enterrado, caso C.

La aplicación de un sistema calefactor ayuda a mantener la temperatura constante, la que también se puede incrementar para que el digestor opere a una mayor a la del ambiente. Con respecto a este punto debe tenerse especial cuidado para no realizar un consumo de energía mayor al que se puede recuperar por el uso del biogás. 
Sobre el digestor anaeróbico enterrado, caso C, se realizaron diferentes aplicaciones:

$\checkmark$ invernadero

$\checkmark$ aislación térmica

$\checkmark$ sistema de calentamiento hibrido solar-eléctrico

Se pretende lograr una temperatura constante en el digestor, mediante la incorporación de un sistema de calefacción hibrido compuesto por un colector solar y un calentamiento eléctrico alternativo. A tales fines se mide la temperatura en diversos puntos durante un período de 7 días.

Los resultados evidencian que el sistema funciona correctamente manteniendo la temperatura constante en el digestor. Para este ensayo, se optó una temperatura de operación de $30^{\circ} \mathrm{C}$. Se advierten pequeñas oscilaciones de $1^{\circ} \mathrm{C}$ entorno a este valor que no son capaces de perturbar el proceso de digestión anaeróbica.

El colector solar está enteramente compuesto de material plástico y no posee cubierta transparente, por lo que, sus temperaturas no son elevadas. Se observa que durante el día la temperatura del colector solar en un período corto, supera los $30^{\circ} \mathrm{C}$ y en este tiempo se calefacciona únicamente por vía solar. Así para una temperatura de operación de digestión como tal, resultaría conveniente un colector solar con otras características que logre temperaturas mayores, o bien bajar la temperatura de operación del digestor. El colector solar realiza solo un pequeño aporte de energía calórica en los momentos de mayor irradiancia solar.

Como se menciona, son diversas las investigaciones acerca del calentamiento de digestores. Todas concluyen que la utilización de la energía solar es una alternativa a ser considerada.

Para el prototipo a estudiar se propone entonces una temperatura de operación menor a $30^{\circ} \mathrm{C}$ a fin de aprovechar más el calentamiento vía solar, dadas las características del colector. Con esto se lograría minimizar la intervención eléctrica para el calentamiento.

\subsection{Conclusiones.}

El digestor tubular operando sin ningún aditamento (invernadero, calefacción, aislación) durante los meses de invierno alcanza temperaturas máximas de entre $12^{\circ}$ y $13^{\circ} \mathrm{C}$. Estos valores tan bajos permiten concluir que no es recomendable la operación de un digestor en estas condiciones. Al incorporarse el invernadero, las máximas alcanzaron los $17^{\circ} \mathrm{C}$. Esta práctica aporta una cantidad significativa de energía, por tanto, resulta muy conveniente, teniendo en cuenta que no tiene un costo elevado. El invernadero también proporciona una protección en los días de lluvia, evita la filtración de agua entre la fosa y el digestor. De esta manera minimiza las pérdidas de calor por la humedad del terreno. 
El sistema de calefacción funciona correctamente manteniendo una temperatura constante en el digestor. En los momentos de mayor radiación se observa el calentamiento dado por el colector solar.

Con la colocación del invernadero se evitan las pérdidas térmicas por acción del viento (pérdidas por convección). 


\section{CAPITULO 8}

\section{ASPECTOS TEÓRICOS DE LA TRANSFERENCIA DE CALOR EN EL DigeSTOR ENTERRADO. MODELO DE SimULACIÓN NUMÉRICA.}




\subsection{Introducción.}

En el Capítulo 7 se probó la funcionalidad del sistema calefactor híbrido compuesto por un suministro eléctrico y uno solar. Se realizaron medidas de temperaturas en el interior del digestor, la cubierta, el colector, el ambiente, a la entrada y salida del intercambiador de calor y de la irradiancia solar.

Es importante conocer cuanta energía es capaz de entregar el colector solar, bajo diversas condiciones de irradiación solar y temperatura ambiente, dado que durante el año varían considerablemente. Para ello se recurre al cálculo de su eficiencia o rendimiento. Con las medidas de temperatura e irradiación solar del Capítulo 7 se lo formaliza en el presente capítulo.

La construcción de un modelo exige el estudio del proceso de transferencia de energía en su totalidad sobre el digestor y sus componentes. La irradiación solar realiza su aporte de energía a través del colector solar plano y del invernadero colocado en la parte superior. Por otro lado, la resistencia eléctrica aporta la energía necesaria para acondicionar el digestor en los momentos en que la irradiación solar es insuficiente o nula. En estos procesos intervienen los tres tipos de transferencia de calor: conducción, convección y/o radiación, que se utilizan en el desarrollo del modelo. El objetivo principal del modelo de simulación es calcular las energías que intervienen como ganancia, tanto la del colector solar como la eléctrica, para un mes completo o para todo el año.

El digestor, para mantener una temperatura constante se abastece de energía eléctrica y solar. El consumo de ambas es un dato importante. Por un lado, con la energía solar se toman decisiones acerca de las características técnicas del colector solar, por ejemplo, si su rendimiento es suficiente. La utilización de energía eléctrica es un dato determinante; su empleo condiciona el volumen del digestor y su temperatura de operación. Por lo tanto, el modelo calcula la energía solar del colector y la energía eléctrica requerida. Esta predicción se realiza con el biodigestor no operativo cargado con agua. Además, se calcula la temperatura del digestor y de su cubierta. Finalmente, elaborado el modelo se lo valida con las medidas expuestas en el Capítulo 7 con el digestor no operativo, cargado con agua.

Se utiliza el programa Scilab versión 6.1.1 para el desarrollo del modelo de simulación. Scilab es un software para análisis numérico, con un lenguaje de programación de alto nivel, desarrollado por Scilab Enterprises. Sus características incluyen análisis numérico, visualización 2-D y 3-D, optimización, análisis estadístico, diseño y análisis de sistemas dinámicos, procesamiento de señales, e interfaces con Fortran, Java, C y C++. 
8.2. Aspectos teóricos de la energía útil, la eficiencia instantánea y global del colector solar.

La energía que llega al colector solar como radiación electromagnética es absorbida por la membrana negra que la compone. Luego de perder calor al entorno, la energía restante se transforma en energía calórica del fluido caloportador que se encuentra en su circuito interno. Este fluido sale del colector solar con una temperatura $T_{s}$ y regresa nuevamente, luego de pasar por el intercambiador de calor (IC) sumergido en el digestor, con una temperatura $T_{e}$. Si el fluido caloportador, tiene un calor específico $c_{p}$ y posee un caudal másico dado por $\dot{m}$, entonces la energía que brinda el colector, $\dot{Q}_{u}$, usualmente llamada energía útil por unidad de tiempo se define mediante la ecuación 8.1 y representa la potencia que entrega el colector solar al digestor anaeróbico enterrado (Duffie, 1991).

$$
\dot{Q}_{u}=\dot{m} c_{p}\left(T_{s}-T_{e}\right)
$$

En estado estacionario, el comportamiento de un colector solar está descrito por un balance de energía entre la incidente, la útil y la pérdida al entorno, dado por la ecuación 8.2.

$$
\text { energía incidente = energía útil + energía perdida }
$$

La energía incidente por unidad de tiempo, $\dot{E}_{\text {inc }}$, (ecuación 8.3) depende del área del colector $A_{c}$, de la irradiación solar incidente $G_{T}$, del producto $\tau \alpha$, que es el coeficiente de transmisión $\tau$ de la cubierta transparente por el de coeficiente de absorción $\alpha$ de la placa absorvedora del colector y del equivalente a la efectividad de un intercambiador de calor convencional $F_{R}$, llamado factor de remoción.

$$
\frac{\text { energía incidente }}{\text { tiempo }}=\dot{E}_{\text {inc }}=A_{c} F_{R}(\tau \alpha) G_{T}
$$

La energía perdida por conducción, convección y radiación infrarroja, $\dot{E}_{\text {perd }}$, se representa por la ecuación 8.4 , donde $U_{L}$, es el coeficiente global de pérdidas y $T_{a}$ la temperatura ambiente (Duffie y Beckman, 1991).

$$
\frac{\text { energía perdida }}{\text { tiempo }}=\dot{E}_{\text {perd }}=A_{c} F_{R} U_{L}\left(T_{e}-T_{a}\right)
$$


Reemplazando en la ecuación 8.2, el balance de energía resulta

$$
A_{c} F_{R}(\tau \alpha) G_{T}=\dot{Q}_{u}+A_{c} F_{R} U_{L}\left(T_{e}-T_{a}\right)
$$

La determinación de la eficiencia es importante pues permite calcular, de acuerdo a las condiciones de irradiancia solar, el área de colección necesaria para abastecer de cierta cantidad de energía calórica al digestor. Para su obtención, se calcula el calor útil que es capaz de entregar el colector a partir de la energía incidente en él.

La eficiencia de un sistema expresa cómo se utilizan los recursos para satisfacer una cierta necesidad. En otras palabras, la eficiencia en el colector solar expresada con un valor que va de 0 al 1 , muestra con que efectividad utiliza la energía disponible para calentar el agua. Mientras más cerca de 1 se encuentre mayor será la eficiencia.

Se define la eficiencia instantánea, representada por $\eta_{i}$, cuando se calcula su valor en cada instante. Se determina con la ecuación 8.6, tomando el cociente entre la energía útil por unidad de tiempo $\dot{Q}_{u}$ y la irradiación incidente sobre el plano del colector de área $A_{c}$.

$$
\eta_{i}=\frac{\dot{Q}_{u}}{A_{c} G_{T}}=\frac{\dot{m} c_{p}\left(T_{s}-T_{e}\right)}{A_{c} G_{T}}
$$

De la ecuación 8.5 se expresa a $\dot{Q}_{u}$ como se presenta en la ecuación 8.7.

$$
\dot{Q}_{u}=A_{c} F_{R}(\tau \alpha) G_{T}-A_{c} F_{R} U_{L}\left(T_{e}-T_{a}\right)
$$

La ecuación 8.8 muestra otra forma de expresar la eficiencia instantánea.

$$
\eta_{i}=F_{R}(\tau \alpha)-F_{R} U_{L} \frac{\left(T_{e}-T_{a}\right)}{G_{T}}
$$

Esta ecuación se representa gráficamente en la Figura 8.1. El eje de las abscisas está dado por la variable $\frac{\left(T_{e}-T_{a}\right)}{G_{T}}$ y el eje de las ordenadas por $\eta_{i}$. Así, la curva toma una forma lineal de pendiente negativa $F_{R} U_{L}$. En la intersección de la recta y el eje de las ordenadas se encuentra el valor de $F_{R}(\tau \alpha)$, que es el producto entre el factor de remoción y los factores de transmisión y absorción de radiación $\tau$ y $\alpha$ respectivamente. 


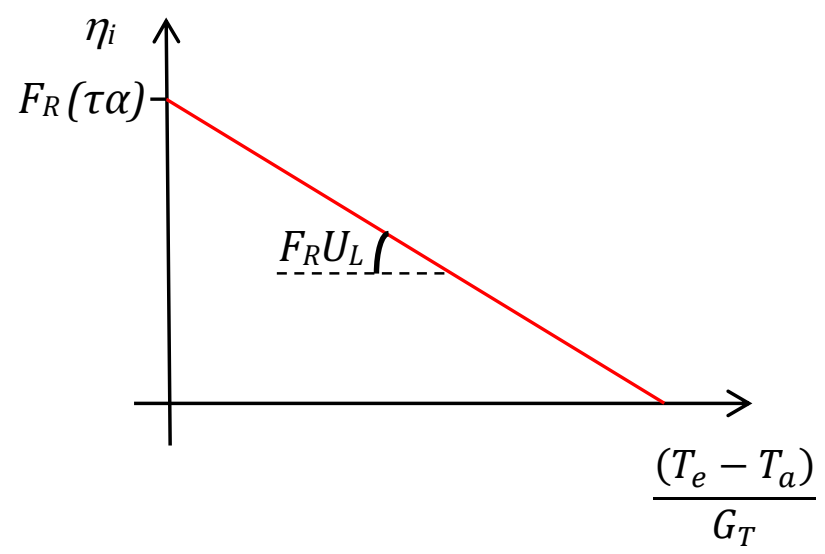

Figura 8.1. Representación gráfica de la eficiencia instantánea $\eta_{i}$ de un colector solar.

Fuente: Elaboración propia.

Los productos $F_{R}(\tau \alpha)$ y $F_{R} U_{L}$ describen el funcionamiento del colector solar. El primero, es un indicador de cómo se absorbe la energía mientras que el segundo, indica la energía que se pierde.

El valor instantáneo es la eficiencia del colector solar en un tiempo determinado y éste cambiará de acuerdo a la irradiación solar incidente y a la temperatura ambiente. Por el contrario, la eficiencia global $\eta$, ecuación 8.9, es un único valor calculado con los datos de todo un día; el que se puede entender como un valor promedio. Así, si durante el día en que se mide con el colector solar se consideran aquellas medidas en donde se obtiene calor útil, se calcula la eficiencia global $\eta$ como se expresa en la ecuación 8.9.

$$
\eta=\frac{\sum \dot{Q}_{u}}{A_{c} \sum G_{T}}
$$

\subsection{Descripción del modelo.}

\subsubsection{Balance energético en el digestor anaeróbico.}

Como se presentó en el Capítulo 6, el digestor anaeróbico enterrado consta de un sistema de calefacción híbrido solar -eléctrico. La carga del digestor recibe dos tipos de flujos de calor para aumentar su temperatura, uno solar y otro eléctrico. El aporte solar ocurre a través de la cubierta del digestor (señalada en la Figura 8.2) y del IC cuando opera el colector solar. El eléctrico, lo brinda la resistencia por medio del IC. 


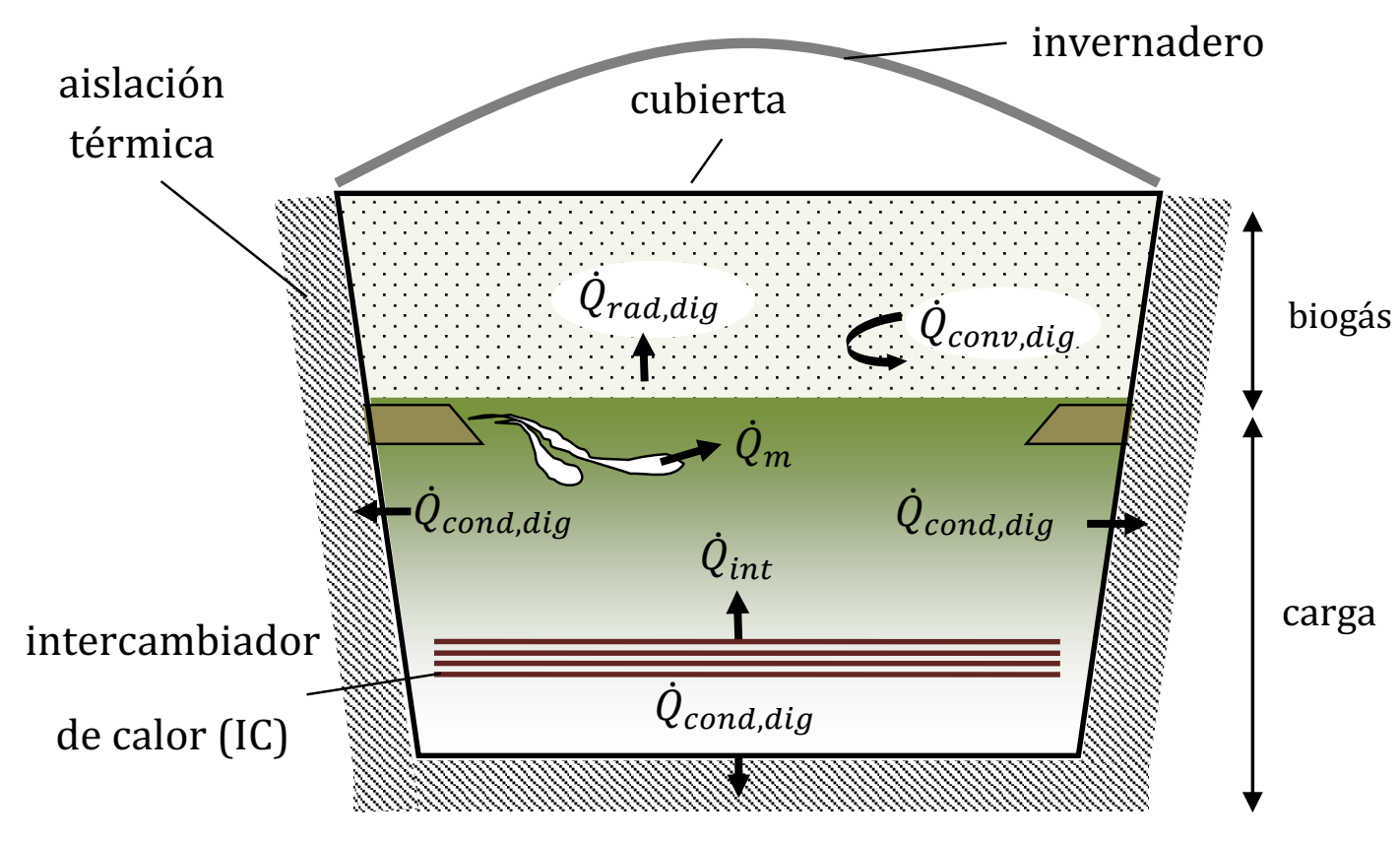

Figura 8.2. Esquema de los flujos de calor desde y hacia la carga del digestor. Fuente: Elaboración propia.

En la Figura 8.2 se esquematizan los flujos de calor desde y hacia la carga del digestor, que hacen descender su temperatura, a saber: el de conducción a través de las paredes internas y el suelo $\dot{Q}_{c o n d, d i g}$, el de convección $\dot{Q}_{c o n v, d i g}$ y el de radiación $\dot{Q}_{r a d, d i g}$ desde la superficie superior de la carga hacia la capa de biogás. Estos últimos flujos resultan una pérdida de calor o un aporte dependiendo de los valores de radiación solar. El flujo de calor proveniente del intercambiador llamado $\dot{Q}_{\text {int }}$ proviene de un suministro eléctrico o del colector solar, como se verá con detalle en el apartado 8.3.3.

En el modelo se asume que la temperatura del digestor es uniforme en todo su volumen. Esta hipótesis es factible si se cuenta con un mezclador. Así, para este modelo, la temperatura solo dependerá del tiempo.

Cuando la temperatura de la carga del digestor cambia desde una inicial $T_{d i g, i}$ a una final $T_{d i g, f}$, la energía interna $\mathrm{E}$ de la carga también se modifica, ecuación 8.10.

$$
E=m_{c} c_{c}\left(T_{d i g, f}-T_{d i g, i}\right)=\rho_{c} V_{c} c_{c}\left(T_{d i g, f}-T_{d i g, i}\right)
$$

donde $c_{c}$ y $m_{c}$ respectivamente son el calor específico y la masa de la carga. Esta última se puede escribir como el producto de la densidad $\rho_{c}$ y del volumen $V_{c}$, (ecuación 8.10). 
Tomando la derivada en función del tiempo de esta ecuación se obtiene la ecuación 8.11 (Doran, 1995); donde los valores $\rho_{c}, V_{c}$ y $c_{c}$ no varían con el tiempo.

$$
\frac{d E}{d t}=\rho_{c} V_{c} c_{c} \frac{d T_{d i g}}{d t}
$$

La temperatura de la carga del digestor $\mathrm{T}_{\text {dig }}$ se modifica por las pérdidas o ganancias de energía como función del tiempo. Estos flujos representados por $\dot{Q}$ (Figura 8.2) se detallan a continuación:

$\checkmark \quad \dot{Q}_{\text {int }}$ es la energía que brinda el intercambiador de calor. Esta energía proviene del colector solar $\dot{Q}_{u}$ ó del sistema eléctrico del que se hablará mas adelante $\dot{Q}_{\text {elec }}$. Ambas siempre aportan energía para mantener las condiciones adecuadas en el digestor. Por supuesto, no lo hacen al mismo tiempo. Por ejemplo, durante la noche solo funciona la resistencia eléctrica.

$\checkmark \dot{Q}_{c o n d, d i g}$ es el flujo de calor por conducción a través de las paredes y el suelo del digestor. Como en general la carga está a una temperatura mayor que el suelo constituye una pérdida.

$\checkmark \dot{Q}_{c o n v, d i g}$ y $\dot{Q}_{\text {rad,dig }}$ son flujos de convección y de radiación entre la capa superior de biogás y la superficie de la carga. Durante el día, la cubierta del digestor se calienta y a la vez calienta la capa de biogás que provee estos flujos positivos a la carga del digestor. Durante la noche como la cubierta se enfría, los flujos son salientes.

$\checkmark \dot{Q}_{m}$ representa un flujo de energía debido al ingreso de material fresco, con una temperatura menor a la de operación del digestor, en el que ingresa. Esta será cero en el caso de una operación discontinua.

El signo de estos flujos dependerá de las condiciones ambientales y de la temperatura del digestor. El flujo de la energía interna de la carga, ecuación 8.11, expresado en función de los flujos de calor está indicada en la ecuación 8.12.

$$
\frac{d E}{d t}=\dot{Q}_{u}+\dot{Q}_{e l e c}+\dot{Q}_{c o n d, d i g}+\dot{Q}_{c o n v, d i g}+\dot{Q}_{r a d, d i g}+\dot{Q}_{m}
$$

Reemplazando la ecuación 8.11obtenemos la ecuación 8.13.

$$
\rho_{c} V_{c} c_{c} \frac{d T_{d i g}}{d t}=\dot{Q}_{u}+\dot{Q}_{e l e c}+\dot{Q}_{c o n d, d i g}+\dot{Q}_{c o n v, d i g}+\dot{Q}_{r a d, d i g}+\dot{Q}_{m}
$$




\subsubsection{Cálculo de los flujos energéticos.}

Teniendo en cuenta que hay un trayecto corto para el fluido caloportador desde el intercambiador al colector, se toma la temperatura a la salida del colector $\left(T_{s}\right)$ igual a la de la entrada al intercambiador; asimismo, la temperatura a la salida del intercambiador se considera igual a la de entrada al colector $\left(T_{e}\right)$, lo que se representa en la Figura 8.3.

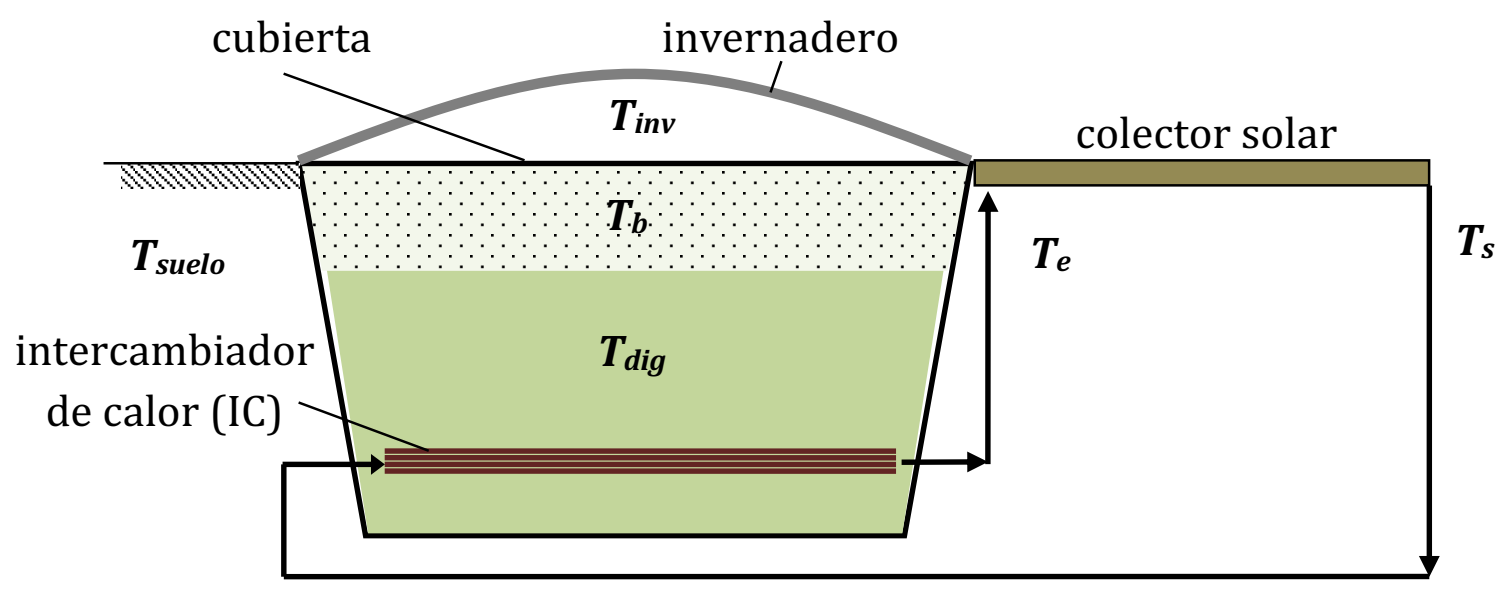

Figura 8.3. Esquema de las temperaturas a la entrada y salida del colector solar e intercambiador.

Fuente: Elaboración propia.

En la misma figura, se señalan también las temperaturas de la carga del digestor $T_{\text {dig }}$, del biogás $T_{b}$ y del suelo $T_{\text {suelo }}$. Esta última representa la temperatura de todo el suelo, es decir de todo el terreno que rodea al digestor por sus paredes laterales y en la base, la que se considera constante.

El flujo energético del sistema eléctrico $\dot{Q}_{e l e c}$ es la energía que libera la resistencia como forma de calor y la energía que le imprime al fluido caloportador la electrobomba al ponerlo en movimiento. Conociendo la diferencia de potencial $V y$ la resistencia $R$ se calcula la potencia eléctrica como lo indica el primer término de la ecuación 8.14.

$$
\dot{Q}_{\text {elec }}=\frac{V^{2}}{R}+\dot{m} \frac{v^{2}}{2}
$$

El segundo término de esta ecuación corresponde al flujo de energía dado por la energía cinética (Cengel, 2012), donde $\dot{m}$ es el caudal másico y $v$ la velocidad del 
fluido caloportador, la que se considera constante. Se desprecian los cambios de energía dado por las variaciones de altura en el circuito hidráulico.

Dos dispositivos controladores de temperatura CTR1 y CTR2 (Figuras 7.2 y 6.22), comandan el funcionamiento del sistema calentador. Uno censa la temperatura del digestor y el otro la del colector solar (Figura 8.4). Cada controlador es programado internamente con una temperatura $T_{\text {sensor }}$ que es a la que se desea que opere el digestor. En todo momento, los controladores miden la temperatura por medio de su sensor y la comparan con $T_{\text {sensor. }}$.

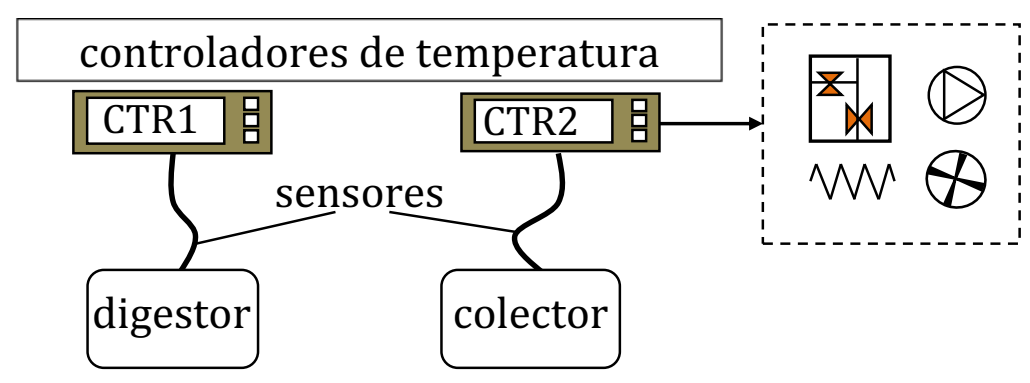

Figura 8.4. Esquema simplificado del funcionamiento de los controladores de temperatura.

Fuente: Elaboración propia.

En el controlador CTR1 ocurre:

$\checkmark$ Si la temperatura del digestor es inferior a $T_{\text {sensor }}$ entonces el controlador CTR1 habilita el funcionamiento de los componentes del sistema calefactor a través de $C T R 2$.

$\checkmark$ Si la temperatura del digestor es superior a $T_{\text {sensor }}$ entonces no se habilita el funcionamiento de los componentes del sistema calefactor a través de CTR2 pues no es necesario calentamiento alguno

En el controlador CTR2 ocurren dos situaciones:

$\checkmark$ Si la temperatura del colector solar es inferior a $T_{\text {sensor }}$ el controlador CTR2 activa el funcionamiento de la resistencia eléctrica y energiza la válvula $V 2$ (Figura 6.22) para que circule el agua caliente que provee esta resistencia por el circuito hidráulico.

$\checkmark$ Si la temperatura del colector solar es superior a $T_{\text {sensor }}$ el controlador CTR2 solo energiza la válvula V1 (Figura 6.22) para que circule agua del colector solar por el circuito hidráulico. 
Como se menciona anteriormente $T_{\text {sensor }}$ se fija previamente a la temperatura a la que se desea mantener operando el digestor, por ejemplo $30^{\circ} \mathrm{C}$. En el algoritmo se mantiene fijo este valor mientras que se calcula continuamente la temperatura del digestor $T_{\text {dig }}$. Luego se comparan ambos valores.

En el tiempo que tarda el controlador en tomar la temperatura del digestor, compararla y activar o desactivar el funcionamiento del sistema calefactor, la temperatura del digestor continúa cambiando. Este retardo en el tiempo, se traduce en un incremento o un descenso de temperatura, el cual se denomina $\Delta T_{S}$. Ocurren dos situaciones:

$\checkmark$ La temperatura del digestor aumenta un cierto valor $\Delta T_{s}$. por encima de la temperatura de operación del digestor $T_{\text {sensor, como consecuencia del }}$ encendido del sistema de calefacción; a continuación, como el digestor debe mantenerse en $T_{\text {sensor, }}$ el controlador desactiva el calentamiento.

$\checkmark$ La temperatura del digestor disminuye un cierto valor $\Delta T_{s}$ por debajo de la temperatura de operación del digestor $T_{\text {sensor, }}$ como consecuencia de que la calefacción se encuentra apagada; a continuación, como el digestor debe mantenerse en $T_{\text {sensor, }}$ el controlador activa el calentamiento.

En la Figura 8.5 se amplifica una parte de la gráfica de la Figura 7.12. Se marca en esta, la temperatura promedio de $30,3^{\circ} \mathrm{C}$ en línea roja sólida y en líneas punteadas los intervalos de temperatura $\Delta T_{S}$ que corresponden a aumentos y disminuciones reiteradas a lo largo del tiempo.

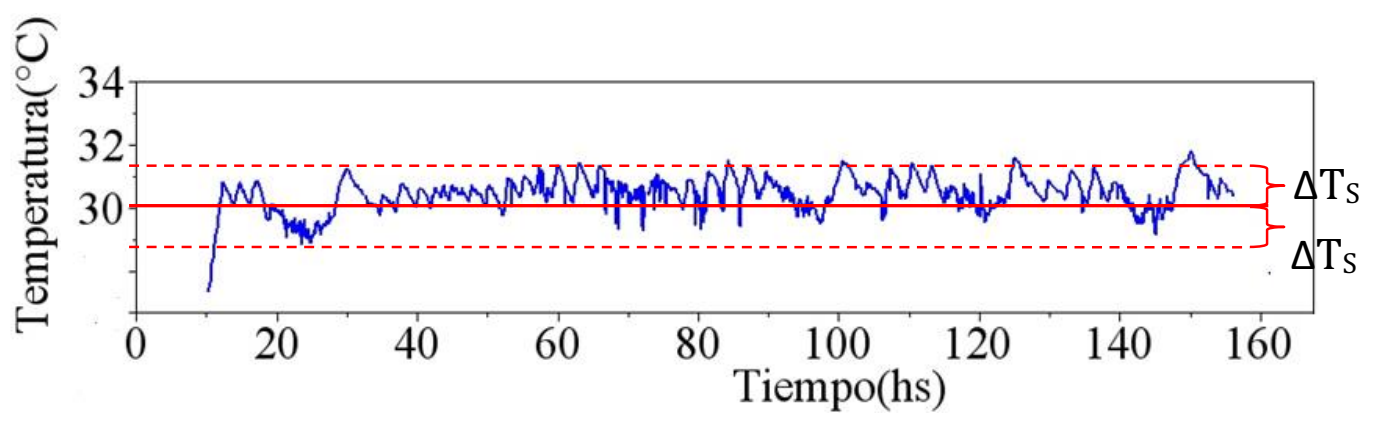

Figura 8.5. Temperatura promedio del digestor, intervalos de temperatura de aumento y disminución $\Delta T_{S}$ en torno al valor promedio. Fuente: Elaboración propia.

El algoritmo que simula esta situación, queda expresado mediante las ecuaciones 8.15 y 8.16 . 


$$
\begin{array}{llll}
\text { si } & T_{\text {dig }}>T_{\text {sensor }}+\Delta T_{s} & \text { no se utiliza } \dot{Q}_{\text {elec }} \text { ni } \dot{Q}_{u} & 8.15 \\
\text { si } & T_{\text {dig }} \leq T_{\text {sensor }}-\Delta T_{s} & \text { se utiliza } \dot{Q}_{\text {elec }} \text { o } \dot{Q}_{u} & 8.16
\end{array}
$$

Las condiciones 8.15 y 8.16 simulan el comportamiento de la temperatura del digestor. En éstas no se especifica si se utilizará $\dot{Q}_{\text {elec }}$ o $\dot{Q}_{u}$. Lo que se muestra es cómo intervienen éstas, de acuerdo a la temperatura del digestor.

$\dot{Q}_{c o n d, d i g}$ representa las pérdidas, por conducción desde las paredes y el suelo, ambas del mismo material aislante y construidas de la misma forma, ecuación 8.17 (Incropera, 1999); donde $k$ es la conductividad térmica, $e$ el espesor, de las paredes del digestor y $A_{p}$ es la suma de las áreas de las paredes y el piso. $T_{\text {suelo }}$ es la temperatura del suelo.

$$
\dot{Q}_{\text {cond }, \text { dig }}=A_{p} \frac{k}{e}\left(T_{\text {dig }}-T_{\text {suelo }}\right)
$$

El flujo de energía por convección $\dot{Q}_{c o n v, d i g}$ entre el biogás y la superficie de la carga se indica en la ecuación 8.18, donde $A_{s}$ es la superficie superior de la carga, $h_{b}$ el coeficiente de convección en el biogás y $T_{b}$ la temperatura de la capa de biogás que se encuentra entre la superficie superior $A_{s}$ y la tapa del digestor.

$$
\dot{Q}_{\text {conv }, \text { dig }}=A_{s} h_{b}\left(T_{\text {dig }}-T_{b}\right)
$$

El flujo de energía por radiación $\dot{Q}_{\text {rad,dig }}$ entre la superficie de la carga y el biogás se indica en la ecuación 8.19, donde $\varepsilon$ es la emisividad y $\sigma$ la constante de StefanBoltzman (Incropera, 1999).

$$
\dot{Q}_{\text {rad, dig }}=A_{s} \varepsilon \sigma\left(T_{\text {dig }}^{4}-T_{b}^{4}\right)
$$

La pérdida de flujo de energía debido al flujo másico $\dot{Q}_{m}$ se expresa en la ecuación 8.20 donde, $\dot{m}_{c d}$ representa la carga que ingresa al digestor medida en kg por segundo con una temperatura $T_{\text {carga diaria }} \mathrm{y}$ su calor específico $c_{c}$

$$
\dot{Q}_{m}=\dot{m}_{c d} c_{c}\left(T_{\text {dig }}-T_{\text {carga diaria }}\right)
$$

Si el digestor no trabaja en forma continua y se lo alimenta por única vez no existirá esta pérdida de energía $\dot{Q}_{m}$ dado que $\dot{m}_{c d}$ es nula.

En síntesis: 


$$
\begin{aligned}
& \rho_{c} V_{c} c_{c} \frac{d T}{d t}=\dot{Q}_{u}+\dot{Q}_{\text {elec }}+\dot{Q}_{c o n d, \text { dig }}+\dot{Q}_{\text {conv }, \text { dig }}+\dot{Q}_{\text {rad,dig }}+\dot{Q}_{m} \\
& \dot{Q}_{u}=A_{c} F_{R}(\tau \alpha) G_{T}-A_{c} F_{R} U_{L}\left(T_{e}-T_{a}\right) \\
& \dot{Q}_{\text {elec }}=\frac{V^{2}}{R}+\dot{m} \frac{v^{2}}{2} \\
& \dot{Q}_{\text {cond,dig }}=A_{p} \frac{k}{e}\left(T_{\text {dig }}-T_{\text {suelo }}\right) \\
& \dot{Q}_{\text {conv,dig }}=A_{s} h_{b}\left(T_{\text {dig }}-T_{b}\right) \\
& \dot{Q}_{\text {rad,dig }}=A_{s} \varepsilon \sigma\left(T_{\text {dig }}^{4}-T_{b}^{4}\right) \\
& \dot{Q}_{m}=\dot{m}_{c d} c_{\text {carga }}\left(T_{\text {dig }}-T_{\text {carga diaria }}\right)
\end{aligned}
$$

\subsubsection{Balance energético en el biogás.}

De la misma manera que se estudian los flujos de calor en la carga del digestor, se procede con el biogás que se encuentra entre la superficie superior de la carga $A_{s} \mathrm{y}$ la cubierta del digestor. Se desea determinar su temperatura ya que influye en la de la carga del digestor.

Un esquema al respecto se observa en la Figura 8.6, en la que se representan los flujos que ingresan y salen del biogás: convectivo $\dot{Q}_{c o n v, b}$ y radiactivo $\dot{Q}_{\text {rad }, b}$ desde la cubierta y la superficie de la carga hacia el biogás. Los flujos $\dot{Q}_{c o n d, b}$ conductivos siempre salen desde el biogás hacia las paredes. 


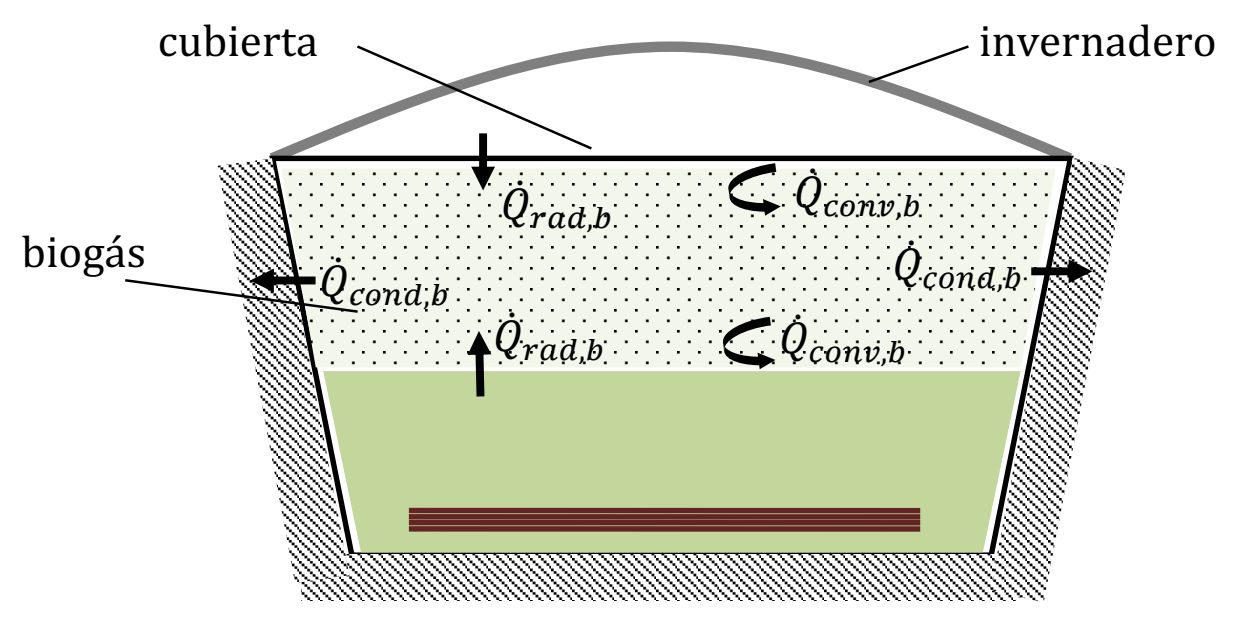

Figura 8.6. Flujos de calor en el biogás.

Fuente: Elaboración propia.

Para determinar la temperatura del biogás se estudian el aporte de energía y las pérdidas a través de la superficie de la carga del digestor, de la cubierta y de las paredes, puesto que el biogás está en contacto con éstas.

El flujo energético $\dot{Q}_{c o n d, b}$ debido a la transmisión por conducción del biogás hacia las paredes se representa en la ecuación 8.21, donde $A_{p b}$, es el área de la pared, $k$ su conductividad térmica y $e$ su espesor; la temperatura del biogás es $T_{b}$ y la del terreno en contacto con las paredes es $T_{\text {suelo. }}$.

$$
\dot{Q}_{\text {cond }, b}=A_{p b} \frac{k}{e}\left(T_{b}-T_{\text {suelo }}\right)
$$

El flujo energético $\dot{Q}_{c o n v, b}$ debido a la transmisión por convección desde la cubierta y la superficie de la carga hacia el biogás se indica en la ecuación 8.22, donde $A_{s}$ es el área de la superficie superior de la carga del digestor y de su cubierta, $h_{b}$ el coeficiente convectivo en la capa de biogás. Este flujo depende de las temperaturas de la cubierta $T_{c u b}$, del digestor $T_{\text {dig }}$ y del biogás $T_{b}$.

$$
\dot{Q}_{c o n v, b}=A_{s} h_{b}\left(T_{c u b}-T_{b}\right)+A_{s} h_{b}\left(T_{d i g}-T_{b}\right)
$$

El flujo energético $\dot{Q}_{r a d, b}$ debido a la transmisión por radiación desde la cubierta y la superficie de la carga hacia el biogás se indica en la ecuación 8.23 , donde $\varepsilon_{c u b} \mathrm{y}$ $\varepsilon_{c}$ son la emisividad térmica de la cubierta del digestor y de su carga.

$$
\dot{Q}_{r a d, b}=A_{s} \varepsilon_{c u b} \sigma\left(T_{c u b}^{4}-T_{b}^{4}\right)+A_{c} \varepsilon_{c} \sigma\left(T_{d i g}^{4}-T_{b}^{4}\right)
$$


Como ocurre con cualquier material, el biogás acumula energía dado que posee cierta masa y calor específico (Axoulopulues 2001, Perrigault 2012). Tal como se procede con la carga del digestor se escribe la energía acumulada por unidad de tiempo $\dot{Q}_{\text {acumulada,b }}$, ecuación 8.24, para el biogás.

$$
\dot{Q}_{\text {acumulad }, b}=\rho_{b} V_{b} c_{b} \frac{d T}{d t}
$$

Donde $\rho_{\mathrm{b}}, \mathrm{V}_{\mathrm{b}} \mathrm{y} \mathrm{c}_{\mathrm{b}}$ son la densidad, el volumen y el calor especifico del biogás.

La ecuación 8.25 representa el balance de energía por unidad de tiempo en el biogás; entre la energía acumulada, $\dot{Q}_{\text {acumulada,b }}$, por el biogás por unidad de tiempo y los flujos de calor que entran o salen del mismo.

$$
\dot{Q}_{a c u m u l a d, b}=\dot{Q}_{c o n d, b}+\dot{Q}_{c o n v, b}+\dot{Q}_{r a d, b}
$$

En síntesis:

$$
\begin{aligned}
& \dot{Q}_{\text {cond }, b}=A_{p b} \frac{k}{e}\left(T_{b}-T_{\text {suelo }}\right) \\
& \dot{Q}_{\text {conv }, b}=A_{s} h_{b}\left(T_{c u b}-T_{b}\right)+A_{s} h_{b}\left(T_{d i g}-T_{b}\right) \\
& \dot{Q}_{\text {rad }, b}=A_{s} \varepsilon_{t} \sigma\left(T_{c u b}^{4}-T_{b}^{4}\right)+A_{s} \varepsilon_{c} \sigma\left(T_{d i g}^{4}-T_{b}^{4}\right) \\
& \dot{Q}_{b, a c u m u l a d a}=\rho_{b} V_{b} c_{b} \frac{d T}{d t} \\
& \rho_{b} V_{b} c_{b} \frac{d T}{d t}=\dot{Q}_{\text {cond }, b}+\dot{Q}_{c o n v, b}+\dot{Q}_{\text {rad }, b}
\end{aligned}
$$

La temperatura del biogás $T_{b}$ se ve fuertemente afectada por la de la cubierta del digestor, la que es muy absorbente energéticamente dado su color negro y alcanza elevadas temperaturas.

La temperatura $T_{c u b}$ se indica en la ecuación 8.26 en función de la temperatura del invernadero $T_{i n v}$ y su coeficiente convectivo $h_{i n v}$, la irradiancia incidente luego de pasar por la cubierta transparente del invernadero $S$ y el coeficiente de absorción de la cubierta $\alpha$ (Ashrae, 1989).

$$
T_{c u b}=T_{i n v}+\frac{\alpha S}{h_{i n v}}
$$


Esta ecuación permite calcular directamente la temperatura de la cubierta sin necesidad de realizar un balance de energía.

\subsubsection{Balance energético en el interior del invernadero y su cubierta transparente.}

La energía acumulada en el invernadero por unidad de tiempo en el interior del invernadero, $\dot{Q}_{\text {acumuladinv }}$, queda representado por la ecuación 8.27 , donde intervienen los flujos de energía por convección $\dot{Q}_{c o n v, i n v}$, por radiación $\dot{Q}_{\text {rad,inv }} \mathrm{y}$ la energía por unidad de tiempo dada por el producto de la irradiancia que llega al interior del invernadero $S$ y el área del invernadero $A_{i n v}$.

$$
\dot{Q}_{\text {acumulad }, i n v}=\dot{Q}_{c o n v, i n v}+\dot{Q}_{\text {rad }, i n v}+S A_{i n v}
$$

donde la ecuación 8.28 representa la energía acumulada por unidad de tiempo

$$
\dot{Q}_{a c u m u l a d a, i n v}=\rho_{i n v} V_{i n v} c_{i n v} \frac{d T}{d t}
$$

Donde $\rho_{\text {inv, }}, V_{\text {inv }}$ y $c_{i n v}$ son la densidad, el volumen y el calor especifico del invernadero.

La ecuación 8.29 representa el intercambio de energía por convección desde la placa transparente y la cubierta del digestor hacia el interior del invernadero,

$$
\dot{Q}_{c o n v, i n v}=A_{c u b t} h_{i n v}\left(T_{c u b, t}-T_{i n v}\right)+A_{c u b} h_{i n v}\left(T_{c u b}-T_{i n v}\right)
$$

La temperatura del interior del invernadero $\left(T_{i n v}\right)$ se ve afectada por la placa transparente y la cubierta del digestor, además recibe la irradiancia solar que atraviesa dicha cubierta. La temperatura de la placa transparente, de área $A_{s t}$, se denomina $T_{c u b, t}$.

La ecuación 8.30 indica la energía radiante proveniente de la cubierta transparente y la del digestor

$$
\dot{Q}_{\text {rad,inv }}=A_{\text {cub } t} \varepsilon_{c u b t} \sigma\left(T_{c u b, t}^{4}-T_{i n v}^{4}\right)+A_{s} \varepsilon_{c u b} \sigma\left(T_{c u b}^{4}-T_{i n v}^{4}\right)
$$

Donde $\varepsilon_{c u b t}$ y $\varepsilon_{c u b}$ son la emisividad de la cubierta transparente y la cubierta del digestor.

$$
S=\tau_{c u b t} G_{T}
$$

y la ecuación 8.31 la contribución dada por la irradiación solar $(S)$. Donde $\tau_{c u b t}$ es el factor de transmisión de la cubierta transparente. 
La cubierta transparente del invernadero interactúa intercambiando energía con el interior del invernadero y con el ambiente exterior. La ecuación 8.32 representa la acumulación de energía por unidad de tiempo, en este, intervienen los parámetros de la cubierta transparente tales como: densidad $\rho_{c u b t}$, espesor $e_{c u b t}$, área $A_{c u b t}$ y calor específico $c_{c u b t}$.

$$
\dot{Q}_{\text {,acumulada,cubt }}=\rho_{\text {cub } t} V_{\text {cub } t} c_{\text {cub } t} \frac{d T}{d t}=\rho_{\text {cub } t} e_{c u b t} A_{\text {cub } t} c_{c u b t} \frac{d T}{d t}
$$

La ecuación 8.33 señala el intercambio por convección,

$$
\dot{Q}_{c o n v, c u b t}=A_{i n v} h_{a}\left(T_{c u b, t}-T_{a}\right)+A_{i n v} h_{i n v}\left(T_{c u b, t}-T_{i n v}\right)
$$

En la ecuación 8.34 se indica el intercambio por radiación

$$
\dot{Q}_{\text {rad,cub } t}=A_{\text {inv }} \varepsilon_{c u b t} \sigma\left(T_{c u b, t}^{4}-T_{a}^{4}\right)+A_{i n v} \varepsilon_{c u b t} \sigma\left(T_{c u b, t}^{4}-T_{i n v}^{4}\right)
$$

y la ecuación 8.35 el balance de energía por unidad de tiempo, donde se observa el aporte dado por la irradiancia solar $G_{T}$.

$$
\dot{Q}_{\text {acumulad,cubt }}=\dot{Q}_{\text {conv }, \text { cub } t}+\dot{Q}_{\text {rad,cubt }}+G_{T} A_{\text {inv }}
$$

\subsubsection{El intercambiador de calor.}

El intercambiador de calor (IC) sumergido en el digestor está caracterizado por su área $A_{\text {int }}$ y su coeficiente global de pérdidas $U_{\text {int }}$. Conocer este último factor es importante a los efectos de estudiar la transmisión desde el intercambiador hacia el digestor. Este coeficiente comprende la transmisión por conducción, convección y radiación. El intercambio de energía $\dot{Q}_{\text {int }}$ (ecuación 8.36) entre el intercambiador y la carga del digestor no es constante, sino que depende de la posición del intercambiador; es decir, en cada punto del intercambiador varía la temperatura.

$$
\dot{Q}_{i n t}=U_{\text {int }} A_{\text {int }} \Delta T_{m}
$$

donde $\Delta T_{m}$ es la diferencia de temperatura media logarítmica, propuesto por Incropera (1996), explicitada en las ecuaciones 8.37 y 8.38 . Se recuerda que $T_{e}$ y $T_{s}$ son las temperaturas a la salida y a la entrada del IC.

$$
\begin{gathered}
\Delta T_{m}=\frac{\Delta T_{2}-\Delta T_{1}}{\ln \left(\Delta T_{2} / \Delta T_{1}\right)} \\
\Delta T_{2}=T_{s}-T_{d i g} ; \Delta T_{1}=T_{e}-T_{d i g}
\end{gathered}
$$


El flujo calórico que brinda el intercambiador $\dot{Q}_{\text {int }}$ (ecuación 8.39) puede expresarse como el producto del caudal $\dot{m} \mathrm{y}$ el calor específico $c_{p}$ del fluido caloportador (en las experiencias se utilizó agua).

$$
\dot{Q}_{i n t}=\dot{m} c_{p}\left(T_{s}-T_{e}\right)
$$

Igualando las ecuaciones 8.36 (en la que se remplaza $\Delta T_{m}$ mediante 8.37 y 8.38 ) y 8.39 se obtiene la 8.40. Puesto que el intercambiador entrega energía este debe llevar el signo menos (lado derecho), el lado izquierdo es considerado la energía que recibe la carga del digestor.

$$
U_{\text {int }} A_{\text {int }} \frac{\Delta T_{2}-\Delta T_{1}}{\ln \left(\Delta T_{2} / \Delta T_{1}\right)}=-\dot{m} c_{p}\left(T_{s}-T_{e}\right)
$$

Despejando de esta última $U_{\text {int }}$ y tomando su módulo, se determina el coeficiente global de pérdidas del intercambiador $U_{\text {int }}$ (ecuación 8.41). Este valor resulta indispensable y depende de valores medidos experimentalmente.

$$
U_{\text {int }}=\frac{\dot{m} c_{p}}{A_{\text {int }}} \frac{\left(T_{s}-T_{e}\right)}{\frac{\Delta T_{2}-\Delta T_{1}}{\ln \left(\Delta T_{2} / \Delta T_{1}\right)}}
$$

Con los datos arrojados en diversos ensayos experimentales de $T_{s}, T_{e}$ y $T_{\text {dig }}$ se evalúa $U_{\text {int }}$ para cada uno de ellos. Se promedian para obtener el valor de $U_{\text {int }}$ a utilizar para calcular $T_{e}$. Esta temperatura se evalúa despejándola de la ecuación 8.40 , obteniendo la 8.42 .

$$
T_{e}=T_{d i g}+\left(T_{s}-T_{d i g}\right) e^{-\frac{U_{i n t} A_{i n t}}{\dot{m} c_{p}}}
$$

\subsection{Resultados de la curva de eficiencia del colector solar.}

Se obtiene la eficiencia instantánea $\eta_{i}$ del colector utilizando el conjunto de valores medidos de la temperatura ambiente $T_{a}$, de la entrada $T_{e}$ y salida del colector $T_{s} \mathrm{y}$ la irradiancia $G_{T}$ para los dias soleados del 19 al 26 de setiembre desde las 9 a.m. a las 18 p.m. Estos valores puntuales se representan en la Figura 8.7, conjuntamente con la recta que los aproxima. 


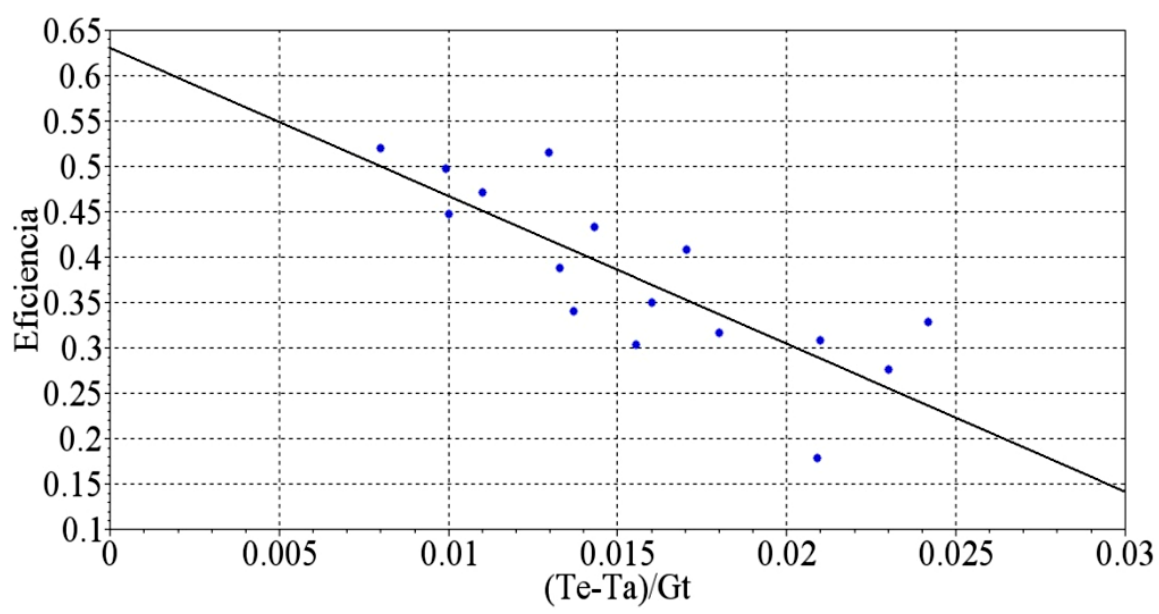

Figura 8.7. Curva de eficiencia del colector solar plano.

Fuente: Elaboración propia.

La ecuación (8.43) se obtiene mediante la aplicación de cuadrados mínimos.

$$
\eta_{i}=0,63-16,27 \mathrm{~W} / \mathrm{m}^{2 \circ} \mathrm{C} \frac{\left(T_{e}-T_{a}\right)}{G_{T}}
$$

Comparando la ecuación 8.43 con la ecuación 8.8

$$
\eta_{i}=F_{R}(\tau \alpha)-F_{R} U_{L} \frac{\left(T_{e}-T_{a}\right)}{G_{T}}
$$

se obtiene un factor $F_{R}(\tau \alpha)$ de 0,63 , el que es relativamente bajo debido a la resistencia térmica de la masa de agua que contiene el colector. De la misma comparación el factor $F_{R} U_{L}$ resulta $16,27 \mathrm{~W} / \mathrm{m}^{2}{ }^{\circ} \mathrm{C}$.

Para los colectores sin cubierta presentan factores de $F_{R}(\tau \alpha)$ y $F_{R} U_{L}$ de 0,75 y 17 $\mathrm{W} / \mathrm{m} 2^{\circ} \mathrm{C}$ respectivamente (Duffie y Beckman ,1991).

Aplicando la ecuación 8.9 se obtiene el valor promedio de la eficiencia térmica global $\eta$ igual a 0,38 .

\subsection{Resultados del modelo de simulación numérica.}

Aplicando el método de diferencias finitas desarrollado en el apartado 5.3.2 se fija una grilla en el espacio físico de estudio tal como se presenta en la Figura 8.8. En ésta los nodos se representan por puntos, los cuales constituyen las temperaturas de interés: ambiente $T_{a}$, placa transparente $\mathrm{T}_{\text {cub,t }}$, invernadero $T_{\text {inv }}$, cubierta $T_{\text {cub }}$ ,biogás $T_{b}$, digestor $T_{\text {dig, }}$ y suelo $T_{\text {suelo. }}$. 


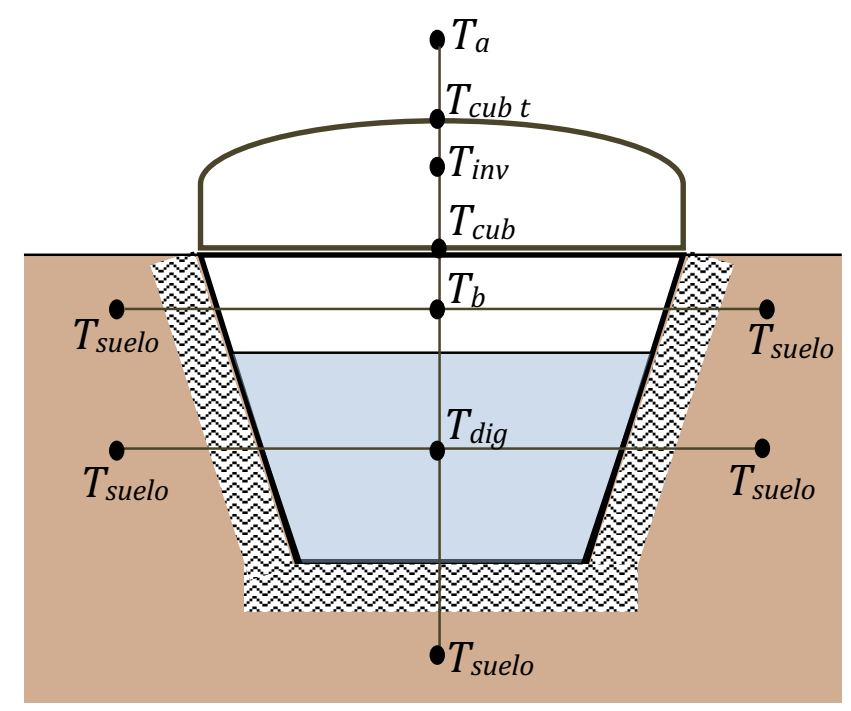

Figura 8.8. Nodos de temperatura para el cálculo de simulación numérica. Fuente: Elaboración propia.

Se toman los valores de densidad del agua y volumen que ocupa en el digestor. El espacio dentro del digestor que normalmente tendría biogás contiene aire. Como se ha llenado solo con agua por única vez, la carga diaria que entra al digestor $\dot{m}_{c d}$ resulta nula. Los parámetros que se utilizan en el modelo se presentan en la Tabla 8.1, en ella se utiliza densidad y calor específico del aire reemplazando los parámetros del biogás.

Tabla 8.1. Datos de los parámetros utilizados en el modelo.

\begin{tabular}{|l|l|c|}
\hline \multicolumn{2}{|c|}{ Cubierta transparente } \\
\hline$A_{\text {cubt }}$ & Área & $3,0 \mathrm{~m}^{2}$ \\
\hline$c_{\text {cubt }}$ & Calor específico & $1200 \mathrm{~J} / \mathrm{kg}^{\circ} \mathrm{C}$ \\
\hline$e_{\text {cubt }}$ & Espesor & $0,004 \mathrm{~m}$ \\
\hline$\varepsilon_{\text {cubt }}$ & Emisividad & 0,11 \\
\hline$\rho_{\text {cubt }}$ & Densidad & $1,20 \mathrm{~g} / \mathrm{cm}^{3}$ \\
\hline$\tau_{\text {cubt }}$ & Transmisión & 0,75 \\
\hline
\end{tabular}

\begin{tabular}{|l|l|c|}
\hline \multicolumn{2}{|c|}{ Invernadero } \\
\hline$c_{c i n v}$ & Calor específico (aire) & $1,005 \mathrm{~J} / \mathrm{Kg}^{\circ} \mathrm{C}$ \\
\hline$h_{\text {inv }}$ & Coeficiente convectivo (aire) & $3,21 \mathrm{~W} / \mathrm{m}^{\circ} \mathrm{C}$ \\
\hline$\rho_{\text {inv }}$ & Densidad (aire) & $1,22 \mathrm{Kg} / \mathrm{m}^{3}$ \\
\hline
\end{tabular}

\begin{tabular}{|l|l|c|}
\hline \multicolumn{3}{|c|}{ Aire en reemplazo de Biogás } \\
\hline$A_{p b}$ & Área de las paredes en contacto con el biogás & $0,384 \mathrm{~m}^{2}$ \\
\hline$c_{b}$ & Calor específico & $1,005 \mathrm{~J} / \mathrm{Kg}^{\circ} \mathrm{C}$ \\
\hline$V_{b}$ & volumen & $600 \mathrm{l}$ \\
\hline$\rho_{b}$ & Densidad & $1,22 \mathrm{Kg} / \mathrm{m}^{3}$ \\
\hline
\end{tabular}




\begin{tabular}{|l|l|c|}
\hline \multicolumn{3}{|c|}{ Cubierta del digestor } \\
\hline$A_{\text {cub }}$ & Área & $0,96 \mathrm{~m}^{2}$ \\
\hline$\alpha$ & Absortancia & 0,8 \\
\hline$\varepsilon_{\text {cub }}$ & Emisividad & 0,8 \\
\hline
\end{tabular}

\begin{tabular}{|l|l|c|}
\hline \multicolumn{2}{|c|}{ Carga del digestor (agua) } \\
\hline$A_{s}$ & Área superior de la carga & $0,96 \mathrm{~m}^{2}$ \\
\hline$c_{c}$ & Calor específico de la carga & $4.179 \mathrm{~J} / \mathrm{kg}^{\circ} \mathrm{C}$ \\
\hline$\varepsilon_{c}$ & Emisividad & 0,95 \\
\hline$m_{c}$ & Masa & $396 \mathrm{~kg}$ \\
\hline$\rho_{c}$ & Densidad & $990 \mathrm{~kg} / \mathrm{m}^{3}$ \\
\hline$V_{c}$ & Volumen & $400 \mathrm{l}$ \\
\hline
\end{tabular}

\begin{tabular}{|l|l|c|}
\hline \multicolumn{3}{|c|}{ Intercambiador de calor } \\
\hline$A_{\text {int }}$ & Área del intercambiador de calor & $0,62 \mathrm{~m}^{2}$ \\
\hline$\dot{m}$ & Caudal del fluido caloportador & $0,8 \mathrm{~kg} / \mathrm{s}$ \\
\hline$U_{\text {int }}$ & $\begin{array}{l}\text { Coeficiente global de pérdidas del } \\
\text { intercambiador }\end{array}$ & $362 \mathrm{~W} / \mathrm{m}^{2}{ }^{\circ} \mathrm{C}$ \\
\hline
\end{tabular}

\begin{tabular}{|l|l|c|}
\hline \multicolumn{2}{|c|}{ Otros } \\
\hline$c_{p}$ & $\begin{array}{l}\text { Calor específico del fluido caloportador (agua } \\
\text { pura) }\end{array}$ & $4.179 \mathrm{~J} / \mathrm{kg}^{\circ} \mathrm{C}$ \\
\hline$\Delta T_{s}$ & Incremento de temperatura en el controlador & $1{ }^{\circ} \mathrm{C}$ \\
\hline$h_{a}$ & Coeficiente convectivo ambiente & $2,8 \mathrm{~W} / \mathrm{m}^{2}{ }^{\circ} \mathrm{C}$ \\
\hline$\dot{m}_{c d}$ & Caudal másico de la carga ingresada & 0 \\
\hline$R$ & Resistencia eléctrica & $32,3 \Omega$ \\
\hline$T_{\text {sensor }}$ & Temperatura establecida en el controlador & $30^{\circ} \mathrm{C}$ \\
\hline$T_{\text {suelo }}$ & Temperatura del suelo & $15^{\circ} \mathrm{C}$ \\
\hline$\sigma$ & Constante de Stefan-Boltzman & $5,67.10^{-8} \mathrm{~W} / \mathrm{m}^{2} \mathrm{~K}^{4}$ \\
\hline$V$ & Tensión eficaz de la red eléctrica & $220 \mathrm{~V}$ \\
\hline$v$ & Velocidad del fluido caloportador & $1,15 \mathrm{~m} / \mathrm{s}$ \\
\hline
\end{tabular}

\begin{tabular}{|l|l|c|}
\hline \multicolumn{3}{|c|}{ Cuerpo del digestor } \\
\hline$A_{p}$ & $\begin{array}{l}\text { Área total interna del digestor en contacto con la } \\
\text { carga }\end{array}$ & $6,08 \mathrm{~m}^{2}$ \\
\hline$k$ & Coeficiente convectivo de las paredes y suelo & $0,045 \mathrm{~W} / \mathrm{m}^{\circ} \mathrm{C}$ \\
\hline$e$ & Espesor de la aislación de las paredes y suelo & $0,08 \mathrm{~m}$ \\
\hline
\end{tabular}

\begin{tabular}{|l|l|c|}
\hline \multicolumn{3}{|c|}{ Colector solar } \\
\hline$F_{R} \tau \alpha$ & $\begin{array}{l}\text { Producto del factor de remoción con la el } \\
\text { coeficiente de absorción y transmisión }\end{array}$ & 0,63 \\
\hline$U_{L} F_{R}$ & $\begin{array}{l}\text { Producto del factor de remoción con el } \\
\text { coeficiente global de perdidas }\end{array}$ & $16,27 \mathrm{~W} / \mathrm{m}^{2 \circ} \mathrm{C}$ \\
\hline
\end{tabular}

Fuente: (Duffie y Beckman ,1991), (Cengel, 2012), (Perrigault, 2012). 
8.5.1 Temperatura del invernadero, de la cubierta y de la carga del digestor.

Se analizan los resultados de la simulación y las medidas de temperatura del invernadero, la cubierta y la carga del digestor. En la Figura 8.9 se muestran los datos del cálculo de la temperatura de la cubierta (rojo) y su correspondiente medida (verde) y la temperatura del interior del digestor (magenta) y su medida (azul).

Las medidas y el cálculo de la temperatura de la cubierta presentan un error promedio del $6 \%$. La diferencia entre ellas aumenta en los momentos de bajas temperaturas.

En cuanto a la carga del digestor el cálculo tiene oscilaciones entre $31^{\circ} \mathrm{C}$ y $29^{\circ} \mathrm{C}$, tal como las medidas, estas se hacen más frecuentes durante la noche. El error cometido tiene un valor promedio de $4 \%$.

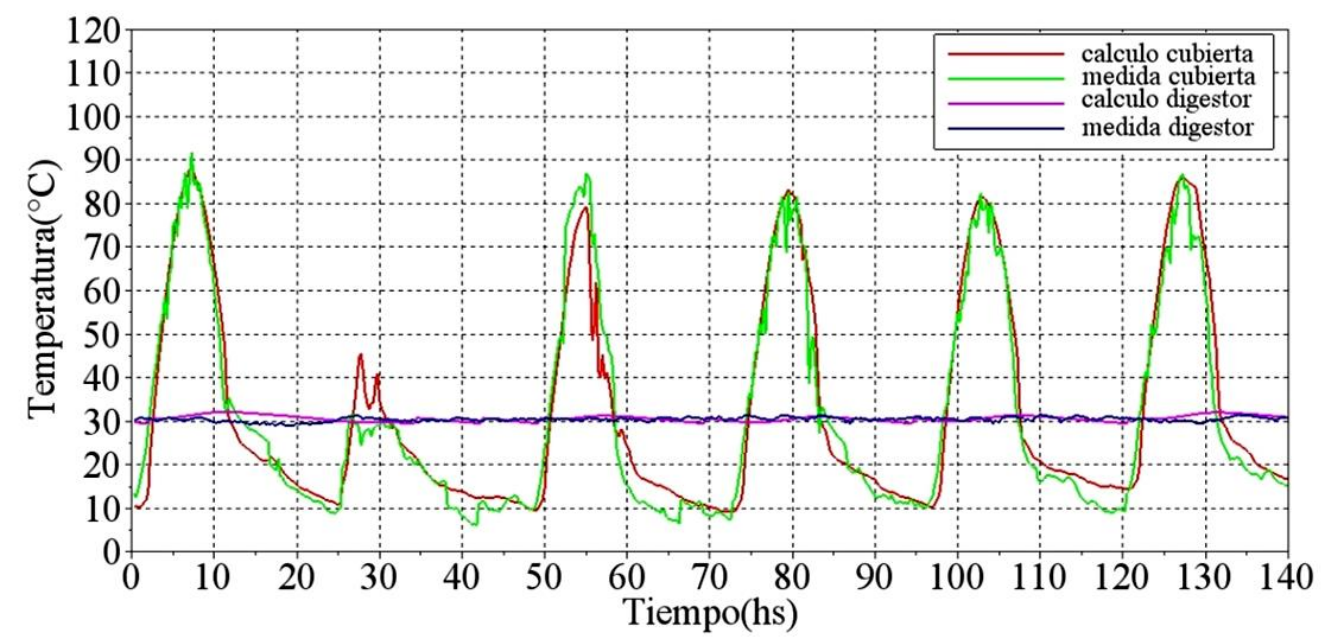

Figura 8.9. Temperatura de la cubierta y carga del digestor: calculada y medida. Fuente: Elaboración propia.

En la Figura 8.10 se presenta las medidas y el cálculo de la temperatura del invernadero, la que presenta un error del $10 \%$ promedio. La diferencia entre la medida y el cálculo se hace más grande cuando la temperatura es más baja, en la noche o durante el día más frío. 


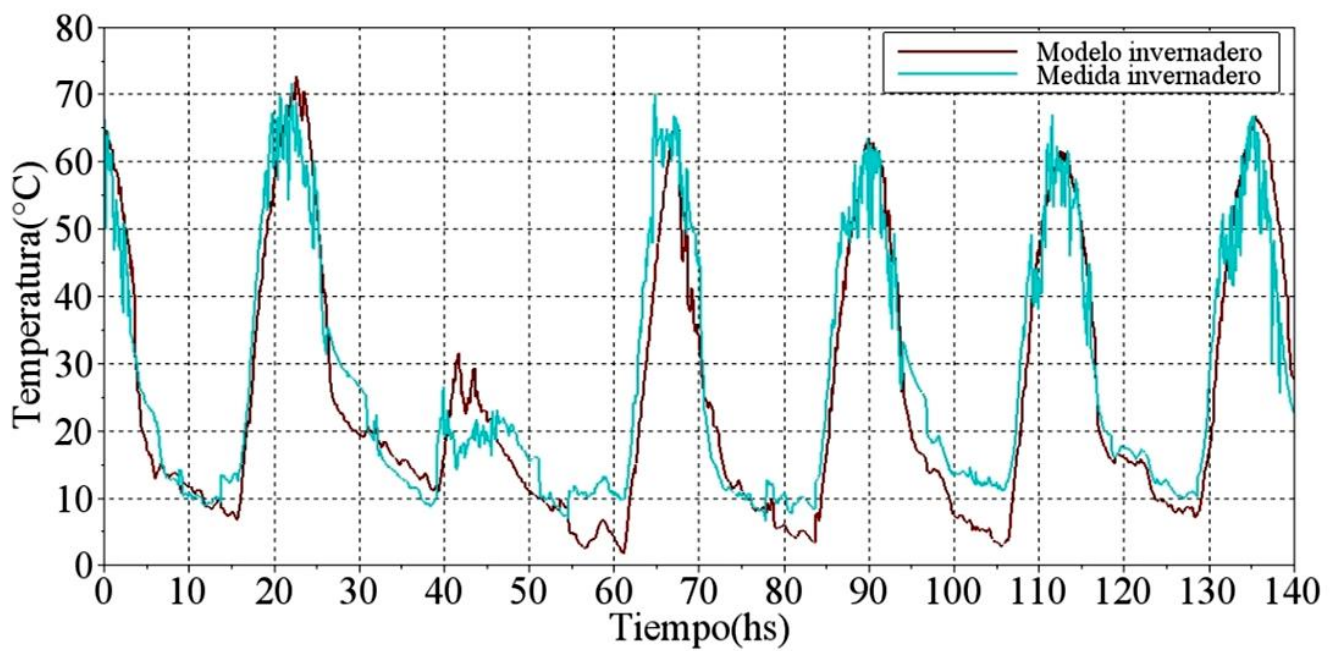

Figura 8.10. Temperatura del invernadero: calculada y medida. Fuente: Elaboración propia.

\subsubsection{Cálculo de la energía solar y energía eléctrica consumida.}

Para el cálculo de la energía eléctrica y la energía solar consumida por el digestor se realizan dos comparaciones: inicialmente se compara la temperatura del controlador $T_{\text {sensor }}$ (se recuerda que esta se fija a $30^{\circ} \mathrm{C}$ que es la temperatura de operación del digestor) y la del digestor $T_{\text {dig }}$ (ecuaciones 8.15 y 8.16). Si esta última resulta menor, entonces se calcula $\dot{Q}_{u}, T_{e}$ y $T_{s}$ (ecuaciones 8.1 al 8.9). Se compara nuevamente $T_{\text {sensor }}$ y $T_{s}$ y si esta última resulta menor se calcula $\dot{Q}_{\text {elec }}$ (ecuación 8.14).

En cada momento se suman tanto $\dot{Q}_{u}$ como $\dot{Q}_{\text {elec }}$, de manera de obtener diariamente la energía utilizada por el digestor.

En la segunda y tercera columna de la Tabla 8.2 se muestra la energía que brinda el colector solar, en la tercer y cuarta se presenta la energía eléctrica utilizada sólo por la resistencia eléctrica, con el aporte de la energía dada por la bomba que impulsa el agua por los conductos.

Tabla 8.2. Energía diaria utilizada por el digestor.

\begin{tabular}{|lcccc|}
\hline Fecha & \multicolumn{2}{c}{$\begin{array}{c}\text { Energía solar } \\
\left(\mathbf{J ~ 1 0}^{6}\right)\end{array}$} & \multicolumn{2}{c|}{$\begin{array}{c}\text { Energía eléctrica } \\
\text { (J 106) }\end{array}$} \\
\hline & Medida & Cálculo & Medida & Cálculo \\
$\mathbf{2 1 - 9 - 1 7}$ & 0 & 0 & 21,4 & 23,9 \\
$\mathbf{2 2 - 9 - 1 7}$ & 4,71 & 3,93 & 15,9 & 15,1 \\
$\mathbf{2 3 - 9 - 1 7}$ & 4,71 & 3,74 & 15,7 & 15,1 \\
$\mathbf{2 4 - 9 - 1 7}$ & 4,75 & 3,97 & 15,5 & 15,1 \\
\hline
\end{tabular}

Fuente: Elaboración propia. 
En el día más frío, donde la irradiancia solar máxima es de $350 \mathrm{~W} / \mathrm{m}^{2}$, insuficiente para lograr una temperatura mayor a $30^{\circ} \mathrm{C}$, la energía que entrega el colector es cero, es decir que en ese día no se utiliza el colector solar con un valor alto de la energía utilizada por la resistencia. En la misma tabla se presentan la energía solar utilizable por el digestor y la eléctrica consumida. Los días que aparecen en ella son desde el tercer al sexto día de iniciada la experiencia; en los días previos el digestor se encontró en proceso de calentamiento y en los posteriores se desactivó el sistema de calefacción. Se recuerda que el modelo de simulación toma $30^{\circ} \mathrm{C}$ como la temperatura inicial del digestor anaeróbico.

\subsubsection{Consumo energético mensual del digestor.}

Se cuenta con los datos de irradiación solar diaria sobre superficie plana y temperatura ambiente con una frecuencia de 15 minutos durante todo el año 2017, provenientes de una estación meteorológica de la zona. Tales medidas son apreciables, ya que junto con las características térmicas del colector solar y del digestor, se calcula la energía solar que utiliza el sistema de calentamiento para mantener una temperatura constante en el digestor durante todo el año. La energía eléctrica también interviene, como se aclara en el modelo, ya que realiza su aporte en los momentos en que la radiación solar no es suficiente. Finalmente, se computa el gasto de energía eléctrica que debe invertirse.

Se utiliza el modelo representado por las ecuaciones presentadas en los apartados 8.2 al 8.4, con la irradiación solar incidente y la temperatura ambiente como datos meteorológicos del lugar. Para este cálculo se toma una carga de $500 \mathrm{~kg}$ y una temperatura de trabajo de $30^{\circ} \mathrm{C}$ y $20^{\circ} \mathrm{C}$.

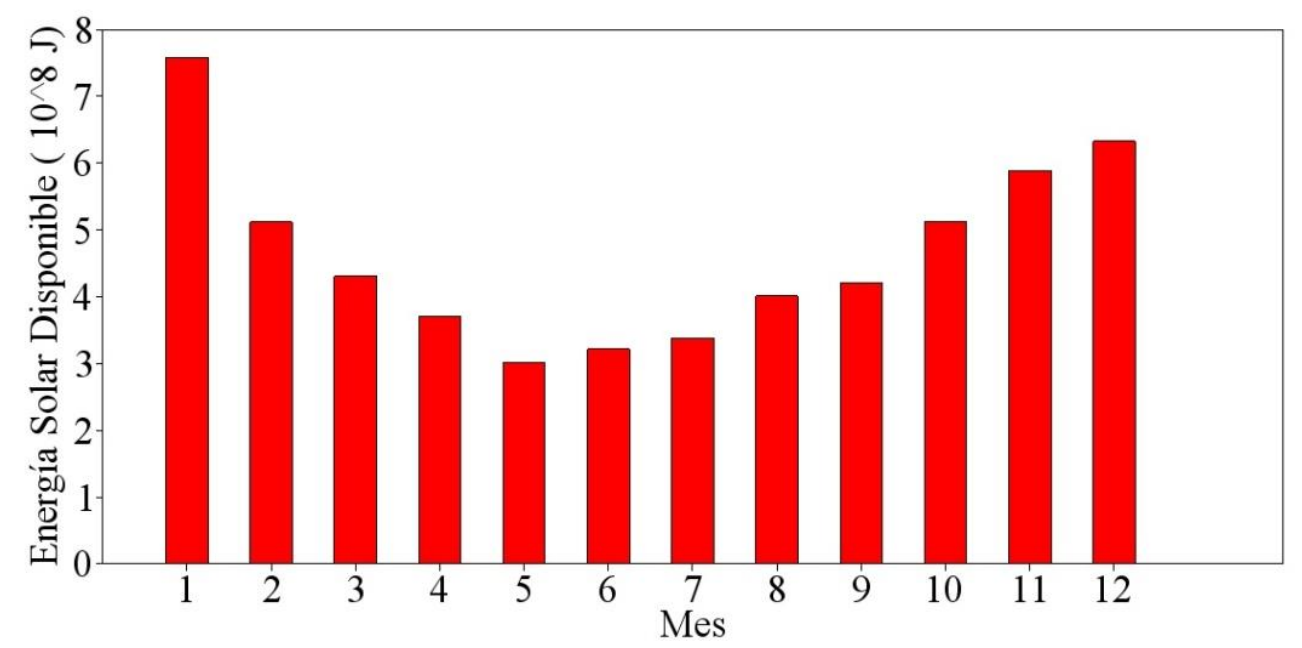

Figura 8.11 Energía solar disponible que brinda el colector solar. Fuente: Elaboración propia. 
La energía útil o energía solar disponible $\dot{Q}_{u}$ que brinda el colector solar, figura 8.11, se calcula como se indica en la ecuación 8.1.

El digestor dispone de esta energía para calentarse, pero por la alternancia en el funcionamiento del sistema calefactor solo utiliza una parte de esta energía disponible durante el día. Cuando la temperatura del digestor llega a la de operación no necesitará más energía, hasta que baje su temperatura y entre en funcionamiento el sistema de calentamiento nuevamente. Esto ocurre siempre, inclusive en horas del día.

En la figura 8.12 se presenta el consumo de energía solar mensual del digestor anaeróbico enterrado operando a $30^{\circ} \mathrm{C}$ (a) y $20^{\circ} \mathrm{C}$ (b), utilizando datos del año 2017.

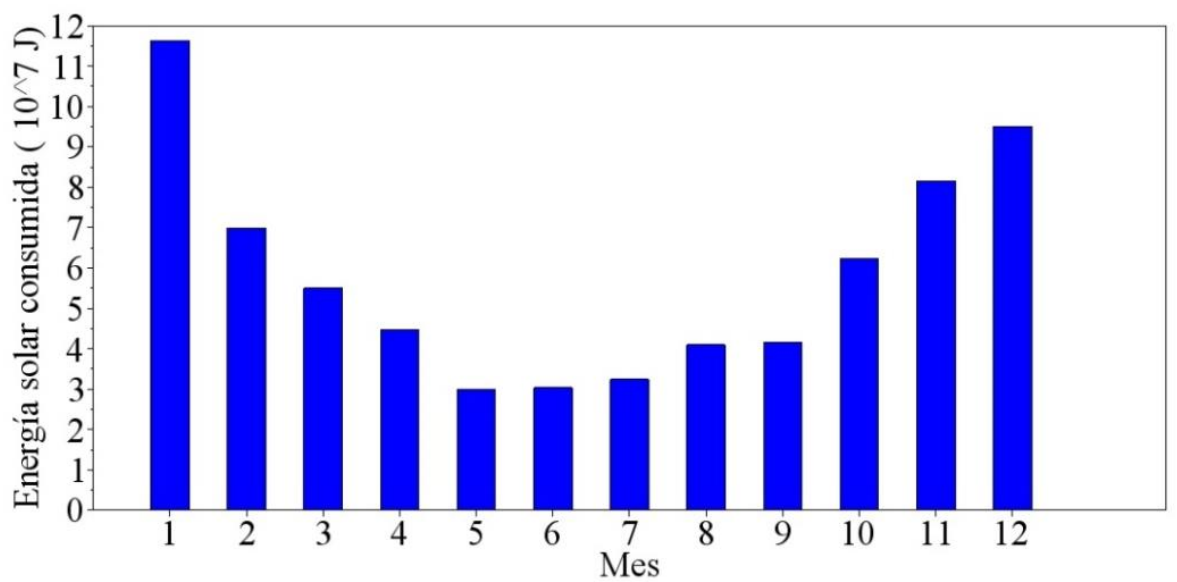

(a) Operando a $20^{\circ} \mathrm{C}$.

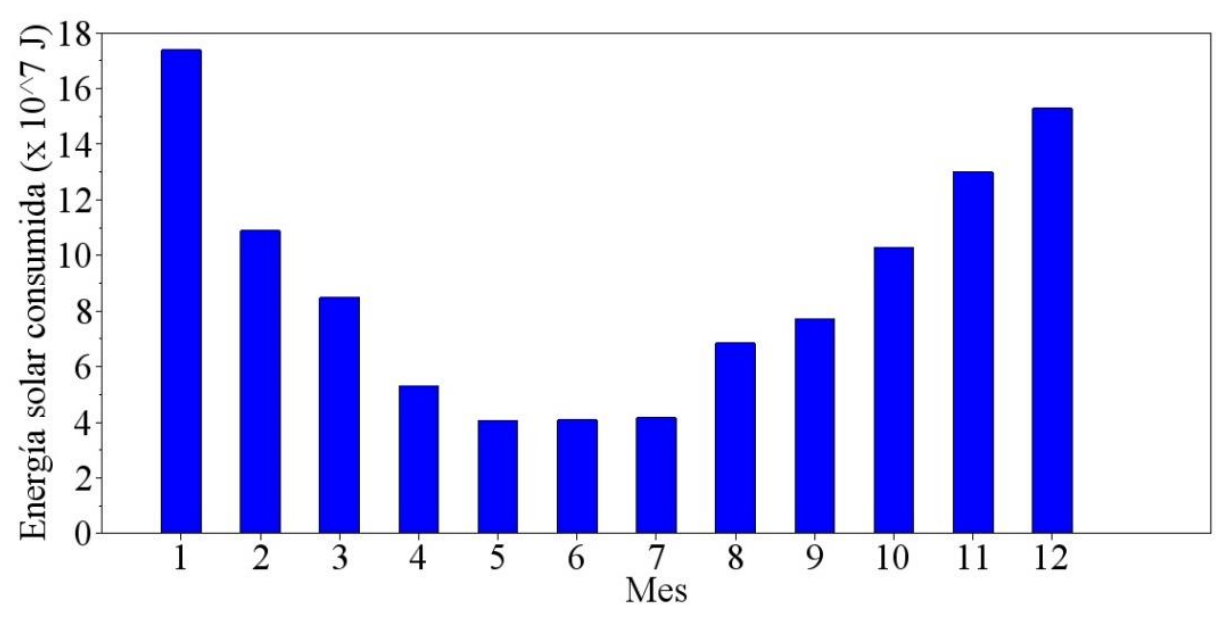

(b) Operando a $30^{\circ} \mathrm{C}$.

Figura 8.12. Energía solar consumida por el digestor anaeróbico enterrado. Operando a (a) $30^{\circ} \mathrm{C}$ y (b) $20^{\circ} \mathrm{C}$.

Fuente: Elaboración propia. 
Ambas gráficas son similares; sin embargo, se observa que cuando el digestor opera a $30^{\circ} \mathrm{C}$, consume más energía solar.

La energía solar que brinda el colector permite reducir el consumo de energía eléctrica, lo que redunda en un beneficio directo de los gastos diarios. En la Figura 8.13 se muestran los consumos de energía eléctrica mensual dada por la resistencia eléctrica en KWh calculados con el modelo de simulación cuando el digestor opera a $30^{\circ} \mathrm{C}$ (a) y $20^{\circ} \mathrm{C}(\mathrm{b})$.

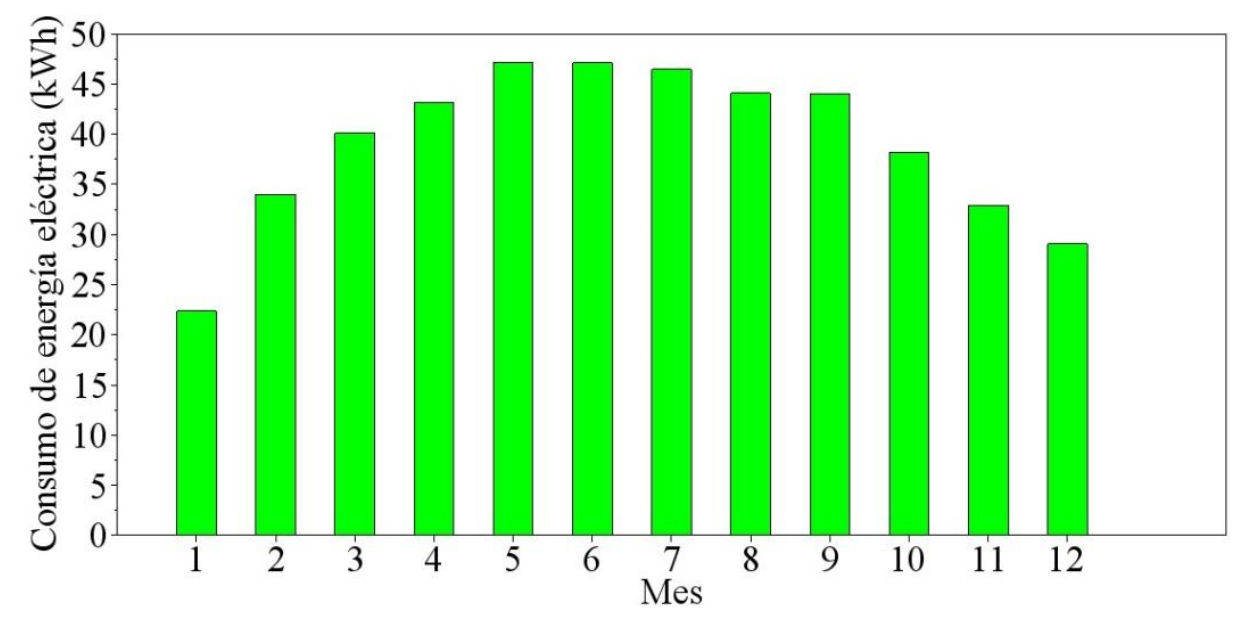

(a) operando a $30^{\circ} \mathrm{C}$

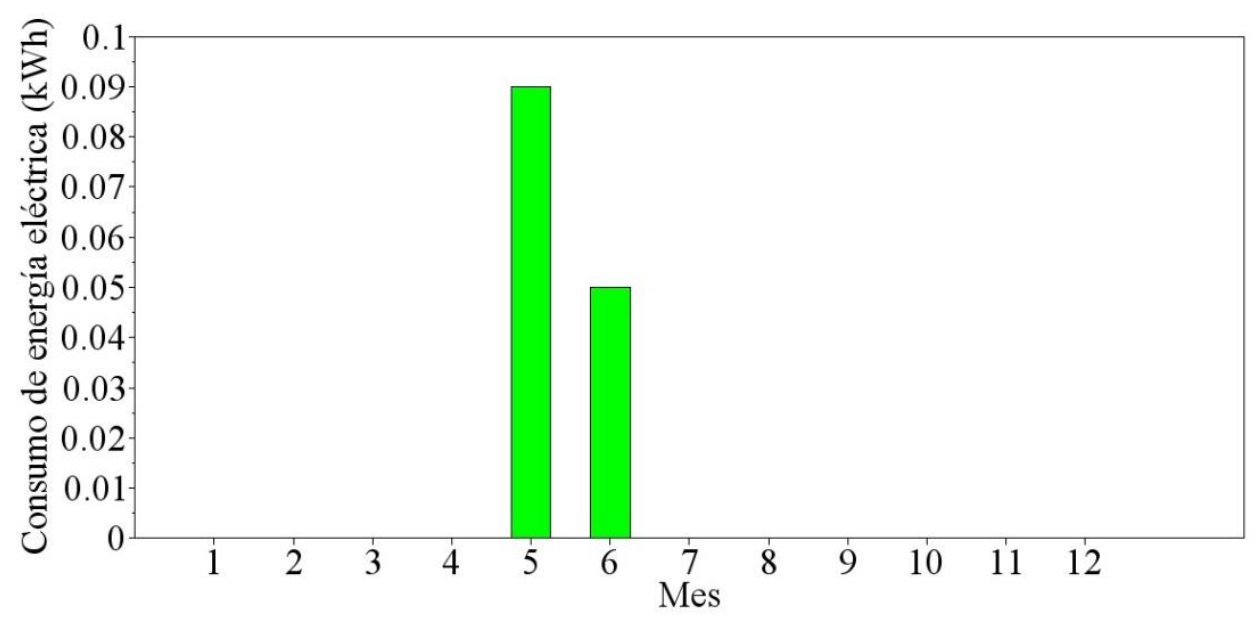

(b) operando a $20^{\circ} \mathrm{C}$

Figura 8.13. Consumo mensual de energía eléctrica del digestor operando a (a) $30^{\circ} \mathrm{C}$ y (b) $20^{\circ} \mathrm{C}$.

Fuente: Elaboración propia.

Se tiene en cuenta el aporte de energía solar mensual. La potencia utilizada es de $1.400 \mathrm{~W}$ dada por la resistencia del dispositivo eléctrico. 
El consumo de energía eléctrica con el digestor operando a $30^{\circ} \mathrm{C}$ es mucho mayor y todos los meses se debe contar con ésta para mantener las condiciones térmicas establecidas. Cuando opera a $20^{\circ} \mathrm{C}$, solamente en los meses de mayo y junio, se utiliza la resistencia eléctrica.

8.5.4 Análisis de la influencia del área y de la eficiencia del colector y del volumen del digestor en el consumo energético.

Si aumenta el área del colector solar se obtiene mayor energía. Siempre que esta área no sea demasiado grande, se puede mantener la misma electrobomba que mueve el fluido caloportador. Con mayor energía solar del colector se abastece, por mayor tiempo, al digestor pues se logra más masa térmica del fluido caloportador a la temperatura del colector.

Si se mantienen las características del colector solar aumentando el área se logra obtener mayor cantidad de fluido caloportador a la misma temperatura. Esto marca un límite a la temperatura de operación del digestor. Con un colector como el construido para acondicionar al digestor, es más conveniente, para economizar energía eléctrica, que el digestor trabaje a $20^{\circ} \mathrm{C}$.

Con un mayor volumen líquido del digestor, se tiene una mayor masa térmica a calentar. Así, los cambios de temperatura se dan con menor frecuencia. El digestor se apartará de su temperatura de operación más lentamente utilizando menos la bomba eléctrica, lo que implica un menor consumo de energía. En la Figura 8.14 se presenta el número de veces que se utiliza la bomba eléctrica por mes para dos volúmenes distintos del digestor: 500 litros y 1.000 litros, cuando se utiliza solamente energía solar.

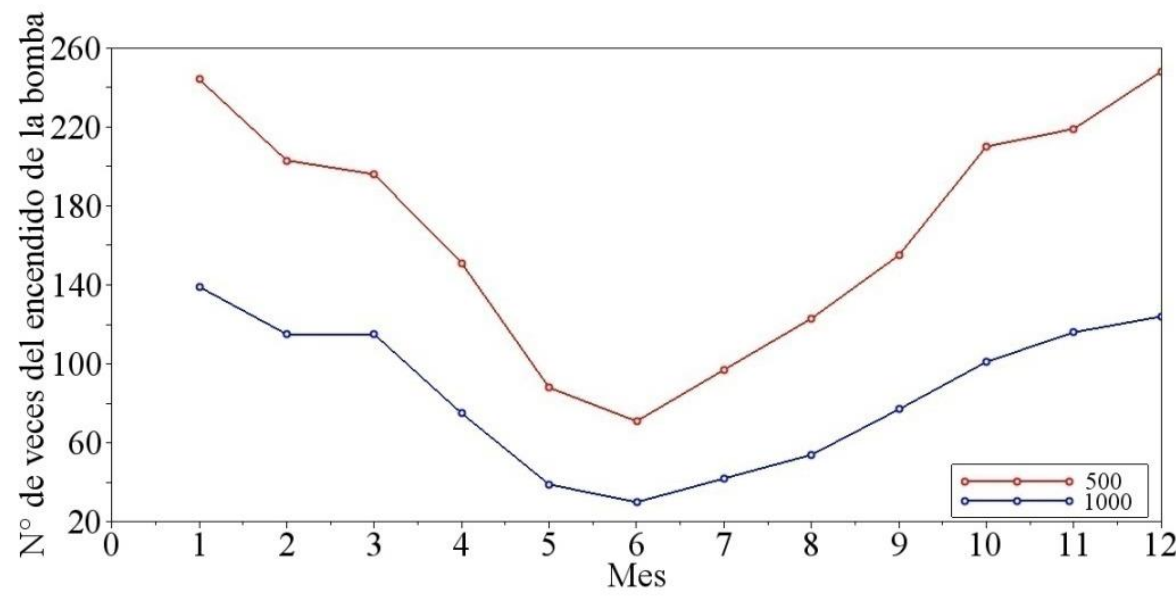

Figura 8.14. Número de veces de encendido de la electrobomba para dos volúmenes diferentes del digestor (500 l y 1.000 l). Fuente: Elaboración propia. 
Si cambian algunos elementos constructivos del colector solar se puede lograr una mayor eficiencia y por lo tanto mayores temperaturas de salida. Por ejemplo, usando metal como placa absorvedora y una cubierta transparente, se mejora la eficiencia, lo que reduce la utilización de la bomba eléctrica.

En la Tabla 8.3 se indica la dependencia de la utilización de la bomba con la eficiencia global del colector. Se utiliza un volumen de 1000 litros y un área de colección de $3 \mathrm{~m}^{2}$.

Tabla 8.3. Número de veces de encendido de la electrobomba en el mes de setiembre en función de la eficiencia.

\begin{tabular}{|cc|}
\hline Eficiencia & $\mathbf{N}^{\circ}$ de veces de encendido de la electrobomba \\
\hline $\mathbf{0 , 3 0}$ & 208 \\
$\mathbf{0 , 5 5}$ & 122 \\
\hline
\end{tabular}

Fuente: Elaboración propia.

\subsection{Discusión.}

El objetivo principal del modelo de simulación es calcular las energías que intervienen como ganancia, tanto la del colector solar como la eléctrica, para un mes completo o para todo el año. En tal sentido, los resultados que arroja el modelo discrepan en un error menor al 10\% con las mediciones.

El modelo permite cambiar los parámetros relacionados con el colector solar $\left(F_{R_{n}}\right.$ $\tau, \alpha$ y de esta manera obtener las características térmicas que debiera tener para cubrir un rango más amplio de la irradiación solar del día.

En el modelo de simulación, se puede modificar las características del digestor anaeróbico como volumen, espesor y conductividad térmica de las paredes y del suelo.

Es interesante recalcar que el modelo de simulación utiliza solo dos parámetros meteorológicos: la temperatura ambiente y la irradiancia solar incidente sobre plano horizontal.

\subsection{Conclusiones.}

El tipo de colector solar incide fuertemente en la decisión que se toma acerca de la temperatura de operación para el funcionamiento del digestor. Como se aprecia en los apartados anteriores para el tipo de colector propuesto, una temperatura de 
$20^{\circ} \mathrm{C}$ resulta una mejor opción para lograr una reducción considerable del consumo eléctrico.

También se observó en los cálculos la influencia del volumen del digestor en las horas de operación de la electrobomba. Un mayor volumen es más apropiado a los fines de reducir la utilización de la bomba.

La eficiencia del colector solar también influye en el uso de la bomba. Una eficiencia mayor reduce el uso de la bomba lo que redunda positivamente en el consumo eléctrico.

Por lo expuesto anteriormente, de acuerdo a la temperatura a la que se desee operar el digestor, se debe analizar detalladamente el tipo de colector solar a utilizar, a fin de minimizar los costos operativos. 


\section{CAPITULO 9}

CAPTACIÓN, CONDUCCIÓN Y CUANTIFICACIÓN DEL BIOGÁS. 


\subsection{Introducción.}

La obtención de biogás del digestor anaeróbico tiene diversos aspectos técnicos a tener en cuenta:

$\checkmark$ Conducción: se refiere a los conductos por donde se dirige el biogás desde el digestor anaeróbico hasta su medición.

$\checkmark$ Acumulación: para contabilizarse, el biogás se acumula primero en un contenedor cuyas características se verán más adelante.

$\checkmark$ Filtración: el biogás contiene gases nocivos que deben removerse

$\checkmark$ Cuantificación: conocer el volumen de biogás es importante a fin de evaluar cómo se comporta el digestor anaeróbico

Además de todas las características técnicas, es importante determinar la composición del biogás; el que contiene principalmente dióxido de carbono y metano. Determinar el volumen de este último es importante, pues, este componente es el que permite su combustión. Para su determinación se extraen muestras cada 2 o 3 días para su correspondiente análisis. El método de determinación es igual al presentado en Capítulo 4 con las soluciones líquidas de hidróxido de potasio (KOH).

En el Capítulo 8 se analizó cómo influye en el consumo de energía la temperatura de operación del digestor. En el apartado 8.6 .3 se muestra como disminuye el consumo de energía eléctrica al tiempo que aumenta la utilización del colector solar cuando la temperatura de operación del digestor disminuye de $30^{\circ} \mathrm{C}$ a $20^{\circ} \mathrm{C}$. Cuando se utiliza energía solar para acondicionar el digestor su temperatura de operación dependerá fuertemente de las condiciones de radiación y de la eficiencia del colector solar.

Existen diversas opciones al momento de utilizar el biogás. La más sencilla y menos costosa es su combustión directa. Por ejemplo, para realizar algunas actividades de un hogar como calentar agua o cocinar. Si la instalación de un digestor se realiza en un hogar de una zona rural, ésta sería la mejor opción.

En este capítulo se presenta todo el sistema de recuperación de biogás del digestor anaeróbico propuesto en este trabajo. Se evalúa la composición y el volumen del biogás. Finalmente se calcula su producción medida como volumen de biogás o metano por kilogramo de sólidos volátiles. Este valor permite una comparación con otros digestores.

\subsection{Sistema de captación, conducción y cuantificación del biogás.}

En la Figura 9.1 se observa una vista frontal superior del digestor. La captación de biogás se realiza a través de dos salidas en el digestor central, conductos (1). Para facilitar su conducción se utiliza una cañería de 3/4 de pulgada en material PVC. El 
biogás conducido se acumula en un reservorio flexible plástico, gasómetro; también de PVC.

El volumen del gasómetro, reservorio flexible (3), es aproximadamente de 450 litros. Antes de llegar al reservorio pasa por el deshumidificador (2), para quitar parte de la humedad. Dentro del digestor, el biogás se encuentra a una temperatura mayor a la ambiente y disminuye al salir, así parte de la humedad se condensa en las cañerías. El deshumidificador es un recipiente cerrado herméticamente en el que simplemente el biogás en vez de seguir un trayecto recto como en los conductos cambia de dirección pasando a ocupar un volumen mayor como se aprecia en la Figura 9.1 y 9.2.

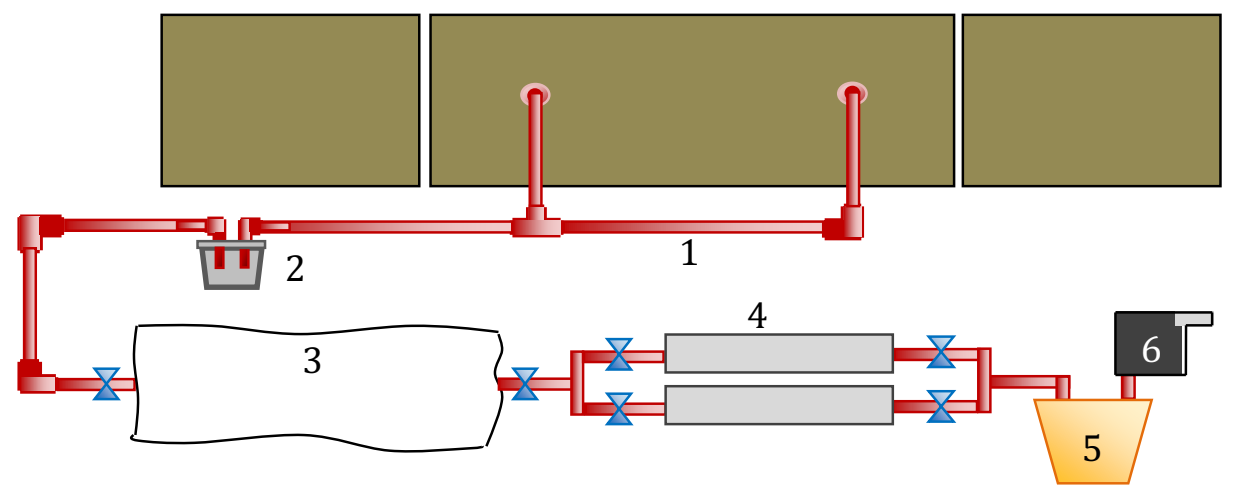

1

2

3

4

5

6

conductos deshumidificador gasómetro

filtros de contador extractor sulfuro de volumétrico de biogás hidrógeno de biogás

Figura 9.1. Representación de la captación, filtración y cuantificación del biogás. Fuente: Elaboración propia.
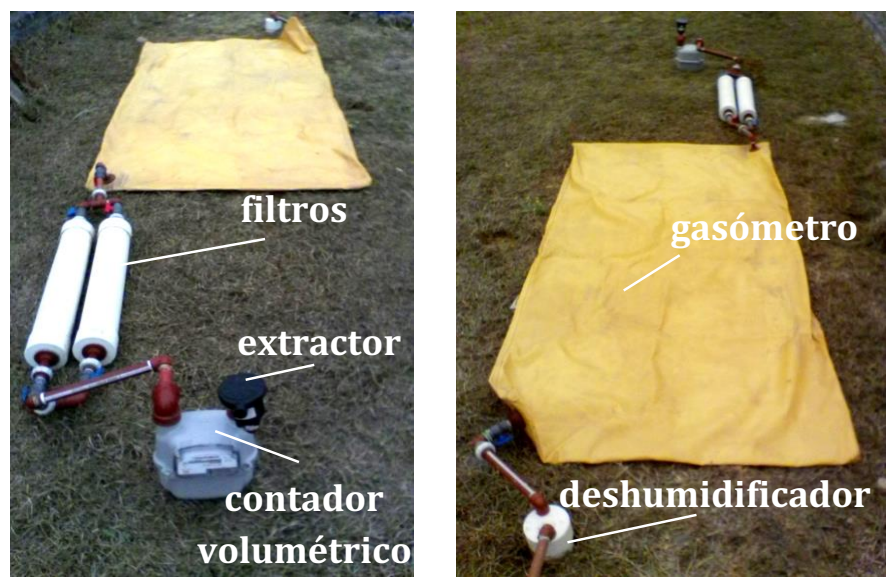

Figura 9.2. Imagen del sistema de captación, filtración y cuantificación del biogás. Fuente: Elaboración propia. 
En la Figuras 9.2 y 9.3 se observan las partes del sistema de captación de biogás: deshumidificador, reservorio flexible (gasómetro), filtro, contador volumétrico y extractor.

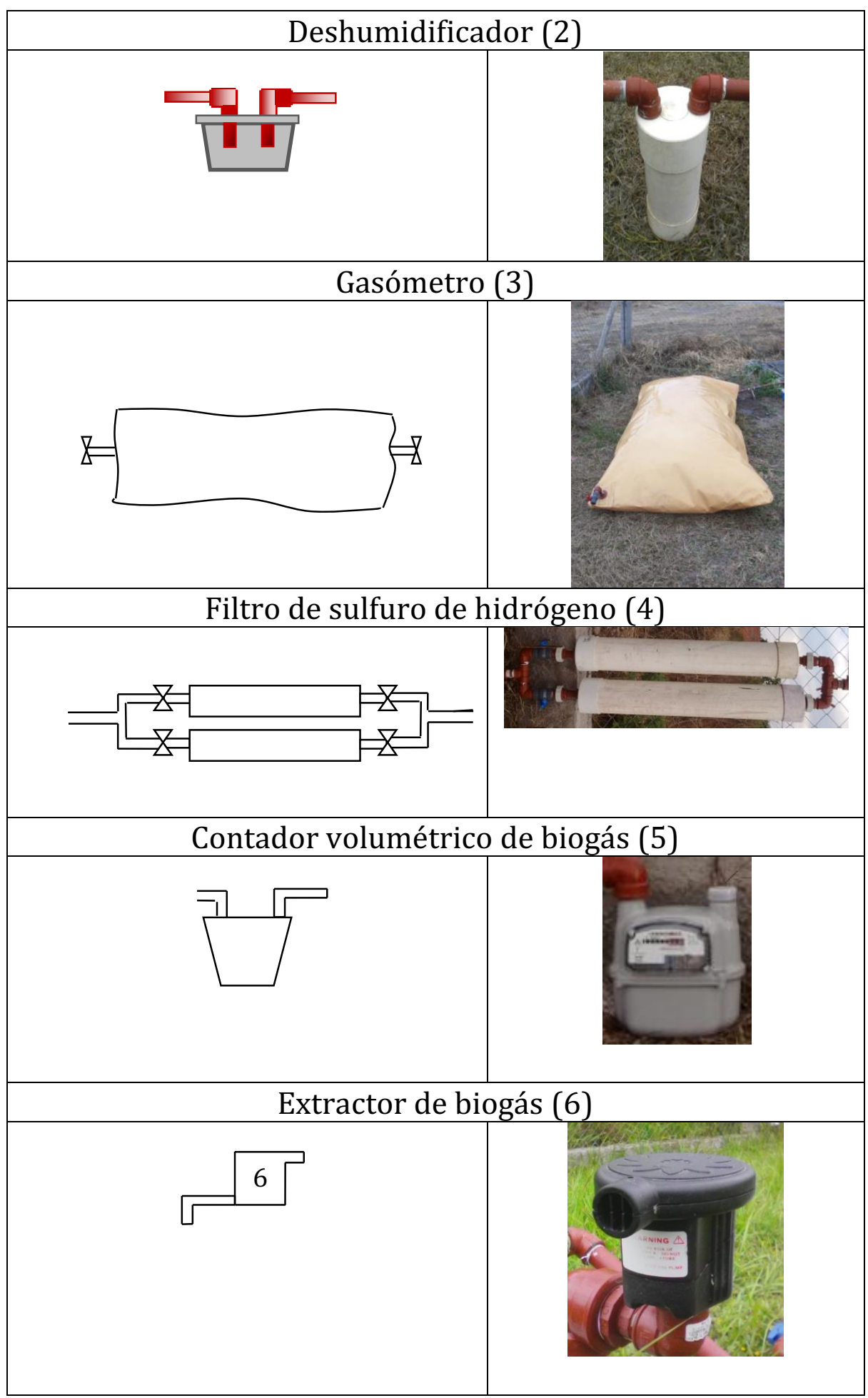

Figura 9.3. Partes del sistema de captación, acumulación, filtración y cuantificación del biogás.

Fuente: Elaboración propia. 
El biogás contiene entre sus componentes sulfuro de hidrógeno $\mathrm{H}_{2} \mathrm{~S}$, capaz de corroer las partes metálicas con las que se encuentre en contacto. Como se observa en la Figura 9.1, luego de acumularse el biogás pasa a un sistema de purificación que logra eliminar el $\mathrm{H}_{2} \mathrm{~S}$ mediante la combinación con el óxido de hierro (III) $\left(\mathrm{Fe}_{2} \mathrm{O}_{3}\right)$, que se encuentra naturalmente en los compuestos de hierro expuestos a la intemperie, filtros (4). Dentro de cada recipiente del filtro hay viruta de hierro oxidada. Los filtros están dispuestos en una conexión en paralelo que permite cambiar alguno de ellos mientras que el otro esté en funcionamiento.

Luego de pasar por los filtros el biogás es conducido hacia un contador volumétrico de gas, (5) de la Figura 9.1. Es necesario aclarar que, si no se purifica el biogás, el medidor puede resultar deteriorado. Este filtro permite a la vez eliminar parte de la humedad por condensación, lo que beneficia su posterior combustión. Para extraer el biogás del gasómetro se necesita de un extractor o compresor, como el que se indica en la figura con el número 6 .

\subsection{Alimentación del digestor anaeróbico enterrado.}

Para alimentar el digestor se recolectó estiércol vacuno procedente de un tambo de la zona rural al oeste de la Capital salteña. Dado que se requiere un volumen considerable de materia prima para llenar el digestor, se acopia durante varios días y no todo el material es fresco. Se cuenta con estiércol de distintos tiempos de permanencia en el suelo. El material fresco posee un bajo valor de sólidos totales y alto valor de sólidos volátiles. En la Tabla 9.1 se indican estos valores para distintas muestras del tambo, para dos de las experiencias realizadas, las que se tuvieron lugar en distintas épocas del año. La recolección se realizó durante el mes de junio y noviembre. En dicha tabla se abrevia "experiencia" como "Exp".

Tabla 9.1. Sólidos totales y volátiles de diferentes muestras de estiércol vacuno proveniente de un tambo de la zona.

\begin{tabular}{|c|c|c|c|c|c|c|}
\hline Muestra & \multicolumn{2}{|c|}{$\begin{array}{c}\text { Sólidos totales } \\
\text { ST (\%) }\end{array}$} & \multicolumn{2}{c|}{$\begin{array}{c}\text { Humedad } \\
\text { (\%) }\end{array}$} & \multicolumn{2}{c|}{$\begin{array}{c}\text { Sólidos volátiles } \\
\text { SV (\%) }\end{array}$} \\
\hline & Exp 1 & Exp 2 & Exp 1 & Exp2 & Exp1 & Exp 2 \\
\hline $\mathbf{1}$ & 17 & 15 & 83 & 85 & 73 & 73 \\
\hline $\mathbf{2}$ & 27 & 16 & 73 & 84 & 71 & 73 \\
\hline $\mathbf{3}$ & 50 & 25 & 50 & 75 & 68 & 70 \\
\hline
\end{tabular}

Fuente: Elaboración propia.

El estiércol vacuno fresco contiene una gran cantidad de humedad que en general se encuentra entre los 55 y 90\% (Varnero y Arellano,1990; Gropelli, 2001). A medida 
que transcurre el tiempo naturalmente se va perdiendo esta humedad más aun cuando el clima es seco. Teniendo en cuenta los dos componentes del material orgánico: sólidos y agua, a medida que este último se pierde aumenta el otro componente, siendo el $100 \%$ la suma de ambos.

De una muestra totalmente seca se determinan los sólidos volátiles. Estos son los compuestos que después de una calcinación se pierden o volatilizan. Es decir, el material que primero se coloca en una estufa para quitarle el agua y secarla, y así calcular los sólidos totales, es puesto luego a calcinar en una mufla para determinar los sólidos volátiles. Con la ecuación 4.2 se calcula este último valor. Por ejemplo, de la Tabla 9.1, de la muestra 1 de la experiencia 1, el 17\% son compuestos sólidos, el resto (83\%) es agua. De esa cantidad de sólidos el 73\% son sólidos volátiles.

Se observa en la misma tabla que hay bastante dispersión en los datos de sólidos totales. Estos indican indirectamente la cantidad de humedad, dado que las muestras tienen distintos tiempos de permanencia en el suelo, aumentando hasta el 50\% para los de mayor tiempo de permanencia de la experiencia 1.

Como se aprecia en la Tabla 9.1 del estiércol recolectado se cuenta con distintos valores de \%ST. Para llenar el digestor se necesita lógicamente agregarle agua. Se quiere lograr una mezcla de agua y estiércol con un valor del 10\% de ST.

Tal como se deduce de los ensayos de laboratorio (Capitulo 4), con este valor se conoce con certeza la producción de biogás, aunque en estos procesos hay cierta dispersión de los datos.

Para determinar cuál es la cantidad suficiente para lograr esta mezcla se toma un valor promedio de \%ST de la Tabla 9.1 para cada experiencia. Para calcular este valor no se tiene en cuenta la muestra 3, con el valor más elevado del $50 \%$ y $25 \%$, ya que se considera que se encuentra en una pequeña cantidad respecto del total, así el promedio es $22 \%$ para la experiencia 1 y de $16 \%$ para la experiencia 2 .

Con estos valores promedios, se calcula la cantidad de agua necesaria para cierta cantidad de estiércol fresco. Se reescribe la ecuación 4.1 del cálculo de sólidos totales, siendo $M_{s}$ y $M_{h}$ la masa seca y la masa húmeda, respectivamente. Esta última es la masa fresca recolectada compuesta por la suma de la masa de agua $M_{a}$ y la masa seca $M_{s .}$

$$
\% S T=\frac{M_{S}}{M_{h}} \cdot 100 \%=\frac{M_{S}}{M_{S}+M_{a}} \cdot 100 \%
$$

De la ecuación 9.1 se desprende la ecuación 9.2 que permite el cálculo de la masa de agua. De esta ecuación \%ST es 10\% (el valor que se quiere alcanzar para la mezcla), 
$M_{S}$ es la masa seca del total recolectado medida en kilogramos (se calcula haciendo el producto del valor de la masa húmeda recolectada por los 0,22 y los 0,16 ).

$$
M_{a}=M_{S} \cdot\left(\frac{100 \%}{\% S T}-1\right)
$$

En la Tabla 9.2 se presentan los datos de la recolección de estiércol fresco, los \%ST promedio de esta recolección, su masa seca y el cálculo de la cantidad de agua necesaria (valores redondeados) para lograr una mezcla del 10\% de ST, utilizando la ecuación 9.2 .

Tabla 9.2. Parámetros relacionados con la cantidad teórica de agua.

\begin{tabular}{|c|c|c|c|c|}
\hline Experiencia & $\begin{array}{c}\text { Estiércol } \\
\text { vacuno } \boldsymbol{M}_{\boldsymbol{h}} \\
\mathbf{( k g )}\end{array}$ & $\begin{array}{c}\text { \%ST } \\
\text { promedio }\end{array}$ & $\begin{array}{c}\text { Masa seca } \\
\text { promedio } \boldsymbol{M}_{\boldsymbol{S}} \\
\mathbf{( k g )}\end{array}$ & $\begin{array}{c}\text { Agua } \\
\text { calculada } \\
\mathbf{( k g )}\end{array}$ \\
\hline $\mathbf{1}$ & 200 & 22 & 44 & 400 \\
\hline $\mathbf{2}$ & 205 & 16 & 33 & 300 \\
\hline
\end{tabular}

Fuente: Elaboración propia.

El valor que brinda la ecuación 9.2 debe tomarse como orientativo, siempre será necesario realizar varias mezclas de distintas cantidades de agua en torno al valor calculado. De estas muestras, la que más se acerque al $10 \%$ será la proporción de agua a tener en cuenta. Así, se logra un valor entre el 8\% y 10\% de ST de la carga del digestor. Se muestran en la Tabla 9.3 los datos de la carga del digestor de ambas experiencias, la cantidad de agua agregada en cada caso, las cantidades de ST y SV promedio y la temperatura de operación. Aunque el peso de estiércol fresco es similar en ambos casos, en la experiencia 1 posee menos humedad como se advierte en la Tabla 9.1, por lo que debe agregarse mayor cantidad de agua.

Tabla 9.3 Datos de la carga del digestor.

\begin{tabular}{|l|c|c|}
\hline \multicolumn{1}{|c|}{ Parámetros } & Experiencia & Experiencia \\
& $\mathbf{1}$ & $\mathbf{2}$ \\
\hline estiércol fresco (kg) & 200 & 205 \\
\hline agua (kg) & 500 & 400 \\
\hline sólidos totales promedio de la mezcla(\%) & 9,5 & 9,0 \\
\hline sólidos volátiles promedio (\%) & 72,0 & 72,2 \\
\hline temperatura de operación( $\left.{ }^{\circ} \mathbf{C}\right)$ & 20 & 20 \\
\hline
\end{tabular}

Fuente: Elaboración propia. 
Como se observa en la tabla la temperatura de operación es de $20^{\circ} \mathrm{C}$ en ambas experiencias. Son varios los motivos por el cual se trabaja con esta temperatura. Por un lado, dadas las características del colector solar, este tiene mayor uso y la energía eléctrica se utiliza menos. Además, es más fácil de controlar puesto que por un corte de luz la temperatura no baja tan bruscamente.

La Figura 9.4 presenta las imágenes del acopio de estiércol vacuno en tachos de 20 y 200 litros, en las inmediaciones del digestor anaeróbico y el momento en el que se realiza el llenado del mismo (imagen derecha).
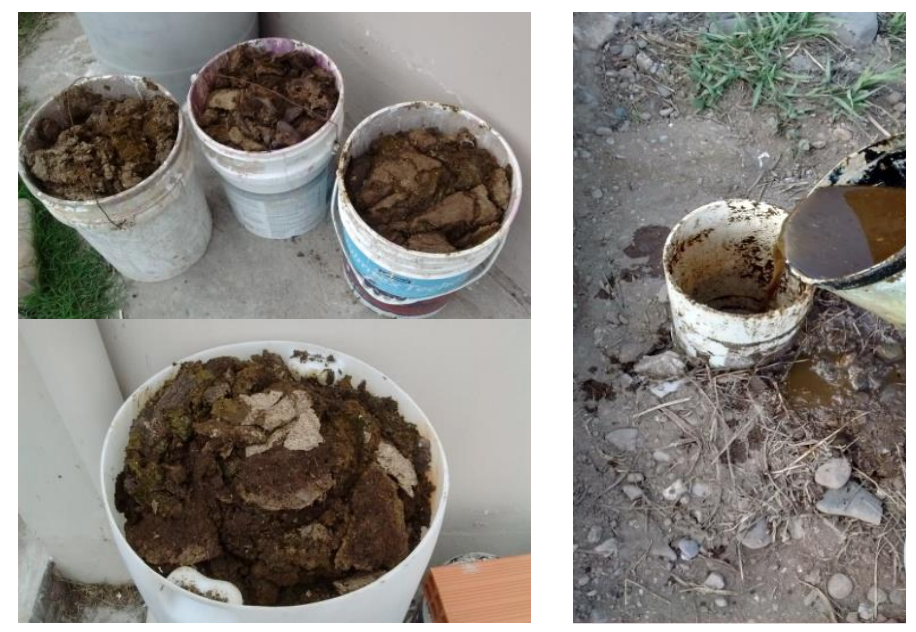

Figura 9.4. Imágenes del acopio de estiércol vacuno y llenado del digestor. Fuente: Elaboración propia.

\subsection{Cuantificación del biogás.}

Dentro del digestor anaeróbico el biogás se va acumulando hasta que la presión es lo suficiente como para que migre al acumulador flexible. Cada día se acumula cierta cantidad de biogás. Cada dos o tres días, dependiendo de la producción, se desagota el acumulador, con ayuda del extractor, para realizar la medida del volumen. El extractor (figuras 9.2 y 9.3) posee una potencia de $20 \mathrm{~W}$ y se alimenta con una fuente de $12 \mathrm{~V}$. Se dificulta medir si hay poco biogás en el acumulador, es por ello que se realiza la extracción cuando hay una cantidad considerable.

En la Figura 9.5 se observa el sistema de medición con más detalle, donde se señala la dirección del flujo de biogás con las flechas rojas. Se muestra también los filtros de biogás, el contador volumétrico y el extractor. 


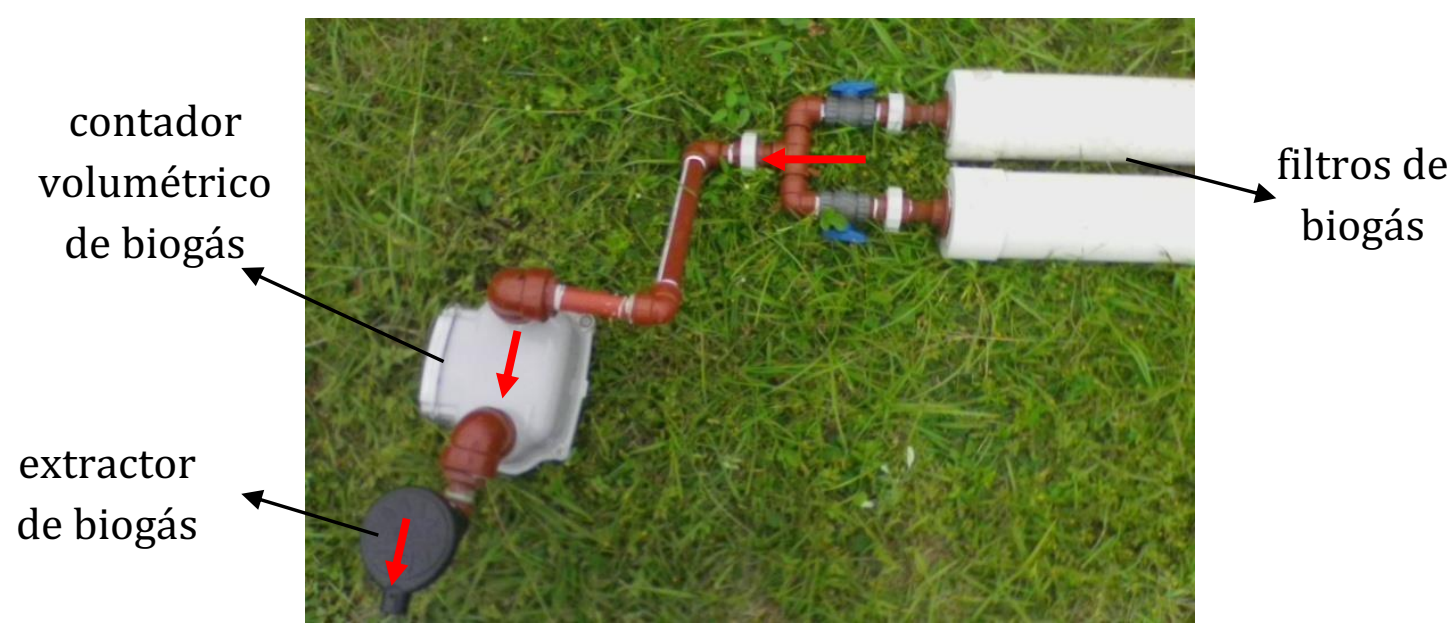

Figura 9.5. Sistema de medición del volumen de biogás.

Fuente: Elaboración propia.

En ambas experiencias se advierte un período de producción nula, un aumento, un máximo y luego una caída. La producción se activa luego de pasadas 3 y 4 semanas para las experiencias 1 y 2 . Al inicio, la producción de biogás tiene valores mínimos y ésta aumenta a medida que transcurre el tiempo. Cada punto de la Figura 9.6a y 9.7a representa una medida del volumen de biogás. Luego de medir, el acumulador se vacía. Los puntos con valores nulos corresponden a los días en que no se mide pues en ellos se acumula. Como se observa, los valores máximos se alcanzan entre los días 40 y 80 en ambas experiencias, y luego empiezan a decaer. Si sobre estos valores se suma la producción total por semana se obtiene una gráfica como la Figura 9.6b y 9.7b. Todos los volúmenes son referidos a $20^{\circ} \mathrm{C}$ y 1 atm de presión. En ella se observa claramente la variación temporal típica de la digestión anaeróbica, en forma de campana que se repite también en los ensayos de laboratorio (Capítulo 4).

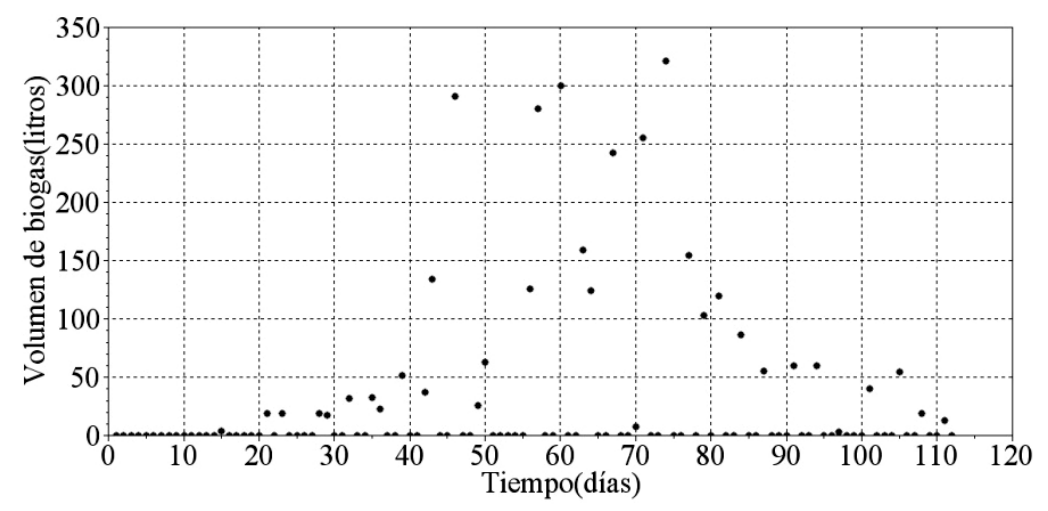

(a) volumen de biogás por día 


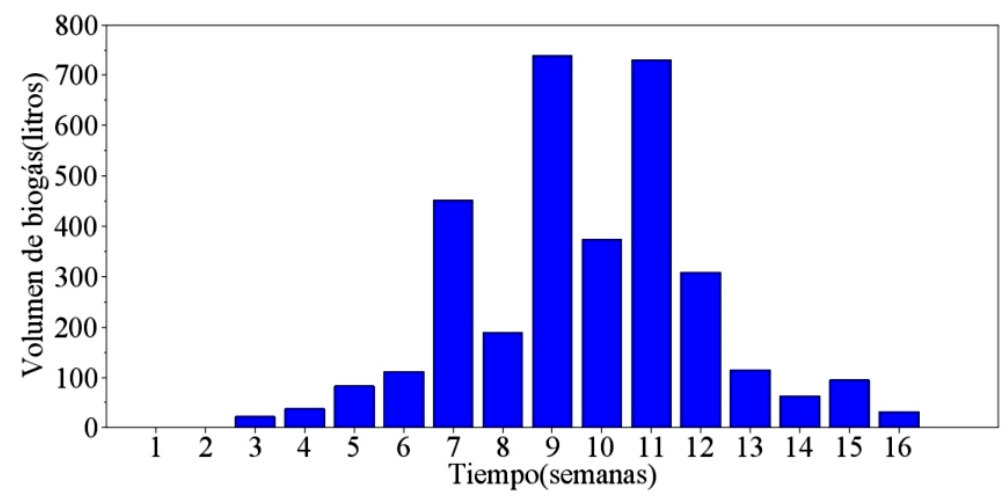

(b) volumen de biogás por semana.

Figura 9.6. Experiencia 1: (a) volumen de biogás por día.

(b) volumen de biogás por semana.

Fuente: Elaboración propia.

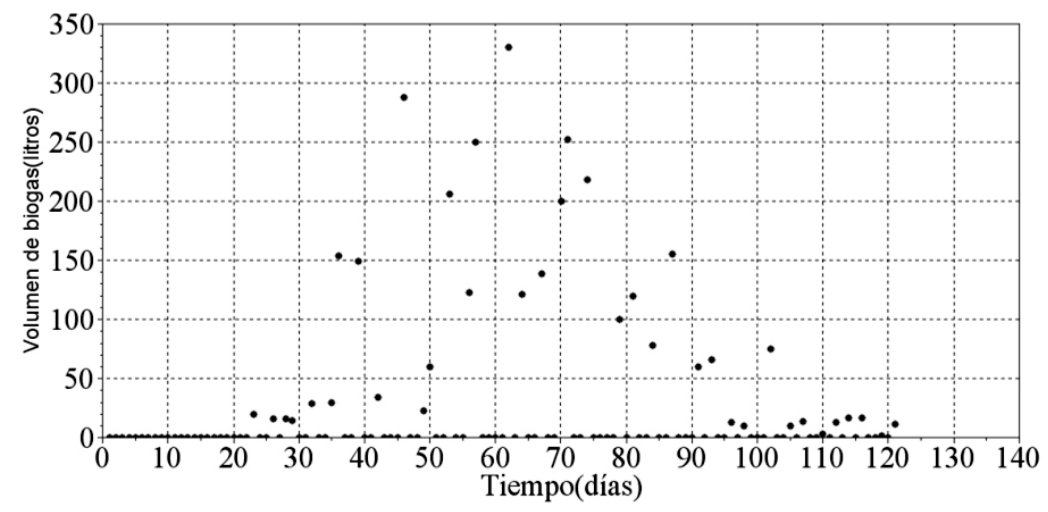

(a) volumen de biogás por día

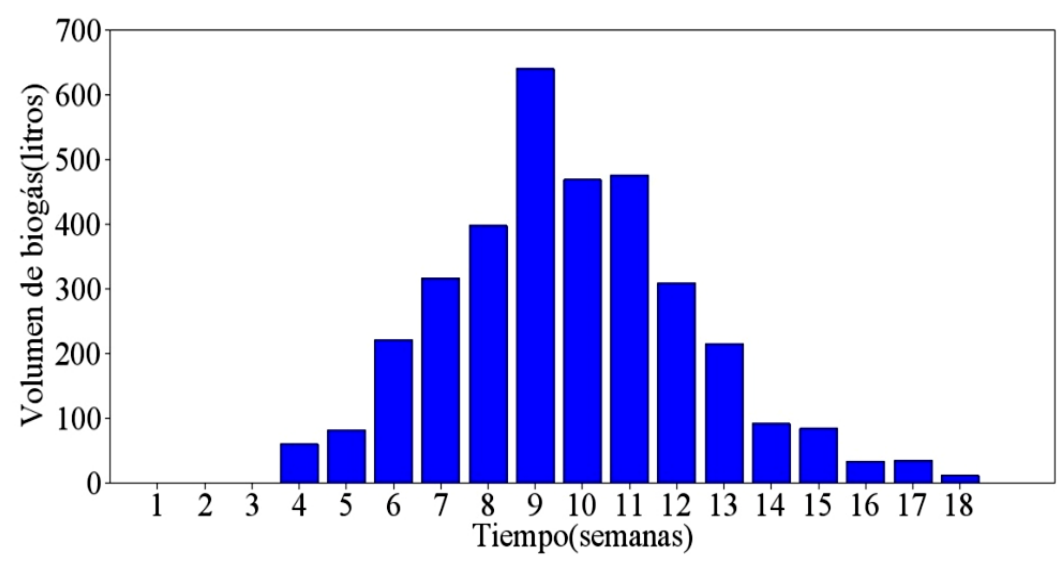

(b) volumen de biogás por semana.

Figura 9.7. Experiencia 2: (a) volumen de biogás por día.

(b) volumen de biogás por semana.

Fuente: Elaboración propia. 
La cantidad total medida de biogás alcanzada para las experiencias 1 y 2 es de 3.355 y 3.438 litros con una proporción promedio de metano de 62\% y 63\%, respectivamente. Un dato comúnmente utilizado para la presentación de la producción dada por un digestor, es expresar en volumen de metano o biogás, por volumen del digestor por día, medidos en $\mathrm{m}^{3} / \mathrm{m}^{3} \mathrm{~d}$ (Marti-Herrero, 2015). Otra cantidad que caracteriza el funcionamiento del digestor es la producción de biogás o metano específica (PEB o PEM) medidos en $\mathrm{m}^{3}$ por $\mathrm{kg}$ de $\mathrm{SV}$ añadidos. Estos datos se muestran en la Tabla 9.4, están referidos a condiciones normales de temperatura y presión $\left(0^{\circ} \mathrm{C}\right.$ y $\left.1 \mathrm{~atm}\right)$.

Tabla 9.4. Parámetros de producción del digestor $\left(0^{\circ} \mathrm{C}, 1 \mathrm{~atm}\right)$.

\begin{tabular}{|c|c|c|c|c|}
\hline & $\mathbf{m}^{\mathbf{3}}$ de biogás & $\mathbf{\%} \mathbf{C H}_{\mathbf{4}}$ & $\begin{array}{c}\mathbf{m}^{\mathbf{3}} \text { biogás } / \mathbf{k g ~ S V} \\
\text { agregados }\end{array}$ & $\begin{array}{c}\mathbf{m}^{\mathbf{3}} \mathbf{C H}_{\mathbf{4}} / \mathbf{k g ~ S V} \\
\text { agregados }\end{array}$ \\
\hline Exp 1 & 3,126 & 62 & 0,098 & 0,060 \\
\hline Exp 2 & 3,169 & 63 & 0,119 & 0,075 \\
\hline Laboratorio & 0,001 & 64 & 0,133 & 0,079 \\
\hline
\end{tabular}

Fuente: Elaboración propia.

A diferencia de lo que ocurre en los ensayos de laboratorio, la actividad microbiana metanogénica se manifiesta pasadas las 3 y 4 semanas en las experiencias con el digestor enterrado, donde los valores específicos de biogás son menores. Una de las razones es la mezcla, pues es más difícil garantizar la homogeneidad de la carga con un volumen mucho mayor. Se recuerda que en el laboratorio se utilizaron Erlenmeyer de $250 \mathrm{ml}$, los cuales eran agitados diariamente. Que las medidas sean menores a los ensayos de laboratorio $\left(0,079 \mathrm{~m}^{3} \mathrm{CH}_{4} / \mathrm{kg} \mathrm{SV}\right)$ no representa una mala experiencia, ya que la situación en el laboratorio es más controlada.

En un estudio en laboratorio Álvarez y Liden (2009) determinan los rendimientos de la cantidad de metano producido de mezclas de estiércol de vaca, oveja y llama. A $18^{\circ} \mathrm{C}$, señalan un rendimiento para el estiércol vacuno de $0,10 \mathrm{~m}^{3} \mathrm{CH}_{4} / \mathrm{kg} \mathrm{SV}$ añadidos, con valores de \%ST y \%SV de 7,8 \% y $76 \%$ respectivamente. Estos valores superiores a los obtenidos en los ensayos presentados se deben a diversas circunstancias, en primer lugar, las condiciones de laboratorio son más controladas que las experiencias de campo, luego, la mezcla más diluida, pudo también tener un efecto positivo en la producción de biogás.

En un digestor tipo Batch operando a $20^{\circ} \mathrm{C}$ con una carga orgánica compuesta por estiércol vacuno al 10\% de sólidos totales y entre un 10 y $11 \%$ de sólidos volátiles 
(calculados sobre base húmeda) Massé (2015) declara un rendimiento de 0,116 $\mathrm{m}^{3} \mathrm{CH}_{4} / \mathrm{kg} \mathrm{SV}$.

En la Tabla 9.5 se presenta la caracterización físico-química del sustrato orgánico una vez terminada la experiencia de digestión. En ésta se especifica el $\mathrm{pH}$, los sólidos totales \%ST y volátiles \%SV. En ella se observa que no hay cambios significativos en cuanto a los sólidos volátiles, que como se sabe, representa la carga orgánica del residuo. Una de las desventajas del proceso de digestión es la baja remoción de la carga orgánica (FAO, 2011), por lo tanto, una reducción de este tipo es esperable.

Tabla 9.5. Caracterización del sustrato final (valores promedios).

\begin{tabular}{|ccc|}
\hline pH & \%ST & \%SV \\
\hline 7,3 & 8,0 & 71,5 \\
7,1 & 8,5 & 71,0 \\
\hline
\end{tabular}

Fuente: Elaboración propia.

Es recomendable a los efectos de concluir con la estabilidad del material aplicar una segunda estrategia para la reducción de la carga orgánica, como lombricompuesto o compostaje.

En la Figura 9.8 se observa la carga del digestor. Luego de concluida las experiencias se quita la tapa y el mezclador y se extrae manualmente el material digerido.

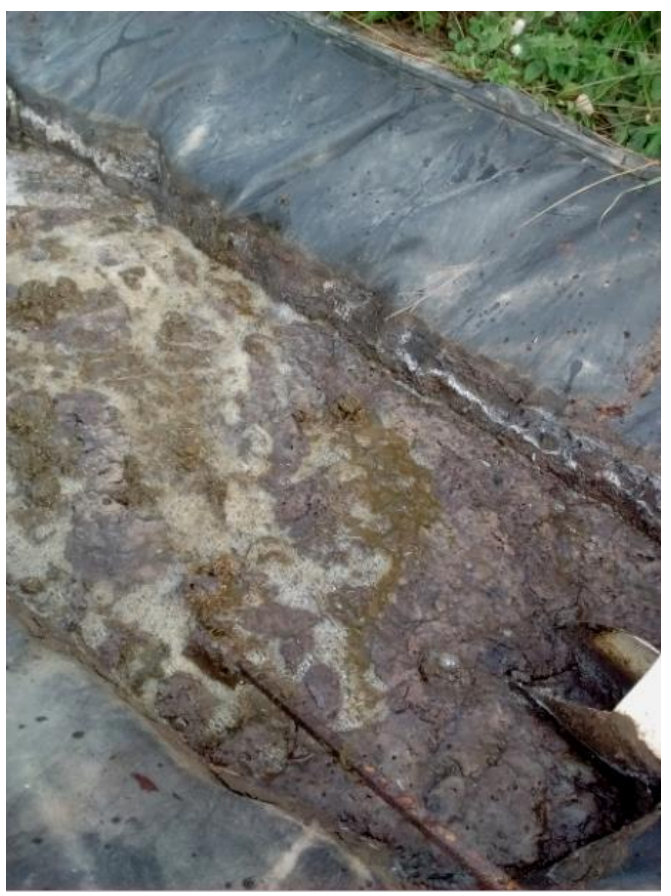

Figura 9.8. Vista del interior del digestor luego de finalizada la experiencia. Fuente: Imagen propia. 


\subsection{Discusión.}

La producción de biogás pasa por cuatro etapas: aclimatación donde no hay producción, crecimiento, máxima producción y finalmente una disminución. Inicialmente no se observa producción alguna hasta la tercera y cuarta semana en las experiencias realizadas. Este tiempo de adaptación de la población bacteriana sin producción, podría considerarse una desventaja; la que es aún mayor si los digestores funcionan en forma discontinua. Con un solo digestor funcionando en discontinuo, una vez agotada su producción o casi agotada, debe vaciarse y llenarse nuevamente. Durante este período no se obtiene biogás.

Por ejemplo, en los ensayos con el digestor enterrado, entre la semana 8 y 9 se obtiene la máxima producción mientras que en la semana 15 y 18 se completa el tiempo de retención hidráulica. Por lo tanto, un segundo digestor debe estar lleno a la semana 4 (de comenzado el primero), de esta manera tendrá su máxima producción cuando el primero tenga que desagotarse.

Esta dificultad se puede subsanar con la operación conjunta de dos digestores. Para un abastecimiento continuo, en por ejemplo una planta de producción de biogás, debe proyectarse con al menos dos digestores, dado que al funcionar en forma discontinua el abastecimiento de un solo digestor es intermitente. Así, se propone el funcionamiento esquematizado en la figura 9.9. Cuando un digestor se encuentra en su máxima producción el otro inicia su producción. Tal situación no es difícil de llevar a cabo, si se conocen los tiempos de retención hidráulica; esto es el tiempo que permanecerá el estiércol dentro del digestor.

Volumen

de biogás

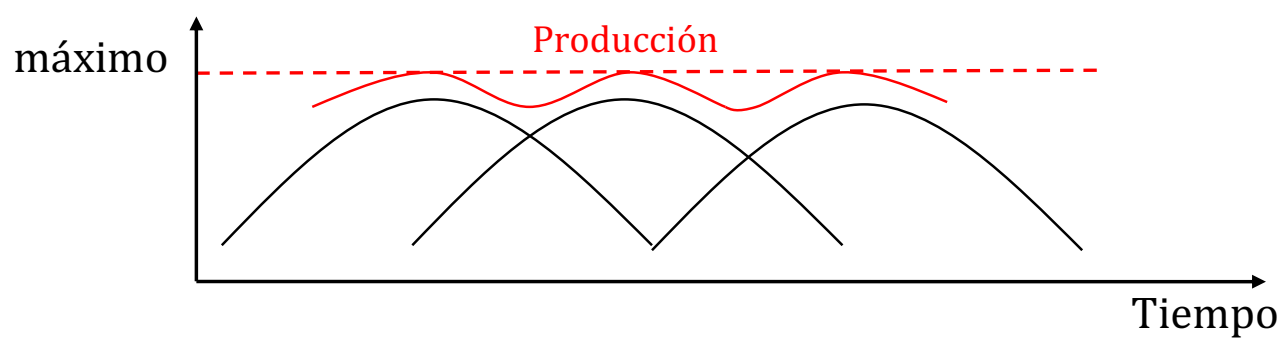

Figura 9.9. Esquema del volumen de biogás en función del tiempo para dos digestores funcionando en forma discontinua.

Fuente: Elaboración propia. 
En la Figura 9.9 se señala como máxima producción el momento en el que el digestor alcanza los valores máximos diarios de biogás, en las experiencias estos volúmenes son de 320 y 330 litros (obtenidos de la Figuras 9.6a y 9.7a).

De esta manera, con dos digestores funcionando, la producción diaria rondará los valores mencionados y se tendría una producción casi constante con un volumen aproximado de entre 300 y 350 litros. Se debe tener en cuenta que las grandes plantas de biogás operan con un conjunto de tres o más digestores (Feiqing Dong y Jiambo Lu, 2013).

\subsection{Conclusión.}

La producción total del digestor en ambas experiencias es de 0,060 y $0,075 \mathrm{~m}^{3} \mathrm{CH}_{4}$ / kg SV agregados, con una temperatura de $20^{\circ} \mathrm{C}$. Comparándolos con los valores medidos en los ensayos de laboratorio para esta temperatura resultan menores. No obstante, el resultado es aceptable pues como se mencionó en condiciones más controladas se obtienen mejores resultados.

El sistema de captación, conducción y filtrado resulta confiable y a la vez es de un costo accesible ya que la mayoría de sus partes son plásticas, las que se utilizan en la conducción de agua en los hogares.

La acumulación del biogás se realiza en un contenedor flexible a baja presión; por lo tanto, para la extracción del biogás se necesita generar una presión ya sea mecánica o succionando el gas con un extractor de aire de baja potencia como se realiza en las experiencias. Dada la intermitencia en la producción de biogás, siempre será necesaria su acumulación en un contenedor de este tipo, con mayor razón si se utilizará directamente para el consumo.

El contenido de materia orgánica medido en porcentaje de sólidos volátiles disminuye solo un 0,5 y 1,2\% respecto del valor inicial. Por esta razón, es necesario realizar un proceso adicional que termine de estabilizar completamente el residuo. Una opción es el lombricompuesto o compostaje.

El biogás saliente del digestor puede contener cantidades mínimas de $\mathrm{H}_{2} \mathrm{~S}$ que corroe las partes metálicas (entre el 0 y 1\%) (Tsagarakis y Papadogiannis, 2006).

Deben tomar medidas de seguridad al almacenar el biogás en los contenedores de plástico. Es recomendable utilizar diariamente toda la producción, evitando la acumulación y así disminuir riesgos y/o accidentes. 


\section{CAPITULO 10}

\section{CÁlCULO Y ANÁLISIS De Los Costos CONSTRUCTIVOS DEL PROTOTIPO.}

Volumen TEÓRICO DE METANo Y SU RELACIÓN CON EL GAS BUTANO. 


\subsection{Introducción.}

Tomar la decisión de instalar un biodigestor exige, como en todo proyecto, conocer la inversión monetaria inicial y conocida ésta, su tiempo de retorno, es decir cuánto se demora en recuperar el valor invertido.

Un dato importante para decidir si se instalará un biodigestor es la cantidad de materia prima disponible o el número de animales con los que se cuenta. Se puede proyectar la construcción de un biodigestor de cualquier volumen y con el debido cuidado, todo biodigestor producirá biogás. Sin embargo, el tamaño y por tanto la cantidad de materia orgánica a procesar, son factores determinantes para establecer si la instalación será económicamente viable. En general, los volúmenes de pequeños digestores de bajo costo implementados en zonas rurales se encuentran entre los $8 \mathrm{y}$ $10 \mathrm{~m}^{3}$ ubicados en zonas de altura (Martí-Herrero, 2007).

El costo final de un biodigestor con seguridad no representa su verdadero valor. La planta crea múltiples beneficios, que generalmente, no se consideran en el análisis económico, ya que es difícil mensurarlos. Por ejemplo, no se tiene en cuenta el valor del lodo estabilizado, un subproducto de la digestión. Su valor radica en la capacidad de enriquecer el suelo como un buen fertilizante. Otro beneficio directo son las mejoras sanitarias al entorno. El estiércol vertido sobre el suelo en cantidad, crea inconvenientes tales como malos olores y constituye vectores de enfermedades. La Ley Provincial 7.070/00 de la Provincia de Salta en su artículo 106 prohíbe enterrar los residuos que se degradan, ya que generan contaminación en acuíferos y cursos de agua. Así, el tratamiento de los residuos pecuarios es un ejercicio que por ley debe cumplirse. Esta ley en su artículo 110 propone la aplicación del tratamiento anaeróbico de la fracción orgánica de los residuos biodegradables.

El beneficio más tangible y medible de un biodigestor anaeróbico es la recuperación del biogás. Éste posee diversas virtudes tales como la de reemplazar los combustibles fósiles. En extensísimas zonas de la provincia de Salta, aquellas alejadas de los grandes centros urbanos y donde la ganadería representa una actividad importante y común, el biogás obtenido puede reemplazar las garrafas de gas butano. En lugares donde no llega la red de gas, su costo es considerablemente mayor que en la ciudad.

Mientras el costo del gas envasado siga en aumento como los demás combustibles de origen fósil, debe considerarse la implementación de un sistema de producción de biogás in situ, si se cuenta con las condiciones para hacerlo.

La implementación de un biodigestor de biogás tiene dos objetivos muy claros. Por un lado, el tratamiento de los residuos pecuarios para ajustarse a la ley vigente provincial y por otro, la recuperación del gas combustible para su consumo. Un 
estudio que muestre la ventaja desde el punto de vista económico, sin duda generará un estímulo para la implementación del proyecto.

En este capítulo se presenta para el prototipo de $1 \mathrm{~m}^{3}$, el cálculo de la inversión inicial y se analizará el volumen de producción de metano. No se tomará en cuenta la conducción del biogás hasta el lugar del consumo.

\subsection{Prototipo de biodigestor.}

El prototipo tiene las dimensiones de un pequeño digestor que seguramente no satisface las necesidades de un establecimiento rural real o vivienda rural. Se investigará la operación del mismo, "CASO 0".

\subsubsection{Dimensiones.}

En la construcción del prototipo (Caso 0) se observó que debe tenerse especial cuidado en la profundidad de la fosa pues si es demasiado profunda la electrobomba no funciona correctamente. Terminada la fosa de 1,8 metros de largo, 0,8 metros de ancho y 1,2 metros de profundidad se coloca la aislación térmica y la membrana. Las medidas se indican en la Tabla 10.1, donde el área total se calcula como la suma de las superficies de las caras del digestor incluidas la parte superior (tapa).

Tabla 10.1. Datos sobre la geometría del prototipo del digestor (Caso 0).

\begin{tabular}{|c|c|c|c|c|c|}
\hline Caso & $\begin{array}{c}\text { Volumen } \\
\left(\mathbf{m}^{\mathbf{3}} \mathbf{)}\right.\end{array}$ & $\begin{array}{c}\text { Ancho } \\
\mathbf{( \mathbf { m } )}\end{array}$ & $\begin{array}{c}\text { Profundidad } \\
\mathbf{( \mathbf { m } )}\end{array}$ & $\begin{array}{c}\text { Largo } \\
\mathbf{( m )}\end{array}$ & $\begin{array}{c}\text { Área total } \\
\left(\mathbf{m}^{\mathbf{2}} \mathbf{)}\right.\end{array}$ \\
\hline 0 & 1,00 & 0,60 & 1,05 & 1,60 & 6,54 \\
\hline
\end{tabular}

Fuente: Elaboración propia.

\subsubsection{Inversión inicial del prototipo- CASO 0.}

Se lista el material requerido en la construcción del digestor anaeróbico enterrado de $1 \mathrm{~m}^{3}$ de volumen (CASO 0). Los detalles de la construcción y las medidas se presentaron en el capítulo 6. Se describen el tipo de material, el costo unitario, la cantidad de material que se utiliza y su costo total, todo en moneda en estadounidense. Se divide el cálculo en: cuerpo del digestor, conducción del biogás, sistema de control, conducción de agua caliente, mezclador, colector solar e invernadero. 
Tabla 10.2. Detalle de costos - Caso 0.

Cotización del dólar se encuentra en el anexo A3

\begin{tabular}{|c|c|c|c|c|}
\hline \multicolumn{5}{|c|}{ COLECTOR SOLAR } \\
\hline Detalle & unidad & $\begin{array}{c}\text { Costo } \\
\text { unitario } \\
\text { (U\$S) }\end{array}$ & Cantidad & $\begin{array}{c}\text { Costo } \\
\text { total } \\
\text { (U\$S) }\end{array}$ \\
\hline arena & $2 \mathrm{~m}^{3}$ & 6,52 & $1 \mathrm{~m}^{3}$ & 3,26 \\
\hline brida $1 / 2$ pulgada & 1 & 1,38 & 3 & 4,14 \\
\hline caño $3 / 4$ pulgada & $6 \mathrm{~m}$ & 7,17 & $8 \mathrm{~m}$ & 9,56 \\
\hline bolsa de cemento & $50 \mathrm{~kg}$ & 8,54 & $1 / 4$ bolsa & 2,13 \\
\hline codo $3 / 4$ pulgada & 1 & 0,39 & 5 & 1,95 \\
\hline conexión gris & $30 \mathrm{~cm} \mathrm{x} 1 / 2$ pulgada & 0,73 & 2 & 1,46 \\
\hline $\begin{array}{l}\text { membrana PVC Zonda } \\
1100\end{array}$ & $1,5 \mathrm{~m}^{2}$ & 6,83 & $5,46 \mathrm{~m}^{2}$ & 24,86 \\
\hline $\begin{array}{l}\text { planchuela de hierro } \\
(15,9 \times 4,76) \mathrm{mm} \text {, largo } 6 \mathrm{~m}\end{array}$ & $6 \mathrm{~m}$ & 7,4 & $4,7 \mathrm{~m}$ & 5,79 \\
\hline $\begin{array}{l}\text { varilla roscada } \\
\text { (Ø5/16 pulgada) }\end{array}$ & $1 \mathrm{~m}$ & 0,87 & $2,4 \mathrm{~m}$ & 2,08 \\
\hline \multicolumn{4}{|c|}{ Subtotal (U\$S) } & 55,23 \\
\hline
\end{tabular}

\begin{tabular}{|c|c|c|c|}
\hline \multicolumn{4}{|c|}{ CONDUCCIÓN DE AGUA CALIENTE } \\
\hline Detalle & $\begin{array}{l}\text { Costo } \\
\text { (U\$S) }\end{array}$ & Cantidad & $\begin{array}{l}\text { Costo } \\
\text { (U\$S) }\end{array}$ \\
\hline $\begin{array}{c}\text { caño PVC } 1 / 2 \text { pulgada bicapa }(6 \mathrm{~m}) \\
\end{array}$ & 5,11 & $2 \mathrm{~m}$ & 1,7 \\
\hline caño PVC $3 / 4$ pulgada bicapa $(6 \mathrm{~m})$ & 7,17 & $8 \mathrm{~m}$ & 9,56 \\
\hline codo $1 / 2$ pulgada & 0,91 & 7 & 6,37 \\
\hline codo $3 / 4$ pulgada & 1,02 & 10 & 10,2 \\
\hline electrobomba periférica $1 \frac{1}{2} \mathrm{hp}$ & 56,92 & 1 & 56,92 \\
\hline pegamento sellarosca $125 \mathrm{cc}$ & 3,22 & 1 & 3,22 \\
\hline unión $\mathrm{T} 1 / 2$ pulgada & 0,37 & 1 & 0,37 \\
\hline válvula eléctrica $1 / 2$ pulgada $(220 \mathrm{~V})$ & 5,69 & 2 & 11,38 \\
\hline \multicolumn{3}{|l|}{ Subtotal (U\$S) } & $\overline{99,72}$ \\
\hline
\end{tabular}

\begin{tabular}{|l|c|c|c|}
\hline \multicolumn{4}{|c|}{ CONDUCCIÓN DEL BIOGÁS } \\
\hline & $\begin{array}{c}\text { Costo } \\
(\mathrm{U} \$ \mathrm{~S})\end{array}$ & Cantidad & $\begin{array}{c}\text { Costo } \\
(\mathrm{U} \$ \mathrm{~S})\end{array}$ \\
\hline brida 3/4 de pulgada & 2,17 & 2 & 4,34 \\
\hline caño PVC 3/4" pulgada bicapa (6m) & 7,17 & $5 \mathrm{~m}$ & 5,97 \\
\hline unión doble de 3/4 de pulgada & 2,00 & 1 & 2,00 \\
\hline válvula 1/2 pulgada PVC & 1,50 & 1 & 1,50 \\
\hline \multicolumn{2}{|c|}{ Subtotal (U\$S) } & 13,81 \\
\hline
\end{tabular}




\begin{tabular}{|c|c|c|c|}
\hline \multicolumn{4}{|c|}{ CUERPO DEL DIGESTOR } \\
\hline Material & $\begin{array}{l}\text { Costo } \\
\text { (U\$S) }\end{array}$ & Cantidad & $\begin{array}{l}\text { Costo } \\
\text { (U\$S) }\end{array}$ \\
\hline $\operatorname{arena}\left(2 \mathrm{~m}^{3}\right)$ & 6,52 & $2 \mathrm{~m}^{3}$ & 6,52 \\
\hline burlete de goma $(4 \times 10 \mathrm{~mm}) 1 \mathrm{~m}$ & 0,5 & 7,2 & 3,6 \\
\hline caño $1 / 2$ pulgada $(6 \mathrm{~m})$ & 5,11 & $1,5 \mathrm{~m}$ & 1,27 \\
\hline caño PVC $110 \mathrm{~mm}(4 \mathrm{~m})$ & 11,61 & $2 \mathrm{~m}$ & 5,8 \\
\hline cemento (1 bolsa) & 8,54 & $1 / 2$ bolsa & 4,27 \\
\hline codo $110 \mathrm{~mm}$ & 1,37 & 2 & 2,74 \\
\hline $\begin{array}{l}\text { membrana PVC Zonda } 1100(1,5 \\
\left.\mathrm{m}^{2}\right)\end{array}$ & 6,83 & $9,42 \mathrm{~m}^{2}$ & 42,89 \\
\hline $\begin{array}{l}\text { planchuela de hierro } \\
(15,9 \times 4,76) \mathrm{mm} \text {, largo }(6 \mathrm{~m})\end{array}$ & 7,4 & $14,2 \mathrm{~m}$ & 17,51 \\
\hline $\begin{array}{l}\text { tuercas y arandela ( } \varnothing 5 / 16 \text { pulg) } \\
100 \text { unidades }\end{array}$ & 2,61 & 100 & 2,61 \\
\hline varilla roscada (Ø $5 / 16$ pulg) $1 \mathrm{~m}$ & 0,87 & 3,6 & 3,13 \\
\hline \multicolumn{3}{|l|}{ Subtotal (I } & 90,34 \\
\hline
\end{tabular}

\begin{tabular}{|l|c|c|c|}
\hline \multicolumn{4}{|c|}{ INVERNADERO } \\
\hline Detalle & $\begin{array}{l}\text { Costo } \\
(\mathrm{U} \$ \mathrm{~S})\end{array}$ & Cantidad & $\begin{array}{c}\text { Costo } \\
\text { (U\$S) }\end{array}$ \\
\hline $\begin{array}{l}\text { hierro estructural cuadrado: } \\
\text { perfil15x15x0.5 mm largo 6 m }\end{array}$ & 7,97 & $6,8 \mathrm{~m}$ & 9,03 \\
\hline $\begin{array}{l}\text { placa policarbonato alveolar de 4 } \\
\left.\text { mm de espesor (12,08 }{ }^{2}\right)\end{array}$ & 128,06 & $3,15 \mathrm{~m}^{2}$ & 33,39 \\
\hline $\begin{array}{l}\text { planchuela de hierro: perfil } \\
(15,9 \times 4,76) \text { mm, largo6m }\end{array}$ & 7,40 & $6,0 \mathrm{~m}$ & 7,40 \\
\hline \multicolumn{2}{|c|}{ Subtotal (U\$S) } \\
\hline
\end{tabular}

\begin{tabular}{|l|c|c|c|}
\hline \multicolumn{4}{|c|}{ MEZCLADOR } \\
\hline Detalle & $\begin{array}{c}\text { Costo } \\
(\mathrm{U} \$ \mathrm{~S})\end{array}$ & Cantidad & $\begin{array}{c}\text { Costo } \\
(\mathrm{U} \$ \mathrm{~S})\end{array}$ \\
\hline motor eléctrico 600 W & 48,38 & 1 & 48,38 \\
\hline $\begin{array}{l}\text { planchuela de hierro 38,10x4,76 } \\
(6 \mathrm{~m})\end{array}$ & 8,08 & $1,2 \mathrm{~m}$ & 1,61 \\
\hline $\begin{array}{l}\text { varilla de hierro redondo } \emptyset 4,7 \\
\mathrm{~mm}(6 \mathrm{~m})\end{array}$ & 7,97 & $0,6 \mathrm{~m}$ & 0,79 \\
\hline \multicolumn{2}{|c|}{ Subtotal (U\$S) } \\
\hline
\end{tabular}




\begin{tabular}{|l|c|c|c|}
\hline \multicolumn{4}{|c|}{ SISTEMA DE CONTROL } \\
\hline Detalle & $\begin{array}{c}\text { Costo } \\
(\mathrm{U} \$ \mathrm{~S})\end{array}$ & Cantidad & $\begin{array}{c}\text { Costo } \\
(\mathrm{U} \$ \mathrm{~S})\end{array}$ \\
\hline cable unipolar 1,5 mm x 1m & 0,08 & $2 \mathrm{~m}$ & 0,16 \\
\hline caja plástica (165x210x80) & 32,61 & 1 & 32,61 \\
\hline contactor & 13,09 & 2 & 26,18 \\
\hline Novus NTC 321 & 68,3 & 2 & 136,6 \\
\hline resistencia eléctrica & 34 & 1 & 34 \\
\hline \multicolumn{2}{|c|}{ Subtotal (U\$S) } & 229,55 \\
\hline
\end{tabular}

Fuente: Elaboración propia.

En la siguiente tabla se resume la inversión y el costo de cada parte o sección del prototipo del digestor anaeróbico.

Tabla 10.3 Inversión del prototipo- CASO 0.

\begin{tabular}{|l|r|}
\hline \multicolumn{1}{|c|}{ Partes del prototipo } & \multicolumn{1}{c|}{$\begin{array}{c}\text { Subtotal } \\
\text { (U\$S) }\end{array}$} \\
\hline Colector solar & 55,23 \\
\hline Conducción de agua caliente & 99,72 \\
\hline Conducción del biogás & 13,81 \\
\hline Cuerpo del biodigestor & 90,34 \\
\hline Invernadero & 49,82 \\
\hline Mezclador & 50,78 \\
\hline Sistema de control & 229,55 \\
\hline \multicolumn{1}{|c|}{ Total Inversión $\mathbf{U} \mathbf{\$ S})$} & $\mathbf{5 8 9 , 2 5}$ \\
\hline
\end{tabular}

Fuente: Elaboración propia.

La inversión para el prototipo resulta de aproximadamente 590 U\$S. Como se observa en la figura 10.1 el mayor costo corresponde al sistema de control, seguido por la conducción de agua caliente y el cuerpo del biodigestor. 


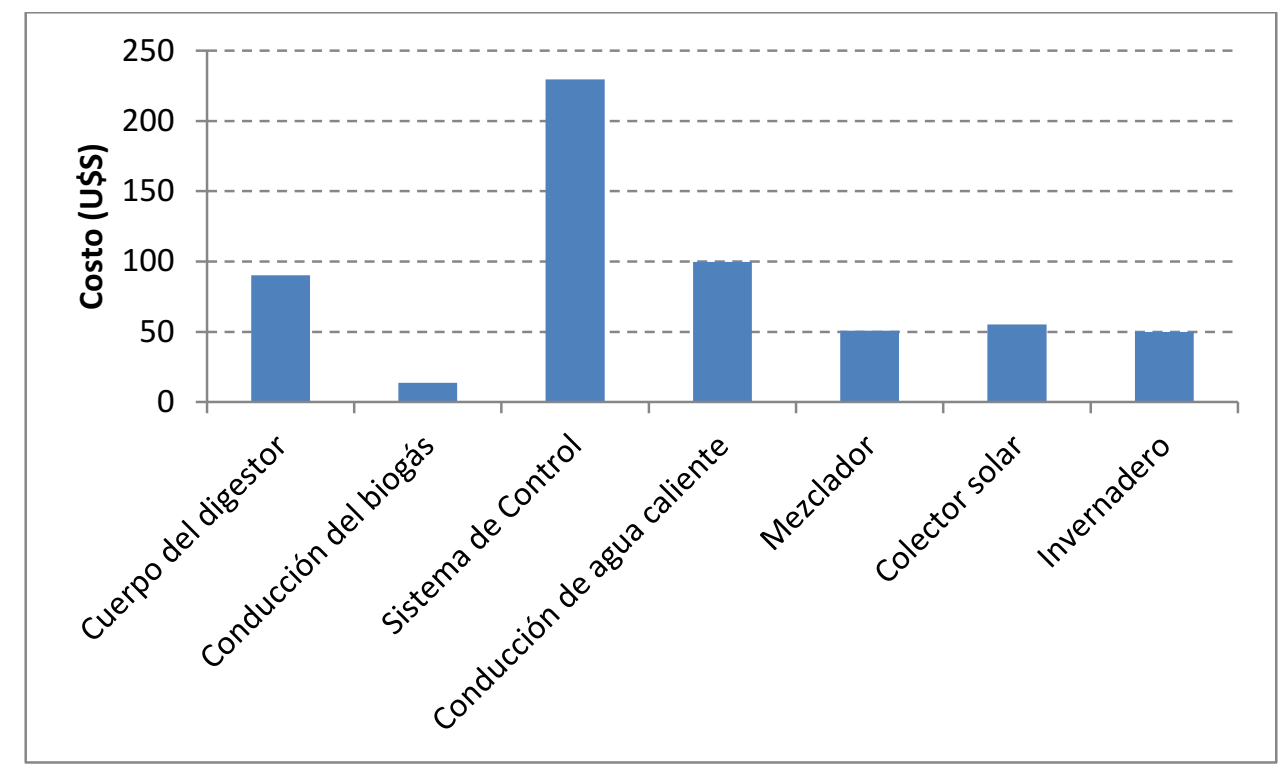

Figura 10.1. Costo en U\$S de las secciones del biodigestor (Caso 0). Fuente: Elaboración propia.

En la Figura 10.2 se muestran todos los porcentajes de los costos de las secciones (cuerpo del digestor, conducción, etc.). El 39\% del costo del biodigestor corresponde al sistema de control, seguido con el 17\% del sistema de conducción de agua caliente. El mezclador, el colector solar y el invernadero tienen costos similares y corresponden al 8-9\% del valor total.

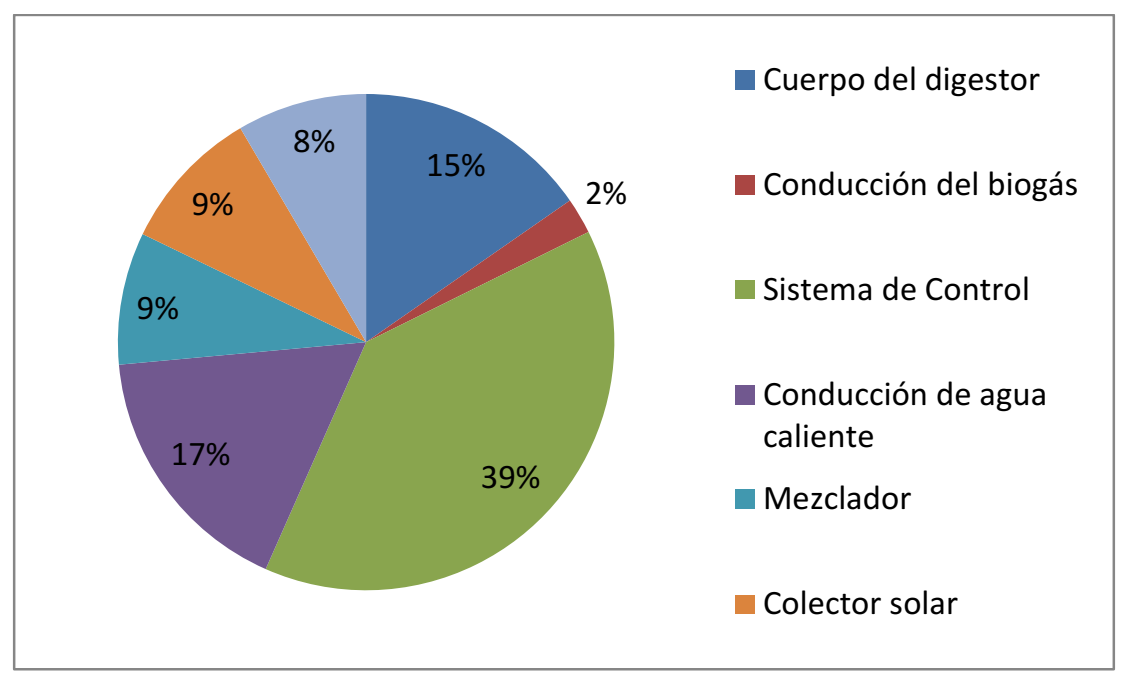

Figura 10.2. Costo en \% de las secciones del biodigestor (Caso 0). Fuente: Elaboración propia.

Analizando las componentes de todo el sistema del biodigestor resulta que los costos más significativos representan casi el 77\% del costo total. Se indican en la Tabla 10.4. 
Tabla 10.4. Costos más significativos en U\$S y en \% de las componentes - CASO 0.

\begin{tabular}{|l|c|c|}
\hline Componente & U\$S & $\mathbf{0}$ \\
\hline Novus NTC 321 & 136,60 & 23,10 \\
\hline membrana PVC Zonda $1100\left(1,5 \mathrm{~m}^{2}\right)$ & 67,75 & 11,46 \\
\hline electrobomba periférica $1 / 2 \mathrm{hp}$ & 56,92 & 9,63 \\
\hline motor eléctrico 600 W & 48,38 & 8,18 \\
\hline resistencia eléctrica & 34,00 & 5,75 \\
\hline placa policarbonato alveolar de 4 mm de espesor $\left(12,08 \mathrm{~m}^{2}\right)$ & 33,39 & 5,65 \\
\hline caja plástica $(165 \times 210 \times 80)$ & 32,61 & 5,51 \\
\hline contactor & 26,18 & 4,43 \\
\hline planchuela de hierro $(15,9 \times 4,76) \mathrm{mm}$, largo $6 \mathrm{~m}(6 \mathrm{~m})$ & 23,31 & 3,94 \\
\hline
\end{tabular}

Fuente: Elaboración propia.

10.2.3 Estimación de la materia prima para el prototipo.

Evaluando la cantidad de materia prima y agua a partir del volumen útil del prototipo, es decir del volumen que ocupará el material a digerir y el rendimiento del digestor presentado en el Capítulo 9 (en $\mathrm{m}^{3} \mathrm{CH}_{4} / \mathrm{kg} \mathrm{SV}$ ) se estima el volumen de metano a producir.

Para llenar el digestor se mezcla agua con estiércol fresco a fin de obtener una concentración de sólidos del 9\% de ST. Es importante contar con los ST promedio del estiércol fresco a fin de calcular la masa de agua.

El volumen de la carga siempre es menor que el del digestor, ya que entre la superficie de la carga y la tapa se encuentra un espacio en donde se acumula parte del biogás. La materia no ocupa la totalidad del digestor. 0 sea, para el cálculo de la materia prima no se considera la profundidad del digestor sino una menor, que es la ocupada por la carga, este volumen menor es llamado volumen útil (también denominado volumen líquido) y se lista en la Tabla 10.5, junto con las dimensiones del líquido. Se establece una pequeña región sobre la superficie de la carga en donde se acumulará el biogás que, como se observa en la tabla, tiene una altura de $20 \mathrm{~cm}$ sobre la superficie de la misma.

Tabla 10.5. Parámetros para el llenado del digestor (Caso 0).

\begin{tabular}{|c|c|c|c|c|}
\hline Caso & $\begin{array}{c}\text { Volumen } \\
\text { del digestor } \\
\mathbf{( m}^{\mathbf{3}} \mathbf{)}\end{array}$ & $\begin{array}{c}\text { Profundidad } \\
\mathbf{( m )}\end{array}$ & $\begin{array}{c}\text { Altura del } \\
\text { líquido } \\
\mathbf{( m )}\end{array}$ & $\begin{array}{c}\text { Volumen } \\
\text { líquido } \\
\mathbf{( m}^{\mathbf{3}} \mathbf{)}\end{array}$ \\
\hline 0 & 1 & 1,05 & 0,85 & 0,81 \\
\hline
\end{tabular}

Fuente: Elaboración propia. 
El cálculo de la materia prima se muestra en la Tabla 10.6. Con el volumen líquido (tercera columna) y sabiendo que la densidad de una mezcla de estiércol y agua del $9 \%$ de ST es $950 \mathrm{~kg} / \mathrm{m}^{3}$ (medidas propias realizadas en el laboratorio) se calcula la masa líquida de la carga (cuarta columna). La masa seca de esta mezcla de estiércol y agua representa el 9\% del total. La quinta columna expresa en kilogramos la masa seca de la mezcla. Entonces, se necesita una cantidad de estiércol fresco, tal que su masa seca sea la expresada en esta quinta columna, a fin de cubrir lo que requiere la mezcla teórica de estiércol y agua.

Tabla 10.6. Cálculo de la materia prima del digestor (Caso 0).

\begin{tabular}{|c|c|c|c|c|c|c|}
\hline Caso & $\begin{array}{c}\text { Volumen } \\
\text { del digestor } \\
\text { (m }^{\mathbf{3}} \mathbf{)}\end{array}$ & $\begin{array}{c}\text { Volumen } \\
\text { líquido } \\
\mathbf{( m}^{\mathbf{3}} \mathbf{)}\end{array}$ & $\begin{array}{c}\text { Masa } \\
\text { liquida } \\
\mathbf{( k g )}\end{array}$ & $\begin{array}{c}\text { Masa } \\
\mathbf{s e c a} \\
\mathbf{( k g )}\end{array}$ & $\begin{array}{c}\text { Estiércol } \\
\text { fresco } \\
\mathbf{( k g )}\end{array}$ & $\begin{array}{c}\text { Agua } \\
\mathbf{( k g )}\end{array}$ \\
\hline $\mathbf{0}$ & 1,00 & 0,81 & 769,50 & 69,25 & 314,79 & 454,71 \\
\hline
\end{tabular}

Fuente: Elaboración propia.

La cantidad de estiércol fresco de la zona se expresa en la sexta columna. El 22\% de esta cantidad es la masa seca expresada en la quinta columna. La cantidad de agua se obtiene de restarle a la masa liquida el estiércol fresco. El dato más importante es el de la masa seca para calcular la masa de sólidos volátiles y finalmente el volumen de metano.

10.2.4. Volumen de metano y su relación con el gas butano de garrafa.

En el cálculo de la producción de biogás es importante considerar la masa de sólidos volátiles SV de la carga del digestor. Esta es la masa que se degradará para convertirse finalmente en el combustible gaseoso. Los SV representan el 72\% de la masa seca (valor medido y presentado en los Capítulos 4 y 9) y se presentan en la Tabla 10.7.

Tabla 10.7. Masa seca y masa de sólidos volátiles (Caso 0).

\begin{tabular}{|c|c|c|}
\hline Caso & $\begin{array}{c}\text { Masa seca } \\
(\mathbf{k g})\end{array}$ & $\begin{array}{c}\text { Masa de SV } \\
(\mathbf{k g})\end{array}$ \\
\hline $\mathbf{0}$ & 69,3 & 49,9 \\
\hline
\end{tabular}

Fuente: Elaboración propia.

De las experiencias presentadas del prototipo del digestor anaeróbico enterrado (Capítulo 9) se calculó el rendimiento promedio, resultando un valor de $0,065 \mathrm{~m}^{3} \mathrm{de}$ 
$\mathrm{CH}_{4} / \mathrm{kg} \mathrm{SV}\left(\right.$ a $0^{\circ} \mathrm{C}$ y $1 \mathrm{~atm}$ ), el que se toma en cuenta para calcular el volumen de metano en $\mathrm{m}^{3}$.

Tabla 10.8. Producción teórica de metano por periodo operativo (Caso 0).

\begin{tabular}{|c|c|c|}
\hline Caso & $\begin{array}{c}\text { Masa de SV } \\
\text { (kg) }\end{array}$ & $\begin{array}{c}\text { Volumen } \mathbf{C H}_{\mathbf{4}} \\
\left(\mathbf{m}^{3}\right)^{*}\end{array}$ \\
\hline $\mathbf{0}$ & 49,9 & 3,244 \\
\hline
\end{tabular}

$*$ a 1 atm y $0^{\circ} \mathrm{C}$

Fuente: Elaboración propia.

El biogás reemplaza aquellos combustibles que son utilizados en tareas rurales que requieran de energía: calefacción, calentamiento de agua, cocción de alimentos, etc. Junto con la leña, las garrafas de $10 \mathrm{~kg}$ cargadas con gas butano son las más utilizadas en aquellos lugares donde no se cuenta con la red de gas natural.

El poder calorífico PC del butano y del metano se presenta en la Tabla 10.9, clasificado en superior PCS e inferior PCI. Si la energía del vapor de agua que se desprende de la combustión del gas también es aprovechada, como ocurre por ejemplo en las calderas de condensación, debe utilizarse para los cálculos el PCS, mientras que si no se aprovecha debe utilizarse el PCI. Este último se utilizará en los cálculos de energía.

Tabla 10.9. Poder calorífico del gas metano y butano.

\begin{tabular}{|l|c|c|c|c|c|}
\hline & Fórmula & $\begin{array}{c}\text { PCS } \\
\left.\text { (kcal/m } \mathbf{m}^{3}\right)\end{array}$ & $\begin{array}{c}\text { PCI } \\
\left.\text { (kcal/m } \mathbf{m}^{3}\right)\end{array}$ & $\begin{array}{c}\text { PCS } \\
\text { (kcal/kg) }\end{array}$ & $\begin{array}{c}\text { PCI } \\
\text { (kcal/kg) }\end{array}$ \\
\hline METANO & $\mathrm{CH}_{4}$ & 9.530 & 8.570 & 13.271 & 11.962 \\
\hline BUTANO & $\mathrm{C}_{4} \mathrm{H}_{10}$ & 32.060 & 29.560 & 11.747 & 10.843 \\
\hline
\end{tabular}

Fuente: (Cengel, 2012).

A los efectos de conocer el ahorro que se hace al disponer de biogás, se calcula a cuantas garrafas equivalen la producción de un periodo operativo. Se calcula la masa equivalente de gas butano en kilogramos (cuarta columna de la Tabla 10.10). Finalmente, el número de garrafas de $10 \mathrm{~kg}$ que equivalen a la cantidad de butano de la cuarta columna se presenta en la última columna de la misma. 
Tabla 10.10. Gas metano producido por periodo operativo y su equivalencia con el número de garrafas de butano de $10 \mathrm{~kg}$. (Caso 0).

\begin{tabular}{|c|c|c|c|c|}
\hline Caso & $\begin{array}{c}\text { Masa de } \\
\mathbf{S V} \\
\mathbf{( k g )}\end{array}$ & $\begin{array}{c}\text { Volumen } \\
\mathbf{C H}_{\mathbf{4}} \\
\mathbf{( m}^{3} \mathbf{)}\end{array}$ & $\begin{array}{c}\text { Masa equivalente } \\
\mathbf{d e} \text { butano } \\
\mathbf{( k g )}\end{array}$ & $\begin{array}{c}\mathbf{N}^{\circ} \mathbf{d e} \\
\text { garrafas }\end{array}$ \\
\hline $\mathbf{0}$ & 49,9 & 3,244 & 2,564 & 0,25 \\
\hline
\end{tabular}

Fuente: Elaboración propia.

Como se observa en la última columna de la Tabla 10.10 el cálculo predice que la producción de biogás del prototipo equivale a menos de una garrafa en un periodo ( 4 meses) operando en las condiciones experimentales expuestas en el Capítulo 9.

En cuanto a las necesidades que cubre el prototipo, la utilización más directa del biogás, es su combustión para aprovechar el calor desprendido. Si, por ejemplo, se consideran dos quemadores medianos, como los utilizados para la cocción de alimentos, se necesitan $0,320 \mathrm{~m}^{3}$ de biogás por hora o aproximadamente $0,208 \mathrm{~m}^{3} \mathrm{de}$ $\mathrm{CH}_{4}$ (Gropelli, 2001). Así, con la cantidad obtenida en la Tabla 10.10, los quemadores funcionarán unas 16 horas. Claramente debe pensarse en volúmenes de digestión mayores y una operación conjunta de dos digestores como se propuso en el apartado 9.5. Este aspecto se analizará en el capítulo siguiente.

\subsection{Discusión.}

En este capítulo se presenta el detalle de los costos constructivos de inversión para el prototipo, las dimensiones. Además, se estima la producción de biogás y su equivalente en número de garrafas de butano de $10 \mathrm{~kg}$.

En el análisis de los costos, de destaca el componente electrónico controlador de temperatura NOVUS N321, fabricado por la empresa brasilera NOVUS Productos Electrónicos Ltda. El controlador consta de un sensor de temperatura, dado por un termistor NTC de $10 \mathrm{~K} \Omega$ y un circuito capaz de comandar la apertura de un relé para energizar de acuerdo a la temperatura un dispositivo eléctrico. Sin duda que puede fabricarse en el país un circuito similar con las mismas prestaciones a fin de lograr abaratar los costos. Sin embargo, las partes que forman al circuito controlador no se fabrican aquí, por esta razón deben estudiarse con detalle estos costos, las ventajas y desventajas acerca de una fabricación nacional.

El prototipo tiene un costo accesible y la operación a $20^{\circ} \mathrm{C}$ no presenta mayor dificultad. Sin embargo, la recuperación del biogás y su equivalente en garrafas de 
butano no es significativa en relación con la inversión monetaria inicial. Si se tiene en cuenta que la retención hidráulica debe ser de 120 días, como se observó en las experiencias de biodigestión del Capítulo 9, se advierte que el biodigestor podrá operar a lo sumo dos o tres veces en el año. Así, el número de garrafas equivalentes llegará a lo sumo a 0,78 por año.

La operación a $20^{\circ} \mathrm{C}$ del prototipo del biodigestor presenta una ventaja importante: por un lado, esta temperatura se encuentra cercana al ambiente prácticamente durante todo el año, por otro lado, ante un eventual corte de electricidad las variaciones térmicas serán menores. La dificultad que se presenta es la baja producción de biogás ( $\mathrm{m}^{3}$ de biogás /kg SV).

\subsection{Conclusiones.}

Cuando se piensa en la instalación de un digestor anaeróbico debe tenerse en cuenta cuál es el objetivo. Si su función es solo la degradación del residuo, entonces siempre que la inversión no sea demasiado elevada, se concentrará el proyecto en colocar el número de digestores suficientes y un volumen tal, que permita el tratamiento de todo el material orgánico.

La temperatura deja de ser un factor determinante en los costos finales, por tal motivo se puede operar el o los biodigestores a valores más elevados, tal como $37^{\circ} \mathrm{C}$. Así, se deberá estudiar más detalladamente el tipo de colector solar, a fin de implementar con éxito el calentamiento híbrido solar-eléctrico.

Si el objetivo es la recuperación del biogás, se requiere analizar no solo los costos constructivos de inversión sino también los costos de operación. Los gastos de traslado no se han considerado en este trabajo pues se propone su utilización in situ.

Desde el punto de vista ambiental se deberá hacer una valoración ambiental de los beneficios que otorga este sistema. Asimismo, desde el punto de vista legal ofrece soluciones al problema de los residuos pecuarios.

Como se ha descripto en el capítulo 1, desde el punto de vista legal, la Ley Provincial $N^{\circ} 7.070 / 00$ de protección del medio ambiente en su artículo $106^{\circ}$, establece la prohibición de enterrar residuos susceptibles de degradarse y emitir contaminantes en acuíferos y cursos de agua. En su artículo $110^{\circ}$, inciso (b) trata sobre la disposición y tratamientos separados de los residuos biodegradables, que dan lugar a la opción del tratamiento anaeróbico de la fracción orgánica. La aplicación directa de los residuos ganaderos al suelo no es una práctica amigable con el medio ambiente, contaminado aguas tanto superficiales como subterráneas y emitiendo a la atmosfera compuestos orgánicos volátiles tales como amoniaco $\left(\mathrm{NH}_{3}\right)$, sulfuro de hidrógeno $\left(\mathrm{SH}_{2}\right)$ u óxidos de nitrógeno $\left(\mathrm{NO}_{\mathrm{x}}\right)$. 


\section{CAPITULO 11}

ANÁLISIS DE LOS Costos ConstruCtivos

Y De Operación DE Una Planta De PRODUCCIÓN DE BIOGÁs. 


\subsection{Introducción.}

Se propone en este capítulo otros volúmenes del biodigestor para satisfacer las necesidades de una vivienda. Se analiza el volumen de producción de metano para todos los casos.

A fin de contar con un volumen de biogás durante todo el año, se propone la operación conjunta de dos digestores formando una planta de producción de biogás, para una producción ininterrumpida y de mayor envergadura. Se realiza un análisis de costos, a fin de descartar aquellos casos que no presenten una ventaja económica. A volúmenes mayores de digestión, mayor será la cantidad de biogás obtenida; sin embargo, los costos de inversión también crecerán. Por ello, es importante realizar un estudio en el que se contemple el período de recupero, a partir del cual el proyecto comenzará a generar utilidades.

Como en el caso del prototipo, se propone una temperatura de operación de $20^{\circ} \mathrm{C}$ y una retención hidráulica de 120 días. A los efectos de producir una cantidad suficiente de metano, los volúmenes de digestión serán de 20 a 50 m³.

Para el análisis de costos se consideran solo los costos de inversión asociados a los materiales de construcción y el consumo eléctrico de los componentes de la planta.

\subsection{Dimensiones del biodigestor.}

Los volúmenes de un biodigestor operando en planta, serán superiores al del prototipo, pues se supone que se cuenta in situ con una cantidad suficiente de materia prima. Por esta razón, se proponen distintas dimensiones de digestores, ampliándose el análisis de 20 a $50 \mathrm{~m}^{3}$ de volumen. En la Tabla 11.1 se detallan las dimensiones de cuatro casos diferentes; en la segunda columna se presenta el volumen del digestor, en la tercera, cuarta y quinta, sus dimensiones y en la última el área total.

Tabla 11.1. Propuesta de casos con diferentes dimensiones del digestor anaeróbico.

\begin{tabular}{|c|c|c|c|c|c|}
\hline Caso & $\begin{array}{c}\text { Volumen } \\
\left(\mathbf{m}^{\mathbf{3}} \mathbf{)}\right.\end{array}$ & $\begin{array}{c}\text { Ancho } \\
\mathbf{( \mathbf { m } )}\end{array}$ & $\begin{array}{c}\text { Profundidad } \\
\mathbf{( m )}\end{array}$ & $\begin{array}{c}\text { Largo } \\
\mathbf{( \mathbf { m } )}\end{array}$ & $\begin{array}{c}\text { Área total } \\
\left(\mathbf{m}^{\mathbf{2}} \mathbf{)}\right.\end{array}$ \\
\hline I & 20 & 2,00 & 2,00 & 5,00 & 48,00 \\
\hline II & 30 & 2,00 & 2,00 & 7,50 & 68,00 \\
\hline III & 40 & 2,00 & 2,50 & 8,00 & 82,00 \\
\hline IV & 50 & 2,00 & 2,50 & 10,00 & 100,00 \\
\hline
\end{tabular}

Fuente: Elaboración propia.

Para obtener las dimensiones del biodigestor se fijan los valores de la profundidad y el ancho. En la construcción del prototipo se observó que debe tenerse especial cuidado en la profundidad de la fosa pues si es demasiado profundo la electrobomba 
no funcionará correctamente. Así se fija un valor aceptable de 1,5 o 2,5 metros de profundidad. El ancho de 2 metros con el que se trabajó en la experiencia (Capítulo 6) no presentó problema alguno; aunque no quita la posibilidad de que se pueda trabajar con uno mayor. Fijado entonces la profundidad y el ancho se calcula el largo haciendo el cociente entre el volumen y el producto de la profundidad con el ancho.

\subsection{Inversión.}

La inversión inicial, es decir, los costos de los materiales y del equipamiento necesario que se necesitan para la instalación de una planta de digestión dependerán del volumen a digerir. Las características del prototipo del biodigestor con el que se practicaron los ensayos se replican para volúmenes mayores, es decir, tanto la forma de construcción como los materiales que se utilizaron en el prototipo se proponen para los biodigestores de mayor envergadura.

Tal como se detalló para el prototipo con el costo total de construcción, se procede igualmente con los casos I a IV. Se enumeran en la Tabla 11.2 las partes que forman el biodigestor junto al costo en dólares.

Tabla 11.2. Costo constructivo - CASO I a IV.

\begin{tabular}{|l|r|r|r|r|}
\hline \multirow{2}{*}{\multicolumn{1}{|c|}{ Partes }} & \multicolumn{4}{c|}{ CASOS } \\
\cline { 2 - 5 } & \multicolumn{1}{|c|}{ I } & \multicolumn{1}{c|}{ II } & \multicolumn{1}{c|}{ III } & \multicolumn{1}{c|}{ IV } \\
\hline Volumen del biodigestor $\left(\mathrm{m}^{3}\right)$ & 20 & 30 & 40 & 50 \\
\hline & \multicolumn{4}{|c|}{ Subtotal (U\$S) } \\
\hline Colector solar & 455,2 & 551,1 & 713,7 & 830,7 \\
\hline Conducción del biogás & 30,5 & 31 & 32,5 & 33,4 \\
\hline Conducción de agua caliente & 123,7 & 133,1 & 139,2 & 147,5 \\
\hline Cuerpo del biodigestor & 313,7 & 386,8 & 470,2 & 536,9 \\
\hline Invernadero & 168,7 & 197 & 211,6 & 214,5 \\
\hline Mezclador & 83,7 & 102,4 & 102,4 & 102,4 \\
\hline Sistema de control & 229,5 & 229,5 & 229,5 & 229,5 \\
\hline Total (U\$S) & $1.405,0$ & $1.630,9$ & $1.899,1$ & $2.094,4$ \\
\hline
\end{tabular}

Fuente: Elaboración propia.

Se destaca en la Tabla 11.2 que el costo del sistema de control se mantiene igual en todos los casos, ya que se utiliza el mismo sistema a pesar de incrementar el tamaño del digestor.

En la Tabla 11.3 se discrimina la inversión total (en el Anexo A4 se detallan los materiales y costos del biodigestor en función de su volumen). A medida que aumenta 
el volumen, lógicamente la inversión es mayor es, pero comparativamente el rendimiento será mayor y dado que el sistema de control se mantiene constante, es proporcionalmente menor el costo.

Tabla 11.3. Inversión total-CASO I al IV.

\begin{tabular}{|c|c|c|}
\hline Caso & $\begin{array}{c}\text { Volumen } \\
\mathbf{( m}^{\mathbf{3}} \mathbf{~}\end{array}$ & $\begin{array}{c}\text { Inversión } \\
\text { (U\$S) }\end{array}$ \\
\hline I & 20 & $1.405,0$ \\
\hline II & 30 & $1.630,9$ \\
\hline III & 40 & $1.899,1$ \\
\hline IV & 50 & $2.094,4$ \\
\hline
\end{tabular}

Fuente: Elaboración propia.

\subsection{Cálculo de la materia prima.}

Para llenar un digestor, cualquiera sea su tamaño, se mezcla agua con estiércol fresco a fin de obtener una concentración del 9\% de sólidos totales (ST) tal como se trabajó con el prototipo. Es importante contar con los ST promedio del estiércol fresco a fin de calcular la masa de agua.

Para el cálculo de la materia prima no se considera el volumen total del digestor sino uno menor llamado volumen líquido, que se lista en la Tabla 11.4, junto con el volumen total del digestor y su profundidad. Los valores se establecen tomando una pequeña región sobre la superficie de la carga en donde se acumulará el biogás, que como se observa en la tabla, tiene una altura de $20 \mathrm{~cm}$ sobre la superficie de la misma.

Tabla 11.4. Parámetros para el llenado del digestor.

\begin{tabular}{|c|c|c|c|c|}
\hline Caso & $\begin{array}{c}\text { Volumen } \\
\text { digestor } \\
\mathbf{( m}^{\mathbf{3}} \mathbf{)}\end{array}$ & Profundidad & $\begin{array}{c}\text { Profundidad } \\
\text { del líquido } \\
\text { (carga) (m) }\end{array}$ & $\begin{array}{c}\text { Volumen } \\
\text { líquido } \\
\mathbf{( m}^{\mathbf{3}} \mathbf{)}\end{array}$ \\
\hline I & 20 & 2,00 & 1,80 & 18,00 \\
\hline II & 30 & 2,00 & 1,80 & 27,00 \\
\hline III & 40 & 2,50 & 2,20 & 35,20 \\
\hline IV & 50 & 2,50 & 2,20 & 44,00 \\
\hline
\end{tabular}

Fuente: Elaboración propia. 
Por ejemplo, en el caso I, con el digestor de $20 \mathrm{~m}^{3}$ de volumen, la carga tiene una profundidad de $1,80 \mathrm{~m}, 20 \mathrm{~cm}$ menos que la profundidad del digestor; esto es, la carga se encuentra a $20 \mathrm{~cm}$ por debajo de la tapa del digestor. Así, el volumen de la carga liquida es $18,00 \mathrm{~m}^{3}$ como se muestra en la quinta columna de la Tabla 11.4.

Los resultados de la materia prima figuran en la Tabla 11.5. Con el volumen líquido (tercera columna) y sabiendo que la densidad de una mezcla de estiércol y agua del $9 \%$ de ST es $950 \mathrm{~kg} / \mathrm{m}^{3}$ (Morales, $\mathrm{M}, 2011$ ) se calcula la masa líquida de la carga que figura en la cuarta columna. La masa seca de esta mezcla teórica de estiércol y agua representa el 9\% del total. La quinta columna expresa en kilogramos la masa seca de la mezcla. A fin de cubrir lo requerido por la mezcla teórica de estiércol y agua, se necesita una cantidad de estiércol fresco tal que su masa seca sea la expresada en la quinta columna.

Tabla 11.5. Detalles de la materia prima.

\begin{tabular}{|c|c|c|c|c|c|c|}
\hline Caso & $\begin{array}{c}\text { Volumen } \\
\text { digestor } \\
\left(\mathrm{m}^{3}\right)\end{array}$ & $\begin{array}{c}\text { Volumen } \\
\text { líquido } \\
\left(\mathrm{m}^{3}\right)\end{array}$ & $\begin{array}{c}\text { Masa } \\
\text { líquida } \\
\text { (kg) }\end{array}$ & $\begin{array}{c}\text { Masa } \\
\text { seca } \\
(\mathrm{kg})\end{array}$ & $\begin{array}{c}\text { Estiércol } \\
\text { fresco } \\
\text { (kg) }\end{array}$ & $\begin{array}{c}\text { Agua } \\
\text { (kg) }\end{array}$ \\
\hline I & 20 & 18,0 & $17.100,0$ & $1.539,0$ & $6.995,5$ & $10.104,5$ \\
\hline II & 30 & 27,0 & $25.650,0$ & $2.308,5$ & 10493,2 & $15.156,8$ \\
\hline III & 40 & 35,2 & $33.440,0$ & $3.009,6$ & 13680,0 & $19.760,0$ \\
\hline IV & 50 & 44,0 & $41.800,0$ & $3.762,0$ & $17.100,0$ & $24.700,0$ \\
\hline
\end{tabular}

Fuente: Elaboración propia.

La cantidad de estiércol fresco se expresa en la sexta columna. El 22\% de esta cantidad, es la masa seca expresada en la quinta columna. La cantidad de agua se obtiene de restarle a la masa liquida el estiércol fresco.

Por ejemplo, en el caso I la masa líquida es $17.100 \mathrm{~kg}$, el 9\% es $1.539 \mathrm{~kg}$ de masa seca. Esta última cantidad se encuentra en los $6.995,5 \mathrm{~kg}$ de estiércol fresco, el necesario para formar la mezcla junto con los $10.104,5 \mathrm{~kg}$ de agua.

En un tambo se recolecta aproximadamente $3 \mathrm{~kg}$ por animal por día y en un feedlot $23,9 \mathrm{~kg}$ por animal por día (FAO, 2016). Con estos valores y teniendo en cuenta un período de acopio de unos 30 días, en la Tabla 11.6 se lista el número aproximado de cabezas de ganado para obtener la cantidad de estiércol fresco necesaria para el llenado del digestor. Puesto que en un tambo se recolecta menos estiércol que en un feedlot, la cantidad de cabezas de ganado en este último caso se reduce notoriamente. 
Tabla 11.6. Número aproximado de cabezas de ganado para el estiércol requerido.

\begin{tabular}{|c|c|c|c|c|}
\hline Caso & $\begin{array}{c}\text { Volumen } \\
\text { Digestor }\end{array}$ & $\begin{array}{c}\text { Estiércol } \\
\text { fresco }\end{array}$ & \multicolumn{2}{|c|}{$\mathbf{N}$ o de cabezas de ganado } \\
\cline { 4 - 5 } & $\mathbf{( m}^{\mathbf{3}} \mathbf{)}$ & $\mathbf{( k g )}$ & (feedlot) & (tambo) \\
\hline I & 20 & $6.995,5$ & 10 & 78 \\
\hline II & 30 & $10.493,2$ & 15 & 117 \\
\hline III & 40 & $13.680,0$ & 19 & 152 \\
\hline IV & 50 & $17.100,0$ & 24 & 190 \\
\hline
\end{tabular}

Fuente: Elaboración propia.

\subsection{Cálculo del volumen de metano y su relación con el gas butano de garrafa.}

Tal como se menciona en el apartado 10.2.4, en el cálculo de la producción de biogás es importante considerar la masa de sólidos volátiles SV de la carga del digestor (72\% de la masa seca) que se presenta en la Tabla 11.7.

Tabla 11.7. Masa seca y masa de sólidos volátiles.

\begin{tabular}{|c|c|c|}
\hline Caso & $\begin{array}{c}\text { Masa seca } \\
\text { (kg) }\end{array}$ & $\begin{array}{c}\text { Masa de SV } \\
\text { (kg) }\end{array}$ \\
\hline I & $1.539,0$ & $1.108,1$ \\
\hline II & $2.308,5$ & $1.662,1$ \\
\hline III & $3.009,6$ & $2.166,9$ \\
\hline IV & $3.762,0$ & $2.708,6$ \\
\hline
\end{tabular}

Fuente: Elaboración propia.

Para las dos experiencias presentadas con el prototipo del digestor anaeróbico enterrado (Capítulo 9) se calculó el rendimiento promedio, resultando un valor de $0,067 \mathrm{~m}^{3} \mathrm{de} \mathrm{CH}_{4} / \mathrm{kg} \mathrm{SV}$. Bajo la hipótesis de que este rendimiento es aplicable al caso de biodigestores de mayor tamaño, para calcular el volumen de metano en $\mathrm{m}^{3}$, se multiplica este valor por la masa de SV.

El volumen de metano se obtiene teniendo en cuenta un período operativo con una retención hidráulica de 120 días, es decir que se carga el digestor en 30 días y luego de este tiempo se toma en cuenta un periodo de 4 meses. En la Tabla 11.8 se expresa la producción teórica de metano por período operativo (4 meses). 
Tabla 11.8. Producción teórica de metano por periodo operativo.

\begin{tabular}{|c|r|r|}
\hline Caso & $\begin{array}{c}\text { Masa de SV } \\
\mathbf{( k g )}\end{array}$ & \multicolumn{1}{|c|}{$\begin{array}{c}\text { Volumen } \mathbf{C H}_{\mathbf{4}} \\
\mathbf{( m}^{\mathbf{3}} \mathbf{)}\end{array}$} \\
\hline I & $1.108,1$ & 74,2 \\
\hline II & $1.662,1$ & 111,4 \\
\hline III & $2.166,9$ & 145,2 \\
\hline IV & $2.708,6$ & 181,5 \\
\hline
\end{tabular}

Fuente: Elaboración propia.

Con estos datos y a los efectos de conocer el ahorro que se hace al disponer de biogás en un establecimiento rural, se calcula a cuántas garrafas equivale la producción dada por un biodigestor para los casos señalados anteriormente (I al IV). Se computa la masa de gas butano equivalente en kilogramos (cuarta columna) de la Tabla 11.9. Por ejemplo, en la primera fila (Caso I) $56,9 \mathrm{~kg}$ de butano equivalen a $72,0 \mathrm{~m}^{3}$ de metano.

Finalmente, el número de garrafas de $10 \mathrm{~kg}$ que equivalen a la cantidad de butano se presenta en la última columna.

Tabla 11.9. Gas metano producido por periodo operativo y su equivalencia con el número de garrafas de butano de $10 \mathrm{~kg}$.

\begin{tabular}{|c|c|c|c|c|}
\hline Caso & $\begin{array}{c}\text { Masa de SV } \\
(\mathbf{k g})\end{array}$ & $\begin{array}{c}\text { Volumen } \mathbf{C H}_{\mathbf{4}} \\
\mathbf{( m}^{\mathbf{3}} \mathbf{)}\end{array}$ & $\begin{array}{c}\text { Masa equivalente de } \\
\text { butano (kg) }\end{array}$ & $\begin{array}{c}\mathbf{N}^{\circ} \text { de } \\
\text { garrafas }\end{array}$ \\
\hline I & $1.108,1$ & 74,2 & 58,6 & 5,8 \\
\hline II & $1.662,1$ & 111,4 & 88,0 & 8,8 \\
\hline III & $2.166,9$ & 145,2 & 114,8 & 11,4 \\
\hline IV & $2.708,6$ & 181,5 & 143,3 & 14,3 \\
\hline
\end{tabular}

Fuente: Elaboración propia.

Si se analiza la producción anual, durante un tiempo de 30 días el digestor se encontrará en proceso de llenado, (amarillo en la Figura 11.1) no se contará con biogás.

\begin{tabular}{|c|l|l|l|l|l|l|l|l|l|l|l|l|}
\hline Meses & 1 & 2 & 3 & 4 & 5 & 6 & 7 & 8 & 9 & 10 & 11 & 12 \\
\cline { 1 - 9 } Digestor & & & & & & & & & & & & \\
\cline { 1 - 7 } & & & & & & & & & & & & \\
\hline
\end{tabular}

Figura 11.1. Esquema de operación anual de un digestor.

Fuente: Elaboración propia. 
Para solucionar esta situación deberá contarse con un biodigestor más, de manera que mientras uno esté llenándose el otro se encuentre en operación. Así, se dispondrá de un flujo continuo de biogás.

Se consigue una disponibilidad casi continua cuando la operación conjunta de ambos se encuentre desfasada un cierto tiempo; es decir mientras que uno se encuentre en su mínima producción, el otro esté en su máxima.

\subsection{Cálculo del área del colector solar.}

Como sucede con el prototipo, la calefacción se realiza mediante un sistema eléctrico más un colector solar. Este colector tendrá un área mayor, cuanto más grande sea el digestor a calefaccionar. En el anexo A5 se presenta un cálculo a fin de estimar el área de colección en función del volumen del digestor. Los resultados se indican en la Tabla 11.10 .

Tabla 11.10. Área del colector solar según el volumen del digestor.

\begin{tabular}{|c|c|c|}
\hline Caso & $\begin{array}{c}\text { Volumen del digestor } \\
\qquad\left(\mathrm{m}^{3}\right)\end{array}$ & $\begin{array}{c}\text { Área de colectores } \\
\left(\mathbf{m}^{2}\right)\end{array}$ \\
\hline I & 20 & 32 \\
\hline II & 30 & 48 \\
\hline III & 40 & 63 \\
\hline IV & 50 & 79 \\
\hline
\end{tabular}

Fuente: Elaboración propia.

Como se explica detalladamente en el anexo A5, el cálculo de dimensionamiento del colector solar se realiza en los periodos más desfavorables, es decir en los meses más fríos de invierno, con datos de radiación térmica y temperatura ambiente. De esta manera se aprovecha el uso del colector solar en el periodo invernal dadas las características del clima, pues los meses de invierno presentan alta radiación térmica. Por lo tanto, todo el acondicionamiento térmico se realizará a través del colector solar, sin utilizar la resistencia eléctrica.

\subsection{Producción de biogás en planta.}

Se propone una planta de producción que cuente con dos digestores y un sistema de calefacción hibrido solar-eléctrico. El sistema de control logrará una independencia funcionando sin intervención alguna. Los digestores funcionarán a $20^{\circ} \mathrm{C}$. Tanto los colectores como todo el circuito hidráulico deberán estar llenos de agua a fin de garantizar su correcta circulación. 
En la Figura 11.2 se presenta un esquema de la distribución espacial del conjunto de colectores para un digestor anaeróbico enterrado de una planta de producción correspondiente al CASO IV.

En la Tabla 11.10, donde se indica el área del colector solar según el volumen del digestor, al caso IV le corresponde $79 \mathrm{~m}^{2}$. En la figura se indica el banco de 5 (cinco) colectores (color negro), cada uno de aproximadamente 15,8 $\mathrm{m}^{2}$, los cuales puede instalarse separado algunos metros del digestor (color turquesa) para evitar inconvenientes en su operatividad.

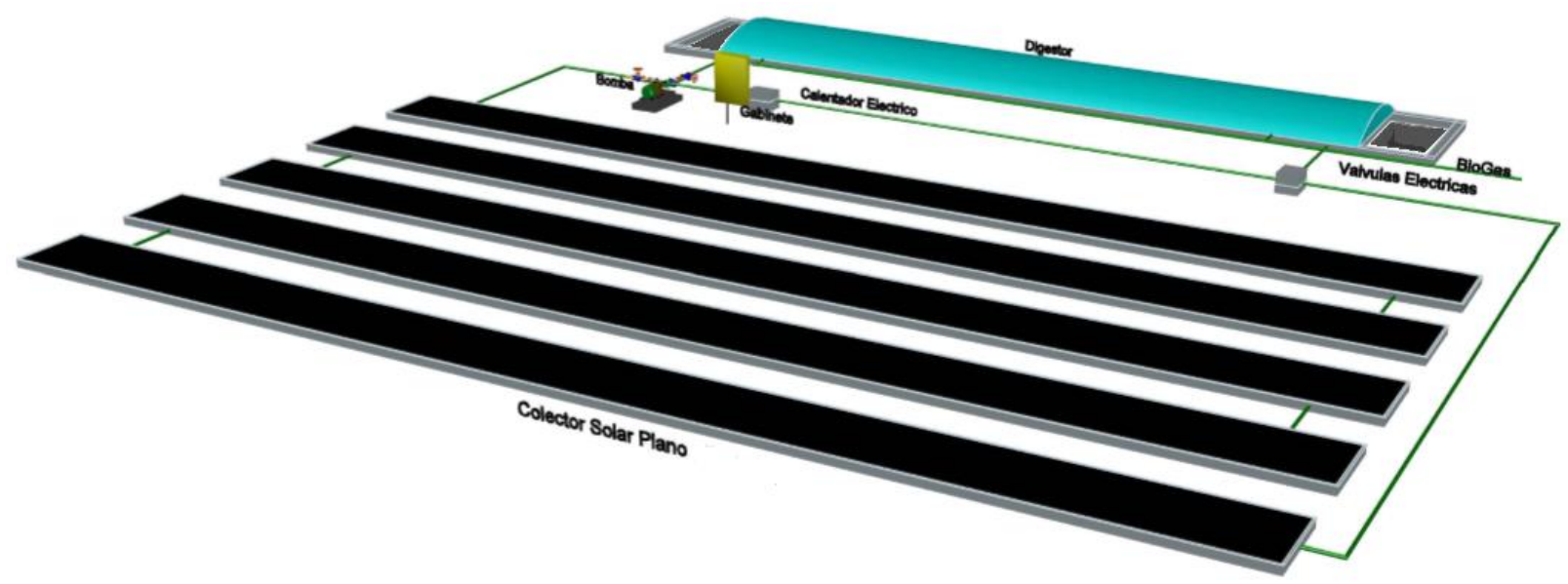

Figura 11.2. Esquema tridimensional del digestor con su sistema de calentamiento hibrido solar-eléctrico.

Fuente: Elaboración propia.

En la Figura 11.3 se esquematiza uno de los posibles escenarios en la operación conjunta de dos digestores, ambos con características similares formando una planta de producción de biogás.

\begin{tabular}{|c|c|c|c|c|c|c|c|c|c|c|c|c|c|}
\hline Meses & 1 & 2 & 3 & 4 & 5 & 6 & 7 & 8 & 9 & 10 & 11 & 12 & Año \\
\hline Digestor & & & & & & & & & & & & & RIIU \\
\hline 1 & & & & & & & & & & & & & \\
\hline 2 & & & & & & & & & & & & & 1 \\
\hline 1 & & & & & & & & & & & & & \\
\hline 2 & & & & & & & & & & & & & 2 \\
\hline
\end{tabular}

\begin{tabular}{l|l|l} 
en operación & & período de descarga/carga
\end{tabular}

sin operar

Figura 11.3. Esquema de operación de una planta compuesta por dos digestores.

Fuente: Elaboración propia. 
En color amarillo se destaca la etapa de "carga del digestor", en la cual, se acopia dentro del digestor durante el periodo de un mes en condiciones anaeróbicas. Luego de llenado, el residuo permanece un tiempo de 120 días a $20^{\circ} \mathrm{C}$ (color rojo). Al final de este periodo se descarga el digestor y se repite el ciclo de carga, permanencia y descarga. En el esquema se presenta la operación de la planta durante dos años. Con esta forma de operar se asegura la disponibilidad ininterrumpida del biogás.

La Tabla 11.11 muestra la inversión en moneda estadounidense para los CASOS I al IV. El monto que se observa como inversión corresponde a un digestor y su sistema de calentamiento.

Tabla 11.11. Inversión total según volumen de digestor. CASO I al IV.

\begin{tabular}{|c|c|c|}
\hline Caso & $\begin{array}{c}\text { Volumen } \\
\text { ( }^{\mathbf{3}} \text { ) }\end{array}$ & $\begin{array}{c}\text { Inversión } \\
\text { (U\$S) }\end{array}$ \\
\hline I & 20 & $1.405,0$ \\
\hline II & 30 & $1.630,9$ \\
\hline III & 40 & $1.899,1$ \\
\hline IV & 50 & $2.094,4$ \\
\hline
\end{tabular}

Fuente: Elaboración propia.

\subsubsection{Costos de operación.}

Los costos de operación incluyen solamente la electricidad. Se considera que la materia prima tiene un costo insignificante, ya que se obtiene del establecimiento donde se instalará el biodigestor y es un elemento de desecho. También el agua tiene costo que puede ser despreciable respecto de los demás puesto que se obtiene de perforaciones in situ que bien podrían ya ser instaladas en el lugar.

A fin de determinar los costos de operación se especifica en la Tabla 11.12 los costos de la energía eléctrica activa (la que se aprovecha como energía útil, como por ejemplo el calor de la resistencia eléctrica) y reactiva (asociada a los aparatos eléctricos con bobinas) en moneda estadounidense (correspondiente a la facturación del mes de setiembre del 2019 en zona rural dada por la distribuidora de energía eléctrica EDESA, Anexo A6). 
Tabla 11.12. Costo de la energía eléctrica.

\begin{tabular}{|c|c|}
\hline \multicolumn{2}{|c|}{ Energía eléctrica (U\$S/kWh) } \\
\hline Activa & 0,071 \\
\hline Reactiva & 0,067 \\
\hline
\end{tabular}

En la Tabla 11.13 se indica la potencia de la maquinaria utilizada: la resistencia eléctrica, el mezclador, la electrobomba y el controlador de temperatura. Estos son los elementos eléctricos cuya potencia afectan significativamente el consumo de energía, los demás componentes tales como el temporizador, los contactores eléctricos y las válvulas eléctricas tienen un consumo reducido.

Tabla 11.13. Potencia de la maquinaria.

\begin{tabular}{|l|c|l|}
\hline Componente & Potencia & Unidad \\
\hline Resistencia eléctrica & 1,400 & $\mathrm{~kW}$ \\
\hline Mezclador & 0,600 & $\mathrm{~kW}$ \\
\hline Electrobomba & 0,337 & $\mathrm{~kW}$ \\
\hline Controlador & 0,005 & $\mathrm{~kW}$ \\
\hline
\end{tabular}

Fuente: Elaboración propia.

La resistencia eléctrica es un elemento indispensable por cualquier eventualidad pues el proceso de biodigestión anaeróbica es sensible a los cambios de temperatura, pero no se toma en cuenta en el cálculo del consumo eléctrico.

En base a las medidas presentadas en el apartado 7.3 se fija el tiempo de encendido promedio de la electrobomba y el mezclador, estableciendo un encendido diario de dos horas para ambos elementos. En la Tabla 11.14 se indican el tiempo de encendido y el costo diario para las tres componentes.

Tabla 11.14. Costo diario del consumo de energía eléctrica.

\begin{tabular}{|c|c|c|c|}
\hline \multicolumn{2}{|c|}{$\begin{array}{c}\text { Tiempo diario promedio de } \\
\text { encendido (hs) }\end{array}$} & $\begin{array}{c}\text { Consumo } \\
\text { diario (kWh) }\end{array}$ & $\begin{array}{c}\text { Costo diario } \\
\text { (U\$S) }\end{array}$ \\
\hline Electrobomba y Mezclador & 2,0 & 1,874 & 0,133 \\
\hline Controlador Total & 24 & 0,12 & 0,009 \\
\hline \multicolumn{2}{|c|}{ Tot } & 1,994 & 0,142 \\
\hline
\end{tabular}

Fuente: Elaboración propia. 
En cada periodo operativo del digestor se repite la misma situación, es decir una etapa de arranque (acopio), donde se alcanza la temperatura de operación, luego el digestor se mantiene a esta temperatura durante el tiempo de permanencia del residuo (120 días) y finalmente se lo desagota.

Cabe señalar que en el cálculo del consumo eléctrico diario y mensual no se ha discriminado por las condiciones de operación, las cuales difieren a lo largo del año de acuerdo a las condiciones climatológicas. En los meses más críticos del invierno la radiación puede ser mayor por falta de nubosidad, la temperatura ambiente menor, requiriendo una provisión de energía mayor para alcanzar y mantener la temperatura de funcionamiento del biodigestor.

\subsubsection{Cálculo de la producción de biogás y su equivalencia en garrafas.}

Se analiza el caso IV con un volumen de $50 \mathrm{~m}^{3}$ considerado el más favorable. Para el cálculo del número de garrafas equivalentes por año que la planta es capaz de producir, se contabiliza el número de operaciones por año por cada digestor. Al final del cuarto mes, se cuenta un periodo operativo. En la tabla siguiente se muestra el esquema de operación.

Tabla 11.15. Número de garrafas equivalentes de la planta de producción de biogás.

\begin{tabular}{|c|c|c|c|c|c|c|c|c|c|c|c|c|c|c|}
\hline \multirow{2}{*}{ Año } & Meses & \multirow[t]{2}{*}{1} & \multirow[t]{2}{*}{2} & \multirow[t]{2}{*}{3} & \multirow[t]{2}{*}{4} & \multirow[t]{2}{*}{5} & \multirow[t]{2}{*}{6} & \multirow[t]{2}{*}{7} & \multirow[t]{2}{*}{8} & \multirow[t]{2}{*}{9} & \multirow[t]{2}{*}{11} & \multirow[t]{2}{*}{12} & \multicolumn{2}{|c|}{ Número de } \\
\hline & Digestor & & & & & & & & & & & & operaciones & $G$ \\
\hline \multirow{2}{*}{1} & 1 & & & & & & & & & & & & 2 & 28,6 \\
\hline & 2 & & & & & & & & & & & & 2 & 28,6 \\
\hline \multirow{2}{*}{2} & 1 & & & & & & & & & & & & 2 & 28,6 \\
\hline & 2 & & & & & & & & & & & & 2 & 28,6 \\
\hline \multirow{2}{*}{3} & 1 & & & & & & & & & & & & 3 & 42,9 \\
\hline & 2 & & & & & & & & & & & & 3 & 42,9 \\
\hline \multirow{2}{*}{4} & 1 & & & & & & & & & & & & 2 & 28,6 \\
\hline & 2 & & & & & & & & & & & & 2 & 28,6 \\
\hline \multirow{2}{*}{5} & 1 & & & & & & & & & & & & 3 & 42,9 \\
\hline & 2 & & & & & & & & & & & & 2 & 28,6 \\
\hline
\end{tabular}

Fuente: Elaboración propia.

En la Tabla 11.15 se presentan el número de garrafas producidas en los primeros cinco años de actividad. A partir del año seis se vuelve a repetir el presente esquema. Se observa que la cantidad de garrafas producida en cada período operativo es de 14,3 . 
Por ejemplo, en el primer año el digestor 1 cuenta con dos operaciones completas (desde el mes 2 hasta el mes 5 y desde el mes 7 hasta el mes 10), igual que el digestor 2, el número de garrafas, se señala en la última columna con la letra "G". Para llenar esta columna se elige un volumen de biodigestión de 50 m³ CASO IV (Tabla 11.9).

\subsubsection{Inversión de la planta de biodigestión.}

Para una planta compuesta por dos digestores anaeróbicos, cada uno con su sistema de calentamiento y funcionando como se detalló en la Tabla 11.15, se calcula la inversión total, la que se presenta en la Tabla 11.16.

Tabla 11.16. Inversión total de la Planta de Biodigestión -CASO I al IV.

\begin{tabular}{|c|c|c|}
\hline Caso & $\begin{array}{c}\text { Volumen de } \\
\text { cada digestor } \\
\mathbf{( m}^{\mathbf{3}} \mathbf{)}\end{array}$ & $\begin{array}{c}\text { Inversión } \\
\text { (U\$S) }\end{array}$ \\
\hline I & 20 & $2.810,0$ \\
\hline II & 30 & $3.261,8$ \\
\hline III & 40 & $3.798,2$ \\
\hline IV & 50 & $4.188,8$ \\
\hline
\end{tabular}

Fuente: Elaboración propia.

Los costos de inversión pueden ser elevados o no, esto dependerá de los beneficios que se obtengan a corto plazo. Autoabastecerse de biogás para emplearlo en diversos usos, como calentar agua, cocinar, etc., puede considerarse un beneficio directo e inmediato. También es importante evaluar el tiempo en el que se recupera lo invertido, a fin de analizar si es una inversión es conveniente.

\subsubsection{Flujo de fondos. Periodo de recuperación de la inversión.}

El flujo de caja o de fondos se compone de cuatro elementos básicos: inversión inicial requerida para la puesta en marcha del proyecto, ingresos y egresos de operación y el valor residual del proyecto.

El proyecto de la instalación de la planta de producción compuesta por dos biodigestores se efectúa sin financiamiento externo, es decir con capitales propios.

El costo de operación es el consumo de energía eléctrica dados por el uso diario del equipo eléctrico, considerados como el egreso.

Cada biodigestor de la planta trabajará siempre de la misma forma, por ello la producción de metano por periodo operativo se considera siempre la misma y se expresa en número de garrafas equivalentes de butano de $10 \mathrm{~kg}$. 
Como ingreso se considera el costo de la garrafa de butano no comprada expresada en dólares. Se hace la hipótesis de un valor constante del precio de la garrafa en dólares durante el periodo del proyecto.

Se presenta en la Tabla 11.17 las hipótesis consideradas para el cálculo del flujo de fondos. Se considera la cotización del dólar constante durante el periodo del proyecto.

Tabla 11.17. Hipótesis para el flujo de fondos.

\begin{tabular}{|l|r|}
\hline Periodo de evaluación (años) & 12 \\
\hline Financiamiento & Capital propio \\
\hline Cotización del dólar $(4 / 9 / 2019)^{* *}$ & $1 / 57$ \\
\hline Costo de la garrafa (U\$S)* & 8,77 \\
\hline Costo anual de la energía eléctrica consumida (U\$S) & 104,5 \\
\hline Volumen de cada biodigestor $\left(\mathrm{m}^{3}\right)$ & 50 \\
\hline *(Facturación eléctrica en Anexo A6) **(Cotización del dólar en Anexo A3) \\
Fuente: Elaboración propia.
\end{tabular}

En el flujo de fondos presentada en la Tabla 11.18 para el CASO IV, se especifica en la primera columna, los años de operatividad de la planta, la inversión inicial, los ingresos dados por el valor monetario de las garrafas equivalentes, los costos de energía (costos variables), el flujo neto (diferencia entre los ingresos y egresos) y el flujo acumulado.

Tabla 11.18. Flujo de fondos- Caso IV

\begin{tabular}{|c|c|c|c|c|c|c|c|c|c|}
\hline \multicolumn{10}{|c|}{ FLUJO DE FONDOS } \\
\hline AÑO & $\mathbf{0}$ & 1 & 2 & 3 & 4 & 5 & 6 & 7 & 8 \\
\hline Inversión & $-4.188,8$ & & & & & & & & \\
\hline Ingresos & & 501,8 & 501,8 & 752,6 & 501,8 & 627,2 & 501,8 & 501,8 & 752,6 \\
\hline Egresos & & 104,5 & 104,5 & 104,5 & 104,5 & 104,5 & 104,5 & 104,5 & 104,5 \\
\hline FF Neto & & 397,3 & 397,3 & 648,2 & 397,3 & 522,7 & 397,3 & 397,3 & 648,2 \\
\hline F Acumulado & & 397,3 & 794,6 & $1.442,7$ & $1.840,0$ & $2.362,8$ & $2.760,1$ & $3.157,3$ & $3.805,5$ \\
\hline
\end{tabular}

\begin{tabular}{|c|c|c|c|c|}
\hline AÑO & $\mathbf{9}$ & $\mathbf{1 0}$ & $\mathbf{1 1}$ & $\mathbf{1 2}$ \\
\hline Ingresos & 501,8 & 627,2 & 501,8 & 501,8 \\
\hline Egresos & 104,5 & 104,5 & 104,5 & 104,5 \\
\hline FF Neto & 397,3 & 522,7 & 397,3 & 397,3 \\
\hline F Acumulado & $\mathbf{4 . 2 0 2 , 8}$ & $4.725,5$ & $5.122,8$ & $5.520,1$ \\
\hline
\end{tabular}

Fuente: Elaboración propia. 
La recuperación de la inversión inicial se da al noveno año de actividad. En los años que siguen todo el flujo neto anual corresponde a ganancias. En la Figura 11.4 se representa en forma gráfica esta situación, en donde se marca en color rojo la inversión inicial y el noveno año en el que se recupera tal inversión.

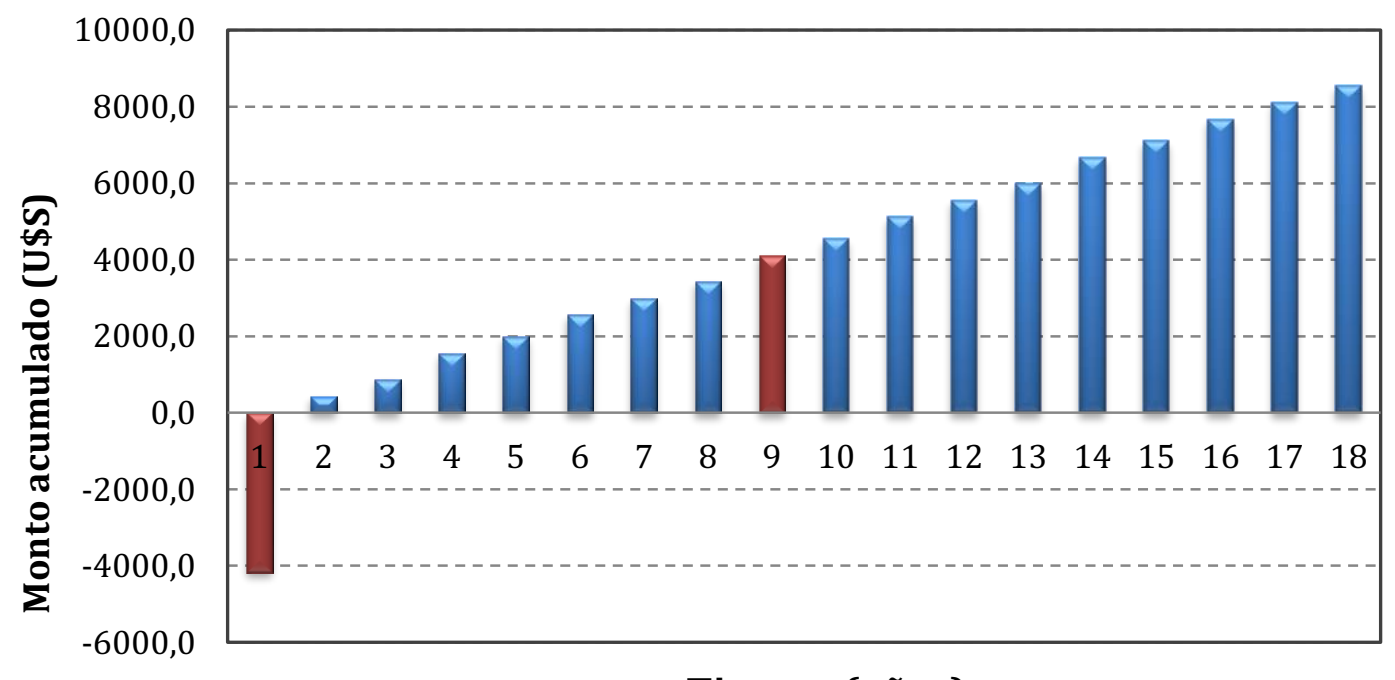

Tiempo (años)

Figura 11.4. Esquema del monto acumulado en función del tiempo. Caso IV. Fuente: Elaboración propia.

Los plásticos PVC tienen una vida útil de entre 15 y 100 años (Asoven, 2018) dependiendo del tipo de aplicación. En el caso del prototipo del biodigestor propuesto y para la planta de biogás, la membrana se encuentra protegida de los rayos solar UV, siendo este factor uno de los principales agentes que más la deterioran.

\subsection{Discusión.}

Como se observa en la Tabla 11.15, el esquema de operación conjunta de dos digestores posibilita la continuidad en el abastecimiento de biogás. La desventaja que surge, es la falta de tratamiento del residuo pecuario en los meses en que no se realiza la carga de los digestores. Para una total utilización del residuo recuperado, puede implementarse un tratamiento aeróbico en pilas o camas donde se dispone el residuo que no se trata por biodigestión anaeróbica.

La planta de producción de biogás tiene dos subproductos, por un lado, de biogás y por otro el lodo. Este último es un residuo menos contaminante que debido a la baja temperatura de operación, debe someterse a un post-tratamiento, tal como lagunas de estabilización, lombricompuesto o digestión aeróbica. Esto crea un beneficio 
adicional: la producción de un biofertilizante. Este ingreso no se contabiliza en el flujo de fondos.

Dado el gran volumen de biogás que produce la planta, el establecimiento donde se instale, se independiza del gas combustible de garrafa. Además, el biogás tiene múltiples aplicaciones. Sin la necesidad de una conversión eléctrica puede usarse para el alumbrado, calentamiento de agua y/o refrigeración.

A medida que el volumen de la planta de digestión disminuye, el tiempo de retorno aumenta. La inversión sigue la misma tendencia, pero no es proporcional con el volumen del biodigestor. La cantidad de material de construcción requerido disminuye para volúmenes de digestores menores. Por ejemplo, se necesita menos membrana de PVC que forma el cuerpo del digestor. Pero el sistema de control de temperatura se mantiene, es decir es el mismo si el digestor es más pequeño o más grande.

\subsection{Conclusiones.}

Debe considerarse el efluente lodo como un producto de mercado con valor monetario. En tal sentido el lombricompuesto es un proceso interesante a aplicarse posteriormente al de biodigestión, que genera un valor agregado a la planta. Como resultado, el material digerido por las lombrices es un abono con una gran riqueza para aplicar directamente a la tierra destinada al cultivo o para ser vendido como fertilizante.

No se ha considerado el costo del agua ya que en general los establecimientos rurales se abastecen de las napas de aguas subterráneas, ríos, acequias, etc. Con el objetivo de preservar el recurso hídrico y dado que la biodigestión necesita de grandes volúmenes es deseable que se estudie la posibilidad de recuperar el agua del efluente (lodo).

Operar una planta de digestión realizando un mejor aprovechamiento de la biomasa residual es un estudio que debe realizarse con mayor detenimiento según cada caso particular. Cuando se realiza un cálculo del residuo pecuario disponible, es deseable que siempre se contabilice en el lugar la cantidad a recuperar por día. Como se ha mencionado anteriormente la recuperación difiere notablemente dependiendo de la actividad (tambo, feedlot).

El tiempo de retorno se encuentra dentro de los valores que se manejan en los proyectos de energías renovables tales como solares y eólicos. 
Con un incentivo económico o financiamiento por parte del Estado (proyectos de PROBIOMASA, por ejemplo) el tiempo de recupero disminuirá.

En los días en que el digestor anaeróbico no utilice el conjunto de colectores solares, como puede suceder en el verano, el agua caliente puede utilizarse para el abastecimiento del hogar o el establecimiento rural en donde está instalada la planta.

Dado que la membrana del biodigestor construida en plástico PVC tiene una vida útil de entre 15 y 100 años y una vez recuperada la inversión a los nueve años, el beneficio financiero durara unas décadas más dependiendo de la vida útil de las demás componentes. 


\section{Discusión general.}

La generación de residuos pecuarios en grandes volúmenes acarrea problemas ambientales y sociales. En tal sentido, las leyes son claras al respecto y exigen su tratamiento. Por ejemplo, la Ley Provincial de Salta $N^{\circ} 7.070$, Artículos $106^{\circ}$ y $110^{\circ}$ sugiere la biodigestión anaeróbica, la cual genera dos subproductos: biogás y lodo, un efluente más estabilizado con una capacidad menor de contaminación, favoreciendo una mejor asimilación en la tierra. El biogás generado es un producto gaseoso rico en metano (60-80\%), el cual puede ser utilizado para diversos fines como, por ejemplo, calentamiento de agua, cocción, refrigeración y alumbrado.

El clima es un factor determinante, dado que el rango de temperatura óptimo de digestión se encuentra entre $\operatorname{los} 37^{\circ}$ y $40^{\circ} \mathrm{C}$. Dada la diversidad del clima y la geografía de la provincia de Salta, se analizaron las zonas de mayor posibilidad para la aplicación del proceso de biodigestión anaeróbica. Por esta razón, se destaca la zona este, El Chaco Salteño, con temperaturas medias en invierno (julio) entre $17^{\circ}-20^{\circ} \mathrm{C}$ y en verano (enero) entre $20^{\circ}$ y $28^{\circ} \mathrm{C}$. Anta, Gral. J. de San Martín y Rosario de la Frontera son los tres departamentos de la provincia pertenecientes a esta zona, que sobresalen de las demás por su gran explotación ganadera y por tanto con una enorme capacidad para la producción de biogás de gran envergadura.

Los parámetros de control utilizados en los ensayos de laboratorio y de campo fueron: $\mathrm{pH}$, alcalinidad, ácidos grasos volátiles, sólidos volátiles y sólidos totales y como parámetro operativo el mezclado.

La proporción de metano en los bioensayos a $20^{\circ} \mathrm{C}(65 \%)$ posibilitaron una buena combustión, aunque con una retención hidráulica de 97 días (promedio), mucho más elevada respecto de los ensayos posteriores, a $30^{\circ}$ y $37^{\circ} \mathrm{C}$, los que fueron de 50 y 53 días (promedio), respectivamente.

Se construyeron tres prototipos de biodigestores, tubular flexible y dos enterrados. Según informan Martí-Herrero y Álvarez (2014), en experiencias con digestores tubulares en zonas frías con temperaturas máximas promedio del medio ambiente entre $15^{\circ}$ y $20^{\circ} \mathrm{C}$, se logran temperaturas de digestión de $16^{\circ} \mathrm{C}$. En tal sentido se manifiesta la necesidad de la incorporación de una energía auxiliar para lograr aumentar la temperatura de operación.

Un informe de la FAO (2016), en un relevamiento de biodigestores instalados en el país, destaca entre los principales problemas en la construcción la falta de aislación térmica.

En el modelo de simulación realizado se destaca el uso de solo dos parámetros climáticos: la irradiación solar y la temperatura ambiente. Se observó que conocer sus 
variaciones anuales resulta primordial, para estudiar cómo incide el colector solar en el acondicionamiento térmico y, por lo tanto, ayuda a decidir si es conveniente su instalación. Emular el comportamiento del controlador de temperatura resultó conveniente a fin de obtener con mejor fidelidad los consumos de energía eléctrica y solar. Con el modelo de simulación se observó que una temperatura de operación de $20^{\circ} \mathrm{C}$ era lo más adecuado para el acondicionamiento del prototipo de biodigestor dadas las características del colector solar. Además, el modelo tiene como ventaja la posibilidad de cambiar ciertos parámetros, tales como: conductividad térmica del material aislante, eficiencia instantánea del colector solar, coeficiente global de pérdidas del intercambiador de calor interno y resistencia eléctrica. Todo ello permitiría tomar una decisión acerca de la implementación de otros materiales en su construcción.

En las experiencias de campo se pusieron a prueba distintas técnicas de calentamiento solar y eléctrica. En el digestor tubular flexible se advierte una mejora sustancial en el aumento de temperatura. Se midieron valores máximos de $13^{\circ} \mathrm{C} \sin$ invernadero y $17^{\circ} \mathrm{C}$ con invernadero. Esto indicó que no es recomendable la operación de un digestor sin ninguna asistencia, para elevar su temperatura. La incorporación de la aislación térmica y al poner a prueba su desempeño expuesto al ambiente se corroboró una efectiva disminución de las pérdidas de energía del digestor. Por esta razón, se propuso la utilización de una aislación térmica constituida por botellas PET rellenas de viruta, abaratando los costos de instalación y propiciando el mantenimiento de una adecuada temperatura dentro del digestor. Se han realizado medidas de la difusividad térmica obteniendo un valor promedio de $5,82 \cdot 10^{-7} \mathrm{~m}^{2} / \mathrm{s}$, que se halla dentro del rango de los aislantes comerciales.

Se consideró el desempeño de la aislación térmica, del circuito eléctrico, del calentamiento, del circuito hidráulico y del invernadero. El análisis de los resultados demostró la eficacia de la aislación térmica, el incremento de la temperatura por la utilización del invernadero y el correcto funcionamiento del circuito eléctrico e hidráulico. También se manifestó la necesidad de incorporar un sistema de control de temperatura y una modificación en su estructura que permita una limpieza interior para un buen mantenimiento.

Se advierte que, para el colector solar construido, las temperaturas máximas medidas se encuentran entre los $37^{\circ}$ y $40^{\circ} \mathrm{C}$. Por lo tanto, resulta conveniente que la temperatura de operación del digestor sea menor a éstas, como la elegida para los ensayos de campo del digestor enterrado.

La operación unitaria de un biodigestor discontinuo conlleva el hecho que hay periodos en donde no se carga el biodigestor. Dado que la ley exige el tratamiento de 
los residuos orgánicos, se propuso el desarrollo de una planta de producción de biogás compuesta por dos biodigestores, con un periodo de carga desfasado, a fin de tener una disponibilidad continua del biogás.

Considerando este tipo de colector solar, para una planta de producción se obtuvo en el cálculo un área total de colectores de $79 \mathrm{~m}^{2}$ para un volumen de digestión de $50 \mathrm{~m}^{3}$ operando a $20^{\circ} \mathrm{C}$. En tal sentido, en una experiencia llevada a cabo en la ciudad de Haining, provincia de Zhejiang, China. Una planta de $1.000 \mathrm{~m}^{3}$ de digestión logra temperaturas de operación de entre 8 y $14^{\circ} \mathrm{C}$ con un área total de colectores de tubo de vacío de $100 \mathrm{~m}^{2}$ (Feiqing, Jiambo Lu, 2013). En una operación discontinua del digestor enterrado de mezcla completa a $20^{\circ} \mathrm{C}$ se obtuvo un rendimiento promedio de $0,067 \mathrm{~m}^{3}$ de metano por $\mathrm{kg}$ de sólidos volátiles que representa un valor bajo respecto de el de un digestor tipo batch operando también a $20^{\circ}$ con $0,116 \mathrm{~m}^{3} \mathrm{CH}_{4} / \mathrm{kg}$ SV (Massé D., 2015). La baja producción puede atribuirse a la falta de homogeneidad en la carga del digestor.

Durante las experiencias, el biogás se almacenó en un gasómetro, contenedor flexible de membrana de PVC de 1100 micrómetros. Se advierte la necesidad de incorporar un mecanismo que permita la succión del biogás cuando el gasómetro este lleno.

De los ensayos de biodigestión se advierte que la materia orgánica es alta y debe someterse a un post-tratamiento, tal como lagunas de estabilización, lombricompuesto o digestión aeróbica. Esto crearía un beneficio adicional: la producción de un biofertilizante para su aplicación directa al suelo.

Finalmente se ha realizado un análisis de costos del prototipo de biodigestor (caso C), para determinar la inversión del mismo.

El análisis de costos de una planta de producción de biogás abarcó un estudio sobre su inversión, describiendo detalladamente la cantidad y el tipo de material a utilizar y el tipo de operación de los biodigestores para los diferentes volúmenes. Para el cálculo de la recuperación de la inversión, se establecieron ciertas hipótesis, tales como: costo anual constante en dólares de la garrafa de butano, financiamiento propio y cotización del dólar constante durante la actividad de la planta. El análisis económico indica una conveniencia en la aplicación de digestores con volúmenes de $50 \mathrm{~m}^{3} \mathrm{o}$ mayores para una temperatura de operación de $20^{\circ} \mathrm{C}$, recuperando la inversión inicial en un período de entre nueve y diez años, reduciéndose este tiempo a medida que aumenta el volumen de digestión. Es de hacer notar que períodos de recupero de este orden son frecuentes también en proyectos de energías renovables como solar y eólica. 
En este trabajo de tesis se ha realizado un aporte novedoso en lo que respecta a la implementación de distintos modos de calentamiento para mantener la temperatura adecuada del digestor. Se propone un sistema de calentamiento híbrido solar-eléctrico, que es capaz de funcionar de manera autónoma. Según las condiciones de irradiación solar, se acciona el colector solar o la resistencia eléctrica, cuando el digestor lo necesite. La conjunción de este sistema, la aislación térmica, el tipo de construcción del digestor y colector solar, reducen los costos de inversión inicial y constituyen el aporte para mantener la temperatura adecuada del digestor.

\section{Conclusión final.}

Anta, Gral. J. de San Martín y Rosario de la Frontera son los tres departamentos de la provincia de Salta que por su gran explotación ganadera poseen una enorme capacidad para la producción de biogás de gran envergadura.

No es conveniente la aplicación de esta tecnología en la región de la Puna Salteña, al oeste de la provincia de Salta, por las características del clima y el escaso desarrollo ganadero en corral.

El análisis económico indica la conveniencia en la aplicación de digestores con volúmenes de $50 \mathrm{~m} 3$ o mayores para una temperatura de operación de $20^{\circ} \mathrm{C}$.

La membrana de material PVC de $1100 \mu \mathrm{m}$ de espesor resulta adecuada para impermeabilizar los digestores. Es un material de fácil acceso en el mercado y bajo costo.

La aislación térmica propuesta con botellas rellenas con viruta posee excelentes propiedades como aislante térmico. La hermeticidad de esta aislación impide la penetración de la humedad, brindando una ventaja en comparación con otras aislaciones convencionales.

El sistema de calefacción híbrido compuesto por un colector solar y un calentamiento eléctrico resulta adecuado para mantener una temperatura constante en el digestor anaeróbico y a la vez permite reducir los gastos del consumo eléctrico.

De los ensayos con el sistema de control se advierten pequeñas oscilaciones de $1^{\circ} \mathrm{C}$ entorno a los $30^{\circ} \mathrm{C}$ del digestor anaeróbico enterrado, que no son capaces de perturbar el proceso de digestión anaeróbica. Es indispensable la incorporación de un controlador de temperatura y un sistema de calentamiento eléctrico a pesar de contar con un abastecimiento de energía solar. 
Los ensayos de biodigestión anaeróbica a $20^{\circ} \mathrm{C}$ muestran un porcentaje de metano adecuado para considerar esta temperatura en experiencias con volúmenes mayores.

El modelo de simulación realizado predice que el tipo de colector solar incide fuertemente en la temperatura de operación del digestor anaeróbico enterrado. Con el modelo se observó que una temperatura de operación de $20^{\circ} \mathrm{C}$ es la más adecuada para el acondicionamiento del prototipo de biodigestor dadas las características del colector solar.

Un volumen mayor del biodigestor resulta más apropiado a fin de reducir la utilización de la bomba. Cuanto mayor es la eficiencia menor es el uso de la bomba, lo que redunda positivamente en el consumo eléctrico.

Perspectivas futuras.

Se proponen futuras líneas de investigación como ser:

- Un estudio que incluya no sólo el análisis económico y energético, sino social y ecológico de la planta de biodigestión.

- Un abordaje de la temática desde lo social, con la finalidad de desarrollar estrategias que posibiliten la integración y el cambio de percepción de todos los actores involucrados en la generación de los residuos.

- Un análisis de las percepciones sociales sobre la posibilidad de implementación de biodigestores en establecimientos ganaderos.

- Estudio y análisis para incorporar el proceso de biodigestión y otros relacionados en la agroindustria, a fin de alentar una economía circular.

- Un estudio termoeconómico en el que intervenga el costo monetarioenergético de cada sistema que intercambia materia y energía en el proceso de biodigestión y su relación con el costo monetario-energético de los productos de la biodigestión tanto para consumo como distribución.

- Una simulación que incorpore el enfoque económico y energético, a fin de que brinde, a partir de un conjunto de entradas como cantidad de materia prima, clima, costo, etc., un escenario posible de aplicación del proceso de biodigestión y otros relacionados.

- Un estudio técnico y económico del subproducto (lodo) y su aplicación en la agroindustria como biofertilizante.

- Un estudio de cogeneración que evalúe formas de aprovechamiento de las energías que se intercambian en el proceso de biodigestión. 


\section{Bibliografía.}

Ahring, B. y Westermann, P. (1987). Thermophilic anaerobic degradation of butyrate by a butyrate-utilizing bacterium in coculture and triculture with methanogenic bacteria. Applied and Environmental Microbiology, 53 (2), 429-433. [online] Disponible en: <https://doi.org/10.1128/aem.53.2.429433.1987> [Acceso 15/10/2021].

Ahring, B., Sandberg, M. y Angelidaki, I. (1995). Volatile fatty acids as indicators of process imbalance in anaerobic digestors. Applied microbiological Biotechnology, 43 (3), 559-565. [online] Disponible en: $<$ https://link.springer.com/article/10.1007/BF00218466> [Acceso $15 / 8 / 2015]$.

Álvarez, R. y Liden, G. (2009). Low temperature anaerobic digestion of mixtures of llama, cow and sheep manure for improved methane production. Biomass Bioenergy, 33, 527-533.

Alzate M., Muñoz R., Rogalla F., Fdz-Polanco, F. y Pérez-Elvira, S. (2013). Biochemical Methane Potential of microalgae biomass after lipid extraction. Chem. Eng. J. , 243, 405-410.

APHA, AWWA, WPCF. (1995). Métodos normalizados para el análisis de aguas y aguas residuales. Ed. Díaz de Santos, S.A. Madrid, España.

Axaopoulos P., Panagakis P., Tsavdaris A. y Georgakakis D. (2001). Simulation and experimental performance of a solar heated anaerobic digester. Solar Energy, 70 (2), 155-164.

Bejan, A. (1993). Heat Transfer. Ed. John Wiley \& Sons, Inc. ISBN 0471502901.

Bioeléctrica. (2021). Empresa que desarrolla proyectos de generación de energía eléctrica a partir de fuentes renovables, mediante procesos de digestión anaeróbicos. [online] Disponible en: <www.bioelectrica.com> [Acceso 15/8/2021].

Bon T. y Templenton M. (2011). History and future of domestic biogas plants in the developing world. Energy Sustainable Dev. 15, 347-354.

Boone, D. y Xun, L. (1987). Effects of $\mathrm{pH}$, temperature and nutrients on propionate degradation by methanogenic enrichment culture. Applied and environmental microbiology. 53(3), 1589-1592.

Botero R. y Preston T. (1987). Biodigestor de bajo costo para la producción de combustible y fertilizante a partir de excretas: Manual para su instalación, operación y utilización. CIPAV, Cali, Colombia.

BP British Petroleum Co. Ltd. (2019). Statistical Review of World Energy. 68th edition, Londres, Inglaterra. [online] Disponible en: $<$ https://www.bp.com/content/dam/bp/businesssites/en/global/corporate/pdfs/energy-economics/statistical-review/bpstats-review-2019-full-report.pdf> [Acceso 15/10/2019]. 
Brinkman, J. (1999). Anaerobic digestion of mixed waste slurries from kitchens, slaughterhouses and meat processing industries. Proceedings of the II International Symposium on Anaerobic Digestion of Soil Waste, 190-191. Barcelona.

Bui Xuan A., Ngo Van M., Duong Nguyen D. y Preston T. (1994). Installation and performance of low cost polyethylene tube biodigester on small scale farms in Vietnam. Proceedings of the National Seminar-workshop in sustainable Livestock production on local feed resources agriculture. Pub house Ho Chi Minh, 95-103.

Campos Pozuelo, A. E. (2001). Optimización de la digestión anaeróbica de purines de cerdo mediante codigestión con residuos orgánicos de la industria agroalimentaria. Universidad de Lleida, Escuela Superior de Ingeniería Agraria, Departamento de Medio Ambiente y Ciencias del Sol, Laboratorio de Ingeniería Ambiental LEA, Tesis doctoral. Lleida, España. [online] Disponible en: <https://www.tdx.cat/bitstream/handle/10803/8229/Tecp1de1.pdf;jses sionid=2096C507D46455DFCC329E84319E28B3?sequence=1> [Acceso 15/01/2017].

Cao E. (2011). Transferencia de Calor en procesos de Ingeniería. Ed. Nueva Librería. ISBN: 9789871104970.

Carlevari, I. y Carlevari, R. (2006). Geografía Humana y Económica. Ed. Grupo Guía. S.A., Capítulo 2, Argentina.

Carneiro Forster, T. (2005). Digestión anaerobia termofílica seca de residuos sólidos urbanos: Estudio de las variables del proceso en el arranque y estabilización del bio-reactor. Departamento de Ingeniería Química, Tecnología de Alimentos y Tecnología del Medio Ambiente. Tesis doctoral. Universidad de Cádiz. España. [online] Disponible en: $<$ https://cetesb.sp.gov.br/biogas/2005/11/01/digestion-anaerobiatermofilica-seca-de-residuos-solidos-urbanos/> [Acceso 15/01/2017].

Cengel, Y. (2012). Termodinámica $7^{\circ}$ Edición. Editor Mc Graw-Hill Interamericana de España S.L. ISBN: 9786071507433.

Chacón, O. (1987). Relación alcalinidad-ácidos grasos volátiles. Manual del curso Arranque y operación de sistemas de flujo ascendente con manto de lodo UASB, p D.1 - D.32. Facultad de Ingeniería. Sección Saneamiento Ambiental. Universidad del Valle. Cali, Colombia. 
Chen, L., Zhao, L., Ren, C. y Wang, F. (2012). The progress and prospects of rural biogas production in China. Energy Policy, 51, 58-63.

Clark, R. y Speece, R. (1989). The $p H$ tolerance of anaerobic digestion. Advanced water pollution research. Int. Conf. 5th, 27/1-27/14.

Coombs, J. (1990). The present and future of anaerobic digestion, en Anaerobic digestion: a waste treatment technology. Editado por Wheatley, Elsevier Applied Science LTD, A. Critical reports on applied chemistry, 31, 93-138.

Doran P. (1995). Bioprocess Engineering Principles. Ed. Academic Press Ltd. ISBN: 8420008532.

DGCe. (2018). Distribuidora de Gas del Centro S.A. Av. Presidente Figueroa Alcorta № 7174, 3o Piso, (C1428BCU). Ciudad Autónoma de Buenos Aires. República Argentina.

Duffie, J. y Beckman, W. (1991). Solar Engineering of thermal process. 4ta Edición. ISBN: 9780470873663.

El Sur del Sur. (2018) Argentina: el país su cultura y su gente. En línea: http://www.surdelsur.com/ganadería-argentina, 2018. [online] Disponible en: <https://cetesb.sp.gov.br/biogas/2005/11/01/digestionanaerobia-termofilica-seca-de-residuos-solidos-urbanos/> 15/01/2018].

ENARGAS (2018). Ente Nacional Regulador del Gas. Suipacha 636. (A1008XX). Ciudad Autónoma de Buenos Aires. [online] Disponible en: $<$ www.enargas.gob.ar>.

Energía Estratégica. (2015). Proyecto busca solucionar el problema de la basura produciendo biogás en un colegio secundario. [online]. Disponible en: $<$ https://www.energiaestrategica.com/proyecto-busca-concientizar-ysolucionar-el-problema-de-la-acumulacion-de-basura-produciendobiogas-en-escuela-rural/> .

Escribanía de Gobierno. (2013). [online]. Disponible en: $<\mathrm{http}: / /$ escribaniadegobierno.salta.gov.ar/?page_id=8117> .

Fannin, K. (1987). Start-up, operation, stability, and control, Anaerobic digestion of biomass. Editado por Chynoweth, D. Y y Isaacson, R. Elsevier, Applied Science LTD.

FAO. (2011). Chile: Remoción de Barreras para la Electrificación Rural con Energías Renovables. Manual de Biogás. Ed. Proyecto CHI/00/G32. ISBN: 978-95306892-0 [online]. Disponible en: <https://www.fao.org/3/as400s/as400s.pdf> [Acceso 6/09/2015]. 
FAO. (2016). Análisis espacial del balance energético derivado de biomasa Metodología WISDOM Provincia de Salta Proyecto para la promoción de la energía derivada de biomasa. (UTF/ARG/020/ARG) Provincia de Salta. [online].

Disponible

en: <http://www.probiomasa.gob.ar/_pdf/WISDOM_Salta_baja.pdf> [Acceso 6/09/2017].

Feiqing, D. y Jiambo, L. (2013). Using solar energy to enhance biogás production from livestock residue- A case study of the Tongren biogás engineering pig farm in South China. Science Direct, Energy, 57, 759 - 765.

Ferguson, T. y Mah, R. (1987). Methanogenic bacteria. Elsevier Applied Science STD.

Fernández, F. y Ollay, M. (1997). Residuos sólidos urbanos: Problemática y tratamiento. En: Carneiro Forster, T. (2005). Digestión anaerobia termofílica seca de residuos sólidos urbanos: Estudio de las variables del proceso en el arranque y estabilización del bio-reactor. Departamento de Ingeniería Química, Tecnología de Alimentos y Tecnología del Medio Ambiente. Tesis doctoral. Universidad de Cádiz. España. [online] Disponible en: $<$ https://cetesb.sp.gov.br/biogas/2005/11/01/digestion-anaerobiatermofilica-seca-de-residuos-solidos-urbanos/> [Acceso 15/01/2017].

Ferrer, I., Garfi, M., Uggetti, E., Ferrer-Marti, L., Calderon, A. y Velo, E. (2011). Biogas production in low-cost household digesters at the Peruvian Andes. Biomass Bioenergy 35, 1166-1674.

Fukuzaki, S., Nishio, N., Shobayashi, M. y Nagai, S. (1990). Inhibition of fermentation of propionate to methane by hydrogen, acetate, and propionate. Applied and Environmental Microbiology, 56 (3), 719-723.

Futuro Sustentable (2012). Revista de edición mensual. Año №8, Edición № 48. ISSN: 18501311. Buenos Aires, Argentina.

Gallardo J. Análisis numérico de ecuaciones diferenciales: Teoría y ejemplos con Python. 2018. Ed. Independently published. ISBN: 9781720050834.

Ghimire P. (2013). SNV supported domestic biogas programmes in Asia and Africa. Renewable Energy, 49, 90-94.

Gropelli, G. (2001). Ambiente y tecnología socialmente apropiada. El camino de la biodigestión. Universidad Nacional del Litoral UNL, Secretaria de Extensión Universitaria, Centro de publicaciones, Ediciones UNL, Colección Ciencia y Técnica, Santa Fe, Argentina. 
Herrero, J. (2008). Biodigestores familiares: Guía de diseño y manual de instalación. Cooperación Técnica Alemana - GTZ. Programa de desarrollo agropecuario (PROAGRO). Componente Acceso a Servicios Energéticos. Cochabamba. Bolivia. [online] Disponible en: <http://pigtrop.cirad.fr/sp/content/pdf/5821> [Acceso 15/01/2015].

Hilbert, J. (2003). Manual para la producción de Biogás. Instituto de Ingeniería Rural. INTA Castelar. Buenos Aires, Argentina. [online] Disponible en: $<$ https://inta.gob.ar/sites/default/files/script-tmpmanual_para_la_produccin_de_biogs_del_iir.pdf> [Acceso 15/01/2015].

Hill, D., Cobb, S. y Bolte, J. (1987). Using Volatile fatty acid relationships to predict anaerobic digester failure. Transactions of the ASAE. 30 (2), 496-501.

Hills, D. y Nakano, K., (1984). Effects of particle size on anaerobic digestion of tomato solid wastes. Agricultural Wastes. 10, 285-295.

IICA-ARPEL. (2009) Instituto Interamericano de Cooperación para la Agricultura (IICA). Manual Anual de biocombustibles, ARPEL Asociación Regional de Empresas de Petróleo y Gas Natural en Latinoamérica y el Caribe, IICA, Instituto Interamericano de Cooperación, San José, Costa Rica. [online] Disponible en: $<$ file:///C:/Users/user/Downloads/Manual_Biocombustibles_ARPEL_IICA. pdf> [Acceso 15/07/2014].

Incropera, F. y Dewitt, D. (1999). Fundamentos de la transferencia de calor. $4^{\circ}$ edición. Ed. Prentice Hall. ISBN: 9701701704.

INDEC. (2021). Instituto Nacional de Estadísticas y censos. [online] Disponible en: <https://www.indec.gob.ar/indec/web/Nivel4-Tema-3-8-87.> [Acceso 15/07/2014].

Infocampo. (2012). En Marcos Paz, una empresa invierte en biogás. [online] Disponible en: <https://www.infocampo.com.ar/en-marcos-paz-unaempresa-invierte-en-biogas/>.

INTI, Instituto Nacional de Tecnología Industrial. (2016). Biogás para pequeños productores. Disponible en: https://www.inti.gob.ar/noticias/21asistencia-regional/118-biogas-para-pequenos-productores.

INTI, Instituto Nacional de Tecnología Industrial. (2017). Relevamiento Nacional de Biodigestores. Ministerio de Producción, Presidencia de la Nación. [online] Disponible en: <https://inta.gob.ar/sites/default/files/inta_-33relevamiento_nacional_de_plantas_de_biogas_-_goicoas_v.pdf> [Acceso 15/01/2018]. 
Iza, J. (1995). Control del proceso anaerobio. I Curs d'enginyeria ambiental. abril de 1995, Universidad de Lleida, Lleida, España.

Kugelman, I. y Chin, K. (1971). Toxicity synergism, and antagonism in anaerobic waste treatment processes. Ananerobic biological treatment processes. Advances in chemistry series, 105 . American chemical society. Washington D.C.

La Gaceta. (2009). Citrusvil inauguró la primera planta de biogás de Argentina, [online]. Disponible en: <http://www.lagaceta.com.ar/nota/346517/economia/citrusvilinauguro-primera-planta-biogasargentina.html.> [Acceso 15/08/2008].

La Gaceta. (2014). El Ingenio Ledesma producirá biogás con la vinaza. Noticia del 27/12/2014 [online]. Disponible en: <http://www.lagaceta.com.ar/nota/407782/rural/ingenio-ledesmaproducira-biogas-vinaza.html $>$ [Acceso 6/08/2015].

Lagrange, B. (1979). Biomethane. Principles, Techniques, Utilisation. Edisual / Energies Alternatives. 2, 249.

Lansing, S., Botero, R. B. y Martin, J. F, (2008). Waste treatment and biogas qualify in small-scale agricultural digester. Bioresource Technology, 99(13), 5881$5890 . \quad$ [online]. Disponible en: < http://usi.earth.ac.cr/glas/sp/gestor/Stephanie/001.pdf> [Acceso 6/09/2015].

Lay, J., Li, Y. y Noike, T., (1997). Influences of $\mathrm{pH}$ and moisture content on the methane production in high-solids sludge digestion. Water Research, 31 (6), 1518-1524. [online]. Disponible en: <https://www.sciencedirect.com/science/article/abs/pii/S00431354960 04137> [Acceso 6/04/2015].

LM La Mañana Neuquén. (2013) Inauguraron una planta de biogás en el basurero municipal [online] Disponible en: $<$ https://www.lmneuquen.com/inauguraron-una-planta-biogas-elbasurero-municipal-n188149> [Acceso 15/08/2013].

Loughlin, R. (2012). Peso vivo de terminación en engordes intensivos de bovinos. Investigación y Desarrollo Agropecuario. República Argentina. Sitio Argentino de Producción Animal. [online] Disponible en: <https://www.produccion-animal.com.ar/> [Acceso 15/08/2013].

Lozada, P. (1993). Control de una planta de tratamiento anaerobio: parámetros, operación y mantenimiento. Universidad del Valle. Cali, Colombia. 
Mapoteca del Ministerio de la Nación, 2019. [online]. Disponible en: <http://mapoteca.educ.ar/.files/index.html.1.2.html>.

Marti-Herrero J. (2011). Reduced hydraulic retention times in low-cost tubular digester: two issues. Biomass Bioenergy 35 (10), 4481-4484.

Marti-Herrero J. (2007). Transfer of low cost transfer biodigester technology at household level in Bolivia. Livestock Research for Rural Development. 19 (12) Article $192 . \quad$ [online]. Disponible en: <www.Irrd.org/Irrd19/12/mart19192.htm> [Acceso 6/10/2015].

Martí-Herrero, J. y Álvarez, R. (2014a). Improvement through low cost biofilm carrier in anaerobic tubular digestion in cold climates regions. Bioresource Technology 167, 87-93.

Martí-Herrero, J., Álvarez, R., Rojas, M., Aliaga, L., Céspedes, R. y Carbonell, J. (2014). Improvement through low cost film carrier in anaerobic tubular digestion in cold climate regions. Bioresource Technology, 167, 87-93.

Martí-Herrero, J., Álvarez, R., Céspedes, R., Rojas, M., Conde, V., Aliaga, L., Balboa, M. y Danov, S. (2015). Cow, sheep and llama manure at psychrophilic anaerobic co-digestion with low cost tubular digesters in cold climate and high altitude. Bioresource Technology. 181, 238-246.

Martí-Herrero, J., Chipana, M., Cuevas, C., Paco, G., Serrano, V., Zymla, B., Heising, K., Sologuren, J. y Gamarra, A. (2014a). Low cost tubular digester as appropriate technology for wispread application: results and lessons learned from Bolivia. Renewable Energy 71, 156-165.

Massé D.I. y Cata Saady, N. M, (2015). High rate psychrophilic anaerobic digestion of undiluted dairy cow feces. Bioresource Technology 187, 128-135.

McCarty, P. (1981). One hundred years of anaerobic treatment. Anaerobic Digest En: Hunghes, et al. Anaerobic digestion (eds). Elsevier Biomedical Press. Amsterdam, 3-22.

Metcalf, D. M. y Eddy, P. (1995). Ingeniería de aguas residuales: tratamiento vertido y reutilización. Mc Graw Hill. Madrid. España.

Morales, M., Sosa, M. y Boucíguez, A. (2021). Captación y medida del volumen de biogás producido por un digestor anaeróbico enterrado. Actas del VII Congreso Argentino de Ingeniería Mecánica (CAIM VII) y II, Congreso Argentino de Ingeniería Ferroviaria CAIFE II, artículo C-57, realizado del 15 al 17 de setiembre en San Nicolás de los Arroyos, Pcia de Bs. As., Argentina. 
Morales, M., Sosa, M. y Boucíguez, A. (2018). Digestor anaeróbico enterrado asistido por energía solar térmica. VI Congreso Argentino de Ingeniería Mecánica, CAIM y I Congreso Argentino de Ingeniería Ferroviaria, CAIFE, realizado en San Miguel de Tucumán, Argentina. ISSN: 978-987-46987-0-4.

Morales, M., Sosa, M. y Boucíguez, A. (2017). Evaluación de un sistema de calefacción solar-eléctrico aplicado a un digestor anaeróbico enterrado. 12th LatinAmerican Congress on Electricity Generation and Transmission, CLAGTEE 2017, Mar del Plata, Argentina. ISBN: 978-8564689-00-8.

Morales, M., Sosa, M. y Boucíguez, A. (2016). Propuesta de un material descartable como aislante térmico: aplicación a un digestor anaeróbico enterrado. XXXIX Reunión de Trabajo de la Asociación Argentina de Energías Renovables y Medio Ambiente, ASADES 2016, 4, 03.59-03.65. ISBN: 978-987-29873-0-5.

Morales, M., Vilte, M., Artunduaga, C. y Barboza, B. (2015). Estudio del rendimiento energético de un digestor anaeróbico. XXXVIII Reunión de Trabajo de la Asociación Argentina de Energías Renovables y Medio Ambiente, ASADES 2015, 3, 06.127-06.135, San Rafael, Mendoza, Argentina. ISBN: 978-9872987305.

Morales, M., Vilte, M., Sosa, M. y Boucíguez, A. (2014). Evaluación de un aislamiento térmico construido a partir de materiales descartables para su utilización en digestores anaeróbicos. IV Congreso Argentino de Ingeniería Mecánica, CAIM 2014. La Plata, Argentina. ISSN: 978-987-45571-1-7.

Morales, M., Sosa, M. y Boucíguez, A. (2013). Diseño y construcción de un digestor de membrana flexible. Distintas alternativas para su acondicionamiento térmico. XI Congreso Iberoamericano de Ingeniería Mecánica, CIBIM 2013, 1, 180. La Plata, Argentina. ISBN 97895034-1026-4.

Morales, M., Martina, P., Aeberhard, R., Corace, J. y Boucíguez, A. (2013). Estudio experimental y numérico del comportamiento térmico de un proceso de biodigestión anaeróbica con mezcla de diversos sustratos. Matemática Aplicada, Computacional e Industrial, 14, 710-713. Ciudad Autónoma de Buenos Aires, Argentina. ISSN: 23143282.

Morales, M., Plaza, G., Boucíguez, A. y Jaramillo, R. (2010). Bioensayo anaeróbico del estiércol de conejo. XXXIII Reunión de Trabajo de la Asociación Argentina de Energías Renovables y Ambiente (ASADES 2010) y XIX Encuentro de la Sección Argentina de la Asociación Internacional para la Educación en Energía Solar, 14, 06.47-06.53, Cafayate, Salta. ISSN 0329-5184.

Morales, M, Boucíguez, A. y Plaza, G. (2009). Acondicionamiento Térmico de Digestores Anaeróbicos con Sustancias de Cambio de Fase. Avances en Energías Renovables y Medio Ambiente, Revista de la Asociación Argentina 
de Energías Renovables y Medio Ambiente, ASADES 2009, 13, 3.135 - 3.140. Rio Cuarto, Córdoba, Argentina. ISSN: 0329-5184.

Morales, M., Boucíguez, A. y Plaza, G. (2009). Estudio de Factibilidad de Acondicionamiento Térmico de un Biodigestor con Sustancias de Cambio de Fase. Mecánica Computacional. Asociación Argentina de Mecánica Computacional. XXVIII, 3093- 3101, Tandil, Buenos Aires, Argentina. ISSN: 16666070.

Muñoz Valero, J., Ortiz Cañavate, J. y Vázquez Minguela, J. (1987). Técnica y aplicaciones agrícolas de la biometanización. Serie Técnica- Ministerio de Agricultura Pesca y Alimentación. Madrid.

Oilfox 2019. Empresa que desarrolla biocombustibles y sus derivados. [online]. Disponible en: < www.oilfox.com.ar > [Acceso 16/09/2019].

Parkin, G. y Owen, W. (1986). Fundamentals of anaerobic digestion wastewater sludges. Journal of Environment Engineering, 112, 867-920.

Paslotathis, S. G. y Girardo-Gomez, E. (1991) Kinetics of Anaerobic Treatment: A Critical Review. Critical Reviews in Environmental Control, 21 (5,6), 411$490 . \quad$ [online]. Disponible en: <http://dx.doi.org/10.1080/10643389109388424> [Acceso 16/09/2015].

Perrigault, T., Marti-Herrero, V., Weatherford, J. y Poggio, D. (2012). Towards thermal design optimization of tubular digester in cold climates: A heat transfer model. Bioresource technology, 124, 259-268.

Samayoa, S., Bueso, C. y Viquez, J. (2012). Guía Implementación de sistemas de biodigestión en ecoempresas. Programa regional de medio ambiente en Centro América. Honduras.

Secretaria de Energía de la Nación. (2018). Balances Energéticos Nacionales, BEN $2018 . \quad$ [online]. Disponible en: <www.argentina.gob.ar/energía/hidrocarburos/balances-energéticos> [Acceso 6/09/2019].

Secretaria de Estado de la Energía del Gobierno de la Provincia de Santa Fe. (2018). Educación Energética, [online]. Disponible en: <http://www.santafe.gob.ar/index.php/web/content/view/full/224309/ (subtema) / 202790> [Acceso 6/09/2019].

Secretaría de Prensa y Comunicación de la Provincia de Salta. (2011). En La Candelaria el Gobernador inauguró el primer biodigestor del país, 14/06. [online]. Disponible en: <www.salta.gov.ar/prensa/noticias/en-la- 
candelaria-el-gobernador-inauguro-el-primer-biodigestor-delpais/11375> [Acceso 6/09/2015].

Secretaria de Prensa y Comunicación de la Provincia de Salta. (2013). El Gobernador Urtubey recorre Planta de Biogás en Vertedero San Javier. [online]. Disponible en: https://www.salta.gob.ar/prensa/videos/institucional1/gobernador-urtubey-recorre-planta-de-biogas-en-vertedero-san-javier070113-gobierno-de-salta-1860.

SENASA- Servicio Nacional de Sanidad y Calidad Agroalimentaria. (2016). Existencias históricas bovinas por categoría y departamento. [online]. Disponible en: http://www.senasa.gob.ar/serie-historica-existenciasbovinas-por-categoria-y-departamento-2008-2016.

SENASA - Servicio Nacional de Sanidad y Calidad Agroalimentaria. (2017). Movimientos de Ganado Bovino. Informe estadístico $N^{o}$ 18. [online]. Disponible en: <http://www.senasa.gob.ar/serie-historica-existenciasbovinas-por-categoria-y-departamento-2008-2016.> [Acceso 6/03/2017].

Siegrist, H., Renggli, D. y Gujer, W. (1993). Mathematical modelling of anaerobic mesophilic sewage sludge treatment. Water Science and Technology. 27 (2), 25-36.

Speece, R. (1987). Nutrient Requirements, an anaerobic digestion of biomass. Editado por Chynowth D. Y y Isaacson, R. Elsevier Applied Science LTD.

Speece, R. (1996). Anaerobic biotechnology for industrial wastewater treatments. Archae Press, Nashvillee, TN, USA.

Stafford, D. (1982). The effects of mixing and volatile fatty acid concentrations on anaerobic digester performance. Biomass, 2, 43-55.

Stams, A. (1994). Metabolic interactions between anaerobic bacteria in methanogenic environments. Antonie van Leeuwenhoek, 66, 271-294. [online]. Disponible en: <https://doi.org/10.1007/BF00871644> [Acceso $6 / 09 / 2015]$.

Tsagarakis, K.P. y Papadogiannis, Ch. (2006). Technical and economic evaluation of the biogas utilization for energy production at Iraklio Municipality, Greece. Energy Conversion and Management, 47 (7-8), 844-857. [online]. Disponible en: <https://doi.org/10.1016/j.enconman.2005.06.017> [Acceso 26/06/2015].

Varnero, M. y Arellano, J. (1990). Aprovechamiento racional de desechos orgánicos. Ministerio de Agricultura, Fondo de Investigación Agropecuaria FIA, Universidad de Chile, Facultad de Ciencias Agrarias y Forestales, Facultad 
de Ciencias Físicas y Matemáticas, Informe Técnico. Santiago, Chile. [online]. $6 / 09 / 2015]$.

Veeken, A. y Hamelers, B. (1999). Effect of temperature on hydrolysis rates of selected biowaste components. Bioresource Technology, 69 (3), 249-254. [online]. Disponible en: <https://doi.org/10.1016/S0960-8524(98)001886> [Acceso 6/09/2015].

Vera Cepis, A. (1996). Fundamentos básicos para el diseño de biodigestores anaeróbicos rurales: producción de gas y saneamiento de efluentes. Centro Panamericano de Ingeniería Sanitaria y Ciencias del Ambiente. Oficina regional de la Organización Mundial de la Salud. Lima, Perú.

Verma, S. (2002) Anaerobic digestion of biodegradable organics in municipal solid waste. Thesis for Master Sciences. Department of Earth \& Environmental Engineering (Henry Krumb School of Mines), Foundation School of Engineering \& Applied Science Columbia University, mayo. [online]. Disponible en: <https://secureservercdn.net/198.71.233.185/epm.300.myftpupload.com /wp-content/uploads/2020/10/Verma_thesis.pdf> [Acceso 6/04/2015].

Vinoth Kumar, K. y Kasturi Bai, R. (2005). Plastic biodigesters -A systematic study. Energy of Sustainable Development, 9 (4), 40-49. [online]. Disponible en: < https://www.sciencedirect.com/science/article/pii/S097308260860498 6> [Acceso 15/08/2008].

Viquez, J. (2011). Digestor anaeróbico de flujo ascendente (UASB) y humedal artificial para el tratamiento de agua residual de la industria porcina. UTN informa al Sector Agropecuario № 57. Revista Oficial de la Universidad Técnica Nacional, Sede Atenas. [online]. Disponible en: <https://www.utn.ac.cr/sites/default/files/attachments/revista57.pdf> [Acceso 6/09/2015].

Leyes Nacionales y de la Provincia de Salta.

Ley Nacional № 26.093/06. (2006). Régimen de regulación y promoción para la producción y uso sustentables de biocombustibles. [online]. Disponible en: < http://servicios.infoleg.gob.ar/infolegInternet/anexos/115000119999/116299/norma.htm > [Acceso 6/09/2017]. 
Ley Nacional № 26.190/06. (2006). Régimen de fomento Nacional para el uso de fuentes renovables de energía destinada a la producción de energía eléctrica. [online]. Disponible en: Morales, M., Sosa, M. y Boucíguez, A. <http://servicios.infoleg.gob.ar/infolegInternet/anexos/120000124999/123565/ norma.htm > [Acceso 6/09/2015].

Ley Nacional № 27.191/15. (2015). Modificaciones a la Ley 26190 Régimen de fomento Nacional para el uso de fuentes renovables de energía destinada a la producción de energía eléctrica. [online]. Disponible en: $<$ http://servicios.infoleg.gob.ar/infolegInternet/anexos/250000254999/253626/norma.htm> [Acceso 6/03/2016].

Ley Provincial de Salta № 7.070/00. (2000) De protección del medio ambiente, Salta, 21 de diciembre de 1999, Boletín Oficial, 27 de enero de 2000, [online]. Disponible en: <http://www.saij.gob.ar/7070-local-salta-proteccionmedio-ambiente-lpa0007070-1999-12-21/123456789-0abc-defg-0707000avorpyel?> [Acceso 6/09/2015].

Resolución 1.076/01. (2001). Creación del Programa Nacional de Biocombustibles relacionado con la problemática del cambio climático. Secretaría de Desarrollo Sustentable y Política Ambiental. [online]. Disponible en: < http://mepriv.mecon.gov.ar/Normas/1076-01.htm> [Acceso 6/09/2015].

Resolución 1.156/04. (2004). Creación del programa Nacional de Biocombustibles. Secretaría de Agricultura, Ganadería, Pesca y Alimentos. [online] Disponible en: <http://servicios.infoleg.gob.ar/infolegInternet/anexos/100000-104999/ 100994/ norma.htm > [Acceso 02/10/2015].

Publicaciones realizadas durante el desarrollo de la Tesis.

Morales, M., Sosa, M. y Boucíguez, A. (2021). Captación y medida del volumen de biogás producido por un digestor anaeróbico enterrado. Actas del VII Congreso Argentino de Ingeniería Mecánica (CAIM VII) y II, Congreso Argentino de Ingeniería Ferroviaria CAIFE II, artículo C-57, realizado del 15 al 17 de setiembre en San Nicolás de los Arroyos, Pcia de Bs. As., Argentina.

Morales, M., Sosa, M. y Boucíguez, A. (2018). Digestor anaeróbico enterrado asistido por energía solar térmica. VI Congreso Argentino de Ingeniería Mecánica, CAIM y I Congreso Argentino de Ingeniería Ferroviaria, CAIFE, realizado en San Miguel de Tucumán, Argentina. ISSN: 978-987-46987-0-4. 
Morales, M., Sosa, M. y Boucíguez, A. (2017). Evaluación de un sistema de calefacción solar-eléctrico aplicado a un digestor anaeróbico enterrado. 12th LatinAmerican Congress on Electricity Generation and Transmission, CLAGTEE 2017, Mar del Plata, Argentina. ISBN: 978-8564689-00-8.

Morales, M., Sosa, M. y Boucíguez, A. (2016). Propuesta de un material descartable como aislante térmico: aplicación a un digestor anaeróbico enterrado. XXXIX Reunión de Trabajo de la Asociación Argentina de Energías Renovables y Medio Ambiente, ASADES 2016, 4, 03.59-03.65. ISBN: 978-987-29873-0-5.

Morales, M., Vilte, M., Artunduaga, C. y Barboza, B. (2015). Estudio del rendimiento energético de un digestor anaeróbico. XXXVIII Reunión de Trabajo de la Asociación Argentina de Energías Renovables y Medio Ambiente, ASADES 2015, 3, 06.127-06.135, San Rafael, Mendoza, Argentina. ISBN: 978-9872987305.

Morales, M., Vilte, M., Sosa, M. y Boucíguez, A. (2014). Evaluación de un aislamiento térmico construido a partir de materiales descartables para su utilización en digestores anaeróbicos. IV Congreso Argentino de Ingeniería Mecánica, CAIM 2014. La Plata, Argentina. ISSN: 978-987-45571-1-7.

Morales, M., Sosa, M. y Boucíguez, A. (2013). Diseño y construcción de un digestor de membrana flexible. Distintas alternativas para su acondicionamiento térmico. XI Congreso Iberoamericano de Ingeniería Mecánica, CIBIM 2013, 1, 180. La Plata, Argentina. ISBN 9789-5034-1026-4.

Morales, M., Martina, P., Aeberhard, R., Corace, J. y Boucíguez, A. (2013). Estudio experimental y numérico del comportamiento térmico de un proceso de biodigestión anaeróbica con mezcla de diversos sustratos. Matemática Aplicada, Computacional e Industrial, 14, 710-713. Ciudad Autónoma de Buenos Aires, Argentina. ISSN: 2314 - 3282.

Morales, M., Plaza, G., Boucíguez, A. y Jaramillo, R. (2010). Bioensayo anaeróbico del estiércol de conejo. XXXIII Reunión de Trabajo de la Asociación Argentina de Energías Renovables y Ambiente (ASADES 2010) y XIX Encuentro de la Sección Argentina de la Asociación Internacional para la Educación en Energía Solar, 14, 06.47-06.53, Cafayate, Salta. ISSN 0329-5184.

Morales, M., Boucíguez, A. y Plaza, G. (2009). Acondicionamiento Térmico de Digestores Anaeróbicos con Sustancias de Cambio de Fase. Avances en Energías Renovables y Medio Ambiente, Revista de la Asociación Argentina de Energías Renovables y Medio Ambiente, ASADES 2009, 13, 3.135 - 3.140. Rio Cuarto, Córdoba, Argentina. ISSN: 0329-5184. 
Morales, M, Boucíguez, A. y Plaza, G. (2009). Estudio de Factibilidad de Acondicionamiento Térmico de un Biodigestor con Sustancias de Cambio de Fase. Mecánica Computacional. Asociación Argentina de Mecánica Computacional. XXVIII, 3093- 3101, Tandil, Buenos Aires, Argentina. ISSN: $1666-6070$. 


\section{ANEXO A1 \\ DETALLE TÉCNICO DE LOS COMPONENTES QUE INTEGRAN \\ LOS SISTEMAS DE CALENTAMIENTO.}

Se presenta a continuación los esquemas extraídos de los capítulos anteriores y el detalle técnico de los componentes utilizados.

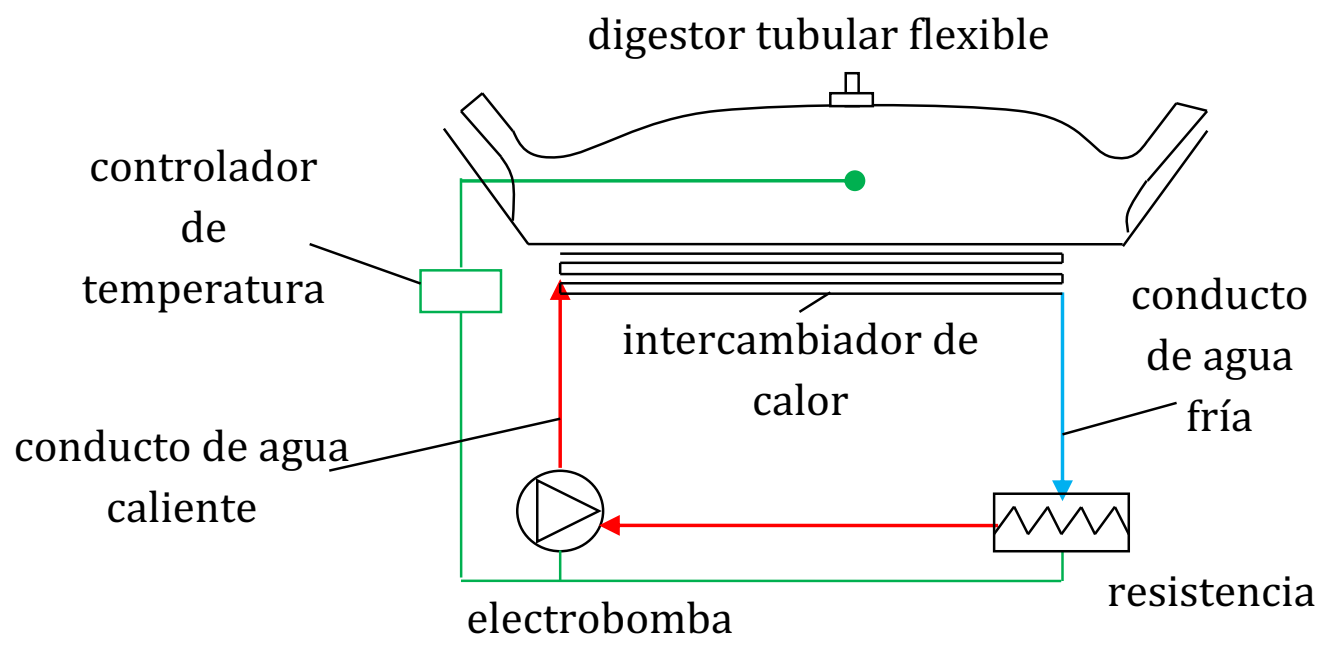

Figura 6.6. Sistema de calentamiento con control de temperatura del digestor tubular flexible.

Controlador de temperatura: marca Novus. Modelo N231. Voltaje de entrada $220 \mathrm{~V}$ AC. Sensores thermistor $\left(-30^{\circ} \mathrm{a}+105^{\circ} \mathrm{C}\right)$. Salida: Relé SPDT: $1 \mathrm{HP} 250 \mathrm{Vac} / 1 / 3 \mathrm{HP}$ 125 Vac (16 A Resisitivo). Resolución: $0,1^{\circ} \mathrm{C}$ entre $-19,9^{\circ}$ a $199,9^{\circ} \mathrm{C}$. Precisión: $\pm 0,5$ ${ }^{\circ} \mathrm{C} /{ }^{\circ} \mathrm{F} \pm 1$ digit (Pt100 / Pt1000 / Thermistor). Muestreo: 1,5 veces por segundo. Dimensiones: 75 × 33 × $75 \mathrm{~mm}$

Electrobomba: marca: ASKOLL. Voltaje de entrada $220 \mathrm{~V}$. Potencia nominal: 30W. Caudal medio: 22 l/min.

Resistencia eléctrica: potencia 1200W. Material: aluminio.

Intercambiador de calor: material: caño de 3/4 de pulgada de PVC. Construcción propia.

Conductos de agua: material (PVC). Caño de 3/4 de pulgada de diámetro. 


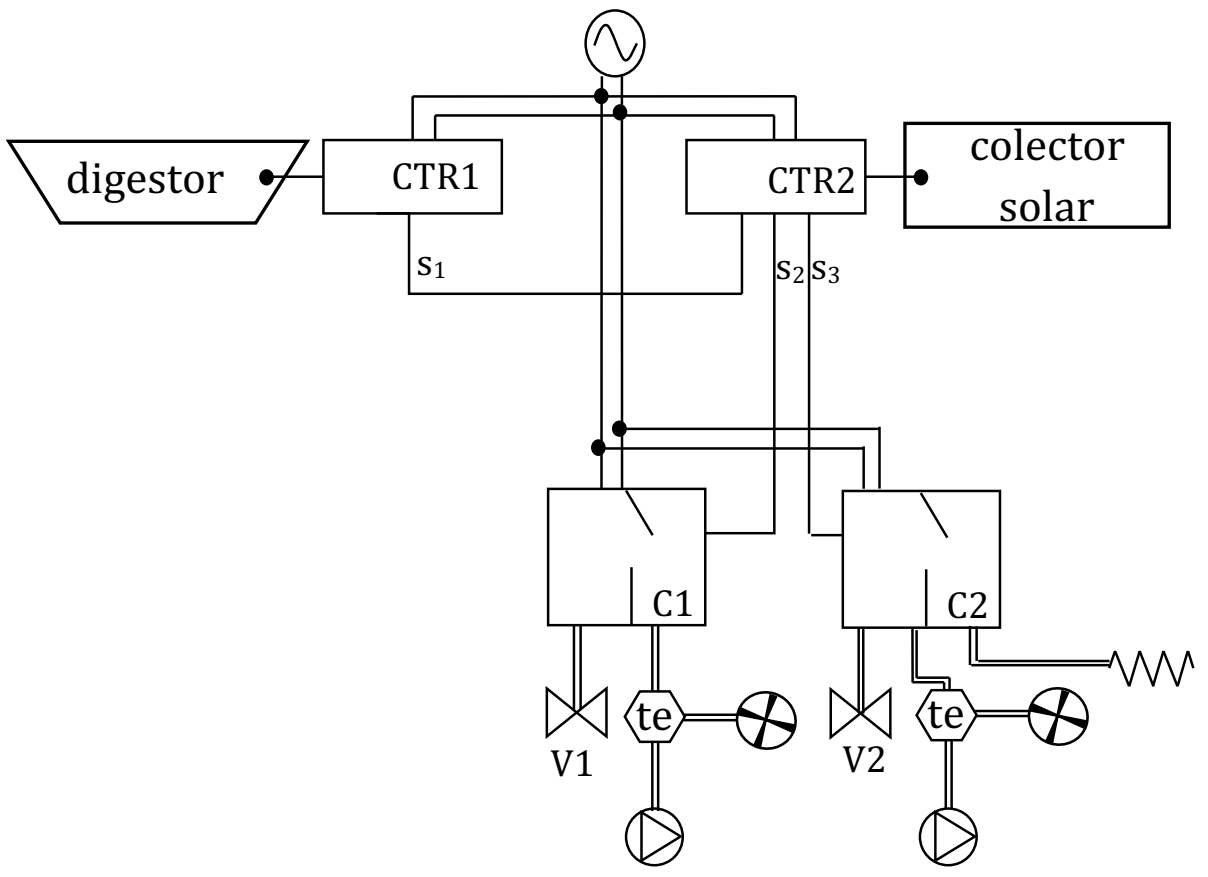

válvula eléctrica
$\mathrm{V} 1, \mathrm{~V} 2$

(1) electrobomba

M resistencia temporizador

te

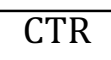

controlador de CTR1, CTR2

$\mathrm{S}_{1}, \mathrm{~s}_{2}, \mathrm{~S}_{3}$ salidas del controlador de temperatura

$\bigotimes$ mezclador

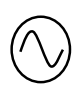

red de voltaje

Figura 6.23. Sistema de control de calentador híbrido solar-eléctrico.

Contactor eléctrico: marca Sica. Modelo: 740910. Voltaje de entrada: $220 \mathrm{~V}$. Amperaje: 9 A. Cantidad de polos 3. Circuitos de control CA.

Electrobomba: marca: Pedrollo. Modelo: Pkm60. Voltaje 220 AC. Potencia $1 / 2 \mathrm{Hp}$. Caudal $0,8 \mathrm{~kg} / \mathrm{s}$.

Intercambiador de calor: material (PVC). Caño de 3/4 de pulgada de diámetro. Construcción propia.

Mezclador: material: hierro. construcción propia

Resistencia eléctrica: marca: DAMFER. Voltaje de entrada $220 \mathrm{~V} \mathrm{AC}$. Rango de $20^{\circ} \mathrm{C}$ a $80^{\circ} \mathrm{C}$. Potencia: $1.500 \mathrm{~W}$. Longitud: $27,5 \mathrm{~cm}$.

Temporizador: voltaje de entrada: $220 \mathrm{~V}$ AC. Corriente nominal: 10 A. Tiempo mínimo 15 min. Tiempo máximo 24 hs. Marca: FODA. Modelo: analógico.

Válvulas eléctricas: voltaje de entrada 220-240 V AC. Frecuencia: 50/60 Hz. Marca: Micron Modelo: Bitron. 

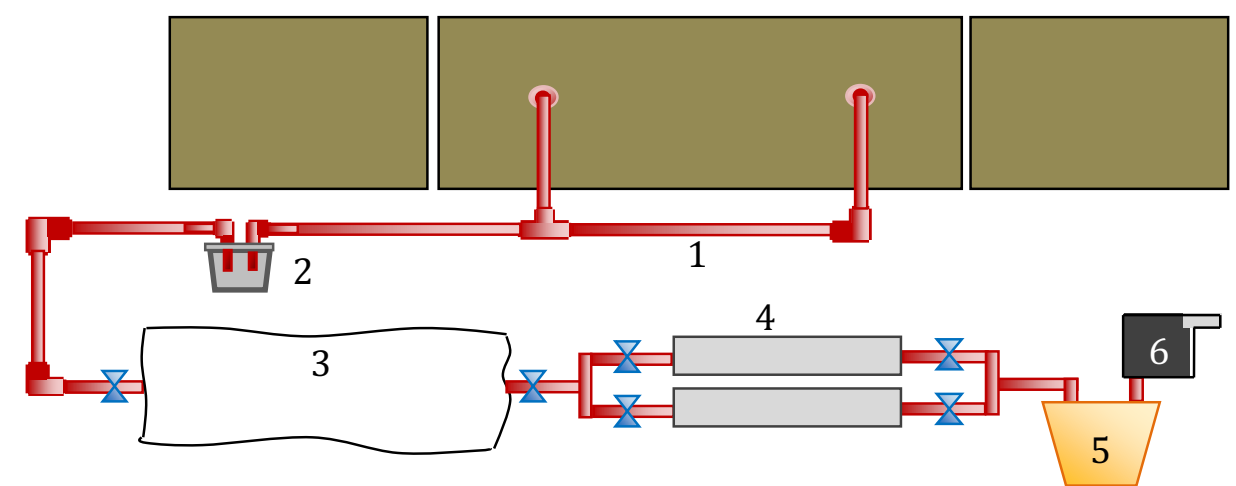

1

conductos

$\begin{array}{ccc}2 & 3 & 4 \\ \text { deshumidificador } & \text { gasómetro } & \text { filtros }\end{array}$

5
contador
volumétrico
de biogás

6 extractor de biogás

Figura 9.1. Representación de la captación, filtración y cuantificación del biogás.

Conductos: material: PVC. Caño de $3 / 4$ de pulgada de diámetro.

Contador volumétrico de biogás: marca Itrón. Modelo Gallus G4. Caudal máximo $6,0 \mathrm{~m}^{3} / \mathrm{h}$. Caudal mínimo $0,04 \mathrm{~m}^{3} / \mathrm{h}$. Potencia máxima 0,5 bar.

Deshumidificador: material: PVC. Caño de 110 cm de diámetro. Construcción propia.

Extractor de biogás: marca: Libercam. Modelo INF-12. voltaje de entrada 12V DC. caudal (medido en el laboratorio). Marca Modelo.

Gasómetro (reservorio flexible): material, membrana flexible de PVC de $1100 \mu \mathrm{m}$. Construcción propia.

Filtros: material: PVC. Caño de 110 cm y 3/4 de pulgada de diámetro. Construcción propia.

En la determinación de la curva de rendimiento del colector solar se utiliza el sensor de irradiancia solar con las siguientes características:

Sensor de irradiancia solar: marca: David Instruments. Temperatura de operación: $-40^{\circ}$ a $65^{\circ} \mathrm{C}$. Temperatura de acumulación: $-45^{\circ}$ a $70^{\circ} \mathrm{C}$. Respuesta espectral 400 a 1.100 nanómetros. Resolución $1 \mathrm{~W} / \mathrm{m}^{2}$. Rango 0 a $1800 \mathrm{~W} / \mathrm{m}^{2}$. 


\section{ANEXO A2 \\ PLANO DEL DIGESTOR ANAEROBICO ENTERRADO}

Digestor anaeróbico enterrado- Corte A-A. 232

Digestor anaeróbico enterrado- Corte B-B. 233

Digestor anaeróbico enterrado - Conducción del biogás. 234

Digestor anaeróbico enterrado - Planta digestor. 235

Digestor anaeróbico enterrado - Invernadero. 236 


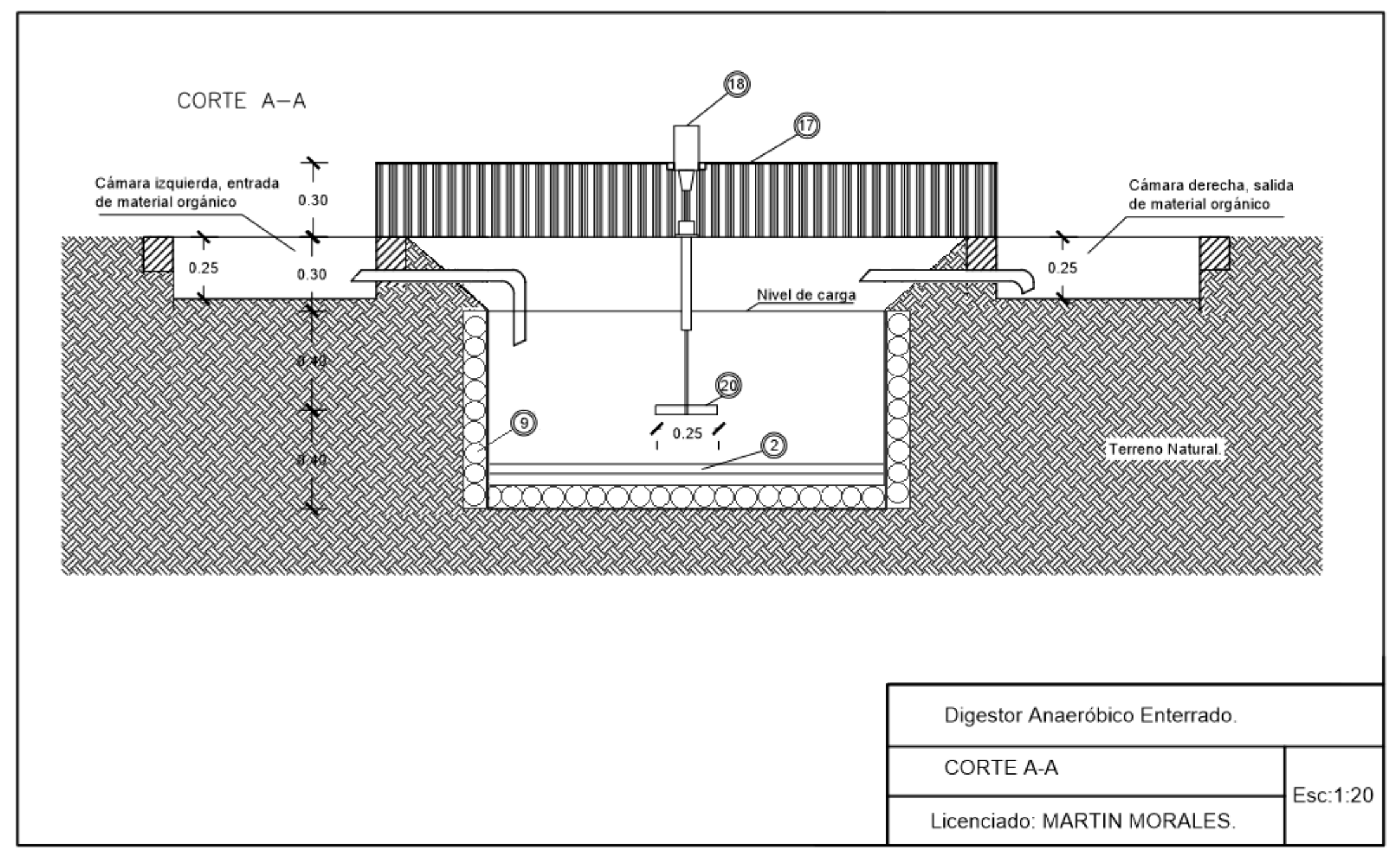




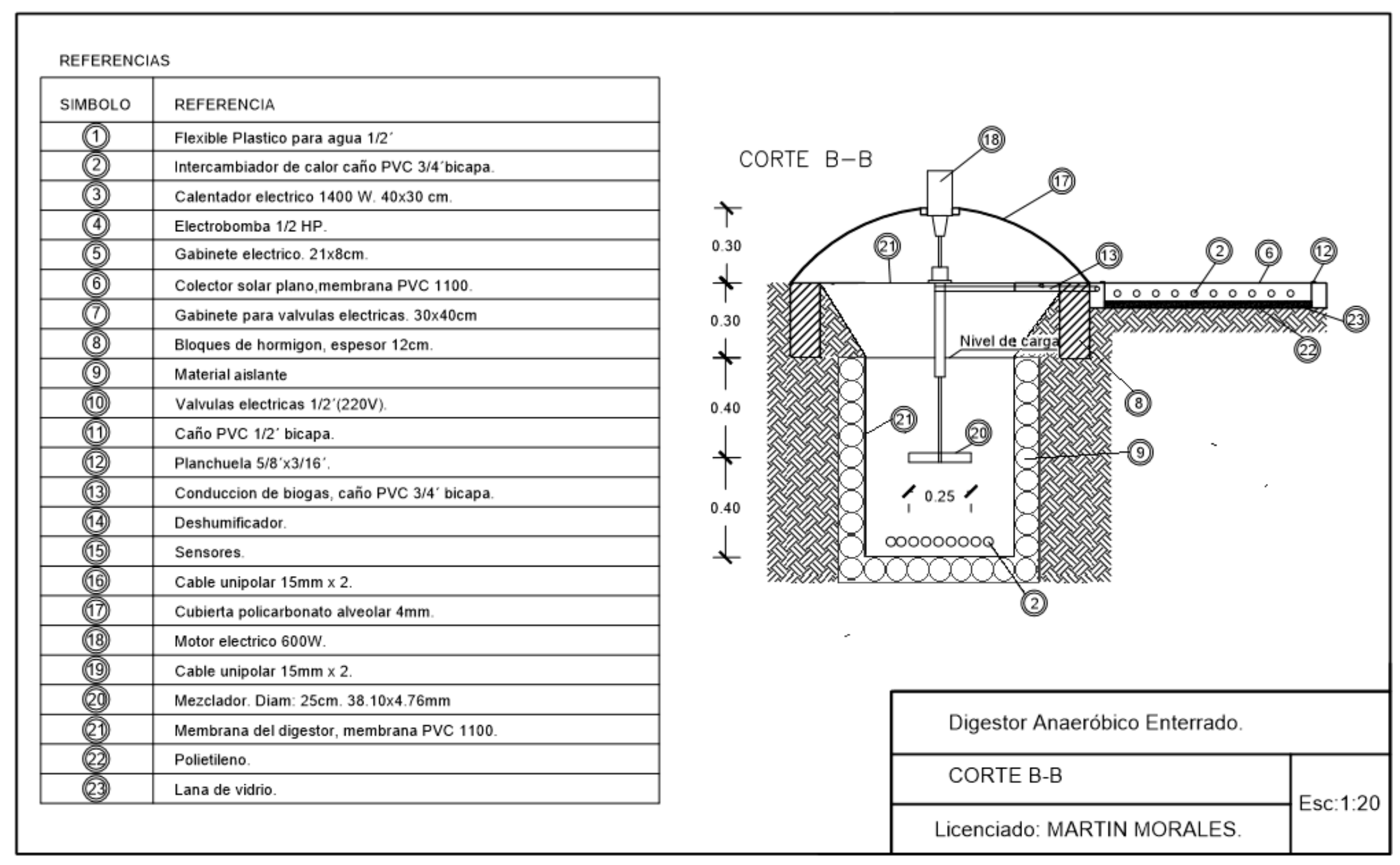




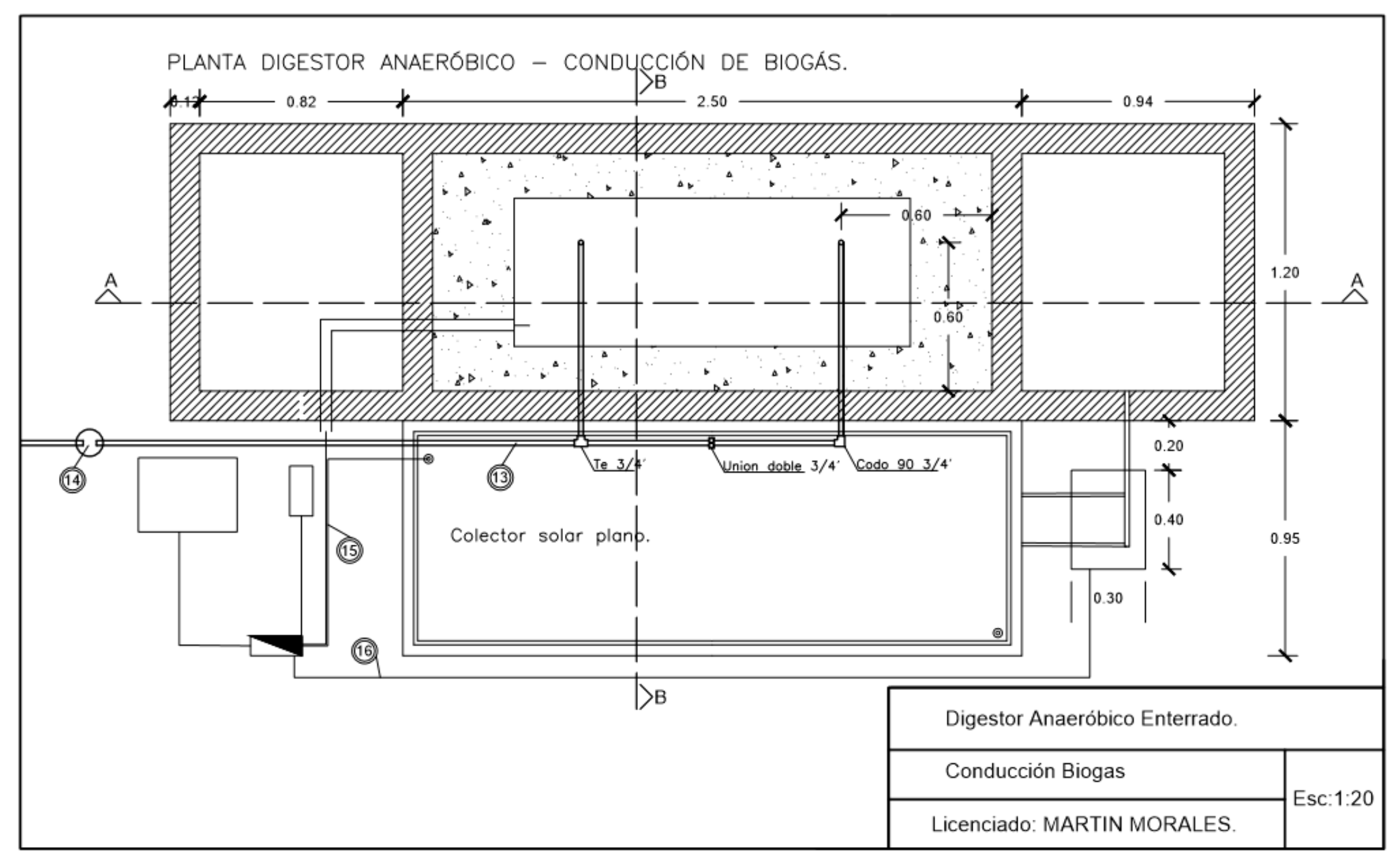




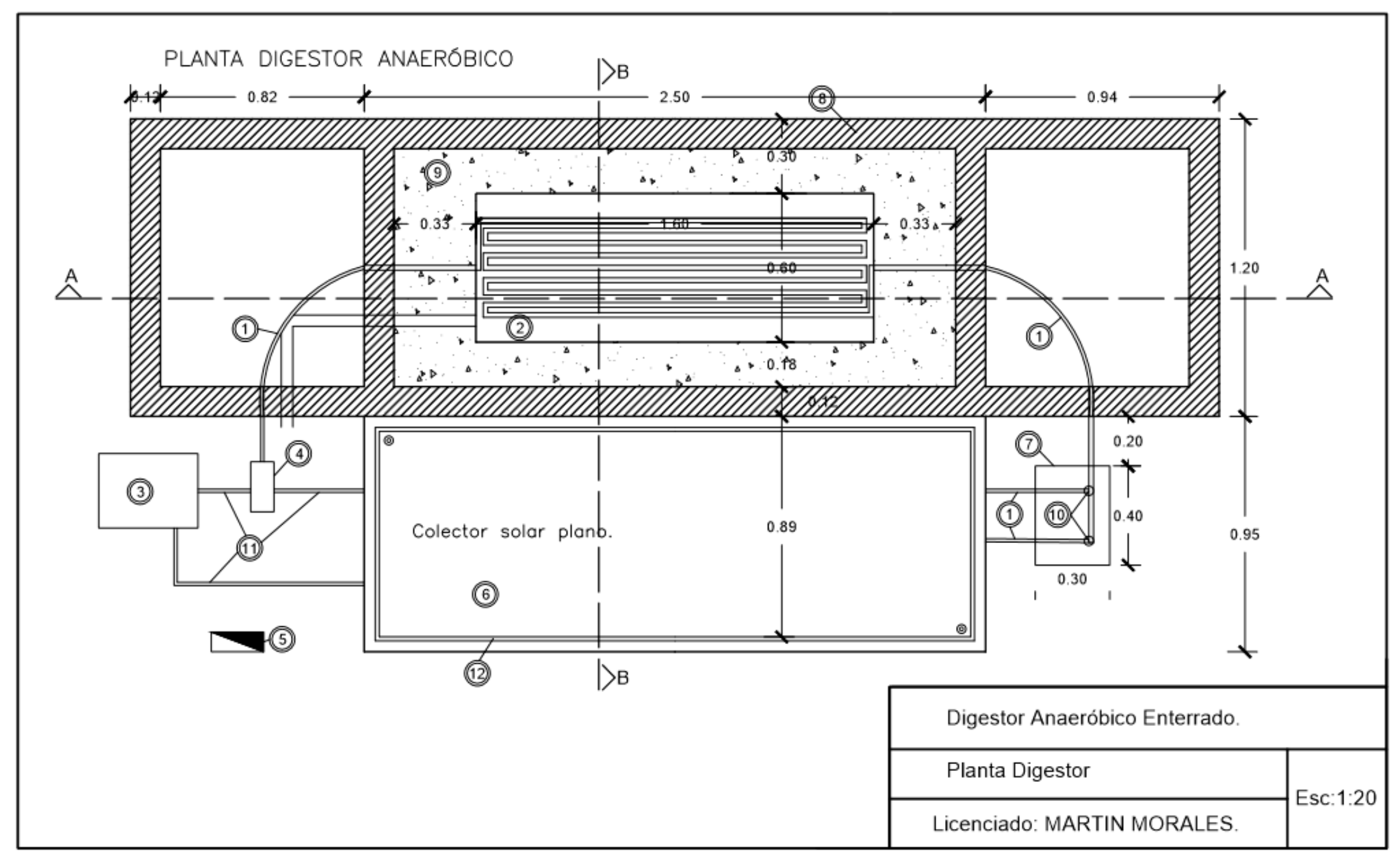




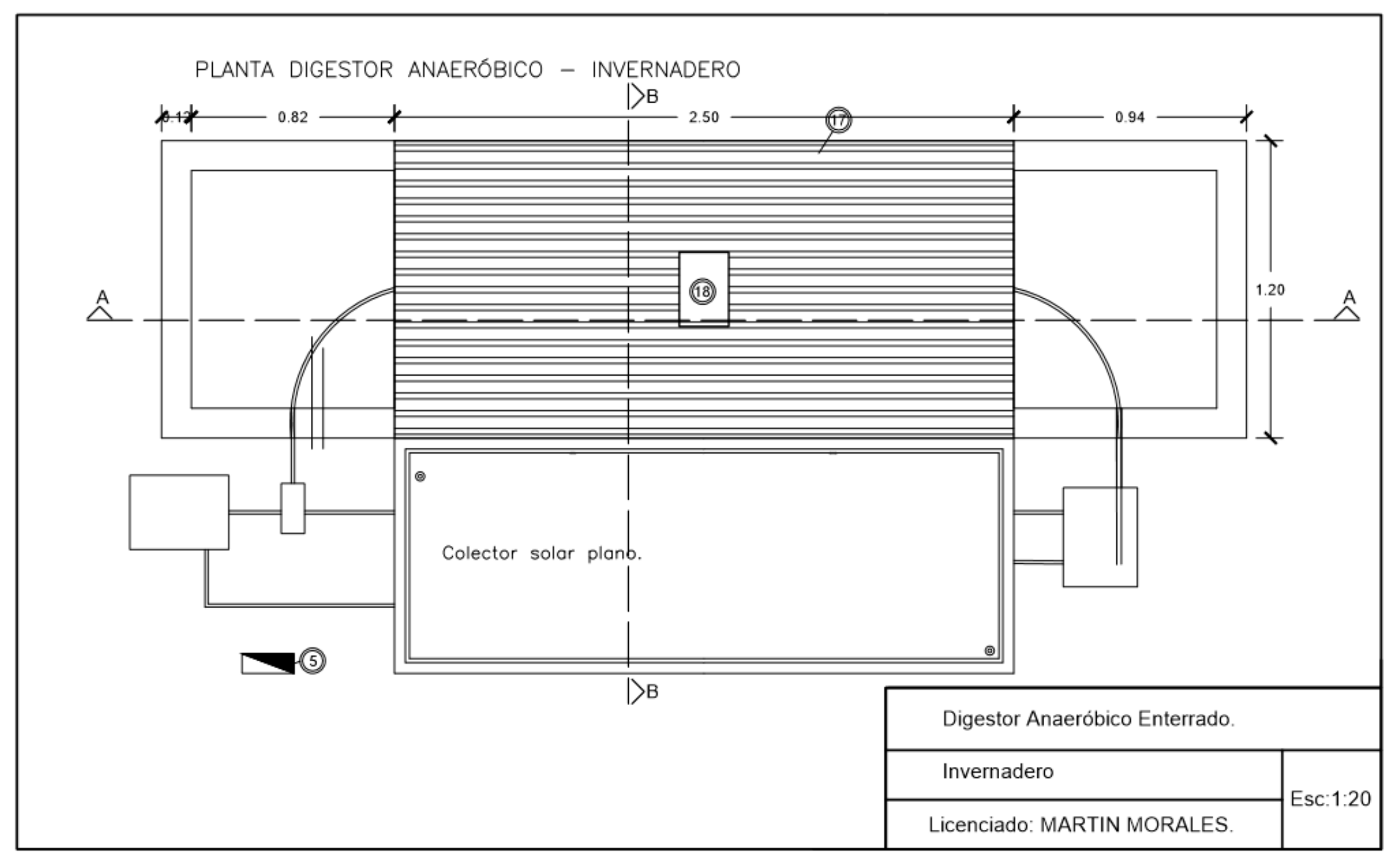




\section{ANEXO A3 \\ COTIZACIÓN DEL DÓLAR.}

En este trabajo se considera la cotización del día 4/9/2019, 1 U\$S =57 \$ arg.

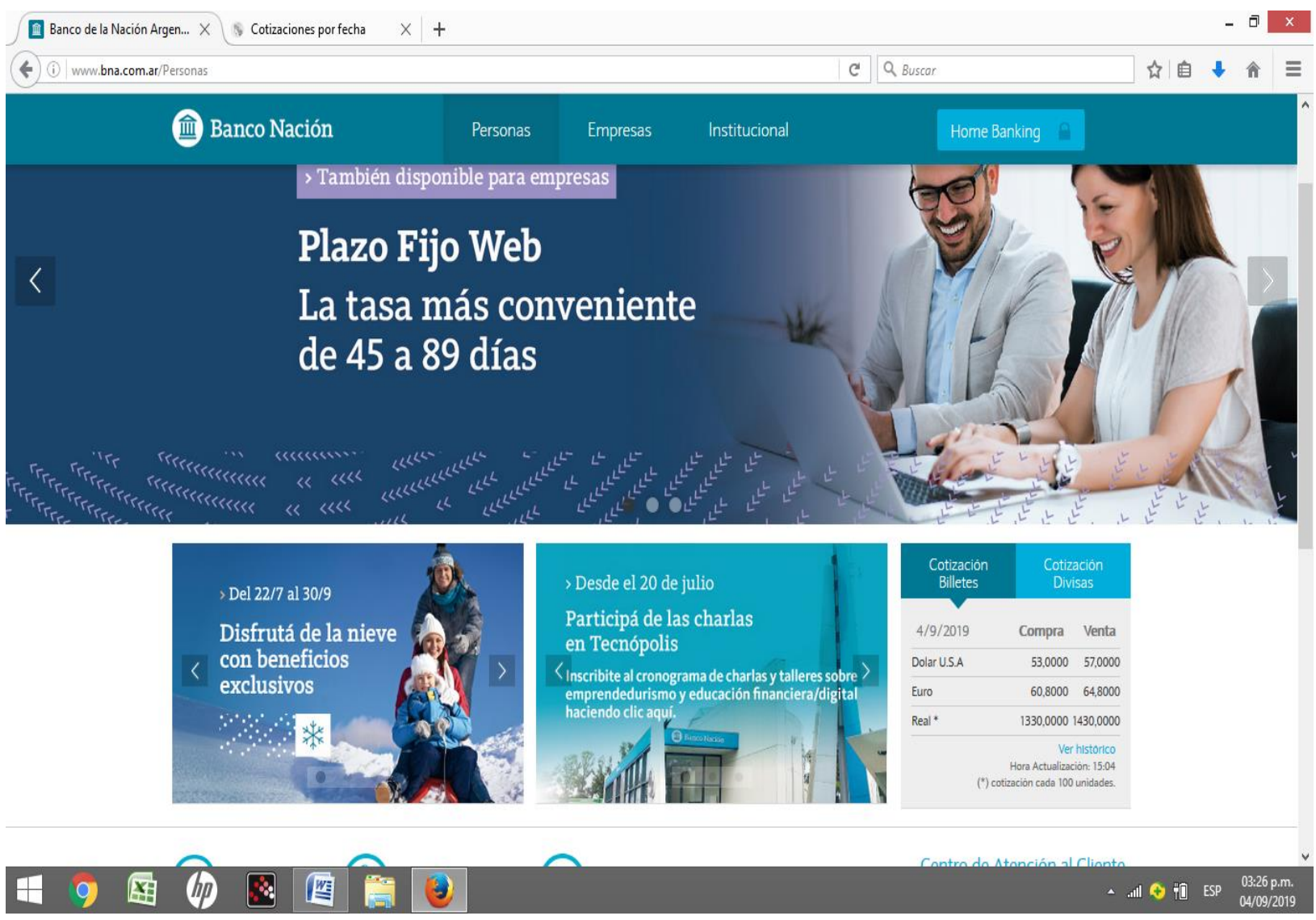

Fuente: Banco de la Nación Argentina. 
ANEXO A4

TABLAS DE MATERIALES Y COSTOS.

\begin{tabular}{|c|c|c|c|}
\hline \multirow{2}{*}{ CASO } & \multicolumn{3}{|c|}{ DIGESTOR } \\
\cline { 2 - 4 } & $\begin{array}{c}\text { largo } \\
(\mathrm{m})\end{array}$ & $\begin{array}{c}\text { ancho } \\
(\mathrm{m})\end{array}$ & $\begin{array}{c}\text { profundidad } \\
(\mathrm{m})\end{array}$ \\
\hline I & 5,00 & 2,50 & 1,60 \\
\hline II & 6,00 & 1,60 & 3,00 \\
\hline III & 7,00 & 1,90 & 3,00 \\
\hline IV & 8,00 & 2,00 & 3,00 \\
\hline
\end{tabular}

\begin{tabular}{|c|c|c|c|c|}
\hline \multirow{2}{*}{ CASO } & \multicolumn{4}{|c|}{ DIGESTOR } \\
\cline { 2 - 5 } & $\begin{array}{c}\text { área total } \\
\left(\mathrm{m}^{2}\right)\end{array}$ & $\begin{array}{c}\text { área superior } \\
\left(\mathrm{m}^{2}\right)\end{array}$ & $\begin{array}{c}\text { perímetro } \\
\text { superior } \\
(\mathrm{m})\end{array}$ & $\begin{array}{c}\text { volumen } \\
\left(\mathrm{m}^{3}\right)\end{array}$ \\
\hline I & 49,0 & 12,5 & 15,0 & 20 \\
\hline II & 64,8 & 9,6 & 15,2 & 30 \\
\hline III & 80,0 & 13,3 & 17,8 & 40 \\
\hline IV & 92,0 & 16,0 & 20,0 & 50 \\
\hline
\end{tabular}

En las siguientes tablas se indica el costo de cada elemento de las diferentes secciones del biodigestor en dólares. Para el cálculo del costo se ha utilizado la cotización del dólar del día 4/9/2019 (1 dólar U\$S =57 \$, ver Anexo III).

1. COLECTOR SOLAR.

2. CONDUCCIÓN DE AGUA CALIENTE.

3. CONDUCCIÓN DEL BIOGÁS.

4. CUERPO DEL DIGESTOR.

5. INVERNADERO.

6. MEZCLADOR.

7. SISTEMA DE CONTROL. 


\begin{tabular}{|c|c|c|c|c|c|}
\hline \multicolumn{7}{|c|}{ COLECTOR SOLAR (U\$S) } \\
\cline { 1 - 4 } CASO & membrana & planchuela & $\begin{array}{c}\text { brida } \\
1 / 2{ }^{\prime \prime}\end{array}$ & $\begin{array}{c}\text { conexión } \\
\text { gris }\end{array}$ & $\begin{array}{c}\text { caño } \\
3 / 4^{\prime \prime}\end{array}$ \\
\hline I & 269,14 & 26,82 & 4,15 & 1,47 & 23,91 \\
\hline II & 319,91 & 33,82 & 4,15 & 1,47 & 28,70 \\
\hline III & 443,21 & 39,80 & 4,15 & 1,47 & 33,48 \\
\hline IV & 533,19 & 43,66 & 4,15 & 1,47 & 38,26 \\
\hline CASO & $\begin{array}{c}\text { codo } \\
\text { Con" }\end{array}$ & $\begin{array}{c}\text { varilla } \\
\text { roscada }\end{array}$ & cemento & arena & \\
\hline I & 1,96 & 19,71 & 82,7 & 25,32 & \\
\hline II & 1,96 & 24,85 & 104,3 & 31,94 & \\
\hline III & 1,96 & 29,25 & 122,8 & 37,59 & \\
\hline IV & 1,96 & 32,08 & 134,7 & 41,23 & \\
\hline
\end{tabular}

\begin{tabular}{|c|c|}
\hline \multicolumn{2}{|c|}{ COLECTOR SOLAR } \\
\hline CASO & TOTAL (U\$S) \\
\hline I & 455,20 \\
\hline II & 551,11 \\
\hline III & 713,70 \\
\hline IV & 830,67 \\
\hline
\end{tabular}

\begin{tabular}{|c|c|c|c|c|}
\hline \multicolumn{6}{|c|}{ CONDUCCIÓN DE AGUA CALIENTE } \\
\hline CASO & $\begin{array}{c}\text { eletrobomba } \\
1 / 2 \mathrm{HP}\end{array}$ & válvula & $\begin{array}{c}\text { caño } \\
3 / 4^{\prime \prime}\end{array}$ & $\begin{array}{c}\text { caño } \\
1 / 2{ }^{\prime \prime}\end{array}$ \\
\hline I & 56,92 & 11,38 & 29,89 & 2,13 \\
\hline II & 56,92 & 11,38 & 35,87 & 2,34 \\
\hline III & 56,92 & 11,38 & 41,85 & 2,47 \\
\hline IV & 56,92 & 11,38 & 47,83 & 2,51 \\
\hline CASO & $\begin{array}{c}\text { codo } \\
\text { 3/4" }\end{array}$ & $\begin{array}{c}\text { codo } \\
1 / 2{ }^{\prime \prime}\end{array}$ & $\begin{array}{c}\text { unión T } \\
1 / 2{ }^{\prime \prime}\end{array}$ & pegamento \\
\hline I & 10,20 & 6,37 & 0,37 & 6,44 \\
\hline II & 10,20 & 6,37 & 0,37 & 9,66 \\
\hline III & 10,20 & 6,37 & 0,37 & 9,66 \\
\hline IV & 10,20 & 6,37 & 0,37 & 11,88 \\
\hline
\end{tabular}

\begin{tabular}{|c|c|}
\hline \multicolumn{2}{|c|}{ CONDUCCIÓN DE AGUA CALIENTE } \\
\hline CASO & TOTAL $($ US) \\
\hline I & 123,70 \\
\hline II & 133,11 \\
\hline III & 139,22 \\
\hline IV & 147,46 \\
\hline
\end{tabular}




\begin{tabular}{|c|c|c|c|c|}
\hline \multicolumn{5}{|c|}{ CONDUCCIÓN DE AGUA CALIENTE (USS) } \\
\hline CASO & $\begin{array}{c}\text { codo } \\
1 / 22^{\prime \prime}\end{array}$ & $\begin{array}{c}\text { unión T } \\
1 / 22^{\prime \prime}\end{array}$ & pegamento & $\begin{array}{c}\text { TOTAL } \\
\text { (U\$S) }\end{array}$ \\
\hline I & 6,37 & 0,37 & 6,44 & 123,70 \\
\hline II & 6,37 & 0,37 & 9,66 & 133,11 \\
\hline III & 6,37 & 0,37 & 9,66 & 139,22 \\
\hline IV & 6,37 & 0,37 & 11,88 & 147,46 \\
\hline
\end{tabular}

\begin{tabular}{|c|c|c|c|c|c|}
\hline \multicolumn{7}{|c|}{ CONDUCCIÓN DEL BIOGÁS (US) } \\
\hline \multirow{2}{*}{ CASO } & $\begin{array}{c}\text { brida } \\
3 / 4 "\end{array}$ & $\begin{array}{c}\text { Caño } \\
3 / 4 "\end{array}$ & $\begin{array}{c}\text { unión doble } \\
3 / 4 "\end{array}$ & $\begin{array}{c}\text { válvula } \\
3 / 4 "\end{array}$ & $\begin{array}{c}\text { TOTAL } \\
\text { (U\$S) }\end{array}$ \\
\hline I & 4,50 & 2,60 & 12,00 & 11,40 & 30,50 \\
\hline II & 4,50 & 3,10 & 12,00 & 11,40 & 31,00 \\
\hline III & 4,50 & 4,60 & 12,00 & 11,40 & 32,50 \\
\hline IV & 4,50 & 5,50 & 12,00 & 11,40 & 33,40 \\
\hline
\end{tabular}

\begin{tabular}{|c|c|c|c|c|c|}
\hline \multicolumn{7}{|c|}{ CUERPO DEL DIGESTOR (U\$S) } \\
\hline \multirow{2}{*}{ CASO } & lona & planchuela & $\begin{array}{c}\text { caño } \\
110\end{array}$ & $\begin{array}{c}\text { codo } \\
110\end{array}$ & $\begin{array}{c}\text { Caño } \\
1 / 2 ”\end{array}$ \\
\hline I & 223,11 & 36,99 & 5,805 & 2,73 & 3,19 \\
\hline II & 295,05 & 37,49 & 5,805 & 2,73 & 3,23 \\
\hline III & 364,26 & 43,90 & 5,805 & 2,73 & 3,79 \\
\hline IV & 418,90 & 49,33 & 5,805 & 2,73 & 4,25 \\
\hline
\end{tabular}

\begin{tabular}{|r|c|c|c|c|c|c|}
\hline & \multicolumn{6}{|c|}{ CUERPO DEL DIGESTOR (U\$S) } \\
\hline CASO & cemento & $\begin{array}{c}\text { varilla } \\
\text { roscada }\end{array}$ & arena & burlete & tuercas & $\begin{array}{c}\text { TOTAL } \\
\text { (U\$S) }\end{array}$ \\
\hline I & 8,89 & 6,52 & 13,59 & 7,50 & 5,43 & 313,77 \\
\hline II & 9,01 & 6,61 & 13,77 & 7,60 & 5,51 & 386,80 \\
\hline III & 10,55 & 7,74 & 16,12 & 8,90 & 6,45 & 470,25 \\
\hline IV & 11,86 & 8,70 & 18,12 & 10,00 & 7,25 & 536,93 \\
\hline
\end{tabular}

\begin{tabular}{|c|c|c|c|c|}
\hline & \multicolumn{4}{|c|}{ INVERNADERO (U\$S) } \\
\hline CASO & policarbonato & hierro & planchuela & $\begin{array}{c}\text { TOTAL } \\
\text { (U\$S) }\end{array}$ \\
\hline I & 131,42 & 19,92 & 17,44 & 168,78 \\
\hline II & 157,71 & 20,19 & 19,10 & 197,00 \\
\hline III & 168,22 & 23,64 & 19,73 & 211,59 \\
\hline IV & 168,22 & 26,56 & 19,73 & 214,51 \\
\hline
\end{tabular}




\begin{tabular}{|c|c|c|c|c|c|c|}
\hline & \multicolumn{6}{|c|}{ MEZCLADOR (U\$S) } \\
\hline CASO & motor & planchuela & $\begin{array}{c}\text { varilla } \\
\text { hierro }\end{array}$ & $\begin{array}{c}\text { chapa } \\
\text { galvanizada }\end{array}$ & $\begin{array}{c}\text { pintura } \\
\text { epoxi }\end{array}$ & $\begin{array}{c}\text { TOTAL } \\
(U \$ S)\end{array}$ \\
\hline I & 48,38 & 0,80 & 1,62 & 7,00 & 26,00 & 83,79 \\
\hline II & 60,00 & 0,80 & 1,62 & 14,00 & 26,00 & 102,41 \\
\hline III & 60,00 & 0,80 & 1,62 & 14,00 & 26,00 & 102,41 \\
\hline IV & 60,00 & 0,80 & 1,62 & 14,00 & 26,00 & 102,41 \\
\hline
\end{tabular}

\begin{tabular}{|c|c|c|c|c|c|c|}
\hline \multicolumn{7}{|c|}{ SISTEMA DE CONTROL $(\mathrm{U} \$ \mathrm{~S})$} \\
\hline CASO & controlador & contactor & $\begin{array}{c}\text { caja } \\
\text { plástica }\end{array}$ & $\begin{array}{c}\text { cable } \\
\text { unipolar }\end{array}$ & $\begin{array}{c}\text { resistencia } \\
\text { eléctrica }\end{array}$ & $\begin{array}{c}\text { TOTAL } \\
\text { (U\$S) }\end{array}$ \\
\hline I & 136,6 & 26,18 & 32,61 & 0,16 & 34,00 & 229,55 \\
\hline II & 136,6 & 26,18 & 32,61 & 0,16 & 34,00 & 229,55 \\
\hline III & 136,6 & 26,18 & 32,61 & 0,16 & 34,00 & 229,55 \\
\hline IV & 136,6 & 26,18 & 32,61 & 0,16 & 34,00 & 229,55 \\
\hline
\end{tabular}

\begin{tabular}{|c|c|c|c|c|}
\hline & \multicolumn{4}{|c|}{ SUBTOTALES (U\$S) } \\
\hline CASO & $\begin{array}{c}\text { cuerpo } \\
\text { del } \\
\text { digestor }\end{array}$ & $\begin{array}{c}\text { sistema de } \\
\text { control }\end{array}$ & $\begin{array}{c}\text { conducción } \\
\text { de agua } \\
\text { caliente }\end{array}$ & $\begin{array}{c}\text { colector } \\
\text { solar }\end{array}$ \\
\hline I & 313,77 & 229,55 & 123,70 & 455,20 \\
\hline II & 386,80 & 229,55 & 133,11 & 551,11 \\
\hline III & 470,25 & 229,55 & 139,22 & 713,70 \\
\hline IV & 536,93 & 229,55 & 147,46 & 830,67 \\
\hline
\end{tabular}

\begin{tabular}{|c|c|c|c|c|}
\hline CASO & invernadero & mezclador & $\begin{array}{c}\text { conducción del } \\
\text { biogás }\end{array}$ & $\begin{array}{c}\text { TOTAL } \\
\text { (U\$S) }\end{array}$ \\
\hline I & 168,78 & 83,79 & 30,50 & $1.405,0$ \\
\hline II & 197,00 & 102,41 & 31,00 & $1.630,9$ \\
\hline III & 211,59 & 102,41 & 32,50 & $1.899,1$ \\
\hline IV & 214,51 & 102,41 & 33,40 & $2.094,4$ \\
\hline
\end{tabular}

La inversión para cada uno de los casos resulta en el rango 1.400 a $2.000 \mathrm{U} \$ \mathrm{~S}$ aproximadamente dependiendo del tamaño del biodigestor. Para el prototipo (caso 0) se observa en la figura 1. A4 el mayor costo corresponde al sistema de control, seguido por la conducción de agua caliente y el cuerpo del biodigestor. 


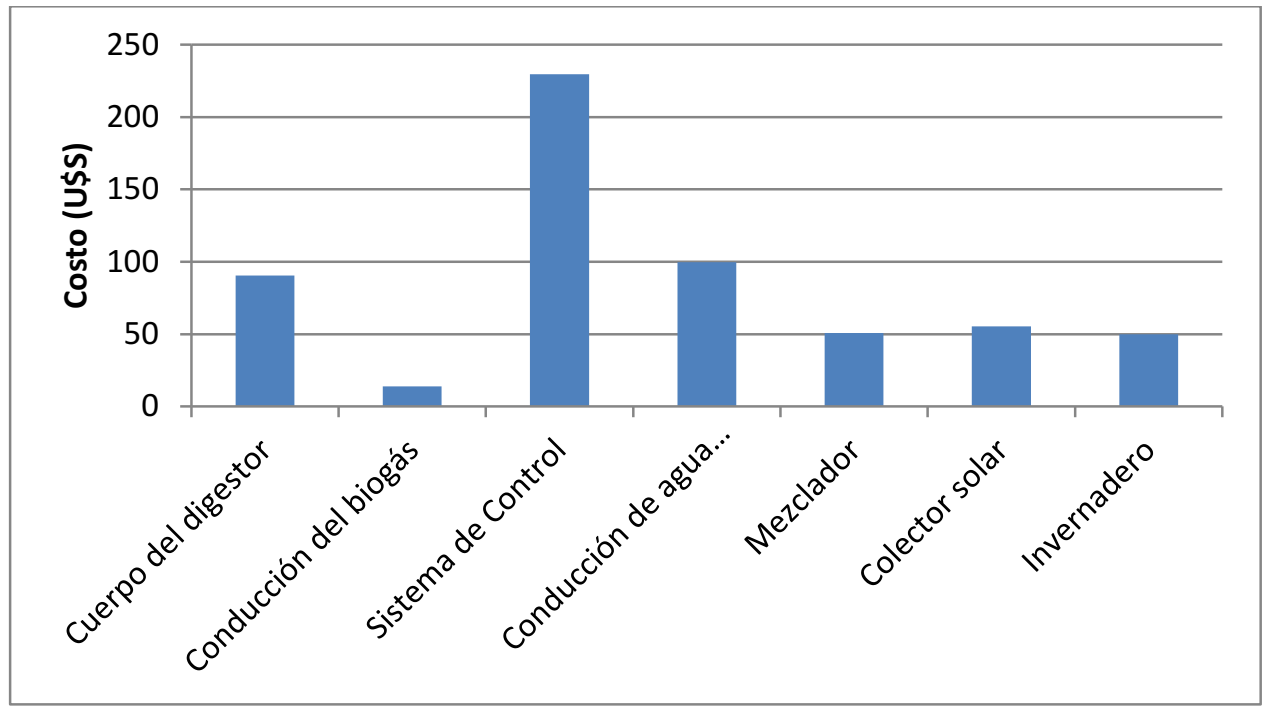

Figura 1. A4. Costos parciales del prototipo (Caso 0).

A diferencia del prototipo (caso 0), se observa en la figura 2.A4 que en los casos III- III- IV el mayor costo es el del colector solar seguido por el cuerpo del biodigestor. El sistema de control y el sistema de conducción del biogás tienen un costo que es independiente del tamaño. Los costos del sistema de conducción de agua caliente, el invernadero y el mezclador prácticamente son constantes.

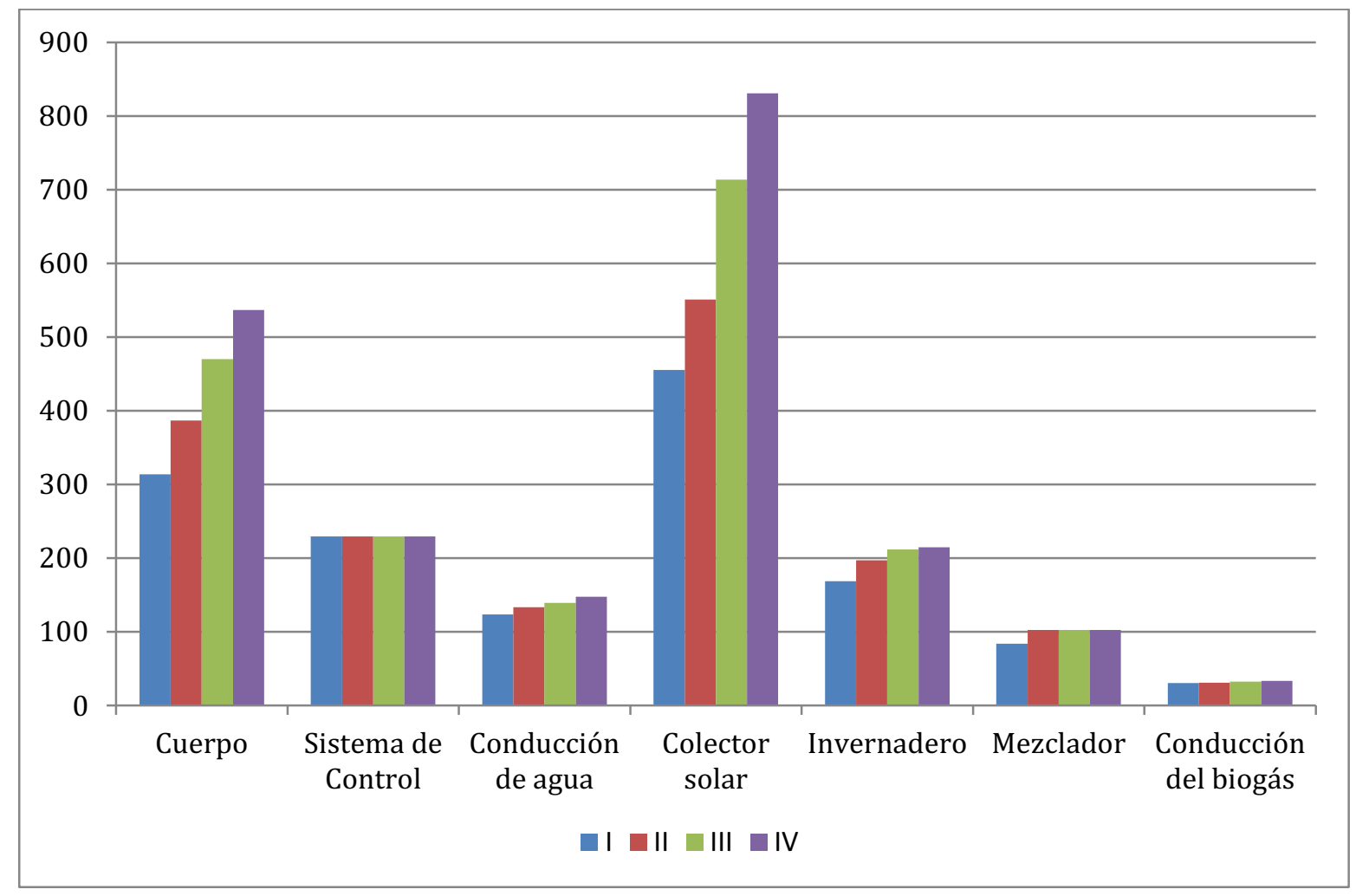

Figura 2. A4. Costo en U\$S de las componentes del biodigestor (Casos I, II, III, IV). 
En la figura 3.A4 se muestran todos los porcentajes de los costos de los componentes para el prototipo El 39\% del costo del biodigestor corresponde al sistema de control, seguido con el 17\% del sistema de conducción de agua caliente. El mezclador, el colector solar y el invernadero tienen costos similares y corresponden al 8-9\% del valor total.

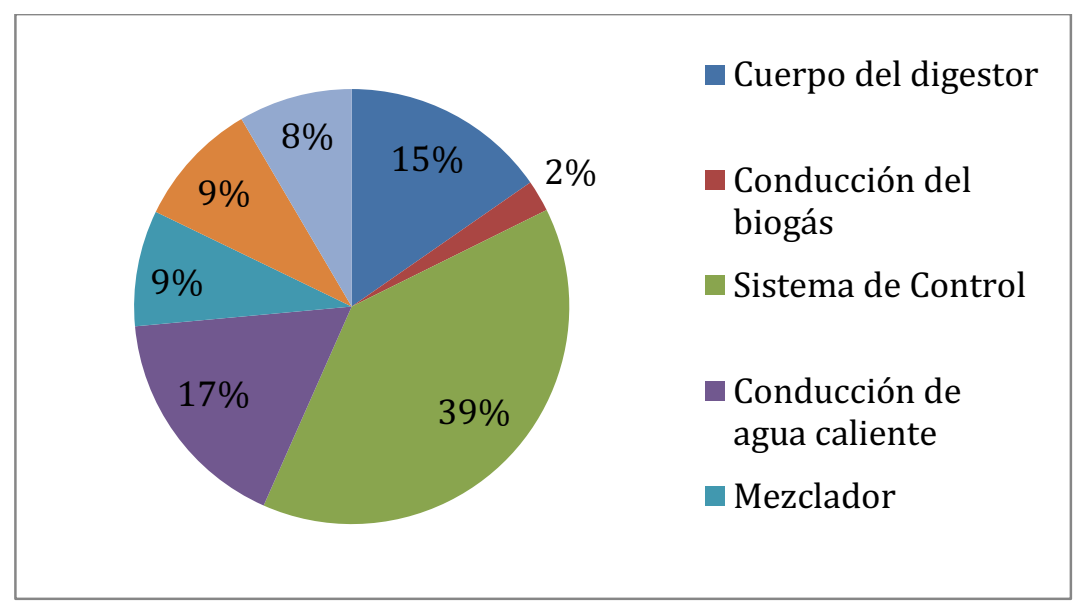

Figura 3. A4. Costo en \% de las componentes del biodigestor (Caso 0).

La siguiente Tabla muestra los costos de las componentes, representados en porcentajes de los cuatro casos, I al IV.

\begin{tabular}{|c|c|c|c|c|}
\hline \multicolumn{5}{|c|}{ SUBTOTALES } \\
\hline CASO & $\begin{array}{c}\text { Cuerpo } \\
\text { biodigestor }\end{array}$ & $\begin{array}{c}\text { Sistema de } \\
\text { Control }\end{array}$ & $\begin{array}{c}\text { Conducción de } \\
\text { agua }\end{array}$ & Colector solar \\
\hline I & $22 \%$ & $16 \%$ & $9 \%$ & $32 \%$ \\
\hline II & $24 \%$ & $14 \%$ & $8 \%$ & $34 \%$ \\
\hline III & $25 \%$ & $12 \%$ & $7 \%$ & $38 \%$ \\
\hline IV & $26 \%$ & $11 \%$ & $7 \%$ & $40 \%$ \\
\hline CASO & Invernadero & Mezclador & $\begin{array}{c}\text { Conducción } \\
\text { del biogás }\end{array}$ & Total \\
\hline I & $12 \%$ & $6 \%$ & $2 \%$ & $100 \%$ \\
\hline II & $12 \%$ & $6 \%$ & $2 \%$ & $100 \%$ \\
\hline III & $11 \%$ & $5 \%$ & $2 \%$ & $100 \%$ \\
\hline IV & $10 \%$ & $5 \%$ & $2 \%$ & $100 \%$ \\
\hline
\end{tabular}

A excepción de la conducción del biogás, el costo de las demás secciones varía a medida que el tamaño del digestor aumenta. 

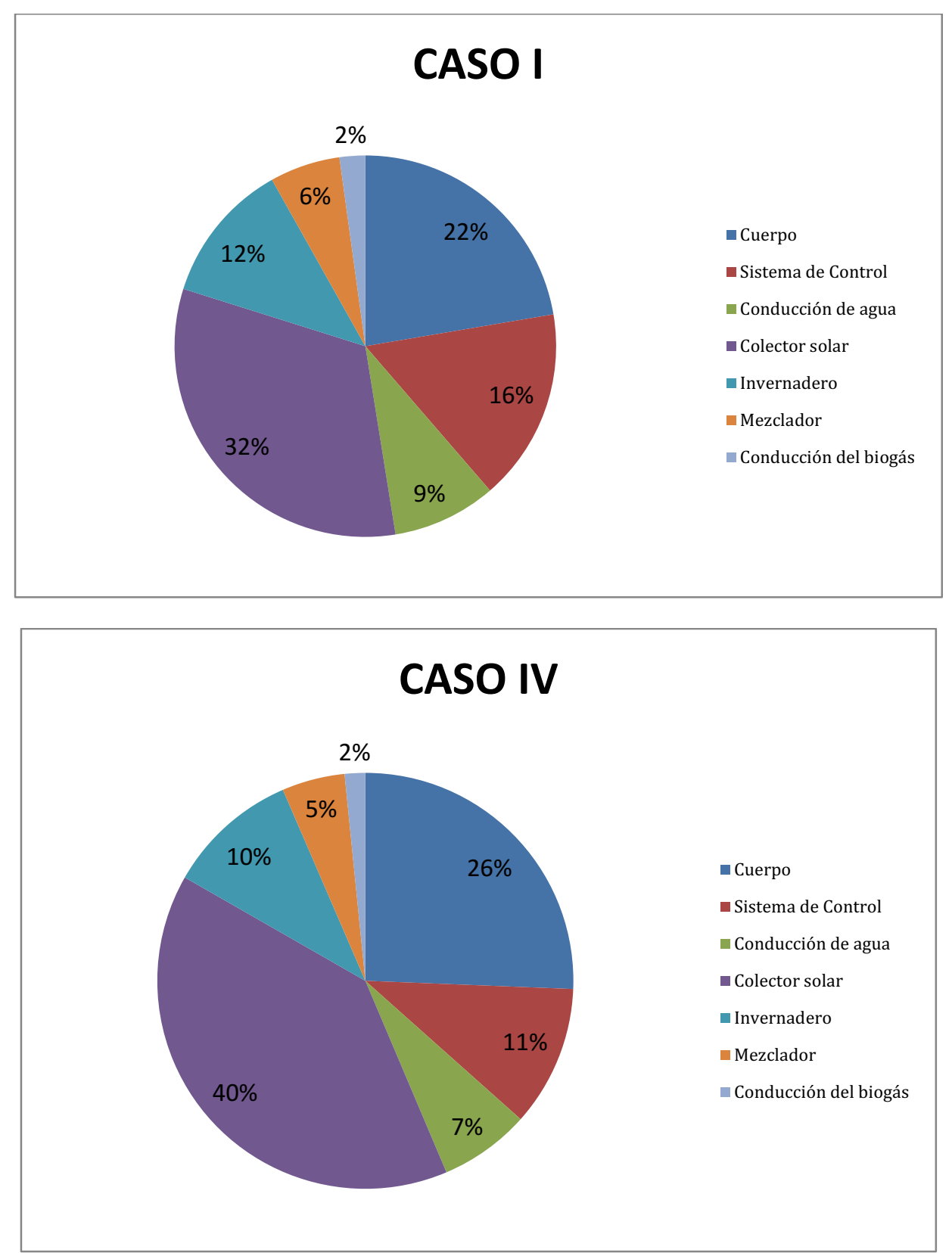

Figura 4. A4. Costo en \% de las secciones del biodigestor (Caso I y IV).

En la figura 4.A4 se compara el costo en \% de las secciones del biodigestor para el caso I $\left(20 \mathrm{~m}^{3}\right)$ con el caso IV $\left(50 \mathrm{~m}^{3}\right)$. El costo en porcentaje del sistema de control, el del invernadero, el del mezclador y el de la conducción de agua caliente disminuyen, mientras que el porcentaje del colector solar y del cuerpo del biodigestor aumentan. 


\section{ANEXo A5 \\ CÁLCULO DEL ÁREA DE COLECTORES}

En el Capítulo 11 se propone el análisis del costo de una planta de producción de biogás compuesta por dos digestores anaeróbicos y un sistema de calentamiento hibrido solar-eléctrico. En el análisis se consideran varios volúmenes de digestión: $20,30,40$ y $50 \mathrm{~m}^{3}$. En todos estos casos la planta de digestión se compone de dos digestores de igual volumen. Además, constan de un conjunto de colectores solares que ayudan a mantener las condiciones térmicas adecuadas. Se propone una temperatura de operación de $20^{\circ} \mathrm{C}$.

A mayor volumen de digestión, mayor es el área de colectores que se necesita para calentarlo. Se calcula el área total de colectores que debe tener cada digestor de la planta de producción de biogás. Se utiliza las ecuaciones 8.1, 8.6 y 8.8 (Capítulo 8), las que se reescriben a continuación.

$$
\begin{gathered}
\dot{Q}_{u}=\dot{m} \cdot c_{p} \cdot\left(T_{s}-T_{e}\right) \\
\eta_{i}=\frac{\dot{Q}_{u}}{A_{c} G_{T}}=\frac{\dot{m} \cdot c_{p} \cdot\left(T_{s}-T_{e}\right)}{A_{c} G_{T}} \\
\eta_{i}=0,63-16,27 \mathrm{~W} / \mathrm{m}^{2 \circ} \mathrm{C} \frac{\left(T_{e}-T_{a}\right)}{G_{T}}
\end{gathered}
$$

donde $\dot{Q}_{u}$ es energía útil por unidad de tiempo, $\dot{m}$ el caudal másico, $c_{p}$ el calor especifico, $G_{T}$ la irradiación solar incidente, $A_{c}$ el área del colector solar, $T_{s}$ la temperatura de salida del intercambiador (IC), Te la temperatura de entrada al IC, $T_{a}$ la temperatura ambiente y $\eta_{i}$, la eficiencia instantánea.

Para empezar el cálculo se elige el mes del año más desfavorable para el funcionamiento del colector, éste es aquel en el que la radiación solar y la temperatura ambiente son los más bajos del año. Si durante el mes más frío se calcula el área del colector para que los días soleados abastezca al digestor, con mayor razón se abastecerá de energía solar en el resto del año. Durante el invierno (del 21 de junio al 21 de setiembre) se dan las temperaturas más bajas, se elige el mes de julio para realizar el cálculo.

En las figuras 1 . A5 y 2. A5 se presentan la temperatura ambiente y la irradiancia solar del mes de julio como función del tiempo. 


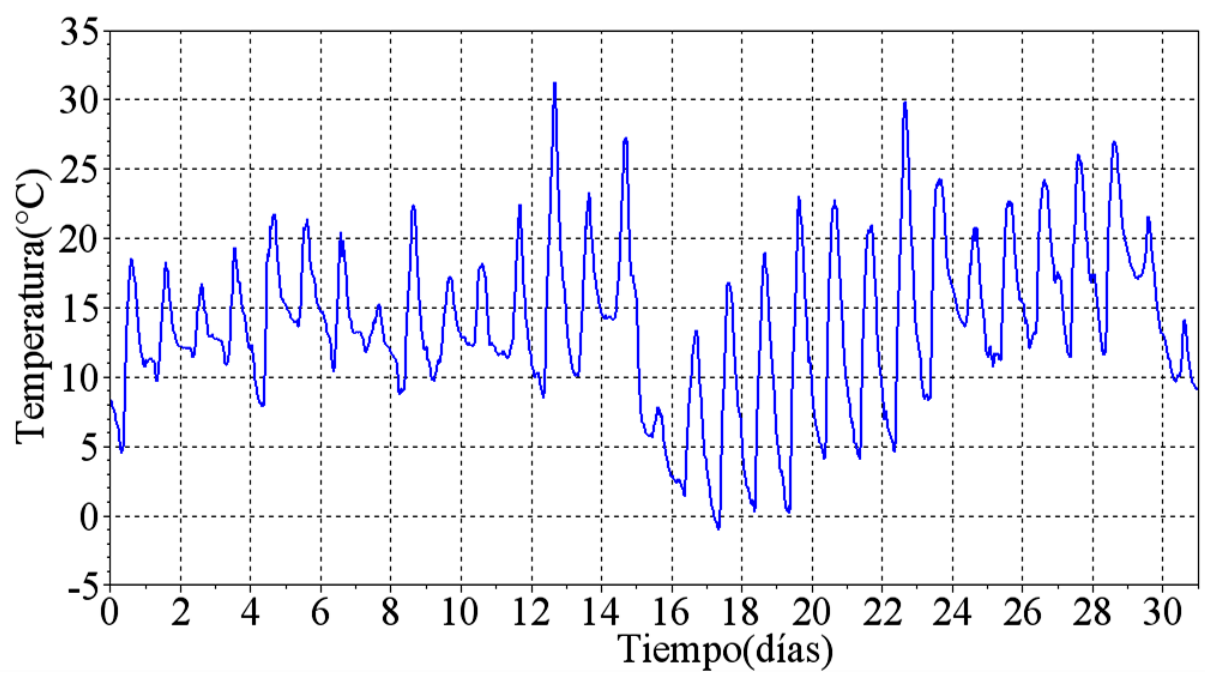

Figura 1. A5. Temperatura ambiente como función del tiempo durante el mes de julio del año 2018.

Fuente: Elaboración propia.

Una característica de esta zona es la gran la amplitud térmica que depende fuertemente de la nubosidad. De la figura 1 . A5. se observa que en solo dos días del mes de julio las amplitudes térmicas logran $23^{\circ}$ y $26^{\circ} \mathrm{C}$. El primero se da en el día 13. La máxima de este día llega a los $31^{\circ} \mathrm{C}$ mientras que la mínima es de $8^{\circ} \mathrm{C}$. El otro ocurre en el día 23 , donde la mínima es de $4^{\circ} \mathrm{C}$ mientras que la máxima alcanza los $30^{\circ} \mathrm{C}$. Estos dos días son los más calurosos.

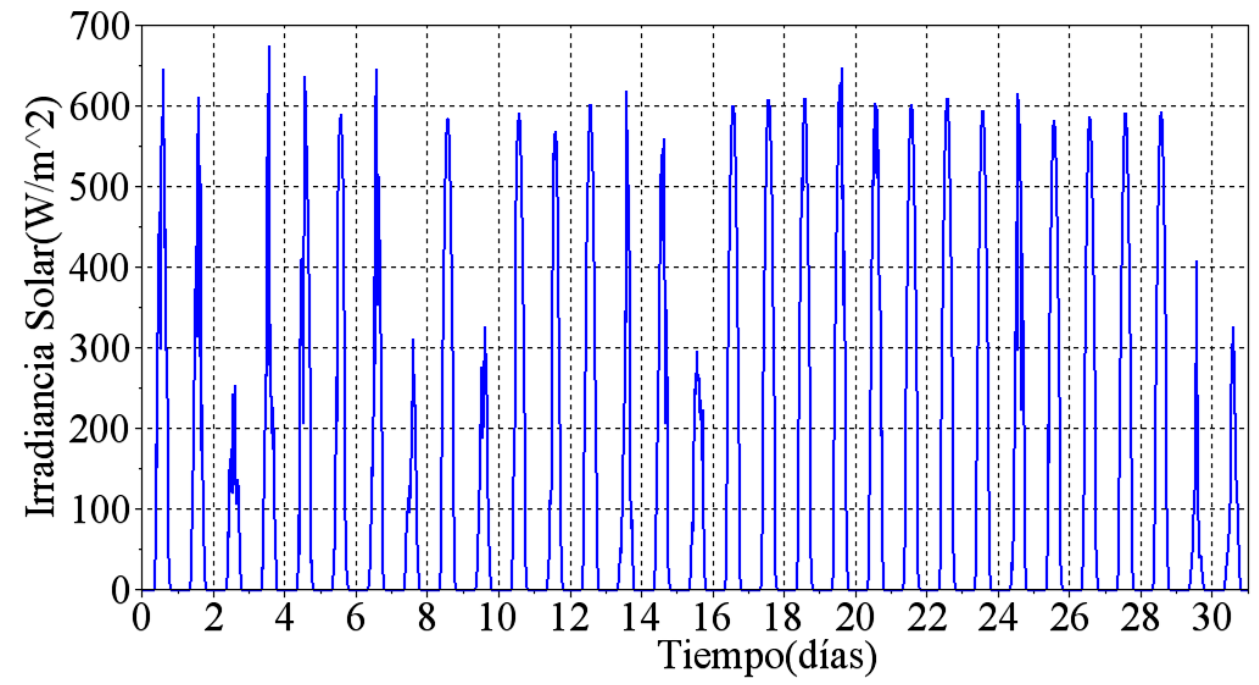

Figura 2. A5. Irradiancia solar como función del tiempo durante el mes de julio. Fuente: Elaboración propia. 
Los días más fríos ocurren cuando la irradiancia no supera los 400 $\mathrm{W} / \mathrm{m}^{2}$.Excluyendo los días calurosos y los fríos se puede decir que las máximas se encuentran entre los $14^{\circ} \mathrm{C}$ y los $25^{\circ} \mathrm{C}$.

Se observa de la Figura 2. A5. que en general los valores pico de las irradiancias de los días soleados alcanzan los $600 \mathrm{~W} / \mathrm{m}^{2}$, mientras que en los días nublados se encuentra entre los 300 o $400 \mathrm{~W} / \mathrm{m}^{2}$.

Considerando todo lo anterior respecto de la temperatura ambiente y de la irradiancia solar del mes de julio se toma una máxima promedio de los días soleados de $19^{\circ} \mathrm{C}$ (exceptuando los días fríos y calurosos) y una radiación pico promedio de $600 \mathrm{~W} / \mathrm{m}^{2}$.

Como se explica en el Capítulo 8, $\dot{Q}_{u}$ es la energía por unidad de tiempo que entrega el colector solar al digestor anaeróbico; ésta es la energía por unidad de tiempo que recibe el digestor y utiliza para elevar su temperatura. De esta manera la ecuación 8.1 se reescribe:

$$
\dot{Q}_{u}=\dot{m} \cdot c_{p} \cdot\left(T_{s}-T_{e}\right)=\frac{m_{d i g} \cdot c_{p} \cdot\left(T_{d i g, f}-T_{d i g, i}\right)}{t}=\frac{m_{d i g} \cdot c_{p} \cdot \Delta T_{d i g}}{t}
$$

En el último miembro $m_{\text {dig }}$ es la masa de la carga del digestor y $c_{p}$ su calor específico. La diferencia entre la temperatura inicial $T_{d i g, i}$ antes de calentarse y la final $T_{\text {digff. }}$ después de calentarse se nombra como $\Delta T_{\text {dig. }}$. El caudal $\dot{m}$ del líquido caloportador que se encuentra en el circuito hidráulico se escribe como el cociente entre masa y tiempo.Notar que esta masa es ahora la masa del digestor $m_{\text {dig. }}$. El tiempo $t$ es lo que le toma al digestor alcanzar la temperatura final. Este tiempo depende de varios factores tales como el tamaño del intercambiador de calor, la masa del digestor, el caudal del circuito hidráulico. Se toma un tiempo de 1 hora y una radiación promedio de $600 \mathrm{~W} / \mathrm{m}^{2}$ que corresponde al mediodía solar.

El digestor anaeróbico cuenta con un dispositivo capaz de controlar su temperatura. Como se observó en las medidas, este controlador logra que se mantenga la temperatura de operación del digestor en torno a $1^{\circ} \mathrm{C}$, por lo tanto, se asigna este valor a $\Delta T_{d i g}$, (figura 8.4 ).

Puesto que la carga del digestor es una mezcla de agua y estiércol vacuno con un valor de sólidos totales del 9\%, para este cálculo se considera solo al agua como componente de la carga. De esta manera $m_{\text {dig }}$ será la masa del agua calculada para la planta de digestión presentada en el Capítulo 10 (Tabla 10.3). 
La temperatura $T_{e}$ presente en todas las ecuaciones es la de la entrada al colector solar. El fluido caloportador sale del digestor anaeróbico e ingresa al colector. Como el digestor opera a $20^{\circ} \mathrm{C}$ y el intercambiador de calor tiene la misma extensión del largo del digestor y además no son elevadas las temperaturas de entrada al digestor cuando se calienta con el colector solar, es de esperar que $T_{e}$ esté cercana a $20^{\circ} \mathrm{C}$. Por esta razón, se asigna este valor a $T_{e}$. Para el cálculo de la eficiencia instantánea $\eta_{\mathrm{i}}$ del colector se toman los valores antes mencionados de $T_{e}$, $T_{a}$ y $G_{T}$ de $600 \mathrm{~W} / \mathrm{m}^{2}$

$$
\eta_{i}=0,63-16,27 \frac{\mathrm{W}}{{ }^{\circ} \mathrm{C} \mathrm{m}^{2}} \frac{\left(T_{e}-T_{a}\right)}{G_{T}}=0,63-16,27 \frac{(20-19)}{600}=0,60
$$

Se presenta en la Tabla 1 . A5 los valores que se utilizan para el cálculo del área del colector solar para cada volumen de biodigestor.

Tabla 1. A5. Valores promedios de los parámetros para el cálculo del área de colección solar.

\begin{tabular}{|l|c|c|}
\hline Eficiencia & $\eta_{i}$ & 0,60 \\
\hline Irradiancia solar pico promedio & $G_{T}$ & $600 \mathrm{~W} / \mathrm{m}^{2}$ \\
\hline Temperatura ambiente promedio & $T_{a}$ & $19^{\circ} \mathrm{C}$ \\
\hline Temperatura de entrada al colector solar & $T_{e}$ & $20^{\circ} \mathrm{C}$ \\
\hline Diferencia promedio de temperatura en el digestor & $\Delta T_{d i g}$ & $1^{\circ} \mathrm{C}$ \\
\hline Tiempo & $t$ & $3600 \mathrm{~s}$ \\
\hline
\end{tabular}

Fuente: Elaboración propia.

Se escribe el área del colector solar de la ecuación 8.6

$$
A=\frac{\dot{Q}_{u}}{\eta_{i} G_{T}}
$$

Ya fijados los parámetros que intervienen en el cálculo del área de colección se presentan los resultados en la Tabla 2. A5. 
Tabla 2. A5. Valores de la masa de agua $m_{\text {dig, }}$ potencia útil $\dot{Q}_{u}$ y área de colección solar A para distintos volúmenes.

\begin{tabular}{|c|c|c|c|c|}
\hline Caso & $\begin{array}{c}\text { Volumen del } \\
\text { digestor }\left(\mathrm{m}^{3}\right)\end{array}$ & $\begin{array}{c}m_{\text {dig }} \\
(\mathrm{kg})\end{array}$ & $\begin{array}{c}\dot{Q}_{u} \\
(\mathrm{~W})\end{array}$ & $\begin{array}{c}A \\
\left(\mathrm{~m}^{2}\right)\end{array}$ \\
\hline I & 20 & $10.104,5$ & $11.729,64$ & 32,58 \\
\hline II & 30 & $15.156,8$ & $17.594,52$ & 48,87 \\
\hline III & 40 & $19.760,0$ & $22.938,07$ & 63,72 \\
\hline IV & 50 & $24.700,0$ & $28.672,58$ & 79,65 \\
\hline
\end{tabular}

Fuente: Elaboración propia.

Como es de esperar a mayor volumen del biodigestor, mayor es el área del colector solar requerido. En la Tabla 3. A5 se indican el volumen y el área del colector requerido para el caso de un sistema de uno y dos biodigestores.

Tabla 3. A5. Volumen y área del colector para sistemas de 1 y 2 biodigestores.

\begin{tabular}{|c|c|c|c|c|}
\hline & \multicolumn{2}{|c|}{$\begin{array}{c}\text { Volumen del sistema } \\
\left(\mathrm{m}^{3}\right)\end{array}$} & \multicolumn{2}{c|}{$\begin{array}{c}\text { Área del colector solar } \\
\left(\mathrm{m}^{2}\right)\end{array}$} \\
\hline Caso & $\begin{array}{c}1 \\
\text { biodigestor }\end{array}$ & $\begin{array}{c}2 \\
\text { biodigestores }\end{array}$ & $\begin{array}{c}1 \\
\text { biodigestor }\end{array}$ & $\begin{array}{c}2 \\
\text { biodigestores }\end{array}$ \\
\hline I & 20 & 40 & 32,58 & 65,16 \\
\hline II & 30 & 60 & 48,87 & 97,74 \\
\hline III & 40 & 80 & 63,72 & 127,44 \\
\hline IV & 50 & 100 & 79,65 & 159,30 \\
\hline
\end{tabular}

Fuente: Elaboración propia. 
ANEXo A6

\section{COSTO DE LA ENERGÍA ELÉCTRICA EN ZONA RURAL.}

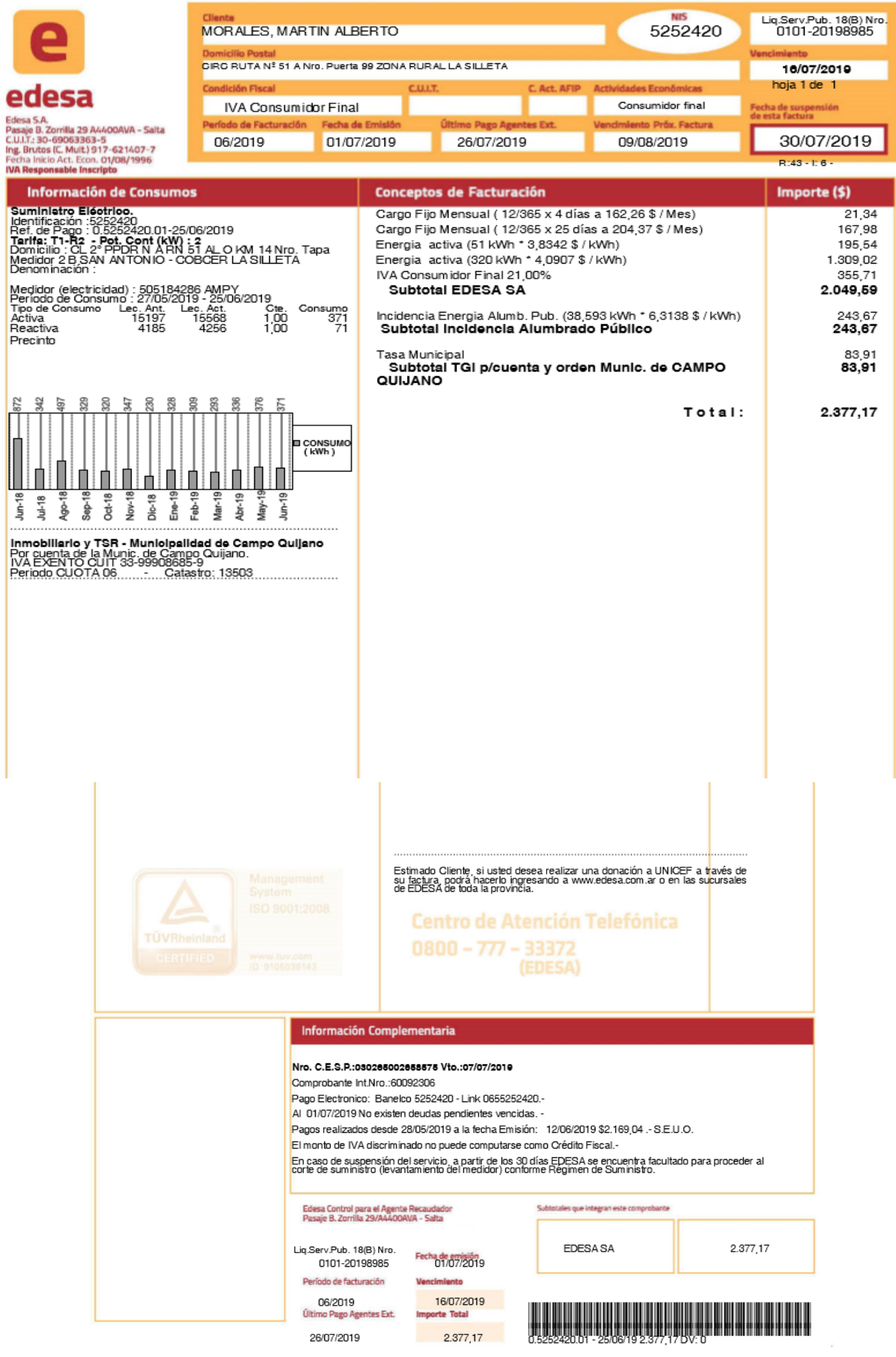


En base a la factura anterior del periodo: 07/2019, en este trabajo se considerarán los siguientes costos de la energía eléctrica, Tabla 1. A6.

Tabla 1. A6. Costos de la energía eléctrica por kWh en pesos.

\begin{tabular}{|c|c|c|}
\hline \multicolumn{3}{|c|}{ Energía eléctrica } \\
\hline \multicolumn{2}{|c|}{$(\$ / \mathrm{kWh})$} & $(\mathrm{U} \$ \mathrm{~S} / \mathrm{kWh})$ \\
\hline Activa & 4,0907 & 0,071 \\
\hline Reactiva & 3,8342 & 0,067 \\
\hline
\end{tabular}

Fuente: EDESA S.A.

Se ha hecho la conversión a dólares, considerando la cotización del día 4/9/2019.

1 dólar U\$S = 57 \$ (Anexo A3) 


\section{Nomenclatura}

\begin{tabular}{|c|c|c|}
\hline$A_{c}$ & Área del colector solar & $\mathrm{m}^{2}$ \\
\hline$A_{\text {cub } t}$ & Área de la cubierta transparente del invernadero & $\mathrm{m}^{2}$ \\
\hline$A_{c u b}$ & Área de la cubierta del digestor & $\mathrm{m}^{2}$ \\
\hline$A_{\text {inv }}$ & Área del invernadero & $\mathrm{m}^{2}$ \\
\hline$A_{p}$ & $\begin{array}{l}\text { Área de las paredes y suelo del digestor en } \\
\text { contacto con la carga }\end{array}$ & $\mathrm{m}^{2}$ \\
\hline$A_{p b}$ & $\begin{array}{l}\text { Área en el biogás en contacto con las paredes del } \\
\text { digestor }\end{array}$ & $\mathrm{m}^{2}$ \\
\hline$A_{s}$ & Área superior de la carga del digestor & $\mathrm{m}^{2}$ \\
\hline$A_{\text {int }}$ & Área del intercambiador de calor & $\mathrm{m}^{2}$ \\
\hline$A G V$ & Ácidos grasos volátiles & $\mathrm{CaCO}_{3} / \mathrm{l}$ \\
\hline Alk & Alcalinidad del medio & $\mathrm{CaCO}_{3} / l$ \\
\hline$c_{b}$ & Capacidad calorífica del biogás & $\mathrm{J} / \mathrm{kg}^{\circ} \mathrm{C}$ \\
\hline$c_{c}$ & Capacidad calorífica de la carga & $\mathrm{J} / \mathrm{kg}^{\circ} \mathrm{C}$ \\
\hline$c_{\text {carga }}$ & Capacidad calorífica de la carga & $\mathrm{J} / \mathrm{kg}^{\circ} \mathrm{C}$ \\
\hline$c_{c u b t}$ & Capacidad calorífica de la cubierta transparente & $\mathrm{J} / \mathrm{kg}^{\circ} \mathrm{C}$ \\
\hline$c_{i n v}$ & Capacidad calorífica del invernadero & $\mathrm{J} / \mathrm{kg}^{\circ} \mathrm{C}$ \\
\hline$c_{p}$ & Calor específico del fluido caloportador & $\mathrm{J} / \mathrm{kg}^{\circ} \mathrm{C}$ \\
\hline$C 1 / 2$ & Contactor eléctrico & - \\
\hline CTR1/2 & Controlador de temperatura & - \\
\hline$\% \mathrm{CH}_{4}$ & Porcentaje de metano & - \\
\hline$e$ & Espesor de las paredes y suelo del digestor & $\mathrm{m}$ \\
\hline$E$ & Energía interna del digestor & $\mathrm{J}$ \\
\hline$e_{\text {cubt }}$ & Espesor de la cubierta transparente & $\mathrm{m}$ \\
\hline$F_{R}$ & Factor de remoción del colector solar & \\
\hline FOD & Fracción orgánica domiciliaria & - \\
\hline$G_{T}$ & Irradiancia solar & $\mathrm{W} / \mathrm{m}^{2}$ \\
\hline$h_{b}$ & Coeficiente convectivo del biogás & $h_{b}$ \\
\hline$h_{i n v}$ & Coeficiente convectivo en el invernadero & $h_{\text {inv }}$ \\
\hline$h_{a}$ & Coeficiente convectivo ambiente & $h_{a}$ \\
\hline$k$ & $\begin{array}{l}\text { Conductividad térmica de las paredes y suelo del } \\
\text { digestor }\end{array}$ & $\mathrm{W} / \mathrm{m}^{\circ} \mathrm{C}$ \\
\hline$\dot{m}_{c d}$ & Carga que ingresa al digestor por tiempo & $\mathrm{kg} / \mathrm{s}$ \\
\hline$\dot{m}$ & Caudal másico del fluido caloportador & $\dot{m}$ \\
\hline$m_{c}$ & Masa de la carga & $m_{c}$ \\
\hline Ms & Masa seca & $\mathrm{Kg}$ \\
\hline$M h$ & Masa húmeda & $\mathrm{Kg}$ \\
\hline$M a$ & Masa de agua & $\mathrm{kg}$ \\
\hline PEB & Producción de biogás específica & $\mathrm{m}^{3} / \mathrm{kg} \mathrm{SV}$ \\
\hline PEM & Producción de metano específica & $\mathrm{m}^{3} / \mathrm{kg} \mathrm{SV}$ \\
\hline PCI & Poder calorífico inferior & $\begin{array}{c}\mathrm{kcal} / \mathrm{m}^{3} \mathrm{o} \\
\mathrm{kcal} / \mathrm{kg}\end{array}$ \\
\hline PCS & Poder calorífico superior & $\mathrm{kcal} / \mathrm{m}^{3} \mathrm{o}$ \\
\hline
\end{tabular}




\begin{tabular}{|c|c|c|}
\hline$p H$ & Concentración del ion hidrogeno & - \\
\hline$\dot{Q}_{\text {,acumulada,cubt }}$ & $\begin{array}{l}\text { Energía acumulada por unidad de tiempo en la } \\
\text { cubierta transparente }\end{array}$ & W \\
\hline$\dot{Q}_{\text {acumulad,inv }}$ & $\begin{array}{l}\text { Energía acumulada por unidad de tiempo en el } \\
\text { invernadero }\end{array}$ & W \\
\hline$\dot{Q}_{b, a c u m u l a d a}$ & $\begin{array}{l}\text { Energía acumulada en el biogás por unidad de } \\
\text { tiempo }\end{array}$ & W \\
\hline$\dot{Q}_{c o n d, b}$ & Flujo de energía por conducción en el biogás & W \\
\hline$\dot{Q}_{\text {cond,dig }}$ & Flujo de energía conductivo en el digestor & W \\
\hline$\dot{Q}_{c o n v, b}$ & Flujo de energía por convección en el biogás & W \\
\hline$\dot{Q}_{c o n v, d i g}$ & Flujo de energía convectivo en el digestor & W \\
\hline$\dot{Q}_{\text {conv,inv }}$ & $\begin{array}{l}\text { Flujo de energía por convección en el } \\
\text { invernadero }\end{array}$ & W \\
\hline$\dot{Q}_{\text {elec }}$ & Flujo de energía del sistema eléctrico & W \\
\hline$\dot{Q}_{i n t}$ & $\begin{array}{l}\text { Flujo de energía desde el intercambiador de } \\
\text { calor }\end{array}$ & W \\
\hline$\dot{Q}_{m}$ & $\begin{array}{l}\text { Flujo de energía por agregación de material de } \\
\text { carga al digestor }\end{array}$ & W \\
\hline$\dot{Q}_{r a d, b}$ & Flujo de energía por radiación en el biogás & W \\
\hline$\dot{Q}_{r a d, d i g}$ & Flujo de energía radiativo en el digestor & W \\
\hline$\dot{Q}_{\text {rad,inv }}$ & Flujo de energía por radiación en el invernadero & W \\
\hline$\dot{Q}_{u}$ & Flujo de energía útil & W \\
\hline$\dot{Q}_{c o n v, c u b t}$ & $\begin{array}{l}\text { Flujo de energía por convección en la cubierta } \\
\text { transparente }\end{array}$ & W \\
\hline$R$ & Resistencia eléctrica & $\Omega$ \\
\hline$S$ & Irradiancia que llega a la cubierta del digestor & $\mathrm{W} / \mathrm{m}^{2}$ \\
\hline$S_{i}$ & Señal del controlador de temperatura & - \\
\hline$S_{i}$ & Sensor de temperatura & - \\
\hline$S T$ & Sólidos totales & $\mathrm{kg}$ \\
\hline$S V$ & Sólidos volátiles & $\mathrm{kg}$ \\
\hline$\% S V$ & Porcentaje de sólidos volátiles & - \\
\hline te & Temporizador & - \\
\hline$T_{i j}$ & Temperatura del punto i,j & ${ }^{\circ} \mathrm{C}$ \\
\hline$T_{a}$ & Temperatura ambiente & ${ }^{\circ} \mathrm{C}$ \\
\hline$T_{b}$ & Temperatura del biogás & ${ }^{\circ} \mathrm{C}$ \\
\hline$T_{\text {carga diaria }}$ & Temperatura de la carga diaria & ${ }^{\circ} \mathrm{C}$ \\
\hline$T_{c u b, t}$ & $\begin{array}{l}\text { Temperatura de la cubierta transparente del } \\
\text { invernadero }\end{array}$ & ${ }^{\circ} \mathrm{C}$ \\
\hline$T_{c u b}$ & Temperatura de la cubierta del digestor & ${ }^{\circ} \mathrm{C}$ \\
\hline$T_{\text {dig,f }}$ & Temperatura final del digestor & ${ }^{\circ} \mathrm{C}$ \\
\hline$T_{\text {dig,i }}$ & Temperatura inicial del digestor & ${ }^{\circ} \mathrm{C}$ \\
\hline$T_{d i g}$ & Temperatura del digestor & ${ }^{\circ} \mathrm{C}$ \\
\hline$T_{d i g}$ & Temperatura del digestor & ${ }^{\circ} \mathrm{C}$ \\
\hline
\end{tabular}




\begin{tabular}{|c|c|c|}
\hline$T_{e}$ & Temperatura a la entrada del colector & ${ }^{\circ} \mathrm{C}$ \\
\hline$T_{i n v}$ & Temperatura del invernadero & ${ }^{\circ} \mathrm{C}$ \\
\hline$T_{s}$ & Temperatura a la salida del colector & ${ }^{\circ} \mathrm{C}$ \\
\hline$T_{\text {suelo }}$ & Temperatura del suelo & ${ }^{\circ} \mathrm{C}$ \\
\hline$U_{L}$ & Coeficiente global de pérdidas del colector solar & $\mathrm{W} / \mathrm{m}^{2 \circ} \mathrm{C}$ \\
\hline$U_{\text {int }}$ & $\begin{array}{l}\text { Coeficiente global de pérdidas del } \\
\text { intercambiador }\end{array}$ & $\mathrm{W} / \mathrm{m}^{2 \circ} \mathrm{C}$ \\
\hline$V_{b}$ & Volumen del biogás & $\mathrm{m}^{3}$ \\
\hline$V_{c}$ & Volumen de la carga & $\mathrm{m}^{3}$ \\
\hline$V_{\text {cub } t}$ & Volumen de la cubierta transparente & $\mathrm{m}^{3}$ \\
\hline$V_{\text {inv }}$ & Volumen del interior del invernadero & $\mathrm{m}^{3}$ \\
\hline$V$ & Voltaje eficaz de la red eléctrica & $\mathrm{V}$ \\
\hline$v$ & Velocidad del flujo caloportador & $\mathrm{m} / \mathrm{s}$ \\
\hline$V 1 / 2$ & Válvula eléctrica de temperatura & \\
\hline$\alpha_{d}$ & Difusividad térmica & $\mathrm{m}^{2} / \mathrm{s}$ \\
\hline$\alpha$ & $\begin{array}{l}\text { Absorción del colector solar y la cubierta del } \\
\text { digestor }\end{array}$ & - \\
\hline$\Delta t$ & Incremento temporal & $\mathrm{S}$ \\
\hline$\Delta x$ & Incremento espacial & $\mathrm{m}$ \\
\hline$\Delta T_{s}$ & $\begin{array}{l}\text { Diferencia de temperatura debida al retardo en } \\
\text { la activación del controlador de temperatura }\end{array}$ & ${ }^{\circ} \mathrm{C}$ \\
\hline$\Delta T_{2}$ & $\begin{array}{l}\text { Diferencia entre la temperatura de la salida del } \\
\text { colector y la del digestor }\end{array}$ & ${ }^{\circ} \mathrm{C}$ \\
\hline$\Delta T_{1}$ & $\begin{array}{l}\text { Diferencia entre la temperatura de la entrada del } \\
\text { colector y la del digestor }\end{array}$ & ${ }^{\circ} \mathrm{C}$ \\
\hline$\Delta T_{m}$ & Temperatura logartimica en el intercambiador & ${ }^{\circ} \mathrm{C}$ \\
\hline$\varepsilon_{c}$ & Emitancia de la carga del digestor & - \\
\hline$\varepsilon_{c u b t}$ & Emitancia de la cubierta transparente & - \\
\hline$\varepsilon_{\text {cub }}$ & Emitancia de la cubierta del digestor & - \\
\hline$\varepsilon_{c u b}$ & Emitancia de la cubierta & - \\
\hline$\varepsilon$ & $\begin{array}{l}\text { Emisividad de la superficie superior de la carga } \\
\text { del digestor }\end{array}$ & - \\
\hline$\eta_{i}$ & Eficiencia instantánea & - \\
\hline$\eta$ & Eficiencia global & - \\
\hline$\rho_{b}$ & Densidad del biogás & $\mathrm{kg} / \mathrm{m}^{3}$ \\
\hline$\rho_{c}$ & Densidad de la carga & $\mathrm{kg} / \mathrm{m}^{3}$ \\
\hline$\rho_{\text {cubt }}$ & Densidad de la cubierta transparente & $\mathrm{kg} / \mathrm{m}^{3}$ \\
\hline$\rho_{\text {inv }}$ & Densidad del interior del invernadero (aire) & $\mathrm{kg} / \mathrm{m}^{3}$ \\
\hline$\sigma$ & Constante de Stefan - Boltzman & $\mathrm{W} / \mathrm{m}^{2{ }^{\circ}} \mathrm{C}^{4}$ \\
\hline$\tau$ & Transmisión del colector solar & \\
\hline$\tau_{\text {cub }}$ & Transmisión de la cubierta transparente & \\
\hline
\end{tabular}




\section{Índice de contenidos.}

Dedicatoria.

Agradecimientos. II

Aclaración. III

Resumen. IV IV IIV IV I

Índice General. $\quad$ V

Capítulo 1: Generalidades. 1

Organización del capítulo. $\quad 2$

$1.1 \quad$ Introducción. 2

$1.2 \quad$ Justificación. 2

$1.3 \quad$ Motivación y preguntas guías que conducirán la investigación. 3

$\begin{array}{lll}1.4 & \text { Objetivos del trabajo. } & 4\end{array}$

Metodología: diseño de la investigación y esquema 5

Estructura y planificación de la Tesis. $\quad 5$

1.7. $\quad$ Alcance y contribución de la Tesis. 6

1.8. $\quad$ Estado del arte de la investigación. $\quad 7$

1.8.1. Consumo energético. $\quad 7$

1.8.2. Biomasa pecuaria. 10

1.8.3. Marco legal: Legislación Nacional y Provincial de Salta. 11

1.9. Antecedentes en Argentina. 13

1.10. $\quad$ Antecedentes en Salta. 17

1.10.1. $\quad$ El digestor anaeróbico del Departamento de La Candelaria. 17

1.10.2. Sistema de captación y quemado del biogás producido en el 19

1.11. Suministro de gas de red en la Provincia de Salta. 21

Capítulo 2: La digestión anaeróbica.

$2.1 \quad$ Introducción. $\quad 24$

2.2. La digestión anaeróbica. 24

2.3. $\quad$ Primeros pasos de la digestión anaeróbica. 24

2.4. El Biogás.

2.4.1. $\quad$ Almacenamiento, usos y tratamiento. 27

2.5. Bioquímica del proceso de digestión. 29

2.5.1. Etapa de hidrólisis. 29

2.5.2 Etapa acetogénica. 30

2.5.3 Etapa acidogénica. 31

2.5.4. Etapa metanogénica.

2.6. Parámetros de digestión. 33

2.6.1. $\quad$ Parámetros de control: Temperatura. 34 
2.6.2. Parámetros de control: $p H$ y Alcalinidad. 34

2.6.3. Parámetros de control: Ácidos grasos volátiles. 35

2.6.4. Parámetros de control: Nutrientes. 35

2.6.5. Parámetros de control: Toxicidad e Inhibición. 36

2.6.6. Parámetros operacionales: Agitación. 37

2.6.7. Parámetros operacionales: Velocidad de carga y tiempo de 37

2.6.8. Parámetros operacionales: Diseño del digestor. 38

2.6.8.1. Respecto a la carga del digestor. 38

2.6.8.2. $\quad$ Respecto a la mezcla. 39

2.6.8.3. Respecto al manejo del sustrato. 39

2.7. Conclusiones. 39

Capítulo 3: Valorización energética de los residuos pecuarios bovinos de la 40 provincia de Salta.

3. 1 .

Introducción.

3.2. La provincia de Salta. 41

3.2.1. Ubicación geográfica. 41

3.2.2. Breve descripción de la orografía. 41

3.3. Distribución del ganado bovino en la provincia de Salta. 44

3.4. Producción teórica de biogás del estiércol bovino. 45

3.4.1. Animales de pastoreo. 45

3.4.2. Animales de feedloty tambos. 49

3.5. Discusión de los resultados. 51

3.6. Conclusiones. 52

Capítulo 4: Ensayos de biodigestión anaeróbica en el laboratorio. 53

4.1. Introducción. 54

4.2. Materiales y métodos. 54

4.2.1 Sólidos totales (ST) y volátiles (SV).

4.2.2. $\quad p H . \quad 55$

4.2.3. Alcalinidad (Alk).

4.2.4. Ácidos grasos volátiles (AGV). 56

4.2.5. Composición del biogás: metano y dióxido de carbono. $\quad 56$

4.3. Biodigestión anaeróbica. Ensayos en el laboratorio. 57

4.3.1. Ensayos con estiércol vacuno a $20^{\circ}, 30^{\circ}$ y $37^{\circ} \mathrm{C}$. $\quad 58$

4.3.2. Codigestión: Fracción orgánica domiciliaria y estiércol vacuno. 65

4.4. Discusión de los resultados. 70

4.5. Conclusiones. 70

Capítulo 5: Cálculo de la difusividad térmica de un aislante construido con 72 material descartable. Método de diferencias finitas.

$\begin{array}{lll}\text { 5.1. } & 73\end{array}$

5.2. $\quad$ Experimentación. Medidas de temperatura. 74

5.2.1. Resultados: medidas de temperatura. 76 


\subsection{3.}

Resultados y discusión: difusividad térmica.

Capítulo 6: Construcción de prototipos de biodigestor y de su sistema de calefacción.

6.1. Introducción. enterrado. semienterrado. aislación térmica en el digestor tubular.

7.5.2 Temperaturas en el intercambiador de calor sumergido en el digestor.

7.8. Conclusiones.

Capítulo 8: Aspectos teóricos de la transferencia de calor en el digestor enterrado. Modelo de simulación numérica. 
8.2. Aspectos teóricos de la energía útil, la eficiencia instantánea y global del colector solar.

8.3. Descripción del modelo.

8.3.4. El intercambiador de calor.

8.4 .

Resultados de la curva de eficiencia del colector solar.

8.5 .

Resultados del modelo de simulación numérica. digestor.

8.5.3.

Cálculo de la energía solar y energía eléctrica consumida.

8.6 . del volumen del digestor en el consumo energético.

8.7.

Discusión.

Capítulo 9: Captación, conducción y cuantificación del biogás.

9.2.

Sistema de captación, conducción y cuantificación del biogás.

9.3. Alimentación del digestor anaeróbico enterrado.

9.4. Cuantificación del biogás.

9.5.

Discusión.

9.6.

$$
\text { Conclusión. }
$$

Capítulo 10: Cálculo y análisis de los costos constructivos del prototipo. Volumen teórico de metano y su relación con el gas butano.

10.1 .

Introducción.

Capítulo 11: Análisis de los costos constructivos y de operación de una planta de producción de biogás. 
11.5. Cálculo del volumen de metano y su relación con el gas butano de garrafa.

11.6. Cálculo del área del colector solar. 193

11.7. $\quad$ Producción de biogás en planta. 193

11.7.1. Costos de operación. 195

11.7.2. $\quad$ Calculo de la producción de biogás y su equivalencia en garrafas. 197

11.7.3. Inversión de la planta de biodigestión. 198

11.7.4. Flujo de fondos. Periodo de recuperación de la inversión. 198

11.8. Discusión. 200

11.9. Conclusiones. 201

Discusión General. 203

Conclusión final. $\quad 206$

$\begin{array}{ll}\text { Perspectivas futuras. } & 207\end{array}$

Bibliografía. 208

Anexo A1: Detalle técnico de los componentes que integran los sistemas de 222 calentamiento.

Anexo A2: Planos del digestor anaeróbico enterrado. 225

Anexo A3: Cotización del dólar.

Anexo A4: Tablas de materiales y costos. 232

Anexo A5: Cálculo del área de colectores. 239

Anexo A6: Costo de la energía eléctrica en zona rural. 244

Nomenclatura. 246

Índice de contenidos.

Índice de Tablas. $\quad 254$

$\begin{array}{ll}\text { Índice de Figuras. } & 257\end{array}$ 
Tabla 1.1 Datos relevantes del digestor anaeróbico en La Candelaria (Salta).

Tabla 2.1 Reseña histórica sobre la digestión anaeróbica. 25

Tabla 2.2 Componentes del biogás en función del substrato utilizado. 27

Tabla 2.3 Reacciones acetogénicas. 31

Tabla 2.4. Reacciones acidogénicas. $\quad 32$

Tabla 2.5. Reacciones metanogénicas. 33

Tabla 3.1 Datos censales del ganado vacuno de la provincia de Salta 47

$\begin{array}{lll}\text { Tabla 3.2 } & \text { Porcentaje por categoría de ganado vacuno. } & 47\end{array}$

Tabla 3.3 Estimación del estiércol vacuno total que produce la 48 provincia de Salta.

Tabla 3.4. Estimación teórica de la energía. $\quad 49$

Tabla 3.5 Factor de conversión para ganado de feedlot y de tambo. $\quad 50$

Tabla 3.6. Estimación del potencial anual de generación de biogás y $\quad 50$ de energía.

Tabla 3.7 Estimación de energía en Tep por año por departamento 51 de la provincia de Salta.

Tabla 4.1 Parámetros físico-químicos de la caracterización de la mezcla de estiércol vacuno y agua para los ensayos a $20^{\circ}$, $30^{\circ}$ y $37^{\circ} \mathrm{C}$.

Tabla 4.2 Masa de los digestores de los distintos ensayos.

Tabla 4.3 Producción de metano para distintos tiempos de retención y a diferentes temperaturas.

Tabla 4.4 Resumen de datos de los ensayos. $\quad 64$

Tabla 4.5 pH, alcalinidad y ácidos grasos de dos muestras diferentes $\quad 66$ de FOD.

Tabla 4.6 Muestras de FOD con soluciones de $\mathrm{NaHCO}_{3}$ y $\mathrm{CaCO}_{3} . \quad 67$

Tabla 4.7 Caracterización físico-química de la mezcla de estiércol 67 vacuno y FOD.

$\begin{array}{lll}\text { Tabla 5.1 Rango de temperatura, conductividad y densidad de diferentes } & 74\end{array}$ materiales.

Tabla 5.2. Registro de temperaturas en ambos ensayos de 77 laboratorio.

Tabla 5.3 Difusividad térmica de algunos materiales aislantes. 84

Tabla 6.1 Ventajas y desventajas en la construcción de los digestores. 110 
Tabla 7.1. Comparación de los tiempos de encendido del sistema 123 eléctrico en las experiencias sin y con aislación.

Tabla 7.2 Valores máximos de temperatura e irradiancia solar.

Tabla 7.3 Temperatura del digestor y del intercambiador IC a la entrada y a la salida, en un periodo (0:10 a las 0:40 am).

Tabla 8.1 Datos de los parámetros utilizados en el modelo.

Tabla 8.2 Energía diaria utilizada por el digestor.

153

Tabla 8.3 Número de veces que se enciende la bomba en el mes de 158 setiembre en función de la eficiencia.

Tabla 9.1 Sólidos totales y volátiles de diferentes muestras de 164 estiércol vacuno proveniente de un tambo de la zona.

Tabla 9.2 Parámetros relacionados con la cantidad teórica de agua. 166

Tabla 9.3 Datos de la carga del digestor. 166

Tabla 9.4 Parámetros de producción del digestor $\left(0^{\circ} \mathrm{C}, 1 \mathrm{~atm}\right) . \quad 170$

Tabla 9.5 Caracterización del sustrato final (valores promedios). $\quad 171$

Tabla 10.1 Datos sobre la geometría del prototipo del digestor (Caso 176 $0)$.

Tabla 10.2 Detalle de costos - Caso 0.

Tabla 10.3 Inversión del prototipo- CASO 0.179

Tabla 10.4 Costos más significativos en U\$S y en \% de las 181 componentes - CASO 0.

Tabla 10.5 Parámetros para el llenado del digestor (Caso 0). 181

Tabla 10.6 Cálculo de la materia prima del digestor (Caso 0). 182

Tabla 10.7 Masa seca y masa de sólidos volátiles (Caso 0). 182

Tabla 10.8 Producción teórica de metano por periodo operativo (Caso 183 $0)$.

Tabla 10.9 Poder calorífico del gas metano y butano.

Tabla 10.10 Gas metano producido por periodo operativo y su 184 equivalencia con el número de garrafas de butano de $10 \mathrm{~kg}$ (Caso 0).

Tabla 11.1 Propuesta de casos con diferentes dimensiones del 187 digestor anaeróbico.

$\begin{array}{lll}\text { Tabla 11.2 Costo del equipamiento del prototipo- CASO I a IV. } & 188\end{array}$

Tabla 11.3 Inversión total-CASO I al IV. $\quad 189$

Tabla 11.4 Parámetros para el llenado del digestor. 189

Tabla 11.5 Detalles de la materia prima. 190

Tabla 11.6 Número aproximado de cabezas de ganado para el 191 estiércol requerido.

Tabla 11.7 Masa seca y masa de sólidos volátiles. 
Tabla 11.8 Producción teórica de metano por periodo operativo

Tabla 11.9 Gas metano producido por periodo operativo y su equivalencia con el número de garrafas de butano de $10 \mathrm{~kg}$.

Tabla 11.10 Área del colector solar según el volumen del digestor.

193

Tabla 11.11 Inversión total por volumen de digestor. CASO I al IV.

195

Tabla 11.12 Costos de la energía eléctrica.

196

Tabla 11.13 Potencia de la maquinaria.

196

Tabla 11.14 Costo diario del consumo de energía eléctrica. 196

Tabla 11.15 Número de garrafas equivalentes de la planta de 194 producción de biogás.

Tabla 11.16 Inversión total de la Planta de Biodigestión -CASO I al IV. 198

Tabla 11.17 Hipótesis para el flujo de fondos. 199

Tabla 11.18 Flujo de fondos- Caso IV. 199

Tabla 1.A5 Valores promedios de los parámetros para el cálculo del 242 área de colección solar.

Tabla 2.A5 Valores de la masa de agua, potencia útil y área de 243 colección solar A para distintos volúmenes.

Tabla 3.A5 Volumen y área del colector para sistemas de 1 y $2 \quad 243$ biodigestores.

Tabla 1.A6 Costos de la energía eléctrica por kWh en pesos. 
Figura 1.1 Evolución del consumo energético a nivel mundial desde 8 1985 al 2018 (BP, 2019).

Figura 1.2 Evolución de la producción de energía primaria de la Nación 9 del 2010 al 2018.

Figura 1.3 Matriz de producción energética nacional del año 2018. 10

Figura 1.4 Distribución en porcentajes de biodigestores en las 14 provincias.

$\begin{array}{lll}\text { Figura 1.5. } & \text { Distribución de biodigestores por sector. } & 14\end{array}$

$\begin{array}{lll}\text { Figura 1.6 Vista del matadero municipal y el digestor anaeróbico. } & 17\end{array}$

$\begin{array}{lll}\text { Figura 1.7 Motor para el mezclado y ductos de recirculación. } & 18\end{array}$

Figura 1.8 Vistas de los tubos perforados y válvula de muestreo. 20

Figura 1.9 Vista del contenedor con viruta de hierro (izquierda) y 20 quemador (derecha).

Figura 1.10 Cobertura nacional de la red de gas en \% y cantidad de 21 viviendas por provincia .

Figura 1.11 Red de gas y localidades abastecidas con gas natural. $\quad 22$

Figura 2.1 Digestor tipo hindú. 25

Figura 2.2 Digestor tipo chino. 26

Figura 2.3 Esquema con los distintos tratamientos. 28

Figura 2.4 Esquema de la utilización del biogás. 28

Figura 2.5 Etapas del proceso de digestión anaeróbica. 29

Figura 2.6 Parámetros operacionales y de control en el proceso de 33 digestión anaeróbica.

Figura 3.1 Mapa físico de la provincia de Salta. $\quad 42$

Figura 3.2 Mapa político de la provincia de Salta. $\quad 45$

Figura 3.3 Distribución de ganado bovino por departamento. 46

Figura 4.1 Esquema de la determinación de metano en la muestra de 56 biogás.

Figura 4.2 Esquema y foto del ensayo de biodigestión realizado en el 58 laboratorio.

Figura 4.3. Producción de biogás del estiércol vacuno en litros por 60 kilogramos de sólidos volátiles a $20^{\circ} \mathrm{C}$.

Figura 4.4 Porcentaje de metano a $20^{\circ} \mathrm{C}$. 61

Figura 4.5 Producción diaria de biogás del estiércol vacuno a $30^{\circ} \mathrm{C}$ en 61 litros por kilogramos de sólidos volátiles.

Figura 4.6. Porcentaje de metano en el ensayo a $30^{\circ} \mathrm{C} . \quad 62$ 
Figura 4.7 Producción de biogás del estiércol vacuno a $37^{\circ} \mathrm{C}$ en litros 62 por kilogramos de sólidos volátiles.

Figura 4.8 Porcentaje de metano en el ensayo a $37^{\circ} \mathrm{C} . \quad 63$

Figura 4.9 Imagen de la cámara con la parrilla y el digestor apoyado 65 sobre ella.

Figura 4.10 Esquema del ensayo de codigestión. 66

Figura 4.11 Volumen diario de biogás y de metano en litros por 68 kilogramos de SV a $37^{\circ} \mathrm{C}$.

Figura 4.12 Alcalinidad a pH de 4,5 y 4,0 y AGV en mg $\mathrm{CaCO}_{3} /$ litro, 69 ensayo de codigestión

Figura 4.13 Variación temporal del pH. , ensayo de codigestión 69

Figura 5.1 Imagen y esquema de la experiencia con las botellas. 75 Ubicación de los termopares (superior, medio e inferior)

Figura 5.2 Dependencia temporal de la temperatura dentro de las 76 botellas con y sin viruta.

Figura 5.3. Puntos de un sector de la grilla. $\quad 79$

Figura 5.4 Volumen de control en un nodo de un sector de la grilla. $\quad 80$

Figura 5.5 Características de la grilla de control. 81

Figura 5.6 Relación entre los nodos para el cálculo de temperatura en 81 la forma explícita.

Figura 5.7 Grilla de temperaturas para la discretización de la ecuación 82 de difusión.

Figura 5.8 Difusividad térmica en función de la temperatura. 83

Figura 5.9 Cálculo y medida de la temperatura en el interior de la 84 botella rellena con viruta en función del tiempo.

Figura 6.1 Vista del digestor desplegado sobre el suelo (izquierda), 89 aislación cubriendo la fosa (derecha).

Figura 6.2 Vista del digestor tubular instalado en el terreno. 90

Figura 6.3 Invernadero sobre el digestor tubular. 90

Figura 6.4 Sistema eléctrico de calefacción. 91

Figura 6.5 Vista de la fosa cubierta con las botellas y tubos del 92 intercambiador.

Figura 6.6 Sistema de calentamiento con control de temperatura del 92 digestor tubular flexible.

Figura 6.7 Construcción del digestor. 93

Figura 6.8. Foto del digestor anaeróbico enterrado y sus partes. 94

Figura 6.9 Imagen de la tapa epoxi y ladrillo premoldeado. 94

Figura 6.10 Esquema del digestor anaeróbico. 95 
Figura 6.11. Perfil del digestor enterrado: colocación y sujeción de las 96 botellas .

Figura 6.12. Esquema de una vista en perspectiva del modo de sujeción 96 de las botellas con hierro.

Figura 6.13 Distintas etapas de la colocación de las botellas. 97

Figura 6.14 Distintas etapas de la construcción del digestor anaeróbico 97 enterrado con mejoras, caso $\mathrm{C}$.

Figura 6.15 Cámaras laterales y el digestor completo- Caso C. 98

Figura 6.16 Esquema del digestor anaeróbico, cámaras y colector solar. 99 Vista de perfil y de planta.

Figura 6.17 Sistemas de sujeción de la membrana. 99

Figura 6.18 Intercambiador de calor. 101

$\begin{array}{lll}\text { Figura 6.19 Colector solar. } & 102\end{array}$

Figura 6.20 Vista transversal y frontal del interior del colector solar. 103

Figura 6.21 Esquema del circuito hidráulico para el calentamiento del 103 digestor enterrado.

Figura 6.22 Componentes del circuito eléctrico. 104

Figura 6.23 Sistema de control de calentador híbrido solar-eléctrico. 105

$\begin{array}{ll}\text { Figura 6.24 Imagen del invernadero. } & 107\end{array}$

Figura 6.25 Sujeción del motor eléctrico y del mezclador. 107

$\begin{array}{lll}\text { Figura 6.26 Mezclador y sistema de sujeción. } & 108\end{array}$

Figura 6.27 Imagen de la electrobomba, resistencia eléctrica, válvulas 109 eléctricas y gabinete eléctrico.

Figura 7.1 Esquema de ubicación de sensores en el digestor tubular 114 flexible semienterrado, caso A.

Figura 7.2 Esquema de digestor anaeróbico tubular e imágenes de los 115 componentes del sistema de calentamiento.

Figura 7.3. Esquema del digestor, caso C, y sistema de calentamiento. 116 Posiciones de los sensores de temperatura. (a) vista de planta, (b) vista lateral.

Figura 7.4 Imágenes y esquema del sistema de calentamiento. 118

$\begin{array}{lll}\text { Figura 7.5 Temperaturas en el digestor tubular. } & 119\end{array}$

Figura 7.6 Temperaturas en el digestor tubular con invernadero. 120

Figura 7.7 Temperaturas medidas en el intercambiador de calor, 122 ambiente externo, interior del digestor y del suelo (por debajo del IC) sin (a) y con aislación (b).

Figura 7.8 Temperaturas ambiente, colector solar, cubierta del 124 digestor e invernadero.

Figura 7.9 Irradiancia solar directa sobre plano horizontal . 
Figura 7.10 Esquema del intercambiador y ubicación de los sensores. 126

Figura 7.11 Temperatura del flujo de agua a la entrada y salida del 126 intercambiador IC en función del tiempo.

Figura 7.12 Temperatura del digestor anaeróbico enterrado. 128

Figura 8.1 Representación gráfica de la eficiencia instantánea de un 136 colector solar.

Figura 8.2 Esquema de los flujos de calor desde y hacia la carga del digestor.

Figura 8.3 Esquema de las temperaturas a la entrada y salida del 139 colector solar e intercambiador.

Figura 8.4 Esquema simplificado del funcionamiento de los 140 controladores de temperatura.

Figura 8.5 Temperatura promedio del digestor, intervalos de 141 temperatura de aumento y disminución $\Delta T_{S}$ en torno al valor promedio.

Figura 8.6 Flujos de calor en el biogás.

Figura 8.7 Curva de rendimiento del colector solar plano. 149

Figura 8.8 Nodos de temperatura para el cálculo de simulación 150 numérica.

Figura 8.9 Temperatura de la cubierta y carga del digestor: calculada y 152 medida.

Figura 8.10 Temperatura del invernadero: calculada y medida.

Figura 8.11 Cálculo de la energía solar útil que brinda el colector solar. 154

Figura 8.12 Energía solar consumida por el digestor anaeróbico 155 enterrado. Operando a (a) $30^{\circ} \mathrm{C}$ y (b) $20^{\circ} \mathrm{C}$.

Figura 8.13 Consumo mensual de energía eléctrica del digestor 156 operando a (a) $30^{\circ} \mathrm{C}$ y (b) $20^{\circ} \mathrm{C}$.

Figura 8.14 Número de veces que enciende la electrobomba para dos volúmenes diferentes del digestor (500 l y 1.000 l).

Figura 9.1 Representación de la captación, filtración y cuantificación del biogás.

Figura 9.2 Imagen del sistema de captación, filtración y cuantificación del biogás.

Figura 9.3. Partes del sistema de captación, acumulación, filtración y 163 cuantificación del biogás.

Figura 9.4 Imágenes del acopio de estiércol vacuno y llenado del 167 digestor.

Figura 9.5 Sistema de medición del volumen de biogás. 
Figura 9.6 Experiencia 1: (a) volumen de biogás por día. (b) volumen 169 de biogás promedio por semana.

Figura 9.7 Experiencia 2: (a) volumen de biogás por día. (b) volumen 169 de biogás por semana.

Figura 9.8 Esquema del volumen en función del tiempo de dos 171 digestores funcionando en forma discontinua.

Figura 9.9 Vista del interior del digestor luego de finalizada la 172 experiencia.

Figura 10.1 Costo en U\$S de las secciones del biodigestor (Caso 0). $\quad 180$

Figura 10.2 Costo en \% de las secciones del biodigestor (Caso 0). 180

Figura 11.1 Esquema de operación anual de un digestor. 192

Figura 11.2 Esquema tridimensional del digestor con su sistema de 194 calentamiento hibrido solar-eléctrico.

Figura 11.3 Esquema de operación de una planta compuesta por dos 194 digestores.

Figura 11.4 Esquema del monto acumulado en función del tiempo. Caso 200 IV.

Figura 1.A4 Costos parciales del prototipo. 236

Figura 2.A4 Costo en U\$S de las componentes del biodigestor (Caso I, II, 236 III, IV).

Figura 3.A4 Costo en \% de las componentes del biodigestor (Caso 0). 237

Figura 4.A4 Costo en \% de las componentes del biodigestor (Caso I y IV). 240

Figura 1.A5 Temperatura ambiente como función del tiempo durante el 240 mes de julio del año 2018.

Figura 2.A5 Irradiancia solar como función del tiempo durante el mes de 240 julio. 